ANTÔNIO ACACIO DE MELO NETO

INFLUÊNCIA DE ADITIVOS REDUTORES E COMPENSADORES DE RETRAÇÃO EM ARGAMASSAS E PASTAS COM CIMENTO DE ESCÓRIA ATIVADA

Tese apresentada à Escola Politécnica da Universidade de São Paulo para obtenção de título de Doutor em Engenharia.

São Paulo

2008 
Tese apresentada à Escola Politécnica da Universidade de São Paulo para obtenção de título de Doutor em Engenharia.

Área de concentração:

Engenharia de Construção Civil e Urbana

Orientador:

Prof $^{\underline{a}}$ Maria Alba Cincotto 
Este exemplar foi revisado e alterado em relação à versão original, sob responsabilidade única do autor e com a anuência de seu orientador.

São Paulo, 10 de janeiro de 2008

Assinatura do autor

Assinatura do orientador

\section{Melo Neto, Antônio Acacio de}

Influência de aditivos redutores e compensadores de retração em argamassas e pastas com cimento de escória ativada. São Paulo, 2002. Edição revisada.

$253 p$.

Tese (Doutorado) - Escola Politécnica da Universidade de São Paulo. Departamento de Engenharia de Construção Civil e Urbana.

1. Cimento de escória 2. Retração 3. Escória de alto forno 4. Ativação alcalina I. Universidade de São Paulo. Escola Politécnica. Departamento de Engenharia de Construção Civil e Urbana Il.t. 
Aos meus pais e à minha família,

Agradeço todo amor, investimento e carinho dedicados a mim. 


\section{Agradecimentos}

Eu inicio agradecendo a $\operatorname{Prof}^{\mathrm{a}}$. Dr $\stackrel{\mathrm{a}}{\text {. Maria }}$ Alba Cincotto pela orientação contínua e


Repette pela coorientação precisa e pelo entusiasmo no tema da retração. Agradeço a Escola Politécnica da Universidade de São Paulo e todos seus professores e funcionários pelo suporte ao desenvolvimento do trabalho.

Agradeço a todos meus amigos, minha família e meus pais pelo apoio financeiro, psicológico, fraternal, entre outros. Com certeza vocês tornaram mais tranqüila a passagem desta etapa da minha vida. Agradeço à Fernanda o companheirismo e a ajuda imprescindível na correção do texto.

Agradeço a Fundação de Amparo à Pesquisa do Estado de São Paulo - FAPESP, pela concessão de recursos de auxílio à pesquisa e pela bolsa de doutorado. Agradeço também a Coordenação de Aperfeiçoamento de Pessoal de Nível Superior - CAPES concessão de recursos de auxílio à pesquisa. Agradeço a INEOS Sílicas, GRACE e a DENKA pela doação de materiais e cooperação com o desenvolvimento desta pesquisa. Por fim, agradeço a todos que de forma direta ou indireta contribuíram para a realização deste trabalho. 
Lista de figuras

Lista de tabelas

Resumo

Abstract

Parte 1 Introdução, revisão bibliográfica e metodologia

Capítulo 1 Introdução

$\begin{array}{lll}1.1 & \text { Contexto e justificativas } & 1\end{array}$

1.2 Objetivo 6

$\begin{array}{lll}1.3 & \text { Estrutura do trabalho } & 7\end{array}$

Capítulo 2 Revisão bibliográfica 9

2.1 Introdução 9

2.2 Retração em materiais cimentícios 9

$\begin{array}{ll}\text { 2.2.1 Variáveis envolvidas na fissuração } & 10\end{array}$

2.2.1.1 Estado da água 10

2.2.1.2 Tensão superficial 11

2.2.1.3 Tensão capilar 12

2.2.1.4 Pressão de separação ou de desligamento 12

2.2.2 Deformações em materiais cimentícios 13

$\begin{array}{lll}2.3 & \text { Cimento de escória ativada com silicato de sódio } & 19\end{array}$

$\begin{array}{lll}2.3 .1 & \text { Hidratação } & 20\end{array}$

2.3.2 Porosidade 22

2.3.3 Propriedades mecânicas $\quad 24$

2.3.4 Comportamento da retração do cimento de escória ativada 25

2.4 Aditivos Compensadores (SCA) e redutores de retração (SRA) 30

2.4.1 Aditivo compensador de Retração (SCA) 30

2.4.2 Aditivo Redutor de Retração (SRA) 35

2.5 Conclusões $\quad 39$

Capítulo 3 Programa experimental $\quad 40$

3.1 Definição do programa experimental 40

$\begin{array}{lll}3.2 & \text { Variáveis } & \mathbf{4 0}\end{array}$

3.2.1 Tipo e concentração dos ativadores 40

3.2.2 Relação água/aglomerante 41

3.2.3 Aditivo compensador (SCA) e redutor de retração (SRA) 42

3.2.4 Dosagem das argamassas 42

3.2.5 Condições de cura e exposição 43

3.3 Planejamento experimental $\quad 43$

3.3.1 Planejamento experimental dos ensaios mecânicos 44

3.3.2 Planejamento experimental dos ensaios de retração 45 
3.3.3 Planejamento experimental dos ensaios de análise da microestrutura 45

3.3.3.1 Termogravimetria 45

3.3.3.2 Análise por difração de raios X (DRX) 46

$\begin{array}{lll}\text { 3.3.3.3 Porosimetria } & 47\end{array}$

$\begin{array}{lll}3.4 & \text { Materiais empregados } & 48\end{array}$

$\begin{array}{lll}\text { 3.4.1 Escória de alto-forno } & 48\end{array}$

3.4.2 Aditivo redutor de retração e aditivo compensador de retração 50

3.4.3 Silicato de sódio 52

3.4.4 Areia 52

3.5 Procedimentos de ensaio $\quad 53$

3.5.1 Preparo e moldagem das argamassas 53

3.5.2 Retração por secagem e retração autógena 54

3.5.2.1 Procedimento de ensaio $\quad 54$

3.5.3 Resistências à compressão e à tração na flexão e módulo de elasticidade 55

3.5.3.1 Procedimento de ensaio 56

3.5.4 Análise por termogravimetria $\quad 57$

3.5.4.1 Procedimento de ensaio $\quad 57$

3.5.5 Porosimetria $\quad 59$

3.5.5.1 Procedimento de ensaio $\quad 59$

3.5.6 Difração de raios X (DRX) 60

$\begin{array}{lll}\text { 3.5.6.1 Procedimento de ensaio } & 60\end{array}$

Capítulo 4 Difração de raios $X$

$\begin{array}{lll}4.1 & \text { Introdução } & 62\end{array}$

4.2 Efeito da relação água/aglomerante $\quad 62$

$\begin{array}{lll}4.3 & \text { Efeito do aditivo redutor de retração (SRA) } & 67\end{array}$

4.4 Discussão e conclusões $\quad 72$

$\begin{array}{lll}\text { 4.4.1 Efeito da relação água/aglomerante } & 72\end{array}$

$\begin{array}{lll}\text { 4.4.2 Efeito do aditivo redutor de retração (SRA) } & 73\end{array}$

Capítulo 5 Termogravimetria $\quad 74$

$\begin{array}{lll}5.1 & \text { Identificação e quantificação dos produtos hidratados } & \mathbf{7 4}\end{array}$

5.2 Efeito da relação água/aglomerante $\quad 75$

$\begin{array}{lll}\text { 5.2.1 Difração de raios X versus termogravimetria } & 77\end{array}$

$\begin{array}{lll}5.3 & \text { Efeito do aditivo redutor de retração (SRA) } & 78\end{array}$

5.4 Discussão e conclusões $\quad \mathbf{8 0}$

5.4.1 Efeito da relação água/aglomerante 80

5.4.2 Efeito do aditivo redutor de retração (SRA) 81

Capítulo 6 Porosimetria $\quad 82$

6.1 Introdução $\quad 82$

6.2 Efeito da relação água/aglomerante $\quad 83$

6.2.1 Porosidade versus termogravimetria 88 
6.3 Efeito do aditivo redutor de retração (SRA) 90

6.3.1 Porosidade versus termogravimetria 94

6.4 Discussão e conclusões $\quad 95$

6.4.1 Efeito da relação água/aglomerante 95

6.4.2 Efeito do aditivo redutor de retração (SRA) 96

Capítulo 7 Propriedades mecânicas $\quad 97$

$\begin{array}{lll}7.1 & \text { Efeito da relação água/aglomerante } & 97\end{array}$

7.1.1 Resistência à compressão versus termogravimetria 102

7.1.2 Resistência à compressão versus porosidade 103

7.2 Efeito do aditivo redutor de retração (SRA) 105

$\begin{array}{lll}\text { 7.2.1 Resistência à compressão } & 105\end{array}$

7.2.2 Resistência à tração na flexão 111

7.2.3 Módulo de elasticidade 116

$\begin{array}{lll}7.3 & \text { Discussão e conclusões } & 121\end{array}$

7.3.1 Efeito da relação água/aglomerante 121

7.3.2 Efeito do aditivo redutor de retração (SRA) 122

Capítulo 8 Retração por secagem e autógena 123

8.1 Efeito da relação água/aglomerante 123

$\begin{array}{ll}\text { 8.1.1 Retração por secagem } & 123\end{array}$

8.1.1.1 Retração por secagem versus perda de massa por evaporação 128

8.1.1.2 Retração por secagem versus porosidade 131

$\begin{array}{lll}\text { 8.1.2 Retração autógena } & 133\end{array}$

8.1.2.1 Retração autógena versus porosidade e termogravimetria 135

8.2 Efeito do aditivo redutor de retração (SRA) 138

8.2.1 Retração por secagem 138

8.2.1.1 Retração por secagem versus perda de massa por evaporação 142

8.2.2 Retração autógena 145

8.2.2.1 Retração autógena versus porosidade 147

$\begin{array}{lll}\text { 8.3 Discussão e conclusões } & 148\end{array}$

$\begin{array}{lll}\text { 8.3.1 Retração por secagem } & 148\end{array}$

$\begin{array}{ll}\text { 8.3.1.1 Efeito da relação água/aglomerante } & 148\end{array}$

8.3.1.2 Efeito do aditivo redutor de retração (SRA) 149

$\begin{array}{lll}\text { 8.3.2 Retração autógena } & 150\end{array}$

8.3.2.1 Efeito da relação água/aglomerante 150

8.3.2.2 Efeito do aditivo redutor de retração (SRA) 151

Parte 3 Aditivo compensador de retração (SCA) 153

Capítulo 9 Difração de raios X 154

9.1 Introdução 154

9.1.1 Hidratação do aditivo compensador de retração (SCA) 154

9.2 Efeito do aditivo compensador de retração (SCA) 157 
$\begin{array}{lll}9.3 & \text { Discussão e conclusões } & 169\end{array}$

Capítulo 10 Termogravimetria 171

$\begin{array}{lll}10.1 & \text { Introdução } & 171\end{array}$

10.1.1 Hidratação do aditivo compensador de retração (SCA) 171

10.2 Efeito do aditivo compensador de retração (SCA) 174

$\begin{array}{lll}10.3 & \text { Discussão e conclusões } & 177\end{array}$

Capítulo 11 Porosimetria $\quad 179$

11.1 Efeito do aditivo compensador de retração (SCA) 179

$\begin{array}{ll}11.2 & \text { Discussão e conclusões } \\ 184\end{array}$

Capítulo 12 Propriedades mecânicas $\quad 185$

12.1 Efeito do aditivo compensador de retração (SCA) 185

$\begin{array}{lll}\text { 12.1.1 Resistência à compressão } & 185\end{array}$

$\begin{array}{ll}\text { 12.1.2 Resistência à tração } & 191\end{array}$

12.1.3 Módulo de elasticidade 196

12.2 Discussão e conclusões 200

Capítulo 13 Retração por secagem e autógena 202

13.1 Retração por secagem $\quad 202$

13.1.1 Retração por secagem versus perda de massa por evaporação 209

$\begin{array}{lll}13.2 & \text { Retração autógena } & 215\end{array}$

13.3 Discussão e conclusões 220

$\begin{array}{lll}\text { 13.3.1 Retração por secagem } & 220\end{array}$

13.3.2 Retração autógena 221

Parte 4 Conclusões $\quad 222$

Capítulo 14 Conclusões e considerações finais 223

14.1 Influência da relação água/aglomerante 223

$\begin{array}{ll}\text { 14.1.1 Microestrutura } & 223\end{array}$

$\begin{array}{lll}\text { 14.1.2 Propriedades mecânicas } & 225\end{array}$

$\begin{array}{ll}\text { 14.1.3 Retração por secagem } & 225\end{array}$

$\begin{array}{lll}\text { 14.1.4 Retração autógena } & 226\end{array}$

14.2 Influência do aditivo redutor de retração (SRA) 228

$\begin{array}{ll}\text { 14.2.1 Microestrutura } & 229\end{array}$

14.2.2 Propriedades mecânicas 230

$\begin{array}{lll}\text { 14.2.3 Retração por secagem } & 231\end{array}$

$\begin{array}{lll}\text { 14.2.4 Retração autógena } & 231\end{array}$

14.2.5 Discussão e conclusões 232

14.3 Influência do aditivo compensador de retração (SCA) 233

$\begin{array}{lll}\text { 14.3.1 Microestrutura } & 234\end{array}$

14.3.2 Propriedades mecânicas 235

$\begin{array}{lll}\text { 14.3.3 Retração por secagem } & 236\end{array}$

$\begin{array}{lll}\text { 14.3.4 Retração autógena } & 236\end{array}$ 
14.3.5 Discussão e conclusões 238

14.4 Aditivo redutor de retração versus aditivo compensador de retração (SCA) 239

$\begin{array}{lll}\text { 14.4.1 Microestrutura } & 239\end{array}$

$\begin{array}{lll}\text { 14.4.2 } & \text { Propriedades mecânicas } & 239\end{array}$

$\begin{array}{lll}\text { 14.4.3 Retração por secagem } & 240\end{array}$

$\begin{array}{lll}\text { 14.4.4 Retração autógena } & 240\end{array}$

$\begin{array}{lll}14.5 & \text { Sugestões para pesquisas futuras } & 240\end{array}$

Referências bibliográficas $\quad 242$

Apêndice A - Resultados da termogravimetria $\quad 254$

Apêndice B - Resultados da porosimetria 261

Apêndice C - Resultados da difração de raios X 267

Apêndice D - Equipamento de retração restringida 291 


\section{Lista de figuras}

Figura 1.1 - Evolução da produção anual de ferro gusa e da estimativa de escória de alto forno (Estima-se que 1 tonelada de ferro gusa resulta em $300 \mathrm{Kg}$ de escória granulada de alto-forno). Fonte: Instituto Brasileiro de Siderurgia - IBS.

Figura 1.2 - Evolução da produção anual de cimento Portland, de cimento Portland comum com adição (CP II) e de cimento Portland de alto-forno (CP III). Fonte: Sindicato Nacional da Indústria do Cimento - SNIC. . 5

Figura 1.3 - Estimativa da produção anual de escória de alto forno e do consumo anual pela indústria do cimento realizada com base nos dados do IBS e do SNIC.

Figura 1.4 - Representação esquemática da estratégia de abordagem do tema 7

Figura 2.1 - Variação da espessura da camada de água adsorvida com a variação da umidade (KOENDERS, 1997)

Figura 2.2 - Representação esquemática da adsorção da água em um capilar de pasta de cimento



Figura 2.3 - Fatores intervenientes na fissuração em concretos (FOLLIARD et al., 2003).

Figura 2.4 - Comportamento típico do concreto submetido à secagem e molhagem (MINDESS; YOUNG, 1981).

Figura 2.5 - Comportamento típico do concreto submetido a carregamento e descarregamento (MINDESS; YOUNG, 1981).

Figura 2.6 - Interação entre a fluência e a retração na fissuração do concreto (MEHTA; MONTEIRO, 1994).

Figura 2.7 - Deformações dependentes de carregamento ao longo do tempo em concreto submetido à carga, sendo $T_{0}$ a idade na qual o concreto foi carregado (NEVILLE, 1981).

Figura 2.8 - Retração autógena das argamassas de cimento de escória ativada com silicato de sódio (4NS=4,5\% $\mathrm{Na}_{2} \mathrm{O}+7,65 \% \mathrm{SiO}_{2} ; \quad 3 \mathrm{NS}=3,5 \% \mathrm{Na}_{2} \mathrm{O}+5,95 \% \mathrm{SiO}_{2} ; \quad 2 \mathrm{NS}=2,5 \% \mathrm{Na}_{2} \mathrm{O}+4,25 \% \mathrm{SiO}_{2}$ ), ativada com hidróxido de sódio $\left(5 \mathrm{~N}=5 \% \mathrm{Na}_{2} \mathrm{O}\right)$ e da argamassa de cimento Portland ARI. Todas com uma relação água/aglomerante igual a 0,48, desmoldadas após 6 horas e colocadas na câmara seca (50\% U.R. e 24우) (MELO NETO, 2002).

Figura 2.9 - Retração por secagem das argamassas de cimento de escória ativada com silicato de sódio (4NS=4,5\% $\mathrm{Na}_{2} \mathrm{O}+7,65 \% \mathrm{SiO}_{2} ; \quad 3 \mathrm{NS}=3,5 \% \mathrm{Na}_{2} \mathrm{O}+5,95 \% \mathrm{SiO}_{2} ; \quad 2 \mathrm{NS}=2,5 \% \mathrm{Na}_{2} \mathrm{O}+4,25 \% \mathrm{SiO}_{2}$ ), ativada com hidróxido de sódio $\left(5 \mathrm{~N}=5 \% \mathrm{Na}_{2} \mathrm{O}\right)$ e da argamassa de cimento Portland ARI. Todas com uma relação água/aglomerante igual a 0,48, desmoldadas após 6 horas e colocadas na câmara seca (50\% U.R. e 24으) (MELO NETO, 2002).

Figura 2.10 - Retração e expansão de um concreto normal e de um concreto expansivo (LUCO et al.,1999).

Figura 2.11 - Representação esquemática das reações de hidratação do aditivo compensador de retração com agente expansivo à base de sulfoaluminato de cálcio anidro (NAGATAKI; GOMI, 1998).....

Figura 2.12 - Efeito do aditivo redutor de retração (SRA) na tensão superficial da água (RONGBING; JIAN, 2005)

Figura 3.1 - Difratograma da escória de alto forno anidra.

Figura 3.2 - Resultado do ensaio de termogravimetria (TG-DTG) (a) e de calorimetria exploratória diferencial



Figura 3.3 - Difratograma do aditivo compensador de retração (SCA) anidro.

Figura 3.4 - Resultado do ensaio de termogravimetria (TG-DTG) do aditivo compensador de retração (SCA) anidro.

Figura 3.5 - Corpos-de-prova de retração autógena e retração por secagem (a) e aparato para a leitura da variação dimensional (b).

Figura 3.6 - Ensaio de resistência à tração na flexão (a) e de resistência à compressão (b), de acordo com a BS EN 196 (1995). Determinação do módulo de elasticidade (c). 
Figura 3.7 - Equipamentos utilizados no preparo e ensaio das amostras de termogravimetria ...... .58

Figura 3.8 - Porosímetro por intrusão de mercúrio Autopore III 9410.

Figura 4.1 - Efeito da relação a/agl na difração de raios X com 6 horas de idade.....................................63

Figura 4.2 - Efeito da relação a/agl na difração de raios X com 12 horas de idade....................................64

Figura 4.3 - Efeito da relação a/agl na difração de raios X com 1 dia de idade .........................................64

Figura 4.4 - Efeito da relação a/agl na difração de raios X com 3 dias de idade. ......................................64

Figura 4.5 - Efeito da relação a/agl na difração de raios $X$ com 7 dias de idade. .....................................65

Figura 4.6 - Efeito da relação a/agl na difração de raios X com 28 dias de idade. ...................................65

Figura 4.7 - Efeito da relação a/agl na evolução da intensidade do pico principal do C-S-H no ângulo ${ }_{2} \Theta=29,36(d(\AA)=3,040)$ a 6 e 12 horas e aos 1, 3, 7 e 28 dias. .........................................................6

Figura 4.8 - Efeito da relação a/agl na intensidade do pico principal de C-S-H determinado no ensaio de difração de raios $X$ até os 28 dias de idade.

Figura 4.9 - Detalhamento do efeito da relação a/agl na intensidade do pico principal de C-S-H determinado no ensaio de difração de raios $X$ nas primeiras idades.

Figura 4.10 - Efeito do teor de aditivo redutor de retração (SRA) na difração de raios $X$ da pasta de cimento de escória com 12 horas de idade. a/agl = 0,48.

Figura 4.11 - Efeito do teor de aditivo reduto de retração (SRA) na difração de raios $X$ da pasta de cimento de escória com 1 dia de idade. a/agl = 0,48.

Figura 4.12 - Efeito do teor de aditivo reduto de retração (SRA) na difração de raios $X$ da pasta de cimento de escória com 3 dias de idade. a/agl = 0,48.

Figura 4.13 - Efeito do teor de aditivo reduto de retração (SRA) na difração de raios $X$ da pasta de cimento de escória com 7 dias de idade. $\mathrm{a} / \mathrm{agl}=0,48$.

Figura 4.14 - Efeito do teor de aditivo reduto de retração (SRA) na difração de raios $X$ da pasta de cimento de escória com 28 dias de idade. a/agl = 0,48.

Figura 4.15 - Efeito do teor de aditivo redutor de retração (SRA) na evolução da intensidade do pico principal do C-S-H no ângulo ${ }^{\circ} 2 \Theta=29,36(\mathrm{~d}(\AA)=3,040)$ a 12 horas e aos $1,3,7$ e 28 dias........................70

Figura 4.16 - Efeito do teor de aditivo redutor de retração (SRA) na intensidade do pico principal de C-S-H determinado no ensaio de difração de raios $X$ até os 28 dias de idade......

Figura 4.17 - Detalhamento do efeito do teor de aditivo redutor de retração (SRA) na intensidade do pico principal de C-S-H determinado no ensaio de difração de raios $\mathrm{X}$ nas primeiras idades.......

Figura 5.1 - Perda de massa (TG/\%) e derivada da curva de perda de massa (DTG) da pasta de cimento de escória ativada com silicato de sódio (4NSA0) a 6 e 12 horas, 1,3,7 e 28 dias de idade. Relação água/aglom $=0,40$.

Figura 5.2 - Exemplo da quantificação dos produtos hidratados utilizando a curva de perda de massa (TG/\%) e a derivada da curva de perda de massa (DTG) da pasta de cimento de escória ativada com silicato de sódio (4NSA0) a 6 e 12 horas, 1,3,7 e 28 dias de idade. Relação água/aglom= 0,40.

Figura 5.3 - Efeito da relação a/agl na quantidade de C-S-H determinada no ensaio de termogravimetria até os 28 dias de idade.

Figura 5.4 - Detalhe do efeito da relação a/agl na quantidade de C-S-H formado nas primeiras idades. .....76

Figura 5.5 - Efeito da relação a/agl na quantidade de C-S-H (\%). Gráfico construído com todos os pontos obtidos.

Figura 5.6 - Influência da relação a/agl na correlação entre a intensidade do pico principal do C-S-H determinado pela difração de raios $\mathrm{X}$ e a quantidade de C-S-H determinado pela termogravimetria.............78

Figura 5.7 - Efeito do teor de aditivo redutor de retração (SRA) na quantidade de C-S-H determinado no ensaio de termogravimetria até os 28 dias de idade na mistura com relação a/agl igual a $0,48 . \ldots \ldots \ldots \ldots \ldots . . .79$

Figura 5.8 - Detalhamento do efeito do teor de aditivo redutor de retração (SRA) na quantidade de C-S-H nas primeiras idades na mistura com relação a/agl igual a 0,48.

Figura 5.9 - Correlação entre o teor de aditivo redutor de retração (SRA) e quantidade de C-S-H (\%) na mistura com relação a/agl igual a 0,48 . Gráfico construído com todos os pontos obtidos. 
Figura 6.1 - Exemplo da faixa de classificação de mesoporos e macroporos nas curvas de evolução da porosidade total e da distribuição de poros da pasta de cimento de escória ativada com silicato de sódio (4NSA0) a 6 e 12 horas, $1,3,7$ e 28 dias de idade. a/agl= 0,40.

Figura 6.2 - Efeito da relação água/aglomerante na porosidade acumulada (a), na porosidade diferencial (b) e na distribuição de poros (c) da pasta de escória ativada com silicato de sódio (4NS) com 12 horas de idade.

Figura 6.3 - Efeito da relação água/aglomerante na porosidade acumulada (a), na porosidade diferencial (b) e na distribuição de poros (c) da pasta de escória ativada com silicato de sódio (4NS) com 1 dia de idade. 84

Figura 6.4 - Efeito da relação água/aglomerante na porosidade acumulada (a), na porosidade diferencial (b) e na distribuição de poros (c) da pasta de escória ativada com silicato de sódio (4NS) com 3 dias de idade.

Figura 6.5 - Efeito da relação água/aglomerante na porosidade acumulada (a), na porosidade diferencial (b) e na distribuição de poros (c) da pasta de escória ativada com silicato de sódio (4NS) com 7 dias de idade.

Figura 6.6 - Efeito da relação água/aglomerante na porosidade acumulada (a), na porosidade diferencial (b) e na distribuição de poros (c) da pasta de escória ativada com silicato de sódio (4NS) com 28 dias de idade.

Figura 6.7 - Evolução da porosidade total das três relações a/agl estudadas até os 28 dias (a) e detalhado nas primeiras idades (b).

Figura 6.8 - Evolução da proporção do volume de mesoporos em relação à porosidade total das três relações a/agl estudadas até os 28 dias (a) e detalhado nas primeiras idades (b).

Figura 6.9 - Correlação entre a relação água/aglomerante e a porosidade total (a), a proporção de macroporos (b) e de mesoporos (c). Gráficos construídos com todos os pontos obtidos.......

Figura 6.10 - Influência da relação a/agl na correlação entre a quantidade de C-S-H e a porosidade total (a), o volume de macroporos (b) e de mesoporos (c).

Figura 6.11 - Efeito do teor de aditivo redutor de retração (SRA) (0\%, 0,5\%, 1,0\%, 1,5\% e 2,0\%) na porosidade acumulada (a), na porosidade diferencial (b) e na distribuição de poros (c) da pasta de escória ativada com silicato de sódio (4NS) com 1 dia de idade. a/agl=0,48(B).

Figura 6.12 - Efeito do teor de aditivo redutor de retração (SRA) (0\%, 0,5\%, 1,0\%, 1,5\% e 2,0\%) na porosidade acumulada (a), na porosidade diferencial (b) e na distribuição de poros (c) da pasta de escória ativada com silicato de sódio (4NS) com 3 dias de idade. a/agl=0,48(B).

Figura 6.13 - Efeito do teor de aditivo redutor de retração (SRA) (0\%, 0,5\%, 1,0\%, 1,5\% e 2,0\%) na porosidade acumulada (a), na porosidade diferencial (b) e na distribuição de poros (c) da pasta de escória ativada com silicato de sódio (4NS) com 7 dias de idade. a/agl=0,48(B).

Figura 6.14 - Efeito do teor de aditivo redutor de retração (SRA) (0\%, 0,5\%, 1,0\%, 1,5\% e 2,0\%) na porosidade acumulada (a), na porosidade diferencial (b) e na distribuição de poros (c) da pasta de escória ativada com silicato de sódio (4NS) com 28 dias de idade. a/agl=0,48(B).

Figura 6.15 - Efeito do teor de aditivo redutor de retração (SRA) na evolução da porosidade total da mistura com relação a/agl igual a 0,48 até os 28 dias (a) e detalhado nas primeiras idades (b).

Figura 6.16 - Efeito do teor de aditivo redutor de retração (SRA) na evolução da proporção do volume de mesoporos em relação à porosidade total da mistura com relação a/agl igual a 0,48 até os 28 dias (a) e detalhado nas primeiras idades (b).

Figura 6.17 - Correlação entre o teor de aditivo redutor de retração (SRA) e a porosidade total (a), a proporção de macroporos (b) e de mesoporos (c) da mistura com relação a/agl igual a 0,48 . Gráficos construídos com todos os pontos obtidos.

Figura 6.18 - Influência do teor de aditivo redutor de retração (SRA) na correlação entre a quantidade de CS-H e a porosidade total da mistura com relação a/agl igual a 0,48 .

Figura 7.1 - Efeito da relação a/agl na resistência à compressão do cimento de escória (4NS)..................98

Figura 7.2 - Variação da resistência à compressão em função da relação a/agl do cimento de escória (4NS).



Figura 7.3 - Efeito da relação a/agl na resistência à tração do cimento de escória (4NS).........................99

Figura 7.4 - Variação da resistência à tração em função da relação a/agl do cimento de escória (4NS)....100 
Figura 7.5 - Efeito da relação a/agl no módulo de elasticidade do cimento de escória (4NS)......

Figura 7.6 - Variação do módulo de elasticidade em função da relação a/agl no cimento de escória (4NS).

Figura 7.7 - Correlação entre a resistência à compressão e a quantidade de C-S-H (\%).

Figura 7.8 - Correlação entre a porosidade total (a),volume de macroporos (b) e volume de mesoporos (c) com a resistência à compressão. Gráficos construídos com todos os pontos obtidos.

Figura 7.9 - Correlação o volume de macroporos (a) e o volume de mesoporos (b) com a resistência à compressão.

Figura 7.10 - Efeito do teor de aditivo SRA na resistência à compressão da argamassa de cimento de escória com relação a/agl igual a 0,40. 106

Figura 7.11 - Efeito do teor de aditivo SRA na resistência à compressão da argamassa de cimento de escória com relação a/agl igual a 0,48. 106

Figura 7.12 - Efeito do teor de aditivo SRA na resistência à compressão da argamassa de cimento de escória com relação a/agl igual a 0,56.

Figura 7.13 - Variação da resistência à compressão em função do teor de aditivo SRA na argamassa de cimento de escória com relação a/agl igual a 0,40.

Figura 7.14 - Variação da resistência à compressão em função do teor de aditivo SRA na argamassa de cimento de escória com relação a/agl igual a 0,48.

Figura 7.15 - Variação da resistência à compressão em função do teor de aditivo SRA na argamassa de cimento de escória com relação a/agl igual a 0,56. 108

Figura 7.16 - Efeito do teor de aditivo SRA e da relação água/aglomerante na resistência à compressão.111

Figura 7.17 - Efeito do teor de aditivo SRA na resistência à tração da argamassa de cimento de escória com relação a/agl igual a 0,40 .

Figura 7.18 - Variação da resistência à tração em função do teor de aditivo SRA na argamassa de cimento de escória com relação a/agl igual a 0,40.....

Figura 7.19 - Efeito do teor de aditivo SRA na resistência à tração da argamassa de cimento de escória com relação a/agl igual a 0,48 . 113

Figura 7.20 - Variação da resistência à tração em função do teor de aditivo SRA na argamassa de cimento de escória com relação a/agl igual a 0,48...... .113

Figura 7.21 - Efeito do teor de aditivo SRA na resistência à tração da argamassa de cimento de escória com relação a/agl igual a 0,56 . 114

Figura 7.22 - Variação da resistência à tração em função do teor de aditivo SRA na argamassa de cimento de escória com relação a/agl igual a 0,56 .

Figura 7.23 - Efeito da interação entre o teor de aditivo SRA e a relação água/aglomerante na resistência à tração.

Figura 7.24 - Efeito do teor de aditivo SRA no módulo de elasticidade da argamassa de cimento de escória com relação a/agl igual a 0,40 .

Figura 7.25 - Variação do módulo de elasticidade em função do teor de aditivo SRA na argamassa de cimento de escória com relação a/agl igual a 0,40.

Figura 7.26 - Efeito do teor de aditivo SRA no módulo de elasticidade da argamassa de cimento de escória com relação a/agl igual a 0,48 .

Figura 7.27 - Variação do módulo de elasticidade em função do teor de aditivo SRA na argamassa de cimento de escória com relação a/agl igual a 0,48.

Figura 7.28 - Efeito do teor de aditivo SRA no módulo de elasticidade da argamassa de cimento de escória com relação a/agl igual a 0,56 .

Figura 7.29 - Variação do módulo de elasticidade em função do teor de aditivo SRA na argamassa de cimento de escória com relação a/agl igual a 0,56.

Figura 7.30 - Efeito da interação entre o teor de aditivo SRA e a relação água/aglomerante no módulo de elasticidade. 
Figura 8.1 - Efeito da relação a/agl na retração por secagem do cimento de escória até os 28 dias de idade (4NS).

Figura 8.2 - Detalhe do efeito da relação a/agl na retração por secagem do cimento de escória até os 3 dias de idade (4NS)

Figura 8.3 - Correlação entre a retração por secagem e a relação a/agl. Gráficos construídos com todos os pontos obtidos nas idades ensaiadas.

Figura 8.4 - Efeito da relação a/agl na variação de massa por evaporação do cimento de escória até os 28 dias de idade.

Figura 8.5 - Correlação entre a variação de massa por secagem e a relação a/agl. Gráficos construídos com todos os pontos obtidos nas idades ensaiadas.

Figura 8.6 - Correlação entre a retração por secagem e perda de massa por evaporação da argamassa de cimento de escória ativada com silicato de sódio com relação a/agl igual a 0,40.

Figura 8.7 - Correlação entre a retração por secagem e perda de massa por evaporação da argamassa de cimento de escória ativada com silicato de sódio com relação a/agl igual a 0,48. 129

Figura 8.8 - Correlação entre a retração por secagem e perda de massa por evaporação da argamassa de cimento de escória ativada com silicato de sódio com relação a/agl igual a 0,56. 130

Figura 8.9 - Correlação da retração por secagem com a porosidade total (a) e com índice de refinamento (volume de mesoporos/volume de macroporos) (b). Gráficos construídos com todos os pontos obtidos....131

Figura 8.10 - Correlação da retração por secagem com o volume de macroporos (a) e com o volume de mesoporos (b). 132

Figura 8.11 - Correlação da variação de massa por secagem com o volume de mesoporos. 133

Figura 8.12 - Efeito da relação a/agl na retração autógena do cimento de escória até os 28 dias de idade. 134

Figura 8.13 - Detalhe do efeito da relação a/agl na retração autógena do cimento de escória até os 3 dias de idade.

Figura 8.14 - Correlação entre a retração autógena e a relação a/agl. Gráficos construídos com todos os

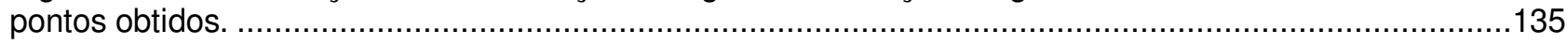

Figura 8.15 - Correlação entre a retração autógena e a quantidade de C-S-H (\%)...................................136

Figura 8.16 - Correlação da retração autógena com o volume de macroporos (a) e com o volume de mesoporos (b)..... 137

Figura 8.17 - Efeito do teor de aditivo redutor de retração (SRA) na retração por secagem do cimento de escória até os 28 dias de idade. $\mathrm{a} / \mathrm{agl}=0,48$. 138

Figura 8.18 - Detalhe do efeito do teor de aditivo redutor de retração (SRA) na retração por secagem do cimento de escória até os 3 dias de idade. a/agl = 0,48... 138

Figura 8.19 - Efeito do teor de aditivo redutor de retração (SRA) na retração por secagem do cimento de escória ativada. Gráficos construídos com todos os pontos obtidos. a/agl = 0,48. 139

Figura 8.20 - Efeito do teor de aditivo redutor de retração (SRA) na variação de massa por evaporação do cimento de escória até os 28 dias de idade. a/agl $=0,48$.

Figura 8.21 - Efeito do teor de aditivo redutor de retração (SRA) na variação de massa por evaporação do cimento de escória ativada. Gráficos construídos com todos os pontos obtidos. a/agl =0,48.

Figura 8.22 - Correlação entre a retração por secagem e perda de massa por evaporação da argamassa de cimento de escória ativada com silicato de sódio com relação a/agl igual a 0,48.

Figura 8.23 - Correlação entre a retração por secagem e perda de massa por evaporação da argamassa de cimento de escória ativada com silicato de sódio com relação a/agl igual a 0,48 e utilizando 0,5\% de aditivo redutor de retração (SRA). 143

Figura 8.24 - Correlação entre a retração por secagem e perda de massa por evaporação da argamassa de cimento de escória ativada com silicato de sódio com relação a/agl igual a 0,48 e utilizando $1 \%$ de aditivo redutor de retração (SRA). 
Figura 8.25 - Correlação entre a retração por secagem e perda de massa por evaporação da argamassa de cimento de escória ativada com silicato de sódio com relação a/agl igual a 0,48 e utilizando 1,5\% de aditivo redutor de retração (SRA).

Figura 8.26 - Correlação entre a retração por secagem e perda de massa por evaporação da argamassa de cimento de escória ativada com silicato de sódio com relação a/agl igual a 0,48 e utilizando $2 \%$ de aditivo redutor de retração (SRA).....

Figura 8.27 - Efeito do teor de aditivo redutor de retração (SRA) na retração autógena do cimento de escória até os 28 dias de idade. a/agl $=0,48$. 145

Figura 8.28 - Detalhe do efeito do teor de aditivo redutor de retração (SRA) na retração autógena do cimento de escória até os 3 dias de idade. a/agl =0,48.

Figura 8.29 - Efeito do teor de aditivo redutor de retração (SRA) na retração autógena do cimento de escória ativada. Gráficos construídos com todos os pontos obtidos. a/agl = 0,48.

Figura 8.30 - Influência do teor de aditivo redutor de retração (SRA) na correlação entre a retração autógena e o volume de mesoporos da mistura com relação a/agl igual a 0,48.

Figura 9.1 - Difratogramas da pasta utilizando apenas o aditivo compensador de retração (SCA) a 6 e 12 horas, $1,3,7$ e 28 dias de idade. Teor de $\mathrm{SCA}=100 \%$. água/aditivo $=0,56$.

Figura 9.2 - Evolução da hidratação do aditivo compensador de retração (SCA), quantificada pela variação da intensidade do pico principal de sulfoaluminato de cálcio (a), da anidrita (b), do óxido de cálcio (c) e da portlandita $(\mathrm{d})$ até os 28 dias de idade. água/aditivo $=0,56$. Teor de SCA $=100 \%$.

Figura 9.3 - Efeito do teor de aditivo compensador de retração (SCA) na difração de raios X com 6 horas de idade. $\mathrm{a} / \mathrm{agl}=0,40$. 158

Figura 9.4 - Efeito do teor de aditivo compensador de retração (SCA) na difração de raios X com 12 horas de idade. $\mathrm{a} / \mathrm{agl}=0,40$. 158

Figura 9.5 - Efeito do teor de aditivo compensador de retração (SCA) na difração de raios X com 1 dia de idade. $\mathrm{a} / \mathrm{agl}=0,40$. 158

Figura 9.6 - Efeito do teor de aditivo compensador de retração (SCA) na difração de raios X com 3 dias de idade. $\mathrm{a} / \mathrm{agl}=0,40$. 159

Figura 9.7 - Efeito do teor de aditivo compensador de retração (SCA) na difração de raios X com 7 dias de idade. $\mathrm{a} / \mathrm{agl}=0,40$.

Figura 9.8 - Efeito do teor de aditivo compensador de retração (SCA) na difração de raios X com 28 dias de idade. $\mathrm{a} / \mathrm{agl}=0,40$. 159

Figura 9.9 - Evolução da intensidade do pico principal do C-S-H no ângulo ${ }^{\circ} 2 \Theta=29,36$ na pasta de cimento de escória ativada com silicato de sódio com relação a/agl = 0,40 (4NSA0). 160

Figura 9.10 - Efeito do teor de aditivo compensador de retração (SCA) na evolução da intensidade do pico principal do C-S-H no ângulo ${ }^{\circ} 2 \Theta=29,36$ e nos picos principais do sulfoaluminato de cálcio no ângulo ${ }^{\circ} 2 \Theta=23,66$ e da anidrita no ângulo ${ }^{\circ} 2 \Theta=25,44$, na mistura de cimento de escória ativada com relação a/agl = 0,40 (4NSA5). Teor de SCA = 5\%.

Figura 9.11 - Efeito do teor de aditivo compensador de retração (SCA) na evolução da intensidade do pico principal do C-S-H no ângulo ${ }^{\circ} 2 \Theta=29,36$ e nos picos principais do sulfoaluminato de cálcio no ângulo ${ }^{\circ} 2 \Theta=23,66$ e da anidrita no ângulo ${ }^{\circ} 2 \Theta=25,44$, na mistura de cimento de escória ativada com relação a/agl = 0,40 (4NSA10). Teor de SCA $=10 \%$

Figura 9.12 - Efeito do teor de aditivo compensador de retração (SCA) na evolução da intensidade do pico principal do C-S-H no ângulo ${ }^{\circ} 2 \Theta=29,36$ e nos picos principais do sulfoaluminato de cálcio no ângulo ${ }^{\circ} 2 \Theta=23,66$ e da anidrita no ângulo ${ }^{\circ} 2 \Theta=25,44$, na mistura de cimento de escória ativada com relação a/agl = 0,40 (4NSA15). Teor de SCA $=15 \%$

Figura 9.13 - Efeito do teor de aditivo compensador de retração (SCA) na intensidade do pico principal de C-S-H determinado no ensaio de difração de raios $X$ até os 28 dias de idade. a/agl $=0,40$ 163

Figura 9.14 - Detalhamento do efeito do teor de aditivo compensador de retração (SCA) na intensidade do pico principal de C-S-H determinado no ensaio de difração de raios $X$ nas primeiras idades. a/agl = 0,40.163 Figura 9.15 - Evolução da intensidade do pico principal do C-S-H no ângulo ${ }^{\circ} 2 \Theta=29,36(d(\AA)=3,040)$ na pasta de cimento de escória ativada com silicato de sódio com relação a/agl = 0,48 (4NSBO)...... 
Figura 9.16 - Efeito do teor de aditivo compensador de retração (SCA) na evolução da intensidade do pico principal do C-S-H no ângulo ${ }^{\circ} 2 \Theta=29,36$ e nos picos principais do sulfoaluminato de cálcio no ângulo ${ }^{\circ} 2 \Theta=23,66$ e da anidrita no ângulo ${ }^{\circ} 2 \Theta=25,44$ na mistura de cimento de escória ativada com relação a/agl = 0,48 (4NSB5). Teor de SCA $=5 \%$. 164

Figura 9.17 - Efeito do teor de aditivo compensador de retração (SCA) na evolução da intensidade do pico principal do C-S-H no ângulo ${ }^{\circ} 2 \Theta=29,36$ e nos picos principais do sulfoaluminato de cálcio no ângulo ${ }^{\circ} 2 \Theta=23,66$ e da anidrita no ângulo ${ }^{\circ} 2 \Theta=25,44$ na mistura de cimento de escória ativada com relação a/agl = 0,48 (4NSB10). Teor de SCA $=10 \%$.

Figura 9.18 - Efeito do teor de aditivo compensador de retração (SCA) na evolução da intensidade do pico principal do C-S-H no ângulo ${ }^{\circ} 2 \Theta=29,36$ e nos picos principais do sulfoaluminato de cálcio no ângulo ${ }^{\circ} 2 \Theta=23,66$ e da anidrita no ângulo ${ }^{\circ} 2 \Theta=25,44$ na mistura de cimento de escória ativada com relação a/agl $=$ 0,48 (4NSB15). Teor de SCA $=15 \%$.

Figura 9.19 - Efeito do teor de aditivo compensador de retração (SCA) na intensidade do pico principal de C-S-H determinado no ensaio de difração de raios $X$ até os 28 dias de idade. $\mathrm{a} / \mathrm{agl}=0,48 \ldots$ .166

Figura 9.20 - Detalhamento do efeito do teor de aditivo compensador de retração (SCA) na intensidade do pico principal de C-S-H determinado no ensaio de difração de raios $X$ nas primeiras idades. a/agl = 0,48.166

Figura 9.21 - Evolução da intensidade do pico principal do C-S-H no ângulo ${ }^{\circ} 2 \Theta=29,36(d(\AA)=3,040)$ na pasta de cimento de escória ativada com silicato de sódio com relação a/agl = 0,56 (4NSC0). 167

Figura 9.22 - Efeito do teor de aditivo compensador de retração (SCA) na evolução da intensidade do pico principal do C-S-H no ângulo ${ }^{\circ} 2 \Theta=29,36$ e nos picos principais do sulfoaluminato de cálcio no ângulo ${ }^{\circ} 2 \Theta=23,66$ e da anidrita no ângulo ${ }^{\circ} 2 \Theta=25,44$ na mistura de cimento de escória ativada com relação a/agl $=$ 0,56 (4NSC5). Teor de SCA $=5 \%$.

Figura 9.23 - Efeito do teor de aditivo compensador de retração (SCA) na evolução da intensidade do pico principal do C-S-H no ângulo ${ }^{\circ} 2 \Theta=29,36$ e nos picos principais do sulfoaluminato de cálcio no ângulo ${ }^{\circ} 2 \Theta=23,66$ e da anidrita no ângulo ${ }^{\circ} 2 \Theta=25,44$ na mistura de cimento de escória ativada com relação a/agl $=$ 0,56 (4NSC10). Teor de SCA $=10 \%$.

Figura 9.24 - Efeito do teor de aditivo compensador de retração (SCA) na evolução da intensidade do pico principal do C-S-H no ângulo ${ }^{\circ} 2 \Theta=29,36$ e nos picos principais do sulfoaluminato de cálcio no ângulo ${ }^{\circ} \Theta=23,66$ e da anidrita no ângulo ${ }^{\circ} 2 \Theta=25,44$ na mistura de cimento de escória ativada com relação a/agl = 0,56 (4NSC15). Teor de SCA $=15 \%$.

Figura 9.25 - Efeito do teor de aditivo compensador de retração (SCA) na intensidade do pico principal de C-S-H determinado no ensaio de difração de raios $X$ até os 28 dias de idade. $a / a g l=0,56 \ldots$ 169

Figura 10.1 - Perda de massa (TG/\%) e derivada da curva de perda de massa (DTG) da pasta utilizando apenas o aditivo compensador de retração (SCAC) a 6 e 12 horas, 1,3,7 e 28 dias de idade. a/agl= 0,56. Teor de SCA $=100 \%$.

Figura 10.2 - Efeito da relação a/agl na quantidade de etringita (AFt) e monossulfoaluminato (AFm) entre $30^{\circ}$ e $195^{\circ} \mathrm{C}$ determinadas no ensaio de termogravimetria até os 28 dias de idade (a) e detalhada até os 3 dias de idade (b).

Figura 10.3 - Efeito da relação a/agl na quantidade de monossulfoaluminato (AFm) entre $195^{\circ} \mathrm{C}$ e $360^{\circ} \mathrm{C}$ determinada no ensaio de termogravimetria até os 28 dias de idade (a) e detalhada até os 3 dias de idade (b).

Figura 10.4 - Perda de massa (TG/\%) e derivada da curva de perda de massa (DTG) da pasta de cimento de escória ativada com silicato de sódio (4NSC15) a 6 e 12 horas, 1,3,7 e 28 dias de idade. a/agl= 0,56. Teor de SCA $=15 \%$

Figura 10.5 - Efeito do teor de aditivo compensador de retração (SCA) na quantidade de C-S-H determinado no ensaio de termogravimetria até os 28 dias (a) com a respectiva redução percentual, detalhado até os 3 dias de idade (b). a/agl $=0,40$. 176

Figura 10.6 - Efeito do teor de aditivo compensador de retração (SCA) na quantidade de C-S-H determinado no ensaio de termogravimetria até os 28 dias (a) com a respectiva redução percentual, detalhado até os 3 dias de idade (b). $\mathrm{a} / \mathrm{agl}=0,48$.

Figura 10.7 - Efeito do teor de aditivo compensador de retração (SCA) na quantidade de C-S-H determinado no ensaio de termogravimetria até os 28 dias (a) com a respectiva redução percentual, detalhado até os 3 dias de idade (b). a/agl = 0,56. 
Figura 10.8 - Correlação entre o teor de aditivo compensador de retração (SCA) e quantidade de C-S-H (\%) nas misturas com relação a/agl igual a 0,40 (a), 0,48 (b) e 0,56 (c). Gráfico construído com todos os pontos obtidos.

Figura 11.1 - Efeito do teor de aditivo compensador de retração (SCA) $(0 \%, 0,5 \%, 1,0 \%, 1,5 \%$ e 2,0\%) na porosidade acumulada (a), na porosidade diferencial (b) e na distribuição de poros (c) da pasta de escória ativada com silicato de sódio (4NS) com 1 dia de idade. a/agl=0,48(B).

Figura 11.2 - Efeito do teor de aditivo compensador de retração (SCA) (0\%, 0,5\%, 1,0\%, 1,5\% e 2,0\%) na porosidade acumulada (a), na porosidade diferencial (b) e na distribuição de poros (c) da pasta de escória ativada com silicato de sódio (4NS) com 3 dias de idade. a/agl=0,48(B).

Figura 11.3 - Efeito do teor de aditivo compensador de retração (SCA) (0\%, 0,5\%, 1,0\%, 1,5\% e 2,0\%) na porosidade acumulada (a), na porosidade diferencial (b) e na distribuição de poros (c) da pasta de escória ativada com silicato de sódio (4NS) com 7 dias de idade. a/agl=0,48(B).

Figura 11.4 - Efeito do teor de aditivo compensador de retração (SCA) (0\%, 0,5\%, 1,0\%, 1,5\% e 2,0\%) na porosidade acumulada (a), na porosidade diferencial (b) e na distribuição de poros (c) da pasta de escória ativada com silicato de sódio (4NS) com 28 dias de idade. a/agl = 0,48(B).....

Figura 11.5 - Efeito do teor de aditivo compensador de retração (SCA) na evolução da porosidade total (a) e na proporção do volume de mesoporos em relação à porosidade total (b) da mistura com relação a/agl igual a 0,48 até os 28 dias. 182

Figura 11.6 - Correlação entre o teor de aditivo compensador de retração (SCA) e a porosidade total (a), a proporção de macroporos (b) e de mesoporos (c) da mistura com relação a/agl igual a 0,48. Gráficos construídos com todos os pontos obtidos.

Figura 12.1 - Efeito do teor de aditivo SCA na resistência à compressão da argamassa de cimento de escória com relação a/agl igual a 0,40.

Figura 12.2 - Efeito do teor de aditivo SCA na resistência à compressão da argamassa de cimento de escória com relação a/agl igual a 0,48. 186

Figura 12.3 - Efeito do teor de aditivo SCA na resistência à compressão da argamassa de cimento de escória com relação a/agl igual a 0,56. 186

Figura 12.4 - Variação da resistência à compressão em função do teor de aditivo SCA na argamassa de cimento de escória com relação a/agl igual a 0,40.

Figura 12.5 - Variação da resistência à compressão em função do teor de aditivo SCA na argamassa de cimento de escória com relação a/agl igual a 0,48.

Figura 12.6 - Variação da resistência à compressão em função do teor de aditivo SCA na argamassa de cimento de escória com relação a/agl igual a 0,56.

Figura 12.7 - Efeito do teor de aditivo SCA e da relação água/aglomerante na resistência à compressão. 190

Figura 12.8 - Efeito do teor de aditivo SCA na resistência à tração da argamassa de cimento de escória com relação água/aglomerante igual a 0,40.

Figura 12.9 - Variação da resistência à tração em função do teor de aditivo SCA na argamassa de cimento de escória com relação água/aglomerante igual a 0,40 .

Figura 12.10 - Efeito do teor de aditivo SCA na resistência à tração da argamassa de cimento de escória com relação água/aglomerante igual a 0,48.

Figura 12.11 - Variação da resistência à tração em função do teor de aditivo SCA na argamassa de cimento de escória com relação água/aglomerante igual a 0,48.

Figura 12.12 - Efeito do teor de aditivo SCA na resistência à tração da argamassa de cimento de escória com relação água/aglomerante igual a 0,56.

Figura 12.13 - Variação da resistência à tração em função do teor de aditivo SCA na argamassa de cimento de escória com relação água/aglomerante igual a 0,56.

Figura 12.14 - Efeito do teor de aditivo SCA e da relação água/aglomerante na resistência à tração.

Figura 12.15 - Efeito do teor de aditivo SCA no módulo de elasticidade da argamassa de cimento de escória com relação água/aglomerante igual a 0,40 .

Figura 12.16 - Variação do módulo de elasticidade em função do teor de aditivo SCA na argamassa de cimento de escória com relação água/aglomerante igual a 0,40...... 
Figura 12.17 - Efeito do teor de aditivo SCA no módulo de elasticidade da argamassa de cimento de escória com relação água/aglomerante igual a 0,48 .

Figura 12.18 - Variação do módulo de elasticidade em função do teor de aditivo SCA na argamassa de cimento de escória com relação água/aglomerante igual a 0,48.

Figura 12.19 - Efeito do teor de aditivo SCA no módulo de elasticidade da argamassa de cimento de escória com relação água/aglomerante igual a 0,56. 198

Figura 12.20 - Variação do módulo de elasticidade em função do teor de aditivo SCA na argamassa de cimento de escória com relação água/aglomerante igual a 0,56.

Figura 12.21 - Efeito da interação entre o teor de aditivo SCA e a relação água/aglomerante no módulo de elasticidade...... 199

Figura 13.1 - Efeito do teor de aditivo compensador de retração (SCA) na retração por secagem das argamassas de cimento de escória ativada com relação a/agl igual 0,40 (a), 0,48 (b) e 0,56 (c)..... 203

Figura 13.2 - Efeito da interação entre o teor de aditivo SCA e a relação água/aglomerante na retração por secagem. 204

Figura 13.3 - Efeito do teor de aditivo compensador de retração (SCA) na retração por secagem das argamassas de cimento de escória ativada com relação a/agl igual 0,40, 0,48 e 0,56. Gráficos construídos com todos os pontos obtidos. 205

Figura 13.4 - Efeito do teor de aditivo compensador de retração (SCA) na variação de massa por evaporação das argamassas de cimento de escória ativada com relação a/agl igual 0,40 (a), 0,48 (b) e 0,56 (c). 208

Figura 13.5 - Efeito do teor de aditivo compensador de retração (SCA) na variação de massa por evaporação das argamassas de cimento de escória ativada com relação a/agl igual 0,40 (a), 0,48 (b) e 0,56 (c). Gráficos construídos com todos os pontos obtidos.

Figura 13.6 - Correlação entre a retração por secagem e a perda de massa por evaporação da argamassa de cimento de escória ativada com silicato de sódio com relação a/agl igual a 0,40. 210

Figura 13.7 - Correlação entre a retração por secagem e a perda de massa por evaporação da argamassa de cimento de escória ativada com silicato de sódio com relação a/agl igual a 0,40 e utilizando $5 \%$ de aditivo compensador de retração (SCA). 210

Figura 13.8 - Correlação entre a retração por secagem e a perda de massa por evaporação da argamassa de cimento de escória ativada com silicato de sódio com relação a/agl igual a 0,40 e utilizando 10\% de aditivo compensador de retração (SCA).

Figura 13.9 - Correlação entre a retração por secagem e a perda de massa por evaporação da argamassa de cimento de escória ativada com silicato de sódio com relação a/agl igual a 0,40 e utilizando 15\% de aditivo compensador de retração (SCA).

Figura 13.10 - Correlação entre a retração por secagem e a perda de massa por evaporação da argamassa de cimento de escória ativada com silicato de sódio com relação a/agl igual a 0,48. .212

Figura 13.11 - Correlação entre a retração por secagem e a perda de massa por evaporação da argamassa de cimento de escória ativada com silicato de sódio com relação a/agl igual a 0,48 e utilizando $5 \%$ de aditivo compensador de retração (SCA). 212

Figura 13.12 - Correlação entre a retração por secagem e a perda de massa por evaporação da argamassa de cimento de escória ativada com silicato de sódio com relação a/agl igual a 0,48 e utilizando 10\% de aditivo compensador de retração (SCA). 212

Figura 13.13 - Correlação entre a retração por secagem e a perda de massa por evaporação da argamassa de cimento de escória ativada com silicato de sódio com relação a/agl igual a 0,48 e utilizando 15\% de aditivo compensador de retração (SCA). 213

Figura 13.14 - Correlação entre a retração por secagem e a perda de massa por evaporação da argamassa de cimento de escória ativada com silicato de sódio com relação a/agl igual a 0,56.

Figura 13.15 - Correlação entre a retração por secagem e a perda de massa por evaporação da argamassa de cimento de escória ativada com silicato de sódio com relação a/agl igual a 0,56 e utilizando $5 \%$ de aditivo compensador de retração (SCA).

Figura 13.16 - Correlação entre a retração por secagem e a perda de massa por evaporação da argamassa de cimento de escória ativada com silicato de sódio com relação a/agl igual a 0,56 e utilizando 10\% de aditivo compensador de retração (SCA). 
Figura 13.17 - Correlação entre a retração por secagem e a perda de massa por evaporação da argamassa de cimento de escória ativada com silicato de sódio com relação a/agl igual a 0,56 e utilizando $15 \%$ de aditivo compensador de retração (SCA)

Figura 13.18 - Efeito do teor de aditivo compensador de retração (SCA) na retração autógena das argamassas de cimento de escória ativada com relação a/agl igual 0,40 (a), 0,48 (b) e 0,56 (c)..............216

Figura 13.19 - Efeito do teor de aditivo compensador de retração (SCA) na retração autógena das argamassas de cimento de escória ativada com relação a/agl igual 0,40, 0,48 e 0,56. Gráficos construídos com todos os pontos obtidos.

Figura 13.20 - Efeito do teor de aditivo compensador de retração (SCA) na taxa de retração autógena das argamassas de cimento de escória ativada com relação a/agl igual 0,40 (a), 0,48 (b) e 0,56 (c)..... 


\section{Lista de tabelas}

Tabela 2.1 - Deformações no concreto em função do tipo de exposição e condições de carregamento. ......19

Tabela 2.2 - Influência da tensão superficial no fenômeno da retração (BENTZ, 2005)...............................37



Tabela 3.2 - Arranjo fatorial elaborado apenas para análise e dimensionamento do projeto experimental....44

Tabela 3.3 - Arranjo experimental dos ensaios mecânicos. ......................................................................45

Tabela 3.4 - Arranjo experimental dos ensaios de termogravimetria.......................................................46

Tabela 3.5 - Arranjo experimental dos ensaios de difração de raios X (DRX) ............................................47



Tabela 3.7 - Características físicas e químicas da escória de alto forno. ..................................................49

Tabela 3.8 - Características físicas e químicas do aditivo compensador de retração (SCA)......................51

Tabela 3.9 - Composição química do silicato de sódio (determinado pelo IPT) e do hidróxido de sódio



Tabela 3.10 - Características físicas e distribuição granulométrica da areia quartzosa. .............................53

Tabela 3.11 - Composição química do silicato de sódio (IPT) após o ajuste do módulo de sílica (MS) (\% em



Tabela 6.1 - Análise da evolução do volume de vazios na pasta de cimento de escória aos 28 dias. ..........89

Tabela 7.1 - Médias aritméticas da resistência à compressão e o efeito da relação a/agl no cimento de



Tabela 7.2 - Médias aritméticas da resistência à tração e o efeito da relação a/agl no cimento de escória ativada (4NS). CV = coeficiente de variação em \%. 100

Tabela 7.3 - Médias aritméticas do módulo de elasticidade e o efeito da relação a/agl no cimento de escória ativada. $\mathrm{CV}=$ coeficiente de variação em \%..... 102

Tabela 7.4 - Médias aritméticas da resistência à compressão e o efeito do teor de aditivo redutor de retração (SRA) no cimento de escória ativada com relação a/agl igual a $\mathbf{0 , 4 0}$. CV = coeficiente de variação em \%.

Tabela 7.5 - Médias aritméticas da resistência à compressão e o efeito do teor de aditivo redutor de retração (SRA) no cimento de escória ativada com relação a/agl igual a $\mathbf{0 , 4 8}$. CV = coeficiente de variação em \%.

Tabela 7.6 - Médias aritméticas da resistência à compressão e o efeito do teor de aditivo redutor de retração (SRA) no cimento de escória ativada com relação a/agl igual a $\mathbf{0 , 5 6}$. CV = coeficiente de variação em \%. 110

Tabela 7.7 - Médias aritméticas da resistência à tração na flexão e o efeito do teor de aditivo redutor de retração (SRA) no cimento de escória ativada com relação a/agl igual a $\mathbf{0 , 4 0}$. CV = coeficiente de variação em \%.

Tabela 7.8 - Médias aritméticas da resistência à tração na flexão e o efeito do teor de aditivo redutor de retração (SRA) no cimento de escória ativada com relação a/agl igual a $\mathbf{0 , 4 8}$. $\mathrm{CV}=$ coeficiente de variação em \%. 114

Tabela 7.9 - Médias aritméticas da resistência à tração na flexão e o efeito do teor de aditivo redutor de retração (SRA) no cimento de escória ativada com relação a/agl igual a $\mathbf{0 , 5 6}$. $\mathrm{CV}=$ coeficiente de variação em \%.

Tabela 7.10 - Médias aritméticas do módulo de elasticidade e o efeito do teor de aditivo redutor de retração (SRA) no cimento de escória ativada com relação a/agl igual a $\mathbf{0 , 4 0}$. CV = coeficiente de variação em \%.118

Tabela 7.11 - Médias aritméticas do módulo de elasticidade e o efeito do teor de aditivo redutor de retração (SRA) no cimento de escória ativada com relação a/agl igual a $\mathbf{0 , 4 8}$. CV = coeficiente de variação em \%.119 
Tabela 7.12 - Médias aritméticas do módulo de elasticidade e o efeito do teor de aditivo redutor de retração (SRA) no cimento de escória ativada com relação a/agl igual a $\mathbf{0 , 5 6}$. CV = coeficiente de variação em $\% .120$

Tabela 8.1 - Médias aritméticas da retração por secagem e o efeito da relação a/agl no cimento de escória ativada. CV = coeficiente de variação em \%....

Tabela 8.2 - Médias aritméticas da variação de massa na secagem e o efeito da relação a/agl no cimento de escória ativada. CV = coeficiente de variação em \%.

Tabela 8.3 - Médias aritméticas da retração autógena e o efeito da relação a/agl no cimento de escória ativada. CV = coeficiente de variação em \%.....

Tabela 8.4 - Médias aritméticas da retração por secagem e o efeito do teor de aditivo redutor de retração (SRA) no cimento de escória ativada com relação a/agl igual a $\mathbf{0 , 4 8}$. CV = coeficiente de variação em \%. 140

Tabela 8.5 - Médias aritméticas da variação de massa na secagem e o efeito do teor de aditivo redutor de retração (SRA) no cimento de escória ativada com relação a/agl igual a $\mathbf{0 , 4 8}$. CV = coeficiente de variação em \%.

Tabela 8.6 - Médias aritméticas da retração autógena e o efeito do teor de aditivo redutor de retração (SRA) no cimento de escória ativada com relação a/agl igual a $\mathbf{0 , 4 8}$. CV = coeficiente de variação em \%.

Tabela 12.1 - Médias aritméticas da resistência à compressão e o efeito do teor de aditivo compensador de retração (SCA) no cimento de escória ativada com relação a/agl igual a $\mathbf{0 , 4 0}$. CV = coeficiente de variação em \%.

Tabela 12.2 - Médias aritméticas da resistência à compressão e o efeito do teor de aditivo compensador de retração (SCA) no cimento de escória ativada com relação a/agl igual a $\mathbf{0 , 4 8}$. CV = coeficiente de variação em \%. 189

Tabela 12.3 - Médias aritméticas da resistência à compressão e o efeito do teor de aditivo compensador de retração (SCA) no cimento de escória ativada com relação a/agl igual a $\mathbf{0 , 5 6}$. CV = coeficiente de variação em \%.

Tabela 12.4 - Médias aritméticas da resistência à tração na flexão e o efeito do teor de aditivo compensador de retração (SCA) no cimento de escória ativada com relação a/agl igual a $\mathbf{0 , 4 0}$. $\mathrm{CV}=$ coeficiente de variação em \%. 192

Tabela 12.5 - Médias aritméticas da resistência à tração na flexão e o efeito do teor de aditivo compensador de retração (SCA) no cimento de escória ativada com relação a/agl igual a $\mathbf{0 , 4 8}$. CV = coeficiente de variação em \%. 193

Tabela 12.6 - Médias aritméticas da resistência à tração na flexão e o efeito do teor de aditivo compensador de retração (SCA) no cimento de escória ativada com relação a/agl igual a $\mathbf{0 , 5 6}$. CV = coeficiente de variação em \%.

Tabela 12.7 - Médias aritméticas do módulo de elasticidade e o efeito do teor de aditivo compensador de retração (SCA) no cimento de escória ativada com relação a/agl igual a $\mathbf{0 , 4 0}$. CV = coeficiente de variação em \%.

Tabela 12.8 - Médias aritméticas do módulo de elasticidade e o efeito do teor de aditivo compensador de retração (SCA) no cimento de escória ativada com relação a/agl igual a $\mathbf{0 , 4 8}$. CV = coeficiente de variação em \%. 198

Tabela 12.9 - Médias aritméticas do módulo de elasticidade e o efeito do teor de aditivo compensador de retração (SCA) no cimento de escória ativada com relação a/agl igual a $\mathbf{0 , 5 6}$. CV = coeficiente de variação em \%. 199

Tabela 13.1 - Médias aritméticas da retração por secagem e o efeito do teor de aditivo compensador de retração (SCA) no cimento de escória ativada com relação a/agl igual a $\mathbf{0 , 4 0}$. CV = coeficiente de variação em \%. 206

Tabela 13.2 - Médias aritméticas da retração por secagem e o efeito do teor de aditivo compensador de retração (SCA) no cimento de escória ativada com relação a/agl igual a $\mathbf{0 , 4 8}$. CV = coeficiente de variação em \%. 206

Tabela 13.3 - Médias aritméticas da retração por secagem e o efeito do teor de aditivo compensador de retração (SCA) no cimento de escória ativada com relação a/agl igual a 0,56. CV = coeficiente de variação em \%. 
Tabela 13.4 - Médias aritméticas da retração autógena e o efeito do teor de aditivo compensador de retração (SCA) no cimento de escória ativada com relação a/agl igual a $\mathbf{0 , 4 0}$. CV = coeficiente de variação em \%.

Tabela 13.5 - Médias aritméticas da retração autógena e o efeito do teor de aditivo compensador de retração (SCA) no cimento de escória ativada com relação a/agl igual a $\mathbf{0 , 4 8}$. CV = coeficiente de variação em \%. 218

Tabela 13.6 - Médias aritméticas da retração autógena e o efeito do teor de aditivo compensador de retração (SCA) no cimento de escória ativada com relação a/agl igual a $\mathbf{0 , 5 6}$. CV = coeficiente de variação em \%.

Tabela 14.1 - Quadro resumo da influência da relação água/aglomerante no cimento de escória. 228

Tabela 14.2 - Quadro resumo da influência do teor de aditivo SRA no cimento de escória. .233

Tabela 14.3 - Quadro resumo da influência do teor de aditivo SCA no cimento de escória. .238 


\title{
INFLUÊNCIA DE ADITIVOS REDUTORES E COMPENSADORES DE RETRAÇÃO EM ARGAMASSAS E PASTAS COM CIMENTO DE ESCÓRIA ATIVADA ${ }^{1}$
}

\author{
Antonio Acacio de Melo Neto
}

\section{Resumo}

O objetivo desta tese foi o estudo da influência do aditivo redutor de retração (SRA) e o aditivo compensador de retração (SCA) em argamassas e pastas de cimento de escória ativada com silicato de sódio. A metodologia foi centrada na análise da retração por secagem e autógena, com o estudo de outras características que influenciam no fenômeno da retração, como as propriedades mecânicas. Para o avanço no conhecimento do efeito dos aditivos no comportamento do cimento de escória, foi caracterizada a microestrutura com a determinação da análise por termogravimetria, porosimetria e difração de raios $X$. Neste estudo foram empregados os seguintes teores de aditivo, porcentagem relativa à massa de aglomerante: $0,5 \%, 1 \%, 1,5 \%$ e $2 \%$ do aditivo SRA e 5\%, $10 \%$ e $15 \%$ do aditivo SCA. Para a análise da influência da relação a/agl foram empregadas três teores: 0,40, 0,48 e 0,56.

No estudo das amostras de referência, sem a utilização de aditivo, observou-se que o aumento da relação a/agl causa o aumento da retração por secagem e da retração autógena do cimento de escória ativada. A diminuição da resistência mecânica com o aumento da relação a/agl, o que torna o esqueleto sólido mais susceptível à deformações, e o aumento das tensões capilares, em razão do aumento da quantidade de água livre para ser evaporada, são os principais fatores para o aumento da retração por secagem. No caso da retração autógena, seu aumento é atribuído ao aumento da auto-secagem com o aumento do volume de poros com diâmetro na faixa de mesoporos, além da diminuição da resistência mecânica.

O aditivo redutor de retração (SRA) conseguiu reduzir a retração por secagem em percentuais de $40 \%$ até $74 \%$ aos 28 dias, no entanto, este tipo de aditivo não obteve êxito no combate a retração autógena. Com relação à resistência mecânica, o aditivo SRA causou a redução de até $40 \%$, efeito atribuído à diminuição do grau de hidratação e retardo do refinamento da porosidade. O aditivo compensador de retração (SCA) amenizou a retração por secagem e a retração autógena, reduzindo em até $64 \%$ e $70 \%$, respectivamente, porém reduziu em até $60 \%$ a resistência mecânica do cimento de escória ativada. Com relação à microestrutura, o aditivo SCA diminuiu o grau de hidratação e aumentou a porosidade total, com o aumento da proporção do volume de macroporos.

Palavras-chave: aditivo redutor de retração (SRA); aditivo compensador de retração (SCA); escória de alto forno; ativação alcalina, microestrutura.

\footnotetext{
${ }^{1}$ MELO NETO, A.A. Influência de aditivos redutores e compensadores de retração em argamassas e pastas com cimento de escória ativada. 2007. 253p. Tese (doutorado) - Escola Politécnica, Universidade de São Paulo.
} 
EFFECT OF SHRINKAGE COMPENSATING AND REDUCING ADMIXTURES IN ALKALI ACTIVATED SLAG MORTARS AND PASTES ${ }^{2}$

\author{
Antonio Acacio de Melo Neto
}

\title{
Abstract
}

The aim of this research was the study of the influence of shrinkage reducing admixture (SRA) and shrinkage compensating admixture (SCA) in mortars and pastes of blast furnace slag activated with sodium silicate. The method was centered in the analysis of free drying and autogenous shrinkage, with other characteristics that affect the shrinkage, as the mechanical properties. The microstructure behavior was accomplished with thermogravimetry (TG), mercury intrusion porosimetry (MIP) and X-ray diffraction (XRD). The samples were prepared with $0,5 \%, 1 \%, 1,5 \%$ and $2 \%$ of SRA admixture and $5 \%, 10 \%$ and $15 \%$ of SCA admixture, by binder mass. The effect of water/binder ratio was accomplished in three contents: $0,40,0,48$ and 0,56 .

In the reference mixtures, without admixtures, it was observed that an increase of water/binder ratio incurs in an increase of drying and autogenous shrinkage of alkali activated slag. The explanations for drying shrinkage behavior are the decrease of mechanical strength as consequence of water/binder increase, that turns the porous structure more susceptible to deformations, and the increase of the capillary tensions, attributed to the increase of free water to be evaporated. The increase of autogenous shrinkage with water/binder ratio is attributed to the increase of pore volume with diameter in the mesopores range, besides the decrease of the mechanical strength.

The shrinkage reducing admixture (SRA) diminish drying shrinkage of $40 \%$ up to $74 \%$ at 28 days, however, this type of admixture was not capable to combat the autogenous shrinkage. About mechanical strength, the SRA admixture incurs in a decrease up to $40 \%$ of compression strength that it was attributed to the decrease of the hydration degree and retard of pore size refinement. The shrinkage compensating admixture (SCA) softened drying and autogenous shrinkage, reducing in up to $64 \%$ and $70 \%$, respectively. However, the SCA admixture decreases in up to $60 \%$ mechanical strength of alkali activated slag. About microstructure, SCA admixture reduced the hydration degree and it increased the total porosity, with the increase of macropores volume.

Keywords: Shrinkage reducing admixture (SRA); shrinkage compensating admixture (SCA); blast furnace slag; alkali activated, microstructure.

\footnotetext{
2 MELO NETO, A.A. Effect of shrinkage compensating and reducing admixtures in alkali activated slag mortars and pastes. 2007. 253p. Ph.D Thesis - Polytechnic School - University of São Paulo.
} 


\section{Parte 1 \\ Introdução, revisão}

bibliográfica e metodologia 


\section{Capítulo 1 Introdução}

\subsection{Contexto e justificativas}

Este trabalho está inserido na linha de pesquisa do Departamento de Construção Civil-PCC da Escola Politécnica da Universidade de São Paulo, que enfoca o reaproveitamento de resíduos na Construção Civil. O resíduo estudado é a escória granulada de alto-forno, subproduto da Indústria Siderúrgica, visando sua aplicação como um cimento hidráulico. Nesta etapa, aborda-se o fenômeno da retração e a utilização de aditivos para combatê-la.

O concreto é considerado o principal material de construção dos países industrializados, em grande parte, conseqüência do seu relativo baixo custo, boa disponibilidade e capacidade de se adequar às mais diversas situações e aplicações. Apesar do seu uso consagrado, o concreto é um material complexo, do ponto de vista científico, e também em termos de qualidade, pois muitas vezes seu desempenho final depende de fatores inerentes à sua natureza, como a utilização de cura adequada. Um dos principais e mais antigos problemas do concreto é a fissuração, pois além provocar danos estéticos, pode induzir a formação de pontos propensos a falhas estruturais com o surgimento de tensões, ou a formação de canais para ingresso de agentes agressivos que reduzem a durabilidade (LURA et al., 2007).

O avanço na tecnologia do concreto caminha para estruturas mais esbeltas e de alta resistência. Esta tendência é acompanhada pelo aumento da preocupação com a fissuração, nos últimos 20 anos, principalmente com o avanço na utilização de concretos de alto desempenho (CAD). Este tipo de concreto é caracterizado pela utilização de relações água/aglomerante baixas e, apesar de apresentar pontos positivos relativos à durabilidade, como elevada resistência e baixa permeabilidade, pode desenvolver elevada retração autógena em razão da auto-secagem ao longo do tempo (CUSSON; REPETTE, 2000). De modo geral, os principais fatores para o 
surgimento de tensões em estruturas de concreto são as deformações térmicas, a retração autógena e por secagem, que ocorrem sob condições restringidas, e a ação de cargas externas. Caso algum destes fatores provoque determinada tensão e esta seja superior à tensão de tração do concreto, a fissuração poderá ocorrer e resultar em prejuízos para a estrutura.

O mesmo problema é observado em sistemas que utilizam outros aglomerantes hidráulicos, como os cimentos de escória. A expressão cimento de escória identifica cimento de escória sem clínquer (JOHN, 1995); neste caso, é necessária a utilização de espécies químicas para a "ativação" da escória, permitindo o desenvolvimento das propriedades aglomerantes. $\mathrm{O}$ desenvolvimento de um aglomerante alternativo ao clínquer baseado na ativação da escória de alto forno tem se apresentado como uma alternativa viável para atender requisitos de desempenho em aplicações específicas, ou mesmo substituir o cimento Portland em aplicações já usuais. Com esta finalidade, estudos foram e estão sendo realizados para o aproveitamento da escória de alto forno como aglomerante sem a utilização de clínquer (JOHN, 1995; MELO NETO, 2002; OLIVEIRA, 2000; SILVA, 1998).

O cimento de escória ativada com silicato de sódio se assemelha ao cimento de alta resistência inicial, porém com maior tendência à fissuração (MELO NETO, 2002). No desenvolvimento do cimento de escória pela Escola Politécnica da Universidade de São Paulo, a retração era a característica que necessitava de um maior enfoque, pois sua magnitude elevada é freqüentemente citada como um fator limitante ao seu uso, principalmente quando do uso do silicato de sódio como ativador. Com o objetivo de avançar no conhecimento do fenômeno da retração neste tipo de cimento, foi caracterizado o comportamento da retração do cimento de escória ativada com diferentes tipos e teores de ativadores, como o hidróxido de sódio, o hidróxido de cálcio e o silicato de sódio (MELO NETO, 2002). Com base nos resultados obtidos e nos objetivos futuros para aplicação do material em situações específicas, como a utilização em pré-moldados, pisos industriais, reparo rápido de estruturas, entre outras, optou-se pela continuação do desenvolvimento do cimento de escória ativado com silicato de sódio. 
No quadro atual, além da necessidade de preenchimento de algumas lacunas no conhecimento sobre o cimento de escória ativada, o mesmo padece de iniciativas para o suporte da sua aplicação na indústria da construção civil. No que diz respeito ao avanço no conhecimento do cimento de escória ativada com silicato de sódio, a melhor compreensão do fenômeno da retração observada no estudo anterior (MELO NETO, 2002) indicou a necessidade da utilização de novos meios para combatê-la. Para amenizar a retração, além da utilização de soluções na tecnologia de emprego do material, como a otimização da dosagem e utilização de armaduras, é possível a utilização de meios que intervenham nas propriedades do material cimentício, como alterações na composição do aglomerante utilizado, emprego de fibras, emprego de aditivos químicos ou de adições minerais. Não obstante este fato, alterações nas propriedades do material podem incorrer em alterações na tecnologia construtiva.

Portanto, com o intuito de combater a retração do cimento de escória ativada com silicato de sódio foram selecionados meios cujo funcionamento interferem diretamente na alteração das propriedades do material em si. A utilização da tecnologia de aditivos está consolidada no desenvolvimento e aplicação de materiais construtivos; no entanto, o uso de aditivos específicos para o combate da retração é relativamente recente. Atualmente, os dois tipos principais de aditivos com este propósito são os aditivos compensadores de retração (SCA, do inglês "shrinkage compensating admixture") e os aditivos redutores de retração (SRA, do inglês "shrinkage reducing admixture"). A aplicação destes tipos de aditivos no Brasil, mesmo em cimentos tradicionais, é muito restrita e são poucos os trabalhos publicados que relatem a sua utilização (SILVA; PITTA, 2000), sendo necessários estudos para o avanço do conhecimento. A aplicação destes aditivos no cimento de escória ativada no meio científico internacional é recente e com poucos trabalhos publicados (COLLINS; SANJAYAN, 2000a; BAKHAREV et al., 2000; PALACIOS; PUERTAS, 2005, 2007).

A escória granulada de alto forno é o resíduo proveniente da produção de ferro gusa, largamente utilizada como adição ao cimento Portland. De acordo com o Instituto Brasileiro de Siderurgia - IBS, a produção anual de ferro gusa aumentou significativamente, de $35 \%$ nos últimos 5 anos, alcançando em torno de 34 milhões 
de toneladas em 2005 (Figura 1.1). Com esses dados, estima-se que a quantidade de escória de alto forno gerada no processo de produção do ferro gusa esteja em torno de 10 milhões de toneladas.



Figura 1.1 - Evolução da produção anual de ferro gusa e da estimativa de escória de alto forno (Estima-se que 1 tonelada de ferro gusa resulta em $300 \mathrm{Kg}$ de escória granulada de alto-forno). Fonte: Instituto Brasileiro de Siderurgia - IBS

Atualmente, o principal uso da escória de alto forno é na substituição parcial do clínquer, trazendo benefícios no que diz respeito à redução do custo do produto, do consumo de energia e da quantidade de escória armazenada. Carvalho (2002) estudou o impacto ambiental da produção do cimento no Brasil e verificou que a adição de escória incorre em menor impacto ambiental e menor consumo de energia elétrica. No Brasil, são produzidos atualmente 2 tipos principais de cimento que utilizam a escória de alto forno como substituição parcial do clínquer: cimento Portland composto com adição de escória de alto forno (CPIIE) - no qual é permitida a substituição em massa de até 34\% do clínquer pela escória e o Cimento Portland de alto forno (CPIII) no qual se pode substituir até $70 \%$ do clínquer pela escória.

Com base na evolução da produção total de cimento Portland é possível afirmar que existe a tendência para os próximos anos de recuperação da produção para o patamar de 40 milhões de toneladas de cimento por ano, assim como o aumento da produção do cimento CPIII (Figura 1.2). Conseqüentemente, este fato acarretará o aumento da utilização da escória de alto forno. No ano de 2000 , cerca de $80 \%$ da produção nacional era de cimento CPII (Tipos E, F e Z) e 7\% de cimento CPIII. 
Porém, com a crescente geração de escória e utilização da mesma pela indústria de cimento, no ano de 2005, a produção de cimento CPII (Tipos E, F e Z) diminuiu para cerca de $68 \%$ da produção nacional e a produção de cimento CPIII aumentou para cerca de $18 \%$ da produção nacional (Fonte: Sindicato Nacional da Indústria do Cimento - SNIC).



Figura 1.2 - Evolução da produção anual de cimento Portland, de cimento Portland comum com adição (CP II) e de cimento Portland de alto-forno (CP III). Fonte: Sindicato Nacional da Indústria do Cimento - SNIC.

A análise da disponibilidade de escória em 1996 indicou que a indústria brasileira de cimento utilizava aproximadamente $50 \%$ do volume disponível e que o excedente acarreta custos elevados de disposição e estocagem para a indústria siderúrgica (SILVA et al., 1996). Analisando o panorama atual da disponibilidade de escória é provável que este percentual tenha aumentado nos últimos 5 anos. O consumo de escória pode ser estimado se algumas considerações forem admitidas. Primeiro, que todo cimento CPIII produzido tenha utilizado o percentual máximo permitido $(70 \%)$ de substituição do clínquer por escória. Segundo, que todo cimento CPIIE produzido tenha utilizado o percentual máximo permitido (34\%) de substituição do clínquer por escória. Terceiro, conjeturando que na região sudeste a maior parte do cimento comercializado seja o tipo CPIIE, em razão da concentração do parque siderúrgico nacional na mesma, e que a região sudeste é responsável por em torno de $50 \%$ da produção nacional do cimento CPII (Sindicato Nacional da Indústria do Cimento SNIC), estima-se que aproximadamente $30 \%$ da produção nacional de CPII seja do tipo CPIIE. 
Porém, esta análise está superestimada, pois é improvável que o cimento CPIII produzido tenha utilizado $70 \%$ de substituição de clínquer, em razão da diminuição das propriedades mecânicas ocasionada pela adição da escória. No entanto, mesmo com o panorama superestimado do consumo de escória, observa-se a existência de um volume disponível da mesma em torno de 3 milhões de toneladas (Figura 1.3).



Figura 1.3 - Estimativa da produção anual de escória de alto forno e do consumo anual pela indústria do cimento realizada com base nos dados do IBS e do SNIC.

\subsection{Objetivo}

O objetivo desta tese é analisar e compreender a interação do aditivo compensador de retração (SCA) e do aditivo redutor de retração (SRA) no cimento de escória ativada com silicato de sódio, de modo a amenizar a elevada retração deste tipo de cimento. Para atingir este objetivo são utilizadas medidas diretas da retração e determinações do desenvolvimento da microestrutura com os aditivos citados. A Figura 1.4 apresenta o desenho esquemático da estratégia elaborada para a realização do estudo. 




Figura 1.4 - Representação esquemática da estratégia de abordagem do tema

\subsection{Estrutura do trabalho}

O trabalho foi dividido em Parte 1, 2, 3 e 4. Na Parte 1 são expostos conhecimentos introdutórios ao tema, sendo o mesmo dividido em: Capítulo 1 - Introdução - no qual a tese tem seu embasamento contextualizado e justificado; capítulo 2 - Revisão bibliográfica - no qual são abordados os mecanismos e tipos de retração, o cimento 
de escória ativada, o aditivo compensador de retração (SCA) e o aditivo redutor de retração (SRA); Capítulo 3 - Programa experimental - no qual são descritos o planejamento experimental, materiais empregados e procedimentos utilizados nos ensaios.

As Partes 2 e 3 estão centradas na utilização do aditivo redutor de retração (SRA) e do aditivo compensador de retração (SCA), respectivamente. São apresentados os resultados da evolução das propriedades mecânicas e da retração em argamassas e os resultados do desenvolvimento da microestrutura em pasta com 0 acompanhamento por ensaios de termogravimetria, difração de raios $\mathrm{X}$, porosimetria por intrusão de mercúrio e calorimetria.

A Parte 4 é constituída das conclusões obtidas com o desenvolvimento da tese, assim como das propostas para o prosseguimento do estudo do tema. Em seguida são apresentadas as referências bibliográficas utilizadas neste estudo. No final do trabalho, encontram-se os apêndices com os resultados obtidos nos ensaios e o desenvolvimento do equipamento de retração restringida. 


\section{Capítulo 2 \\ Revisão bibliográfica}

\subsection{Introdução}

Neste capítulo são apresentados os conceitos sobre os aditivos compensadores de retração (SCA), os aditivos redutores de retração (SRA) e sobre os métodos para a determinação da retração. Os conceitos sobre o fenômeno da retração e sobre o cimento de escória ativada foram expostos de forma sucinta, pois trabalhos anteriores já contribuíram no desenvolvimento dos mesmos e são citados no decorrer deste capítulo.

\subsection{Retração em materiais cimentícios}

Freqüentemente, as deformações em razão da retração são discutidas no âmbito de uma escala reduzida, enfatizando a ação dos mecanismos em termos de variação de tensão superficial na estrutura porosa e da relação com o diâmetro do poro. Com isto, a análise do estado de tensões ocasionado pela retração é muitas vezes explorada segundo uma abordagem de microescala. Porém, também é necessária a análise do fenômeno da retração em uma abordagem mais ampla, onde seja possível a análise dos mecanismos de microescala da retração no comportamento do estado de tensões em uma magnitude maior.

A fissuração em concretos está freqüentemente associada a problemas de durabilidade a longo prazo; no entanto, a fissuração está cada vez mais se tornando um problema já nas primeiras idades. Este fato está relacionado ao desenvolvimento de concretos cada vez mais resistentes nas primeiras idades (denominados concretos de alto desempenho - CAD), os quais trouxeram não apenas benefícios nas propriedades mecânicas quando comparados a concretos normais, mas com grande avanço na melhoria da durabilidade frente à ação de agentes agressivos (PIGEON et al., 2000). Porém, o aumento da utilização de concretos de alto 
desempenho revelou a sua susceptibilidade à fissuração nas primeiras horas ou dias, após o final da moldagem. Esta característica motiva também a necessidade de estudo mais amplo sobre características antes consideradas não tão importantes, como a retração autógena. Diferentemente do observado nos concretos convencionais, este tipo de concreto freqüentemente apresenta tendência à fissuração nas primeiras idades e sem que haja exposição ao ambiente, ou seja, dentro das fôrmas ou sob cura úmida (CUSSON; REPETTE, 2007).

\subsubsection{Variáveis envolvidas na fissuração}

Os mecanismos envolvidos no fenômeno da fissuração são complexos por envolverem variáveis que têm comportamento e fatores dinâmicos. É consensual que a fissuração está correlacionada à deformação em razão da variação de umidade nos poros da pasta de cimento endurecida e com o estado de tensões ao qual o material está submetido. A discussão dos mecanismos associados à variação de umidade está relatada em publicações recentes (HUA et al., 1995; BASTOS, 2000; MELO NETO, 2002; LURA, 2003), portanto, apenas definições básicas são apresentadas para o melhor entendimento do texto.

\subsubsection{Estado da água}

De forma resumida, pode-se dizer que a água em sistemas cimentícios está presente em duas formas: água não evaporável (quimicamente combinada) e água evaporável (POWERS, 1968; TAYLOR, 1997). O cimento Portland completamente hidratado tem cerca de $22 \%$ de sua massa de cimento anidro composta de água quimicamente combinada (POWERS, 1968), a qual só pode ser totalmente removida com aplicação de temperaturas acima de $100{ }^{\circ} \mathrm{C}$. A água evaporável é formada pela soma da água adsorvida e a água capilar (livre). A água adsorvida é formada em razão da força de atração molecular e permanece fisicamente retida na superfície dos produtos sólidos do aglomerante, sendo o seu teor dependente da umidade relativa do sistema poroso que constitui a matriz cimentícia. Com a queda da umidade relativa ocorre a diminuição da espessura da camada de água adsorvida à superfície sólida, atingindo uma espessura de 2,76 ̊̊ em 20\% de umidade relativa (KOENDERS, 1997) (Figura 2.1). A água adsorvida só pode ser removida, sem 
aplicação de elevação de temperatura, em umidades relativas abaixo de $11 \%$, sendo esta denominada de água interlamelar, pois ocupa espaços entre as camadas internas da estrutura do C-S-H (TAYLOR, 1997). A água livre está presente nos grandes poros capilares e, como será descrito posteriormente, sua remoção não apresenta grandes implicações na variação de volume.



Figura 2.1 - Variação da espessura da camada de água adsorvida com a variação da umidade (KOENDERS, 1997)

\subsubsection{Tensão superficial}

A tensão superficial é a força resultante do desequilíbrio das ligações intermoleculares na interface sólido-líquido ou líquido-líquido na superfície dos materiais, decorrente de cargas não neutralizadas presentes na interface. Resumidamente, a retração ou expansão pode ser resultante da variação na tensão superficial das partículas sólidas de gel (LURA, 2003): quando há aumento da adsorção de água ocorre a redução da tensão superficial e a expansão; contrariamente, a remoção da água adsorvida resulta em retração. A tensão superficial está correlacionada a outros mecanismos de retração, podendo até mesmo ser definida como o fenômeno básico da variação dimensional. No caso específico dos materiais cimentícios, a grande área específica resultante da formação dos produtos hidratados incorre na formação de inúmeras interfaces sólido-líquido nos meniscos formados (Figura 2.2). Com a diminuição da umidade relativa aumenta a tensão superficial na interface sólido - líquido em cada um dos meniscos, que resulta em uma retração macroscópica significativa do material. 


\subsubsection{Tensão capilar}

De acordo com Young (1988), os poros na matriz cimentícia são classificados em poros de gel, relacionados à estrutura interna do C-S-H e com diâmetro na faixa de microporos $(\varnothing<2 n m)$, e em poros capilares, relacionados aos vazios intergranulares (BUIL; OLLIVIER, 1992), com diâmetro na faixa de mesoporos $(2<\varnothing<50 \mathrm{~nm})$ e macroporos $(\varnothing>50 \mathrm{~nm})$. A tensão capilar é resultante de variações no menisco arágua formado em poros capilares parcialmente preenchidos, principalmente na faixa de mesoporos. O menisco é resultante da variação da umidade interna da matriz cimentícia, seja em razão da perda de umidade para o ambiente ou para as reações de hidratação. A diminuição do raio do menisco provocará um aumento da pressão capilar e, conseqüentemente, da força de atração entre as partículas, manifestada pela retração do material (WITTMANN, 1982; YOUNG, 1988; BASTOS, 2001).



Figura 2.2 - Representação esquemática da adsorção da água em um capilar de pasta de cimento (BAZANT, 1972).

\subsubsection{Pressão de separação ou de desligamento}

De modo geral, o fenômeno da pressão de separação está presente no poro juntamente com a pressão capilar do menisco, porém em superfícies sólidas muito mais próximas do que no menisco (Figura 2.2). A pressão de separação é a tensão normal localizada nas camadas adsorvidas entre as duas superfícies formadas pelo estreitamento do poro, que impede assim uma aproximação maior entre as mesmas (XI; JENNINGS, 1989, HUA et al., 1995; MELO NETO, 2002). 


\subsubsection{Deformações em materiais cimentícios}

De modo geral, existe uma tendência mundial para enfatizar pesquisas que detalhem o comportamento de retração e fluência nas primeiras idades de concretos, embasadas em conceitos relacionados à análise de tensões. O concreto pode sofrer deformações ao longo de sua vida útil, sendo este fenômeno causado pela aplicação de carregamento e pela variação volumétrica. Pode-se afirmar, que no estado livre, ou seja, com grau de restrição igual a zero e sem algum tipo de ação de força externa, o concreto poderá deformar sem incorrer em tensões com magnitude que lhe cause algum dano, como fissuras. Sabe-se que, mesmo nestas condições, o volume de agregados oferecerá uma restrição às deformações que venham a ocorrer no concreto, gerando tensões. Porém, a situação mais crítica é quando o concreto se encontra no estado restringido, como em vigas, pisos e colunas. Neste caso, as deformações citadas anteriormente podem causar o surgimento de tensões internas no concreto, provocando diversos problemas de durabilidade (MOKAREM, 2002). O resumo dos fatores intervenientes na fissuração dos concretos é apresentado na Figura 2.3 (FOLLIARD et al., 2003).



Figura 2.3 - Fatores intervenientes na fissuração em concretos (FOLLIARD et al., 2003).

A restrição pode ter origem externa, como o atrito com uma base e o confinamento entre outros elementos estruturais, e origem interna, como a armadura de reforço, gradientes de deformação entre a camada interna e externa do concreto e até 
mesmo a restrição causada pelos agregados (PERSSON, 1998; HOSSAIN, 2003; LURA, 2003). Portanto, no estado livre as deformações podem ser ditas "deformações independentes de carregamento", usualmente determinadas em ensaios de retração por secagem, retração autógena e de dilatação térmica. No estado restringido, as deformações podem ser ditas "deformações dependentes de carregamento", sendo usualmente determinadas em ensaios de fluência e retração restringida.

A principal deformação independente de carregamento em materiais cimentícios ocorre em razão da variação dimensional com a exposição ao ambiente, comumente denominada de retração. Existem quatro tipos principais de retração: plástica, autógena, por secagem e por carbonatação. A retração plástica ocorre no estado fresco pela evaporação rápida da água de amassamento, através da superfície exposta da mistura cimentícia, resultando em fissuração superficial. A retração autógena ocorre sem perda de umidade da mistura cimentícia para o meio ambiente, resultante da retração química mais o efeito físico da auto-secagem (TAZAWA et al., 2000).

A retração química é a redução de volume em conseqüência da reação química entre os compostos do cimento e a água, onde o volume do produto da reação é menor do que o volume inicial dos materiais reagentes utilizados (CHEN; BROUWERS, 2007). Este fenômeno provoca uma retração inerente do produto da reação. A auto-secagem ocorre com o consumo da água dos capilares em razão do prosseguimento das reações de hidratação resultando na retração do material. A retração por carbonatação ocorre em razão da diminuição de volume causada pela reação de produtos hidratados com o dióxido de carbono presente no meio ambiente e é, geralmente, limitada à superfície do componente.

A retração por secagem acontece depois do fim da pega do cimento e ocorre devido à redução dimensional causada pela variação da tensão capilar, da pressão de desligamento e da variação da tensão superficial com a evaporação da água de poro da mistura cimentícia para o ambiente. A retração por secagem pode ser considerada a retração total, pois a sua evolução ocorre concomitantemente à 
evolução da retração plástica e autógena. Outra característica da retração por secagem é o fato de maior parte de sua magnitude total ocorrer na primeira secagem e ter caráter irreversível (MINDESS; YOUNG, 1981). Após a primeira secagem, parte da retração pode apresentar caráter reversível, pois com a molhagem ocorre uma recuperação parcial da deformação ocorrida com a secagem (MEHTA; MONTEIRO, 1994). No entanto, a magnitude da retração reversível não é capaz de provocar o retorno à dimensão original (Figura 2.4). Porém, a definição da parcela irreversível e reversível da retração por secagem pode ser utilizada como uma vantagem na utilização de práticas para a melhoria da estabilidade dimensional após a primeira secagem, como, por exemplo, em peças de concreto pré-fabricado (MINDESS; YOUNG, 1981).



Figura 2.4 - Comportamento típico do concreto submetido à secagem e molhagem (MINDESS; YOUNG, 1981).

De modo geral, com a aplicação de tensão ao concreto ocorrem deformações elásticas instantâneas reversíveis e, ao longo do tempo, as deformações inelásticas lentas denominadas de fluência (MOKAREM, 2002). A fluência é a principal deformação dependente de carregamento em materiais cimentícios. Assim como a retração por secagem, a fluência também é causada pela perda ou movimentação da água presente no concreto, porém, a forma com que a água é perdida difere significativamente entre os dois fenômenos. O principal mecanismo do fenômeno da retração por secagem é a perda de água em razão da evaporação, enquanto a fluência é resultante da aplicação de tensão ao concreto (FOLLIARD et al., 2003). Apesar de complexo, é consensual que o fenômeno da fluência tem como origem a resposta de natureza viscoelástica da estrutura formada pelo $\mathrm{C}-\mathrm{S}-\mathrm{H}$ quando 
submetida a tensões (MINDESS; YOUNG, 1981; MEHTA; MONTEIRO, 1994; KANGVANPANICH, 2002). Semelhante à retração, a fluência também pode apresentar parte de sua magnitude total com características reversíveis, no entanto, diferentemente da retração, a recuperação da deformação é causada pela retirada da tensão de carregamento (Figura 2.5).



Figura 2.5 - Comportamento típico do concreto submetido a carregamento e descarregamento (MINDESS; YOUNG, 1981).

Outra característica da fluência acontece na situação clássica de fissuração do concreto (Figura 2.6). Nesta situação, a restrição da retração induz ao surgimento de tensões no concreto, propiciando também o surgimento da fluência no mesmo, a qual permite que o concreto escoe em pequenas deformações e acabe por promover o fenômeno denominado "relaxação" do concreto. Resumidamente, a fluência pode reduzir as tensões causadas pela restrição da retração e retardar a fissuração do concreto conforme observado na Figura 2.6.



Figura 2.6 - Interação entre a fluência e a retração na fissuração do concreto (MEHTA; MONTEIRO, 1994). 
As definições e nomenclatura sugeridas por Neville (1981) são comumente utilizadas para a descrição e classificação do fenômeno da fluência. A fluência básica é definida como a deformação dependente de carregamento que ocorre quando o concreto é submetido à carga na condição selada, ou seja, sem perda de umidade para o ambiente (Figura 2.7 (c)). Quando o concreto é simultaneamente submetido a carregamento e exposto ao ambiente, observa-se que a fluência total é maior do que a fluência básica (Figura 2.7 (d)) (KOVLER, 1999). Para explicar este excesso da fluência sob secagem comparada à fluência básica, Pickett (1942) apud Kovler (1999) introduziu o conceito de fluência por secagem ${ }^{3}$.

Em outras palavras, a fluência por secagem expressa a incongruência da deformação total dependente de carregamento não ser igual à soma da deformação resultante da parcela separada da deformação resultante da retração livre e da deformação resultante da fluência básica (Figura 2.7 (b) e (d)) (YOUNG, 1988; KOVLER, 1999)). Percebe-se que são feitas afirmações sobre a soma (ou decomposição) de deformações seguindo o princípio de que os fenômenos são aditivos. Este princípio é freqüentemente criticado, pois não apresenta um quadro realístico, no qual os fenômenos podem ocorrer simultaneamente e interagir entre si (KOVLER, 1999; BENBOUDJEMA, 2002).

Portanto, a fluência total seria a soma da fluência básica mais a fluência por secagem (Figura 2.7 (d)). Nos ensaios experimentais é freqüente a não distinção entre a fluência básica e a fluência por secagem (YOUNG, 1988), sendo a fluência igual à diferença entre a deformação obtida em 2 corpos-de-prova idênticos sujeitos às mesmas condições de temperatura e umidade, sendo 1 corpo-de-prova submetido a carregamento e o outro livre de carregamentos (ATRUSHI, 2003).

\footnotetext{
${ }^{3}$ Algumas vezes também denominada internacionalmente como "Pickett effect", primeiro pesquisador a reportar o fenômeno (YOUNG, 1988)
} 




(a) Retração de um elemento não carregado



(c) Fluência de um elemento carregado em equilíbrio higroscópico com o meio



(b) Variação da deformação em elemento carregado e submetido a secagem



(d) Variação da deformação de um elemento carregado e submetido a secagem

Figura 2.7 - Deformações dependentes de carregamento ao longo do tempo em concreto submetido à carga, sendo $T_{0}$ a idade na qual o concreto foi carregado (NEVILLE, 1981).

Com a finalidade de estabelecer definições sobre as deformações no concreto, pode-se adotar parâmetros para a sua análise: tipo de exposição ao ambiente e condições de carregamento. As condições de exposição podem ser: exposto ao ambiente ou selado (sem perda de umidade para o ambiente), ambos os casos com temperatura do ambiente controlada. Quanto às condições de carregamento: sem carregamento (sem aplicação de cargas externas e sem tensões restringidas) ou com carregamento (oriundas de cargas externas e tensões restringidas).

Inicialmente, consideramos que o concreto está selado e sem carregamento. Nestas condições, a deformação total é a soma da deformação resultante da retração autógena e da variação de temperatura em razão do calor de hidratação (Tabela 2.1, Equação 1). Com a exposição ao ambiente, soma-se a deformação resultante da retração por secagem (Tabela 2.1, Equação 2). Considerando o concreto selado e com carregamento, a Equação 1 é adicionada pela deformação resultante da fluência básica e a deformação elástica (Tabela 2.1, Equação 3). Com a exposição ao ambiente, soma-se a deformação resultante da fluência por secagem (Tabela 2.1, Equação 4). 
Tabela 2.1 - Deformações no concreto em função do tipo de exposição e condições de carregamento.

\begin{tabular}{|c|c|c|}
\hline Nomenclatura & Deformações & \\
\hline$\varepsilon_{\text {Total }}$ & Deformação total & \\
\hline$\varepsilon_{\mathrm{RA}}$ & Retração autógena & \\
\hline$\varepsilon_{\mathrm{DT}}$ & Variação de temperatura & \\
\hline$\varepsilon_{\mathrm{RS}}$ & Retração por secagem & \\
\hline$\varepsilon_{\mathrm{EL}}$ & Deformação elástica resultante do carregamento & \\
\hline$\varepsilon_{\mathrm{FB}}$ & Fluência básica & \\
\hline$\varepsilon_{\mathrm{FS}}$ & Fluência por secagem & \\
\hline Condições & Equação & \\
\hline Selado e sem carregamento & $\varepsilon_{\text {Total }}=\varepsilon_{\mathrm{RA}}+\varepsilon_{\mathrm{DT}}$ & Equação 1 \\
\hline Exposto e sem carregamento & $\varepsilon_{\text {Total }}=\varepsilon_{\mathrm{RS}}+\varepsilon_{\mathrm{RA}}+\varepsilon_{\mathrm{DT}}$ & Equação 2 \\
\hline Selado e com carregamento & $\varepsilon_{\text {Total }}=\varepsilon_{\mathrm{EL}}+\varepsilon_{\mathrm{FB}}+\varepsilon_{\mathrm{RA}}+\varepsilon_{\mathrm{DT}}$ & Equação 3 \\
\hline Exposto e com carregamento & $\varepsilon_{\text {Total }}=\varepsilon_{\mathrm{FS}}+\varepsilon_{\mathrm{EL}}+\varepsilon_{\mathrm{FB}}+\varepsilon_{\mathrm{RA}}+\varepsilon_{\mathrm{RS}}+\varepsilon_{\mathrm{DT}}$ & Equação 4 \\
\hline
\end{tabular}

\subsection{Cimento de escória ativada com silicato de sódio}

Trabalhos precedentes (TALLING; BRANDSTETR, 1989; GLUKHOVSKY, 1994; KRIVENKO, 1994; JOHN, 1995; WANG, 1995; SILVA, 1998; OLIVEIRA, 2000; MELO NETO, 2002) apresentam revisão bibliográfica recente sobre este tema. Para o melhor entendimento, alguns pontos básicos referentes ao cimento de escória ativada com silicato de sódio são apresentados a seguir.

O potencial aglomerante da escória de alto forno é bastante conhecido e pode-se dizer que os ativadores mais antigos são o cimento Portland, hidróxido de cálcio e o sulfato de cálcio. A ativação da escória com álcalis é conhecida desde 1940, em trabalho realizado por Purdon (1940), na Bélgica, que utilizou escórias com composições variadas ativadas com hidróxido de sódio. A ativação com silicato de sódio teve início em Kiev na ex-União Soviética, onde a ativação com silicato de sódio não só foi estudada, mas também houve experiências na produção e operação de estruturas de concreto (GLUKHOVSKY et al.,1980).

Como uma definição geral, o cimento de escória pode ser descrito como o aglomerante composto de escória e um ou mais ativadores, que são espécies químicas capazes de propiciar e acelerar as reações de hidratação. A maior parte dos estudos para o desenvolvimento do cimento de escória ativada utiliza escória de 
alto forno básica ${ }^{4}$, em razão das suas características químicas e mineralógicas propiciarem maior potencial aglomerante (JOHN, 1995). Outra definição mais específica para a ativação da escória com álcalis é descrita por Wang et al. (1995), na qual o cimento de escória ativada com álcalis (do inglês "alkali-activated slag cement”) é composto por escória moída e uma espécie química alcalina. Usualmente, as espécies químicas podem ser hidróxidos alcalinos $(\mathrm{ROH})$, sais não silicosos $\left(\mathrm{R}_{2} \mathrm{CO}_{3}, \mathrm{R}_{2} \mathrm{~S}, \mathrm{RF}\right)$ ou sais silicosos do tipo $\mathrm{R}_{2} \mathrm{O} \cdot(\mathrm{n}) \mathrm{SiO}_{2}$, onde $\mathrm{R}$ é um metal alcalino, $\mathrm{Na}, \mathrm{K}$ ou Li.

\subsubsection{Hidratação}

A cinética da hidratação e a natureza dos produtos hidratados do cimento de escória são similares aos já conhecidos no cimento Portland, portanto, algumas considerações sobre o comportamento do cimento de escória são corroboradas com base na natureza do comportamento do cimento Portland. Mas, existem algumas diferenças claras entre as características de ambos os cimentos, expostas ao longo desta discussão.

A hidratação da escória ocorre por dissolução e precipitação nas primeiras idades, no entanto, a dissolução da escória apenas em água é dificultada pela formação de uma película deficiente em $\mathrm{Ca}^{2+}$ que inibe o avanço da hidratação (VOINOVITCH et al.,1980), sendo necessário o ataque hidroxílico (ataque pelos íons $\mathrm{OH}^{-}$) para permitir a dissolução dessa película e, conseqüentemente, o avanço da hidratação. Analisando em paralelo ao cimento Portland, a dissolução do clínquer ocorre, resumidamente, pela dissolução por ataque hidrolítico (ação das moléculas de água) e a alcalinidade mantida pelo hidróxido de cálcio e álcalis liberados.

Nos últimos anos, a necessidade de propiciar um meio adequado à hidratação da escória motivaram os estudos sobre o cimento de escória preferencialmente por ativação da escória com álcalis, em razão de sua capacidade de elevar o $\mathrm{pH}$ do meio. $\mathrm{O}$ pH é determinante para a evolução satisfatória da cinética da reação de

\footnotetext{
${ }^{4} \mathrm{~A}$ escória é dita básica quando apresenta uma relação $\mathrm{CaO} / \mathrm{SiO}_{2}$ superior a 1 , caso contrário, a escória é dita ácida.
} 
hidratação da escória, sendo necessária a sua elevação para um valor maior do que 12,6 (VOINOVITCH et al.,1980). Assim como no cimento Portland, o silicato de cálcio hidratado C-S-H é o principal produto hidratado do cimento de escória ativada com silicato de sódio; outro produto hidratado é a hidrotalcita ${ }^{5}$ (MELO NETO, 2002; ROY, 1999; ROY et al., 2000).

No entanto, algumas características diferem a natureza dos produtos hidratados dos dois tipos de cimento. Com relação à estequiometria: o C-S-H formado no cimento de escória ativada apresenta relação $\mathrm{Ca} / \mathrm{Si}$ entre 1 e 1,2, enquanto no cimento Portland esta relação tem valor entre 1,5 e 1,8 (TAYLOR, 1990; WANG et al., 1995); ocorre também a incorporação de álcalis (oriundos do ativador e da dissolução da própria escória) no C-S-H (BROUGH; ATKINSON, 2002; RICHARDSON; CABRERA, 2000). Com relação à morfologia do C-S-H: o cimento de escória ativada apresenta morfologia descrita como sendo de textura lisa e granular (HÄKKINEN, 1992) ou folicular, ao contrário do cimento Portland que apresenta C-S-H com morfologia fibrilar (RICHARDSON; CABRERA, 2000).

Algumas considerações gerais sobre a hidratação do cimento de escória ativada com silicato de sódio são importantes para fundamentar a sua análise. Apesar de ter como principal produto o C-S-H, assim como cimento Portland, a ausência significativa de outros produtos hidratados, faz com que, de forma geral, a natureza do cimento de escória seja diferente quando comparada ao cimento Portland (MELO NETO, 2002). Pode-se afirmar que cimento de escória ativada com silicato de sódio é formado quase que em sua totalidade por C-S-H (MELO NETO, 2002) fortemente ligados à hidrotalcita (BROUGH; ATKINSON, 2002), enquanto o cimento Portland apresenta quantidades significativas de outros produtos hidratados, como 0 hidróxido de cálcio, etringita, monossulfoaluminato de cálcio hidratado e hidrogranada. Como descrito por Melo Neto (2002), esta característica influencia significativamente as propriedades do cimento de escória ativada.

\footnotetext{
${ }^{5}$ A hidrotalcita propriamente dita é um mineral natural com fórmula igual a $\mathrm{Mg}_{6} \mathrm{Al}_{2} \mathrm{CO}_{3}(\mathrm{OH})_{16} \bullet 4 \mathrm{H}_{2} \mathrm{O}$ e tem estrutura baseada em camadas de brucita intercaladas por moléculas de água e íons de $\mathrm{CO}_{3}{ }^{-2}$ (WANG; SCRIVENER, 1995).
} 
Chen e Brouwers (2007) pesquisaram a aplicação e adaptação de resultados experimentais do cimento de escória ativada determinados por outros autores em alguns modelos de reação, com o objetivo de estimar a quantidade de produtos hidratados, a retração química e a porosidade. Os autores confirmam os resultados de termogravimetria obtidos por Melo Neto (2002), sendo constatada a predominância quase que total do C-S-H como produto hidratado do cimento de escória ativada: $92 \%$ de C-S-H, $6 \%$ de hidrotalcita e o restante composto por outros produtos hidratados. Com base no trabalho realizado por Melo Neto (2002), pode-se afirmar também que o aumento do teor de silicato de sódio incorre no aumento do grau de hidratação e, conseqüentemente, na quantidade de C-S-H.

Estudos por calorimetria de condução mostram que no cimento de escória ativada com silicato de sódio o aumento da concentração de $\mathrm{Na}_{2} \mathrm{O}$ encurta o período de indução e aumenta o calor total liberado (SHI; DAY, 1996, MELO NETO, 2002), porém, com taxa de evolução do calor de hidratação e calor acumulado menores do que os valores observados no cimento Portland (SHI; DAY, 1996, MELO NETO, 2002).

\subsubsection{Porosidade}

De forma similar ao cimento Portland, parte das propriedades do cimento de escória ativada com silicato de sódio pode ser explicada pela natureza de sua porosidade. Em estudos realizados por Collins e Sanjayan (2000c), Melo Neto (2002), Oliveira (2000) e Shi (1996) evidenciam-se as seguintes características da porosidade do cimento de escória ativada com silicato de sódio:

- Porosidade total significativamente menor quando comparada ao cimento Portland. Em estudos realizados por Shi (1996), o cimento de escória apresentou porosidade total aos 3 dias menor do que a porosidade total apresentada pelo cimento Portland aos 90 dias; 
- Distribuição de poros significativamente diferente da apresentada pelo cimento Portland, com grande volume de poros localizado na faixa de mesoporos ${ }^{6}$ (COLLINS; SANJAYAN, 2000c). Em estudo realizado por Melo Neto (2002), o cimento de escória apresenta uma porosidade total constituída em sua maior parte $(\approx 95 \%)$ por mesoporos ao contrário do cimento Portland da alta resistência inicial $(\approx 54 \%)$.

- O refinamento da porosidade do cimento de escória ativada com silicato tem um desenvolvimento mais rápido do que o observado no cimento Portland, porém com estabilização mais rápida da distribuição (MELO NETO, 2002). No cimento Portland, o refinamento pode demorar anos para alcançar a estabilização.

- O diâmetro limite ${ }^{7}$, parâmetro de durabilidade, do cimento de escória ativada tem valor situado na faixa de mesoporos, enquanto no cimento Portland está situado na faixa de macroporos. Esta característica propicia a baixa permeabilidade de compósitos com cimento de escória (WANG et al., 1995).

Esta porosidade singular do cimento de escória ativada foi utilizada por Shi (1996) para a aplicação em modelos que correlacionam a porosidade total com a resistência à compressão, sendo obtidas correlações significativas. Porém, Shi (1996) afirmava que pouco se sabe sobre o porquê desta distribuição de poros tão distinta da observada no cimento Portland. Com base no estudo realizado por Melo Neto (2002), um dos principais fatores para esta porosidade característica do cimento de escória ativada com silicato de sódio é a formação de produtos hidratados com uma predominância quase que total de C-S-H. Conforme descrito no item 2.2.1, o C-S-H apresenta estrutura porosa com elevada área específica e com distribuição de poros concentrada na faixa de microporos e mesoporos (YOUNG, 1988), portanto, a elevada proporção volumétrica do C-S-H no cimento de escória ativada confere a porosidade singular citada.

\footnotetext{
${ }^{6}$ De acordo com a IUPAC - International Union of Pure and Applied Chemistry, os poros podem ser classificados em três categorias de acordo com o diâmetro $(\varnothing)$ : microporos $\varnothing<2 \mathrm{~nm}$; mesoporos $2<\varnothing<50 \mathrm{~nm}$ e macroporos $\varnothing>50 \mathrm{~nm}$ (IUPAC, 1997).

7 Sato (1998) define o diâmetro limite como a menor dimensão de poro acima da qual se estabelece uma trajetória de poros conectados de uma extremidade a outra da amostra, determinado pela inflexão na curva de porosidade acumulada.
} 
Chen e Brouwers (2007) utilizaram modelos de reação e obtiveram resultados estimados, os quais demonstram que o cimento de escória ativada apresenta elevado volume de poros de gel e baixo volume de poros capilares comparado ao cimento Portland. Os resultados obtidos confirmam as tendências concluídas por Melo Neto (2002), onde a porosidade do cimento de escória ativada é menor ou similar do cimento Portland e sua distribuição de poros é caracterizada pela elevada proporção de poros de gel. Utilizando os modelos de previsão, os autores calcularam uma porosidade total de aproximadamente $35 \%$, sendo a mesma constituída em torno de $72 \%$ por poros de gel. Os autores também atribuem esta porosidade singular à predominância do C-S-H em comparação aos demais produtos hidratados do cimento de escória ativada.

\subsubsection{Propriedades mecânicas}

De modo geral, o cimento de escória ativada com silicato de sódio apresenta resistências mecânicas (à compressão, à tração e módulo de elasticidade) superiores às observadas no cimento Portland. As propriedades mecânicas foram amplamente estudadas (SHI et al., 1992; JIMÉNEZ et al., 1999; COLLINS; SANJAYAN, 2001; MELO NETO, 2002) e suas características podem ser resumidas em:

- Na resistência à compressão, o nível de relevância foi nesta ordem: natureza do ativador > concentração do ativador > finura da escória. De modo geral, o silicato de sódio é o ativador que apresenta os maiores resultados quando comparados com os resultados obtidos com hidróxido de sódio, carbonato de sódio, cal hidratada (JIMÉNEZ et al., 1999; MELO NETO, 2002).

- O tipo de cura é fundamental no desenvolvimento apropriado da resistência mecânica do cimento de escória ativada. A ausência de cura úmida incorre em uma redução significativa da resistência à compressão, principalmente na ativação com silicato de sódio (MELO NETO, 2002). De acordo com Collins e Sanjayan (2001), a falta de cura úmida reduz em até $17,2 \%$ a resistência à compressão aos 28 dias e em até $53,5 \%$ aos 365 dias em escórias ativadas com silicato de sódio. 
No estudo realizado por Melo Neto (2002), as conclusões obtidas confirmam o melhor desempenho obtido pelo cimento de escória ativado com silicato. A argamassa (1:2:0,48, sendo aglomerante:areia:água) ensaiada com o maior teor de silicato de sódio apresentou elevada resistência inicial à compressão $(\approx 37 \mathrm{MPa}$ a 1 dia e $\approx 57 \mathrm{MPa}$ aos 3 dias), estatisticamente igual à argamassa com cimento Portland de alta resistência inicial - ARI até 3 dias de idade. Porém, a partir desta idade, o cimento de escória ativada com silicato de sódio apresentou valores estatisticamente superiores a todas as argamassas estudadas, sendo a sua resistência à compressão em torno de $50 \%$ maior do que no cimento Portland ARI (102 MPa aos 56 dias contra $75 \mathrm{MPa}$ da argamassa ARI).

De acordo com as conclusões de Melo Neto (2002), determinados fenômenos que causam a elevada retração do cimento de escória também são responsáveis por vantagens apresentadas pelo mesmo, como a elevada resistência à compressão e durabilidade, as quais estão correlacionadas com a porosidade e grau de hidratação. Isto indica que o desafio é conseguir amenizar a retração sem prejudicar de forma significativa as características positivas do cimento de escória.

\subsubsection{Comportamento da retração do cimento de escória ativada}

A tendência à fissuração dos cimentos de escória ativada com álcalis está registrada em inúmeras referências bibliográficas internacionais. Em todas as fontes pesquisadas, o cimento de escória ativada com silicato de sódio apresentou maior retração. Porém, em compensação, apresentou outras características relativamente superiores, como resistência à compressão, módulo de elasticidade, resistência à tração, entre outras, melhores do que outros ativadores como cal hidratada, hidróxido de sódio, carbonato de sódio, sulfatos de sódio e de cálcio.

No exterior, vários autores (ANDERSSON; GRAM, 1988; WANG et al., 1995; TAYLOR, 1997; BAKHAREV et al.,1999; COLLINS; SANJAYAN, 1999b) apresentam resultados da retração em cimentos de escoria ativada que confirmam a elevada retração do mesmo quando comparada ao cimento Portland. Porém, poucos detalharam de maneira aprofundada o comportamento da retração, carecendo de 
resultados de retração autógena e do papel do desenvolvimento da microestrutura na retração.

Melo Neto (2002) pesquisou o comportamento de retração a partir das primeiras idades caracterizando o fenômeno e correlacionando com a porosidade, calor de hidratação e termogravimetria. Comparando misturas de escória ativada com silicato de sódio (variando a concentração de $\mathrm{Na}_{2} \mathrm{O}$ e $\mathrm{SiO}_{2}$ ) ou hidróxido de sódio com uma mistura de controle confeccionada com cimento Portland da alta resistência inicial, o autor chegou às seguintes conclusões:

- A retração das misturas de escória ativada, independentemente do tipo de ativador, é maior do que a apresentada pela mistura de cimento Portland. Nas misturas de escória ativada com silicato de sódio, tanto a retração autógena como a retração por secagem estão correlacionadas com o teor de ativador de maneira que o aumento do teor de ativador incorre num aumento da retração. A mistura com maior teor de silicato apresentou retração autógena (Figura 2.8) em torno de 4,5 vezes, e retração por secagem (Figura 2.9) em torno 8 vezes maior do que na mistura de cimento Portland.

- De acordo com os resultados obtidos pela termogravimetria, o cimento de escória apresenta uma quantidade de produtos hidratados maior do que o cimento Portland, mais evidente no caso da ativação com silicato de sódio. E como em geral o produto hidratado tem um volume hidratado menor do que o volume anidro, isto indica uma retração química maior para o cimento de escória.

- O cimento de escória ativada apresenta porosidade total e distribuição de poros singular. Em geral, o mesmo apresenta porosidade total similar ou menor do que o cimento Portland e volume de poros concentrado em sua maior parte ( $95 \%)$ na faixa de mesoporos. Estas características permitem sugerir que a água presente na mistura com cimento de escória ativada incorre em uma pressão capilar no poro maior com a movimentação da água presente (seja consumida pelas reações de hidratação ou perdida para o ambiente) e, conseqüentemente, maior retração. 
- Pode-se afirmar que um efeito sinérgico entre a elevada retração química e a elevada retração devido à auto-secagem no cimento de escória ativada com silicato de sódio é a principal razão para a elevada retração autógena deste tipo de cimento



Figura 2.8 - Retração autógena das argamassas de cimento de escória ativada com silicato de sódio (4NS=4,5\% $\mathrm{Na}_{2} \mathrm{O}+7,65 \% \mathrm{SiO}_{2} ; \quad 3 \mathrm{NS}=3,5 \% \mathrm{Na}_{2} \mathrm{O}+5,95 \% \mathrm{SiO}_{2} ; \quad 2 \mathrm{NS}=2,5 \% \mathrm{Na}_{2} \mathrm{O}+4,25 \% \mathrm{SiO}_{2}$ ), ativada com hidróxido de sódio $\left(5 \mathrm{~N}=5 \% \mathrm{Na}_{2} \mathrm{O}\right)$ e da argamassa de cimento Portland ARI. Todas com uma relação água/aglomerante igual a 0,48 , desmoldadas após 6 horas e colocadas na câmara seca $(50 \%$ U.R. e $\left.24^{\circ} \mathrm{C}\right)$ (MELO NETO, 2002).



Figura 2.9 - Retração por secagem das argamassas de cimento de escória ativada com silicato de sódio (4NS=4,5\% $\left.\mathrm{Na}_{2} \mathrm{O}+7,65 \% \mathrm{SiO}_{2} ; \quad 3 \mathrm{NS}=3,5 \% \mathrm{Na}_{2} \mathrm{O}+5,95 \% \mathrm{SiO}_{2} ; \quad 2 \mathrm{NS}=2,5 \% \mathrm{Na}_{2} \mathrm{O}+4,25 \% \mathrm{SiO}_{2}\right)$, ativada com hidróxido de sódio $\left(5 \mathrm{~N}=5 \% \mathrm{Na}_{2} \mathrm{O}\right)$ e da argamassa de cimento Portland ARI. Todas com uma relação água/aglomerante igual a 0,48, desmoldadas após 6 horas e colocadas na câmara seca (50\% U.R. e $24^{\circ} \mathrm{C}$ ) (MELO NETO, 2002). 
Atualmente, não existem referências sobre o cimento de escória ativada que abordem a retração química ou a auto-secagem com a realização de medidas diretas. Chen e Brouwers (2007) compilaram dados experimentais de outros autores e aplicaram em modelos de reação. As estimativas obtidas demonstram que a retração química do cimento de escória ativada é em torno de 12-14 ml/100g, muito maior do que no cimento Portland, aproximadamente de 6-10 ml/100g (POWERS, 1968). Os autores não explicam a causa da elevada retração química do cimento de escória ativada, porém, pode-se supor que o fato deste tipo de cimento apresentar predominância do C-S-H, grande velocidade de dissolução (quando ativado com álcalis) e porosidade caracterizada pela predominância do volume de mesoporos (MELO NETO, 2002), contribua decisivamente para este comportamento. Com base no estudo realizado Melo Neto (2002), é provável que o aumento do teor de silicato de sódio resulte no aumento da retração química, explicado pelo aumento do grau e velocidade de hidratação.

Com o avanço da hidratação, ocorre a retração química e também o surgimento de vazios no interior do material. Sabe-se que a porosidade, a distribuição de poros e conectividade entre os poros influenciam bastante nas propriedades mecânicas da pasta. Sabe-se também que a retração autógena é o resultado macroscópico do efeito da retração química mais o efeito da auto-secagem. Portanto, a elevada retração autógena do cimento de escória pode ser explicada pela elevada retração química e pela elevada pressão capilar decorrente da auto-secagem. Neste caso, a auto-secagem, provavelmente, é maior do que no cimento Portland e aumenta com o teor de silicato de sódio. Esta afirmação é suportada pelos resultados de porosimetria (MELO NETO, 2002), nos quais o aumento do teor de silicato de sódio incorreu na diminuição da porosidade total e no aumento do refinamento dos poros.

Assim como Collins e Sanjayan (2000c), Melo Neto (2002) verificou que a mistura com cimento Portland teve retração por secagem maior do que a mistura com escória ativada, porém com uma perda de massa maior em razão da secagem. Esta falta de correlação entre a retração por secagem e a quantidade de perda de massa, pode ser explicada pela porosidade do cimento de escória ativada com silicato de sódio, quase que totalmente constituída por mesoporos. Esta característica faz com 
que se tenha uma dificuldade maior para a saída da água da mistura do que a água presente na mistura com cimento Portland, mas que incorre em uma pressão capilar no poro de maior magnitude, tendo como conseqüência uma retração maior com menor perda de massa. Conclui-se que o fenômeno da retração do cimento de escória é ocasionado pelos mesmos mecanismos que ocorrem no cimento Portland, questionando-se por que é tão maior. Com base nas conclusões constantes deste item, pode-se elaborar uma descrição geral do fenômeno da retração no cimento de escória ativada.

Nas primeiras idades, com a exposição ao ambiente, ocorre uma primeira retração elevada em razão da pouca resistência do material, o que faz com que o mesmo colapse. No caso especifico do cimento de escória, a retração química e o crescimento da resistência ocorrem de forma abrupta, resultando em uma elevada primeira retração (CHEN; BROUWERS, 2007; CINCOTTO et al., 2003). De acordo com os resultados obtidos por Melo Neto (2002), o aumento do teor de silicato de sódio causa o aumento da primeira retração por secagem, provavelmente decorrente do crescimento da retração química e do grau de hidratação, constatado pelo aumento da quantidade de C-S-H.

Com a consolidação do crescimento da resistência, ocorre a restrição das deformações e com isso a redução da retração externa. No entanto, o avanço da hidratação incorre no crescimento dos vazios internos e, conseqüentemente, da formação de menisco no poro que levam ao crescimento das tensões capilares, resultando em forças de contração e, novamente, a retração. No caso especifico do cimento de escória, o crescimento de vazios ocorre rapidamente e com grande proporção de mesoporos, como observado por vários autores (COLLINS; SANJAYAN, 2000c; CHEN; BROUWERS, 2007; CINCOTTO et al., 2003). Este fato suporta a explicação da elevada retração deste tipo de cimento, pois o refinamento da porosidade (COLLINS; SANJAYAN, 2000c; CHEN; BROUWERS, 2007; CINCOTTO et al., 2003) contribui significativamente para o aumento das tensões capilares. De acordo com os resultados obtidos por Melo Neto (2002), pode-se concluir também que o aumento do teor de silicato de sódio causa o aumento da 
segunda retração por secagem, provavelmente decorrente da diminuição da porosidade total acompanhada de início mais rápido do refinamento da porosidade.

\subsection{Aditivos Compensadores (SCA) e redutores de retração (SRA)}

A retração em misturas cimentícias pode ser amenizada com soluções que intervenham em ajustes na dosagem, utilização de armaduras, aplicação de cura eficiente e a minimização da relação água/cimento. Os aditivos constituem-se em mais uma contribuição para o controle da retração. Basicamente, existem dois tipos: os redutores de retração e os compensadores de retração. Ainda existe certa confusão com respeito à denominação dos aditivos; para esta tese definem-se as seguintes denominações: SRA (abreviação da expressão original em inglês "shrinkage reducing admixture") que age reduzindo a retração, e SCA (abreviação da expressão original em inglês "shrinkage compensating admixture") que age gerando uma expansão de modo a compensar a retração. Sha et al. (1992) afirmam que os aditivos expansores já foram uma solução viável, mas que atualmente não são muito utilizados. No entanto, neste estudo, será utilizado o SCA, pois a retração do cimento de escória é um assunto pouco estudado e não se sabe o efeito da utilização do aditivo SCA, assim como pouco se sabe sobre o efeito da utilização do aditivo SRA.

\subsubsection{Aditivo compensador de Retração (SCA)}

A primeira tentativa de prevenir a retração do concreto foi o desenvolvimento de estudos sobre cimentos expansivos e aditivos expansores, realizados quase que totalmente em países estrangeiros. O princípio do aditivo expansor é induzir o surgimento de tensões de compressão de modo a compensar o surgimento de tensões de tração resultantes da restrição da retração. Neste tipo de aditivo, 0 principal responsável pela expansão induzida é a formação da etringita, uma espécie química normalmente considerada inconveniente, por causar danos muitas vezes irreversíveis quando formada após o endurecimento do concreto. Henri Lossier é considerado o pioneiro na descoberta do potencial da etringita para o controle da 
fissuração e para a aplicação de protensão química ao concreto $(A C l$ 223, 1970; LEES et al., 1996).

Em meados dos anos 70, o Comitê do American Concrete Institute (ACl 223, 1970) já indicava duas utilizações principais para o cimento expansivo, classificadas de acordo com a magnitude da expansão e a sua aplicação (LEES et al., 1996): (a) Controle da retração - a restrição da expansão causada pelo cimento induz uma tensão de compressão compensando a tensão de tração gerada pela retração por secagem; (b) Protensão química - a tensão de compressão induzida pela hidratação do cimento expansivo deve ser de magnitude elevada o suficiente para que, mesmo após a retração, resulte em uma tensão residual de compressão significativa propiciando a protensão da estrutura.

Os cimentos expansivos existentes no mercado mundial são classificados de acordo com os seus agentes expansores e seu mecanismo de expansão. Nos Estados Unidos, a norma ASTM C 845 (1996) define três tipos de cimentos expansivos:

- Tipo K: Cimento Portland misturado com sulfoaluminato de cálcio anidro (também denominada "hauyne" (NAGATAKI; GOMI, 1998)) $\left(3 \mathrm{CaO}-3 \mathrm{Al}_{2} \mathrm{O}_{3}-\mathrm{CaSO}_{4}\right)$, anidrita $\left(\mathrm{CaSO}_{4}\right)$ e cal virgem $(\mathrm{CaO})$.

Estequiometria ${ }^{8}$ da reação: $\mathrm{C}_{4} \mathrm{~A}_{3} \overline{\mathrm{S}}+8 \mathrm{C} \overline{\mathrm{S}}+6 \mathrm{CH}+\mathrm{H} \rightarrow \mathrm{C}_{6} \mathrm{~A}_{3} \mathrm{H}_{32}$

- Tipo M: Cimento Portland misturado com cimento aluminoso e anidrita $\left(\mathrm{CaSO}_{4}\right)$ em proporção adequada.

Estequiometria da reação: $\mathrm{CA}+3 \mathrm{C} \overline{\mathrm{S}}+2 \mathrm{CH}+\mathrm{H} \rightarrow \mathrm{C}_{6} \mathrm{~A}_{3} \mathrm{H}_{32}$

- Tipo S: Cimento Portland comum formulado para apresentar elevada quantidade de aluminato tricálcico $\left(\mathrm{C}_{3} \mathrm{~A}\right)$ e adicionado um excesso de anidrita $\left(\mathrm{CaSO}_{4}\right)$. Estequiometria da reação: $\mathrm{C}_{3} \mathrm{~A}+3 \mathrm{C} \overline{\mathrm{S}}+\mathrm{H} \rightarrow \mathrm{C}_{6} \mathrm{~A} \overline{\mathrm{S}}_{3} \mathrm{H}_{32}$

\footnotetext{
${ }^{8}$ Onde $\mathrm{C}=\mathrm{CaO}, \mathrm{A}=\mathrm{Al}_{2} \mathrm{O}_{3}, \overline{\mathrm{S}}=\mathrm{SO}_{3}, \mathrm{H}=\mathrm{H}_{2} \mathrm{O}, \mathrm{C}_{4} \mathrm{~A}_{3} \overline{\mathrm{S}}=$ sulfoaluminato de cálcio anidro, $\mathrm{C} \overline{\mathrm{S}}$ = sulfato de cálcio, $\mathrm{CH}=$ hidróxido de cálcio, $\mathrm{CA}=$ aluminato de cálcio, $\mathrm{C}_{3} \mathrm{~A}=$ aluminato tricálcico.
} 
De acordo com pesquisa bibliográfica realizada, constatou-se que dentre estes três tipos de cimento expansivo, apenas o Tipo $\mathrm{K}$ está disponível no mercado dos Estados Unidos. Os cimentos expansivos têm o inconveniente de sofrer perda rápida de consistência e ter tempo de pega rápido, devido à grande necessidade de água para a formação de etringita durante as primeiras horas de hidratação (TAYLOR, 1996). A cura também é outro aspecto fundamental para o desenvolvimento da expansão (FOLLIARD; BERKE, 1997), pois existe a necessidade de água disponível para a formação da etringita.

Deve-se atentar para o fato de que no caso dos concretos expansivos a formação da etringita não é um efeito deletério e sim desejado; a mesma não deverá ocorrer em pontos isolados de uma peça de concreto. A distribuição uniforme e intencional da etringita faz com que o seu efeito deixe de ser negativo, conferindo ao material uma característica desejada. A retração e a expansão de um concreto normal e de um concreto expansivo podem ser vistas na Figura 2.10.



Figura 2.10 - Retração e expansão de um concreto normal e de um concreto expansivo (LUCO et al.,1999).

Os concretos expansivos desenvolvidos no Japão foram preparados com aditivos expansores; diferentemente dos desenvolvidos na América e na Europa, preparados com cimento expansivo; o que possibilitou um melhor controle da magnitude de expansão (NAGATAKI; GOMI, 1998). Quando se adiciona ao concreto algum constituinte com o intuito de provocar uma expansão, pode-se chamar o concreto produzido de concreto expansivo e o elemento propiciador da expansão, de aditivo expansor. Nagataki e Gomi (1998) citam a definição japonesa para aditivos 
expansores: "são aqueles aditivos que misturados com cimento e água, produzem etringita $\left(3 \mathrm{CaO}-3 \mathrm{Al}_{2} \mathrm{O}_{3} \cdot \mathrm{CaSO}_{4} \cdot 32 \mathrm{H}_{2} \mathrm{O}\right)$ ou hidróxido de cálcio $\left(\mathrm{Ca}(\mathrm{OH})_{2}\right)$ e, em conseqüência a essa reação de hidratação, provocam a expansão do concreto". A expansão pode ser provocada pelo aditivo incorporado já no cimento ou adicionado no momento da produção do concreto. A vantagem do uso de aditivos expansores diretamente na produção do concreto é a de se poder dosar a quantidade de aditivo que venha a resultar na expansão desejada.

Atualmente, os aditivos expansores são denominados de aditivos compensadores de retração (SCA). Dentre a grande maioria dos aditivos compensadores comercialmente existentes, os dois tipos principais são à base de sulfoaluminato de cálcio e à base de cal virgem. Os aditivos à base de sulfoaluminatos de cálcio são os mais usados, pois os aditivos à base de cal virgem são de difícil controle em razão da sua quase que imediata reação quando em contato com a água (MORIOKA et al., 2003, YAMAMOTO et al., 2003). Repette e Mailvaganam (1999) estudaram alguns dos principais tipos de aditivos expansores comercialmente disponíveis, à base de sulfoaluminato de cálcio, Hauyne, cimento aluminoso e cimento aluminoso préhidratado. Um novo tipo de aditivo compensador, à base de aluminatos de cálcio hidratados, foi desenvolvido recentemente e apresentou resultados mais adequados à compensação da retração de materiais à base de cimento Portland do que seus predecessores (REPETTE et al., 1998; REPETTE; MAILVAGANAM, 2000).

A formação da etringita em concretos com aditivos expansores à base de sulfoaluminato de cálcio se dá nas primeiras idades e esta expansão deve ser restringida por tensões contrárias à tensão gerada pela retração, para que seja compensada e evitada a formação de fissuras. É consensual nos trabalhos consultados que os cimentos expansivos são menos eficientes na produção da expansão, sendo preferível o uso de aditivos SCA no concreto (REPETTE et al., 1998; MORIOKA et al., 2003a-b). A falta de controle do momento em que ocorre a expansão gerada pelo cimento expansivo é o fator principal pela não preferência do mesmo. Exemplificando a importância do momento da expansão gerada, caso a mesma aconteça com o concreto ou argamassa no estado fresco, toda ela será dispersa pela grande deformabilidade nas primeiras horas. Os aditivos SCA com 
base de sulfoaluminato são produzidos em processos nos quais a sinterização da matéria prima é realizada de forma a proporcionar a expansão após o ganho de resistência mecânica (YAMAMOTO et al., 2003).

A hidratação dos aditivos SCA com base de sulfoaluminato é descrita na Figura 2.11. Como ressaltado anteriormente, é de fundamental importância que a formação de etringita ocorra após o início de pega. Inicialmente, o óxido de cálcio reage rapidamente com a água formando hidróxido de cálcio. Em seguida, o sulfoaluminato de cálcio anidro reage com a água e com hidróxido de cálcio formando cristais com morfologia de placas hexagonais, cuja composição da solução sólida é constituída de monossulfoaluminato $\left(3 \mathrm{CaO} \cdot \mathrm{Al}_{2} \mathrm{O}_{3} \cdot \mathrm{CaSO}_{4} \cdot 12 \mathrm{H}_{2} \mathrm{O}\right)$ e aluminato de cálcio hidratado $\left(4 \mathrm{CaO} \cdot \mathrm{Al}_{2} \mathrm{O}_{3} \cdot 13 \mathrm{H}_{2} \mathrm{O}\right)$ (REPETTE et al., 1998). Subseqüentemente, ocorre a reação topoquímica do sulfato de cálcio na superfície dos grãos hidratados formados anteriormente e formação dos cristais aciculares de etringita, apenas neste momento ocorre a expansão. Segundo Konik et al. (2007), o momento da expansão relativa à formação da etringita deve ocorrer entre 24 horas e 72 horas após a mistura com a água.



Figura 2.11 - Representação esquemática das reações de hidratação do aditivo compensador de retração com agente expansivo à base de sulfoaluminato de cálcio anidro (NAGATAKI; GOMI, 1998). 
A pouca popularidade dos aditivos SCA se deve principalmente ao rigoroso controle de qualidade necessário para que ele atenda às necessidades para as quais foi projetado, ao seu custo mais elevado e à pouca divulgação do produto. Kuperman (1989) enfatiza a necessidade de diminuir o custo dos concretos expansivos por meio de diversas fontes de suprimentos de matérias primas, citando como exemplo: alumina, sulfato e outros materiais adicionados testados (cal, pozolana, cinza volante, escória de alto forno, calcário). Esse autor cita em seu trabalho que concretos feitos com cimentos expansivos eram $20 \%$ mais caros do que os concretos feitos com o cimento Portland comum. Outro fator limitante ao uso dos aditivos SCA é a dificuldade em controlar o momento e a magnitude da expansão gerada, para que essa expansão atue de maneira eficaz no controle da retração (FOLLIARD; BERKE, 1997).

O uso dos concretos expansivos praticamente não existe no Brasil, porém nos Estados Unidos, Japão e Europa os concretos com aditivos expansores têm sido usados para os mais variados fins, como pavimentos, lajes pré-fabricadas, lajes quimicamente protendidas, pontes, reservatórios, etc. De acordo com o levantamento bibliográfico realizado, não há relatos do uso de cimento expansivo, aditivo compensador de retração ou produto similar em cimentos de escória ativada.

\subsubsection{Aditivo Redutor de Retração (SRA)}

Pode-se dizer que os aditivos redutores de retração são a mais recente tentativa de prevenir a retração de misturas cimentícias. Por ser um produto mais recente e em desenvolvimento contínuo existem poucas publicações a respeito, assim como uma dificuldade por parte dos estudos em diferenciar a composição dos aditivos existentes no mercado, protegidas pelos fabricantes.

A introdução do uso de aditivos de natureza orgânica para o fim específico de reduzir a retração é atribuída a Sato ${ }^{9}$ et al. (1983) apud Nmai et al. (1998). Os primeiros aditivos redutores de retração (SRA) apresentavam baixa viscosidade,

\footnotetext{
${ }^{9}$ SATO, T.; GOTO, T.; SAKAI, K. Mechanism for Reducing Drying Shrinkage of Hardened Cement by Organic Additives. Cement Association of Japan (CAJ) Review, pp. 52-54, 1983.
} 
solubilidade em água e tinham a função de reduzir a tensão capilar que se desenvolve nos poros do concreto com a secagem (NMAl et al., 1998). Outra característica citada é a possibilidade de utilizar o aditivo desenvolvido diretamente na superfície do concreto, como uma solução tópica para amenizar a retração. Segundo $\mathrm{He}$ et al. (2006), a maior parte dos aditivos redutores de retração são líquidos orgânicos com base em derivados do glicol. Atualmente, o propileno glicol $\left(\mathrm{CH}_{3}-\mathrm{CH}_{2}-\mathrm{CH}-\left(\mathrm{CH}_{2}-\mathrm{OH}\right)_{2}\right)$ e o neopentil glicol $\left(\left(\mathrm{CH}_{2}\right)_{2}-\mathrm{C}-\left(\mathrm{CH}_{2}-\mathrm{OH}\right)_{2}\right)$ são alguns dos derivados do glicol utilizados para a obtenção dos aditivos SRA, sendo os derivados do propileno mais utilizados para este fim (COLLEPARDI et al., 2005).

Bentz et al. (2001) realizaram ensaios experimentais para determinar o efeito do aditivo redutor de retração na tensão superficial da água, obtendo uma tensão superficial para água destilada igual a $0,0765 \mathrm{~N} / \mathrm{m}$ e com a utilização do aditivo SRA (6\% da massa de água destilada) ocorreu a redução para uma tensão de 0,0325 $\mathrm{N} / \mathrm{m}$. Folliard e Berke (1997) obtiveram redução semelhante da tensão superficial da água com a utilização do aditivo SRA, para aproximadamente 0,040 N/m. Rongbing e Jian (2005), em estudos direcionados ao desenvolvimento do processo químico de obtenção do aditivo SRA, apresentam resultados similares aos obtidos por Bentz et al. (2001) para a redução da tensão superficial da água (Figura 2.12).



Figura 2.12 - Efeito do aditivo redutor de retração (SRA) na tensão superficial da água (RONGBING; JIAN, 2005) 
A teoria que embasa o funcionamento do aditivo SRA é descrita e explicada por Bentz $(2005,2006)$, estando as afirmações seguintes baseadas na discussão do autor. Resumidamente, os aditivos SRA influenciam na tensão superficial e na viscosidade da água presente nos poros do concreto, isto acarretará em efeitos significativos no mesmo. Sabe-se, de acordo com equação de Kelvin-Laplace (Equação 5), que tensões capilares surgiram na solução aquosa remanescente dentro dos poros (admite-se que os poros têm formato cilíndrico) de um concreto parcialmente saturado. A redução da tensão superficial da água do poro incorrerá na redução da pressão capilar da mesma e, conseqüentemente, na redução da retração. Analisando a equação de Kelvin-Laplace e com resultados experimentais, Bentz $(2005,2006)$ obteve conclusões importantes sobre a influência da tensão superficial no fenômeno da retração (Tabela 2.2). Dentre as conclusões do autor, destaca-se a menor perda de massa por secagem quando utilizado o aditivo SRA, atribuída à hipótese de que a secagem inicial causa a formação de uma solução concentrada de SRA na superfície e esta inibe a futura evaporação da água de amassamento (Bentz et al., 2001).

$\sigma_{\text {cap }}=\frac{2 \gamma}{r}=\frac{-\ln (\mathrm{RH} / 100 \%) \mathrm{RT}}{\mathrm{V}_{\mathrm{m}}}$

Onde:

$\sigma_{\text {cap }}=$ tensão capilar

$\mathrm{R}=$ constante universal dos gases

$\mathrm{Y}=$ tensão superficial da água do poro

$\mathrm{T}=$ temperatura absoluta

$\mathrm{r}=$ raio do maior poro parcialmente saturado

$\mathrm{V}_{\mathrm{m}}=$ volume molar da solução do poro

$\mathrm{RH}=$ umidade relativa em porcentagem

Tabela 2.2 - Influência da tensão superficial no fenômeno da retração (BENTZ, 2005).

\begin{tabular}{ll}
\hline Fenômeno & Influência da redução da tensão superficial \\
\hline \multirow{2}{*}{ Retração por secagem } & Redução no equilíbrio da saturação \\
& Redução na taxa de secagem (menor perda de massa) \\
\hline \multirow{2}{*}{ Retração autógena } & Redução da tensão capilar \\
& Redução da umidade relativa interna \\
\hline \multirow{2}{*}{ Evaporação nas primeiras idades } & Alteração do perfil da curva de secagem \\
& Redução da taxa de secagem \\
\hline
\end{tabular}


Na prática, sabe-se que os aditivos redutores não eliminam a retração, mas reduzem a retração final na ordem de 25\% a 50\% (HOLT; LEIVO, 2000). Bentz et al. (2001) relatam os resultados obtidos em ensaios em argamassas e pastas de cimento Portland com e sem adição de aditivo SRA. Foram realizados ensaios para determinação da retração autógena nas argamassas e a medida da variação de umidade relativa interna das pastas. Neste estudo o uso do SRA reduziu a retração em mais de $50 \%$, além de atenuar consideravelmente a redução da umidade relativa interna dos corpos-de-prova ao longo do tempo. Um detalhe importante é que os autores também determinaram a resistência à compressão; estatisticamente o SRA não teve influência nesta propriedade. Este fato é incomum, pois existem relatos abordando a redução da resistência à compressão com o uso do SRA (BROOKS; JIANG, 1997; FOLLIARD; BERKE, 1997), e mesmo os fabricantes deste tipo de aditivo admitem a redução da resistência à compressão em até 15\% aos 28 dias.

Apesar da pouca divulgação, os aditivos redutores têm alguns efeitos negativos, 0 principal é que a ação de reduzir a tensão superficial implica na alteração de algumas propriedades da mistura cimentícia. O retardo do início da pega e a redução da resistência à compressão são as mais divulgadas e comprovadas, tendo como possível explicação que a redução da tensão superficial pode reduzir também a força de atração entre as partículas na fase de floculação do aglomerante, afetando as propriedades citadas anteriormente (BROOKS et al., 2000). Existem poucos relatos do uso do aditivo redutor de retração (SRA) em cimentos de escória ativada. Nos estudos desenvolvidos na Austrália, Collins e Sanjayan (2000b) e Bakharev et al. (2000) relatam de forma confusa os resultados obtidos, pois não deixam claro informações básicas como dosagem de ativador e de aditivo SRA. Apesar deste fato, os autores concluem que o aditivo SRA é eficiente na redução da tendência à fissuração do cimento de escória ativada com silicato de sódio, porém reduz de forma significativa a resistência à compressão e outras propriedades mecânicas.

Palacios e Puertas $(2005,2007)$ realizaram vários estudos sobre a ativação da escória com silicato de sódio. Quando da abordagem do uso de aditivos redutores de retração (SRA), o fato dos estudos realizados pelos autores citados terem focado 
o preparo das argamassas com base na manutenção da consistência constante (ao invés da manutenção da relação água aglomerante constante), prejudicou a análise do efeito do aditivo SRA. Por exemplo, a utilização do aditivo SRA causou, no trabalho dos autores citados, o aumento da resistência à compressão. Analisando a proporção dos materiais empregada, observa-se que a mistura de escória ativada com silicato de sódio com $2 \%$ (em relação à massa de aglomerante) de SRA teve uma relação água/aglomerante igual a 0,50, enquanto na mistura sem SRA a relação foi igual a 0,58 . Com este procedimento, torna-se claro porque a mistura com $2 \%$ de SRA apresentou maior resistência à compressão do que a mistura sem o emprego do SRA.

Pode-se afirmar que o aditivo redutor de retração tem efeito ao longo do tempo e combate à retração à medida que a mesma for surgindo, pois interfere na tensão superficial da água que, por sua vez, tem papel fundamental na evolução das reações de hidratação. O aditivo compensador de retração (SCA) tem efeito no combate à retração em determinados intervalos de tempo, geralmente nas idades iniciais.

\subsection{Conclusões}

Com base no levantamento bibliográfico apresentado neste capítulo, conclui-se que a utilização de aditivos redutores de retração (SRA) ou de aditivos compensadores de retração (SCA) pode ser uma alternativa viável para amenizar a elevada retração do cimento de escória ativada. Comparado ao aditivo SCA, os aditivos SRA ainda não são amplamente difundidos e estudados na aplicação em cimento Portland no meio científico internacional. Mais tradicional, os aditivos SCA apresentam maior número de estudos da sua aplicação para amenizar a retração do cimento Portland. Ambos aditivos têm pouquíssimos relatos de sua utilização com o cimento de escória ativada, no entanto, como este se assemelha em algumas características com o cimento Portland, vislumbra-se que sua aplicação apresentará resultados interessantes no cimento de escória ativada. 


\section{Capítulo 3 Programa experimental}

\subsection{Definição do programa experimental}

Este programa experimental foi elaborado com o objetivo de caracterizar o comportamento da retração do cimento de escória ativada com silicato de sódio e a utilização de aditivos compensadores (SCA) e redutores (SRA) de retração. A análise dos resultados da retração foi apoiada na determinação da cinética das reações de hidratação, natureza e quantidade dos produtos hidratados formados e porosidade. Complementam esses ensaios a caracterização de propriedades mecânicas básicas, como resistência à compressão, resistência à tração e módulo de elasticidade.

Este trabalho está inserido no contexto de trabalhos anteriores e integra uma série de trabalhos realizados no Departamento de Construção Civil da Escola Politécnica da USP com enfoque na ativação da escória de alto forno com silicato de sódio. Por isto, dando prosseguimento aos trabalhos desta linha de pesquisa, algumas das variáveis adotadas foram extraídas de estudos anteriores de John (1995), Silva (1998), Oliveira (2000) e Melo Neto (2002).

\subsection{Variáveis}

\subsubsection{Tipo e concentração dos ativadores}

Em trabalhos anteriores, John (1995) (tema: "Cimentos de escória ativada com silicatos de sódio"); Silva (1998) (tema: "Cura térmica dos cimentos de escória"); Oliveira (2000) (tema: "Água do poro de pastas de cimento de escória”) e Melo Neto (2002) (tema: "Retração dos cimentos de escória") utilizaram várias concentrações de sódio e silicato, assim como diferentes módulos de sílica (relação $\mathrm{SiO}_{2} / \mathrm{Na}_{2} \mathrm{O}$ ). 
Conforme descrito no Capítulo 1, a seleção do tipo e concentração de ativador foi realizada com base na sua capacidade de conferir propriedades ao cimento de escória ativada, de modo a viabilizar sua utilização em algumas aplicações específicas, como a utilização em pré-moldados, pisos industriais, reparo rápido de estruturas, entre outras. Portanto, de acordo com os resultados obtidos por MELO NETO (2002), a ativação que apresenta desempenho mecânico e outras características interessantes para sua aplicação é utilizando o silicato de sódio com concentração de $4,5 \%$ de $\mathrm{Na}_{2} \mathrm{O}, 7,65 \%$ de $\mathrm{SiO}_{2}$ e módulo de sílica (MS) igual a 1,7 (designada nesta tese por 4NS).

\subsubsection{Relação água/aglomerante}

O aditivo compensador de retração (SCA) é composto basicamente de sulfoaluminato de cálcio, sulfato de cálcio e óxido de cálcio que adicionado à água tem o objetivo de formar etringita (item 2.4.1). Esta reação química é caracterizada pelo grande consumo de água. Portanto, é fundamental a variação da relação água/aglomerante para a análise do desempenho do aditivo SCA na amenização da retração. No caso do aditivo redutor de retração (SRA), este interfere diretamente nas propriedades da água disponível para mistura (item 2.4.2). Porém, seu desempenho não é tão dependente da quantidade de água disponível quando comparado com o aditivo SCA.

De modo geral, foram adotadas três relações água/aglomerante: 0,40, 0,48 e 0,56. Inicialmente estava previsto que as relações seriam 0,35, 0,45 e 0,55, porém foram realizados estudos exploratórios e foi verificado que as misturas com relação água/aglomerante igual a 0,35 não permitiam a moldagem com o aditivo SCA. Como citado por Melo Neto (2002), as misturas de cimento de escória ativada com silicato de sódio perdem rapidamente a trabalhabilidade (em torno de 20 minutos). Na relação água/aglomerante de 0,35 , o acréscimo do aditivo SCA causou a perda de trabalhabilidade ainda mais brusca e a mistura endureceu na argamassadeira, travando-a. O elevado consumo de água pelas reações de hidratação deste tipo de aditivo é a causa provável do agravamento da perda de trabalhabilidade no cimento de escória ativada com silicato de sódio. 


\subsubsection{Aditivo compensador (SCA) e redutor de retração (SRA)}

Atualmente, o mercado brasileiro não apresenta disponibilidade comercial do aditivo compensador de retração (SCA). Em contato com representantes comerciais, foi obtida a doação do aditivo compensador de retração (SCA), nome comercial "Denka CSA 20", produzido pela Denka, empresa sediada no Japão. De acordo com o levantamento bibliográfico e com instruções do fabricante, o teor de aditivo SCA dever ser de no máximo $20 \%$ da massa de aglomerante, sendo este valor, no entanto, mais indicado para a obtenção de protensão química. Foram adotados os seguintes teores em substituição de aditivo SCA: 0\%, 5\%, 10\% e 15\% da massa de aglomerante (REPETTE et al. 1999).

Foi utilizado o aditivo redutor de retração (SRA) de nome comercial "Eclipse" produzido pela Grace Brasil, pois se encontra disponível no mercado e é específico para a redução da retração. De acordo com o levantamento bibliográfico e instruções do fabricante, o teor máximo indicado para amenização da retração é de $2 \%$ da massa de aglomerante. Foram utilizados os seguintes teores do aditivo SRA: $0 \%, 0,5 \%, 1 \%, 1,5 \%$ e $2 \%$ da massa de aglomerante. Em ambos os aditivos, alguns teores não foram testados em determinados ensaios, constando, neste caso, os teores utilizados na descrição de cada ensaio.

\subsubsection{Dosagem das argamassas}

Foi empregada a proporção de aglomerante:agregado de 1:2, em massa, variandose a relação água/aglomerante conforme descrito no item 3.2.2. Esta proporção foi empregada por se mostrar adequada às condições de moldagem e sem exsudação de água elevada. No caso do aditivo compensador de retração, fornecido na forma de pó, neste estudo, foi considerado que o aglomerante corresponde à soma da massa de escória mais a fração sólida do ativador e a fração sólida do aditivo. No caso do aditivo redutor de retração que é fornecido na forma de líquido, a fração líquida do ativador mais a fração líquida do aditivo foram subtraídas da massa de água total a ser adicionada à mistura. 


\subsubsection{Condições de cura e exposição}

Para os ensaios de resistência à compressão, resistência à tração e módulo de elasticidade, os corpos-de-prova foram desmoldados após 24 horas e estocados em uma câmara úmida $\left(T=24^{\circ} \mathrm{C}, \mathrm{U} . \mathrm{R} .=100 \%\right)$. Para os ensaios de retração por secagem e retração autógena, os corpos-de-prova foram estocados em câmara seca $\left(T=24^{\circ} \mathrm{C}, \mathrm{U} \cdot \mathrm{R} .=50 \%\right)$.

\subsection{Planejamento experimental}

De acordo com a análise sobre a viabilidade dos ensaios aplicáveis, os ensaios mecânicos apresentam maior disponibilidade e facilidade na execução quando comparado aos demais ensaios. Além destes fatores, o desempenho mecânico é um parâmetro importante na análise do material e do efeito dos aditivos utilizados, podendo ser utilizado na seleção da faixa ótima para empregar os aditivos testados. Portanto, optou-se pela elaboração de planos experimentais distintos para os ensaios mecânicos, os ensaios de retração e os ensaios de análise da microestrutura. A Tabela 3.1 apresenta um resumo de todo o programa experimental elaborado para este trabalho, com o detalhamento apresentado em seguida.

Tabela 3.1 - Resumo do programa experimental

\begin{tabular}{|c|c|c|c|c|}
\hline \multirow{2}{*}{ Ensaios e propriedades } & \multicolumn{3}{|c|}{ Variáveis } & \multirow{2}{*}{$\begin{array}{l}\text { Idade de } \\
\text { ensaios }\end{array}$} \\
\hline & Teor de SCA & Teor de SRA & a/agl & \\
\hline $\begin{array}{l}\text { Resistência à compressão } \\
\text { Resistência à tração } \\
\text { Módulo de elasticidade }\end{array}$ & $\begin{array}{c}0 \%, 5 \%, 10 \% \text { e } \\
15 \%\end{array}$ & $0 \%, 0,5 \%, 1 \%, 1,5 \%$ e $2 \%$ & $\begin{array}{l}0,40 \\
0,48 \\
0,56\end{array}$ & $1,3,7$ e 28 dias \\
\hline \multirow{2}{*}{$\begin{array}{l}\text { Retração por secagem } \\
\text { Variação de massa } \\
\text { Retração autógena }\end{array}$} & $\begin{array}{c}0 \%, 5 \%, 10 \% \text { e } \\
15 \%\end{array}$ & ------ & $\begin{array}{l}0,40 \\
0,48 \\
0,56\end{array}$ & \multirow{2}{*}{$\begin{array}{l}1 \text { até } 7 \text { dias, } 9 \\
11,14,21 \text { e } 28 \\
\text { dias }\end{array}$} \\
\hline & ------ & $0 \%, 0,5 \%, 1 \%, 1,5 \%$ e $2 \%$ & 0,48 & \\
\hline \multirow[t]{2}{*}{ Termogravimetria } & $\begin{array}{c}0 \%, 5 \%, 10 \% \text { e } \\
15 \%\end{array}$ &  & $\begin{array}{l}0,40 \\
0,48 \\
0,56\end{array}$ & \multirow[t]{2}{*}{$\begin{array}{l}6 \text { e } 12 \text { horas, } 1, \\
3,7 \text { e } 28 \text { dias }\end{array}$} \\
\hline & $---\cdot-$ & $0 \%, 0,5 \%, 1 \%, 1,5 \%$ e $2 \%$ & 0,48 & \\
\hline \multirow[t]{2}{*}{ Difração de raios $X$} & $\begin{array}{c}0 \%, 5 \%, 10 \% \text { e } \\
15 \%\end{array}$ & & $\begin{array}{l}0,40 \\
0,48 \\
0,56\end{array}$ & $\begin{array}{l}6 \text { e } 12 \text { horas, } 1 \\
3,7 \text { e } 28 \text { dias }\end{array}$ \\
\hline & ----- & $0 \%, 0,5 \%, 1 \%$ e $1,5 \%$ & 0,48 & $\begin{array}{l}12 \text { horas, } 1,3,7 \\
\text { e } 28 \text { dias }\end{array}$ \\
\hline \multirow[b]{2}{*}{ Porosimetria } & $\begin{array}{c}0 \%, 5 \%, 10 \% \text { e } \\
15 \%\end{array}$ & $0 \%, 0,5 \%, 1 \%, 1,5 \%$ e $2 \%$ & 0,48 & $1,3,7$ e 28 dias \\
\hline & $0 \%$ & $0 \%$ & $\begin{array}{l}0,40 \\
0,48 \\
0,56\end{array}$ & $\begin{array}{l}12 \text { horas, } 1,3,7 \\
\text { e } 28 \text { dias }\end{array}$ \\
\hline
\end{tabular}




\subsubsection{Planejamento experimental dos ensaios mecânicos}

Uma etapa importante para a estruturação do planejamento experimental é a definição dos fatores que serão estudados e uma possível interação deles. No caso específico dos ensaios mecânicos, optou-se pela elaboração de um planejamento experimental de modo a possibilitar a análise dos resultados com auxílio de tratamento estatístico, utilizando programas computacionais.

Um arranjo fatorial mais complexo (Tabela 3.2) mostrou-se inviável, pois, analisando este tipo de arranjo fatorial, percebe-se que o mesmo é do tipo $1^{1} \times 5^{2} \times 3^{1}\left(x^{y}\right.$, onde "x" é número de níveis e "y" é o número de fatores), não homogêneo (pois há fatores com diferentes números de níveis), perfazendo um total de 75 combinações. Assim, para o caso do ensaio de resistência à compressão onde seriam confeccionados 3 corpos-de-prova para cada combinação, teríamos 225 corpos-de-prova a serem ensaiados apenas para uma idade de ensaio, inviabilizando o ensaio.

Tabela 3.2 - Arranjo fatorial elaborado apenas para análise e dimensionamento do projeto experimental

\begin{tabular}{|c|c|}
\hline Fatores $(1,2,3,4, \ldots)$ & Níveis (A, B, C, D, E, ...) \\
\hline 1 - Tipo de cimento & A - Cimento de escória ativada com silicato de sódio (4NS) \\
\hline $\begin{array}{l}2 \text { - Teor de aditivo redutor de } \\
\text { retração (SRA) }\end{array}$ & $\mathbf{A}-0 \% \mathbf{B}-0,5 \% \mathbf{C}-1,0 \% \mathbf{D}-1,5 \% \mathbf{E}-2,0 \%$ \\
\hline $\begin{array}{l}3 \text { - Teor de aditivo compensador de } \\
\text { retração (SCA) }\end{array}$ & A $-0 \%$ B $-5 \%$ C $-10 \%$ D $-15 \%$ E $-20 \%$ \\
\hline 4 - Relação água/aglomerante & $\mathbf{A}-0,40 \mathbf{B}-0,48 \mathbf{C}-0,56$ \\
\hline
\end{tabular}

Com o intuito de reduzir o número de combinações, para este estudo exploratório foi descartada a interação dos fatores 2 (SRA) e 3 (SCA), sendo também reduzido o número de níveis. Com isto, tem-se o plano experimental exploratório apresentado na Tabela 3.3. Analisando este tipo de arranjo, percebe-se que com a variação dos níveis adotados e sem a interação do SRA com o SCA, tem-se 15 combinações para o aditivo SRA e 9 combinações para o aditivo SCA. Foram confeccionados 6 corposde-prova prismáticos $(4 \times 4 \times 16 \mathrm{~cm})$ para cada combinação e para cada idade $(1,3,7$ e 28 dias), perfazendo um total de 144 corpos-de-prova para cada idade de ensaio e um total de 576 corpos-de-prova a serem ensaiados. 
Tabela 3.3 - Arranjo experimental dos ensaios mecânicos.

\begin{tabular}{|l|l|}
\hline \multicolumn{1}{|c|}{ Fatores $(\mathbf{1}, \mathbf{2}, \mathbf{3}, \mathbf{4}, \ldots)$} & \multicolumn{1}{c|}{ Níveis (A, B, C, D, E, ...) } \\
\hline $\begin{array}{l}\mathbf{1}-\text { Tipo de cimento } \\
\mathbf{2}-\text { Teor de aditivo redutor de de } \\
\text { retração (SRA) }\end{array}$ & $\mathbf{A}-$ Cimento de escória ativada com silicato de sódio (4NS) \\
\hline $\begin{array}{l}\mathbf{3}-\text { Teor de aditivo compensador de } \\
\text { retração (SCA) }\end{array}$ & $\mathbf{A}-5 \% \mathbf{B}-0,5 \% \mathbf{C}-1,0 \% \mathbf{D}-1,5 \% \mathbf{E}-2,0 \%$ \\
\hline $\mathbf{4}-$ Relação água/aglomerante $-15 \%$ \\
\hline
\end{tabular}

\subsubsection{Planejamento experimental dos ensaios de retração}

De acordo com capacidade de moldagem e leitura de medidas, foi definido: (a) testar o aditivo redutor de retração (SRA) apenas nas misturas com relação água/aglomerante igual a 0,48 e (b) testar o aditivo compensador de retração (SCA) em todas as relações água/aglomerante previstas $(0,40,0,48$ e 0,56). Esta decisão foi baseada no levantamento bibliográfico, o qual evidencia a dependência do desempenho do aditivo SCA da quantidade de água disponível. Com o planejamento experimental elaborado será possível concluir sobre: (a) influência da relação água/aglomerante na retração sem a utilização de aditivos, (b) influência da relação água/aglomerante na retração com a utilização do aditivo SCA e (c) o efeito do aditivo SRA na retração das misturas com relação água/aglomerante igual a 0,48.

\subsubsection{Planejamento experimental dos ensaios de análise da microestrutura}

Diferentemente dos ensaios tradicionais, como a resistência à compressão, os ensaios para a análise do comportamento da microestrutura são realizados em apenas uma amostra para cada combinação, sem repetições. Este procedimento ocorre em parte pela boa reprodutibilidade das técnicas utilizadas. Com a realização de uma amostra para cada combinação é inviável a utilização de análise estatística nos resultados de caracterização da microestrutura.

\subsubsection{Termogravimetria}

A retração está correlacionada à hidratação e a sua análise em conjunto com a termogravimetria mostrou se importante no entendimento do fenômeno (MELO NETO, 2002). Portanto, o ensaio de termogravimetria foi definido como ensaio fundamental da microestrutura para a compreensão do fenômeno da retração. Por 
esta razão, optou-se por adotar planejamento experimental idêntico ao dos ensaios de retração (item 3.3.2). A Tabela 3.4 exemplifica o arranjo experimental elaborado.

Tabela 3.4 - Arranjo experimental dos ensaios de termogravimetria.

\begin{tabular}{|c|c|c|c|c|}
\hline $\begin{array}{l}\text { Mistura } \\
\text { (nomenclatura) }\end{array}$ & $\begin{array}{c}\text { Teor de SRA } \\
(\%)\end{array}$ & $\begin{array}{c}\text { Teor de SCA } \\
(\%)\end{array}$ & $\begin{array}{c}\text { Relação } \\
\text { água/aglomerante }\end{array}$ & Idades de ensaio \\
\hline 4NSA0 &  & --- & 0,40 & \multirow{4}{*}{$\begin{array}{c}6 \text { horas, } 12 \text { horas, } 1 \text { dia, } 3 \\
\text { dias, } 7 \text { dias e } 28 \text { dias }\end{array}$} \\
\hline 4NSA5 & ------ & 5,00 & 0,40 & \\
\hline 4NSA10 & ----- & 10,00 & 0,40 & \\
\hline 4NSA15 & ----- & 15,00 & 0,40 & \\
\hline 4NSB0 & ----- & ----- & 0,48 & \multirow{8}{*}{$\begin{array}{c}6 \text { horas, } 12 \text { horas, } 1 \text { dia, } 3 \\
\text { dias, } 7 \text { dias e } 28 \text { dias }\end{array}$} \\
\hline 4NSB0,5 & 0,50 & ----- & 0,48 & \\
\hline 4NSB1 & 1,00 & ------ & 0,48 & \\
\hline 4NSB1,5 & 1,50 & ----- & 0,48 & \\
\hline 4NSB2 & 2,00 & ----- & 0,48 & \\
\hline 4NSB5 & ----- & 5,00 & 0,48 & \\
\hline 4NSB10 & ----- & 10,00 & 0,48 & \\
\hline 4NSB15 & ----- & 15,00 & 0,48 & \\
\hline $4 \mathrm{NSCO}$ & ----- & ----- & 0,56 & \multirow{4}{*}{$\begin{array}{l}6 \text { horas, } 12 \text { horas, } 1 \text { dia, } 3 \\
\text { dias, } 7 \text { dias e } 28 \text { dias }\end{array}$} \\
\hline $4 \mathrm{NSC} 5$ & ----- & 5,00 & 0,56 & \\
\hline 4NSC10 & ----- & 10,00 & 0,56 & \\
\hline 4NSC15 & ----- & 15,00 & 0,56 & \\
\hline
\end{tabular}

Onde:



$4 \mathrm{NSB} 0,5$

Teor de aditivo SCA ( $5 \%, 10 \%$ ou $15 \%)$ ou SRA $(0,5 \%, 1 \%, 1,5 \%$ ou $2 \%)$ $\rightarrow$ Escória ativada com $4,5 \% \mathrm{Na}_{2} \mathrm{O}+7,65 \% \mathrm{SiO}_{2}, \mathrm{MS}=1,7$

\subsubsection{Análise por difração de raios $X(D R X)$}

O planejamento experimental do ensaio de DRX foi similar ao do ensaio de termogravimetria, porém com variações dos teores de aditivos, relação água/aglomerante e de algumas idades ensaiadas. Com base no levantamento bibliográfico, optou-se por analisar com maior detalhe o efeito do aditivo SCA no cimento de escória, pois os produtos hidratados formados por este tipo de aditivo, sendo mais cristalinos, possivelmente permitiriam melhor identificação no ensaio de DRX. Portanto, o aditivo SRA não foi testado no teor de $2 \%$ e nem na idade de 6 horas, conforme detalhado na Tabela 3.5. Este arranjo experimental permitirá concluir: (a) influência da relação água/aglomerante na hidratação sem a utilização de aditivos, (b) influência da relação água/aglomerante na hidratação com a utilização do aditivo SCA e (c) o efeito do aditivo SRA na hidratação das misturas com relação água/aglomerante igual a 0,48. 
Tabela 3.5 - Arranjo experimental dos ensaios de difração de raios X (DRX).

\begin{tabular}{|c|c|c|c|c|}
\hline $\begin{array}{l}\text { Mistura } \\
\text { (nomenclatura) }\end{array}$ & $\begin{array}{c}\text { Teor de SRA } \\
(\%)\end{array}$ & $\begin{array}{c}\text { Teor de SCA } \\
(\%)\end{array}$ & $\begin{array}{c}\text { Relação } \\
\text { água/aglomerante }\end{array}$ & Idades de ensaio \\
\hline 4NSA0 & $-\cdots$ & $-1---$ & 0,40 & \multirow{4}{*}{$\begin{array}{c}6 \text { horas, } 12 \text { horas, } 1 \text { dia, } 3 \\
\text { dias, } 7 \text { dias e } 28 \text { dias }\end{array}$} \\
\hline 4NSA5 & ----- & 5,00 & 0,40 & \\
\hline 4NSA10 & ------ & 10,00 & 0,40 & \\
\hline 4NSA15 & ------ & 15,00 & 0,40 & \\
\hline 4NSB0 & ------ & ----- & 0,48 & $\begin{array}{c}6 \text { horas, } 12 \text { horas, } 1 \text { dia, } 3 \\
\text { dias, } 7 \text { dias e } 28 \text { dias }\end{array}$ \\
\hline 4NSB0,5 & 0,50 & ----- & 0,48 & \multirow{2}{*}{$\begin{array}{c}12 \text { horas, } 1 \text { dia, } 3 \text { dias, } 7 \\
\text { dias e } 28 \text { dias }\end{array}$} \\
\hline $\begin{array}{l}\text { 4NSB1 } \\
\text { 4NSB1 } 5\end{array}$ & 1,00 & ---- & 0,48 & \\
\hline $\begin{array}{l}\text { 4NSB1,5 } \\
\text { 4NSB5 }\end{array}$ & $\begin{array}{l}1,50 \\
----\end{array}$ & 5,00 & $\begin{array}{l}0,48 \\
0,48\end{array}$ & \multirow{3}{*}{$\begin{array}{l}6 \text { horas, } 12 \text { horas, } 1 \text { dia, } 3 \\
\text { dias, } 7 \text { dias e } 28 \text { dias }\end{array}$} \\
\hline 4NSB10 & -.---- & 10,00 & 0,48 & \\
\hline 4NSB15 & ----- & 15,00 & 0,48 & \\
\hline $4 \mathrm{NSCO}$ & ------ & ----- & 0,56 & \multirow{4}{*}{$\begin{array}{l}6 \text { horas, } 12 \text { horas, } 1 \text { dia, } 3 \\
\text { dias, } 7 \text { dias e } 28 \text { dias }\end{array}$} \\
\hline 4NSC5 & ------ & 5,00 & 0,56 & \\
\hline 4NSC10 & ------ & 10,00 & 0,56 & \\
\hline 4NSC15 & ----- & 15,00 & 0,56 & \\
\hline
\end{tabular}

\subsubsection{Porosimetria}

Com base na disponibilidade do equipamento de porosimetria e no custo elevado de cada ensaio no mesmo, optou-se pela realização do testes com os aditivos SCA e SRA apenas com a relação água/aglomerante igual a 0,48 e nas idades de 1, 3, 7 e 28 dias. Para análise do efeito da relação água/aglomerante nas misturas de referência, sem a utilização de aditivos, foram realizados ensaios em misturas com todas as relações água/aglomerante $(0,40,0,48$ e 0,56) nas idades de 12 horas, 1, 3,7 e 28 dias. A Tabela 3.6 exemplifica o arranjo experimental, o qual permitirá concluir: (a) influência da relação água/aglomerante na hidratação sem a utilização de aditivos e (b) o efeito do aditivo SCA e SRA na hidratação das misturas com relação água/aglomerante igual a 0,48. 
Tabela 3.6 - Arranjo experimental do ensaio de porosimetria.

\begin{tabular}{|c|c|c|c|c|}
\hline $\begin{array}{l}\text { Mistura } \\
\text { (nomenclatura) }\end{array}$ & $\begin{array}{c}\text { Teor de SRA } \\
(\%)\end{array}$ & $\begin{array}{c}\text { Teor de SCA } \\
(\%)\end{array}$ & $\begin{array}{c}\text { Relação } \\
\text { água/aglomerante }\end{array}$ & Idades de ensaio \\
\hline 4NSA0 & ---- & ---- & 0,40 & $\begin{array}{c}12 \text { horas, } 1 \text { dia, } 3 \text { dias, } 7 \\
\text { dias e } 28 \text { dias }\end{array}$ \\
\hline 4NSBO & ------ & ------ & 0,48 & $\begin{array}{c}12 \text { horas, } 1 \text { dia, } 3 \text { dias, } 7 \\
\text { dias e } 28 \text { dias }\end{array}$ \\
\hline 4NSB0,5 & 0,50 & ----- & 0,48 & \\
\hline 4NSB1 & 1,00 & ------ & 0,48 & \\
\hline 4NSB1,5 & 1,50 & ------ & 0,48 & \\
\hline 4NSB2 & 2,00 & ------ & 0,48 & 1 dia, 3 dias, 7 dias e 28 dias \\
\hline 4NSB5 & ----- & 5,00 & 0,48 & \\
\hline 4NSB10 & ------ & 10,00 & 0,48 & \\
\hline 4NSB15 & ------ & 15,00 & 0,48 & \\
\hline 4NSC0 & ------ & ------ & 0,56 & $\begin{array}{c}12 \text { horas, } 1 \text { dia, } 3 \text { dias, } 7 \\
\text { dias e } 28 \text { dias }\end{array}$ \\
\hline
\end{tabular}

\subsection{Materiais empregados}

\subsubsection{Escória de alto-forno}

A escória de alto forno foi doada (Cimento Mizu S/A) já moída com uma finura Blaine de $470 \mathrm{~m}^{2} / \mathrm{kg}$, constando na Tabela 3.7 os ensaios de caracterização. A caracterização química da escória foi realizada por fluorescência de raios-X no Laboratório de Caracterização Tecnológica (LCT) do Departamento de Minas e Petróleo da USP. Analisando o resultado (Tabela 3.7), classifica-se como sendo uma escória básica, pois a relação $\mathrm{CaO} / \mathrm{SiO}_{2}$ é igual a 1,31 (>1), o que atende aos requisitos do projeto para a sua utilização como aglomerante.

$\mathrm{Na}$ caracterização com a difração de raios-X (Figura 3.1), observa-se que a escória apresenta um halo amorfo com centro próximo ao ângulo $2 \Theta$ igual a $30^{\circ}$ e a presença de alguns picos cristalinos correspondentes às espécies químicas carbonato de cálcio, mervinita, gelenita, óxido de silício e akermanita. A metodologia aplicada na identificação das fases no ensaio de difração de raios- $X$ está descrita no item 3.5.6 e do ensaio de termogravimetria e calorimetria exploratória diferencial (DSC) no item 3.5.4.

No resultado do ensaio de termogravimetria (Figura 3.2a), ressalta-se: a presença de carbonato de cálcio, caracterizada pelo pico de descarbonatação próximo a $700^{\circ} \mathrm{C}$; uma leve perda de massa, provavelmente em razão da umidade no material, 
com pico máximo em torno de $100^{\circ} \mathrm{C}$; e um leve ganho de massa, provavelmente em razão da reação entre o nitrogênio utilizado na atmosfera do ensaio e o silício presente na escória resultando no nitreto de silício (WŁODEK et al., 2007), com pico máximo em torno de $960^{\circ} \mathrm{C}$.

Tabela 3.7 - Características físicas e químicas da escória de alto forno.



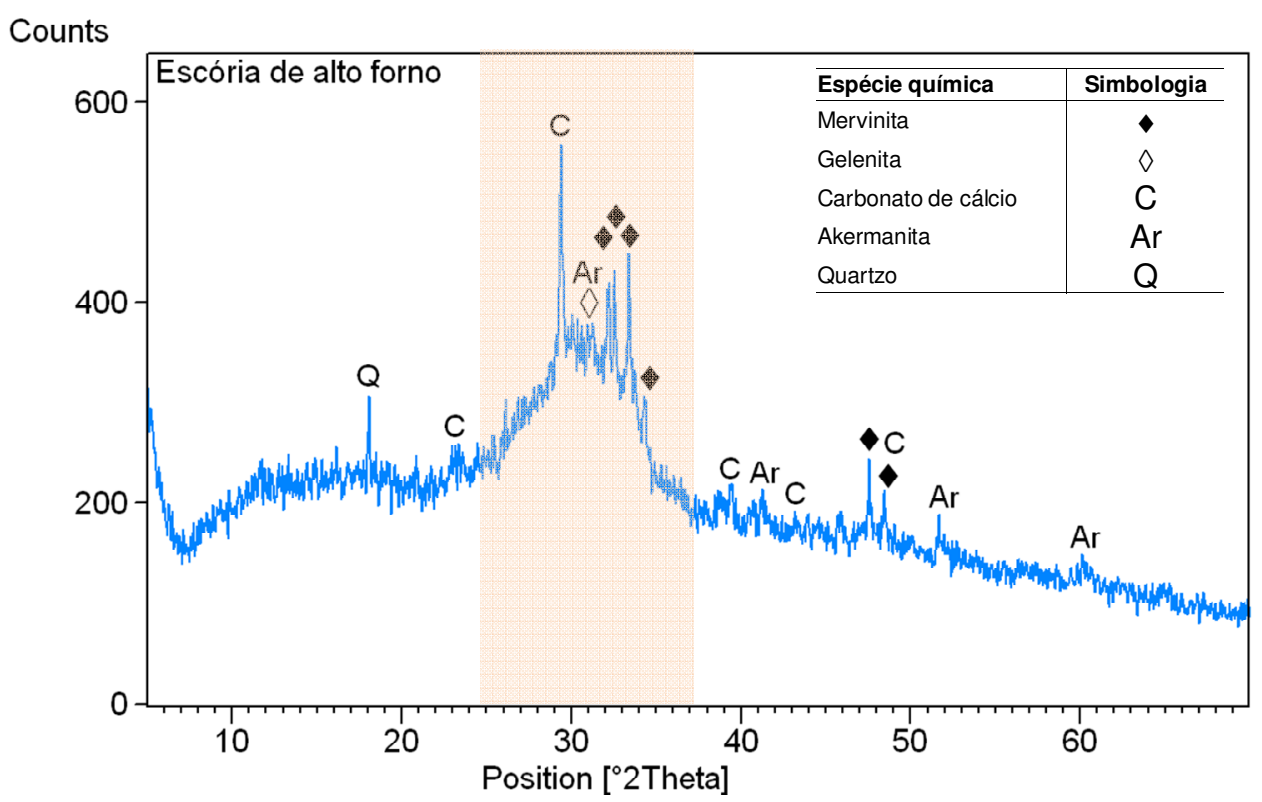

Figura 3.1 - Difratograma da escória de alto forno anidra.

$10 D_{10}=$ Diâmetro no qual $10 \%$ das partículas passam (tamanho medido por volume). $\mathrm{D}_{50}=$ Diâmetro no qual $50 \%$ das partículas passam (tamanho medido por volume).

$D_{90}=$ Diâmetro no qual $90 \%$ das partículas passam (tamanho medido por volume) .

$\mathrm{D}_{[4,3]}=$ Média da distribuição do tamanho de partículas medida pelo seu volume, também denominado como diâmetro médio de Herdan ou de Brouckere (BRITO et al., 2005; MANICKUM; VERBEEK, 1994).

$D_{[3,2]}=$ Média da distribuição do tamanho de partículas medida pela sua superfície, também denominado como diâmetro médio de Sauter (BRITO et al., 2005) 
A cristalização da escória é evidenciada no ensaio de calorimetria exploratória diferencial (DSC) (Figura 3.2b), onde se observa: um pico endotérmico $\left(689,4^{\circ} \mathrm{C}\right)$ referente à dissociação do dióxido de carbono do carbonato de cálcio; uma alteração endotérmica em torno de $774^{\circ} \mathrm{C}$ do patamar da linha base, referente à transição vítrea da escória (DUBRAWSKI, 1997; FREDERICCI et al., 2000); e dois picos exotérmicos $\left(845,7^{\circ} \mathrm{C}\right.$ e $\left.929,9^{\circ} \mathrm{C}\right)$ indicando a cristalização da escória (DUBRAWSKI, 1997; FREDERICCl et al., 2000).

a)

b)


Figura 3.2 - Resultado do ensaio de termogravimetria (TG-DTG) (a) e de calorimetria exploratória diferencial (DSC) (b) da escória de alto forno anidra.

\subsubsection{Aditivo redutor de retração e aditivo compensador de retração}

O aditivo compensador de retração (SCA) utilizado foi o "Denka CSA 20" doado pela Denka, cujos resultados da caracterização constam da Tabela 3.8. O aditivo foi fornecido na forma de pó, sendo os ensaios de difração de raios-X (Figura 3.3) e fluorescência quantitativa de raios- $X$ realizados no Laboratório de Caracterização Tecnológica (LCT) do Departamento de Minas e Petróleo da USP. De acordo com a composição química e o difratograma, confirma-se que o aditivo SCA tem como principais componentes sulfoaluminato de cálcio, sulfato de cálcio e óxido de cálcio (NAGATAKI; GOMI, 1998), e em menor teor portlantida, óxido de magnésio, sulfato de alumínio e aluminato de cálcio. No resultado do ensaio de termogravimetria (Figura 3.4), identifica-se apenas o pico de desidratação da portlandita na temperatura em torno de $430^{\circ} \mathrm{C}$. É provável que esta espécie química seja oriunda da hidratação do óxido de cálcio durante o transporte e armazenamento do produto. 
Tabela 3.8 - Características físicas e químicas do aditivo compensador de retração (SCA).

\begin{tabular}{|c|c|c|c|c|c|c|c|}
\hline \multirow{2}{*}{\multicolumn{4}{|c|}{$\begin{array}{l}\text { Características físicas } \\
\text { Massa específica: } 2,96 \mathrm{~g} / \mathrm{cm}^{3} \\
\text { Finura Blaine: } 500 \mathrm{~m}^{2} / \mathrm{kg} \\
\text { Área específica (gran.laser): } 512 \mathrm{~m}^{2} / \mathrm{kg}\end{array}$}} & \multicolumn{2}{|c|}{ - Distribuição discreta (\%) } & \multicolumn{2}{|c|}{ - - Distribuição acumulada (\%) } \\
\hline & & & & \multirow{8}{*}{  } & \multirow[t]{7}{*}{$\begin{array}{l}\text { Aditivo compensador de } \\
\text { retração (SCA) }\end{array}$} & & \multirow{8}{*}{  } \\
\hline \multicolumn{4}{|c|}{ Diâmetro médio das partículas ( $\mu \mathrm{m})$} & & & & \\
\hline \multicolumn{2}{|c|}{$\begin{array}{ll}D_{10}=1,62 & D_{5} \\
D_{[4,3]}=13,85 & D_{[3} \\
\end{array}$} & $\begin{array}{l}3,29 \quad D_{90}=33 \\
3,96\end{array}$ & & & & & \\
\hline \multicolumn{4}{|c|}{ Composição química (\%) } & & & & \\
\hline $\mathrm{CaO}$ & 53,10 & $\mathrm{Fe}_{2} \mathrm{O}_{3}$ & 0,46 & & & & \\
\hline $\mathrm{SO}_{3}$ & 27,70 & $\mathrm{TiO}_{2}$ & 0,12 & & & & \\
\hline $\mathrm{AL}_{2} \mathrm{O}_{3}$ & 11,00 & $\mathrm{P}_{2} \mathrm{O}_{5}$ & 0,05 & & & & \\
\hline $\mathrm{MgO}$ & 1,37 & $\mathrm{Na}_{2} \mathrm{O}$ & 0,0 & & & & \\
\hline $\mathrm{SiO}_{2}$ & 0,95 & Perda ao Fogo & 5,10 & & Diés & $o(\mu \mathrm{m})$ & 1000,0 \\
\hline
\end{tabular}



Figura 3.3 - Difratograma do aditivo compensador de retração (SCA) anidro.



Figura 3.4 - Resultado do ensaio de termogravimetria (TG-DTG) do aditivo compensador de retração (SCA) anidro. 
Foi utilizado o aditivo redutor de retração (SRA) "Eclipse" produzido pela Grace Brasil, pois se encontra disponível no mercado e é específico para a redução da retração. $O$ aditivo foi fornecido na forma líquida (densidade $=0,96 \mathrm{~g} / \mathrm{cm}^{3}$ ) e tem como base química o polipropileno glicol segundo dados fornecidos pelo fabricante.

\subsubsection{Silicato de sódio}

O silicato de sódio foi fornecido pela Ineos Sílicas Brasil Ltda com um módulo de sílica (MS) (relação $\mathrm{SiO}_{2} / \mathrm{Na}_{2} \mathrm{O}$, em massa) igual a 3,3. Para corrigir este módulo com o intuito de obter-se o valor fixado igual a 1,7, foi adicionada solução de hidróxido de sódio, cujo procedimento de preparo está detalhado no item 3.5.1. Foram retiradas amostras e enviadas para a determinação do teor de óxidos $\left(\mathrm{Na}_{2} \mathrm{O}\right.$ e $\mathrm{SiO}_{2}$ ) no Instituto de Pesquisas Tecnológicas de São Paulo - IPT As características do silicato de sódio e do hidróxido de sódio estão apresentadas na Tabela 3.9.

Tabela 3.9 - Composição química do silicato de sódio (determinado pelo IPT) e do hidróxido de sódio fornecido pelo fabricante (\% em massa).

\begin{tabular}{c|c|c}
\hline Elemento químico & Silicato de sódio (\%) & Hidróxido de sódio (\%) \\
\hline $\mathrm{Na}_{2} \mathrm{O}$ & 9,20 & 77,50 \\
$\mathrm{SiO}_{2}$ & 29,90 & ----- \\
$\mathrm{H}_{2} \mathrm{O}$ & 60,90 & ---- \\
\hline
\end{tabular}

\subsubsection{Areia}

No preparo dos corpos-de-prova de argamassa foi utilizada a areia quartzosa, lavada, passada na peneira de abertura de $4,8 \mathrm{~mm}$ e a secagem da fração passante em estufa (105ํ $\mathrm{C}$ por 24 horas) e armazenamento para a espera de utilização. As características físicas e a distribuição granulométrica da areia estão apresentadas na Tabela 3.10. 
Tabela 3.10 - Características físicas e distribuição granulométrica da areia quartzosa.



\subsection{Procedimentos de ensaio}

\subsubsection{Preparo e moldagem das argamassas}

As argamassas foram preparadas em laboratório $\left(\mathrm{T}=24^{\circ} \mathrm{C}\right)$ com a proporção em massa igual a 1:2 (aglomerante: areia), sendo a relação água/aglomerante variada em: 0,40 (A), 0,48 (B) e 0,56 (C). As argamassas ativadas com silicato de sódio tiveram as soluções de ativadores dosados em massa, em relação à massa de aglomerante (escória + ativador). No cálculo foi utilizada apenas a parte sólida do ativador, ou seja, foram utilizadas apenas as concentrações de $\mathrm{Na}_{2} \mathrm{O}$ e $\mathrm{SiO}_{2}$ fornecidas pelo fabricante. A quantidade de água de composição dos ativadores foi considerada como parte da água total de mistura.

O procedimento detalhado do preparo das soluções de ativadores está descrito no trabalho de Melo Neto (2002). A solução de hidróxido de sódio foi preparada para o ajuste do módulo de sílica do silicato de sódio para o valor de 1,7, pois o material fornecido pelo fabricante apresentava módulo igual a 3,3. Após o ajuste do módulo, foram retiradas amostras e enviadas ao IPT para verificação da concentração, cujos resultados constam da Tabela 3.11. 
Tabela 3.11 - Composição química do silicato de sódio (IPT) após o ajuste do módulo de sílica (MS) (\% em massa).

\begin{tabular}{c|c|c}
\hline Elemento químico & $\begin{array}{c}\text { Silicato de sódio } \\
\text { fornecido MS = 3,3 }\end{array}$ & $\begin{array}{c}\text { Silicato de sódio após o } \\
\text { ajuste para MS = 1,7 }\end{array}$ \\
\hline $\mathrm{Na}_{2} \mathrm{O}$ & $9,20 \%$ & $16,70 \%$ \\
\hline $\mathrm{SiO}_{2}$ & $29,90 \%$ & $28,40 \%$ \\
\hline $\mathrm{H}_{2} \mathrm{O}$ & $60,90 \%$ & $54,90 \%$ \\
\hline
\end{tabular}

$\mathrm{Na}$ etapa de moldagem dos corpos-de-prova, as misturas preparadas com o silicato de sódio apresentaram características auto-nivelantes, exceto para as misturas com relação água/aglomerante igual a 0,40 (A), bastando verter a argamassa nos moldes, necessitando-se de pouca vibração para o adensamento. Confirmando dados de vários autores (WANG et al., 1995; JOHN, 1995; SILVA, 1998; BAKHAREV et al., 1999), os cimentos de escória ativada com silicato de sódio têm uma rápida perda de trabalhabilidade, em torno de 20 minutos, acentuada pelo aditivo SCA (item 3.2.2).

\subsubsection{Retração por secagem e retração autógena}

A leitura da variação dimensional foi realizada de 1 até 7 dias, depois aos 9, 11, 14, 21 e 28 dias. Foram preparados em uma única batelada 8 corpos-de-prova para cada variação definida no planejamento experimental (item 3.3.2), sendo 4 corposde-prova para o ensaio de retração por secagem e 4 corpos-de-prova para o ensaio de retração autógena. O procedimento detalhado deste ensaio é descrito no trabalho realizado por Melo Neto (2002).

\subsubsection{Procedimento de ensaio}

A norma ASTM C 490 (1997) e a norma NBR 8490 (1984) foram utilizadas como referência para a realização do experimento. O ensaio de retração por secagem e de retração autógena foram realizados em corpos-de-prova prismáticos $(25 \times 25 \times 285$ $\mathrm{mm}$ ) com o objetivo de caracterizar o seu comportamento no estado livre. Após a moldagem, os corpos-de-prova foram acondicionados em câmara úmida por 24 horas. Em seguida à desmoldagem, nos corpos-de-prova destinados ao ensaio de retração por secagem foram feitas a leitura da dimensão inicial e 0 acondicionamento em câmara seca $\left(T=24^{\circ} \mathrm{C}\right.$, U.R.=50\%). Os corpos-de-prova destinados ao ensaio de retração autógena foram embalados com filme plástico de 
PVC (policloreto de vinila) e com acabamento finalizado por fita adesiva plástica de modo a garantir a total vedação do corpo-de-prova (Figura 3.5a). Após a vedação, os corpos-de-prova destinados ao ensaio de retração autógena foram acondicionados na mesma câmara seca utilizada para acondicionar os corpos-deprova destinados ao ensaio de retração por secagem.
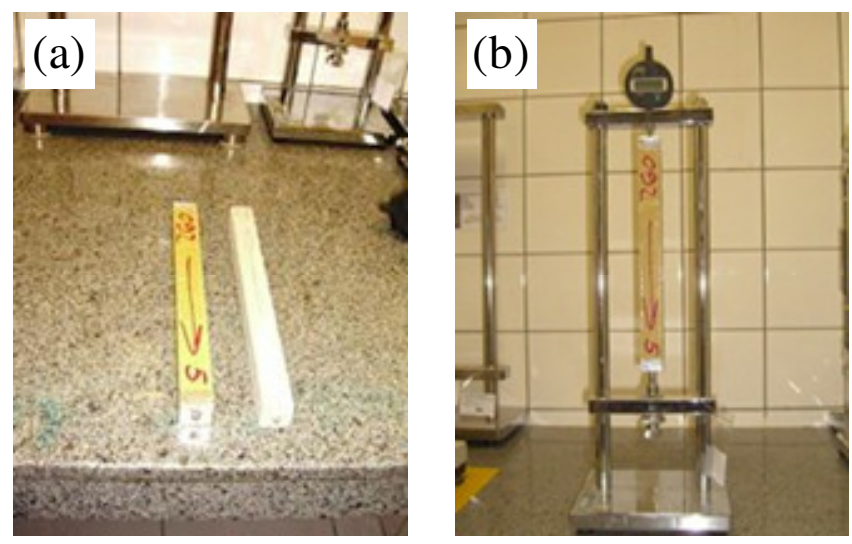

Figura 3.5 - Corpos-de-prova de retração autógena e retração por secagem (a) e aparato para a leitura da variação dimensional (b).

A eficiência da vedação foi verificada no momento da pesagem da massa dos corpos-de-prova destinados ao ensaio de retração por secagem, com a pesagem simultânea dos corpos-de-prova destinados aos ensaios de retração autógena em balança com precisão de 0,01g antes de realizar a leitura da retração. A perda de massa ocorreu, mas pode ser considerada não significativa, pois alcançou no máximo $0,18 \%$ aos 28 dias em uma das misturas, enquanto sem vedação atingiu $10,6 \%$ aos 28 dias. A variação de temperatura foi determinada com a inserção de termopares na argamassa e deformação resultante descontada dos valores obtidos no ensaio da retração por secagem e retração autógena.

\subsubsection{Resistências à compressão e à tração na flexão e módulo de elasticidade}

As propriedades mecânicas foram avaliadas nas idades de 1, 3, 7 e 28 dias. Foi utilizada a prensa hidráulica fabricada pela Shimadzu-modelo UH-200A com célula de carga de 20 toneladas para o ensaio de resistência à compressão e a prensa hidráulica fabricada pela Emic-modelo DL10000 com célula de carga de 10 toneladas para o ensaio de resistência à tração na flexão e módulo de elasticidade. 
O procedimento detalhado deste ensaio é descrito no trabalho realizado por Melo Neto (2002).

\subsubsection{Procedimento de ensaio}

Foram preparados em uma única batelada 6 corpos-de-prova para cada variação definida no planejamento experimental (item 3.3.1), com desmoldagem após 24 horas e acondicionamento em cura úmida ( $\left.T=24^{\circ} \mathrm{C}, U . R .=100 \%\right)$. Inicialmente foi realizado o ensaio de resistência à tração com aplicação da carga (2400 N/s) perpendicularmente ao sentido da maior dimensão do corpo-de-prova, no ponto central, de acordo com a BS EN - 196 parte 1 (1995). Como o corpo-de-prova é biapoiado, resultam duas metades (Figura 3.6a).

Com as duas metades restantes foram realizados os ensaios de resistência à compressão (Figura 3.6b) e módulo de elasticidade (Figura 3.6c), ou seja, foram ensaiados 6 corpos-de-prova para a resistência à compressão e 6 corpos-de-prova para a determinação do módulo de elasticidade. $O$ ensaio de resistência à compressão foi realizado de acordo com a BS EN 196 utilizando uma velocidade de carregamento igual a $2400 \mathrm{~N} / \mathrm{s}$. Para a determinação do módulo de elasticidade foram aplicados $(2400 \mathrm{~N} / \mathrm{s})$ dois ciclos a 10\% e 50\% da carga limite de ruptura estimada a partir dos resultados obtidos na resistência à compressão. Simultaneamente à aplicação de carga, as deformações resultantes foram mensuradas com a utilização de dois extensômetros acoplados (Figura 3.6c) ao corpo-de-prova, com distância base dos extensômetros igual a $16 \mathrm{~mm}$. O cálculo do módulo de elasticidade foi realizado com base na curva tensão-deformação, sendo o módulo secante determinado entre $10 \%$ e $50 \%$ da carga limite de ruptura.


Figura 3.6 - Ensaio de resistência à tração na flexão (a) e de resistência à compressão (b), de acordo com a BS EN 196 (1995). Determinação do módulo de elasticidade (c). 


\subsubsection{Análise por termogravimetria}

O ensaio foi realizado em equipamento da marca NETSZCH modelo STA 409-PG Luxx (Figura 3.7 (a)) que permite a realização simultânea da análise termogravimétrica (TG) e da calorimetria exploratória diferencial (DSC) em uma amostra.

\subsubsection{Procedimento de ensaio}

Antes do início dos ensaios, foram realizados testes em 6 amostras de carbonato de cálcio com pureza analítica nas mesmas condições de ensaio para aferição da variabilidade do equipamento. A decomposição térmica teórica do dióxido de carbono de um carbonato de cálcio puro deve incorrer na perda de massa de $43,97 \%$. Os resultados da análise indicam a excelente confiabilidade do equipamento e do ensaio, sendo obtido um valor médio de $43,54 \%$ (desvio padrão igual a $0,22 \%$ e coeficiente de variação de $1,87 \%$ ) de dióxido de carbono liberado.

Foi realizada uma determinação para cada variação definida no planejamento experimental (item 3.3.3.1). O ensaio foi realizado em pasta preparada em misturador mecânico (Figura 3.7 (b)) em uma única batelada. Em seguida, foram confeccionados os corpos-de-prova utilizando sacos plásticos como moldes. Após a moldagem, os corpos-de-prova foram estocados sob vácuo em dessecadores (Figura 3.7 (c)) contendo sílica gel, evitando a absorção de umidade, e hidróxido de bário que retém $\circ \mathrm{CO}_{2}$ do ar contido no dessecador, evitando a carbonatação até a idade estabelecida para a interrupção da hidratação. $\mathrm{Na}$ idade estabelecida para ensaio, o corpo-de-prova foi imerso em nitrogênio líquido $\left(-180^{\circ} \mathrm{C}\right)$ para $\mathrm{O}$ congelamento instantâneo da água livre, interrompendo a hidratação.

Após o congelamento, a amostra foi seccionada em pedaços, acondicionada em tubos plásticos com tampa e estocadas em refrigerador com temperatura constante de $-30^{\circ} \mathrm{C}$ até $\mathrm{O}$ momento da liofilização. A liofilização ${ }^{11}$ consiste na aplicação de

\footnotetext{
${ }^{11} \mathrm{O}$ congelamento seguido de liofilização também é denominado internacionalmente de Freeze drying.
} 
baixa pressão $\left(0,25 \times 10^{-4}\right.$ torr) e baixa temperatura $\left(-60^{\circ} \mathrm{C}\right)^{12}$, seguida de aumento gradual e lento da temperatura durante 24 horas até $20^{\circ} \mathrm{C}$, o qual proporciona a secagem da amostra por meio da sublimação da água. Este método garante que, durante a secagem, a água presente na amostra não passará para o estado líquido antes de evaporar, ou seja, a amostra não irá hidratar durante a sua secagem, estabelecendo o controle e uniformização do grau de hidratação para todas as amostras. Para a liofilização foi utilizado o liofilizador modelo LC 1500 do fabricante Terroni - Fauvel (Figura 3.7 (d)).

Outra vantagem da liofilização é proporcionar a secagem de amostras e ao mesmo tempo estabelecer atmosfera com umidade relativa inferior a $11 \%$, condição na qual é liberada a água interlamelar da estrutura do C-S-H (TAYLOR ,1997) e, assim, a perda de massa determinada durante o aquecimento será em razão apenas da água quimicamente combinada dos produtos hidratados.

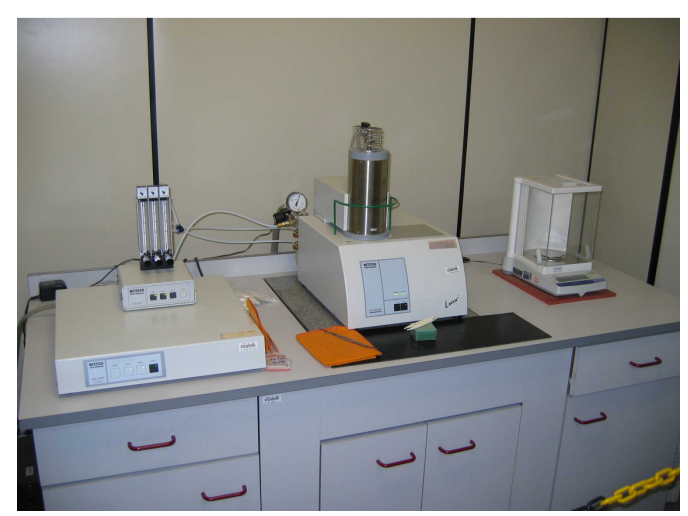

(a)



(c)



(b)



(d)

Figura 3.7 - Equipamentos utilizados no preparo e ensaio das amostras de termogravimetria

\footnotetext{
${ }^{12}$ A pressão e a temperatura aplicadas estão bem abaixo das medidas referentes ao ponto triplo da água $\left(0,01^{\circ} \mathrm{C}\right.$ e 4,58 torr) que é o ponto onde existe equilíbrio entre sólido, líquido e vapor. Em temperaturas e pressões abaixo desse ponto, é possível a passagem do estado sólido para estado de vapor (sublimação).
} 
Após a liofilização, as amostras foram moídas em almofariz e peneiradas. Foram utilizadas peneiras com aberturas de malha de $150 \mu \mathrm{m}$ e $75 \mu \mathrm{m}$, utilizando no ensaio apenas a fração retida na $75 \mu \mathrm{m}$ e passante na $150 \mu \mathrm{m}$. Este procedimento foi utilizado para homogeneizar a granulometria das amostras. A termogravimetria foi realizada com o aquecimento (taxa de $10^{\circ} \mathrm{C} / \mathrm{min}$.) de uma amostra em pó, da pasta, com cerca de $40 \mathrm{mg}$ estocada em temperatura ambiente $\left(26^{\circ} \mathrm{C}\right)$. Foi aplicado fluxo de gás nitrogênio de $60 \mathrm{ml} / \mathrm{min}$ para manutenção de atmosfera inerte. A temperatura inicial do forno foi mantida utilizando banho termo-regulador de água em $26^{\circ} \mathrm{C}$ e $\mathrm{O}$ aquecimento foi iniciado imediatamente após a inserção da amostra no seu interior. Foi utilizado um cadinho de alumina vazio como referência na realização do ensaio de DSC

\subsubsection{Porosimetria}

A distribuição e tamanho dos poros foram obtidos através do método de intrusão por mercúrio, utilizando-se um equipamento da marca Micromeritics, modelo Autopore III 9410, que detecta um diâmetro mínimo de $3 \times 10^{-9} \mathrm{~m}(3 \mathrm{~nm})$.



Figura 3.8 - Porosímetro por intrusão de mercúrio Autopore III 9410.

\subsubsection{Procedimento de ensaio}

Foi realizada uma determinação para cada variação definida no planejamento experimental (item 3.3.3.3). Foram utilizadas amostras de pasta em pedaços, as mesmas preparadas para o ensaio de termogravimetria (item 3.5.4.1). Para o cálculo 
do diâmetro do poro, assumiu-se que os poros têm formato cilíndrico, tensão superficial do mercúrio igual a $0,485 \mathrm{~N} / \mathrm{mm}^{2}$, densidade do mercúrio igual a 13,5413 $\mathrm{g} / \mathrm{cm}^{3}$, e o ângulo de contato entre o mercúrio e sólido igual a 130․․

\subsubsection{Difração de raios X (DRX)}

Este ensaio foi realizado com o objetivo de se identificar os compostos hidratados e também orientar na análise dos ensaios de termogravimetria. Foi utilizado um difratômetro PANalytical, modelo X'Pert MPD (radiação Cu a, dados coletados entre os ângulos $5^{\circ}(2 \Theta)$ e $70^{\circ}(2 \Theta)$, varredura com passo angular de $0,02^{\circ}(2 \Theta)$ com tempo de coleta de 20 segundos por passo).

\subsubsection{Procedimento de ensaio}

Foi realizada uma determinação para cada para cada variação definida no planejamento experimental (item 3.3.3.2). As amostras foram obtidas pelo mesmo procedimento empregado para a análise por termogravimetria, descrito no item 3.5.4.1. A pasta em pó foi prensada manualmente formando as pastilhas necessárias para o ensaio. A identificação das fases cristalinas foi obtida por comparação do difratograma da amostra com o banco de dados do ICDD International Centre for Diffraction Data realizada automaticamente pelo programa computacional do difratômetro. As fases também foram identificadas com base em Taylor (1997), John (1995), Silva (1998), Oliveira (2000) e Melo Neto (2002) 


\section{Parte 2}

Aditivo redutor de retração (SRA) 


\section{Capítulo 4 Difração de raios $X$}

\subsection{Introdução}

O ensaio de difração de raios $X$ foi realizado com o intuito de observar possíveis alterações na formação dos produtos hidratados do cimento de escória ativada com silicato de sódio, em três relações água/aglomerante, e com a utilização dos aditivos redutor (SRA) e compensador (SCA) de retração. A identificação dos compostos foi realizada por comparação do difratograma da amostra com o banco de dados do ICDD - International Centre for Diffraction Data e com base em Taylor (1997), John (1995), Silva (1998), Oliveira (2000) e Melo Neto (2002). No apêndice C constam as fichas do ICDD utilizadas na identificação dos compostos, assim como os resultados de todas as amostras ensaiadas. Apesar de ser considerado um método semi-quantitativo, a comparação da intensidade dos picos principais observados na difração de raios X é indicativa da evolução da hidratação do cimento de escória. A identificação dos compostos e a quantificação da evolução da intensidade dos picos principais estão ilustradas nas figuras constantes deste capítulo.

\subsection{Efeito da relação água/aglomerante}

Da Figura 4.1 até a Figura 4.6 constam os difratogramas do cimento de escória ativada com silicato de sódio com três relações a/agl. Confirmando os dados do levantamento bibliográfico, observa-se a formação de um pico principal do C-S-H tipo I no ângulo ${ }^{\circ} 2 \Theta=29,36(\mathrm{~d}(\AA)=3,040)$ e de dois picos relacionados à hidrotalcita no ângulo de ${ }^{\circ} 2 \Theta=11,27(d(\AA)=7,844)$ e no ângulo de ${ }^{\circ} 2 \Theta=22,70(d(\AA)=3,914)$. Conforme descrito na análise do difratograma da escória anidra (item 3.4.1, pág.48), observa-se a existência de um pico referente à calcita na mesma faixa angular do C-S-H, o que poderia dificultar a análise. No entanto, com o avanço da hidratação ocorre o nítido aumento do pico nesta faixa, podendo o mesmo ser atribuído apenas 
à formação do C-S-H. Esta afirmação é coerente com os resultados de termogravimetria que confirmam o aumento da quantidade de $\mathrm{C}-\mathrm{S}-\mathrm{H}$ sem que se tenha o aumento da quantidade de calcita.

$\mathrm{Na}$ mistura com relação a/agl igual a 0,40 com 6 horas de idade (Figura 4.1) e na mistura com relação a/agl igual a 0,48 com 28 dias de idade (Figura 4.6) existe a presença de um pico referente à formação do C-S-H do tipo II no ângulo de $02 \Theta=26,59(\mathrm{~d}(\AA)=3,35)$. O C-S-H(I) e C-S-H(II) estão associados às fases cristalinas tobermorita $\left(\mathrm{C}_{5} \mathrm{~S}_{6} \mathrm{H}_{9}\right)$ e jenita $\left(\mathrm{C}_{9} \mathrm{~S}_{6} \mathrm{H}_{11}\right)$, respectivamente (TAYLOR, 1997). Contribui para esta identificação o fato da escória de alto forno anidra apresentar relação $\mathrm{C} / \mathrm{S}$ $\left(\mathrm{CaO} / \mathrm{SiO}_{2}\right)$ em torno de 1,3. Portanto, o C-S-H formado na ativação da escória com silicato de sódio deve apresentar relação C/S inferior a 1,3; visto que não existe nenhuma fonte externa de cálcio; o que é congruente com a relação $\mathrm{C} / \mathrm{S}$ teórica dos tipos de C-S-H identificados.

Para todas as relações a/agl estudadas, o C-S-H do tipo I foi composto de maior intensidade dentre os compostos identificados. Com o avanço da idade, a evolução da hidratação é constatada pelo crescimento do pico principal do C-S-H no ângulo o2 $\Theta=29,36(d(\AA)=3,040)$. Ocorre também a formação da hidrotalcita, observada com maior evidência pelo aumento do pico no ângulo de $\stackrel{\circ}{2} \Theta=22,70(\mathrm{~d}(\AA)=3,914)$ na Figura 4.5 e Figura 4.6. O pico é identificável com maior evidência nas amostras com maior relação a/agl e após 7 dias de hidratação.



Figura 4.1 - Efeito da relação a/agl na difração de raios X com 6 horas de idade. 




Figura 4.2 - Efeito da relação a/agl na difração de raios X com 12 horas de idade.



Figura 4.3 - Efeito da relação a/agl na difração de raios $X$ com 1 dia de idade.



Figura 4.4 - Efeito da relação a/agl na difração de raios X com 3 dias de idade. 




Figura 4.5 - Efeito da relação a/agl na difração de raios $\mathrm{X}$ com 7 dias de idade.



Figura 4.6 - Efeito da relação a/agl na difração de raios $X$ com 28 dias de idade.

Na Figura 4.7 está apresentado o efeito da relação a/agl na evolução da intensidade do pico principal do C-S-H no ângulo ${ }^{\circ} 2 \Theta=29,36(d(\AA)=3,040)$. Observa-se que o aumento da relação a/agl incorre no retardo da hidratação, pois o momento de aceleração constatado foi de 6 horas a 12 horas para a relação a/agl igual a 0,40,12 horas a 1 dia para a relação 0,48 e entre 1 e 3 dias para a relação a/agl igual a 0,56. Apesar de apresentar resultados a partir de 6 horas de hidratação, é de se supor que este comportamento seja decorrente de alterações na aglomeração inicial com o aumento da relação a/agl, refletindo no desenvolvimento da hidratação. Conforme descrito no capítulo de análise da porosidade, esta alteração da aglomeração inicial é fisicamente refletida nos resultados da porosidade deste tipo de cimento. 



Figura 4.7 - Efeito da relação a/agl na evolução da intensidade do pico principal do C-S-H no ângulo ${ }^{\circ} 2 \Theta=29,36(d(\AA)=3,040)$ a 6 e 12 horas e aos $1,3,7$ e 28 dias.

Na Figura 4.8 consta a evolução da intensidade do pico de C-S-H determinado pelo ensaio de difração de raios X. Observa-se que, independentemente da relação a/agl empregada, ocorre o aumento da intensidade do pico com o avanço da idade. No detalhamento nas primeiras idades (Figura 4.9), constata-se o retardo da hidratação com o aumento da relação a/agl, porém, aos 28 dias, a intensidade do pico de C-S$\mathrm{H}$ é similar para todas as relações a/agl ensaiadas. Este fato reflete apenas a evolução das reações químicas de hidratação do cimento de escória ativada com silicato de sódio, pois, sabe-se que o aumento da relação a/agl tem efeito significativo nas propriedades mecânicas. 




Figura 4.8 - Efeito da relação a/agl na intensidade do pico principal de C-S-H determinado no ensaio de difração de raios $X$ até os 28 dias de idade.



Figura 4.9 - Detalhamento do efeito da relação a/agl na intensidade do pico principal de C-S-H determinado no ensaio de difração de raios $X$ nas primeiras idades.

\subsection{Efeito do aditivo redutor de retração (SRA)}

Da Figura 4.10 até a Figura 4.14 constam os difratogramas do cimento de escória ativada com silicato de sódio com relação a/agl igual a 0,48 e a utilização de 0,5\%, $1 \%$ e $1,5 \%$ de aditivo redutor de retração (SRA). Observa-se que os resultados de difração de raios $X$ indicam que o aditivo SRA não interagiu quimicamente com os compostos hidratados do cimento de escória a ponto de se identificar algum composto diferente do observado na mistura sem utilização de aditivo. O C-S-H(I), com pico identificado no ângulo ${ }^{\circ} 2 \Theta=29,36(d(\AA)=3,040)$, continua sendo o principal produto hidratado do cimento de escória ativada com silicato de sódio. Observa-se também a formação da hidrotalcita, mais evidente aos 7 e 28 dias com o aumento do pico no ângulo de ${ }^{\circ} 2 \Theta=22,70(d(\AA)=3,914)$ (Figura 4.13 e Figura 4.14). 




Figura 4.10 - Efeito do teor de aditivo redutor de retração (SRA) na difração de raios $X$ da pasta de cimento de escória com 12 horas de idade. a/agl = 0,48.



Figura 4.11 - Efeito do teor de aditivo reduto de retração (SRA) na difração de raios $X$ da pasta de cimento de escória com 1 dia de idade. $\mathrm{a} / \mathrm{agl}=0,48$.



Figura 4.12 - Efeito do teor de aditivo reduto de retração (SRA) na difração de raios $X$ da pasta de cimento de escória com 3 dias de idade. a/agl = 0,48. 




Figura 4.13 - Efeito do teor de aditivo reduto de retração (SRA) na difração de raios $X$ da pasta de cimento de escória com 7 dias de idade. a/agl = 0,48.



Figura 4.14 - Efeito do teor de aditivo reduto de retração (SRA) na difração de raios $X$ da pasta de cimento de escória com 28 dias de idade. a/agl = 0,48.

Na Figura 4.15 está apresentado o efeito do teor de aditivo redutor de retração (SRA) na evolução da intensidade do pico principal do C-S-H no ângulo ${ }^{\circ} 2 \Theta=29,36$ $(d(\AA)=3,040)$. O principal efeito do aditivo SRA é o retardo do desenvolvimento da hidratação, constatado pela alteração do momento de aceleração da hidratação, o qual passa de 12 horas para 1 dia com 0,5\% de SRA e para 3 dias com 1\% e 1,5\% de SRA. Conforme descrito anteriormente, o aditivo SRA não interage quimicamente com os compostos hidratados do cimento de escória ativada a ponto de formar um novo composto hidratado. No entanto, é possível que ocorra algum efeito físicoquímico entre o aditivo e as partículas do aglomerante nas primeiras idades que interfira na aglomeração inicial do cimento de escória, causando o retardo do desenvolvimento da hidratação. 



Figura 4.15 - Efeito do teor de aditivo redutor de retração (SRA) na evolução da intensidade do pico principal do C-S-H no ângulo $\stackrel{\circ}{2} \Theta=29,36(d(\AA)=3,040)$ a 12 horas e aos $1,3,7$ e 28 dias. 
Segundo Brooks et al. (2000), a diminuição da tensão superficial da água do poro pode causar a redução das forças de atração interpartículas durante a fase de floculação, resultando no retardo das reações de hidratação e do desenvolvimento das propriedades mecânicas. He et al. (2006) acompanharam a hidratação por meio da variação da resistividade e do calor de hidratação, observando que realmente ocorre um retardo da hidratação do concreto. Os autores supõem, que na fase inicial de dissolução, o aditivo SRA pode interagir com os íons precipitados da hidratação do cimento e isto levaria ao retardo do desenvolvimento da microestrutura.

Os resultados do efeito do aditivo SRA no cimento de escória ativada obtidos nesta tese corroboram e confirmam que este tipo de aditivo interfere na hidratação do cimento de escória, provocando o retardo do desenvolvimento da microestrutura e redução da formação dos produtos hidratados. A Figura 4.16 embasa a afirmação de que o aditivo redutor de retração, além de retardar o desenvolvimento da hidratação (Figura 4.17) nas primeiras idades, reduz a quantidade total de $\mathrm{C}-\mathrm{S}-\mathrm{H}$ formado. $\mathrm{O}$ retardo para $0,5 \%$ de aditivo SRA foi de 1 dia, mas com formação contínua em seguida. Para 1\% e 1,5\% de aditivo SCA, a evolução é praticamente igual quando se iniciou a formação do C-S-H aos 3 dias, crescendo até os 7 dias e estabilizando em seguida. Os resultados de termogravimetria (Capítulo 5, pág.74) também sustentam esta afirmação.



Figura 4.16 - Efeito do teor de aditivo redutor de retração (SRA) na intensidade do pico principal de C-S-H determinado no ensaio de difração de raios $X$ até os 28 dias de idade. 




Figura 4.17 - Detalhamento do efeito do teor de aditivo redutor de retração (SRA) na intensidade do pico principal de C-S-H determinado no ensaio de difração de raios $\mathrm{X}$ nas primeiras idades.

\subsection{Discussão e conclusões}

\subsubsection{Efeito da relação água/aglomerante}

Os principais compostos identificados no ensaio de difração de raios $\mathrm{X}$ foram 0 silicato de cálcio hidratado (C-S-H) do tipo I e a hidrotalcita, confirmando os dados do levantamento bibliográfico. Também foram identificados picos referentes ao C-S$\mathrm{H}$ do tipo II, porém, de modo aleatório, sem seguir nenhum padrão que pudesse caracterizar uma situação específica. De acordo com os resultados obtidos, o aumento da relação a/agl afeta a hidratação do cimento de escória ativada com silicato de sódio com maior intensidade nas primeiras idades, provocando um retardo do desenvolvimento das reações de hidratação. Porém, com o avanço da idade, as reações de hidratação se desenvolvem e não há diferença significativa entre as intensidades do pico principal do C-S-H determinado pela difração de raios $X$ aos 28 dias nas misturas estudadas.

Ressalta-se que este ensaio permite detalhar 0 conhecimento sobre 0 desenvolvimento das reações de hidratação do cimento de escória ativada, o que pode não representar o desenvolvimento do efeito físico do mesmo. Este comportamento é detalhado nos capítulos de análise da porosidade (Capítulo 6, pág.82) e das propriedades mecânicas (Capítulo 7, pág.97). 


\subsubsection{Efeito do aditivo redutor de retração (SRA)}

Não foi constatada a interação química entre o aditivo SRA e o cimento de escória ativada com silicato de sódio, pois nenhum composto foi identificado além do que já tinha se observado na mistura sem utilização de aditivo. De acordo com os resultados de difração de raios $\mathrm{X}$, o efeito mais intenso do aditivo redutor de retração (SRA) no cimento de escória ativada com silicato de sódio foi o retardo significativo do desenvolvimento do C-S-H. Nas idades iniciais, a utilização do aditivo SRA provocou o retardo de até 3 dias no avanço das reações de hidratação, constatado pela redução da intensidade do pico principal do C-S-H. O teor de $0,5 \%$ de SRA apresentou uma retardo de 1 dia no desenvolvimento da hidratação, mas logo em seguida apresentou comportamento mais próximo ao observado sem a utilização do aditivo. Com aumento do teor de aditivo ocorreu a redução significativa da intensidade do pico principal do C-S-H aos 28 dias.

Os resultados obtidos indicam que o aditivo interfere de forma mais intensa no comportamento físico da formação da matriz porosa e na dinâmica de perda de água do cimento de escória ativada com silicato de sódio. Porém, o desenvolvimento das reações químicas de hidratação também é afetado pelo efeito físico do aditivo SRA, provavelmente, por interferir no desenvolvimento da aglomeração das partículas. 


\section{Capítulo 5 \\ Termogravimetria}

\subsection{Identificação e quantificação dos produtos hidratados}

Com base no levantamento bibliográfico (Capítulo 2, item 2.3, pág. 19) e comprovado nos ensaios realizados, apresentado no capitulo anterior, sabe-se que o cimento de escória ativada com silicato de sódio tem como produtos hidratados principais o C-S-H e a hidrotalcita até os 28 dias. O tratamento por freeze-dry das amostras, descrito no item 3.5.4, permite afirmar que a água presente nos produtos hidratados esteja apenas quimicamente combinada, com quantidades mínimas de água adsorvida. Na análise por termogravimetria, o C-S-H é caracterizado pelo início da sua decomposição em torno de $50^{\circ} \mathrm{C}$ e final até em torno de $500^{\circ} \mathrm{C}$, com pico máximo na faixa entre $85^{\circ} \mathrm{C}$ e $120^{\circ} \mathrm{C}$ (TAYLOR, 1997). A termogravimetria da hidrotalcita é caracterizada pelo início da decomposição em torno de $75^{\circ} \mathrm{C}$ e final até em torno de $600^{\circ} \mathrm{C}$, com pico máximo na faixa entre $300^{\circ}$ e $400^{\circ} \mathrm{C}$.

A Figura 5.1 exemplifica o resultado típico da perda de massa por termogravimetria do cimento de escória ativada com silicato de sódio e a evolução da hidratação ao longo do tempo. Utilizando-se a derivada desta curva é possível identificar os picos característicos dos principais produtos hidratados do cimento de escória ativada. $O$ pico referente ao C-S-H é o mais intenso e apresenta-se isolado (em torno de $95^{\circ} \mathrm{C}$ ), ou seja, sem sobreposição de outro pico referente a outro produto hidratado. Esta característica permite a quantificação do C-S-H formado em uma faixa específica, fornecendo informações sobre o grau de hidratação do cimento. Neste trabalho foi adotada a faixa de $30^{\circ} \mathrm{C}$ até $300^{\circ}$ para a quantificação do $\mathrm{C}-\mathrm{S}-\mathrm{H}$, conforme consta na Figura 5.2, que se mostrou adequada por abranger maior parte da decomposição do C-S-H.

Além do C-S-H, apenas a hidrotalcita pode ser identificada com a termogravimetria, sendo a mesma caracterizada por um evento térmico em torno de $350^{\circ} \mathrm{C}$. A quantificação da hidrotalcita pela termogravimetria mostrou que não houve variação 
significativa com o avanço da idade, sendo mantida uma perda de massa em torno de $3 \%$. Assim sendo, a análise foi realizada com base na quantificação do C-S-H com o objetivo de acompanhar a evolução da hidratação e a sua relação com o efeito observado nas demais propriedades estudadas. Todas as curvas obtidas no ensaio de termogravimetria estão apresentadas no Apêndice A.


Figura 5.1 - Perda de massa (TG/\%) e derivada da curva de perda de massa (DTG) da pasta de cimento de escória ativada com silicato de sódio (4NSA0) a 6 e 12 horas, 1,3,7 e 28 dias de idade. Relação água/aglom= 0,40.


Figura 5.2 - Exemplo da quantificação dos produtos hidratados utilizando a curva de perda de massa (TG/\%) e a derivada da curva de perda de massa (DTG) da pasta de cimento de escória ativada com silicato de sódio (4NSA0) a 6 e 12 horas, 1,3,7 e 28 dias de idade. Relação água/aglom= 0,40.

\subsection{Efeito da relação água/aglomerante}

O efeito da relação água/aglomerante no grau de hidratação, quantificado pelo teor de C-S-H formado, consta da Figura 5.3, e está detalhado para as primeiras idades na Figura 5.4. Observa-se que quanto maior a relação a/agl, maior o retardo do desenvolvimento da hidratação até 1 dia. Porém, após o retardo, o avanço das reações de hidratação é tal que aos 28 dias não há diferença entre os teores de C- 
$\mathrm{S}-\mathrm{H}$ formados nas relações a/agl estudadas. Portanto, no que diz respeito ao efeito químico, o aumento da relação a/agl apenas retarda a hidratação do cimento de escória ativada com silicato de sódio, sem alteração significativa no grau de hidratação, quantificado pelo teor de C-S-H formado, aos 28 dias. Este comportamento ressalta o efeito físico do aumento da relação a/agl no comportamento do cimento de escória ativada com silicato de sódio. É interessante ressaltar a semelhança entre o perfil destas curvas com o das curvas de evolução do C-S-H obtidas na análise dos resultados de difração de raios X (Figura $4.8 \mathrm{e}$ Figura 4.9, pág.67), o que indica a boa confiabilidade dos resultados obtidos.



Figura 5.3 - Efeito da relação a/agl na quantidade de C-S-H determinada no ensaio de termogravimetria até os 28 dias de idade.



Figura 5.4 - Detalhe do efeito da relação a/agl na quantidade de C-S-H formado nas primeiras idades. 
O aumento da quantidade de água disponível retarda a hidratação nas primeiras idades, pois tem-se maior distanciamento entre as partículas, fato que se reflete numa porosidade maior e no retardo do início do refinamento dos poros. Esta tendência, observada nas primeiras idades, pode ser visualizada na Figura 5.5, na qual estão comparados os resultados de 6 até 24 horas com os de 3 a 28 dias. Observa-se que, quanto maior a relação a/agl, menor a quantidade de C-S-H formado; com o avanço da idade, ocorre o aumento do grau de hidratação, porém, sem que o aumento da relação a/agl altere a quantidade de $\mathrm{C}-\mathrm{S}-\mathrm{H}$ formado aos 28 dias.



Figura 5.5 - Efeito da relação a/agl na quantidade de C-S-H (\%). Gráfico construído com todos os pontos obtidos.

\subsubsection{Difração de raios $X$ versus termogravimetria}

$\mathrm{Na}$ Figura 5.6 consta a correlação entre a evolução da intensidade do pico associado à formação do C-S-H quantificado pela difração de raios $\mathrm{X}$ e a quantidade de C-S-H formado determinado pela termogravimetria. Detalhes da evolução da intensidade da formação do C-S-H nos ensaios de difração de raios $X$ constam no Capítulo 4 (pág.62). Assim como no ensaio de difração de raios $X$, no ensaio de termogravimetria a análise é simplificada pela presença majoritária do C-S-H como produto hidratado. Observa-se que a correlação é muito forte entre a intensidade do pico do C-S-H determinado pela difração de raios $\mathrm{X}$ e a quantidade de $\mathrm{C}-\mathrm{S}-\mathrm{H}$ formado determinado pela termogravimetria. Porém, como ambas as medidas proporcionam a quantificação dos produtos hidratados, não fornecendo informações 
sobre estrutura física da matriz cimentícia, o aumento da relação a/agl não apresenta influência na correlação dos resultados dos ensaios citados.



Figura 5.6 - Influência da relação a/agl na correlação entre a intensidade do pico principal do C-S-H determinado pela difração de raios $\mathrm{X}$ e a quantidade de $\mathrm{C}$-S-H determinado pela termogravimetria.

\subsection{Efeito do aditivo redutor de retração (SRA)}

A utilização do aditivo redutor de retração (SRA) não resultou em alterações dos compostos hidratados, mantendo-se o C-S-H e a hidrotalcita como principais produtos hidratados. Observou-se apenas uma alteração no perfil do pico da hidrotalcita (apêndice A), o qual se apresentou mais definido, porém com a mesma perda de massa, em torno de $3 \%$, da apresentada na mistura sem aditivo. Como será descrito no decorrer desta análise, o aditivo SRA inibe a formação de C-S-H, portanto, esta maior definição do pico de hidrotalcita pode ser decorrente da sua melhor resolução na termogravimetria, causada pela diminuição do pico do C-S-H.

Na Figura 5.7 consta a influência do aditivo SRA na evolução da quantidade de C-S$\mathrm{H}$ formado na pasta de cimento de escória com relação a/agl igual a 0,48, com o detalhamento das primeiras idades na Figura 5.8. Observa-se que a redução da quantidade de C-S-H causada pelo aditivo SRA é nítida e com maior intensidade nas primeiras idades. Aos 28 dias ocorre uma recuperação do avanço das reações de hidratação, porém não o suficiente para alcançar o patamar da mistura sem aditivo, 
sendo observada uma redução em torno de $20 \%$ da quantidade de $\mathrm{C}-\mathrm{S}-\mathrm{H}$ formado aos 28 dias.



Figura 5.7 - Efeito do teor de aditivo redutor de retração (SRA) na quantidade de C-S-H determinado no ensaio de termogravimetria até os 28 dias de idade na mistura com relação a/agl igual a 0,48.



Figura 5.8 - Detalhamento do efeito do teor de aditivo redutor de retração (SRA) na quantidade de C$\mathrm{S}-\mathrm{H}$ nas primeiras idades na mistura com relação a/agl igual a 0,48.

O aditivo redutor de retração (SRA) tem seu princípio de ação baseado na redução da tensão superficial da água do poro. Neste estudo, os resultados indicam que esta alteração da tensão superficial causa, com maior intensidade nas primeiras idades, retardo e diminuição da formação do C-S-H no cimento de escória ativada com silicato de sódio (Figura 5.8). Ocorre, também, uma diminuição brusca do C-S-H 
formado com a utilização de $0,5 \%$ de aditivo SRA, porém, não ocorre a proporcionalidade com o aumento do teor de aditivo (Figura 5.9).



Figura 5.9 - Correlação entre o teor de aditivo redutor de retração (SRA) e quantidade de C-S-H (\%) na mistura com relação a/agl igual a 0,48 . Gráfico construído com todos os pontos obtidos.

Conforme discutido na análise dos resultados de difração de raios X (Capítulo 4), é provável que a diminuição da tensão superficial da água do poro decorrente do efeito do aditivo SRA afete a cinética de hidratação do cimento de escória ativada. Como resultado, ocorre o retardo do desenvolvimento da hidratação e a diminuição da quantidade de C-S-H formado. Este efeito é determinante no desempenho mecânico dos compostos cimentícios, explicando o comportamento das propriedades mecânicas do cimento de escória ativada com silicato de sódio utilizando o aditivo redutor de retração (SRA).

\subsection{Discussão e conclusões}

\subsubsection{Efeito da relação água/aglomerante}

De acordo com os resultados obtidos, o aumento da relação a/agl afeta a hidratação do cimento de escória ativada com silicato de sódio com maior intensidade nas primeiras idades, provocando um retardo do desenvolvimento das reações de hidratação. Porém, com o avanço da idade, as reações de hidratação se desenvolvem e não há diferença entre os teores de C-S-H formados aos 28 dias nas misturas estudadas. Este comportamento ressalta a importância da relação a/agl no aspecto físico do desenvolvimento da matriz porosa, pois, neste estudo, para 
quantidades similares de C-S-H vai se ter porosidades diferentes e, conseqüentemente, comportamentos distintos nas propriedades mecânicas e na retração. No entanto, os resultados quantitativos da termogravimetria são importantes para o detalhamento da evolução da hidratação e complementar na análise da evolução das resistências mecânicas.

\subsubsection{Efeito do aditivo redutor de retração (SRA)}

De acordo com os resultados de termogravimetria, os principais efeitos do aditivo redutor de retração (SRA) no cimento de escória ativada com silicato de sódio foram o retardo significativo do desenvolvimento do C-S-H e a diminuição da quantidade final do mesmo. Nas idades iniciais, a utilização do aditivo SRA provocou o retardo de até 3 dias no avanço das reações de hidratação, quantificada pela formação de C-S-H. Existe a proporcionalidade entre a diminuição da quantidade de C-S-H e o aumento do teor de aditivo SRA nas primeiras idades. No entanto, a diminuição da quantidade de C-S-H não foi proporcional ao teor de aditivo aos 7 e 28 dias, constatando-se uma redução em torno de $20 \%$ da quantidade de C-S-H independentemente do teor de aditivo SRA utilizado.

Sabe-se que o mecanismo de ação do aditivo redutor de retração (SRA) é a redução da tensão superficial da água do poro. De acordo com os resultados obtidos, este efeito parece afetar a floculação e a aglomeração, refletindo nas condições de desenvolvimento das reações químicas de hidratação. Resumindo, apesar do seu mecanismo de atuação ter como base a alteração da tensão superficial da fase líquida, não é possível desprezar o seu efeito na cinética de hidratação do cimento de escória ativada com silicato de sódio. Com base apenas nos resultados de termogravimetria, o teor de $0,5 \%$ é mais adequado para situações onde se deseja utilizar o aditivo SRA sem que ocorra grande retardo da hidratação nas primeiras idades. Caso seja necessário utilizar teores maiores de aditivo SRA, é benéfica a redução da relação a/agl, o que propicia a aceleração do desenvolvimento das reações de hidratação conforme descrito anteriormente. 


\section{Capítulo 6 \\ Porosimetria}

\subsection{Introdução}

Com base no levantamento bibliográfico (item 2.2), sabe-se que o fenômeno da retração está relacionado à evolução da distribuição de poros e do seu volume em sistemas cimentícios hidratados, o que ressalta a importância do ensaio de porosimetria por intrusão de mercúrio. Apesar das dúvidas e polêmicas sobre o método, ele tem se mostrado de grande utilidade na correlação com as propriedades mecânicas de sistemas cimentícios e a sua evolução com a hidratação. Permite também a explicação de comportamentos quando a porosidade total não varia significativamente, mas que estejam relacionados a alterações no perfil da distribuição dos poros. Neste trabalho, a análise da porosidade foi sempre realizada com base na quantificação da porosidade total e da caracterização do perfil da distribuição de poros, com a classificação em macroporos $(\varnothing>50 \mathrm{~nm})$ e mesoporos $(2<\varnothing<50 \mathrm{~nm})$. A Figura 6.1 exemplifica um resultado típico da evolução da porosidade acumulada e a distribuição de poros do cimento de escória ativada com silicato de sódio, estando todas as curvas obtidas no ensaio de porosimetria apresentadas no Apêndice B.
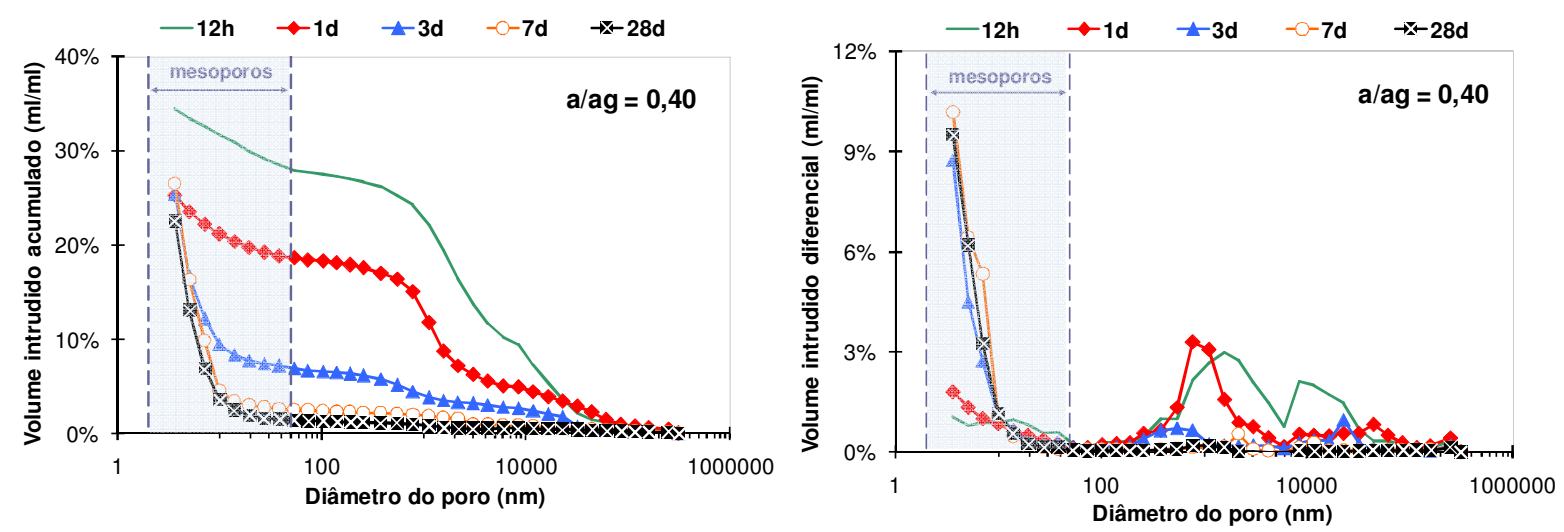

Figura 6.1 - Exemplo da faixa de classificação de mesoporos e macroporos nas curvas de evolução da porosidade total e da distribuição de poros da pasta de cimento de escória ativada com silicato de sódio (4NSA0) a 6 e 12 horas, 1,3,7 e 28 dias de idade. a/agl= 0,40. 


\subsection{Efeito da relação água/aglomerante}

O efeito da relação água/aglomerante na porosidade e na distribuição dos poros do cimento de escória ativada com silicato de sódio consta da Figura 6.2 até a Figura 6.6. Observa-se que quanto maior a relação a/agl, maior a porosidade total em qualquer das idades estudadas, devido à diminuição da compacidade da matriz porosa em razão do maior distanciamento das partículas com o emprego de maior quantidade de água. Neste trabalho, define-se que o refinamento da porosidade é caracterizado pela ocorrência simultânea do aumento do volume de mesoporos e a diminuição do volume de macroporos, decorrente da evolução da formação do C-SH. O aumento da relação a/agl incorre no retardo do início do refinamento da porosidade, retardo este que diretamente proporcional ao aumento da relação a/agl. A distribuição de poros do cimento de escória ativada com silicato de sódio difere da observada no cimento Portland, pois apresenta uma predominância de poros situados na faixa de mesoporos, confirmando os dados obtidos no levantamento bibliográfico.

O refinamento da porosidade do cimento de escória ativada com silicato de sódio é caracterizado pela rapidez com que ocorre o aumento do volume de mesoporos, alcançando-se em torno de $75 \%$ de mesoporos aos 3 dias de idade na mistura com relação a/agl igual a 0,40. Com 12 horas de idade, apenas a mistura com relação a/agl igual a 0,40 apresenta uma proporção significativa de mesoporos, em torno de $20 \%$ (Figura 6.2), indicando que o refinamento da sua porosidade ocorreu antes da idade de determinação, dado este observado anteriormente no trabalho realizado por MELO NETO (2002). Na mistura com relação a/agl igual a 0,48 o refinamento da porosidade ocorre com 1 dia de idade e, com 0,56, o refinamento ocorre apenas aos 3 dias de idade. Aos 28 dias, o mesmo perfil de distribuição de poros é observado para as três relações a/agl estudadas, com cerca de $94 \%$ de mesoporos. 



\begin{tabular}{lccc}
\multirow{2}{*}{12 horas } & \multicolumn{3}{c}{ Relação água/aglomerante } \\
\cline { 2 - 4 } & 0,40 & 0,48 & 0,56 \\
\hline Porosidade total & $34,4 \%$ & $47,2 \%$ & $53,3 \%$ \\
\hline $\begin{array}{l}\text { Mesoporos/ } \\
\text { Porosidade total }\end{array}$ & $19 \%$ & $2 \%$ & $2 \%$ \\
\hline $\begin{array}{l}\text { Macroporos/ } \\
\text { Porosidade total }\end{array}$ & $81 \%$ & $98 \%$ & $98 \%$ \\
\hline
\end{tabular}

Figura 6.2 - Efeito da relação água/aglomerante na porosidade acumulada (a), na porosidade diferencial (b) e na distribuição de poros (c) da pasta de escória ativada com silicato de sódio (4NS) com 12 horas de idade.


\begin{tabular}{lccc}
\multirow{2}{*}{1 dia } & \multicolumn{3}{c}{ Relação água/aglomerante } \\
\cline { 2 - 4 } & 0,40 & 0,48 & 0,56 \\
\hline Porosidade total & $25,3 \%$ & $33,1 \%$ & $54,1 \%$ \\
\hline $\begin{array}{l}\text { Mesoporos/ } \\
\text { Porosidade total }\end{array}$ & $27 \%$ & $17 \%$ & $1 \%$ \\
\hline $\begin{array}{l}\text { Macroporos/ } \\
\text { Porosidade total }\end{array}$ & $73 \%$ & $83 \%$ & $99 \%$ \\
\hline
\end{tabular}

Figura 6.3 - Efeito da relação água/aglomerante na porosidade acumulada (a), na porosidade diferencial (b) e na distribuição de poros (c) da pasta de escória ativada com silicato de sódio (4NS) com 1 dia de idade. 



\begin{tabular}{lccc}
\multirow{2}{*}{3} & \multicolumn{3}{c}{ Relação água/aglomerante } \\
\cline { 2 - 4 } & 0,40 & 0,48 & 0,56 \\
\hline Porosidade total & $25,4 \%$ & $30,4 \%$ & $37,6 \%$ \\
\hline $\begin{array}{l}\text { Mesoporos/ } \\
\text { Porosidade total }\end{array}$ & $73 \%$ & $66 \%$ & $75 \%$ \\
\hline $\begin{array}{l}\text { Macroporos/ } \\
\text { Porosidade total }\end{array}$ & $27 \%$ & $34 \%$ & $25 \%$ \\
\hline
\end{tabular}

Figura 6.4 - Efeito da relação água/aglomerante na porosidade acumulada (a), na porosidade diferencial (b) e na distribuição de poros (c) da pasta de escória ativada com silicato de sódio (4NS) com 3 dias de idade.
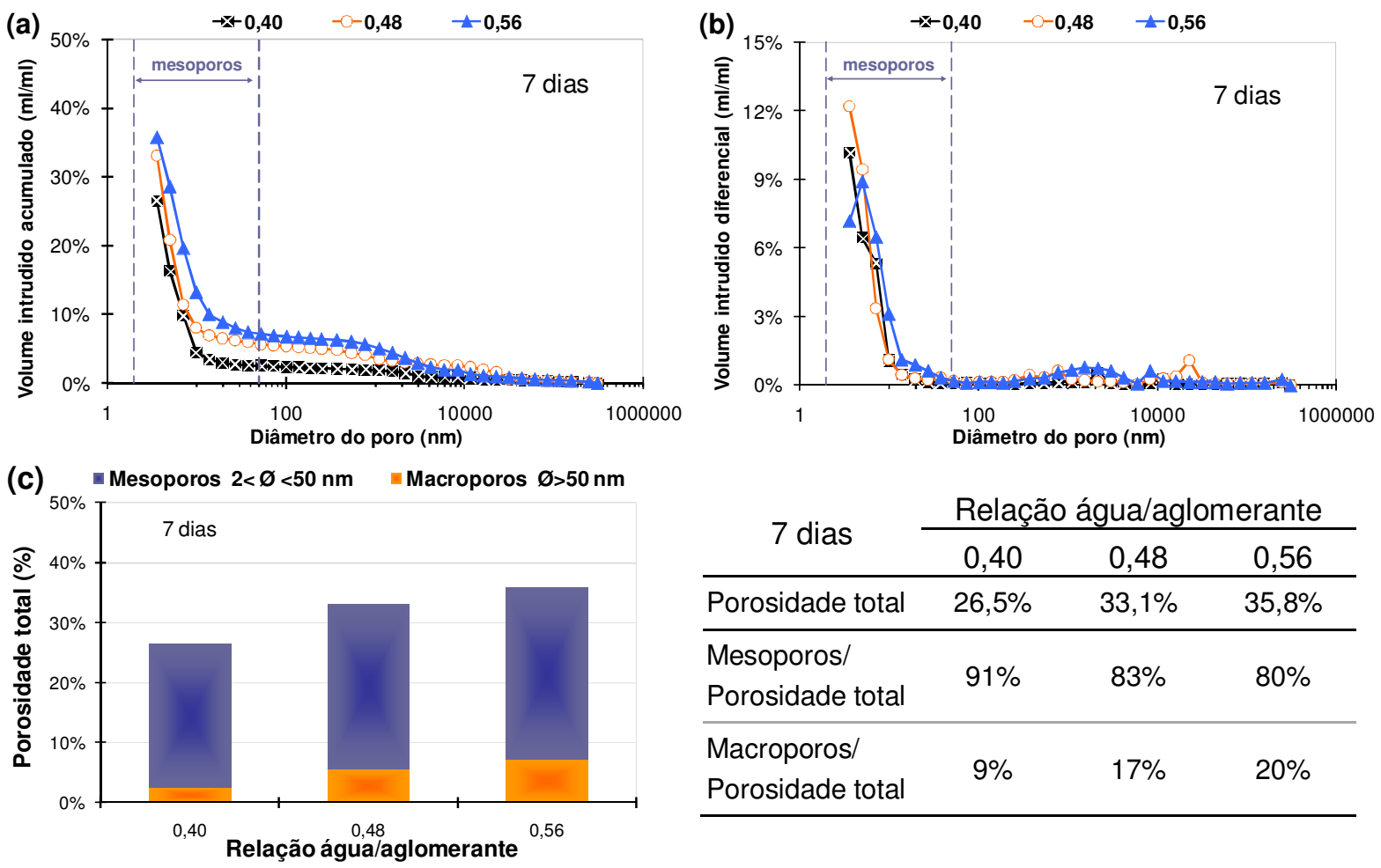

\begin{tabular}{lccc}
\multirow{2}{*}{7 dias } & \multicolumn{3}{c}{ Relação água/aglomerante } \\
\cline { 2 - 4 } & 0,40 & 0,48 & 0,56 \\
\hline Porosidade total & $26,5 \%$ & $33,1 \%$ & $35,8 \%$ \\
\hline $\begin{array}{l}\text { Mesoporos/ } \\
\text { Porosidade total }\end{array}$ & $91 \%$ & $83 \%$ & $80 \%$ \\
\hline $\begin{array}{l}\text { Macroporos/ } \\
\text { Porosidade total }\end{array}$ & $9 \%$ & $17 \%$ & $20 \%$ \\
\hline
\end{tabular}

Figura 6.5 - Efeito da relação água/aglomerante na porosidade acumulada (a), na porosidade diferencial (b) e na distribuição de poros (c) da pasta de escória ativada com silicato de sódio (4NS) com 7 dias de idade. 



\begin{tabular}{lccc}
\multirow{2}{*}{28 dias } & \multicolumn{3}{c}{ Relação água/aglomerante } \\
\cline { 2 - 4 } & 0,40 & 0,48 & 0,56 \\
\hline Porosidade total & $22,5 \%$ & $30,7 \%$ & $37,3 \%$ \\
\hline $\begin{array}{l}\text { Mesoporos/ } \\
\text { Porosidade total }\end{array}$ & 94 & 94 & 92 \\
\hline $\begin{array}{l}\text { Macroporos/ } \\
\text { Porosidade total }\end{array}$ & 6 & 6 & 8 \\
\hline
\end{tabular}

Figura 6.6 - Efeito da relação água/aglomerante na porosidade acumulada (a), na porosidade diferencial (b) e na distribuição de poros (c) da pasta de escória ativada com silicato de sódio (4NS) com 28 dias de idade.

$\mathrm{Na}$ análise da evolução da porosidade total em cada relação a/agl estudada (Figura 6.7), observa-se que após 3 dias de idade a porosidade total não se altera significativamente em qualquer das relações a/agl estudadas. Na Figura 6.8, observa-se, com o avanço da idade, que ocorre o aumento da proporção de mesoporos, decorrente do preenchimento de vazios com o avanço da hidratação, e que a mistura com relação a/agl igual a 0,40 apresenta maior velocidade de refinamento da porosidade. O refinamento da porosidade é um dado aplicado na interpretação da alteração nas propriedades mecânicas mesmo sem variação da porosidade total, como na resistência à compressão, por exemplo. 



Figura 6.7 - Evolução da porosidade total das três relações a/agl estudadas até os 28 dias (a) e detalhado nas primeiras idades (b).


Figura 6.8 - Evolução da proporção do volume de mesoporos em relação à porosidade total das três relações a/agl estudadas até os 28 dias (a) e detalhado nas primeiras idades (b).

Os gráficos da Figura 6.9 apresentam um tendência geral da correlação entre porosidade e relação a/agl. Observa-se que o aumento da relação a/agl incorre no aumento da porosidade total e no retardo do início do refinamento da porosidade, caracterizado pela diminuição da proporção de mesoporos nas idades de 12 horas e 1 dia. Esta porosidade e distribuição de poros característica deste tipo de cimento é a explicação para a sua elevada resistência inicial e final, excelente durabilidade em ambientes agressivos, mas também é a principal causa da elevada retração do mesmo. Pode-se afirmar que o cimento de escória ativada com silicato de sódio, em virtude de sua porosidade mais compacta, é propício ao surgimento de tensões capilares resultantes da perda de água para o ambiente ou para as reações de hidratação. 



Figura 6.9 - Correlação entre a relação água/aglomerante e a porosidade total (a), a proporção de macroporos (b) e de mesoporos (c). Gráficos construídos com todos os pontos obtidos.

\subsubsection{Porosidade versus termogravimetria}

Os gráficos da Figura 6.10 apresentam um panorama geral da correlação entre o grau de hidratação, representado pela quantificação do C-S-H, e a porosidade. De modo geral, observa-se que o aumento do grau de hidratação resulta na diminuição da porosidade total, assim como no aumento do refinamento da porosidade, caracterizado pela ocorrência simultânea da diminuição do volume de macroporos e o aumento do volume de mesoporos. Esta correlação é coerente com a base de conhecimento existente, pois segue o comportamento clássico de que quanto maior o grau de hidratação, menor a porosidade total.

No entanto, quando se analisa o efeito do aumento da relação a/agl na correlação da porosidade com a termogravimetria, observa-se que para quantidades similares de $\mathrm{C}-\mathrm{S}-\mathrm{H}$ formado têm-se diferentes porosidades totais. Este fato é explicado pelo 
efeito físico da maior disponibilidade de água na aglomeração e consolidação dos produtos hidratados. Pode-se exemplificar este efeito físico com a análise da quantidade de água inicial, o grau de hidratação e a porosidade apresentada Tabela 6.1. Observa-se que, aos 28 dias, a água quimicamente combinada não se altera substancialmente com o aumento da relação a/agl e a diferença desta para o volume inicial de água resulta em valores próximos à porosidade total obtida no ensaio de porosimetria. Com isto, é evidente que a água livre é a maior responsável pela formação de vazios no cimento de escória; porém, ressalta-se que o volume de produtos hidratados, notadamente o C-S-H, também contribui para a formação de vazios.

Tabela 6.1 - Análise da evolução do volume de vazios na pasta de cimento de escória aos 28 dias.

\begin{tabular}{lccc}
\multirow{2}{*}{28 dias } & \multicolumn{3}{c}{ Relação água/aglomerante } \\
\cline { 2 - 4 } & 0,40 & 0,48 & 0,56 \\
\hline Volume de água inicial (\%) & 40 & 48 & 56 \\
\hline Água quimicamente combinada (TG) & 20,1 & 21,9 & 21,1 \\
\hline Água livre (\%) & 19,9 & 26,1 & 34,9 \\
\hline Porosidade total (\%) & 22,5 & 30,7 & 37,3 \\
\hline
\end{tabular}


Figura 6.10 - Influência da relação a/agl na correlação entre a quantidade de C-S-H e a porosidade total (a), o volume de macroporos (b) e de mesoporos (c). 


\subsection{Efeito do aditivo redutor de retração (SRA)}

O efeito do aditivo redutor de retração está apresentado da Figura 6.11 até a Figura 6.14. Observa-se que a utilização do aditivo SRA incorre no aumento da porosidade total em todas as idades ensaiadas e no retardo significativo do refinamento da distribuição de poros, quando comparados com a mistura de referência sem aditivo. Com 1 dia de idade, a utilização de $0,5 \%$ do aditivo SRA provocou o aumento da porosidade total de um valor em torno de $33 \%$ para um valor em torno de $51 \%$, além de alterar significativamente a distribuição de poros, passando de uma proporção de mesoporos de 17\% para em torno de 6\%. Com 3 dias de idade, a mistura com teor de $0,5 \%$ de SRA já apresenta o refinamento da porosidade, porém ainda com uma porosidade total maior do que a observada na mistura de referência. Aos 7 dias de idade, todas as misturas com o aditivo SRA apresentam o refinamento da porosidade, inclusive com proporção de mesoporos maior do que na mistura de referência, porém com porosidade total também maior.


\begin{tabular}{lc|c|c|c|c}
\multirow{2}{*}{1 dia } & \multicolumn{5}{c}{ Teor de aditivo SRA } \\
\cline { 2 - 6 } & $0 \%$ & $0,5 \%$ & $1 \%$ & $1,5 \%$ & $2 \%$ \\
\hline Porosidade total & $33,1 \%$ & $51,7 \%$ & $50,6 \%$ & $51,1 \%$ & $51,8 \%$ \\
\hline $\begin{array}{l}\text { Mesoporos/ } \\
\text { Porosidade total }\end{array}$ & $17 \%$ & $6 \%$ & $5 \%$ & $5 \%$ & $5 \%$ \\
\hline $\begin{array}{l}\text { Macroporos/ } \\
\text { Porosidade total }\end{array}$ & $83 \%$ & $94 \%$ & $95 \%$ & $95 \%$ & $95 \%$ \\
\hline
\end{tabular}

Figura 6.11 - Efeito do teor de aditivo redutor de retração (SRA) (0\%, 0,5\%, 1,0\%, 1,5\% e 2,0\%) na porosidade acumulada (a), na porosidade diferencial (b) e na distribuição de poros (c) da pasta de escória ativada com silicato de sódio (4NS) com 1 dia de idade. a/agl=0,48(B). 



\begin{tabular}{|c|c|c|c|c|c|}
\hline \multirow{2}{*}{3 dias } & \multicolumn{5}{|c|}{ Teor de aditivo SRA } \\
\hline & $0 \%$ & $0,5 \%$ & $1 \%$ & $1,5 \%$ & $2 \%$ \\
\hline Porosidade total & $30,4 \%$ & $35,7 \%$ & $48,6 \%$ & $53,1 \%$ & $52,9 \%$ \\
\hline $\begin{array}{l}\text { Mesoporos/ } \\
\text { Porosidade total }\end{array}$ & $66 \%$ & $79 \%$ & $10 \%$ & $10 \%$ & $4 \%$ \\
\hline $\begin{array}{l}\text { Macroporos/ } \\
\text { Porosidade total }\end{array}$ & $34 \%$ & $21 \%$ & $90 \%$ & $90 \%$ & $96 \%$ \\
\hline
\end{tabular}

Figura 6.12 - Efeito do teor de aditivo redutor de retração (SRA) (0\%, 0,5\%, 1,0\%, 1,5\% e 2,0\%) na porosidade acumulada (a), na porosidade diferencial (b) e na distribuição de poros (c) da pasta de escória ativada com silicato de sódio (4NS) com 3 dias de idade. a/agl= 0,48(B).


\begin{tabular}{lc|c|c|c|c}
\multirow{2}{*}{7 dias } & \multicolumn{5}{c|}{ Teor de aditivo SRA } \\
\cline { 2 - 6 } & $0 \%$ & $0,5 \%$ & $1 \%$ & $1,5 \%$ & $2 \%$ \\
\hline Porosidade total & $33,1 \%$ & $36,1 \%$ & $37,3 \%$ & $40,8 \%$ & $41,6 \%$ \\
\hline $\begin{array}{l}\text { Mesoporos/ } \\
\text { Porosidade total }\end{array}$ & $83 \%$ & $95 \%$ & $94 \%$ & $95 \%$ & $92 \%$ \\
\hline $\begin{array}{l}\text { Macroporos/ } \\
\text { Porosidade total }\end{array}$ & $17 \%$ & $5 \%$ & $6 \%$ & $5 \%$ & $8 \%$ \\
\hline
\end{tabular}

Figura 6.13 - Efeito do teor de aditivo redutor de retração (SRA) $(0 \%, 0,5 \%, 1,0 \%, 1,5 \%$ e $2,0 \%)$ na porosidade acumulada (a), na porosidade diferencial (b) e na distribuição de poros (c) da pasta de escória ativada com silicato de sódio (4NS) com 7 dias de idade. $a / a g l=0,48(B)$. 



\begin{tabular}{lc|c|c|c|c}
\multirow{2}{*}{28 dias } & \multicolumn{5}{c|}{ Teor de aditivo SRA } \\
\cline { 2 - 6 } & $0 \%$ & $0,5 \%$ & $1 \%$ & $1,5 \%$ & $2 \%$ \\
\hline Porosidade total & $30,7 \%$ & $33,0 \%$ & $35,4 \%$ & $32,8 \%$ & $32,4 \%$ \\
\hline $\begin{array}{l}\text { Mesoporos/ } \\
\text { Porosidade total }\end{array}$ & $94 \%$ & $96 \%$ & $97 \%$ & $97 \%$ & $96 \%$ \\
\hline $\begin{array}{l}\text { Macroporos/ } \\
\text { Porosidade total }\end{array}$ & $6 \%$ & $4 \%$ & $3 \%$ & $3 \%$ & $4 \%$ \\
\hline
\end{tabular}

Figura 6.14 - Efeito do teor de aditivo redutor de retração (SRA) (0\%, 0,5\%, 1,0\%, 1,5\% e 2,0\%) na porosidade acumulada (a), na porosidade diferencial (b) e na distribuição de poros (c) da pasta de escória ativada com silicato de sódio (4NS) com 28 dias de idade. a/agl= 0,48(B).

$\mathrm{Na}$ Figura 6.15 consta o efeito do teor de aditivo redutor de retração (SRA) na evolução da porosidade total da mistura com relação a/agl igual a 0,48. Observa-se que o aumento do teor de aditivo SRA altera o perfil da curva de evolução da porosidade total nas primeiras idades, afastando-a do perfil da curva da mistura sem aditivo em razão do aumento da porosidade total. A partir dos 7 dias de idade os perfis são similares, porém, confirma-se que o aditivo SRA incorre no aumento da porosidade total. Na Figura 6.16 consta o efeito do teor de aditivo redutor de retração (SRA) na evolução da proporção do volume de mesoporos relativa à porosidade total da pasta de cimento de escória. O teor de 0,5\% de SRA é o que mais se aproxima do perfil da curva de referência, apresentando o refinamento da distribuição de poros caracterizado pelo aumento da proporção de mesoporos aos 3 dias de idade. Com o aumento do teor de aditivo SRA, confirma-se o retardo do início do refinamento da distribuição de poros, ocorrendo o aumento da proporção de mesoporos somente aos 7 dias de idade. 



Figura 6.15 - Efeito do teor de aditivo redutor de retração (SRA) na evolução da porosidade total da mistura com relação a/agl igual a 0,48 até os 28 dias (a) e detalhado nas primeiras idades (b).
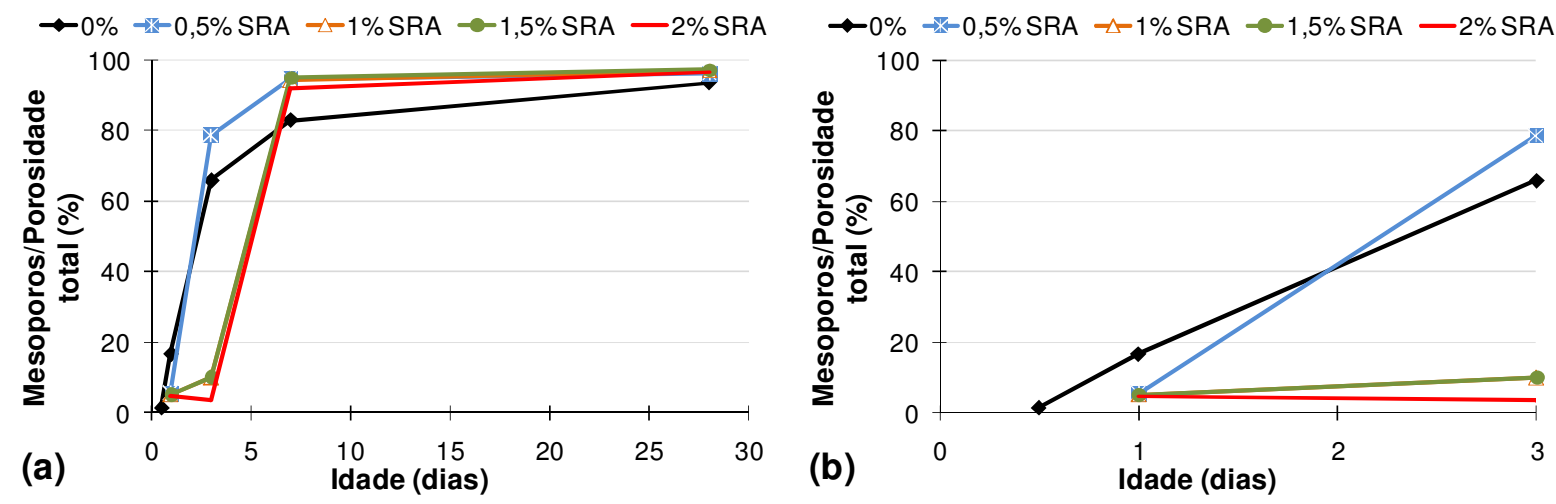

Figura 6.16 - Efeito do teor de aditivo redutor de retração (SRA) na evolução da proporção do volume de mesoporos em relação à porosidade total da mistura com relação a/agl igual a 0,48 até os 28 dias (a) e detalhado nas primeiras idades (b).

Os gráficos da Figura 6.17 apresentam um panorama geral da correlação entre porosidade e o teor de aditivo redutor de retração (SRA). Observa-se que o aumento do teor de aditivo SRA incorre no aumento proporcional da porosidade total para todas as idades ensaiadas. O comportamento da distribuição de poros é distinto nas primeiras idades, onde o aumento do teor de aditivo SRA causa a diminuição da proporção de mesoporos e o aumento da proporção de macroporos. Com o avanço da idade, ocorre o refinamento da porosidade e a distribuição de poros com a utilização do aditivo SRA, similar à observada na mistura de referência, porém, ressalta-se, a porosidade total do cimento de escória ativada com silicato de sódio utilizando este tipo de aditivo continua sendo maior.

Portanto, além de reduzir a tensão superficial da água do poro, diminuindo as tensões oriundas da perda de água, o aditivo redutor de retração (SRA) também 
altera a porosidade total e a distribuição de poros, provavelmente em conseqüência da diminuição da aglomeração inicial do cimento de escória ativada. Esta alteração da porosidade traz como conseqüência positiva a diminuição da retração por secagem, mas, como negativa a diminuição da resistência mecânica.


Figura 6.17 - Correlação entre o teor de aditivo redutor de retração (SRA) e a porosidade total (a), a proporção de macroporos (b) e de mesoporos (c) da mistura com relação a/agl igual a 0,48. Gráficos construídos com todos os pontos obtidos.

\subsubsection{Porosidade versus termogravimetria}

Observa-se na Figura 6.18 que para quantidades de $\mathrm{C}-\mathrm{S}-\mathrm{H}$ similares, as misturas com utilização do aditivo SRA apresentam porosidade total maior do que a da mistura sem aditivo. Este comportamento pode indicar que o aditivo SRA afeta mais a estrutura da matriz porosa do que o desenvolvimento das reações de hidratação deste tipo de cimento, pois altera com maior intensidade o histórico de formação da matriz porosa do que o teor de C-S-H formado. 




Figura 6.18 - Influência do teor de aditivo redutor de retração (SRA) na correlação entre a quantidade de C-S-H e a porosidade total da mistura com relação a/agl igual a 0,48.

\subsection{Discussão e conclusões}

\subsubsection{Efeito da relação água/aglomerante}

De acordo com os resultados obtidos, conclui-se que o aumento da relação a/agl incorre no aumento proporcional da porosidade total, explicado pelo efeito físico do maior número de vazios na compacidade da matriz porosa causado pela maior quantidade de água. A porosidade total da mistura com relação a/agl igual a 0,40 é em torno $22 \%$ aos 28 dias; com o aumento da relação a/agl para 0,48 e 0,56, a porosidade atinge valores em torno de $30 \%$ e $37 \%$, respectivamente. Com relação à distribuição de poros, a maior relação a/agl retarda o início do refinamento da porosidade nas primeiras idades, decorrente do retardo do desenvolvimento da hidratação constatado na análise dos resultados de difração de raios $\mathrm{X} e$ termogravimetria.

Com o avanço da idade, ocorre a aceleração da hidratação e o conseqüente refinamento da porosidade. Na mistura com relação a/agl igual a 0,40 o início do refinamento ocorre às 12 horas de idade; com o aumento da relação a/agl para 0,48 e 0,56 , o refinamento ocorre com 1 e 3 dias de idade, respectivamente. Com 28 dias, o refinamento da porosidade já ocorreu em todas as relações a/agl estudadas, sendo o cimento de escória ativada com silicato de sódio caracterizado pela elevada proporção de mesoporos, em torno de $94 \%$ da porosidade total, em qualquer uma das relações a/agl estudadas. 


\subsubsection{Efeito do aditivo redutor de retração (SRA)}

O aditivo redutor de retração (SRA) claramente altera o desenvolvimento da matriz porosa do cimento de escória ativada com silicato de sódio, provocando um aumento proporcional da porosidade total com o aumento do teor de aditivo SRA e o retardo do início do refinamento da porosidade. O aumento da porosidade total com a utilização do aditivo SRA é mais intenso nas primeiras idades, onde com 1 dia de idade a porosidade total passa de em torno de $30 \%$ na mistura sem aditivo para em torno de 50\% com qualquer teor de aditivo SRA utilizado.

Conforme discutido anteriormente, e com base nas conclusões de He et al. (2006) e Brooks et al.(2004), as evidências indicam que a diminuição da tensão superficial inibe a velocidade de floculação do cimento de escória ativada com silicato de sódio nas primeiras idades. Com o avanço da hidratação, ocorre o aumento da quantidade de compostos hidratados e a aceleração das reações de hidratação, resultando no refinamento da porosidade. No entanto, a alteração da cinética de hidratação causada pelo aditivo nas primeiras idades acaba por afetar o desenvolvimento até os 28 dias da estrutura física da matriz porosa e na quantidade de C-S-H formado, resultando em maior porosidade total e menor grau de hidratação do cimento de escória ativada com silicato de sódio.

Assim como a porosidade total, a distribuição de poros é fortemente afetada nas primeiras idades, onde, com 1 dia de idade, a proporção do volume de mesoporos passa de $17 \%$ sem a utilização de aditivo para em torno de $6 \%$ com a utilização do aditivo SRA. Com o avanço da idade, apesar da porosidade total aumentar com a utilização do aditivo SRA, o perfil da distribuição de poros torna-se similar ao observado sem a utilização do aditivo, ou seja, com uma proporção de mesoporos em torno de $94 \%$. O efeito da alteração da porosidade com a utilização do aditivo redutor de retração (SRA) é facilmente percebido na diminuição da resistência mecânica do cimento de escória, porém, deve ser também fator positivo na diminuição da retração por secagem. 


\section{Capítulo 7 Propriedades mecânicas}

\subsection{Efeito da relação água/aglomerante}

A influência da relação água/aglomerante na resistência à compressão do cimento de escória ativada com silicato de sódio consta da Figura 7.1, onde estão apresentados valores médios com a representação gráfica da dispersão dos resultados (barras verticais). A dispersão em torno da média foi calculada multiplicando-se o desvio padrão por 1,96, valor adotado para uma distribuição normal, o que garante que estatisticamente $95 \%$ dos resultados obtidos estão inseridos na dispersão. Nos resultados obtidos, observa-se que a evolução da resistência à compressão do cimento de escória ativada ocorre de modo rápido, obtendo-se elevadas resistências nas primeiras idades, e que o aumento da relação a/agl causou a redução significativa da resistência, notadamente nas primeiras idades.

Observa-se na Figura 7.2 que a relação a/agl está diretamente relacionada com a resistência à compressão do cimento de escória, porém, com o avanço da idade de hidratação o efeito é atenuado quando comparados os resultados das relações 0,40 e 0,48. No caso da relação a/agl 0,56, o aumento da quantidade de água incorre na redução da resistência à compressão em qualquer idade, com maior intensidade nas primeiras idades. Utilizando a mistura com relação a/agl igual a 0,40 como referência, o aumento da relação a/agl para 0,48 e 0,56 causou a redução da resistência a 1 dia de idade de $31 \%$ e $96,1 \%$, respectivamente (Tabela 7.1). No entanto, a mistura com relação a/agl de 0,48 apresentou uma excelente recuperação já a partir dos 3 dias de idade e, aos 28 dias, apresentou uma redução de apenas $5,2 \%$ da resistência à compressão, quando comparada à mistura com relação a/agl igual a 0,40. 




Figura 7.1 - Efeito da relação a/agl na resistência à compressão do cimento de escória (4NS).



Figura 7.2 - Variação da resistência à compressão em função da relação a/agl do cimento de escória (4NS).

Tabela 7.1 - Médias aritméticas da resistência à compressão e o efeito da relação a/agl no cimento de escória ativada (4NS). CV = coeficiente de variação em \%.

\begin{tabular}{|c|c|c|c|c|c|c|c|}
\hline & \multirow[b]{3}{*}{ Idade } & \multicolumn{6}{|c|}{ Relação água/aglomerante } \\
\hline & & \multicolumn{2}{|c|}{0,40} & \multicolumn{2}{|c|}{0,48} & \multicolumn{2}{|c|}{0,56} \\
\hline & & $\mathbf{R c}$ & $\mathrm{CV}$ & $\mathbf{R c}$ & $\mathrm{CV}$ & $\mathbf{R c}$ & $\mathrm{CV}$ \\
\hline \multirow{4}{*}{$\begin{array}{l}\text { Resistência à } \\
\text { compressão (MPa) }\end{array}$} & $1 \mathrm{dia}$ & 44,0 & $3,9 \%$ & 30,3 & $2,4 \%$ & 1,7 & $9,1 \%$ \\
\hline & 3 dias & 67,7 & $2,9 \%$ & 60,0 & $3,7 \%$ & 35,2 & $6,3 \%$ \\
\hline & 7 dias & 80,5 & $2,2 \%$ & 77,4 & $3,1 \%$ & 51,7 & $5,8 \%$ \\
\hline & 28 dias & 91,1 & $1,4 \%$ & 86,4 & $1,5 \%$ & 59,9 & $2,9 \%$ \\
\hline \multirow{4}{*}{$\begin{array}{l}\text { Variação da } \\
\text { resistência à } \\
\text { compressão (\%) }\end{array}$} & $1 \mathrm{dia}$ & \multicolumn{2}{|c|}{0,0} & \multicolumn{2}{|c|}{$-31,0$} & \multicolumn{2}{|c|}{$-96,1$} \\
\hline & 3 dias & \multicolumn{2}{|c|}{0,0} & \multicolumn{2}{|c|}{$-11,4$} & \multicolumn{2}{|c|}{$-48,0$} \\
\hline & 7 dias & \multirow{2}{*}{\multicolumn{2}{|c|}{$\begin{array}{l}0,0 \\
0,0\end{array}$}} & \multirow{2}{*}{\multicolumn{2}{|c|}{$\begin{array}{l}-3,8 \\
-5,2\end{array}$}} & \multirow{2}{*}{\multicolumn{2}{|c|}{$\begin{array}{l}-35,7 \\
-34,2\end{array}$}} \\
\hline & 28 dias & & & & & & \\
\hline
\end{tabular}


Os resultados de resistência à tração do cimento de escória ativada com silicato de sódio constam da Figura 7.3. Inicialmente, ressalta-se a maior dispersão dos resultados obtidos com este ensaio, possivelmente em razão do método de ensaio e da natureza do estado de tensões do material. Não existem relatos conclusivos sobre esta variabilidade dos resultados na determinação da resistência à tração na flexão, supondo-se que a maior variabilidade dos resultados obtidos com este ensaio ocorra em razão da maior sensibilidade do método frente às possíveis falhas no preparo dos corpos-de-prova e no procedimento de ensaio. Apesar da elevada variabilidade, observa-se que os resultados da resistência apresentaram tendência similar aos resultados de resistência à compressão, sendo que o aumento da relação a/agl incorreu na redução da resistência à tração, sendo seu efeito mais intenso nas primeiras idades (Figura 7.4).

Observa-se na Tabela 7.2 que o aumento da relação a/agl causou maior redução da resistência à tração com 1 dia de idade, assim como observado nos resultados de resistência à compressão. A partir desta idade, pode-se afirmar que os resultados da resistência à tração das misturas com relação a/agl 0,40 e 0,48 foram iguais estatisticamente e que a relação 0,56 apresentou recuperação razoável da resistência aos 28 dias, porém com baixa recuperação nas primeiras idades.



Figura 7.3 - Efeito da relação a/agl na resistência à tração do cimento de escória (4NS). 


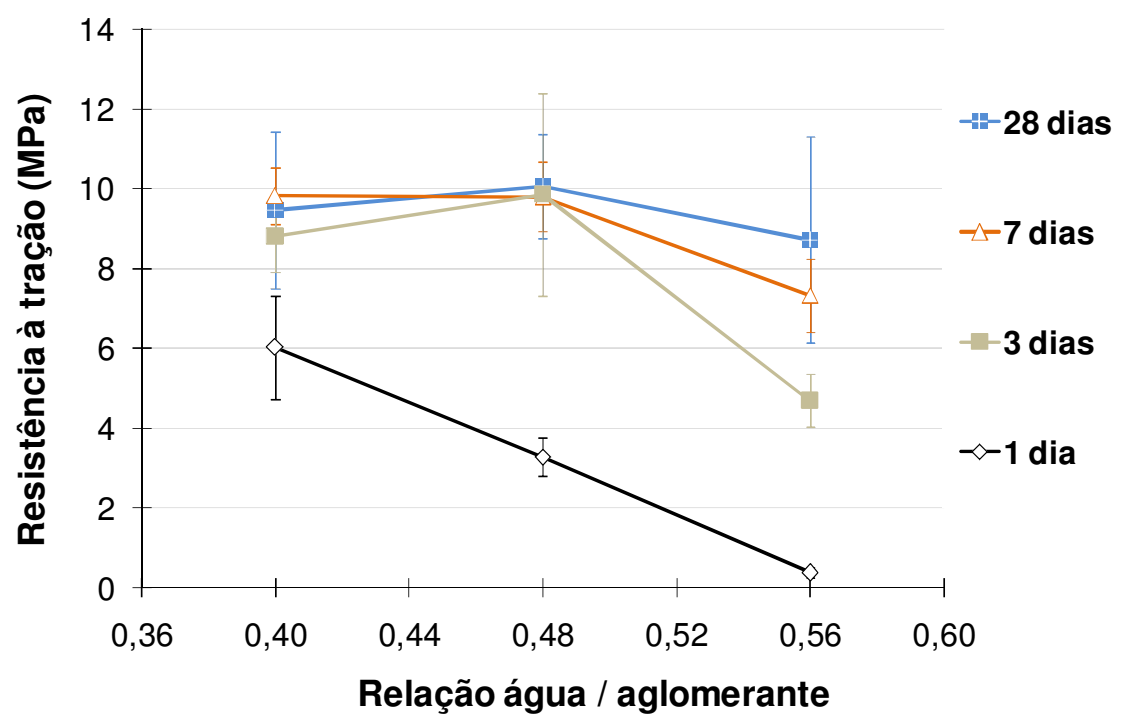

Figura 7.4 - Variação da resistência à tração em função da relação a/agl do cimento de escória (4NS).

Tabela 7.2 - Médias aritméticas da resistência à tração e o efeito da relação a/agl no cimento de escória ativada (4NS). CV = coeficiente de variação em \%.

\begin{tabular}{|c|c|c|c|c|c|c|c|}
\hline & \multirow[b]{3}{*}{ Idade } & \multicolumn{6}{|c|}{ Relação água/aglomerante } \\
\hline & & \multicolumn{2}{|c|}{0,40} & \multicolumn{2}{|c|}{0,48} & \multicolumn{2}{|c|}{0,56} \\
\hline & & Rt & $\mathrm{CV}$ & $\mathbf{R t}$ & $\mathrm{CV}$ & Rt & $\mathrm{CV}$ \\
\hline \multirow{4}{*}{$\begin{array}{l}\text { Resistência à tração } \\
\text { na flexão (MPa) }\end{array}$} & 1 dia & 6,0 & $11,0 \%$ & 3,3 & $7,4 \%$ & 0,4 & $17,9 \%$ \\
\hline & 3 dias & 8,8 & $5,2 \%$ & 9,9 & $13,2 \%$ & 4,7 & $7,2 \%$ \\
\hline & 7 dias & 9,8 & $3,6 \%$ & 9,8 & $4,5 \%$ & 7,3 & $6,3 \%$ \\
\hline & 28 dias & 9,5 & $10,6 \%$ & 10,1 & $6,6 \%$ & 8,7 & $15,1 \%$ \\
\hline \multirow{4}{*}{$\begin{array}{l}\text { Variação da } \\
\text { resistência à tração } \\
\text { na flexão (\%) }\end{array}$} & $1 \mathrm{dia}$ & \multicolumn{2}{|c|}{0,0} & \multicolumn{2}{|c|}{$-45,5$} & \multicolumn{2}{|c|}{$-93,7$} \\
\hline & 3 dias & \multicolumn{2}{|c|}{0,0} & \multicolumn{2}{|c|}{$+12,0$} & \multicolumn{2}{|c|}{$-46,6$} \\
\hline & 7 dias & \multicolumn{2}{|c|}{0,0} & \multicolumn{2}{|c|}{$-0,2$} & \multicolumn{2}{|c|}{$-25,3$} \\
\hline & 28 dias & \multicolumn{2}{|c|}{0,0} & \multicolumn{2}{|c|}{$+6,4$} & \multicolumn{2}{|c|}{$-7,9$} \\
\hline
\end{tabular}

Os resultados do módulo de elasticidade do cimento de escória ativada com silicato de sódio constam da Figura 7.5. O perfil do efeito da relação a/agl no módulo de elasticidade foi similar ao obtido na resistência à compressão. Os resultados de módulo de elasticidade corroboram a afirmação de que a resistência mecânica do cimento de escória ativada com silicato de sódio é mais suscetível à relação a/agl nas primeiras idades.

Na Figura 7.6 está apresentada a correlação entre os resultados de módulo de elasticidade e a relação a/agl. Assim como na resistência à compressão, os resultados das relações a/agl 0,40 e 0,48 são similares a partir dos 3 dias de idade e a relação 0,56 reduz de forma significativa o módulo de elasticidade. Na Tabela 7.3 
estão apresentadas as reduções do módulo de elasticidade utilizando como referência a mistura com relação a/agl igual a 0,40. O percentual de redução das relações a/agl 0,48 e 0,56 alcançou valores de $26,2 \%$ e 98,5\%, respectivamente, com 1 dia de idade, porém as misturas com relação 0,48 apresentam recuperação com o avanço da idade. Com o avanço da idade, a mistura com relação a/agl igual a 0,56 recuperou parte do valor relativo à mistura com relação 0,40 , porém ainda assim com uma redução de $26,4 \%$ no resultado de módulo aos 28 dias de idade.



Figura 7.5 - Efeito da relação a/agl no módulo de elasticidade do cimento de escória (4NS).

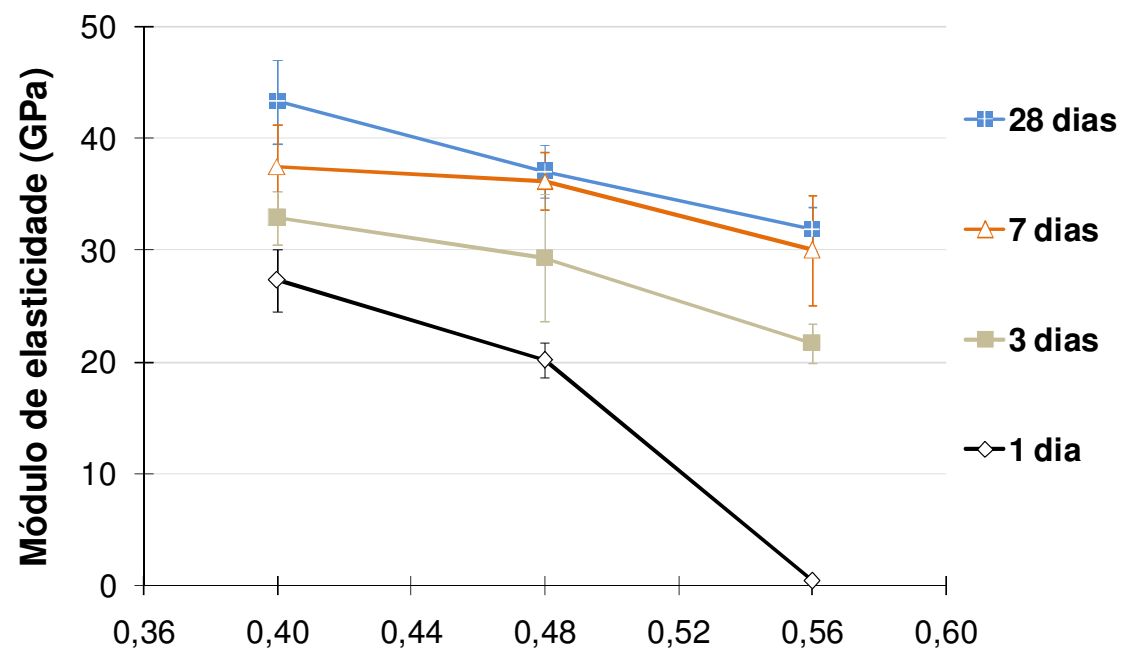

Relação água / aglomerante

Figura 7.6 - Variação do módulo de elasticidade em função da relação a/agl no cimento de escória (4NS). 
Tabela 7.3 - Médias aritméticas do módulo de elasticidade e o efeito da relação a/agl no cimento de escória ativada. CV = coeficiente de variação em \%.

\begin{tabular}{|c|c|c|c|c|c|c|c|}
\hline & \multirow[b]{3}{*}{ Idade } & \multicolumn{6}{|c|}{ Relação água/aglomerante } \\
\hline & & \multicolumn{2}{|c|}{0,40} & \multicolumn{2}{|c|}{0,48} & \multicolumn{2}{|c|}{0,56} \\
\hline & & Md & $\mathrm{CV}$ & Md & $\mathrm{CV}$ & Md & $\mathrm{CV}$ \\
\hline \multirow{4}{*}{$\begin{array}{l}\text { Módulo de } \\
\text { elasticidade (GPa) }\end{array}$} & $1 \mathrm{dia}$ & 27,3 & $5,2 \%$ & 20,1 & $4,0 \%$ & 0,4 & $20,4 \%$ \\
\hline & 3 dias & 32,9 & $3,7 \%$ & 29,3 & $9,9 \%$ & 21,7 & $4,3 \%$ \\
\hline & 7 dias & 37,4 & $5,2 \%$ & 36,2 & $3,7 \%$ & 30,0 & $8,4 \%$ \\
\hline & 28 dias & 43,3 & $4,4 \%$ & 37,0 & $3,2 \%$ & 31,9 & $3,2 \%$ \\
\hline \multirow{4}{*}{$\begin{array}{l}\text { Variação do módulo } \\
\text { de elasticidade (\%) }\end{array}$} & $1 \mathrm{dia}$ & \multicolumn{2}{|c|}{0,0} & \multicolumn{2}{|c|}{$-26,2$} & \multicolumn{2}{|c|}{$-98,5$} \\
\hline & 3 dias & \multicolumn{2}{|c|}{0,0} & \multicolumn{2}{|c|}{$-10,9$} & \multicolumn{2}{|c|}{$-34,2$} \\
\hline & 7 dias & \multirow{2}{*}{\multicolumn{2}{|c|}{0,0}} & \multirow{2}{*}{\multicolumn{2}{|c|}{$\begin{array}{r}-3,3 \\
145\end{array}$}} & \multicolumn{2}{|c|}{$-19,9$} \\
\hline & 28 dias & & & & & \multicolumn{2}{|c|}{$-26,4$} \\
\hline
\end{tabular}

\subsubsection{Resistência à compressão versus termogravimetria}

A resistência à compressão de compósitos cimentícios, obviamente, está diretamente relacionada ao grau de hidratação, dentre outras propriedades, como a porosidade. No cimento de escória ativada com silicato de sódio esta relação é mais evidente, pelo fato do mesmo ter como produto hidratado majoritário o $\mathrm{C}-\mathrm{S}-\mathrm{H}$. Portanto, era esperado que os resultados do ensaio de termogravimetria correlacionassem com os resultados de resistência à compressão, conforme consta na Figura 7.7.

É interessante observar que para quantidades similares de C-S-H, têm-se valores totalmente diferentes de resistência à compressão. Isto pode ser explicado pelo fato do aumento da relação a/agl resultar no aumento da porosidade e na alteração do perfil da distribuição dos poros nas primeiras idades. O teor de C-S-H obtido no ensaio de termogravimetria fornece excelente correlação com a resistência à compressão do cimento de escória ativada com silicato de sódio, porém a explicação do efeito da relação a/agl se completa com a compreensão do comportamento da porosidade. 




Figura 7.7 - Correlação entre a resistência à compressão e a quantidade de C-S-H (\%).

\subsubsection{Resistência à compressão versus porosidade}

A correlação entre a resistência mecânica e a porosidade é clássica, sabendo-se que quanto maior a porosidade, menor a resistência mecânica. No caso específico do cimento de escória ativada com silicato de sódio, o comportamento é similar quando a análise é realizada comparando misturas com diferentes a/agl, ou seja, com o aumento da relação a/agl ocorre a diminuição da resistência à compressão decorrente do aumento da porosidade total.

Na Figura 7.8(a) consta a correlação entre resistência à compressão e porosidade total, na qual se observa que o aumento da relação a/agl incorre em uma grande variação da porosidade total, refletindo numa diminuição significativa da resistência à compressão. Na Figura 7.8(b)(c) está evidente a papel do refinamento da porosidade na evolução da resistência à compressão, no qual o aumento do volume de mesoporos e diminuição do volume de macroporos incorre no aumento da resistência à compressão. 



Figura 7.8 - Correlação entre a porosidade total (a),volume de macroporos (b) e volume de mesoporos (c) com a resistência à compressão. Gráficos construídos com todos os pontos obtidos.

Quando se analisa cada relação a/agl isoladamente, a evolução da resistência à compressão e a porosidade total não apresentam correlação. Isto pode ser explicado pelo fato do cimento de escória ativada com silicato de sódio apresentar uma redução da porosidade total com o avanço da idade, porém, em determinado instante, ocorre uma estabilização da porosidade total (item 6.2, pág.83). Esta estabilização é o motivo da falta de correlação entre a evolução da resistência à compressão e a porosidade total quando analisada, isoladamente, para cada relação a/agl. Nesta situação, destaca-se a importância do ensaio de porosimetria por intrusão de mercúrio, uma vez que permite detalhar a distribuição dos poros. Com a distribuição dos poros, observa-se que apesar da porosidade total se manter quase constante a partir de certa idade, a distribuição dos poros se altera de forma significativa, ocorrendo o refinamento da porosidade. llustrando esta análise, a Figura 7.9 apresenta a correlação entre a evolução do volume de macroporos (a) e mesoporos (b) com a resistência à compressão em cada relação a/agl estudada. 



Figura 7.9 - Correlação o volume de macroporos (a) e o volume de mesoporos (b) com a resistência à compressão.

\subsection{Efeito do aditivo redutor de retração (SRA)}

\subsubsection{Resistência à compressão}

O efeito do teor de aditivo SRA na resistência à compressão do cimento de escória ativada com silicato de sódio nas três relações a/agl ensaiadas estão apresentadas nas Figura 7.10, Figura 7.11 e Figura 7.12. Confirmando os dados levantados na revisão bibliográfica (item 2.4.2) referentes ao efeito no cimento Portland, o aditivo redutor de retração também reduz a resistência mecânica do cimento de escória ativada com silicato de sódio. De acordo com os resultados da caracterização da microestrutura, o aditivo SRA inibe as reações de hidratação, principalmente nas primeiras idades. A provável causa deste comportamento é seu mecanismo de ação, que reduz a tensão superficial da água do poro. Segundo Brooks et al. (2000), isto 
faz com que ocorra um retardo da aglomeração das partículas e, conseqüentemente, um retardo do desenvolvimento das reações de hidratação.

Observa-se que o comportamento do aditivo SRA foi similar nas três relações a/agl estudadas, porém o efeito conjunto do aumento do teor de aditivo e do aumento da relação a/agl causou a maximização da redução da resistência à compressão observada na análise do efeito do aumento da relação a/agl. Este efeito é claro na relação 0,56, na qual a resistência à compressão apresentou valores próximos a zero até 3 dias de idade com a utilização de teores 1\%, 1,5\% e 2\% de SRA (Figura $7.12)$.



Figura 7.10 - Efeito do teor de aditivo SRA na resistência à compressão da argamassa de cimento de escória com relação a/agl igual a 0,40.



Figura 7.11 - Efeito do teor de aditivo SRA na resistência à compressão da argamassa de cimento de escória com relação a/agl igual a 0,48. 




Figura 7.12 - Efeito do teor de aditivo SRA na resistência à compressão da argamassa de cimento de escória com relação a/agl igual a 0,56.

Os resultados da resistência à compressão relacionados ao teor de aditivo redutor de retração obtidos nas três relações a/agl estudadas constam da Figura 7.13, Figura 7.14 e Figura 7.15. Observa-se a evidente correlação entre a diminuição da resistência à compressão com o aumento do teor de aditivo SRA, ressaltando-se que os teores de $0,5 \%$ e $1 \%$ de SRA apresentaram menor redução da resistência à compressão aos 28 dias quando comparado aos demais teores estudados. Analisando-se o efeito conjunto do teor de aditivo SRA e da relação a/agl é novamente observada a redução mais intensa da resistência à compressão nas primeiras idades e com a utilização de maiores teores de aditivo SRA.



Figura 7.13 - Variação da resistência à compressão em função do teor de aditivo SRA na argamassa de cimento de escória com relação a/agl igual a 0,40. 




Figura 7.14 - Variação da resistência à compressão em função do teor de aditivo SRA na argamassa de cimento de escória com relação a/agl igual a 0,48.



Figura 7.15 - Variação da resistência à compressão em função do teor de aditivo SRA na argamassa de cimento de escória com relação a/agl igual a 0,56.

O efeito do aditivo SRA foi amenizado com o avanço da idade na mistura com relação a/agl igual a 0,40 e 0,5\% do aditivo SRA, obtendo-se valores até mesmo maiores do que na mistura sem utilização de aditivo aos 7 e 28 dias de idade (Tabela 7.4). No uso do aditivo redutor de retração (SRA) no cimento Portland, os fabricantes e pesquisas anteriores relatam a diminuição da resistência à compressão em percentuais de até $15 \%$. As conseqüências da utilização do aditivo SRA na resistência inicial é pouco relatado; resultados obtidos por Folliard e Berke (1997) indicaram que com 1 dia de idade ocorreu a redução de $20 \%$ da resistência à compressão de um concreto com cimento Portland utilizando 1,5\% de aditivo SRA. 
No cimento de escória ativada com silicato de sódio, a diminuição da resistência causada pelo uso do aditivo SRA apresenta percentuais similares apenas nas idades finais e com baixa relação a/agl, conforme apresentado na Tabela 7.4.

Conforme descrito na análise da influência da relação a/agl no cimento de escória (item 7.1), o aumento da relação a/agl no cimento de escória ativado com silicato de sódio tem efeito mais intenso nas primeiras idades; com a utilização do aditivo SRA ocorre maximização desse comportamento (Figura 7.14 e Figura 7.15). Supõe-se que este comportamento ocorre em razão da diminuição da aglomeração causada pelo efeito conjunto do maior distanciamento entre as partículas com o aumento da relação a/agl e da diminuição da tensão superficial com o aumento do teor de aditivo SRA.

Utilizando como referência as misturas sem utilização do aditivo SRA foi quantificado o seu efeito na resistência à compressão, apresentado na Tabela 7.4, Tabela 7.5 e Tabela 7.6. Constata-se que a utilização do aditivo SRA provocou maior redução da resistência à compressão nas misturas com relação a/agl de 0,48 e 0,56 do que a observada na mistura com relação a/agl de 0,40. Na mistura com relação a/agl de 0,48 a redução foi intensa nas primeiras idades e proporcional ao aumento do teor de aditivo SRA, sendo observada uma recuperação a partir dos 3 dias de idade. $\mathrm{Na}$ mistura com relação a/agl igual a 0,56, a recuperação da resistência à compressão aconteceu aos 7 dias de idade e com maior efeito na mistura com teor de $0,5 \%$ de SRA.

Tabela 7.4 - Médias aritméticas da resistência à compressão e o efeito do teor de aditivo redutor de retração (SRA) no cimento de escória ativada com relação a/agl igual a $\mathbf{0 , 4 0}$. $\mathrm{CV}=$ coeficiente de variação em \%.

\begin{tabular}{|c|c|c|c|c|c|c|c|c|c|c|c|}
\hline \multicolumn{2}{|c|}{ Relação a/agl = 0,40 } & \multicolumn{10}{|c|}{ Teor de aditivo redutor de retração (SRA) } \\
\hline & \multirow[b]{2}{*}{ Idade } & \multicolumn{2}{|c|}{$0 \%$} & \multicolumn{2}{|c|}{$0,5 \%$} & \multicolumn{2}{|c|}{$1 \%$} & \multicolumn{2}{|c|}{$1,5 \%$} & \multicolumn{2}{|c|}{$2 \%$} \\
\hline & & $\mathbf{R C}$ & $\mathrm{CV}$ & $\mathbf{R C}$ & $\mathrm{CV}$ & Rc & $\mathrm{CV}$ & Rc & $\mathrm{CV}$ & Rc & $\mathrm{CV}$ \\
\hline \multirow{4}{*}{$\begin{array}{l}\text { Resistência à } \\
\text { compressão (MPa) }\end{array}$} & $1 \mathrm{dia}$ & 44,0 & $3,9 \%$ & 34,6 & $3,8 \%$ & 11,5 & $4,4 \%$ & 2,9 & $5,4 \%$ & 1,0 & $9,8 \%$ \\
\hline & 3 dias & 67,7 & $2,9 \%$ & 57,9 & $3,5 \%$ & 49,4 & $4,7 \%$ & 40,3 & $4,8 \%$ & 33,2 & $4,9 \%$ \\
\hline & 7 dias & 80,5 & $2,2 \%$ & 85,3 & $0,9 \%$ & 70,7 & $3,7 \%$ & 62,0 & $5,7 \%$ & 56,1 & $1,7 \%$ \\
\hline & 28 dias & 91,1 & $1,4 \%$ & 93,0 & $0,8 \%$ & 86,9 & $5,4 \%$ & 77,1 & $4,9 \%$ & 75,4 & $6,9 \%$ \\
\hline \multirow{4}{*}{$\begin{array}{l}\text { Variação da } \\
\text { resistência à } \\
\text { compressão (\%) }\end{array}$} & $1 \mathrm{dia}$ & \multicolumn{2}{|c|}{0,0} & \multicolumn{2}{|c|}{$-21,3$} & \multicolumn{2}{|c|}{73,8} & \multicolumn{2}{|r|}{3,4} & \multicolumn{2}{|c|}{$-97,8$} \\
\hline & 3 dias & \multicolumn{2}{|c|}{0,0} & \multirow{2}{*}{\multicolumn{2}{|c|}{$-14,4$}} & \multicolumn{2}{|c|}{$-27,0$} & \multicolumn{2}{|c|}{$-40,5$} & \multicolumn{2}{|c|}{$-50,9$} \\
\hline & 7 dias & \multicolumn{2}{|c|}{0,0} & \multirow{2}{*}{\multicolumn{2}{|c|}{$\begin{array}{l}+6,0 \\
+2,1\end{array}$}} & \multirow{2}{*}{\multicolumn{2}{|c|}{$\begin{array}{r}-12,1 \\
-4,6\end{array}$}} & \multicolumn{2}{|c|}{$-23,0$} & \multicolumn{2}{|c|}{$-30,3$} \\
\hline & 28 dias & \multicolumn{2}{|c|}{0,0} & & & & & \multicolumn{2}{|c|}{$-15,4$} & \multicolumn{2}{|c|}{$-17,2$} \\
\hline
\end{tabular}


Tabela 7.5 - Médias aritméticas da resistência à compressão e o efeito do teor de aditivo redutor de retração (SRA) no cimento de escória ativada com relação a/agl igual a $\mathbf{0 , 4 8}$. $\mathrm{CV}=$ coeficiente de variação em \%.

\begin{tabular}{|c|c|c|c|c|c|c|c|c|c|c|c|}
\hline \multicolumn{2}{|c|}{ Relação a/agl = 0,48 } & \multicolumn{10}{|c|}{ Teor de aditivo redutor de retração (SRA) } \\
\hline & \multirow[b]{2}{*}{ Idade } & \multicolumn{2}{|c|}{$0 \%$} & \multicolumn{2}{|c|}{$0,5 \%$} & \multicolumn{2}{|c|}{$1 \%$} & \multicolumn{2}{|c|}{$1,5 \%$} & \multicolumn{2}{|c|}{$2 \%$} \\
\hline & & $\mathbf{R c}$ & $\mathrm{CV}$ & Rc & $\mathrm{CV}$ & $\mathbf{R c}$ & $\mathrm{CV}$ & Rc & $\mathrm{CV}$ & Rc & $\mathrm{CV}$ \\
\hline \multirow{4}{*}{$\begin{array}{l}\text { Resistência à } \\
\text { compressão (MPa) }\end{array}$} & $1 \mathrm{dia}$ & 30,3 & $2,4 \%$ & $\overline{1,6}$ & $2,2 \%$ & 0,6 & $8,5 \%$ & 0,5 & $12,0 \%$ & 0,3 & $9,7 \%$ \\
\hline & 3 dias & 60,0 & $3,7 \%$ & 41,0 & $3,8 \%$ & 28,6 & $4,7 \%$ & 24,8 & $4,2 \%$ & 19,6 & $5,9 \%$ \\
\hline & 7 dias & 77,4 & $3,1 \%$ & 59,8 & $2,2 \%$ & 57,7 & $3,7 \%$ & 48,8 & $2,9 \%$ & 45,7 & $3,2 \%$ \\
\hline & 28 dias & 86,4 & $1,5 \%$ & 67,0 & $3,3 \%$ & 59,2 & $4,5 \%$ & 56,3 & $3,9 \%$ & 51,0 & $4,2 \%$ \\
\hline \multirow{4}{*}{$\begin{array}{l}\text { Variação da } \\
\text { resistência à } \\
\text { compressão (\%) }\end{array}$} & $1 \mathrm{dia}$ & \multicolumn{2}{|c|}{0,0} & \multicolumn{2}{|c|}{$-94,9$} & \multicolumn{2}{|c|}{$-98,1$} & \multicolumn{2}{|c|}{$-98,3$} & \multicolumn{2}{|c|}{$-98,9$} \\
\hline & 30 & \multicolumn{2}{|c|}{0,0} & \multicolumn{2}{|c|}{$-31,7$} & \multicolumn{2}{|c|}{$-52,4$} & \multicolumn{2}{|c|}{$-58,6$} & \multicolumn{2}{|c|}{$-67,3$} \\
\hline & 7 dias & \multicolumn{2}{|c|}{0,0} & \multicolumn{2}{|c|}{$-22,7$} & \multicolumn{2}{|c|}{$-25,5$} & \multicolumn{2}{|c|}{$-37,0$} & \multicolumn{2}{|c|}{$-40,9$} \\
\hline & 28 dias & \multicolumn{2}{|c|}{0,0} & \multicolumn{2}{|c|}{$-22,4$} & \multicolumn{2}{|c|}{$-31,4$} & \multicolumn{2}{|c|}{$-34,8$} & \multicolumn{2}{|c|}{$-40,9$} \\
\hline
\end{tabular}

Tabela 7.6 - Médias aritméticas da resistência à compressão e o efeito do teor de aditivo redutor de retração (SRA) no cimento de escória ativada com relação a/agl igual a $\mathbf{0 , 5 6}$. CV $=$ coeficiente de variação em \%.

\begin{tabular}{|c|c|c|c|c|c|c|c|c|c|c|c|}
\hline \multicolumn{2}{|c|}{ Relação a/agl = 0,56 } & \multicolumn{10}{|c|}{ Teor de aditivo redutor de retração (SRA) } \\
\hline & \multirow[b]{2}{*}{ Idade } & \multicolumn{2}{|c|}{$0 \%$} & \multicolumn{2}{|c|}{$0,5 \%$} & \multicolumn{2}{|c|}{$1 \%$} & \multicolumn{2}{|c|}{$1,5 \%$} & \multicolumn{2}{|c|}{$2 \%$} \\
\hline & & $\mathbf{R c}$ & $\mathrm{CV}$ & Rc & $\mathrm{CV}$ & Rc & $\mathrm{CV}$ & Rc & $\mathrm{CV}$ & Rc & $\mathrm{CV}$ \\
\hline \multirow{4}{*}{$\begin{array}{l}\text { Resistência à } \\
\text { compressão (MPa) }\end{array}$} & $1 \mathrm{dia}$ & 1,7 & $9,1 \%$ & 0,3 & $9,8 \%$ & 0,3 & $0,0 \%$ & 0,3 & $0,0 \%$ & 0,3 & $0,0 \%$ \\
\hline & 3 dias & 35,2 & $6,3 \%$ & 14,5 & $7,8 \%$ & 0,4 & $10,0 \%$ & 0,4 & $10,0 \%$ & 0,4 & $10,0 \%$ \\
\hline & 7 dias & 51,7 & $5,8 \%$ & 41,9 & $4,3 \%$ & 30,8 & $5,9 \%$ & 23,7 & $5,3 \%$ & 18,9 & $7,0 \%$ \\
\hline & 28 dias & 59,9 & $2,9 \%$ & 52,2 & $2,3 \%$ & 42,5 & $3,0 \%$ & 40,6 & $4,7 \%$ & 42,0 & $3,4 \%$ \\
\hline \multirow{4}{*}{$\begin{array}{l}\text { Variação da } \\
\text { resistência à } \\
\text { compressão (\%) }\end{array}$} & 1 dia & \multicolumn{2}{|c|}{0,0} & \multicolumn{2}{|c|}{$-84,7$} & \multicolumn{2}{|c|}{$-85,3$} & \multicolumn{2}{|c|}{$-85,3$} & \multicolumn{2}{|c|}{$-85,3$} \\
\hline & $3 d$ & \multicolumn{2}{|c|}{0,0} & \multicolumn{2}{|c|}{$-58,9$} & \multicolumn{2}{|c|}{$-99,0$} & \multicolumn{2}{|c|}{$-99,0$} & \multicolumn{2}{|c|}{$-99,0$} \\
\hline & 7 dias & \multicolumn{2}{|c|}{0,0} & \multicolumn{2}{|c|}{$-18,9$} & \multicolumn{2}{|c|}{$-40,5$} & \multicolumn{2}{|c|}{ - 54,2 } & \multicolumn{2}{|c|}{$-63,4$} \\
\hline & 28 dias & \multicolumn{2}{|c|}{0,0} & \multicolumn{2}{|c|}{$-12,9$} & \multicolumn{2}{|c|}{$-29,1$} & \multicolumn{2}{|c|}{$-32,3$} & \multicolumn{2}{|c|}{$-29,9$} \\
\hline
\end{tabular}

Nos gráficos da Figura 7.16 está apresentado o efeito do teor de aditivo SRA e da relação a/agl na resistência à compressão. Observa-se a redução da resistência à compressão é maximizada com o aumento simultâneo da relação a/agl e do teor de aditivo SCA. Com base nos resultados obtidos, conclui-se que o aumento do teor de aditivo SRA pode inviabilizar a utilização do cimento de escória ativada em aplicações onde seja necessária elevada resistência inicial. As misturas que utilizaram os teores de $0,5 \%$ e $1 \%$ do aditivo SRA apresentaram valores próximos aos obtidos sem a sua utilização. A interação do efeito do aditivo SRA e a relação água/aglomerante no cimento de escória ativada com silicato de sódio se mostrou importante, pois a redução da resistência à compressão causada pelo aumento de ambos é um importante parâmetro para a decisão de utilizar determinado teor de aditivo em conjunto determinada relação a/agl. 
1 dia



Teor de aditivo redutor de retração (SRA) (\%)

7 dias

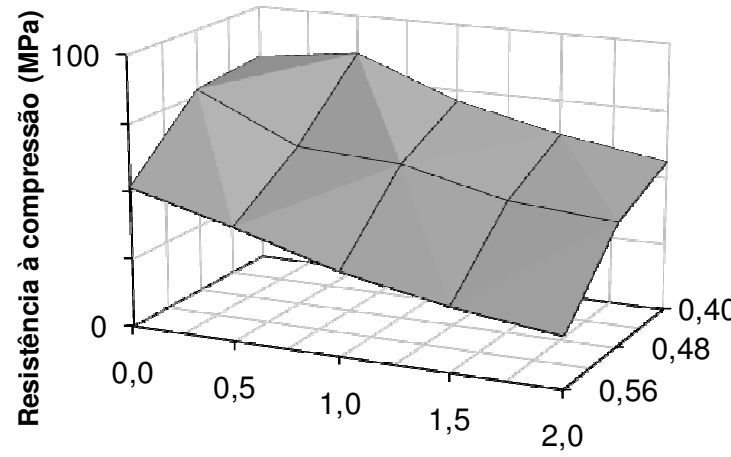

Teor de aditivo redutor de retração (SRA) (\%)
3 dias


Teor de aditivo redutor de retração (SRA) (\%)

28 dias



Teor de aditivo redutor de retração (SRA) (\%)

Figura 7.16 - Efeito do teor de aditivo SRA e da relação água/aglomerante na resistência à compressão.

\subsubsection{Resistência à tração na flexão}

A influência do aditivo redutor de retração (SRA) na resistência à tração na flexão foi similar ao observado na resistência à compressão (item 7.2.1). Assim como descrito na análise do efeito da relação água/aglomerante na resistência à tração na flexão, observa-se a elevada variabilidade deste ensaio (Tabela 7.7). Apesar deste fato, pode-se afirmar que o aditivo SRA reduz a resistência à tração com mais intensidade com 1 dia de idade. Na mistura com relação a/agl igual a 0,40 (Figura 7.17), observa-se que o efeito do teor de aditivo SRA é maior com 1 dia de idade e que os teores de $0,5 \%$ e $1 \%$ de SRA não causam redução da resistência à tração nas demais idades. Esta tendência é evidenciada na Figura 7.18 e na Tabela 7.7; onde o aumento do teor de aditivo SRA incorre na redução da resistência à tração em torno de $90 \%$ a 1 dia de idade, porém, as misturas com os teores de $0,5 \%$ e $1 \%$ apresentam recuperação ou valores superiores aos de referência. 


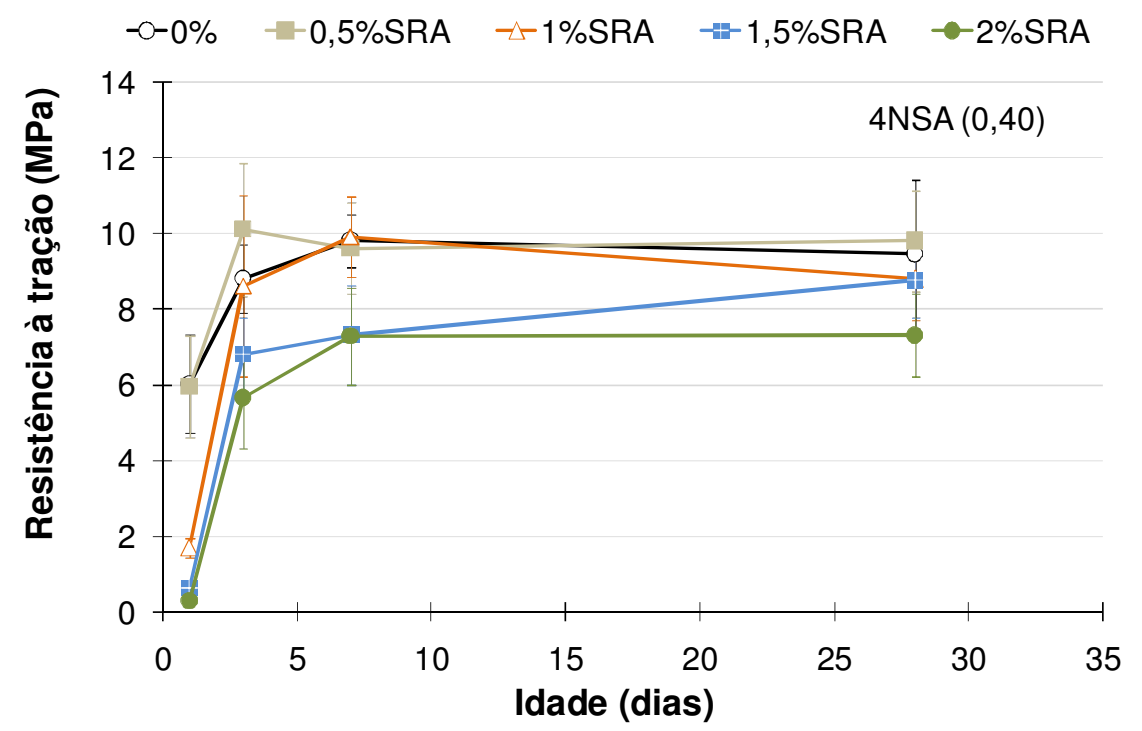

Figura 7.17 - Efeito do teor de aditivo SRA na resistência à tração da argamassa de cimento de escória com relação a/agl igual a 0,40.



Figura 7.18 - Variação da resistência à tração em função do teor de aditivo SRA na argamassa de cimento de escória com relação a/agl igual a 0,40.

Tabela 7.7 - Médias aritméticas da resistência à tração na flexão e o efeito do teor de aditivo redutor de retração (SRA) no cimento de escória ativada com relação a/agl igual a $\mathbf{0 , 4 0}$. CV $=$ coeficiente de variação em \%.

\begin{tabular}{|c|c|c|c|c|c|c|c|c|c|c|c|}
\hline \multicolumn{2}{|c|}{ Relação a/agl = 0,40 } & \multicolumn{10}{|c|}{ Teor de aditivo redutor de retração (SRA) } \\
\hline & \multirow[b]{2}{*}{ Idade } & \multicolumn{2}{|c|}{$0 \%$} & \multicolumn{2}{|c|}{$0,5 \%$} & \multicolumn{2}{|c|}{$1 \%$} & \multicolumn{2}{|c|}{$1,5 \%$} & \multicolumn{2}{|c|}{$2 \%$} \\
\hline & & $\overline{\mathbf{R t}}$ & $\mathrm{CV}$ & $\mathbf{R t}$ & $\mathrm{CV}$ & $\mathbf{R t}$ & $\mathrm{CV}$ & $\mathbf{R t}$ & $\mathrm{CV}$ & $\mathbf{R t}$ & $\mathrm{CV}$ \\
\hline \multirow{4}{*}{$\begin{array}{l}\text { Resistência à tração } \\
\text { na flexão (MPa) }\end{array}$} & $1 \mathrm{dia}$ & 6,0 & $11,0 \%$ & 6,0 & $11,6 \%$ & 1,7 & $7,4 \%$ & 0,6 & $1,6 \%$ & 0,3 & $7,4 \%$ \\
\hline & 3 dias & 8,8 & $5,2 \%$ & 10,1 & $8,9 \%$ & 8,6 & $14,2 \%$ & 6,8 & $7,3 \%$ & 5,7 & $12,1 \%$ \\
\hline & 7 dias & 9,8 & $3,6 \%$ & 9,6 & $6,4 \%$ & 9,9 & $5,4 \%$ & 7,3 & $9,1 \%$ & 7,3 & $9,0 \%$ \\
\hline & 28 dias & 9,5 & $10,6 \%$ & 9,8 & $6,9 \%$ & 8,8 & $6,3 \%$ & 8,8 & $5,8 \%$ & 7,3 & $7,6 \%$ \\
\hline \multirow{4}{*}{$\begin{array}{l}\text { Variação da } \\
\text { resistência à tração } \\
\text { na flexão (\%) }\end{array}$} & $1 \mathrm{dia}$ & \multicolumn{2}{|c|}{0,0} & \multicolumn{2}{|c|}{$-1,2$} & \multicolumn{2}{|c|}{$-71,8$} & \multicolumn{2}{|c|}{$-89,5$} & \multicolumn{2}{|c|}{$-95,2$} \\
\hline & 3 dias & \multicolumn{2}{|c|}{0,0} & \multicolumn{2}{|c|}{$+14,9$} & \multicolumn{2}{|c|}{$-2,0$} & \multicolumn{2}{|c|}{$-22,7$} & \multicolumn{2}{|c|}{$-35,7$} \\
\hline & 7 dias & \multicolumn{2}{|c|}{0,0} & \multicolumn{2}{|c|}{$-2,1$} & \multicolumn{2}{|c|}{$+1,1$} & \multicolumn{2}{|c|}{$-25,3$} & \multicolumn{2}{|c|}{$-25,8$} \\
\hline & 28 dias & \multicolumn{2}{|c|}{0,0} & \multicolumn{2}{|c|}{$+3,7$} & \multicolumn{2}{|c|}{$-6,9$} & \multicolumn{2}{|c|}{$-7,3$} & \multicolumn{2}{|c|}{$-22,7$} \\
\hline
\end{tabular}


A Figura 7.19 apresenta o efeito do teor de aditivo na evolução da resistência à tração até os 28 dias da mistura de escória ativada com silicato de sódio e relação a/agl igual a 0,48 . Nota-se que o efeito do aditivo foi de diminuição da resistência à tração com 1 dia de idade em qualquer teor de SRA utilizado. A partir dos 3 dias de idade, a mistura com teor de $0,5 \%$ de aditivo já apresenta uma considerável recuperação, passando de uma redução da resistência à tração de $87,7 \%$ com 1 dia para 9,2\% aos 3 dias (Tabela 7.8), e valores superiores aos observados na mistura sem aditivo com o avanço da idade.

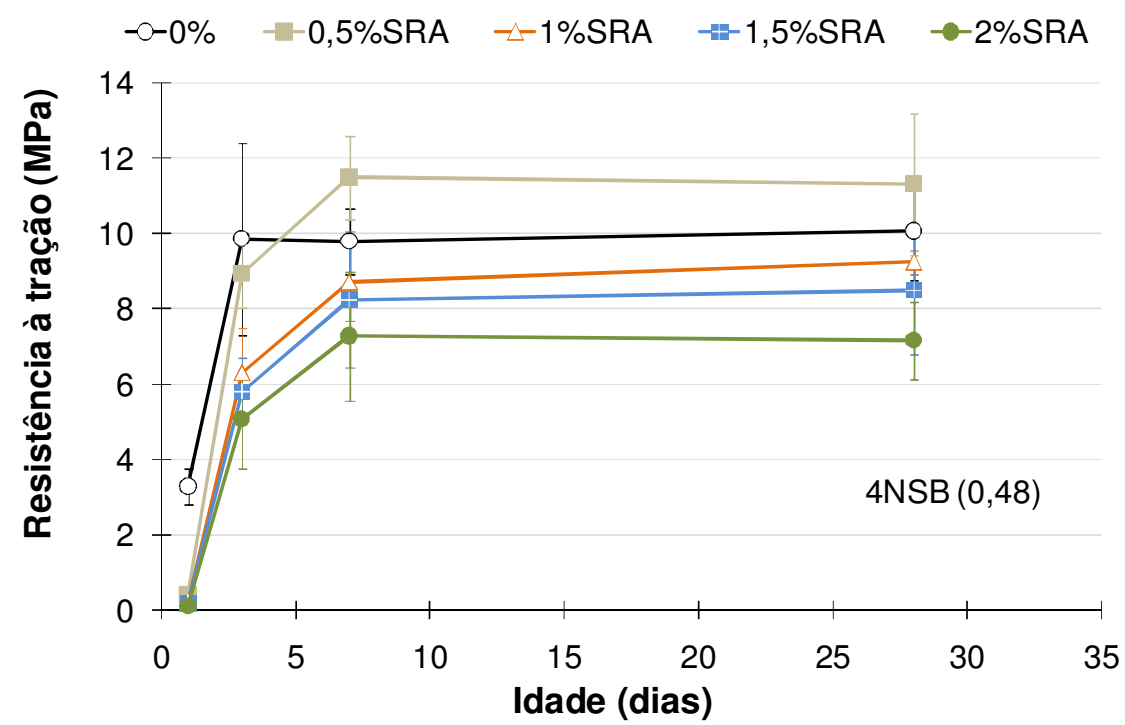

Figura 7.19 - Efeito do teor de aditivo SRA na resistência à tração da argamassa de cimento de escória com relação a/agl igual a 0,48.



Figura 7.20 - Variação da resistência à tração em função do teor de aditivo SRA na argamassa de cimento de escória com relação a/agl igual a 0,48. 
Tabela 7.8 - Médias aritméticas da resistência à tração na flexão e o efeito do teor de aditivo redutor de retração (SRA) no cimento de escória ativada com relação a/agl igual a $\mathbf{0 , 4 8}$. CV $=$ coeficiente de variação em \%.

\begin{tabular}{|c|c|c|c|c|c|c|c|c|c|c|c|}
\hline \multicolumn{2}{|c|}{ Relação a/agl = 0,48 } & \multicolumn{10}{|c|}{ Teor de aditivo redutor de retração (SRA) } \\
\hline & \multirow[b]{2}{*}{ Idade } & \multicolumn{2}{|c|}{$0 \%$} & \multicolumn{2}{|c|}{$0,5 \%$} & \multicolumn{2}{|c|}{$1 \%$} & \multicolumn{2}{|c|}{$1,5 \%$} & \multicolumn{2}{|c|}{$2 \%$} \\
\hline & & $\mathbf{R t}$ & $\mathrm{CV}$ & $\mathbf{R t}$ & $\mathrm{CV}$ & $\mathbf{R t}$ & $\mathrm{CV}$ & $\mathbf{R t}$ & $\mathrm{CV}$ & $\mathbf{R t}$ & $\mathrm{CV}$ \\
\hline \multirow{4}{*}{$\begin{array}{l}\text { Resistência à tração } \\
\text { na flexão (MPa) }\end{array}$} & 1 dia & 3,3 & $7,4 \%$ & $\overline{0,4}$ & $15,3 \%$ & 0,2 & $23,2 \%$ & 0,2 & $9,0 \%$ & 0,1 & $14,9 \%$ \\
\hline & 3 dias & 9,9 & $13,2 \%$ & 8,9 & $5,2 \%$ & 6,3 & $9,6 \%$ & 5,8 & $7,8 \%$ & 5,1 & $13,1 \%$ \\
\hline & 7 dias & 9,8 & $4,5 \%$ & 11,5 & $4,9 \%$ & 8,7 & $6,1 \%$ & 8,3 & $11,2 \%$ & 7,3 & $11,9 \%$ \\
\hline & 28 dias & 10,1 & $6,6 \%$ & 11,3 & $8,4 \%$ & 9,2 & $1,8 \%$ & 8,5 & $10,2 \%$ & 7,2 & $7,3 \%$ \\
\hline \multirow{4}{*}{$\begin{array}{l}\text { Variação da } \\
\text { resistência à tração } \\
\text { na flexão (\%) }\end{array}$} & 1 dia & \multicolumn{2}{|c|}{0,0} & \multicolumn{2}{|c|}{$-87,7$} & \multicolumn{2}{|c|}{$-94,4$} & \multicolumn{2}{|c|}{$-94,3$} & \multicolumn{2}{|c|}{$-96,8$} \\
\hline & 3 dias & \multicolumn{2}{|c|}{0,0} & \multicolumn{2}{|c|}{$-9,2$} & \multicolumn{2}{|c|}{$-36,0$} & \multicolumn{2}{|c|}{$-41,1$} & \multicolumn{2}{|c|}{$-48,6$} \\
\hline & 7 dias & \multicolumn{2}{|c|}{0,0} & \multicolumn{2}{|c|}{$+17,2$} & \multicolumn{2}{|c|}{$-11,1$} & \multicolumn{2}{|c|}{$-15,8$} & \multicolumn{2}{|c|}{$-25,8$} \\
\hline & 28 dias & \multicolumn{2}{|c|}{0,0} & \multicolumn{2}{|c|}{$+12,4$} & \multicolumn{2}{|c|}{$-8,2$} & \multicolumn{2}{|c|}{$-15,7$} & \multicolumn{2}{|c|}{$-28,8$} \\
\hline
\end{tabular}

Com o aumento da relação a/agl para 0,56, mais uma vez ocorre o efeito conjunto do aditivo SRA e da quantidade de água. Isto faz com que ocorra a redução da resistência à tração com a utilização do aditivo SRA e causa o retardo do ganho de resistência (Figura 7.21), porém não ocorre a diminuição significativa da resistência final (Figura 7.22). As misturas com teores de 1\%, 1,5\% e 2\% de SRA resultaram em resistências nulas até os 3 dias de idade, conforme apresentado na Tabela 7.9. Com o avanço da idade ocorre a recuperação da resistência à tração e, com base na variabilidade dos resultados, não há distinção entre a mistura com e sem aditivo aos 28 dias. No entanto, ressalta-se o baixo desempenho nas primeiras idades da argamassa produzida com esta relação a/agl e com a utilização do aditivo SRA.

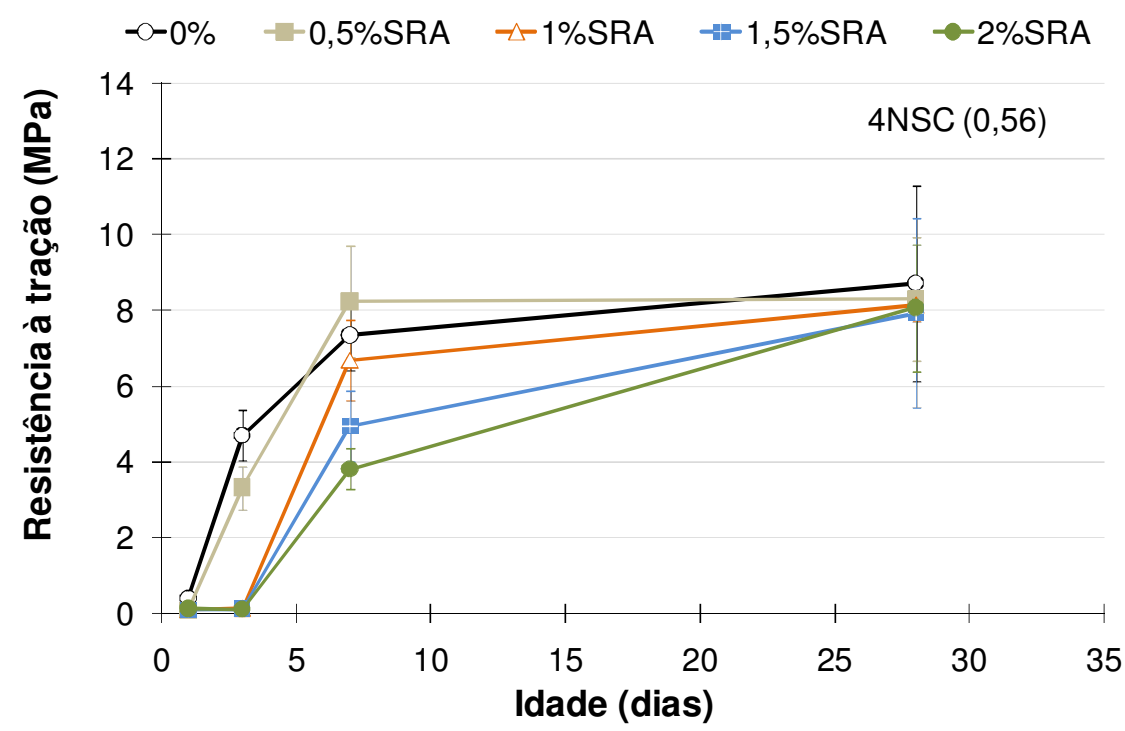

Figura 7.21 - Efeito do teor de aditivo SRA na resistência à tração da argamassa de cimento de escória com relação a/agl igual a 0,56. 


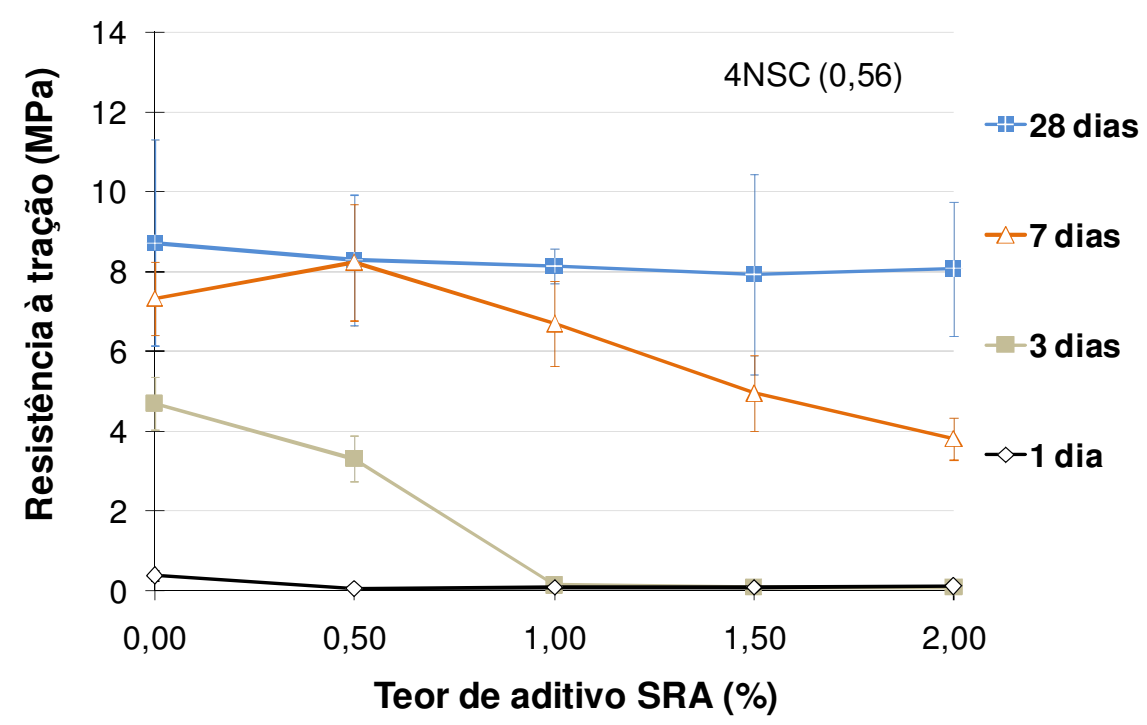

Figura 7.22 - Variação da resistência à tração em função do teor de aditivo SRA na argamassa de cimento de escória com relação a/agl igual a 0,56

Tabela 7.9 - Médias aritméticas da resistência à tração na flexão e o efeito do teor de aditivo redutor de retração (SRA) no cimento de escória ativada com relação a/agl igual a $\mathbf{0 , 5 6}$. CV $=$ coeficiente de variação em \%.

\begin{tabular}{|c|c|c|c|c|c|c|c|c|c|c|c|}
\hline \multicolumn{2}{|c|}{ Relação a/agl = 0,56 } & \multicolumn{10}{|c|}{ Teor de aditivo redutor de retração (SRA) } \\
\hline & \multirow[b]{2}{*}{ Idade } & \multicolumn{2}{|c|}{$0 \%$} & \multicolumn{2}{|c|}{$0,5 \%$} & \multicolumn{2}{|c|}{$1 \%$} & \multicolumn{2}{|c|}{$1,5 \%$} & \multicolumn{2}{|c|}{$2 \%$} \\
\hline & & $\mathbf{R t}$ & $\mathrm{CV}$ & $\mathbf{R t}$ & $\mathrm{CV}$ & Rt & $\mathrm{CV}$ & $\mathbf{R t}$ & $\mathrm{CV}$ & $\mathbf{R t}$ & $\mathrm{CV}$ \\
\hline \multirow{4}{*}{$\begin{array}{l}\text { Resistência à tração } \\
\text { na flexão (MPa) }\end{array}$} & 1 dia & 0,4 & $17,9 \%$ & 0,1 & $16,0 \%$ & 0,1 & $11,3 \%$ & 0,1 & $11,2 \%$ & 0,1 & $7,4 \%$ \\
\hline & 3 dias & 4,7 & $7,2 \%$ & 3,3 & $8,9 \%$ & 0,1 & $35,1 \%$ & 0,1 & $15,3 \%$ & 0,1 & $15,9 \%$ \\
\hline & 7 dias & 7,3 & $6,3 \%$ & 8,2 & $9,1 \%$ & 6,7 & $8,1 \%$ & 4,9 & $9,7 \%$ & 3,8 & $7,2 \%$ \\
\hline & 28 dias & 8,7 & $15,1 \%$ & 8,3 & $10,0 \%$ & 8,1 & $2,8 \%$ & 7,9 & $16,1 \%$ & 8,1 & $10,6 \%$ \\
\hline \multirow{4}{*}{$\begin{array}{l}\text { Variação da } \\
\text { resistência à tração } \\
\text { na flexão (\%) }\end{array}$} & 1 dia & \multicolumn{2}{|c|}{0,0} & \multicolumn{2}{|c|}{$-80,9$} & \multicolumn{2}{|c|}{$-73,2$} & \multicolumn{2}{|c|}{$-74,7$} & \multicolumn{2}{|c|}{$-69,7$} \\
\hline & $3 \mathrm{di}$ & \multicolumn{2}{|c|}{0,0} & \multicolumn{2}{|c|}{$-29,4$} & \multicolumn{2}{|c|}{$-97,0$} & \multicolumn{2}{|c|}{ - 97,7 } & \multicolumn{2}{|c|}{$-98,1$} \\
\hline & 7 dias & \multicolumn{2}{|c|}{0,0} & \multicolumn{2}{|c|}{$+12,2$} & \multicolumn{2}{|c|}{$-8,8$} & \multicolumn{2}{|c|}{$-32,6$} & \multicolumn{2}{|c|}{$-48,0$} \\
\hline & 28 dias & \multicolumn{2}{|c|}{0,0} & \multicolumn{2}{|c|}{$-4,8$} & \multicolumn{2}{|c|}{$-6,5$} & \multicolumn{2}{|c|}{$-8,9$} & \multicolumn{2}{|c|}{$-7,4$} \\
\hline
\end{tabular}

Na Figura 7.23 consta o efeito da interação entre teor de aditivo SRA e relação a/agl na resistência à tração na flexão. Nas idades de 1 e 3 dias, o perfil da superfície de resposta é similar ao obtido nos resultados de resistência à compressão, no entanto, nas idades de 7 e 28 dias a superfície de resposta é diferente. Nestas idades, a superfície de resposta não apresenta uma inclinação (rampa) no sentido dos maiores valores do encontro entre o eixo do teor de aditivo SRA e o eixo da relação a/agl, isto indica que o efeito de ambos os fatores na resistência à compressão é menor nas idades de 7 e 28 dias. 
1 dia

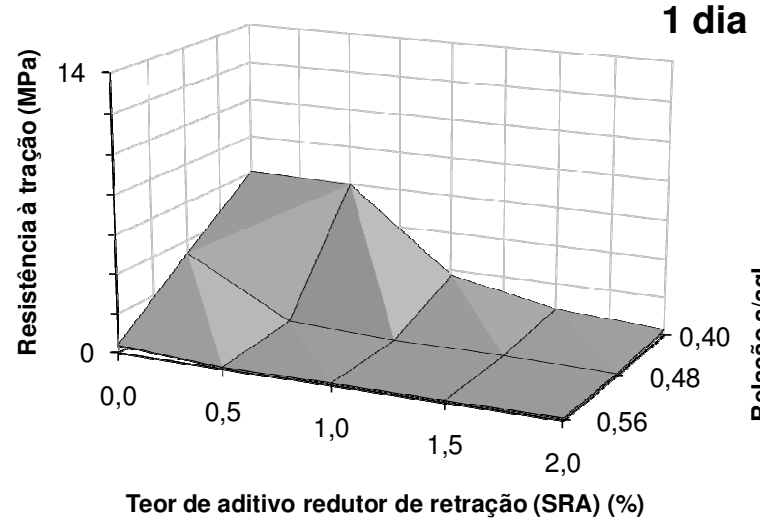

7 dias

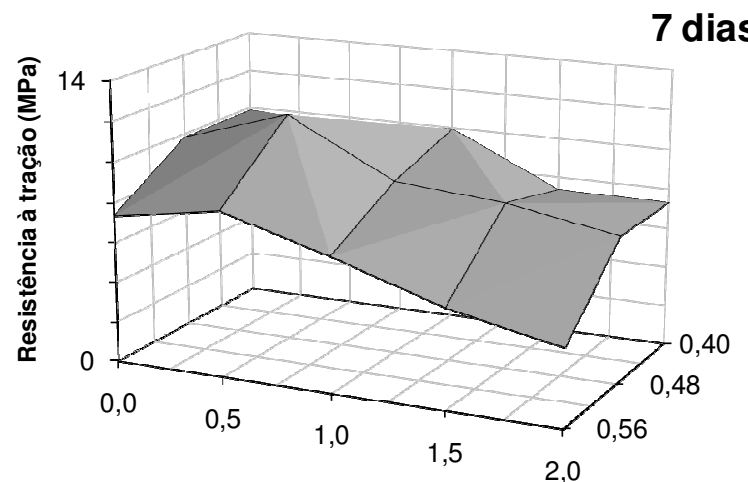

Teor de aditivo redutor de retração (SRA) (\%)
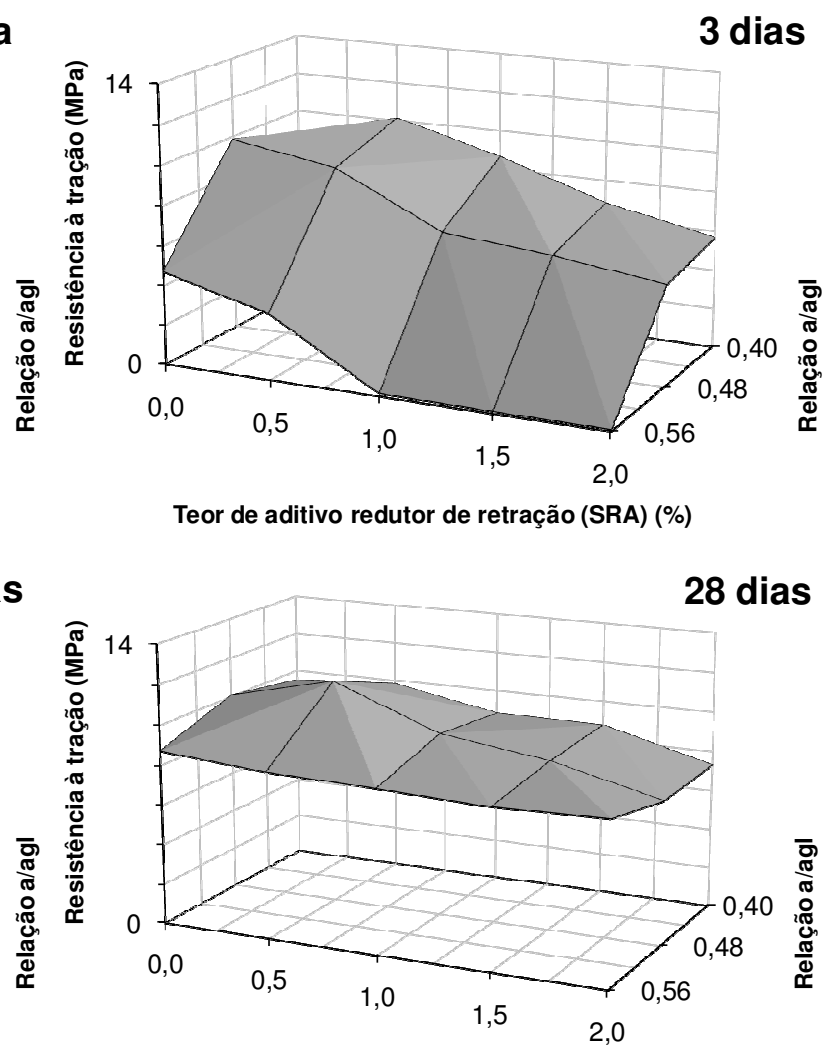

Teor de aditivo redutor de retração (SRA) (\%)

Figura 7.23 - Efeito da interação entre o teor de aditivo SRA e a relação água/aglomerante na resistência à tração.

\subsubsection{Módulo de elasticidade}

O módulo de elasticidade do cimento de escória ativada com silicato de sódio apresentou comportamento semelhante ao observado nos resultados de resistência à compressão. Não se esperava nada diferente, visto que usualmente o comportamento da resistência à compressão reflete o comportamento geral das propriedades mecânicas de compósito cimentício. Os resultados do módulo de elasticidade do cimento de escória ativada com silicato de sódio e com as relações a/agl iguais a 0,40, 0,48 e 0,56 constam da Figura 7.24, Figura 7.26 e Figura 7.28. Observa-se que o efeito do aditivo SRA é de diminuição do módulo de elasticidade, independentemente do teor e relação a/agl utilizados. 


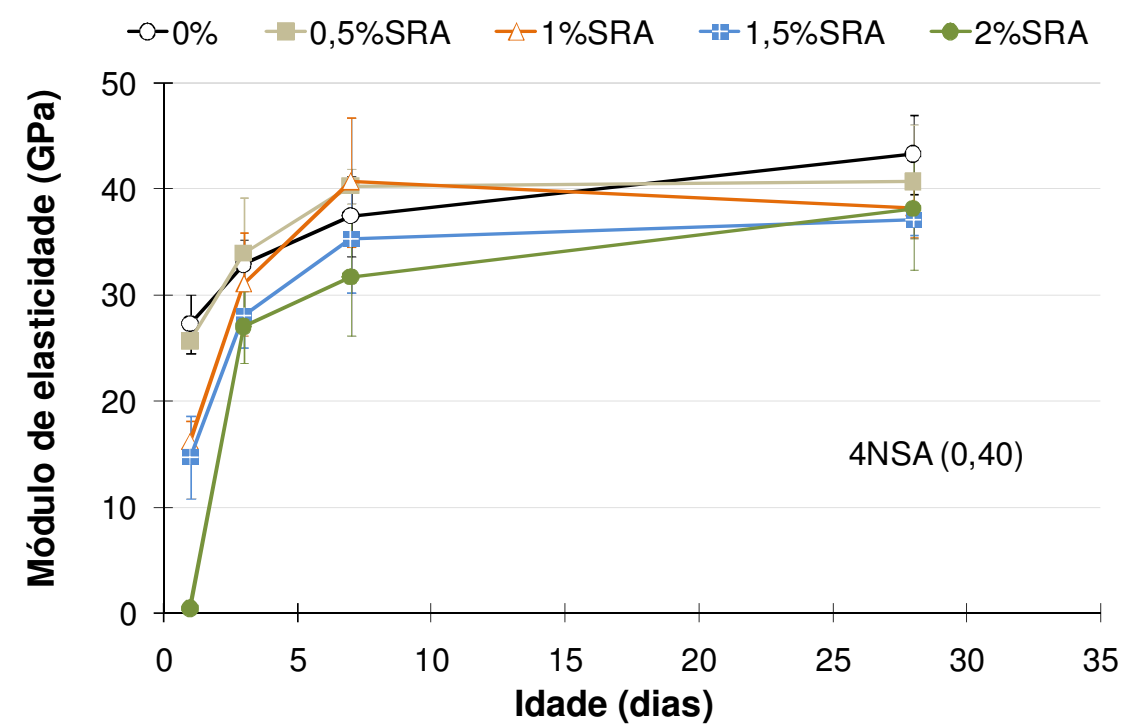

Figura 7.24 - Efeito do teor de aditivo SRA no módulo de elasticidade da argamassa de cimento de escória com relação a/agl igual a 0,40.



Figura 7.25 - Variação do módulo de elasticidade em função do teor de aditivo SRA na argamassa de cimento de escória com relação a/agl igual a 0,40.

O perfil comum do efeito do aditivo SRA no módulo de elasticidade de todas as combinações estudadas pode ser constatado na análise da mistura com relação a/agl igual a 0,40. Observa-se o maior efeito do aditivo SRA na idade de 1 dia, resultando em valores nulos com o aumento do teor de aditivo (Figura 7.25). Com o avanço da idade, ocorre a recuperação dos valores de módulo de elasticidade para resultados próximos à mistura sem aditivo, notadamente a mistura com teor de $0,5 \%$ de SRA, a qual apresenta a menor redução do módulo aos 28 dias, 6\% (Tabela 7.10). 
Tabela 7.10 - Médias aritméticas do módulo de elasticidade e o efeito do teor de aditivo redutor de retração (SRA) no cimento de escória ativada com relação a/agl igual a $\mathbf{0 , 4 0}$. CV = coeficiente de variação em \%.

\begin{tabular}{|c|c|c|c|c|c|c|c|c|c|c|c|}
\hline \multicolumn{2}{|c|}{ Relação a/agl = 0,40 } & \multicolumn{10}{|c|}{ Teor de aditivo redutor de retração (SRA) } \\
\hline & \multirow[b]{2}{*}{ Idade } & \multicolumn{2}{|c|}{$0 \%$} & \multicolumn{2}{|c|}{$0,5 \%$} & \multicolumn{2}{|c|}{$1 \%$} & \multicolumn{2}{|c|}{$1,5 \%$} & \multicolumn{2}{|c|}{$2 \%$} \\
\hline & & Md & $\mathrm{CV}$ & Md & $\mathrm{CV}$ & Md & $\mathrm{CV}$ & Md & $\mathrm{CV}$ & Md & $\mathrm{CV}$ \\
\hline \multirow{4}{*}{$\begin{array}{l}\text { Módulo de } \\
\text { elasticidade (GPa) }\end{array}$} & $1 \mathrm{dia}$ & 27,3 & $5,2 \%$ & 25,6 & $1,2 \%$ & 16,2 & $6,2 \%$ & 14,7 & $13,5 \%$ & 0,4 & $20,4 \%$ \\
\hline & 3 dias & 32,9 & $3,7 \%$ & 34,0 & $7,8 \%$ & 31,1 & $8,0 \%$ & 28,0 & $5,5 \%$ & 27,0 & $6,5 \%$ \\
\hline & 7 dias & 37,4 & $5,2 \%$ & 40,3 & $2,1 \%$ & 40,7 & $7,7 \%$ & 35,3 & $7,2 \%$ & 31,7 & $8,9 \%$ \\
\hline & 28 dias & 43,3 & $4,4 \%$ & 40,7 & $6,8 \%$ & 38,2 & $3,6 \%$ & 37,1 & $1,9 \%$ & 38,2 & $7,7 \%$ \\
\hline \multirow{4}{*}{$\begin{array}{l}\text { Variação do módulo } \\
\text { de elasticidade (\%) }\end{array}$} & $1 \mathrm{dia}$ & \multicolumn{2}{|c|}{0,0} & \multicolumn{2}{|c|}{$-6,1$} & \multicolumn{2}{|c|}{$-40,7$} & \multicolumn{2}{|c|}{$-46,2$} & \multicolumn{2}{|c|}{$-98,5$} \\
\hline & 3 dias & \multicolumn{2}{|c|}{0,0} & \multicolumn{2}{|c|}{$+3,3$} & \multicolumn{2}{|c|}{$-5,5$} & \multicolumn{2}{|c|}{$-14,8$} & \multicolumn{2}{|c|}{$-18,0$} \\
\hline & 7 dias & \multicolumn{2}{|c|}{0,0} & \multicolumn{2}{|c|}{$+7,6$} & \multicolumn{2}{|c|}{$+8,7$} & \multicolumn{2}{|c|}{$-5,8$} & \multicolumn{2}{|c|}{$-15,4$} \\
\hline & 28 dias & \multicolumn{2}{|c|}{0,0} & \multicolumn{2}{|c|}{$-6,0$} & \multicolumn{2}{|c|}{$-11,7$} & \multicolumn{2}{|c|}{$-14,2$} & \multicolumn{2}{|c|}{$-11,9$} \\
\hline
\end{tabular}

Os resultados obtidos nas misturas com relação a/agl de 0,48 e 0,56 estão apresentados na Figura 7.26 e Figura 7.28. O aumento da relação a/agl e a utilização do aditivo SRA resultaram na diminuição significativa do módulo de elasticidade do cimento de escória ativada com silicato de sódio. Conforme constatado nas demais propriedades mecânicas, é intensa a diminuição do módulo de elasticidade nas primeiras idades com a utilização do aditivo redutor de retração (SRA), evidenciado na correlação entre o teor de aditivo SRA e os resultados de módulo de elasticidade apresentados na Figura 7.27 e Figura 7.29.

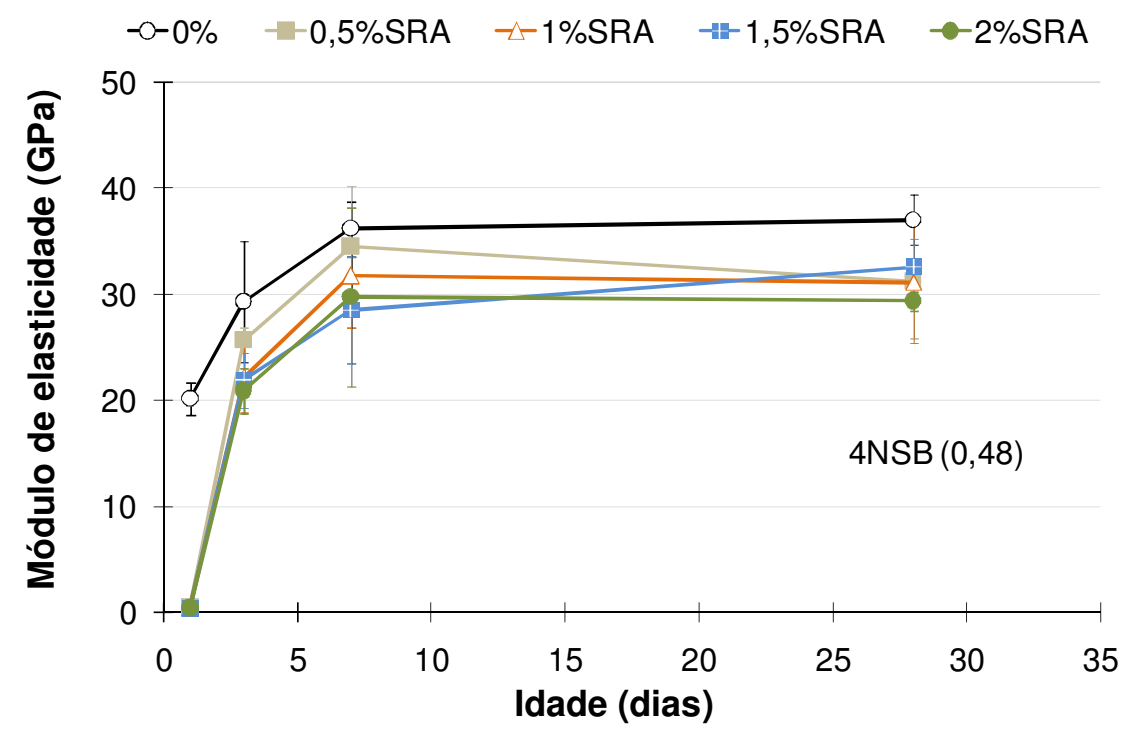

Figura 7.26 - Efeito do teor de aditivo SRA no módulo de elasticidade da argamassa de cimento de escória com relação a/agl igual a 0,48. 


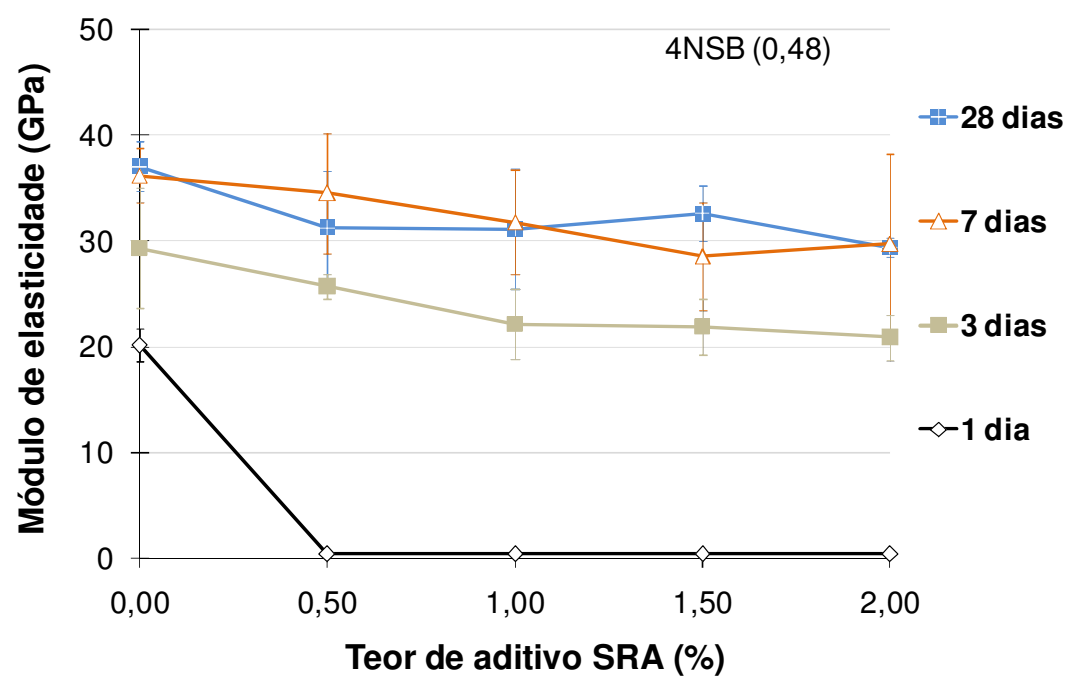

Figura 7.27 - Variação do módulo de elasticidade em função do teor de aditivo SRA na argamassa de cimento de escória com relação a/agl igual a 0,48.

Tabela 7.11 - Médias aritméticas do módulo de elasticidade e o efeito do teor de aditivo redutor de retração (SRA) no cimento de escória ativada com relação a/agl igual a $\mathbf{0 , 4 8}$. CV = coeficiente de variação em \%.

\begin{tabular}{|c|c|c|c|c|c|c|c|c|c|c|c|}
\hline \multicolumn{2}{|c|}{ Relação a/agl = 0,48 } & \multicolumn{10}{|c|}{ Teor de aditivo redutor de retração (SRA) } \\
\hline & \multirow[b]{2}{*}{ Idade } & \multicolumn{2}{|c|}{$0 \%$} & \multicolumn{2}{|c|}{$0,5 \%$} & \multicolumn{2}{|c|}{$1 \%$} & \multicolumn{2}{|c|}{$1,5 \%$} & \multicolumn{2}{|c|}{$2 \%$} \\
\hline & & Md & $\mathrm{CV}$ & Md & $\mathrm{CV}$ & Md & $\mathrm{CV}$ & Md & $\mathrm{CV}$ & Md & $\mathrm{CV}$ \\
\hline \multirow{4}{*}{$\begin{array}{l}\text { Módulo de } \\
\text { elasticidade (GPa) }\end{array}$} & $1 \mathrm{dia}$ & 20,1 & $4,0 \%$ & $\overline{0,4}$ & $20,4 \%$ & $\overline{0,4}$ & $20,4 \%$ & 0,4 & $20,4 \%$ & 0,4 & $20,4 \%$ \\
\hline & 3 dias & 29,3 & $9,9 \%$ & 25,7 & $2,3 \%$ & 22,1 & $7,7 \%$ & 21,9 & $6,0 \%$ & 20,9 & $5,3 \%$ \\
\hline & 7 dias & 36,2 & $3,7 \%$ & 34,5 & $8,4 \%$ & 31,8 & $7,9 \%$ & 28,5 & $9,0 \%$ & 29,8 & $14,5 \%$ \\
\hline & 28 dias & 37,0 & $3,2 \%$ & 31,3 & $8,7 \%$ & 31,1 & $9,3 \%$ & 32,6 & $4,1 \%$ & 29,4 & $1,6^{\circ}$ \\
\hline \multirow{4}{*}{$\begin{array}{l}\text { Variação do módulo } \\
\text { de elasticidade (\%) }\end{array}$} & $1 \mathrm{dia}$ & \multicolumn{2}{|c|}{0,0} & \multicolumn{2}{|c|}{$-98,0$} & \multicolumn{2}{|c|}{$-98,0$} & \multicolumn{2}{|c|}{$-98,0$} & \multicolumn{2}{|c|}{$-98,0$} \\
\hline & 3 dias & \multicolumn{2}{|c|}{0,0} & \multicolumn{2}{|c|}{$-12,4$} & \multicolumn{2}{|c|}{$-24,5$} & \multicolumn{2}{|c|}{$-25,3$} & \multicolumn{2}{|c|}{$-28,8$} \\
\hline & 7 dias & \multicolumn{2}{|c|}{0,0} & \multicolumn{2}{|c|}{$-4,6$} & \multicolumn{2}{|c|}{$-12,3$} & \multicolumn{2}{|c|}{$-21,2$} & \multicolumn{2}{|c|}{$-17,8$} \\
\hline & 28 dias & \multicolumn{2}{|c|}{0,0} & \multicolumn{2}{|c|}{$-15,6$} & \multicolumn{2}{|c|}{$-16,0$} & \multicolumn{2}{|c|}{$-11,9$} & \multicolumn{2}{|c|}{$-20,7$} \\
\hline
\end{tabular}

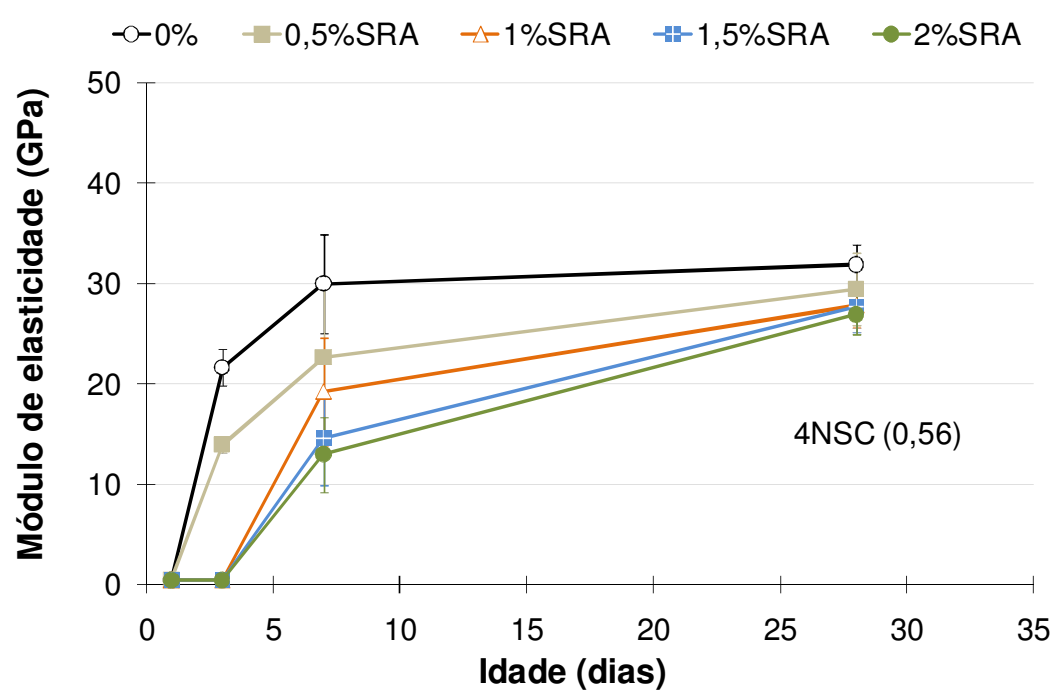

Figura 7.28 - Efeito do teor de aditivo SRA no módulo de elasticidade da argamassa de cimento de escória com relação a/agl igual a 0,56. 




Figura 7.29 - Variação do módulo de elasticidade em função do teor de aditivo SRA na argamassa de cimento de escória com relação a/agl igual a 0,56.

Tabela 7.12 - Médias aritméticas do módulo de elasticidade e o efeito do teor de aditivo redutor de retração (SRA) no cimento de escória ativada com relação a/agl igual a $\mathbf{0 , 5 6}$. $\mathrm{CV}=$ coeficiente de variação em \%.

\begin{tabular}{|c|c|c|c|c|c|c|c|c|c|c|c|}
\hline \multicolumn{2}{|c|}{ Relação a/agl = 0,56 } & \multicolumn{10}{|c|}{ Teor de aditivo redutor de retração (SRA) } \\
\hline & \multirow[b]{2}{*}{ Idade } & \multicolumn{2}{|c|}{$0 \%$} & \multicolumn{2}{|c|}{$0,5 \%$} & \multicolumn{2}{|c|}{$1 \%$} & \multicolumn{2}{|c|}{$1,5 \%$} & \multicolumn{2}{|c|}{$2 \%$} \\
\hline & & Md & $\mathrm{CV}$ & Md & $\mathrm{CV}$ & Md & $\mathrm{CV}$ & Md & $\mathrm{CV}$ & Md & $\mathrm{CV}$ \\
\hline \multirow{4}{*}{$\begin{array}{l}\text { Módulo de } \\
\text { elasticidade (GPa) }\end{array}$} & 1 dia & 0,4 & $20,4 \%$ & 0,4 & $20,4 \%$ & 0,4 & $20,4 \%$ & 0,4 & $20,4 \%$ & 0,4 & $20,4 \%$ \\
\hline & 3 dias & 21,7 & $4,3 \%$ & 13,9 & $2,9 \%$ & 0,4 & $20,4 \%$ & 0,4 & $20,4 \%$ & 0,4 & $20,4 \%$ \\
\hline & 7 dias & 30,0 & $8,4 \%$ & 22,6 & $17,3 \%$ & 19,3 & $14,2 \%$ & 14,6 & $16,5 \%$ & 13,0 & $14,8 \%$ \\
\hline & 28 dias & 31,9 & $3,2 \%$ & 29,5 & $6,2 \%$ & 27,8 & $4,1 \%$ & 27,7 & $4,5 \%$ & 26,9 & 3,8 \\
\hline \multirow{4}{*}{$\begin{array}{l}\text { Variação do módulo } \\
\text { de elasticidade (\%) }\end{array}$} & 1 dia & \multicolumn{2}{|c|}{0,0} & \multicolumn{2}{|c|}{$+0,0$} & \multicolumn{2}{|c|}{$+0,0$} & \multicolumn{2}{|c|}{$+0,0$} & \multicolumn{2}{|c|}{$+0,0$} \\
\hline & 3 dias & \multicolumn{2}{|c|}{0,0} & \multicolumn{2}{|c|}{$-35,6$} & \multicolumn{2}{|c|}{ - 98,2 } & \multicolumn{2}{|c|}{$-98,2$} & \multicolumn{2}{|c|}{ - 98,2 } \\
\hline & 7 dias & \multicolumn{2}{|c|}{0,0} & \multicolumn{2}{|c|}{$-24,6$} & \multicolumn{2}{|c|}{$-35,8$} & \multicolumn{2}{|c|}{$-51,4$} & \multicolumn{2}{|c|}{$-56,7$} \\
\hline & 28 dias & \multicolumn{2}{|c|}{0,0} & \multicolumn{2}{|c|}{$-7,6$} & \multicolumn{2}{|c|}{$-12,7$} & \multicolumn{2}{|c|}{$-13,2$} & \multicolumn{2}{|c|}{$-15,6$} \\
\hline
\end{tabular}

Na Figura 7.30 constam os gráficos do efeito da interação do teor de aditivo SRA e a relação a/agl no módulo de elasticidade. Nas idades de 1, 3 e 7 dias, o efeito desta interação é mais pronunciado e a superfície de resposta tem perfil similar ao observado nos resultados de resistência à compressão, ou seja, com uma diminuição do módulo de elasticidade com o aumento do teor de aditivo SRA e o aumento da relação a/agl. Aos 28 dias, a diminuição do módulo de elasticidade é mais suave, com valores próximos aos obtidos nas misturas sem a utilização de aditivo. 
1 dia
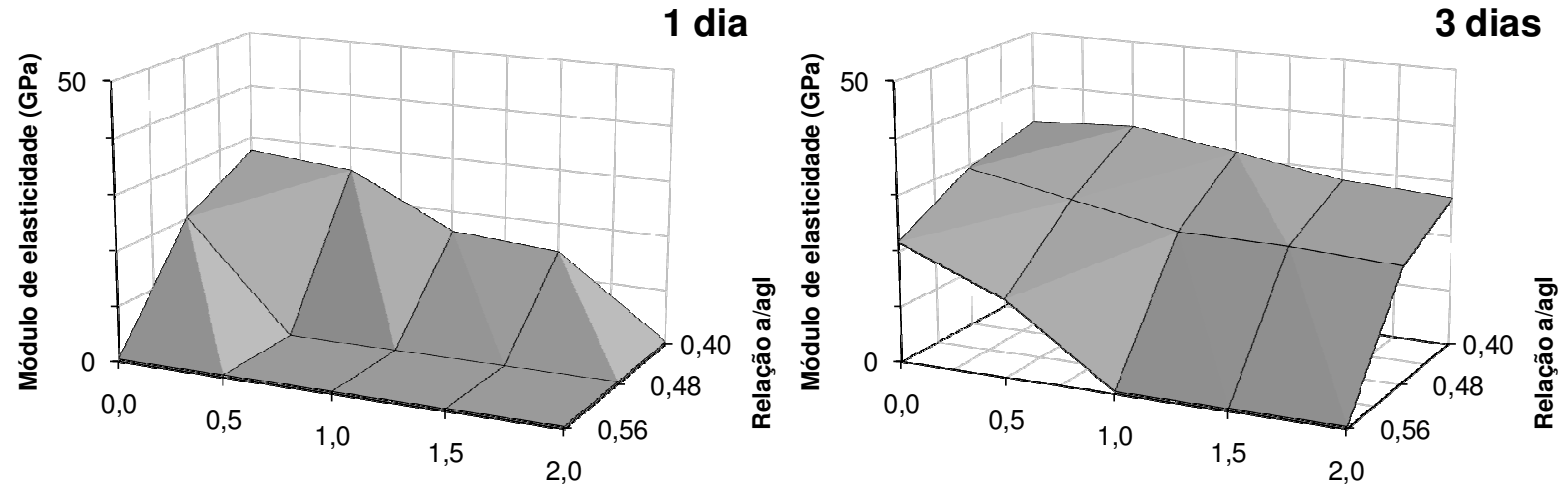

Teor de aditivo redutor de retração (SRA) (\%)

Teor de aditivo redutor de retração (SRA) (\%)

7 dias

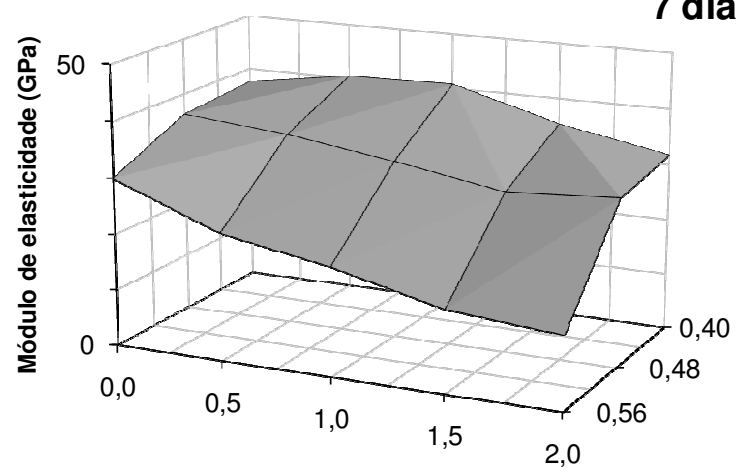

Teor de aditivo redutor de retração (SRA) (\%)



Teor de aditivo redutor de retração (SRA) (\%)

Figura 7.30 - Efeito da interação entre o teor de aditivo SRA e a relação água/aglomerante no módulo de elasticidade.

\subsection{Discussão e conclusões}

\subsubsection{Efeito da relação água/aglomerante}

Assim como no cimento Portland, o cimento de escória ativada com silicato de sódio é bastante influenciado pela relação água/aglomerante. No entanto, nas condições específicas aplicadas neste trabalho, é possível afirmar que o aumento da relação a/agl aparenta não influenciar de modo significativo com o aumento da relação de 0,40 para 0,48 . Com o aumento da relação a/agl para 0,56 , já ocorre uma redução intensa da resistência mecânica do cimento de escória ativada com silicato de sódio. Conforme discutido nos capítulos de caracterização da microestrutura, a redução da resistência mecânica está associada ao aumento da porosidade em razão do aumento da relação a/agl. Observou-se também que o aumento da relação a/agl tem maior efeito nas primeiras idades, explicado pela redução do grau de hidratação e retardo do refinamento da porosidade. 


\subsubsection{Efeito do aditivo redutor de retração (SRA)}

O aditivo redutor de retração (SRA) causou a diminuição da resistência mecânica do cimento de escória ativada com silicato de sódio. Esta redução da resistência é mais acentuada nas primeiras idades, apenas na mistura com relação a/agl igual a 0,40 e com $0,5 \%$ de SRA ocorreu uma recuperação para um patamar similar ao da mistura de referência (sem aditivo) aos 28 dias. Com base nos resultados de caracterização da microestrutura e no principio de ação do aditivo SRA, pode-se afirmar que o aditivo causa o retardo da hidratação em virtude da diminuição da tensão superficial da água do poro, o que interfere diretamente na aglomeração. Este efeito do aditivo redutor de retração (SRA) resulta na diminuição do grau de hidratação e aumento da porosidade, conseqüentemente, provocando a diminuição da resistência mecânica do cimento de escória ativada com silicato de sódio. Conclui-se também que a diminuição da resistência é diretamente proporcional ao aumento do teor de aditivo SRA e da relação a/agl. A utilização de teores de SRA superiores a $1 \%$ juntamente com relações água/aglomerante superiores a 0,48 poderá inviabilizar a utilização do cimento de escória ativada com silicato de sódio nas primeiras idades, em razão das baixas resistências mecânicas apresentadas. 


\section{Capítulo 8 Retração por secagem e autógena}

\subsection{Efeito da relação água/aglomerante}

\subsubsection{Retração por secagem}

Em materiais cimentícios tradicionais, como o cimento Portland, a quantidade de água está diretamente relacionada com a retração por secagem. Quanto mais água disponível, maior a retração por secagem decorrente do somatório de tensões capilares oriundas da perda de água para o ambiente. Sabe-se que para o cimento de escória ativada com silicato de sódio observa-se a mesma tendência, porém com maior magnitude do que no cimento Portland, em torno de 8 vezes maior (MELO NETO, 2002).

O efeito da relação água/aglomerante na retração por secagem do cimento de escória ativada com silicato de sódio consta da Figura 8.1, onde estão apresentados valores das médias com a representação gráfica da dispersão dos resultados (barras verticais). A dispersão em torno da média foi calculada multiplicando-se o desvio padrão por 1,96, valor adotado para uma distribuição normal, o que garante que estatisticamente $95 \%$ dos resultados obtidos estão inseridos na dispersão. Nos resultados obtidos, observa-se que, em qualquer das relações a/agl estudadas, a evolução da retração por secagem do cimento de escória ativada ocorre de modo rápido, alcançando aos 3 dias em torno $75 \%$ do valor da retração por secagem aos 28 dias. Assim como relatado no comportamento do cimento Portland, o aumento da relação a/agl causou o aumento significativo da retração por secagem, notadamente nas primeiras idades (Figura 8.2). 


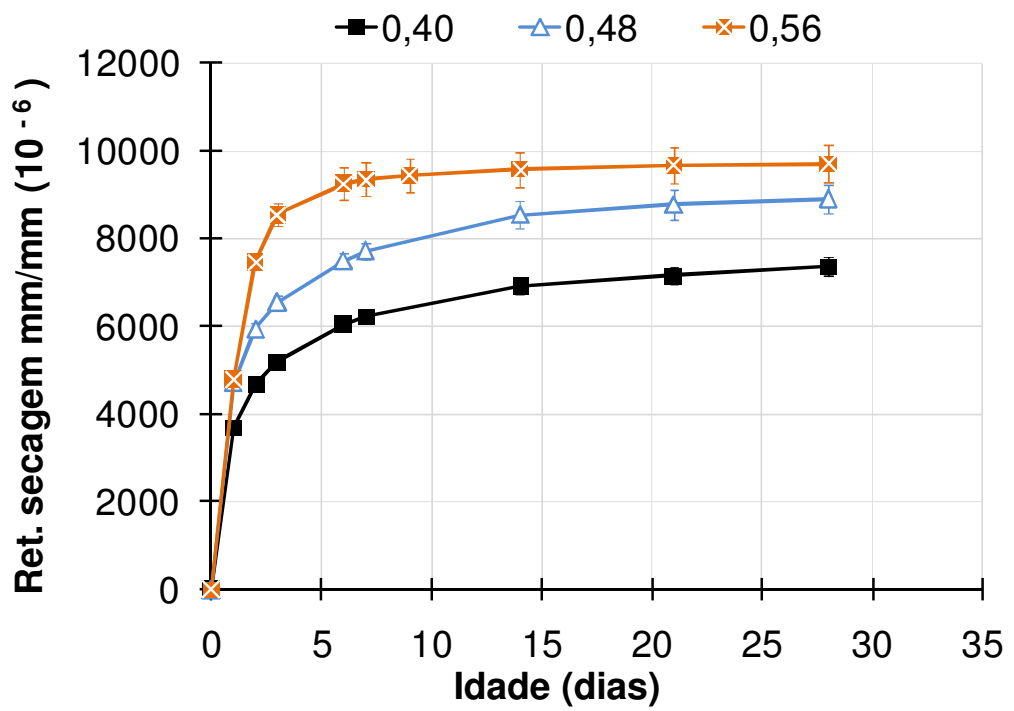

Figura 8.1 - Efeito da relação a/agl na retração por secagem do cimento de escória até os 28 dias de idade (4NS).

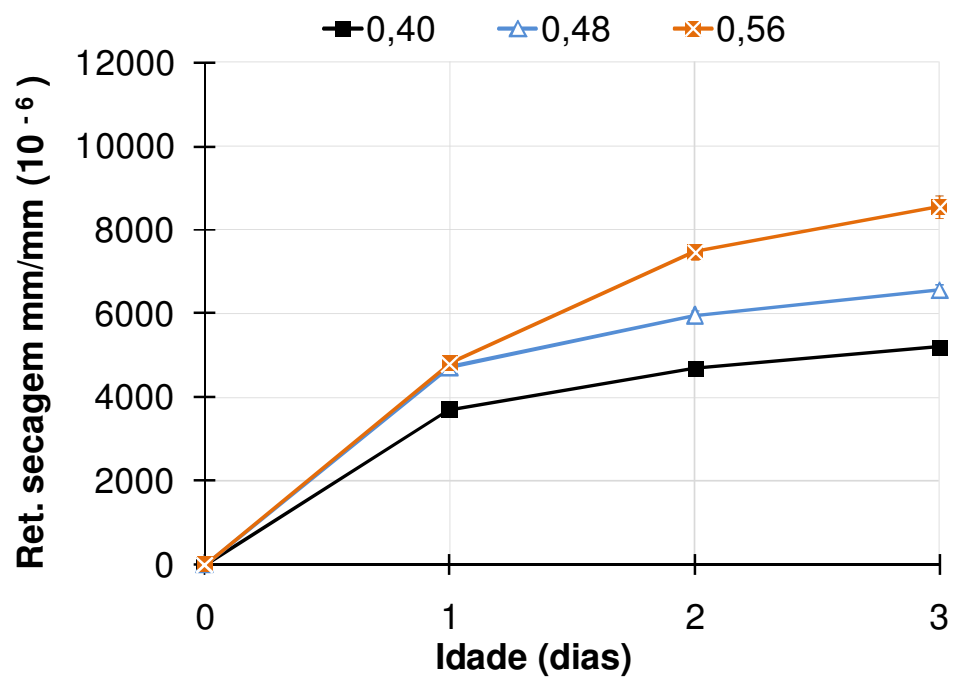

Figura 8.2 - Detalhe do efeito da relação a/agl na retração por secagem do cimento de escória até os 3 dias de idade (4NS).

Na Figura 8.3 está apresentado um panorama geral da influência da relação a/agl na retração por secagem do cimento de escória ativada com silicato de sódio. Observase que existe uma correlação clara entre o aumento da relação a/agl e o aumento da retração por secagem do cimento de escória ativada com silicato de sódio. Este comportamento é atribuído ao maior somatório de tensões capilares causado pela maior quantidade de água perdida para o ambiente. Outro fato que também contribui é a maior susceptibilidade frente às deformações tensões oriundas da perda de 
água com a diminuição da resistência da matriz cimentícia em função do aumento da relação a/agl.

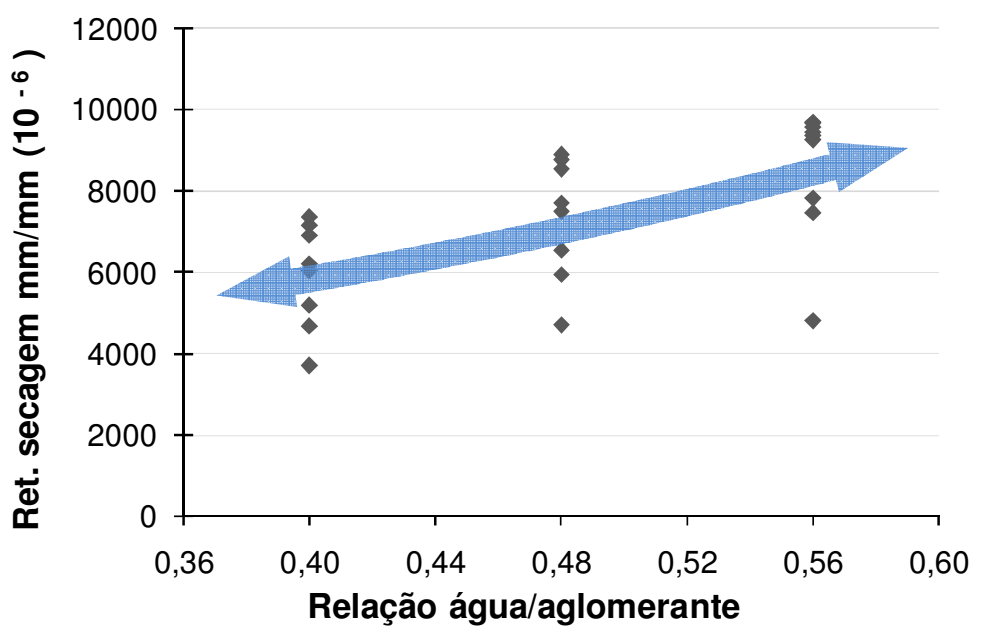

Figura 8.3 - Correlação entre a retração por secagem e a relação a/agl. Gráficos construídos com todos os pontos obtidos nas idades ensaiadas.

Utilizando a mistura com relação a/agl igual a 0,40 como referência, foi calculado o efeito do aumento da relação a/agl para 0,48 e 0,56 (Tabela 8.1). Na mistura com relação a/agl igual a 0,48, observa-se que o aumento da retração por secagem é praticamente constante até os 28 dias de idade, com valores em torno de $25 \%$ maiores do que os observados na mistura com relação a/agl igual a 0,40. O aumento da relação a/agl para 0,56 é o que apresenta maior impacto no perfil da retração por secagem, caracterizada pelo aumento brusco de 1 para 3 dias de idade, passando de um valor de $29,6 \%$ para $64,4 \%$ maior do que na mistura com relação com a/agl igual a 0,40 .

É provável que este comportamento ocorra em razão do refinamento da porosidade desta mistura que ocorre exatamente aos 3 dias de idade, conforme a análise dos resultados de porosidade. Isto faz com que ocorra o aumento das tensões capilares decorrente da baixa porosidade com elevada proporção de mesoporos e elevada quantidade de água disponível para ser perdida para o ambiente. Com o avanço da idade, a mistura com relação a/agl igual a 0,56 apresenta a diminuição da taxa de crescimento da retração por secagem e a amenização da diferença em relação à mistura com relação a/agl igual a 0,40 para em torno de $31 \%$ aos 28 dias. 
Tabela 8.1 - Médias aritméticas da retração por secagem e o efeito da relação a/agl no cimento de escória ativada. $\mathrm{CV}=$ coeficiente de variação em \%.

\begin{tabular}{|c|c|c|c|c|c|c|c|}
\hline & \multirow[b]{3}{*}{ Idade } & \multicolumn{6}{|c|}{ Relação água/aglomerante } \\
\hline & & \multicolumn{2}{|c|}{0,40} & \multicolumn{2}{|c|}{0,48} & \multicolumn{2}{|c|}{0,56} \\
\hline & & Rsec & $\mathrm{CV}$ & Rsec & $\mathrm{CV}$ & Rsec & $\mathrm{CV}$ \\
\hline \multirow{4}{*}{$\begin{array}{l}\text { Retração por secagem } \\
\mathrm{mm} / \mathrm{mm}\left(10^{-6}\right)\end{array}$} & 1 dia & 3708,3 & $0,8 \%$ & 4714,1 & $0,3 \%$ & 4805,8 & $0,9 \%$ \\
\hline & 3 dias & 5200,2 & $1,1 \%$ & 6554,1 & $1,2 \%$ & 8547,6 & $1,6 \%$ \\
\hline & 7 dias & 6226,5 & $1,2 \%$ & 7712,3 & $1,2 \%$ & 9349,2 & $2,0 \%$ \\
\hline & 28 dias & 7356,5 & $1,5 \%$ & 8899,8 & $1,8 \%$ & 9666,1 & $2,2 \%$ \\
\hline \multirow{4}{*}{$\begin{array}{l}\text { Variação da retração } \\
\text { por secagem (\%) }\end{array}$} & 1 dia & \multicolumn{2}{|c|}{0,0} & \multicolumn{2}{|c|}{$+27,1$} & \multicolumn{2}{|c|}{$+29,6$} \\
\hline & 3 dias & \multicolumn{2}{|c|}{0,0} & \multicolumn{2}{|c|}{$+26,0$} & \multicolumn{2}{|c|}{$+64,4$} \\
\hline & 7 dias & \multicolumn{2}{|c|}{0,0} & \multicolumn{2}{|c|}{$+23,9$} & \multicolumn{2}{|c|}{$+50,2$} \\
\hline & 28 dias & \multicolumn{2}{|c|}{0,0} & \multicolumn{2}{|c|}{$+21,0$} & \multicolumn{2}{|c|}{$+31,4$} \\
\hline
\end{tabular}

O efeito da relação água/aglomerante na massa de água evaporada para o ambiente do cimento de escória ativada com silicato de sódio consta da Figura 8.4. O comportamento observado já era esperado, pois é coerente que, nas mesmas condições de temperatura e umidade relativa, a maior disponibilidade de água incorra em maior perda de massa por evaporação. Considerando que os corpos-deprova têm variações mínimas no seu volume, observa-se que o aumento da relação a/agl provoca o aumento intenso da perda de água para o ambiente. Na Figura 8.5 está apresentado um panorama geral da influência da relação a/agl na perda de massa por secagem, na qual observa-se que existe uma correlação clara entre o aumento da relação a/agl e o aumento da perda de massa por secagem.

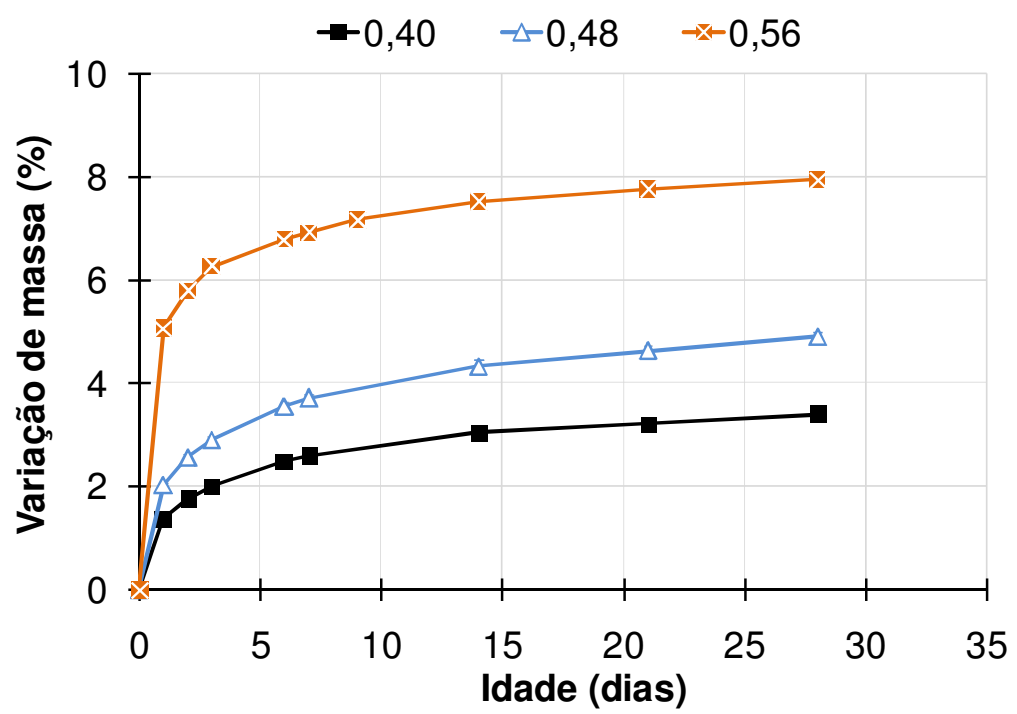

Figura 8.4 - Efeito da relação a/agl na variação de massa por evaporação do cimento de escória até os 28 dias de idade. 
Como descrito na análise dos dados da termogravimetria, o aumento da relação a/agl causou um retardo do grau de hidratação nas primeiras idades, sem diferença significativa aos 28 dias. Isto explica o resultado da elevada taxa de perda de massa da mistura com relação a/agl igual a 0,56, em torno de $267 \%$ maior do que na mistura com relação a/agl igual a 0,40 nas primeiras idades (Tabela 8.2). Porém, com o avanço da hidratação e a conseqüente consolidação da matriz porosa, ocorre uma redução da taxa de perda de massa de $267 \%$ para $129 \%$. Assim como na retração por secagem, o aumento da relação a/agl para 0,48 resultou em resultados maiores de variação de massa quando comparado à mistura com relação igual a 0,40 e com valor praticamente constante até os 28 dias de idade, em torno de $45 \%$.

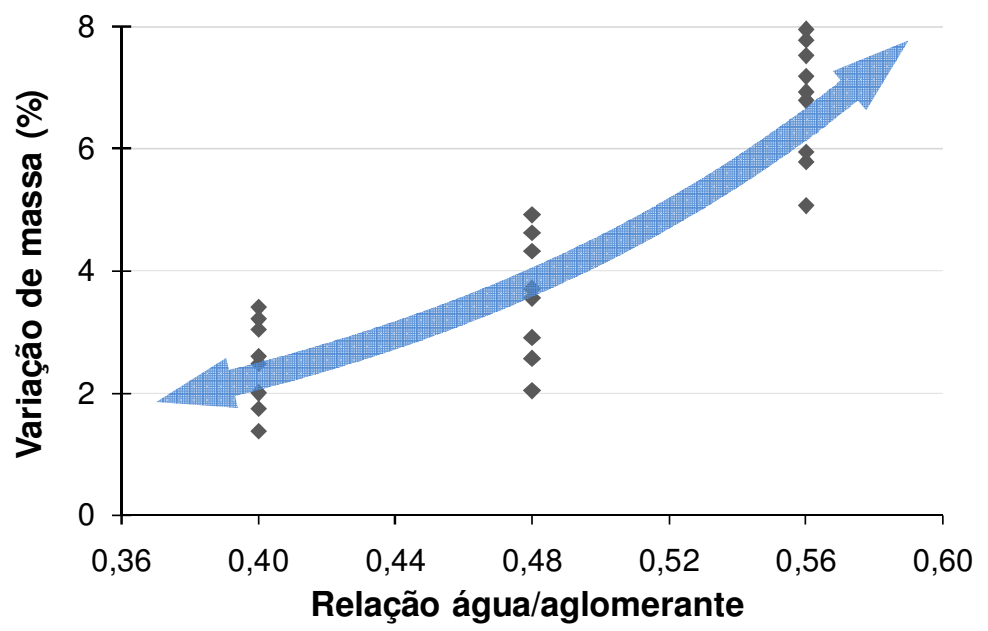

Figura 8.5 - Correlação entre a variação de massa por secagem e a relação a/agl. Gráficos construídos com todos os pontos obtidos nas idades ensaiadas.

Tabela 8.2 - Médias aritméticas da variação de massa na secagem e o efeito da relação a/agl no cimento de escória ativada. CV = coeficiente de variação em \%.

\begin{tabular}{|c|c|c|c|c|c|c|c|}
\hline & \multirow[b]{3}{*}{ Idade } & \multicolumn{6}{|c|}{ Relação água/aglomerante } \\
\hline & & \multicolumn{2}{|c|}{0,40} & \multicolumn{2}{|c|}{0,48} & \multicolumn{2}{|c|}{0,56} \\
\hline & & Vmas & $\mathrm{cV}$ & Vmas & $\mathrm{CV}$ & Vmas & $\mathrm{CV}$ \\
\hline \multirow{4}{*}{ Variação de massa (\%) } & $1 \mathrm{dia}$ & 1,4 & $3,8 \%$ & 2,0 & $1,4 \%$ & 5,1 & $1,1 \%$ \\
\hline & 3 dias & 2,0 & $1,9 \%$ & 2,9 & $1,3 \%$ & 6,3 & $0,5 \%$ \\
\hline & 7 dias & 2,6 & $1,4 \%$ & 3,7 & $1,2 \%$ & 6,9 & $0,3 \%$ \\
\hline & 28 dias & 3,4 & $0,7 \%$ & 4,9 & $0,9 \%$ & 7,8 & $0,2 \%$ \\
\hline \multirow{4}{*}{$\begin{array}{c}\text { Variação da variação } \\
\text { de massa (\%) }\end{array}$} & $1 \mathrm{dia}$ & \multicolumn{2}{|c|}{0,0} & \multicolumn{2}{|c|}{$+47,1$} & \multicolumn{2}{|c|}{$+267,4$} \\
\hline & 3 dias & \multicolumn{2}{|c|}{0,0} & \multicolumn{2}{|c|}{$+44,8$} & \multicolumn{2}{|c|}{$+212,8$} \\
\hline & 7 dias & \multirow{2}{*}{\multicolumn{2}{|c|}{0,0}} & \multicolumn{2}{|c|}{$+43,0$} & \multicolumn{2}{|c|}{$+166,6$} \\
\hline & 28 dias & & & \multicolumn{2}{|c|}{+44.5} & \multicolumn{2}{|c|}{$+128,8$} \\
\hline
\end{tabular}




\subsubsection{Retração por secagem versus perda de massa por evaporação}

Na Figura 8.6 consta a correlação entre a retração por secagem e a variação de massa em razão da evaporação da argamassa de cimento de escória com relação a/agl igual a 0,40 até os 28 dias. Observa-se que o perfil da curva indica que a dinâmica da retração por secagem ocorre em duas fases, um trecho $A B$ logo após a desmoldagem e um trecho $B C$ até os 28 dias. Nesta mistura, a identificação destas duas fases foi realizada com o ajuste linear dos resultados para cada trecho, resultando na equação do tipo $y=a x+b$, onde "a" é o coeficiente angular da reta de ajuste que representa a taxa de cada unidade de retração por secagem para cada unidade de variação de massa (gramas de água evaporada por grama de amostra). Esta análise ressalta a existência de duas fases na dinâmica da retração por secagem, a primeira (trecho $\mathrm{AB}$ ) com elevada taxa de retração, em torno de 2675 $\mu \mathrm{m} / \%$, decorrente da grande perda de água logo após a desmoldagem até 3 dias; e segundo, com taxa de retração menor, em torno de $1628 \mu \mathrm{m} / \%$, decorrente da perda gradual do restante de água disponível de 3 até 28 dias.

Nesta análise é importante identificar o estado da matriz porosa no momento da desmoldagem e se alterações ocorrem ao longo do tempo. Conforme os resultados de porosidade, a mistura com relação a/agl igual a 0,40 é que apresenta menor porosidade total e maior velocidade de refinamento da distribuição de poros, ou seja, no instante da desmoldagem a porosidade desta mistura já está praticamente consolidada e com avançado refinamento da distribuição de poros. Portanto, justifica-se a elevada taxa de retração no trecho $A B$, pois o corpo-de-prova é submetido à exposição brusca com a desmoldagem e a evaporação da água já encontra uma porosidade com características favoráveis ao surgimento de tensões capilares e, conseqüentemente, de retração por secagem. 


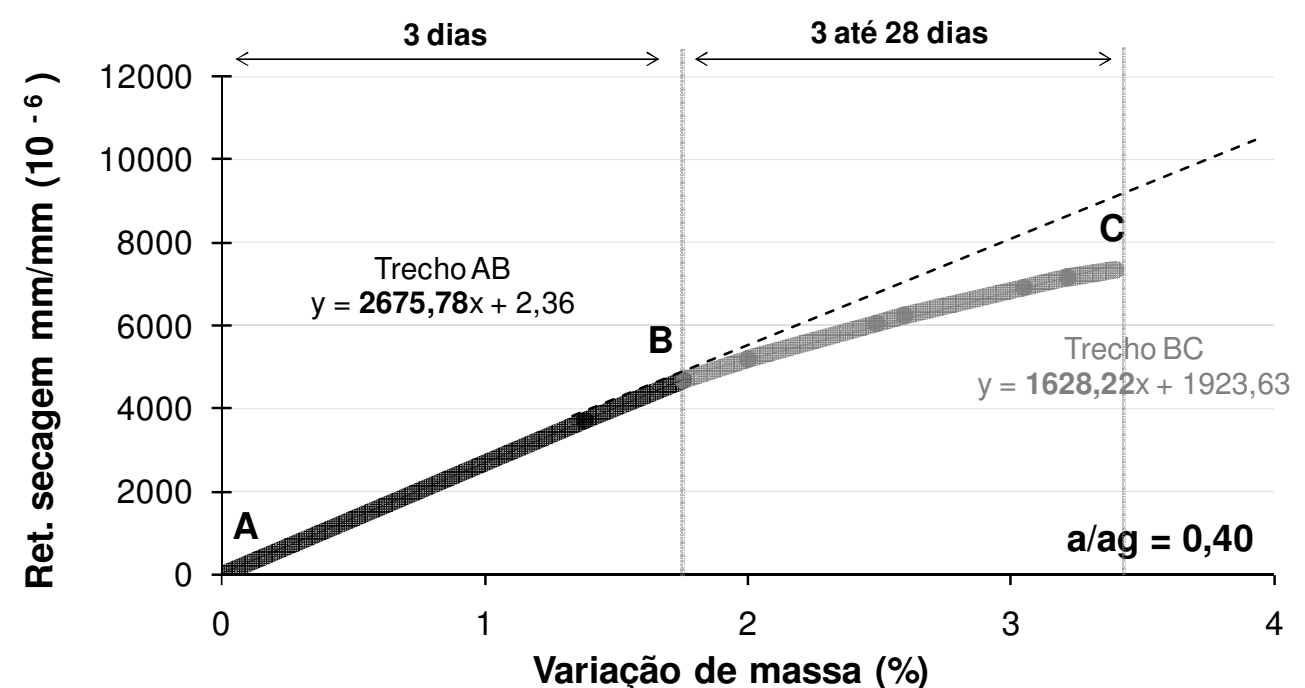

Figura 8.6 - Correlação entre a retração por secagem e perda de massa por evaporação da argamassa de cimento de escória ativada com silicato de sódio com relação a/agl igual a 0,40.

Com o aumento da relação a/agl para 0,48, observa-se na Figura 8.7 que o perfil da curva indica três fases na dinâmica da retração por secagem: um primeiro trecho $A B$ logo após a desmoldagem até os 3 dias de idade, o segundo trecho $\mathrm{BC}$ de 3 dias até 14 dias e o terceiro trecho $C D$ de 14 dias até 28 dias. Nesta mistura, o trecho $A B$ apresenta uma elevada taxa de retração, em torno de $2283 \mu \mathrm{m} / \%$, decorrente do impacto da desmoldagem na secagem brusca do corpo-de-prova, resultando em uma elevada retração até os 3 dias de idade. Após 3 dias, a taxa de retração reduzse para em torno $1392 \mu \mathrm{m} / \%$, porém continua a se desenvolver até os 14 dias de idade. A partir desta idade, ocorre uma redução da taxa de retração para em torno de $616 \mu \mathrm{m} / \%$ no trecho CD, o que praticamente significa a estabilização da retração.

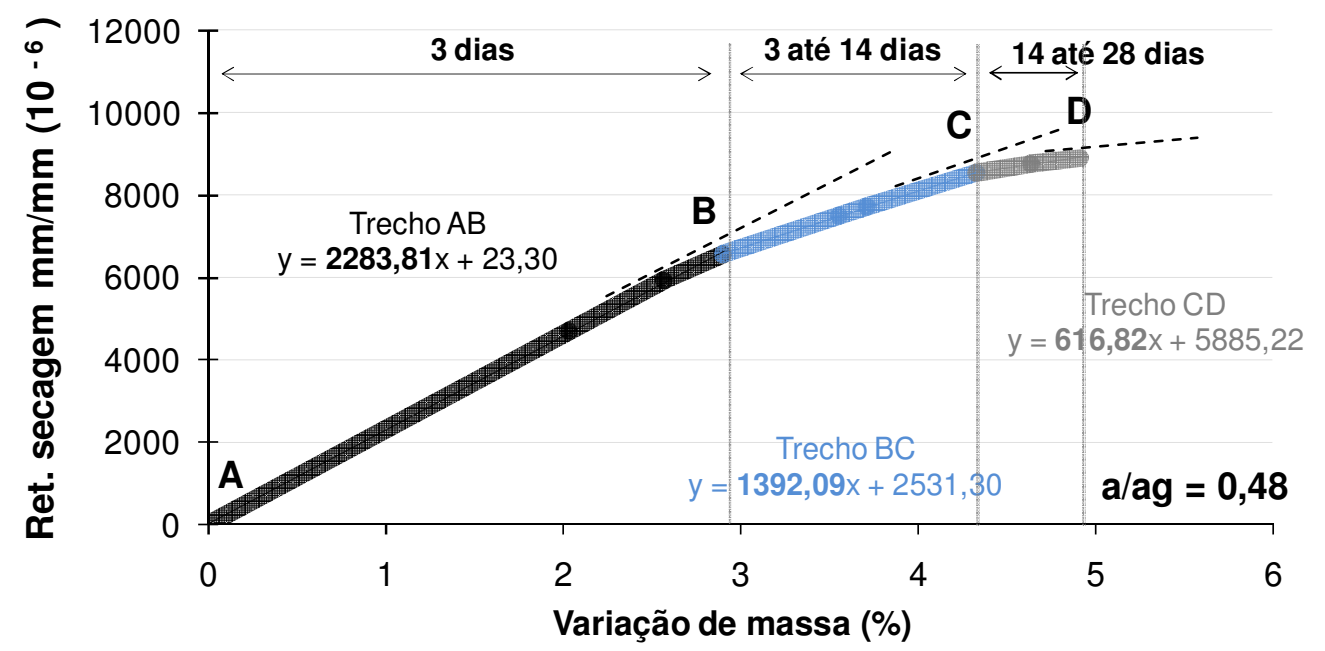

Figura 8.7 - Correlação entre a retração por secagem e perda de massa por evaporação da argamassa de cimento de escória ativada com silicato de sódio com relação a/agl igual a 0,48. 
Na Figura 8.8 consta a correlação entre a retração por secagem e a variação de massa em razão da evaporação da argamassa de cimento de escória com relação a/agl igual a 0,56 até os 28 dias. O perfil da curva indica também a ocorrência de três fases na dinâmica da retração por secagem, um primeiro trecho AB logo após a desmoldagem até 1 dia de idade, o segundo trecho BC de 1 até 6 dias e o terceiro trecho CD de 6 até 28 dias. Observa-se que o trecho AB é caracterizado por uma rápida retração por secagem que ocorre até 1 dia de idade, com uma taxa de retração em torno de $947 \mu \mathrm{m} / \%$, decorrente da secagem brusca com a desmoldagem do corpo-de-prova.

No trecho BC ocorre uma elevação intensa da taxa de retração para um valor em torno de $2545 \mu \mathrm{m} / \%$ até os 6 dias de idade. Conforme os resultados de porosidade, esta aceleração da taxa ocorre em razão do refinamento intenso da porosidade que ocorre aos 3 dias de idades. O papel da porosidade na retração por secagem é mais evidente nesta análise, na qual se constata que até 1 dia de idade a água disponível é perdida para o ambiente, resultando em retração; com o refinamento da porosidade, a água disponível continua a evaporar, porém esta perda resulta em maiores tensões capilares visto que a tensão capilar é inversamente proporcional ao diâmetro do poro. Após 6 dias de idade, a taxa de retração reduz-se para em torno de $380 \mu \mathrm{m} / \%$ até 28 dias de idade, com a retração por secagem atingindo um patamar de equilíbrio.

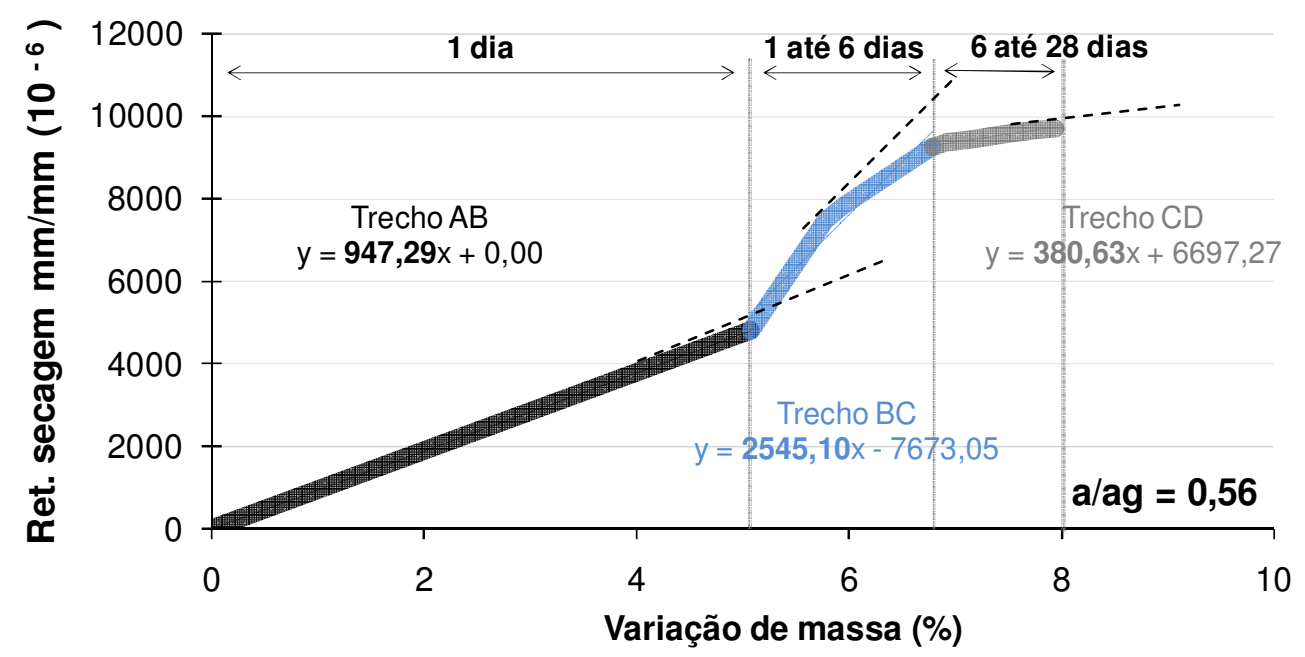

Figura 8.8 - Correlação entre a retração por secagem e perda de massa por evaporação da argamassa de cimento de escória ativada com silicato de sódio com relação a/agl igual a 0,56. 


\subsubsection{Retração por secagem versus porosidade}

Em razão da natureza do fenômeno da retração por secagem, conforme detalhado na revisão bibliográfica (Capítulo 2, pág.9), a porosidade é o parâmetro fundamental no entendimento do comportamento deste fenômeno. Quando se analisa a correlação entre os resultados de retração por secagem e a porosidade total obtida no ensaio de porosimetria por intrusão de mercúrio (Figura 8.9(a)), observa-se que o resultado não expressa com coerência a relação entre a retração por secagem e a porosidade. Este comportamento é explicado pela estabilidade dos resultados do ensaio de porosimetria do ponto de vista da porosidade total apenas. Conforme descrito na análise dos dados da porosidade, a porosidade total do cimento de escória tende à estabilização logo nas primeiras idades. A chave da questão é o refinamento da distribuição de poros, pois, esta sim, é alterada significativamente com o avanço da hidratação.
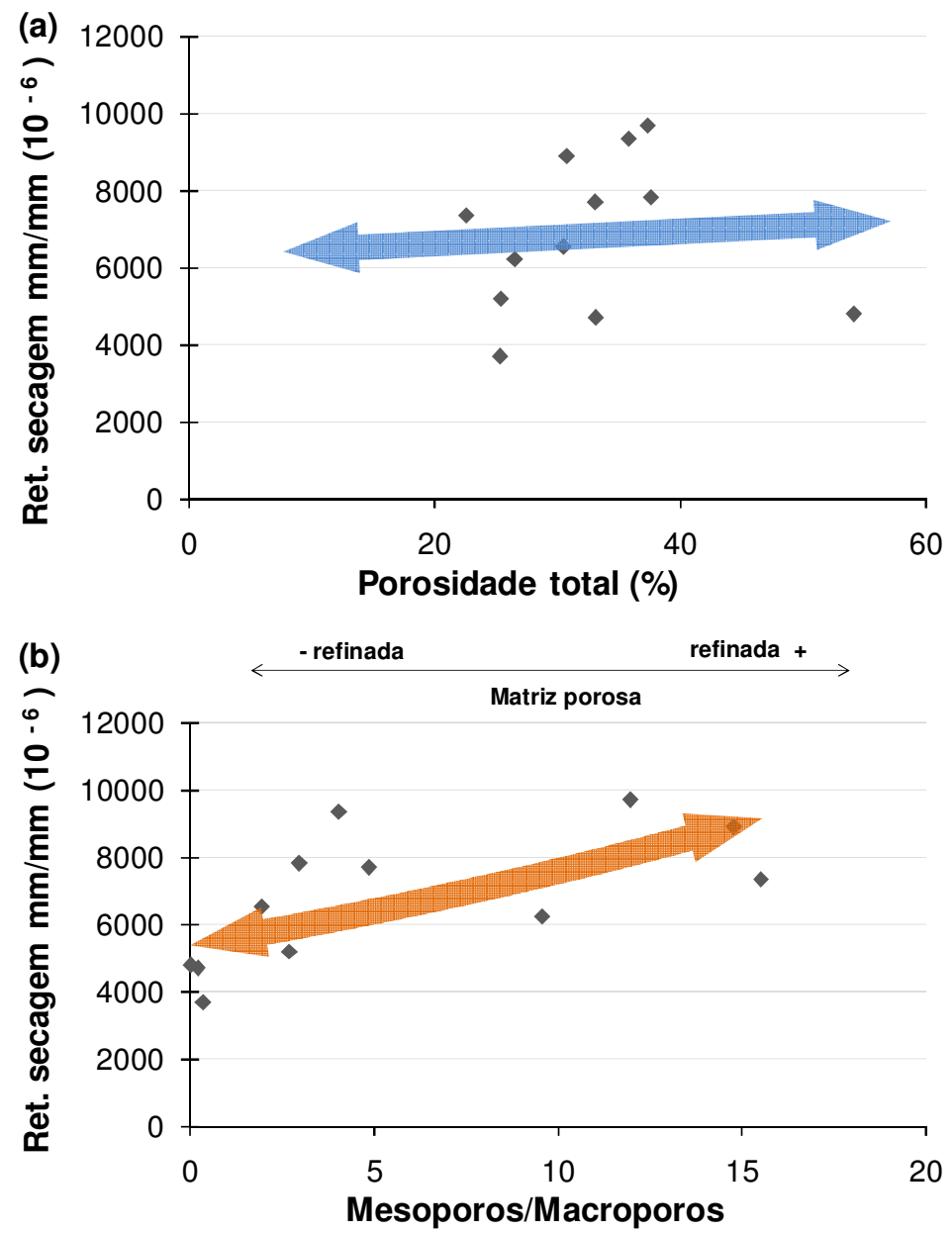

Figura 8.9 - Correlação da retração por secagem com a porosidade total (a) e com índice de refinamento (volume de mesoporos/volume de macroporos) (b). Gráficos construídos com todos os pontos obtidos. 
Definindo-se que o índice de refinamento é a relação entre o volume de mesoporos e o volume de macroporos, quanto maior o seu valor, maior é o refinamento da distribuição de poros da matriz porosa. Com este índice foi construído o gráfico da sua correlação com a retração por secagem, conforme apresentado na Figura 8.9(b). Portanto, o aumento da retração por secagem está diretamente relacionado com a distribuição de poros, ou seja, com as condições e tipo de estrutura porosa através da qual a água é evaporada para o ambiente. Levando em conta esta afirmação, a relação entre a retração por secagem e distribuição de poros é claramente evidenciada na Figura 8.10(a)(b). Observa-se que, para uma determinada porosidade total, o aumento do volume de mesoporos incorre no aumento da retração por secagem. Na Figura 8.11 consta a correlação entre a variação de massa por evaporação e o volume de mesoporos. Observa-se que o aumento da relação a/agl causou o aumento da perda de água por evaporação e do volume total de mesoporos, este efeito conjunto é determinante no aumento da retração por secagem do cimento de escória.
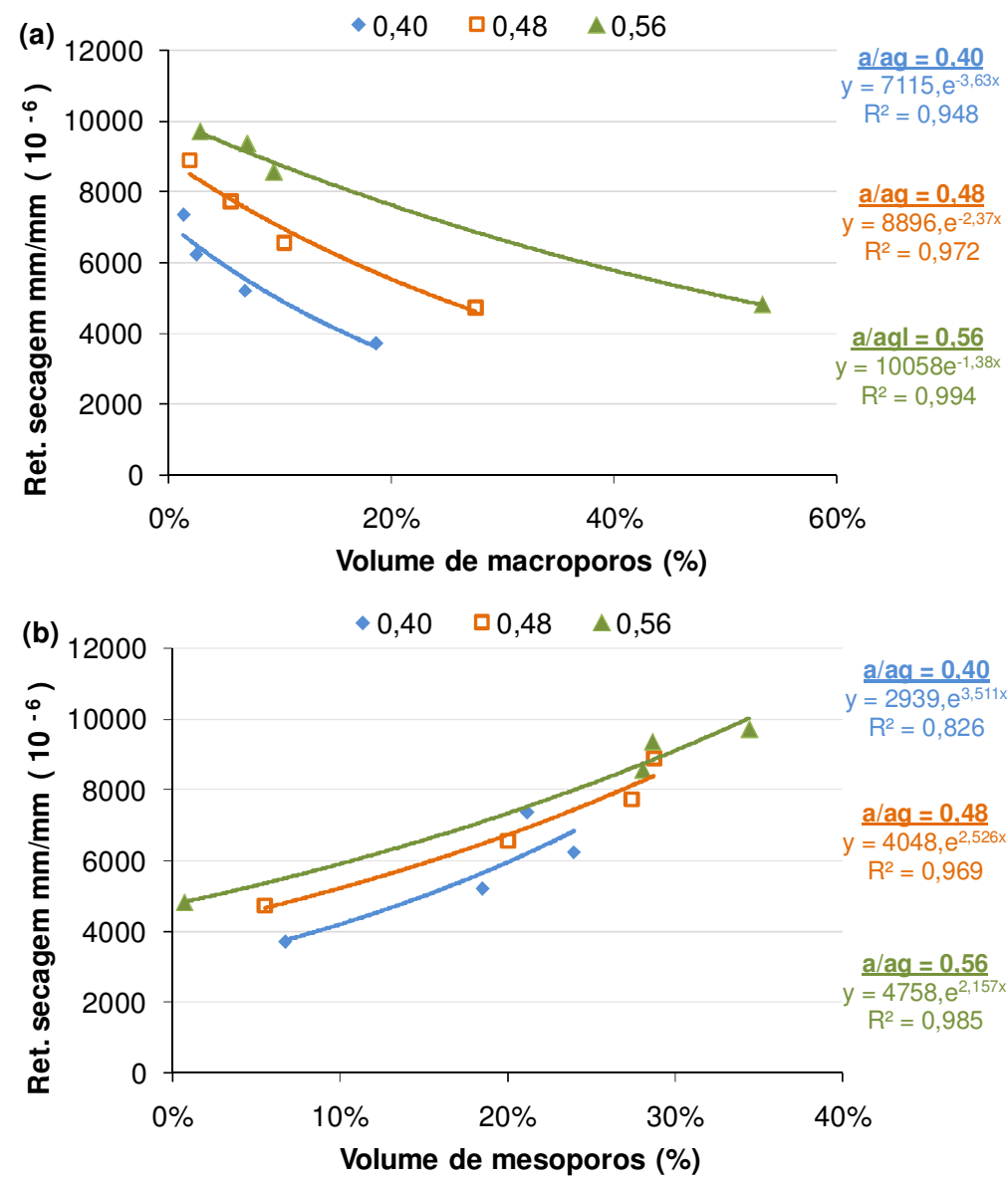

Figura 8.10 - Correlação da retração por secagem com o volume de macroporos (a) e com o volume de mesoporos (b). 


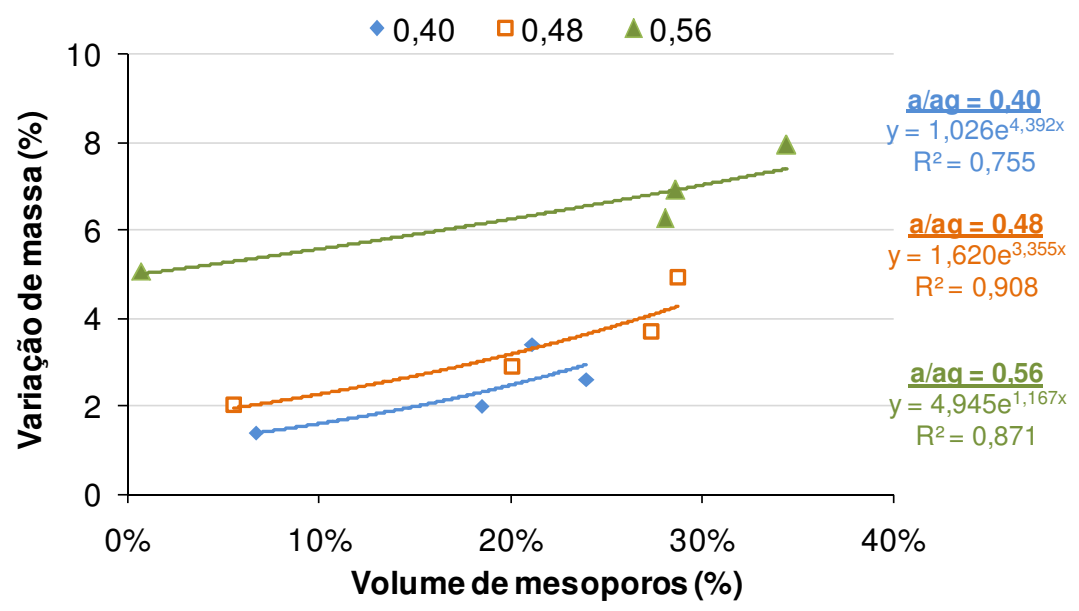

Figura 8.11 - Correlação da variação de massa por secagem com o volume de mesoporos.

\subsubsection{Retração autógena}

A retração autógena de materiais cimentícios está relacionada à queda da umidade interna consumida pelas reações de hidratação e ao surgimento de tensões capilares com a formação de meniscos nos vazios. No cimento Portland, a retração autógena é mais característica no emprego de baixas relações a/agl, pois aumenta a parcela de retração química e da auto-secagem. É consensual nas publicações existentes (TAZAWA et al., 1995; JENSEN; HANSEN, 2001) que a retração autógena do cimento Portland aumenta com a diminuição da relação a/agl, porém, este comportamento não é observado no cimento de escória ativada com silicato de sódio. O efeito da relação água/aglomerante na retração autógena do cimento de escória ativada com silicato de sódio consta da Figura 8.12, onde estão apresentados valores médios com a representação gráfica da dispersão dos resultados (barras verticais).

Observa-se que o aumento da relação a/agl causou o aumento significativo da retração autógena. É provável que a porosidade singular do cimento de escória ativada com silicato de sódio seja a causa deste comportamento, pois, independentemente da relação a/agl, é caracterizada pela elevada proporção de mesoporos. A análise da influência da porosidade é descrita com maiores detalhes em seguida, no item 8.1.2.1 (pág.135). A maior parte da retração autógena do cimento de escória ocorre até os 3 dias de idade, em torno de $60 \%$ do valor obtido aos 28 dias, conforme apresentado na Figura 8.13. 


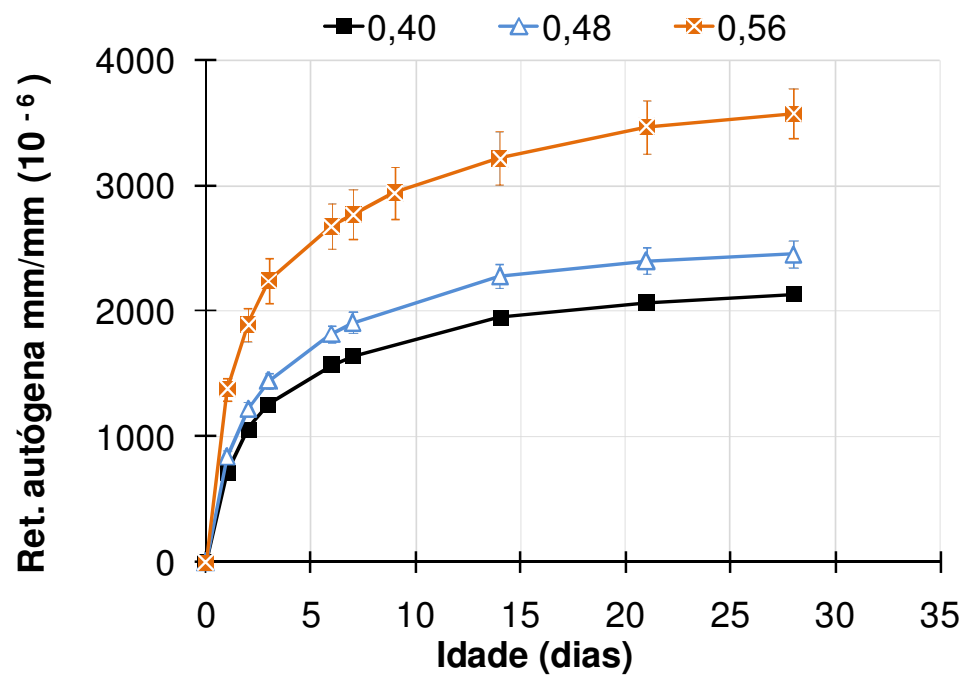

Figura 8.12 - Efeito da relação a/agl na retração autógena do cimento de escória até os 28 dias de idade.

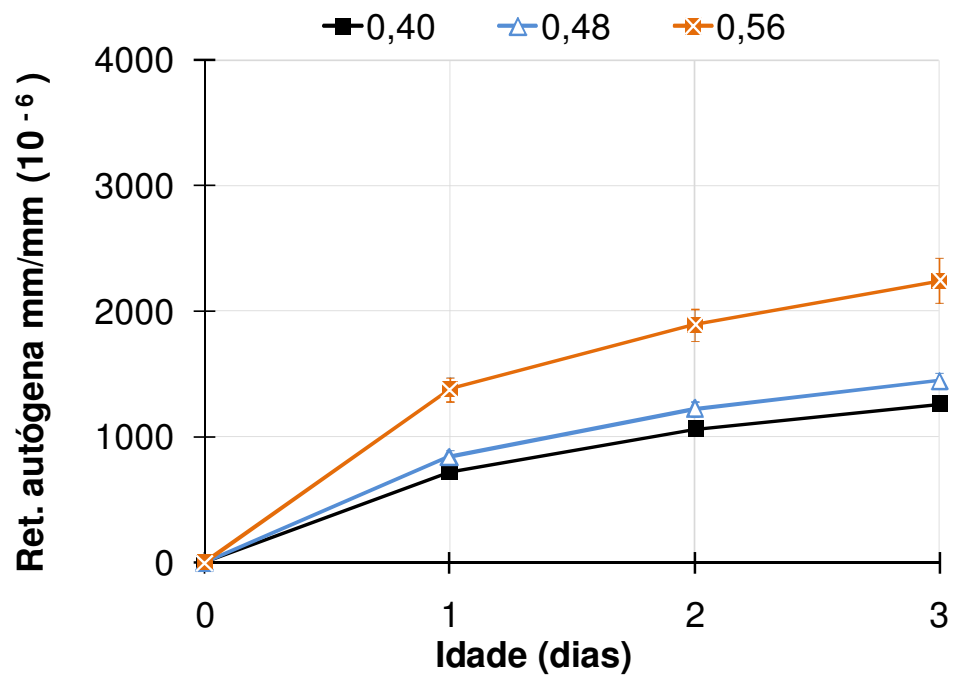

Figura 8.13 - Detalhe do efeito da relação a/agl na retração autógena do cimento de escória até os 3 dias de idade.

Na Figura 8.14 está apresentado um panorama geral da influência da relação a/agl na retração autógena do cimento de escória ativada com silicato de sódio. Observase que existe a correlação entre o aumento da relação a/agl e o aumento da retração autógena deste tipo de cimento, atribuído ao efeito do maior volume de poros no somatório de tensões capilares. Utilizando a mistura com relação a/agl igual a 0,40 como referência, calcula-se que o aumento da relação a/agl para 0,48 e 0,56 causou o aumento da retração autógena a 1 dia de idade em 16,9\% e 91,3\%, respectivamente (Tabela 8.3). A diferença entre as misturas com relação a/agl igual a 0,40 e 0,48 se mantém constante até os 28 dias, enquanto a mistura com relação 
a/agl igual a 0,56 apresenta retração autógena de 67\% maior do que na mistura com relação a/agl igual a 0,40 .

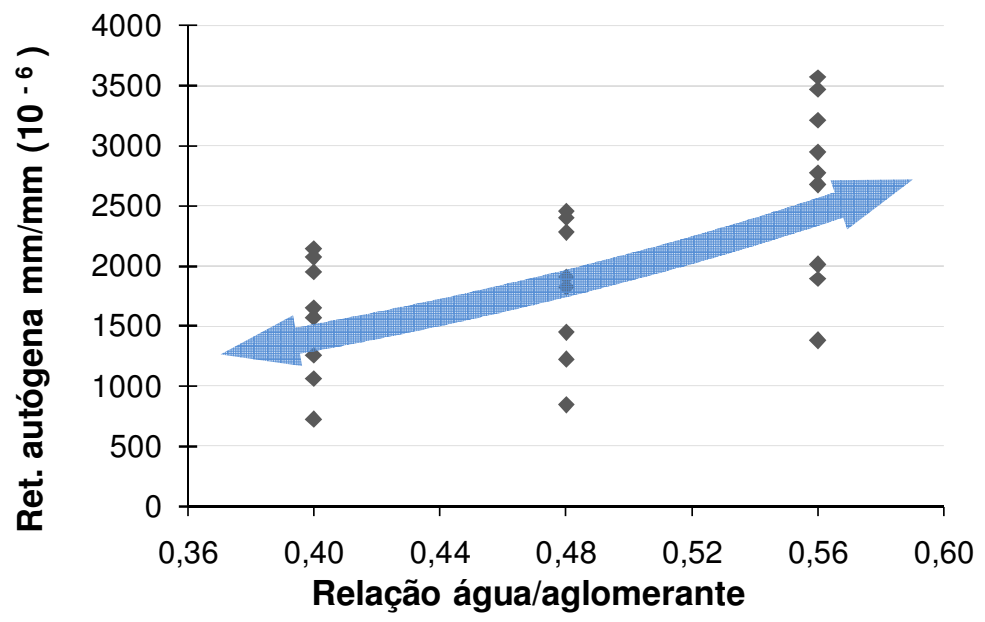

Figura 8.14 - Correlação entre a retração autógena e a relação a/agl. Gráficos construídos com todos os pontos obtidos.

Tabela 8.3 - Médias aritméticas da retração autógena e o efeito da relação a/agl no cimento de escória ativada. CV = coeficiente de variação em \%.

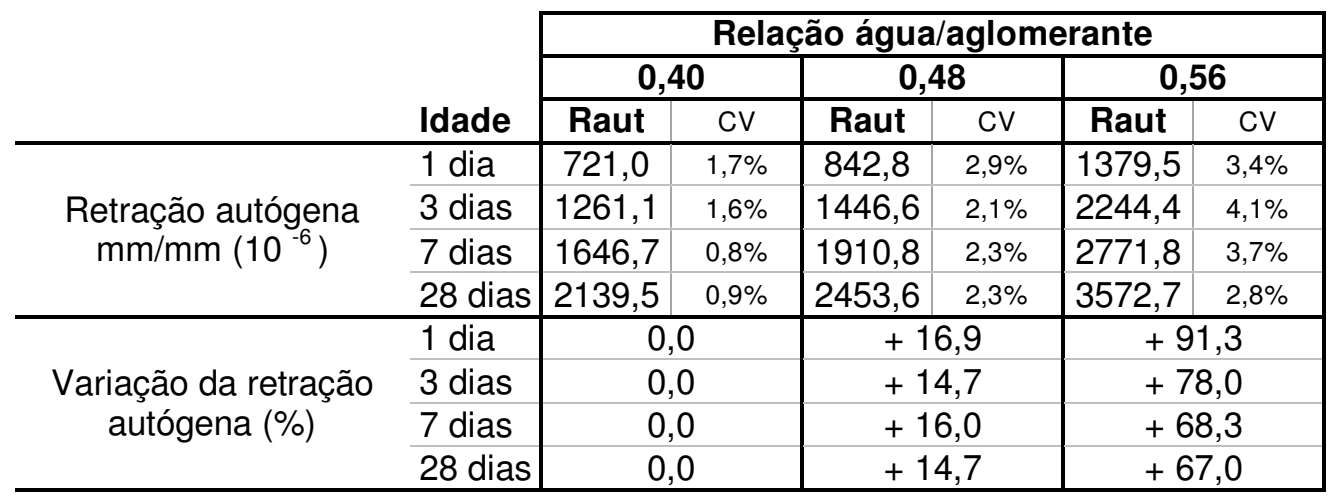

\subsubsection{Retração autógena versus porosidade e termogravimetria}

Conforme a análise dos resultados da termogravimetria, o aumento da relação a/agl não incorre no aumento do grau de hidratação do cimento de escória ativada com silicato de sódio aos 28 dias, o que faz com que a maior a disponibilidade de água resulte em maior número de vazios. Para explicar o efeito contrário da relação a/agl no comportamento do cimento de escória ativada com silicato de sódio quando comparado ao do cimento Portland, ressalta-se que o aumento da relação a/agl causa o retardo do início do refinamento da porosidade e altera a distribuição de poros, com a elevação da proporção do volume de macroporos (MELO NETO, 2002). Já no cimento de escória ativada com silicato de sódio, conforme a análise 
dos resultados da porosidade (Capítulo 6, pág.82), está evidente que o aumento da relação a/agl no cimento de escória ativada com silicato de sódio apenas retarda o início do refinamento da porosidade, mas aos 28 dias tem-se em torno de $95 \%$ de mesoporos em qualquer das relações a/agl estudadas.

A retração autógena está diretamente relacionada com a soma das parcelas resultantes da retração química e da auto-secagem. Uma vez que o grau de hidratação é o mesmo para as três relações a/agl, pode-se supor que a parcela química da retração autógena do cimento de escória ativada com silicato de sódio seja similar para as três relações a/agl estudadas. Conseqüentemente, isto incorre na conclusão de que, neste caso, a parcela referente à auto-secagem tenha maior influência na retração autógena. A análise da correlação entre a retração autógena e a formação de C-S-H (Figura 8.15) demonstra que as relações a/agl de 0,40 e 0,48 apresentam curvas de correlação praticamente idênticas, indicando que a formação do C-S-H nestas condições causa respostas similares na retração autógena.

Com o aumento da relação a/agl para 0,56 , observa-se que para a mesma quantidade de $\mathrm{C}-\mathrm{S}-\mathrm{H}$ formada nas demais relações testadas ocorre maior retração autógena. Este fato indica que a maior disponibilidade de água nesta mistura incorre em maior efeito físico relacionado à auto-secagem, possivelmente decorrente de uma seqüência de fatores e reações ligadas entre si, como o maior número de vazios com o aumento da relação a/agl, com isto o maior volume de mesoporos, maior número de meniscos formados, resultando em maior somatório de tensões capilares e de desligamento, tendo como efeito macroscópico a retração autógena.

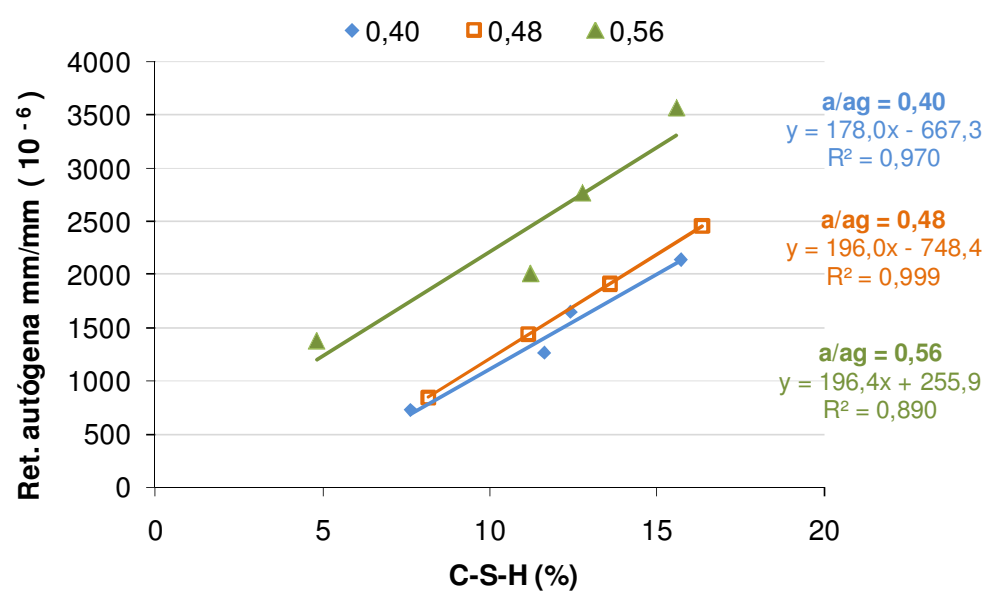

Figura 8.15 - Correlação entre a retração autógena e a quantidade de C-S-H (\%). 
A correlação entre a retração autógena e o volume de macroporos e mesoporos consta da Figura 8.16. Observa-se que o maior volume de mesoporos incorre em maior retração autógena em qualquer das relações a/agl estudadas, o que, associado ao grau de hidratação determinado na termogravimetria, permite afirmar que o aumento da relação a/agl no cimento de escória ativada com silicato de sódio causa o aumento do volume de poros na faixa de mesoporos, o qual está relacionado ao aumento da retração autógena. Portanto, conclui-se que a retração autógena é bastante influenciada pela dinâmica de desenvolvimento da microestrutura, notadamente a proporção e volume de mesoporos e macroporos na distribuição de poros. Este efeito associado à diminuição da resistência mecânica com o aumento da relação a/agl é esclarecedor para entender a causa do aumento da retração autógena com o aumento da relação a/agl, pois é coerente que o quadro de aumento ou manutenção das tensões capilares associada à diminuição da resistência mecânica seja mais susceptível ao aumento da retração autógena deste tipo de cimento.
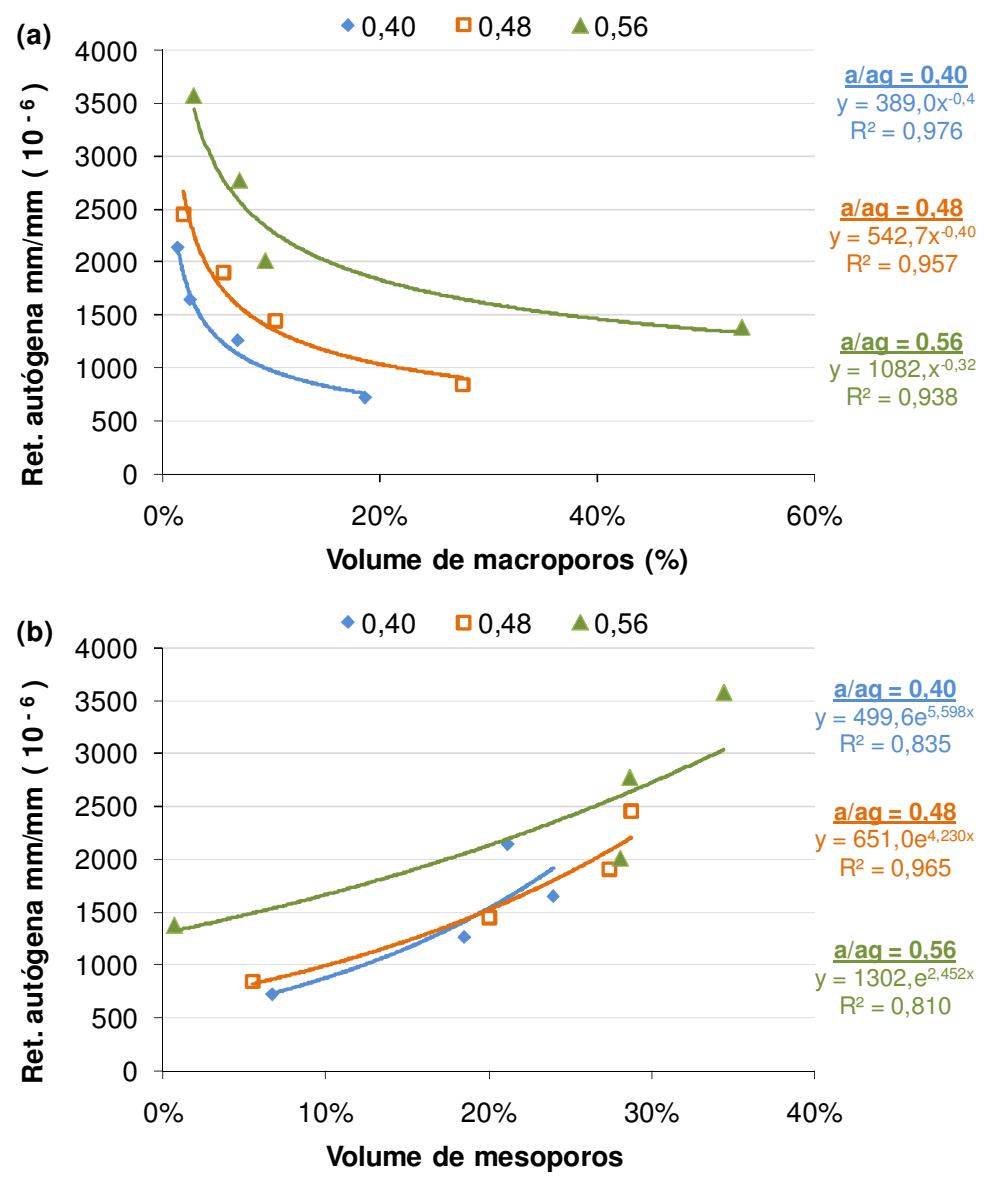

Figura 8.16 - Correlação da retração autógena com o volume de macroporos (a) e com o volume de mesoporos (b). 


\subsection{Efeito do aditivo redutor de retração (SRA)}

\subsubsection{Retração por secagem}

O efeito do teor de aditivo redutor de retração (SRA) na retração por secagem do cimento de escória está apresentado na Figura 8.17 e detalhado nas primeiras idades na Figura 8.18. Observa-se que o aditivo foi eficiente na redução da retração por secagem, sendo a redução proporcional ao aumento do teor de aditivo SRA. Além de reduzir a retração por secagem total, o aditivo SRA retardou o início da retração nas primeiras idades.

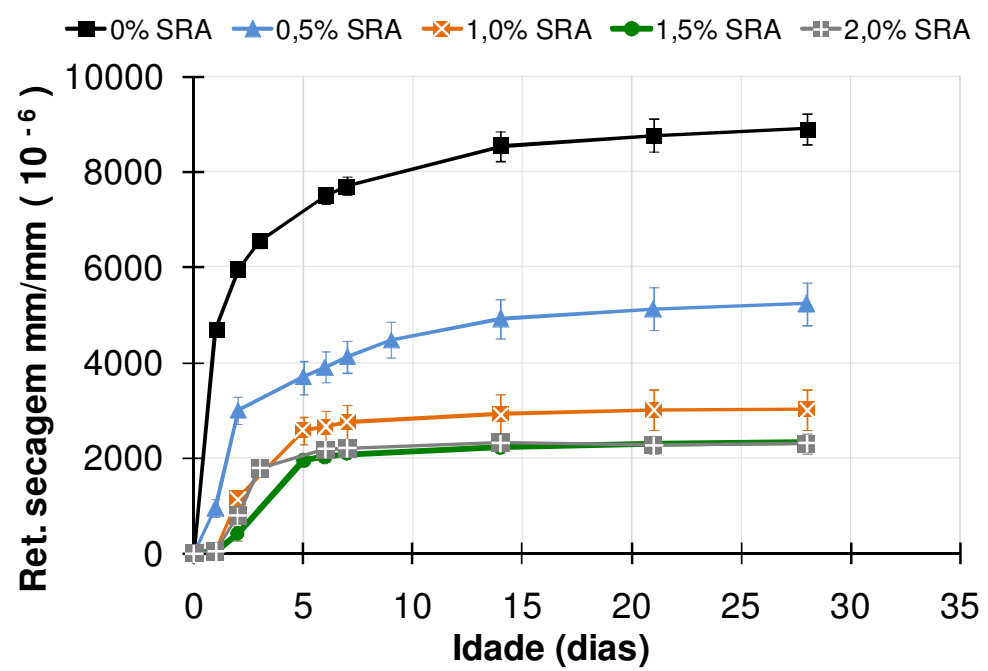

Figura 8.17 - Efeito do teor de aditivo redutor de retração (SRA) na retração por secagem do cimento de escória até os 28 dias de idade. $\mathrm{a} / \mathrm{agl}=0,48$.



Figura 8.18 - Detalhe do efeito do teor de aditivo redutor de retração (SRA) na retração por secagem do cimento de escória até os 3 dias de idade. $a / a g l=0,48$. 
De acordo com os resultados obtidos, a redução da tensão superficial da água do poro foi eficaz na redução das tensões capilares e, conseqüentemente, na redução da retração por secagem. Na Figura 8.19 está apresentado um panorama geral da influência do teor de aditivo redutor de retração (SRA) na retração por secagem do cimento de escória ativada com silicato de sódio. Existe a correlação evidente entre a diminuição da retração por secagem e o aumento do teor de aditivo SRA, atribuída ao efeito da redução da tensão superficial da água do poro na diminuição das tensões capilares.

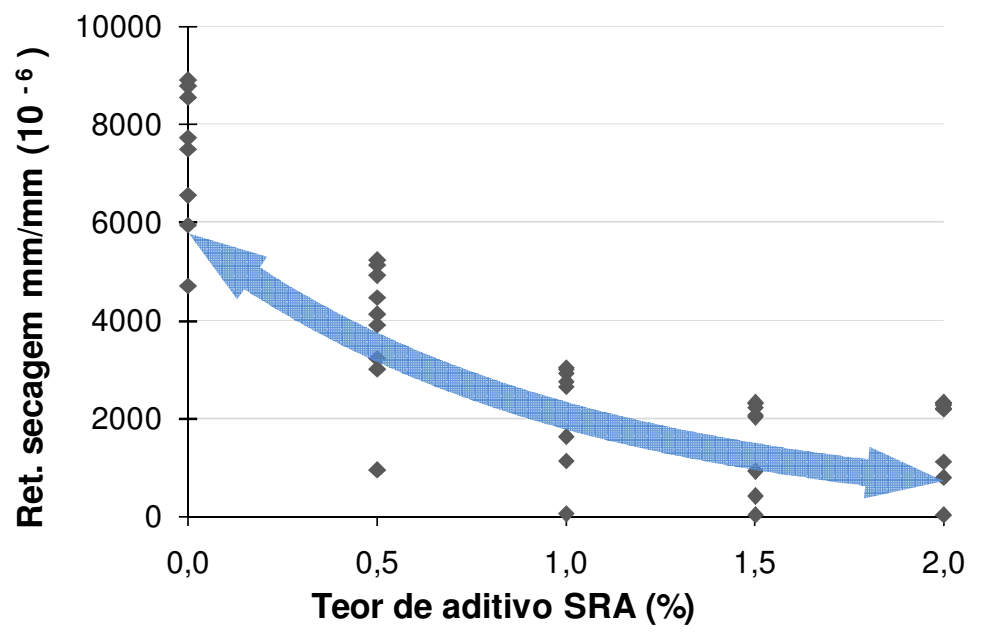

Figura 8.19 - Efeito do teor de aditivo redutor de retração (SRA) na retração por secagem do cimento de escória ativada. Gráficos construídos com todos os pontos obtidos. a/agl = 0,48.

Utilizando a mistura sem aditivo como referência, calcula-se que a utilização do aditivo SRA proporcionou a redução da retração por secagem em todas as idades e teores empregados (Tabela 8.4). Aos 28 dias, o aditivo SRA proporcionou reduções na retração por secagem da ordem de 40\% com a utilização de 0,5\% de aditivo até $75 \%$ com $2 \%$ da retração. A redução foi mais intensa nas primeiras idades, sendo a retração por secagem praticamente nula com o emprego de teores elevados de aditivo SRA. Apesar de combater a retração por secagem com sucesso nas primeiras idades, é importante relembrar que o aditivo SRA afetou a resistência mecânica de modo que não houve desenvolvimento significativo no mesmo período de tempo. Do ponto de vista prático, é aconselhável avaliar os efeitos do aditivo no maior número de parâmetros possíveis, de modo a prever o uso adequado do aditivo com este tipo de cimento. 
Tabela 8.4 - Médias aritméticas da retração por secagem e o efeito do teor de aditivo redutor de retração (SRA) no cimento de escória ativada com relação a/agl igual a $\mathbf{0 , 4 8}$. $\mathrm{CV}=$ coeficiente de variação em \%.

\begin{tabular}{|c|c|c|c|c|c|c|c|c|c|c|c|}
\hline \multicolumn{2}{|c|}{ Relação a/agl = 0,48 } & \multicolumn{10}{|c|}{ Teor de aditivo redutor de retração (SRA) } \\
\hline & \multirow[b]{2}{*}{ Idade } & \multicolumn{2}{|c|}{$0 \%$} & \multicolumn{2}{|c|}{$0,5 \%$} & \multicolumn{2}{|c|}{$1 \%$} & \multicolumn{2}{|c|}{$1,5 \%$} & \multicolumn{2}{|c|}{$2 \%$} \\
\hline & & Rsec & $\mathrm{CV}$ & Rsec & $\mathrm{CV}$ & Rsec & $\mathrm{CV}$ & Rsec & $\mathrm{CV}$ & Rsec & $\mathrm{CV}$ \\
\hline \multirow{4}{*}{$\begin{array}{l}\text { Retração por } \\
\text { secagem } \\
\mathrm{mm} / \mathrm{mm}\left(10^{-6}\right)\end{array}$} & $1 \mathrm{dia}$ & 4714,1 & $0,3 \%$ & 947,2 & $9,8 \%$ & 58,4 & $10,1 \%$ & 34,4 & $11,1 \%$ & 30,4 & $12,4 \%$ \\
\hline & 3 dias & 6554,1 & $1,2 \%$ & 3229,5 & $4,9 \%$ & 1624,1 & $6,0 \%$ & 928,6 & $5,7 \%$ & 1127,7 & $3,4 \%$ \\
\hline & 7 dias & 7712,3 & $1,2 \%$ & 4124,5 & $4,2 \%$ & 2753,6 & $6,8 \%$ & 2083,4 & $0,9 \%$ & 2205,8 & $3,5 \%$ \\
\hline & 28 dias & 8899,8 & $1,8 \%$ & 5237,0 & $4,4 \%$ & 3017,9 & $7,2 \%$ & 2322,5 & $1,0 \%$ & 2306,0 & $4,7 \%$ \\
\hline \multirow{4}{*}{$\begin{array}{l}\text { Variação da } \\
\text { retração por } \\
\text { secagem (\%) }\end{array}$} & $1 \mathrm{dia}$ & \multicolumn{2}{|c|}{0,0} & \multicolumn{2}{|c|}{$-79,9$} & \multicolumn{2}{|c|}{$-98,8$} & \multicolumn{2}{|c|}{$-99,3$} & \multicolumn{2}{|c|}{$-99,4$} \\
\hline & 3 dias & \multirow{2}{*}{\multicolumn{2}{|c|}{0,0}} & \multicolumn{2}{|c|}{$-50,7$} & \multicolumn{2}{|c|}{$-75,2$} & \multicolumn{2}{|c|}{$-85,8$} & \multicolumn{2}{|c|}{$-82,8$} \\
\hline & 7 dias & & & \multirow{2}{*}{\multicolumn{2}{|c|}{$-46,5$}} & \multicolumn{2}{|c|}{$-64,3$} & \multicolumn{2}{|c|}{$-73,0$} & \multicolumn{2}{|c|}{$-71,4$} \\
\hline & 28 dias & \multicolumn{2}{|c|}{$\begin{array}{l}0,0 \\
0,0\end{array}$} & & & \multicolumn{2}{|c|}{$-66,1$} & \multicolumn{2}{|c|}{$-73,9$} & \multicolumn{2}{|c|}{$-74,1$} \\
\hline
\end{tabular}

No cimento Portland, o aditivo redutor de retração (SRA) não interfere na quantidade de água evaporada, inclusive chega a reduzir a quantidade de água perdida para o ambiente (BENTZ, 2005). Ainda não há explicações definitivas para este comportamento, constando no item 2.4 .2 (pág.35) as possíveis explicações. Com base no mecanismo de ação do aditivo redutor de retração, o mais provável seria que ocorresse maior evaporação de água para o ambiente decorrente da diminuição da tensão superficial da água do poro. De modo geral, o aditivo facilitaria a evaporação por tornar mais fraca a ligação da água do poro à superfície das partículas. Ao contrário do que ocorre no cimento Portland, o aditivo SRA altera o perfil de secagem no cimento de escória ativada com silicato de sódio, fazendo com que ocorra o aumento da quantidade de água perdida para o ambiente, que aumenta com teor utilizado (Figura 8.20).

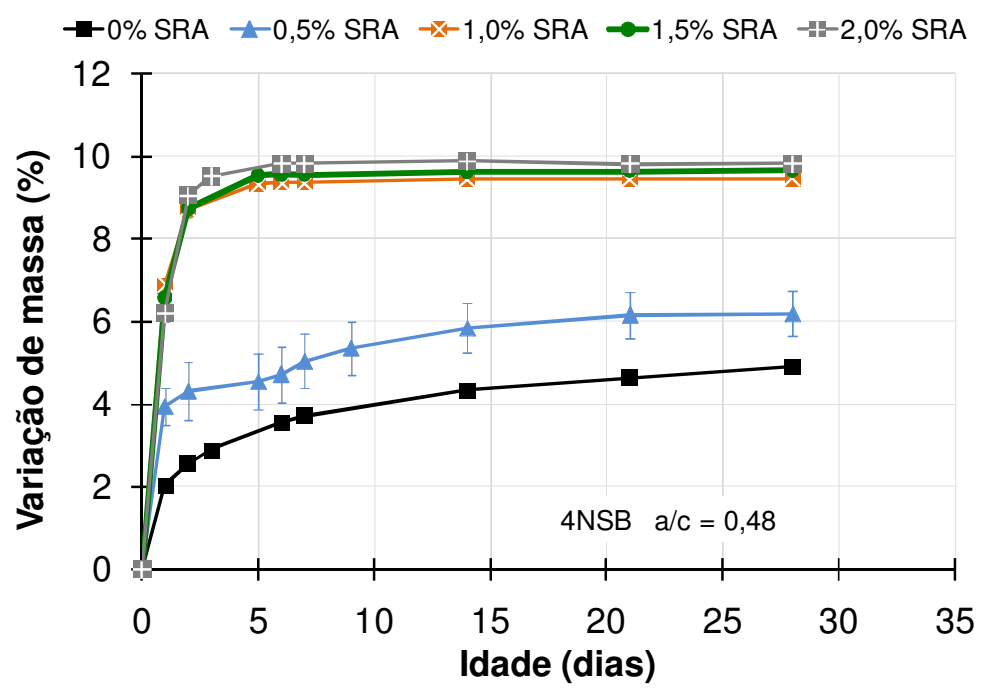

Figura 8.20 - Efeito do teor de aditivo redutor de retração (SRA) na variação de massa por evaporação do cimento de escória até os 28 dias de idade. a/agl = 0,48 
Na Figura 8.21 está apresentada a correlação entre o teor de aditivo redutor de retração (SRA) e a perda de massa por secagem do cimento de escória ativada com silicato de sódio. Verifica-se a existência da correlação e o aumento da perda de massa por secagem do cimento de escória ativada com silicato de sódio com o aumento do teor de aditivo SRA. Utilizando como referência a mistura sem aditivo, calcula-se que a utilização do aditivo SRA incorreu no aumento da quantidade de água evaporada em todas as idades e teores empregados (Tabela 8.5). $O$ aumento da quantidade de água evaporada com a utilização do aditivo SRA foi mais intenso nas primeiras idades, alcançando em torno de $200 \%$ de diferença para a mistura sem aditivo.

Este comportamento é explicado pelo retardo do desenvolvimento da microestrutura causado pelo aditivo SRA, descrito anteriormente, o que aumenta a disponibilidade e, conseqüentemente, a taxa de evaporação da água livre. Aos 28 dias, a perda de massa por evaporação das misturas com 1\%, 1,5\% e 2\% de aditivo SRA foi em torno de $100 \%$ maior do que na mistura sem aditivo. Apenas a mistura com $0,5 \%$ de aditivo SRA apresentou um valor próximo, em torno de $26 \%$ maior aos 28 dias, da mistura sem aditivo.



Figura 8.21 - Efeito do teor de aditivo redutor de retração (SRA) na variação de massa por evaporação do cimento de escória ativada. Gráficos construídos com todos os pontos obtidos. a/agl = 0,48 . 
Tabela 8.5 - Médias aritméticas da variação de massa na secagem e o efeito do teor de aditivo redutor de retração (SRA) no cimento de escória ativada com relação a/agl igual a $\mathbf{0 , 4 8}$. CV = coeficiente de variação em \%.

\begin{tabular}{|c|c|c|c|c|c|c|c|c|c|c|c|}
\hline \multicolumn{2}{|c|}{ Relação a/agl = 0,48 } & \multicolumn{10}{|c|}{ Teor de aditivo redutor de retração (SRA) } \\
\hline & \multirow[b]{2}{*}{ Idade } & \multicolumn{2}{|c|}{$0 \%$} & \multicolumn{2}{|c|}{$0,5 \%$} & \multicolumn{2}{|c|}{$1 \%$} & \multicolumn{2}{|c|}{$1,5 \%$} & \multicolumn{2}{|c|}{$2 \%$} \\
\hline & & Vmas & $\mathrm{CV}$ & Vmas & $\mathrm{CV}$ & Vmas & $\mathrm{CV}$ & Vmas & $\mathrm{CV}$ & Vmas & $\mathrm{CV}$ \\
\hline \multirow{4}{*}{$\begin{array}{c}\text { Variação de massa } \\
(\%)\end{array}$} & $1 \mathrm{dia}$ & 2,0 & $1,4 \%$ & 3,9 & $5,6 \%$ & 6,9 & $0,3 \%$ & 6,6 & $0,7 \%$ & 6,2 & $1,7 \%$ \\
\hline & 3 dias & 2,9 & $1,3 \%$ & 4,4 & $8,0 \%$ & 8,9 & $0,8 \%$ & 9,0 & $0,4 \%$ & 9,2 & $0,8 \%$ \\
\hline & 7 dias & 3,7 & $1,2 \%$ & 5,0 & $6,7 \%$ & 9,4 & $0,2 \%$ & 9,6 & $0,3 \%$ & 9,8 & $0,4 \%$ \\
\hline & 28 dias & 4,9 & $0,9 \%$ & 6,2 & $4,4 \%$ & 9,5 & $0,2 \%$ & 9,7 & $0,2 \%$ & 9,8 & $0,5 \%$ \\
\hline \multirow{4}{*}{$\begin{array}{c}\text { Variação da } \\
\text { variação de massa } \\
(\%)\end{array}$} & 1 dia & \multicolumn{2}{|c|}{0,0} & \multicolumn{2}{|c|}{$+94,0$} & \multicolumn{2}{|c|}{$+238,4$} & \multicolumn{2}{|c|}{$+223,4$} & \multicolumn{2}{|c|}{$+205,4$} \\
\hline & 3 dias & \multicolumn{2}{|c|}{0,0} & \multicolumn{2}{|c|}{$+51,3$} & \multicolumn{2}{|c|}{$+207,5$} & \multicolumn{2}{|c|}{$+210,1$} & \multicolumn{2}{|c|}{$+217,5$} \\
\hline & 7 dias & \multicolumn{2}{|c|}{0,0} & \multicolumn{2}{|c|}{$+35,7$} & \multicolumn{2}{|c|}{$+152,4$} & \multicolumn{2}{|c|}{$+157,5$} & \multicolumn{2}{|c|}{$+164,9$} \\
\hline & 28 dias & \multicolumn{2}{|c|}{0,0} & \multicolumn{2}{|c|}{$+26,1$} & \multicolumn{2}{|c|}{$+92,6$} & \multicolumn{2}{|c|}{$+96,5$} & \multicolumn{2}{|c|}{$+100,1$} \\
\hline
\end{tabular}

\subsubsection{Retração por secagem versus perda de massa por evaporação}

Para analisar o efeito do aditivo redutor de retração (SRA) foi empregada a mesma análise utilizada para correlacionar a retração por secagem e a perda de massa por evaporação descrita no item 8.1.1.1 (pág.128). Na Figura 8.22 está o perfil da curva de correlação para a mistura com relação a/agl igual a 0,48 e sem a utilização do aditivo SRA, na qual se observa a existência de três trechos caracterizados por diferentes taxa de retração. Com a utilização de $0,5 \%$ de aditivo SRA (Figura 8.23), observa-se que o perfil da curva continua apresentando três trechos, porém, ocorrem mudanças significativas na dinâmica de secagem que se refletem nas taxas de retração.

Observa-se que o primeiro trecho apresenta taxa de retração bem mais baixa, em torno de $240 \mu \mathrm{m} / \%$, do que a observada na mistura de referência, em torno de 2283 $\mu \mathrm{m} / \%$. Portanto, conclui-se que o aditivo SRA incorre na redução da taxa de retração de modo que grande parte da água livre seja evaporada sem que resulte em tensões capilares significativas. Conforme descrito anteriormente, com o avanço da idade ocorre a aceleração da hidratação e, conseqüentemente, o refinamento da porosidade, resultando no aumento da taxa de retração no trecho BC para em torno $3919 \mu \mathrm{m} / \%$ (Figura 8.23).

Com o aumento do teor de aditivo SRA para 1\%, 1,5\% e $2 \%$, o comportamento foi o mesmo (Figura 8.24, Figura 8.25 e Figura 8.26), ocorrendo uma redução significativa da taxa de retração no primeiro trecho $(A B)$ para valores praticamente nulos. 
Portanto, nestes teores, o aditivo SRA praticamente anula a retração por secagem até 1 dia de idade, fazendo com que em torno de $70 \%$ da quantidade de água livre seja evaporada sem que ocorra retração. Em seguida, identifica-se o trecho BC que ocorre de 1 até 2 dias e parece ser um trecho de transição atribuído ao início evolução da hidratação, com a consolidação da matriz porosa tem início o trecho CD. Este último trecho é caracterizado pela elevação significativa da taxa de retração atribuída ao aumento das tensões capilares com a evaporação da água em poros com maior refinamento.

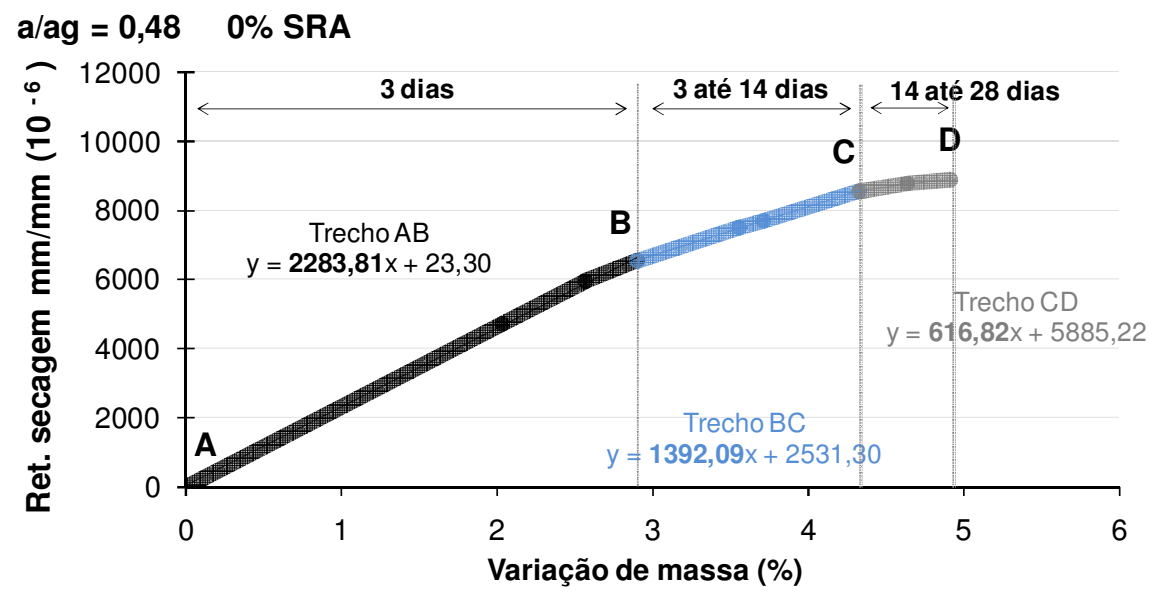

Figura 8.22 - Correlação entre a retração por secagem e perda de massa por evaporação da argamassa de cimento de escória ativada com silicato de sódio com relação a/agl igual a 0,48.

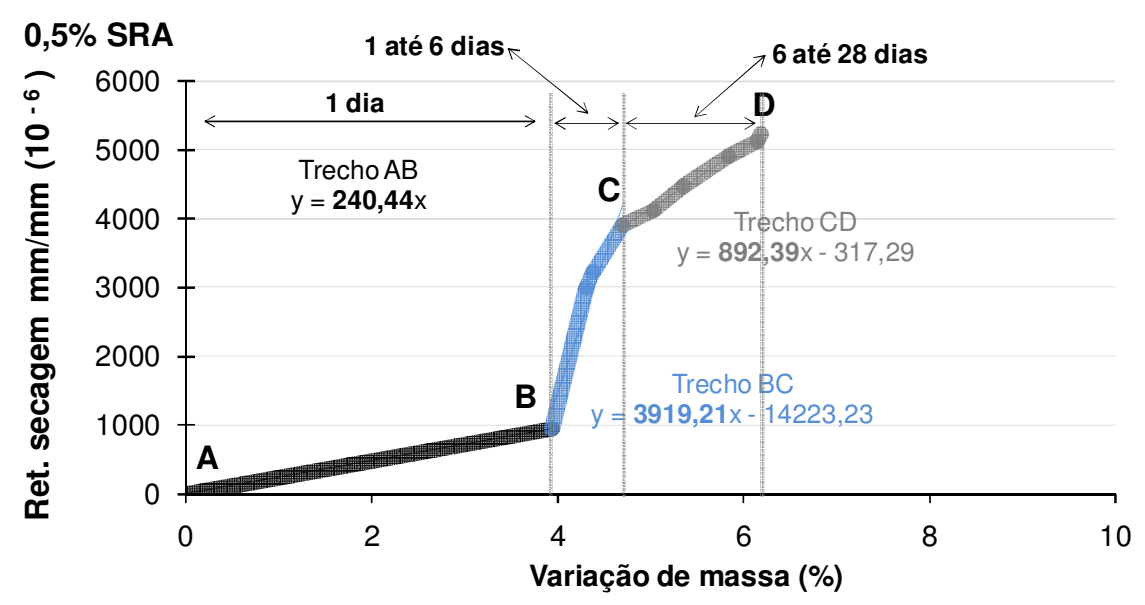

Figura 8.23 - Correlação entre a retração por secagem e perda de massa por evaporação da argamassa de cimento de escória ativada com silicato de sódio com relação a/agl igual a 0,48 e utilizando $0,5 \%$ de aditivo redutor de retração (SRA). 


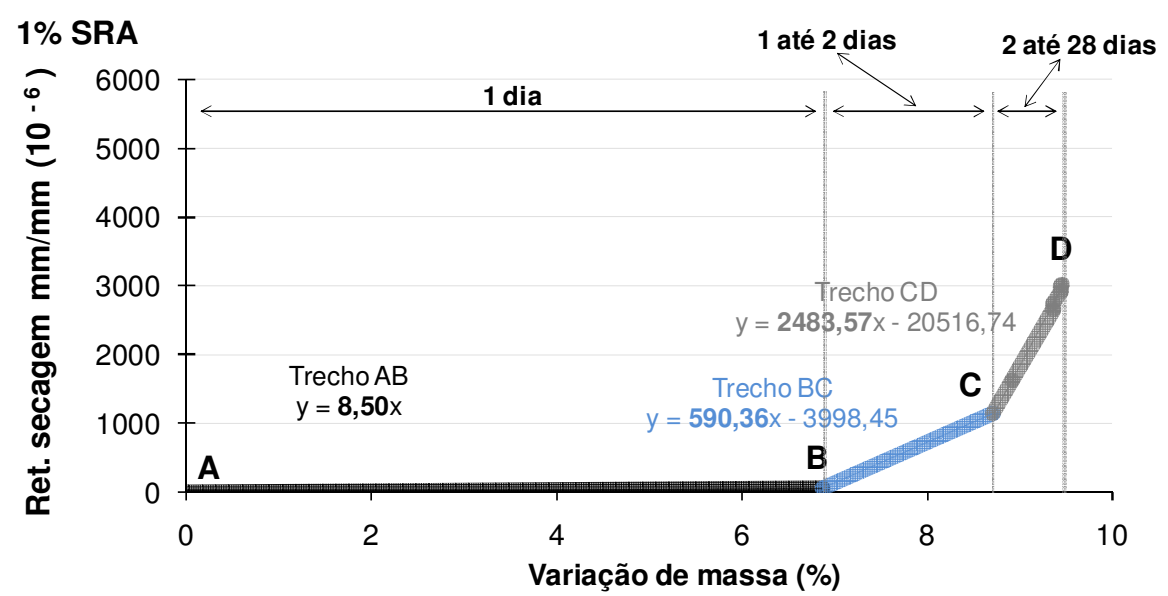

Figura 8.24 - Correlação entre a retração por secagem e perda de massa por evaporação da argamassa de cimento de escória ativada com silicato de sódio com relação a/agl igual a 0,48 e utilizando $1 \%$ de aditivo redutor de retração (SRA).

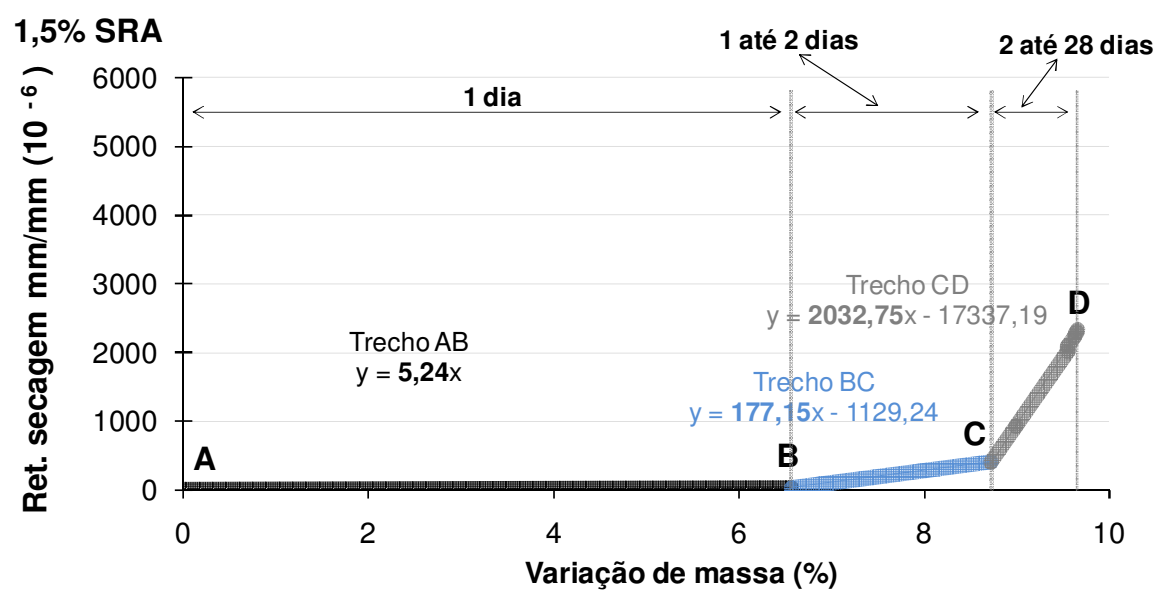

Figura 8.25 - Correlação entre a retração por secagem e perda de massa por evaporação da argamassa de cimento de escória ativada com silicato de sódio com relação a/agl igual a 0,48 e utilizando $1,5 \%$ de aditivo redutor de retração (SRA).

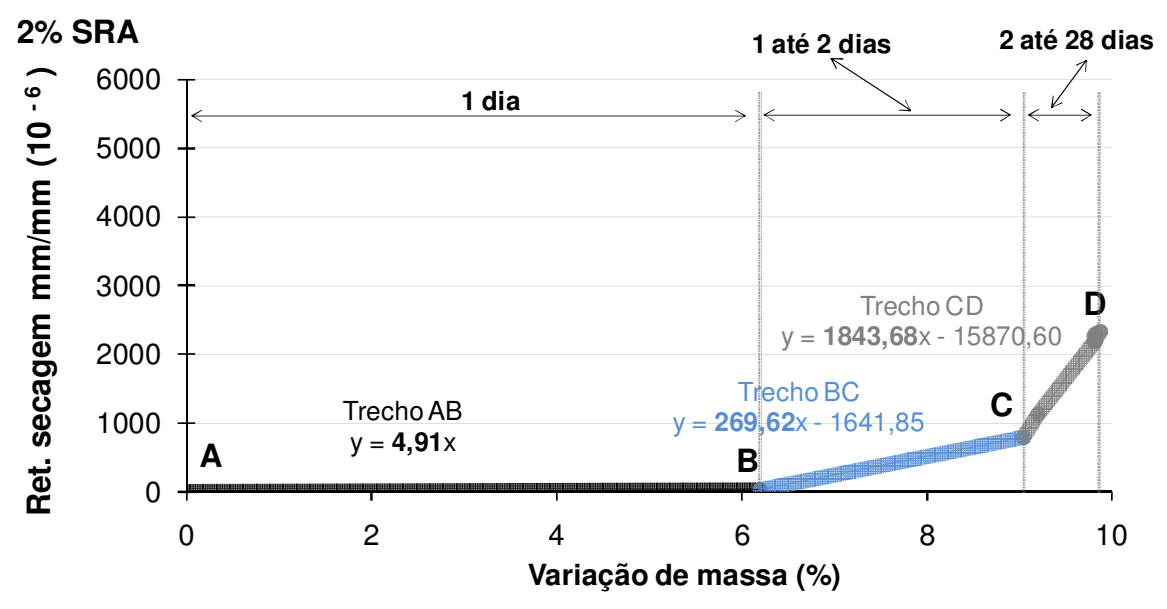

Figura 8.26 - Correlação entre a retração por secagem e perda de massa por evaporação da argamassa de cimento de escória ativada com silicato de sódio com relação a/agl igual a 0,48 e utilizando $2 \%$ de aditivo redutor de retração (SRA). 


\subsubsection{Retração autógena}

O efeito do teor de aditivo redutor de retração (SRA) na retração autógena do cimento de escória está apresentado na Figura 8.27 e detalhado nas primeiras idades na Figura 8.28. Observa-se que o aditivo SRA não foi eficiente na redução da retração autógena deste tipo de cimento e que não houve diferença entre a mistura sem aditivo e as misturas com aditivo aos 28 dias. Apenas nas primeiras idades ocorreu uma redução, atribuída ao retardo do desenvolvimento da microestrutura, tanto que, com a retomada do desenvolvimento da microestrutura, já não ocorre mais a redução da retração autógena a partir dos 7 dias de idade.

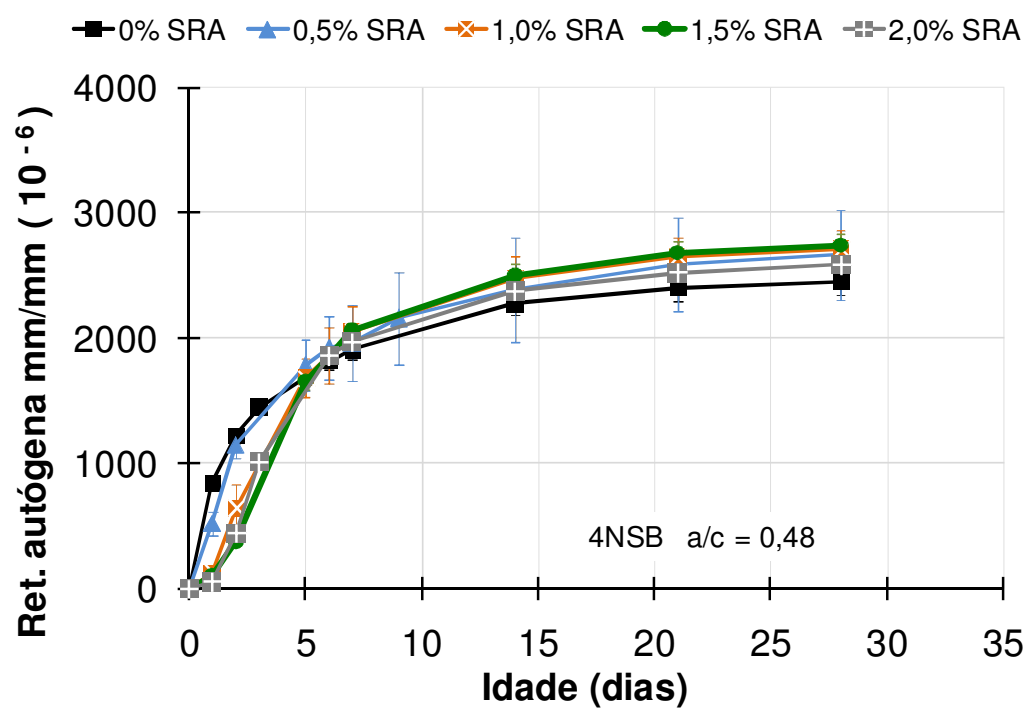

Figura 8.27 - Efeito do teor de aditivo redutor de retração (SRA) na retração autógena do cimento de escória até os 28 dias de idade. a/agl = 0,48.

Conforme discutido na análise do efeito da relação a/agl na retração autógena, a distribuição e volume de poros são fatores fundamentais para o cimento de escória ativada com silicato de sódio. De acordo com os resultados de porosidade, o aditivo redutor de retração (SRA) aumenta a porosidade inicial e retarda o refinamento da distribuição de poros nas primeiras idades. Este comportamento explica a redução da retração autógena proporcionada pelo aditivo SRA nas primeiras idades, detalhada na Figura 8.28. 


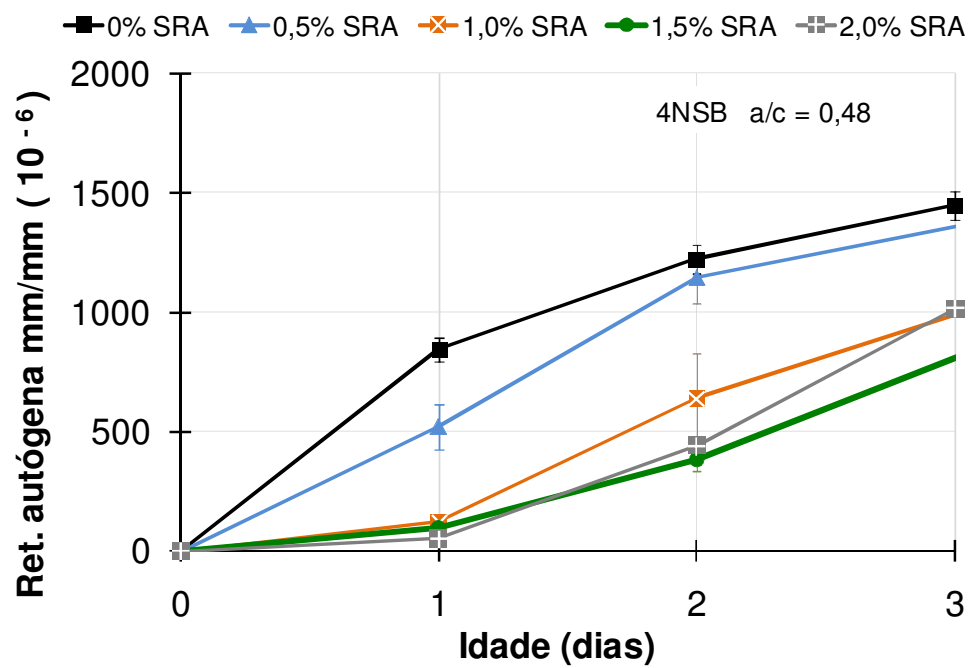

Figura 8.28 - Detalhe do efeito do teor de aditivo redutor de retração (SRA) na retração autógena do cimento de escória até os 3 dias de idade. $\mathrm{a} / \mathrm{agl}=0,48$.

Na Figura 8.29 consta o panorama geral da correlação entre a retração autógena e o teor de aditivo SRA, confirmando que o aumento do mesmo só foi capaz de amenizar a retração autógena até os 3 dias de idade. Utilizando como referência a mistura sem aditivo, calculou-se, em termos percentuais, o efeito da utilização do aditivo SRA durante os 28 dias de hidratação (Tabela 8.6). A redução da retração autógena com 1 dia de idade foi proporcional ao aumento do teor de aditivo SRA; com 3 dias a mistura com $0,5 \%$ de SRA já apresenta valor próximo à mistura de referência. De 3 dias de idade em diante, o aditivo SRA não apresenta resultados que permitam diferenciar, dentro da dispersão calculada, algum efeito, sendo os resultados das misturas com ou sem a utilização do aditivo SRA praticamente idênticos.

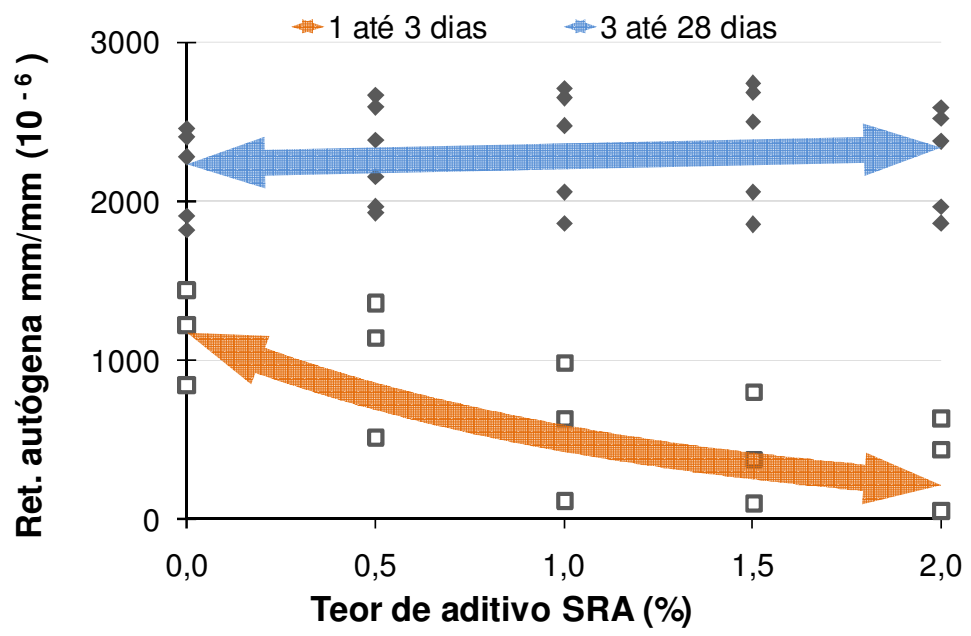

Figura 8.29 - Efeito do teor de aditivo redutor de retração (SRA) na retração autógena do cimento de escória ativada. Gráficos construídos com todos os pontos obtidos. a/agl = 0,48. 
Tabela 8.6 - Médias aritméticas da retração autógena e o efeito do teor de aditivo redutor de retração (SRA) no cimento de escória ativada com relação a/agl igual a $\mathbf{0 , 4 8}$. CV = coeficiente de variação em $\%$.

\begin{tabular}{|c|c|c|c|c|c|c|c|c|c|c|c|}
\hline \multicolumn{2}{|c|}{ Relação a/agl = 0,48 } & \multicolumn{10}{|c|}{ Teor de aditivo redutor de retração (SRA) } \\
\hline & \multirow[b]{2}{*}{ Idade } & \multicolumn{2}{|c|}{$0 \%$} & \multicolumn{2}{|c|}{$0,5 \%$} & \multicolumn{2}{|c|}{$1 \%$} & \multicolumn{2}{|c|}{$1,5 \%$} & \multicolumn{2}{|c|}{$2 \%$} \\
\hline & & Raut & $\mathrm{CV}$ & Raut & $\mathrm{CV}$ & Raut & $\mathrm{CV}$ & Raut & $\mathrm{CV}$ & Raut & $\mathrm{CV}$ \\
\hline \multirow{4}{*}{$\begin{array}{l}\text { Retração autógena } \\
\mathrm{mm} / \mathrm{mm}\left(10^{-6}\right)\end{array}$} & $1 \mathrm{dia}$ & 842,8 & $2,9 \%$ & 521,1 & $9,2 \%$ & 122,9 & $8,2 \%$ & 97,8 & $5,2 \%$ & 52,2 & $7,0 \%$ \\
\hline & 3 dias & 1446,6 & $2,1 \%$ & 1357,7 & $5,3 \%$ & 986,9 & $9,2 \%$ & 805,7 & $3,3 \%$ & 1014,8 & $1,5 \%$ \\
\hline & 7 dias & 1910,8 & $2,3 \%$ & 1963,9 & $7,9 \%$ & 2056,8 & $5,0 \%$ & 2057,8 & $1,6 \%$ & 1968,2 & $1,6 \%$ \\
\hline & 28 dias & 2453,6 & $2,3 \%$ & 2666,2 & $6,8 \%$ & 2714,0 & $2,7 \%$ & 2743,1 & $1,7 \%$ & 2589,9 & $1,5 \%$ \\
\hline \multirow{4}{*}{$\begin{array}{c}\text { Variação da } \\
\text { retração autógena } \\
(\%)\end{array}$} & $1 \mathrm{dia}$ & \multicolumn{2}{|c|}{0,0} & \multicolumn{2}{|c|}{$-38,2$} & \multicolumn{2}{|c|}{$-85,4$} & \multicolumn{2}{|c|}{$-88,4$} & \multicolumn{2}{|c|}{$-93,8$} \\
\hline & 3 dias & \multirow{2}{*}{\multicolumn{2}{|c|}{0,0}} & \multirow{2}{*}{\multicolumn{2}{|c|}{$\begin{array}{r}-6,1 \\
+28\end{array}$}} & \multirow{2}{*}{\multicolumn{2}{|c|}{$\begin{array}{r}-31,8 \\
76\end{array}$}} & \multicolumn{2}{|c|}{$-44,3$} & \multicolumn{2}{|c|}{$-29,9$} \\
\hline & 7 dias & & & & & & & \multirow{2}{*}{\multicolumn{2}{|c|}{$\begin{array}{r}+7,7 \\
+11,8\end{array}$}} & \multirow{2}{*}{\multicolumn{2}{|c|}{$\begin{array}{l}+3,0 \\
+5,6\end{array}$}} \\
\hline & 28 dias & \multicolumn{2}{|c|}{0,0} & \multicolumn{2}{|c|}{$\begin{array}{r}+8,7 \\
+8\end{array}$} & \multicolumn{2}{|c|}{$+10,6$} & & & & \\
\hline
\end{tabular}

\subsubsection{Retração autógena versus porosidade}

Conforme descrito na análise do efeito da relação a/agl na retração autógena do cimento de escória ativada com silicato de sódio, o refinamento da distribuição de poros, representado pelo volume de mesoporos, é preponderante na magnitude da retração autógena deste tipo de cimento. Conforme os resultados de porosidade, o aditivo redutor de retração (SRA) aumenta a porosidade total nas primeiras idades, em razão do retardo do desenvolvimento da microestrutura, porém, não altera a distribuição de poros aos 28 dias. Como foi descrito na análise da influência da relação a/agl (item 8.1.2, pág.133), a retração autógena está correlacionada com o volume de mesoporos e o aditivo SRA não altera este volume, explica-se o motivo do mesmo não apresentar eficiência para amenizar a retração autógena.

Na Figura 8.30 consta a influência do teor de aditivo SRA na correlação entre a retração autógena e o volume de mesoporos. Observa-se que as misturas com o aditivo seguem o mesmo perfil da mistura sem aditivo, ou seja, o aumento da retração com o aumento do volume de mesoporos. Portanto, na condição de cura autógena, o aspecto físico da diminuição da tensão superficial causado pelo aditivo não tem efeito na retração autógena nas condições apresentadas pelo cimento de escória ativada com silicato de sódio. 


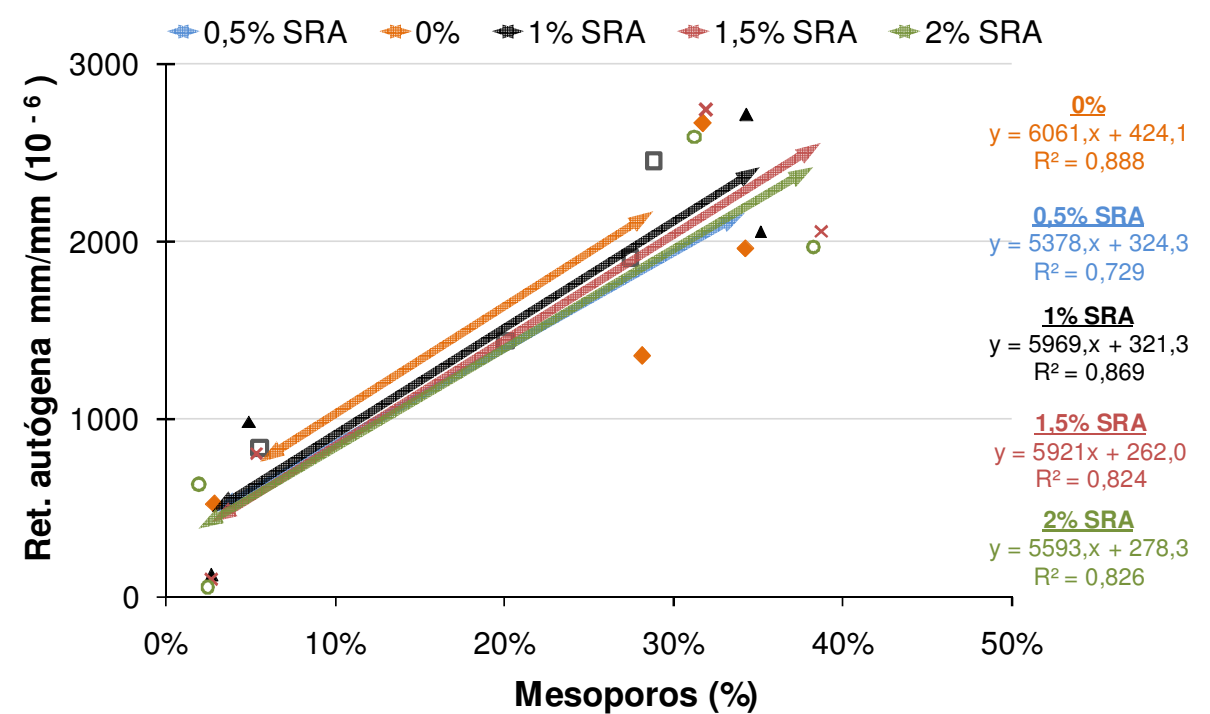

Figura 8.30 - Influência do teor de aditivo redutor de retração (SRA) na correlação entre a retração autógena e o volume de mesoporos da mistura com relação a/agl igual a 0,48.

\subsection{Discussão e conclusões}

\subsubsection{Retração por secagem}

\subsubsection{Efeito da relação água/aglomerante}

De acordo com os resultados obtidos, o aumento da relação água/aglomerante incorre no aumento significativo da retração por secagem do cimento de escória ativada com silicato de sódio. Conforme descrito na análise da termogravimetria, o grau de hidratação aos 28 dias foi igual para todas as relações a/agl estudadas, portanto, o aumento da relação a/agl possibilita a maior disponibilidade de água livre. Esta maior quantidade de água livre, associada à porosidade singular deste cimento, caracterizada pela proporção majoritária de poros na faixa de mesoporos, é responsável pelo aumento das tensões capilares com o aumento da relação a/agl e, conseqüentemente, pelo aumento da retração por secagem. E como o aumento da relação a/agl também é responsável pela diminuição significativa da resistência mecânica, as tensões capilares resultam em maior deformação e, conseqüentemente, retração por secagem.

A correlação entre os resultados da retração (por secagem e autógena) e a quantidade de C-S-H permitiu conclusões importantes sobre o fenômeno da retração 
do cimento de escória ativada com silicato de sódio e o efeito da relação a/agl. Observou-se que o aumento da relação a/agl não tem efeito significativo na reação química de formação de C-S-H, porém o efeito na compacidade da estrutura física é significativo. Este fato confirma que a retração por secagem do cimento de escória está diretamente relacionada com a estrutura da matriz porosa e com a quantidade de água disponível para ser perdida para o ambiente. A correlação entre a retração autógena e a quantidade de C-S-H permite afirmar que a parcela referente à retração química do cimento de escória ativada com silicato de sódio não é afetada pelo aumento da relação a/agl e que a parcela referente à auto-secagem aumenta de forma significativa com o aumento do volume de mesoporos. Portanto, do ponto de vista prático, para amenizar a retração por secagem do cimento de escória ativada com silicato de sódio é recomendada a utilização de menores relações a/agl. Porém, ressalta-se que, mesmo diminuindo a relação a/agl, a retração observada neste tipo de cimento é em torno de 8 vezes maior do que a observada no cimento Portland de alta resistência inicial (MELO NETO, 2002), o que continua a limitar o uso do cimento de escória ativada.

\subsubsection{Efeito do aditivo redutor de retração (SRA)}

De acordo com os resultados obtidos, o aditivo redutor de retração (SRA) foi capaz de amenizar a retração por secagem do cimento de escória ativada com silicato de sódio. O aditivo SRA reduziu em até $74 \%$, para o teor de $2 \%$, a retração por secagem e ainda retardou de forma significativa o início da retração. Também foi observado que a redução da retração por secagem foi proporcional ao aumento do teor de aditivo SRA. Conclui-se que o aditivo, além de reduzir as deformações oriundas das tensões capilares, retarda o desenvolvimento da hidratação, o que de certa forma contribui para a redução da retração por secagem, pois, comprovou-se que este retardo possibilita uma quantidade maior de água livre, a qual é facilmente perdida para o ambiente sem que ocorra retração significativa.

No entanto, é preciso estabelecer uma análise paralela entre o efeito do aditivo redutor de retração (SRA) na retração e nas propriedades mecânicas, pois não tem sentido prático que o material tenha sua retração amenizada, mas que ao mesmo 
tempo comprometa significativamente a resistência mecânica. Portanto, com os resultados obtidos neste trabalho, é possível estabelecer teores de aditivo e relações a/agl para o uso do cimento de escória ativada com silicato de sódio em situações específicas. Para o emprego em aplicações que necessitem de elevada resistência inicial é aconselhável a utilização de teores menores que 1\% de SRA e relações a/agl menores que 0,48 , pois, como visto, a diminuição da relação a/agl incorre na redução da retração por secagem e autógena do cimento de escória ativada. Aplicações que necessitem apenas de resistência a longo prazo podem fazer uso de teores maiores de aditivo SRA e maiores relações a/agl, pois são alcançados valores significativos aos 28 dias.

\subsubsection{Retração autógena}

\subsubsection{Efeito da relação água/aglomerante}

De acordo com os resultados obtidos, o aumento da relação água/aglomerante incorre no aumento significativo da retração autógena do cimento de escória ativada com silicato de sódio. Esta afirmação é totalmente contrária ao relatado para o cimento Portland, onde o aumento da relação a/agl incorre na diminuição da retração autógena. Atribui-se este comportamento à porosidade singular do cimento de escória, caracterizada pela elevada proporção e volume de mesoporos. Constatou-se a correlação entre a retração autógena e o volume de mesoporos, na qual o aumento do volume de mesoporos na condição saturada incorre no aumento da retração autógena do cimento de escória ativada com silicato de sódio. Portanto, se o aumento da relação a/agl necessariamente causará o aumento das tensões capilares e a diminuição da resistência mecânica do cimento de escória ativada com silicato de sódio, é evidente que este quadro é propício ao aumento da retração autógena.

Conforme os resultados de porosidade, o aumento da relação a/agl causou 0 aumento da porosidade total e o retardo do refinamento da distribuição de poros, porém, com o desenvolvimento da microestrutura, a distribuição de poros do cimento de escória é similar, em torno de $95 \%$ de mesoporos, em qualquer relação a/agl estudada. Portanto, o aumento da relação a/agl tem como efeito principal o aumento 
da porosidade total sem alteração da distribuição de poros e a diminuição da resistência mecânica, resultando no aumento da retração autógena. Mais uma vez ressalta-se que a redução da a/agl por si só não é suficiente para amenizar a retração autógena do cimento de escória para patamares próximos aos observados no cimento Portland, visto que a retração autógena do cimento de escória é em torno de 4 vezes maior do que no cimento Portland (MELO NETO, 2002).

\subsubsection{Efeito do aditivo redutor de retração (SRA)}

De acordo com os resultados obtidos, o aditivo redutor de retração (SRA) não foi capaz de reduzir a retração autógena do cimento de escória ativada com silicato de sódio, sendo observada apenas uma redução na intensidade da retração autógena nas primeiras idades. Aos 28 dias, os resultados da retração autógena da mistura sem aditivo SRA e das misturas com aditivo são praticamente idênticos, independentemente do teor estudado. Conforme constatado na análise do efeito do aditivo SRA na retração por secagem, apesar da interferir no desenvolvimento da microestrutura, a redução da tensão superficial é fundamental na diminuição das tensões capilares resultantes da secagem. Na condição de cura autógena, o aspecto físico da redução da tensão não apresenta efeito algum na magnitude total da retração autógena do cimento de escória ativada com silicato de sódio, ocorrendo apenas uma redução da magnitude nas primeiras idades atribuída ao retardo do desenvolvimento da microestrutura causado pelo aditivo.

A magnitude da retração autógena do cimento de escória ativada com silicato de sódio está mais associada à distribuição de poros, representada pelo volume de mesoporos. Conforme os resultados da porosidade, o aditivo SRA não altera o perfil final da distribuição de poros. Portanto, é coerente que para uma mesma relação a/agl tenhamos valores similares para 0 volume final de mesoporos independentemente do teor de aditivo SRA utilizado. Conseqüentemente, a retração autógena resultante da formação da matriz porosa vai ser a mesma com a utilização do aditivo redutor de retração (SRA), ocorrendo apenas um retardo inicial do seu crescimento. 
Do ponto de vista de emprego do aditivo redutor de retração (SRA) no caso específico do cimento de escória ativada com silicato de sódio, está evidente que a sua utilização é eficiente apenas para amenizar a retração por secagem deste tipo de cimento. De acordo com os resultados obtidos neste trabalho, uma primeira tentativa seria a redução da relação a/agl. A utilização de aditivos compensadores de retração (SCA) obteve êxito na redução da retração autógena deste tipo de cimento, conforme descrito na Parte 3 desta tese. 


\section{Parte 3}

Aditivo compensador de retração (SCA) 


\section{Capítulo 9 Difração de raios $X$}

\subsection{Introdução}

A metodologia empregada para a análise dos resultados de difração de raios $\mathrm{X}$ está descrita no Capítulo 4 (pág.62). De acordo com a caracterização do aditivo compensador de retração (SCA) e os dados obtidos no levantamento bibliográfico (Capítulo 2, item 2.4.1, pág.30), sabe-se que os principais compostos anidros deste aditivo são o sulfoaluminato de cálcio, anidrita e o óxido de cálcio. Portanto, o seu emprego no cimento de escória ativada com silicato de sódio resultará na inclusão dos picos principais destes compostos anidros na análise dos resultados de difração de raios $\mathrm{X}$, assim como compostos oriundos da hidratação destes compostos.

\subsubsection{Hidratação do aditivo compensador de retração (SCA)}

De modo a ter-se o conhecimento da contribuição do aditivo SCA nos resultados da análise por difração de raios $\mathrm{X}$, este foi misturado apenas com água e hidratado nas mesmas condições das pastas das misturas de cimento de escória, utilizando-se também três teores de água: 0,40,0,48 e 0,56. Os ensaios nas pastas de aditivo SCA puro foram realizados com 6, 12 horas, 1, 3, 7 e 28 dias, sendo o preparo das amostras idêntico ao utilizado nas pastas de cimento de escória (item 3.5.4, pág.57).

Na Figura 9.1 está apresentada a evolução da hidratação de uma pasta confeccionada apenas com o aditivo compensador de retração (SCA) e água, no caso uma relação água/aditivo igual a 0,56. As demais relações água/aditivo foram analisadas de modo idêntico e os resultados completos constam no Apêndice C. Foram identificados os picos principais do sulfoaluminato de cálcio $\left(3 \mathrm{CaO} \cdot 3 \mathrm{Al}_{2} \mathrm{O}_{3}\right.$ - $\left.\mathrm{CaSO}_{4}\right)$ no ângulo ${ }^{\circ} 2 \Theta=23,66(\mathrm{~d}(\AA)=3,758)$, da anidrita $\left(\mathrm{CaSO}_{4}\right)$ no ângulo 을 $2925,44(\mathrm{~d}(\AA)=3,498)$ e do óxido de cálcio $(\mathrm{CaO})$ no ângulo ${ }^{\circ} 2 \Theta=37,36(\mathrm{~d}(\AA)=$ 2,405). 


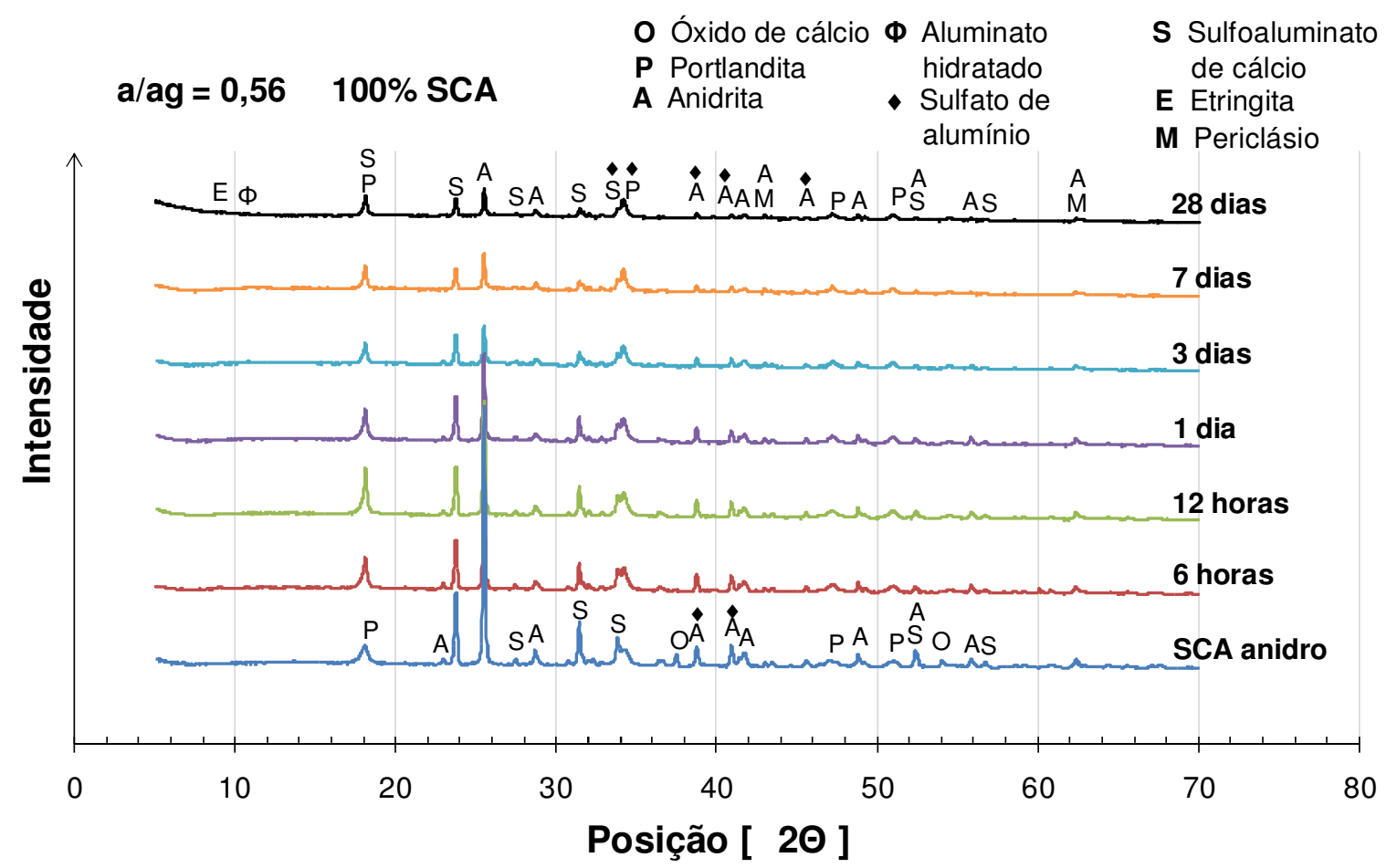

Figura 9.1 - Difratogramas da pasta utilizando apenas o aditivo compensador de retração (SCA) a 6 e 12 horas, $1,3,7$ e 28 dias de idade. Teor de SCA $=100 \%$. água/aditivo $=0,56$.

Com a hidratação, observa-se claramente a redução da intensidade dos picos de sulfoaluminato de cálcio e anidrita, e o consumo completo do oxido de cálcio. $\mathrm{O}$ consumo do óxido de cálcio é caracterizado pelo aumento da intensidade do pico da portlandita no ângulo ${ }^{\circ} 2 \Theta=18,01(\mathrm{~d}(\AA)=4,922)$. Na Figura 9.2(c)(d) pode-se observar que a formação de portlandita atinge o pico máximo com 12 horas e depois diminui até os 28 dias de idade. Com base na teoria de hidratação deste tipo de aditivo (item 2.4.1, pág.30), observa-se a ocorrência da rápida hidratação do óxido de cálcio e a da formação da portlandita. Simultaneamente, ocorre a reação do sulfoaluminato de cálcio e da anidrita com a água, conforme constatado na Figura 9.2(a)(b).

Segundo Nagataki e Gomi (1998), o sulfoaluminato de cálcio que reagiu com a água, deveria se combinar com a portlandita, e desta maneira formar a denominada etringita precursora $\left(3 \mathrm{CaO} \cdot \mathrm{Al}_{2} \mathrm{O}_{3} \cdot \mathrm{CaSO}_{4} \cdot 12 \mathrm{H}_{2} \mathrm{O}-2\left\{3 \mathrm{CaO} \cdot \mathrm{Al}_{2} \mathrm{O}_{3} \cdot \mathrm{Ca}(\mathrm{OH})_{2} \cdot 12 \mathrm{H}_{2} \mathrm{O}\right\}\right)$. Em seguida, a anidrita, que também reagiu com a água, combina-se com a etringita precursora, por meio de uma reação topoquímica, resultando na etringita e, conseqüentemente, na expansão desejada. 

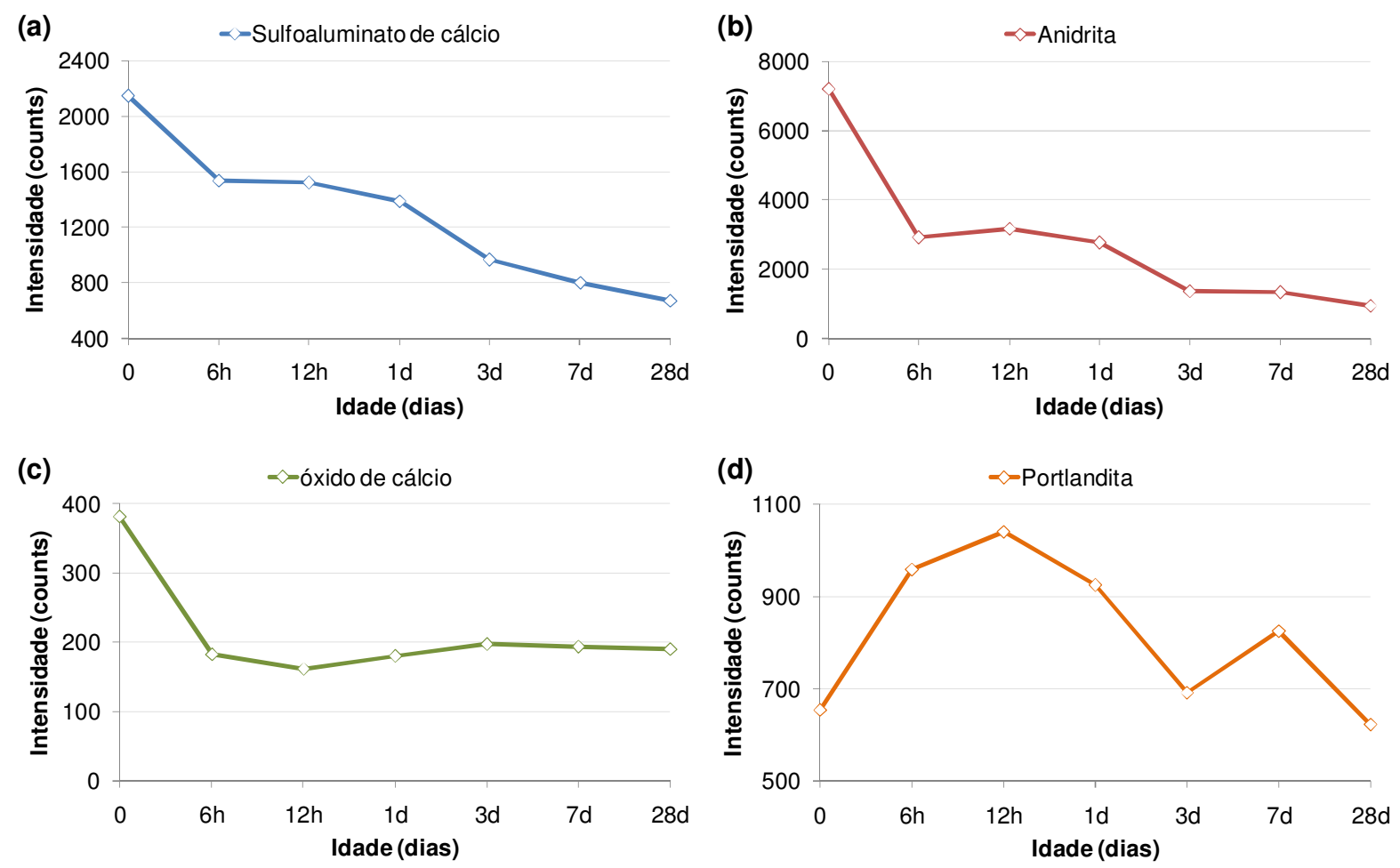

Figura 9.2 - Evolução da hidratação do aditivo compensador de retração (SCA), quantificada pela variação da intensidade do pico principal de sulfoaluminato de cálcio (a), da anidrita (b), do óxido de cálcio (c) e da portlandita (d) até os 28 dias de idade. água/aditivo $=0,56$. Teor de SCA $=100 \%$.

No entanto, os picos de etringita e monossulfoaluminato de cálcio hidratado identificados não foram tão intensos como a redução dos picos referentes aos compostos anidros do aditivo SCA. Não foi encontrada nenhuma explicação para este comportamento no levantamento bibliográfico. É possível que no processo de secagem da amostra tenha acontecido alguma alteração no grau de cristanilidade destes compostos hidratados. Para esta verificação foi utilizada a análise por termogravimetria, a qual possibilitou a identificação clara dos picos associados à estes compostos. Com a limitação da quantificação do pico de etringita, a análise da hidratação do aditivo SCA na utilização no cimento de escória ativada foi centralizada no consumo dos seus principais compostos anidros, o sulfoaluminato de cálcio e a anidrita, caracterizado pela diminuição da intensidade do pico nos resultados de difração de raios $X$. 


\subsection{Efeito do aditivo compensador de retração (SCA)}

Da Figura 9.3 até a Figura 9.8 constam os difratogramas das pastas de cimento de escória ativada com silicato de sódio com relação a/agl igual a 0,40 e 5\%, 10\% e $15 \%$ de aditivo SCA em substituição ao aglomerante. Observa-se, a presença obrigatória dos picos do sulfoaluminato de cálcio e da anidrita com intensidades proporcionais ao teor de aditivo SCA utilizado. Identifica-se também a portlandita, no ângulo ${ }^{\circ} 2 \Theta=18,01(d(\AA)=4,922)$, oriunda da hidratação do óxido de cálcio presente no aditivo. Ao contrário do observado na análise da influência do aditivo redutor de retração (SRA), o aditivo SCA reagiu com os produtos hidratados oriundos do cimento de escória, formando o monocarboaluminato de cálcio hidratado, observável nos ângulos ${ }^{\circ} 2 \Theta=21,66(d(\AA)=4,099),{ }^{\circ} 2 \Theta=19,15(d(\AA)=4,630)$ e ${ }^{\circ} 2 \Theta=40,85(d(\AA)=$ 2,207).

Segundo Bonavetti et al. (2001), de modo geral, a formação de monocarboaluminato de cálcio é resultante da reação entre fases aluminato hidratadas, notadamente o monossulfoaluminato de cálcio hidratado, e o carbonato de cálcio, o qual pode ser oriundo do aglomerante ou da carbonatação da amostra. A carbonatação da amostra não ocorreu, pois na análise por termogravimetria (Capítulo 10, pág.171), constatou-se que a presença de fases hidratadas com carbonato de cálcio ocorreu apenas com a utilização do aditivo SCA no cimento de escória ativada. Já na hidratação do aditivo SCA puro e do cimento de escória sem aditivo não foram identificados estes compostos. Desta maneira, conclui-se que a formação do monocarboaluminato de cálcio hidratado foi resultante da reação entre o monossulfoaluminato de cálcio hidratado, oriundo da hidratação do aditivo, e o carbonato de cálcio, originário da escória anidra.

Em termos de análise da evolução da influência do aditivo compensador de retração (SCA) na hidratação do cimento de escória, a presença do carbonato de cálcio dificulta a quantificação da intensidade dos picos principais do C-S-H, pois o pico principal do carbonato de cálcio ocorre no ocorre ângulo ${ }^{\circ} 2 \Theta=29,40(d(\AA)=3,035)$, sobrepondo-se ao pico do C-S-H no ângulo ${ }^{\circ} 2 \Theta=29,36(d(\AA)=3,040)$. 


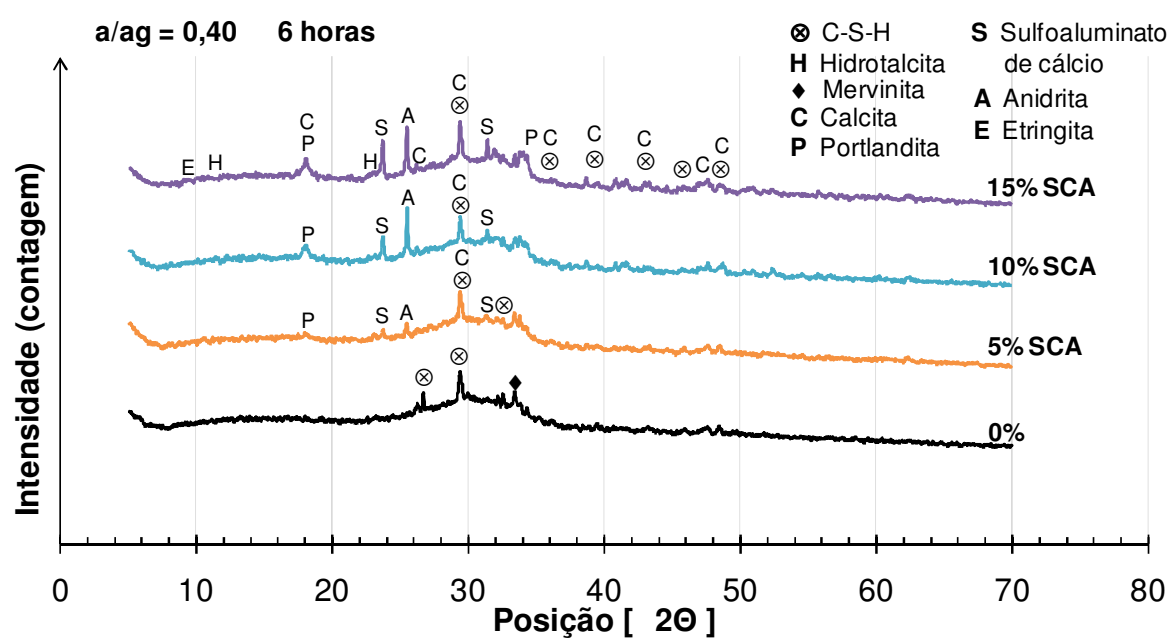

Figura 9.3 - Efeito do teor de aditivo compensador de retração (SCA) na difração de raios X com 6 horas de idade. $\mathrm{a} / \mathrm{agl}=0,40$.

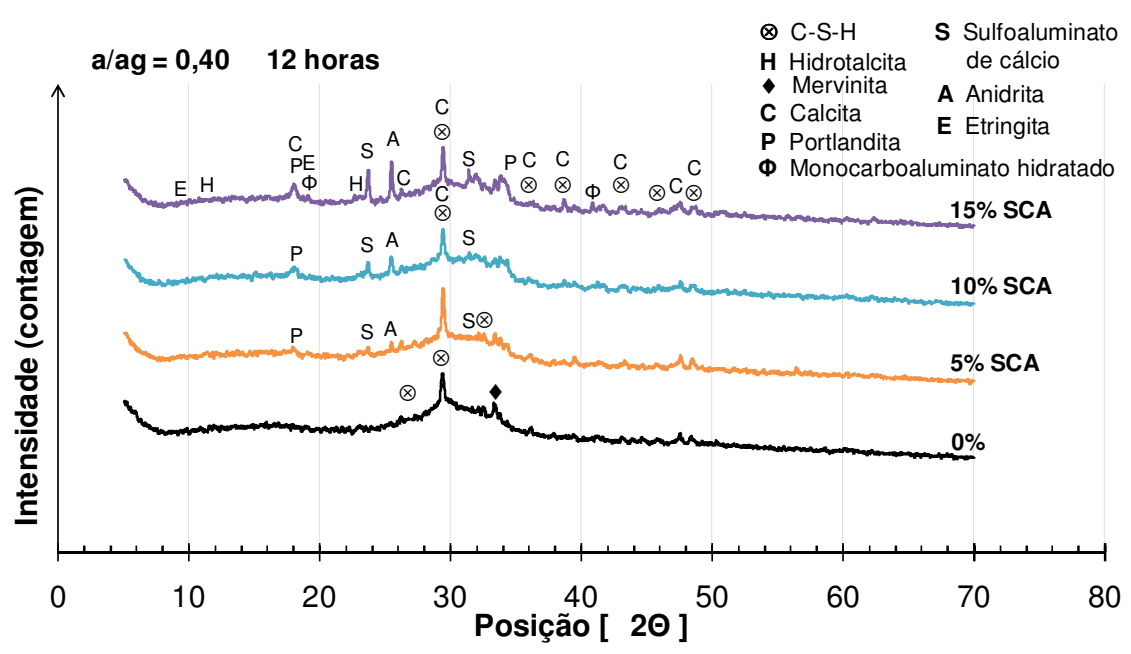

Figura 9.4 - Efeito do teor de aditivo compensador de retração (SCA) na difração de raios X com 12 horas de idade. $\mathrm{a} / \mathrm{agl}=0,40$.

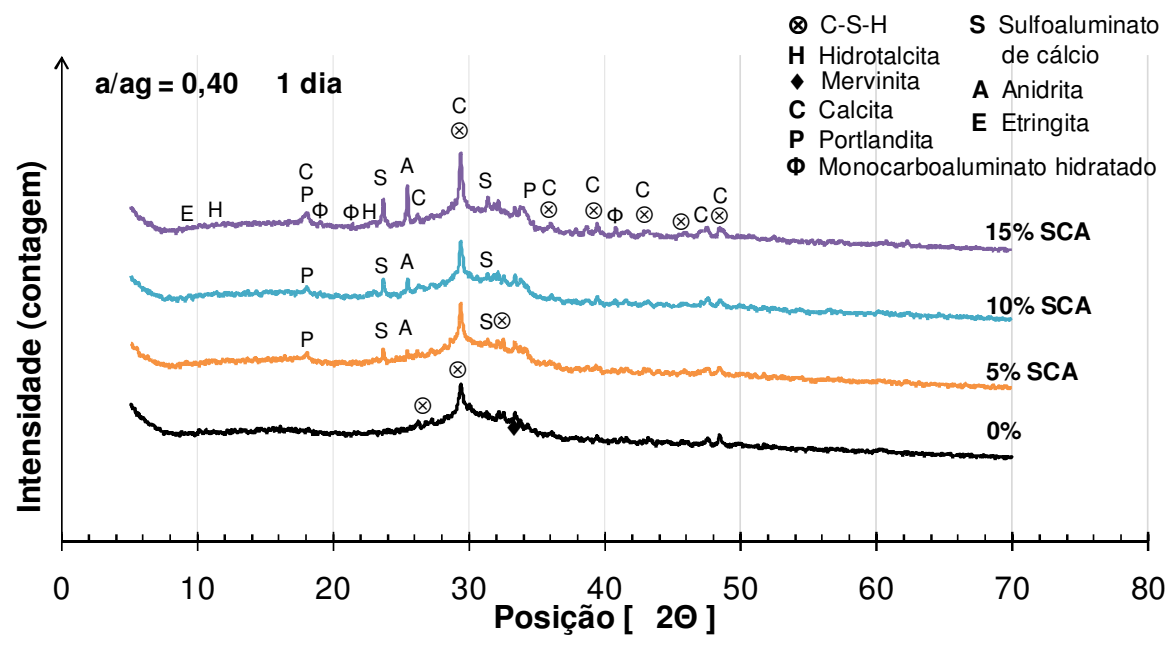

Figura 9.5 - Efeito do teor de aditivo compensador de retração (SCA) na difração de raios $\mathrm{X}$ com 1 dia de idade. $\mathrm{a} / \mathrm{agl}=0,40$. 


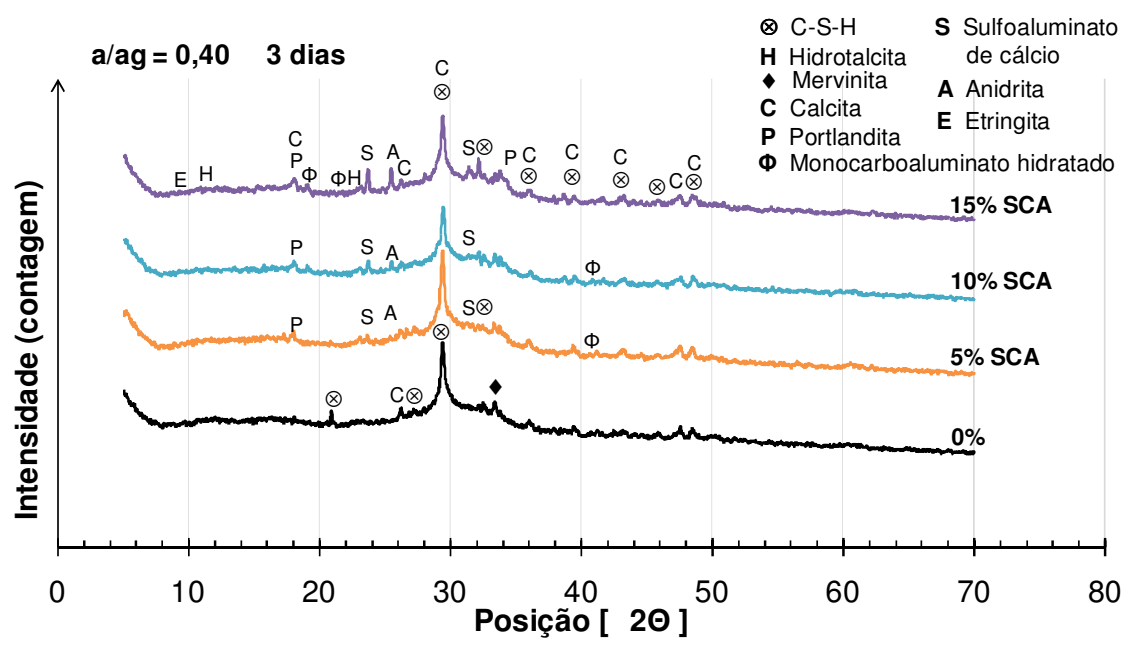

Figura 9.6 - Efeito do teor de aditivo compensador de retração (SCA) na difração de raios X com 3 dias de idade. $\mathrm{a} / \mathrm{agl}=0,40$.

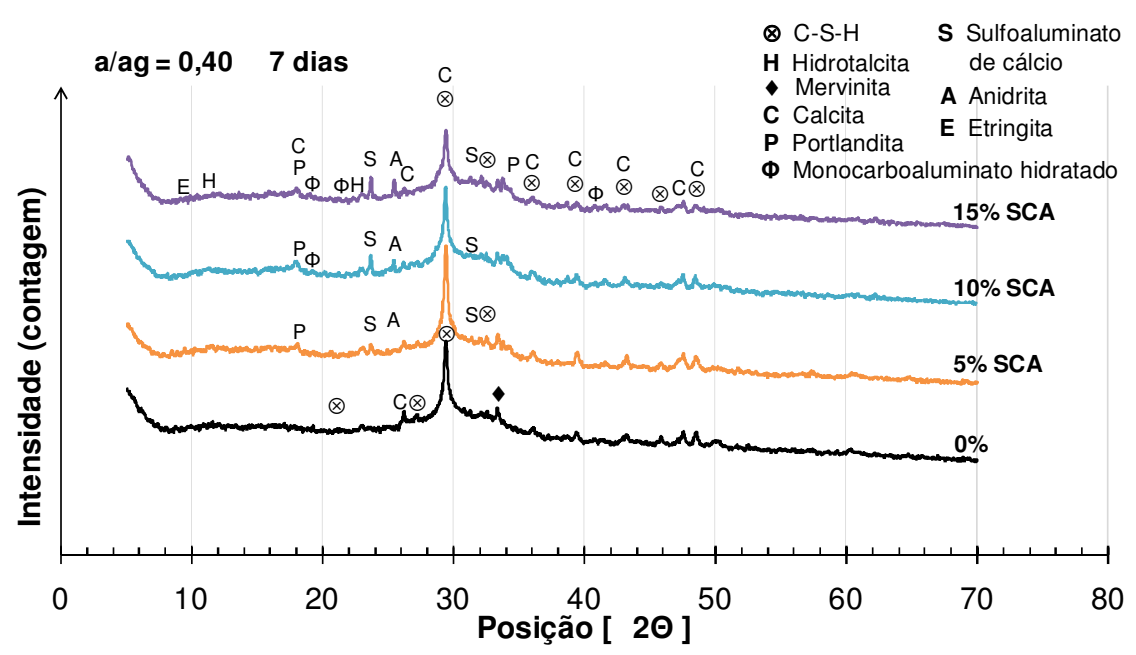

Figura 9.7 - Efeito do teor de aditivo compensador de retração (SCA) na difração de raios X com 7 dias de idade. $\mathrm{a} / \mathrm{agl}=0,40$.



Figura 9.8 - Efeito do teor de aditivo compensador de retração (SCA) na difração de raios X com 28 dias de idade. $\mathrm{a} / \mathrm{agl}=0,40$. 
Da Figura 9.9 até a Figura 9.12 consta o efeito do teor de aditivo compensador de retração (SCA) na evolução da intensidade do pico principal do C-S-H no ângulo

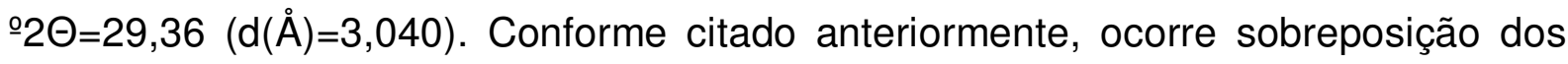
picos dos produtos hidratados oriundos do aditivo compensador de retração (SCA) com o pico principal do C-S-H, encobrindo o efeito do aditivo na evolução do mesmo. Porém, com a análise conjunta da evolução do pico principal do sulfoaluminato de cálcio e da anidrita, é possível obter conclusões a respeito da hidratação do cimento de escória ativada com silicato de sódio e da hidratação do aditivo SCA. Observa-se que a aditivo SCA aparentemente aumenta a formação do C-S-H até os 7 dias de idade, independentemente do teor estudado, porém, este efeito pode ser atribuído à formação de produtos hidratados oriundos do aditivo que apresentam pico na mesma faixa do C-S-H.

Contribui para esta conclusão, o fato da posterior diminuição do pico do C-S-H aos 28 dias, indicando que o aumento anterior a esta idade é causado pela hidratação do aditivo SCA. Na análise da evolução do pico principal do sulfoaluminato de cálcio e da anidrita é evidente a hidratação do aditivo, caracterizada pelo consumo inicial da anidrita seguido pelo consumo do sulfoaluminato de cálcio. Este perfil de hidratação do aditivo compensador de retração (SCA) é coerente com a teoria que embasa o seu fundamento, pois a hidratação começa com algumas horas e o consumo do sulfoaluminato de cálcio ocorre com maior intensidade entre 3 e 7 dias. Apesar de não ter sido identificada de forma intensa, como se esperava, atribui-se esta reação à formação da etringita.

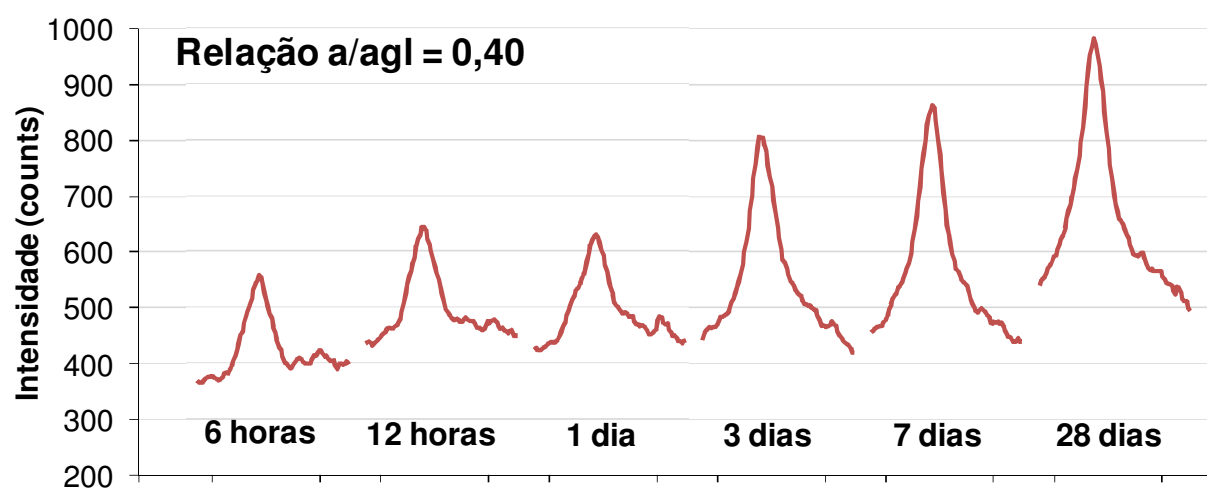

Figura 9.9 - Evolução da intensidade do pico principal do C-S-H no ângulo ${ }^{\circ} 2 \Theta=29,36$ na pasta de cimento de escória ativada com silicato de sódio com relação a/agl = 0,40 (4NSA0). 

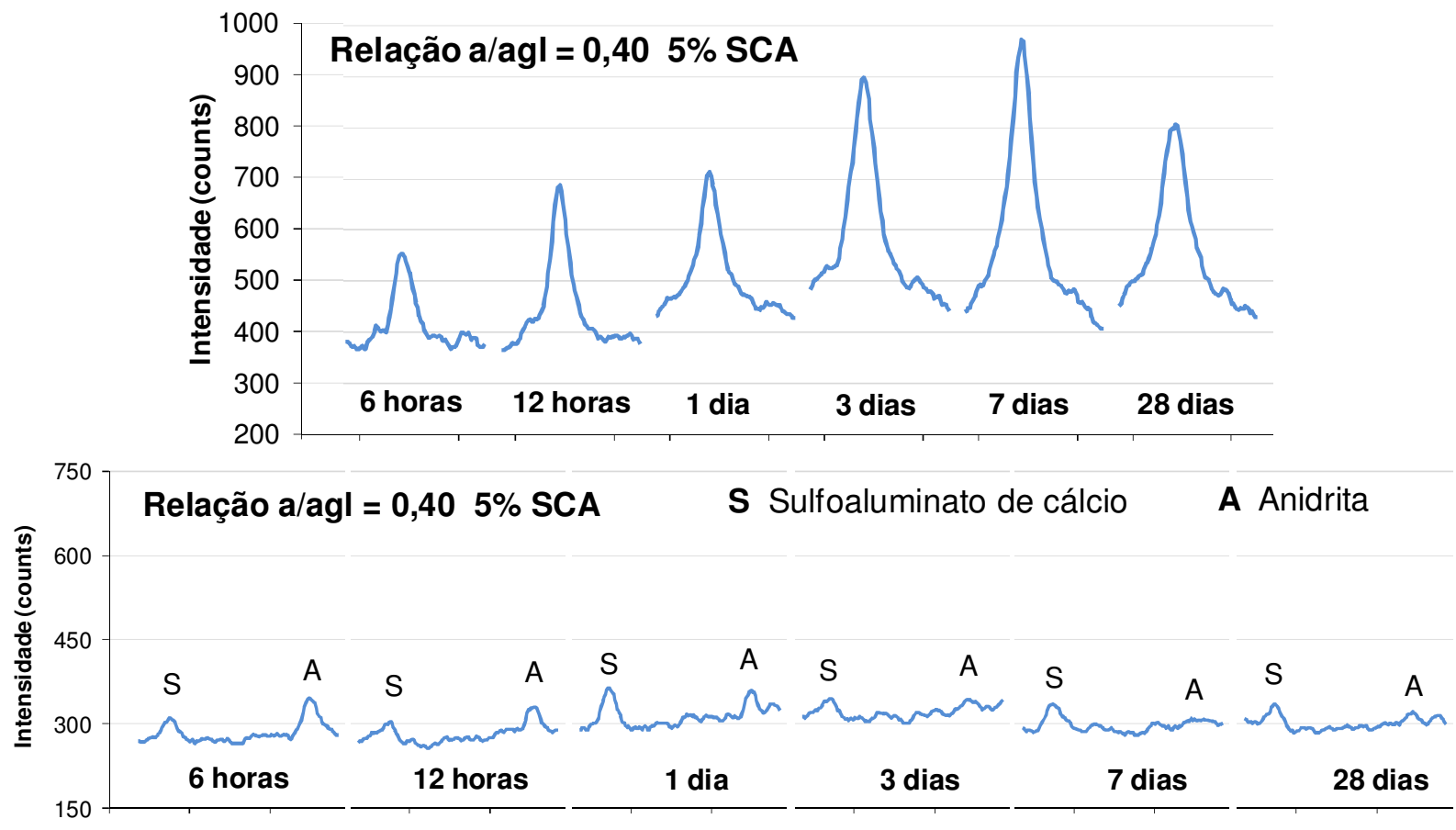

Figura 9.10 - Efeito do teor de aditivo compensador de retração (SCA) na evolução da intensidade do pico principal do C-S-H no ângulo ${ }^{\circ} 2 \Theta=29,36$ e nos picos principais do sulfoaluminato de cálcio no ângulo ${ }^{\circ} 2 \Theta=23,66$ e da anidrita no ângulo ${ }^{\circ} 2 \Theta=25,44$, na mistura de cimento de escória ativada com relação $\mathrm{a} / \mathrm{agl}=0,40$ (4NSA5). Teor de SCA $=5 \%$
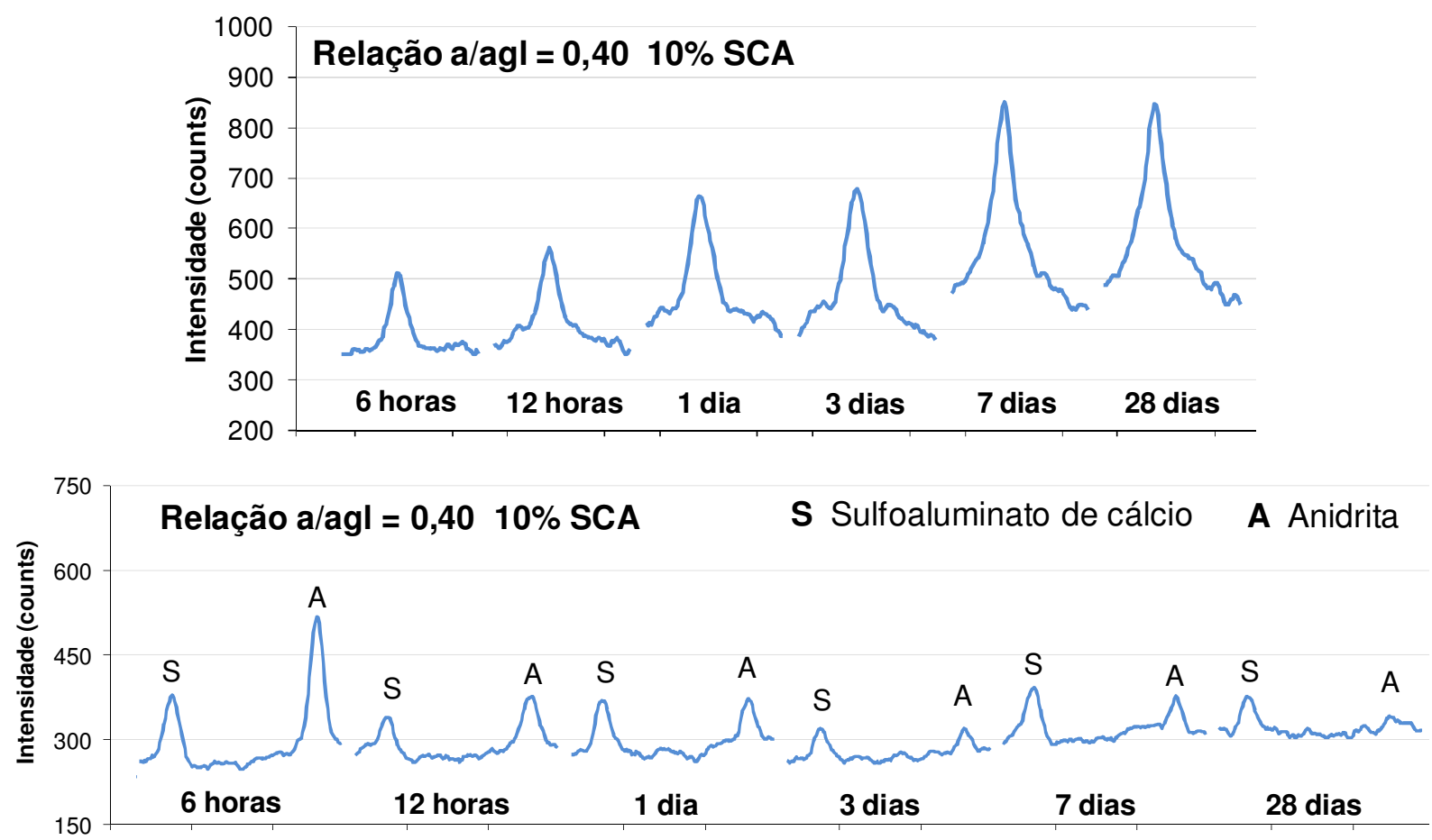

Figura 9.11 - Efeito do teor de aditivo compensador de retração (SCA) na evolução da intensidade do pico principal do C-S-H no ângulo ${ }^{\circ} 2 \Theta=29,36$ e nos picos principais do sulfoaluminato de cálcio no ângulo ${ }^{\circ} 2 \Theta=23,66$ e da anidrita no ângulo ${ }^{\circ} 2 \Theta=25,44$, na mistura de cimento de escória ativada com relação a/agl $=0,40$ (4NSA10). Teor de SCA $=10 \%$ 




Figura 9.12 - Efeito do teor de aditivo compensador de retração (SCA) na evolução da intensidade do pico principal do C-S-H no ângulo ${ }^{\circ} 2 \Theta=29,36$ e nos picos principais do sulfoaluminato de cálcio no ângulo ${ }^{\circ} 2 \Theta=23,66$ e da anidrita no ângulo ${ }^{\circ} 2 \Theta=25,44$, na mistura de cimento de escória ativada com relação $\mathrm{a} / \mathrm{agl}=0,40$ (4NSA15). Teor de SCA $=15 \%$

Na Figura 9.13 consta a influência do aditivo compensador de retração (SCA) na intensidade do pico principal do C-S-H da mistura com relação a/agl igual a 0,40 e detalhado nas primeiras idades na Figura 9.14. Confirma-se que o aditivo SCA diminui a formação do C-S-H no cimento de escória ativada com silicato de sódio aos 28 dias. A explicação para este comportamento pode estar relacionada à competição e à interação entre a hidratação deste tipo de aditivo e a hidratação da escória ativada com silicato de sódio. Sabe-se que a formação da etringita é caracterizada pelo elevado consumo de água pelas reações de hidratação, o que, certamente, afeta a quantidade de água disponível para a hidratação do cimento de escória. Some-se a este fato a elevada velocidade e grau de hidratação do cimento de escória ativada com silicato de sódio (MELO NETO, 2002), o que torna a hidratação deste tipo de cimento mais complexa com a utilização do aditivo compensador de retração (SCA). 


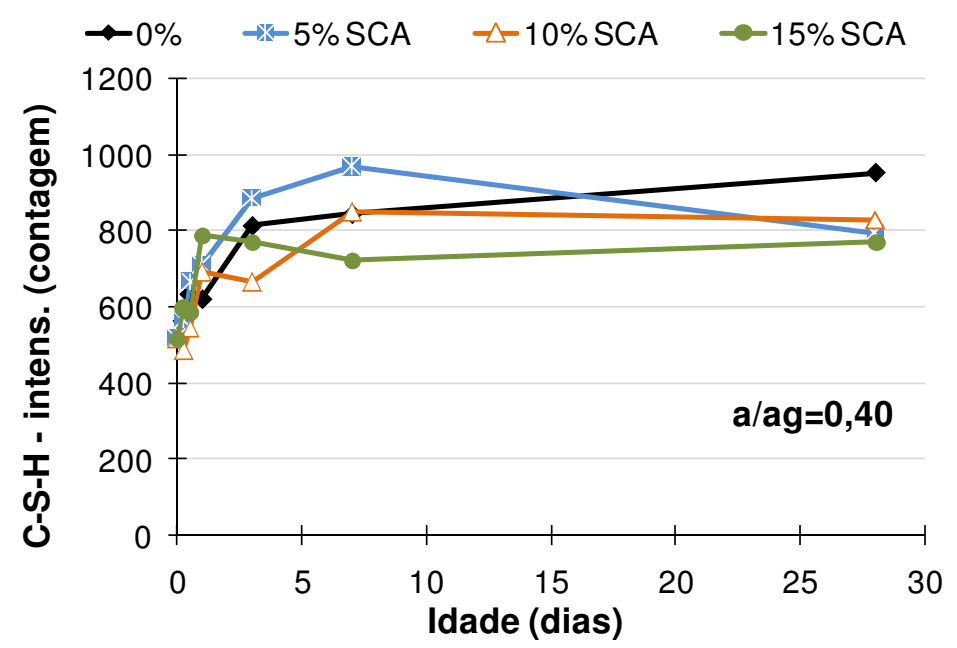

Figura 9.13 - Efeito do teor de aditivo compensador de retração (SCA) na intensidade do pico principal de C-S-H determinado no ensaio de difração de raios $X$ até os 28 dias de idade. a/agl $=0,40$

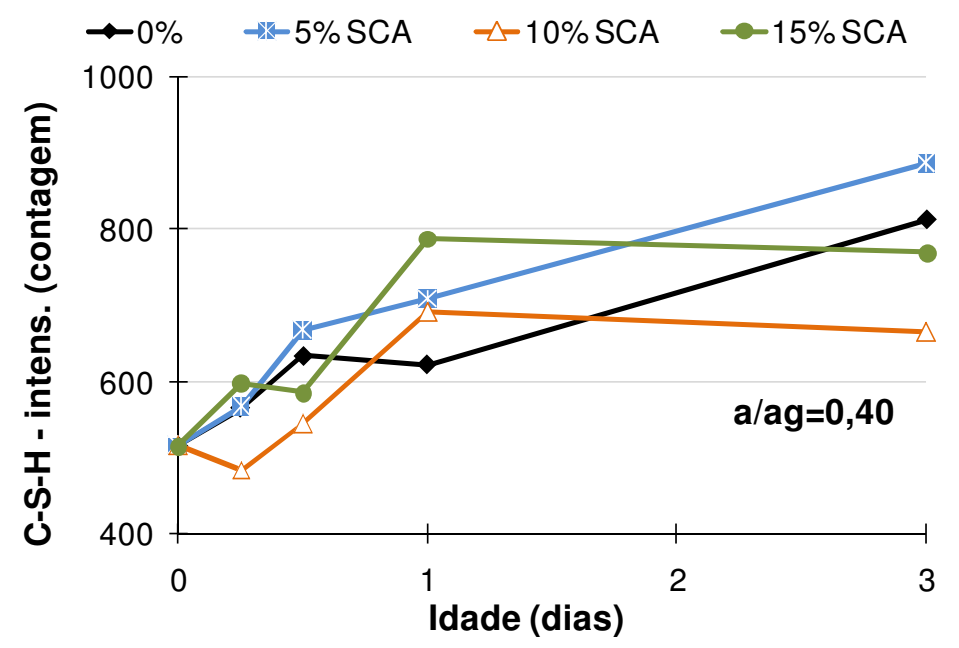

Figura 9.14 - Detalhamento do efeito do teor de aditivo compensador de retração (SCA) na intensidade do pico principal de $\mathrm{C}-\mathrm{S}-\mathrm{H}$ determinado no ensaio de difração de raios $\mathrm{X}$ nas primeiras idades. $\mathrm{a} / \mathrm{agl}=0,40$

Com o aumento da relação a/agl para 0,48 e 0,56, não foram constatadas alterações na natureza dos compostos hidratados, sendo o perfil dos difratogramas similares ao da mistura com relação a/agl igual a 0,40. Os difratogramas da influência do teor do aditivo SCA nas misturas com relação a/agl iguais a 0,48 e 0,56 estão apresentados no Apêndice $C$. $O$ efeito da relação a/agl foi observado na alteração da intensidade dos picos principais do sulfoaluminato de cálcio e da anidrita (Figura 9.15 até Figura 9.18), observando-se o maior consumo destes compostos em razão da maior disponibilidade de água. 


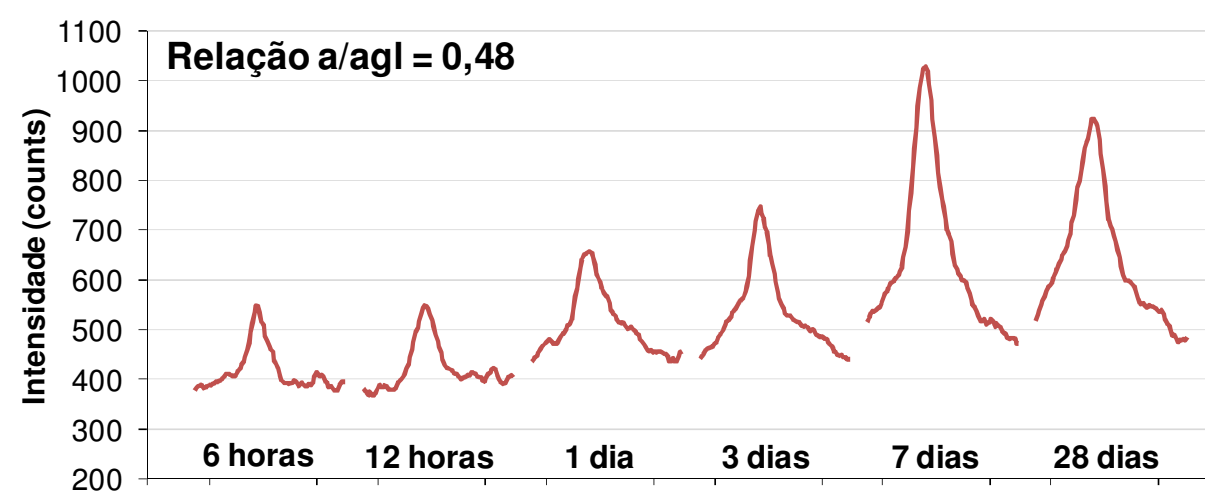

Figura 9.15 - Evolução da intensidade do pico principal do C-S-H no ângulo ${ }^{\circ} 2 \Theta=29,36(d(\AA)=3,040)$ na pasta de cimento de escória ativada com silicato de sódio com relação a/agl = 0,48 (4NSB0).
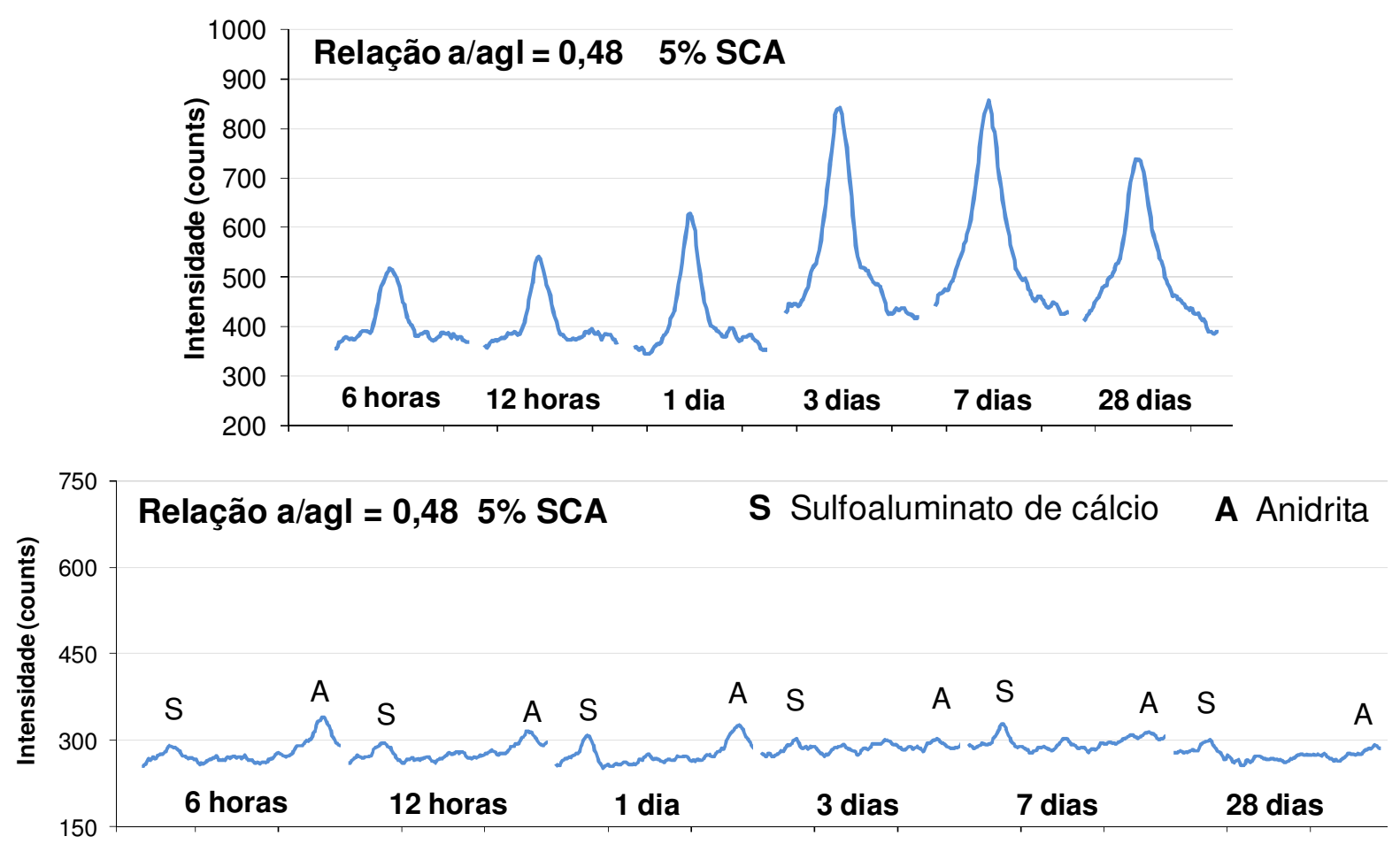

Figura 9.16 - Efeito do teor de aditivo compensador de retração (SCA) na evolução da intensidade do pico principal do C-S-H no ângulo ${ }^{\circ} 2 \Theta=29,36$ e nos picos principais do sulfoaluminato de cálcio no ângulo ${ }^{\circ} 2 \Theta=23,66$ e da anidrita no ângulo ${ }^{\circ} 2 \Theta=25,44$ na mistura de cimento de escória ativada com relação $\mathrm{a} / \mathrm{agl}=0,48$ (4NSB5). Teor de SCA $=5 \%$ 


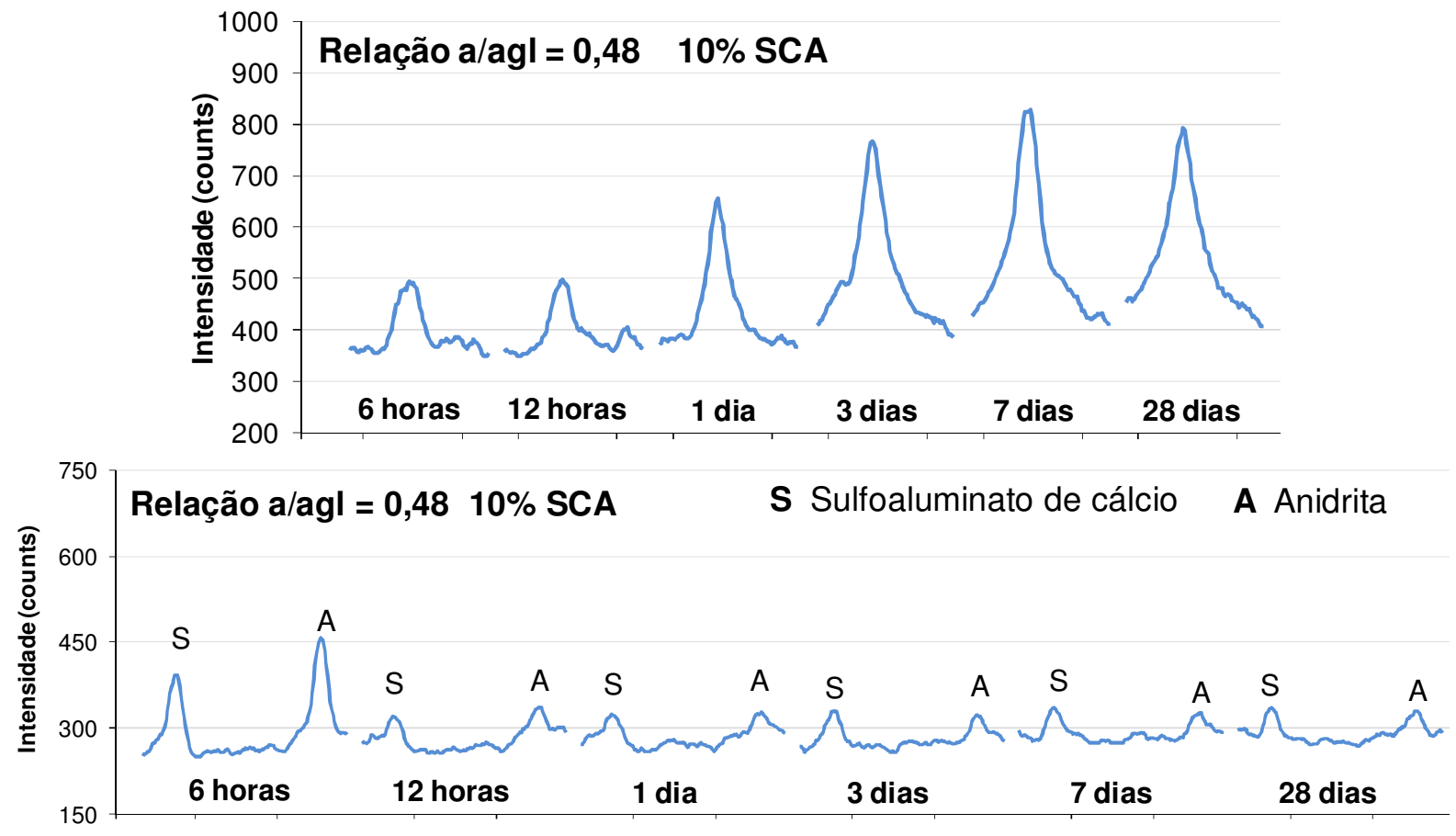

Figura 9.17 - Efeito do teor de aditivo compensador de retração (SCA) na evolução da intensidade do pico principal do C-S-H no ângulo ${ }^{\circ} 2 \Theta=29,36$ e nos picos principais do sulfoaluminato de cálcio no ângulo ${ }^{\circ} 2 \Theta=23,66$ e da anidrita no ângulo ${ }^{\circ} 2 \Theta=25,44$ na mistura de cimento de escória ativada com relação $\mathrm{a} / \mathrm{agl}=0,48$ (4NSB10). Teor de SCA $=10 \%$
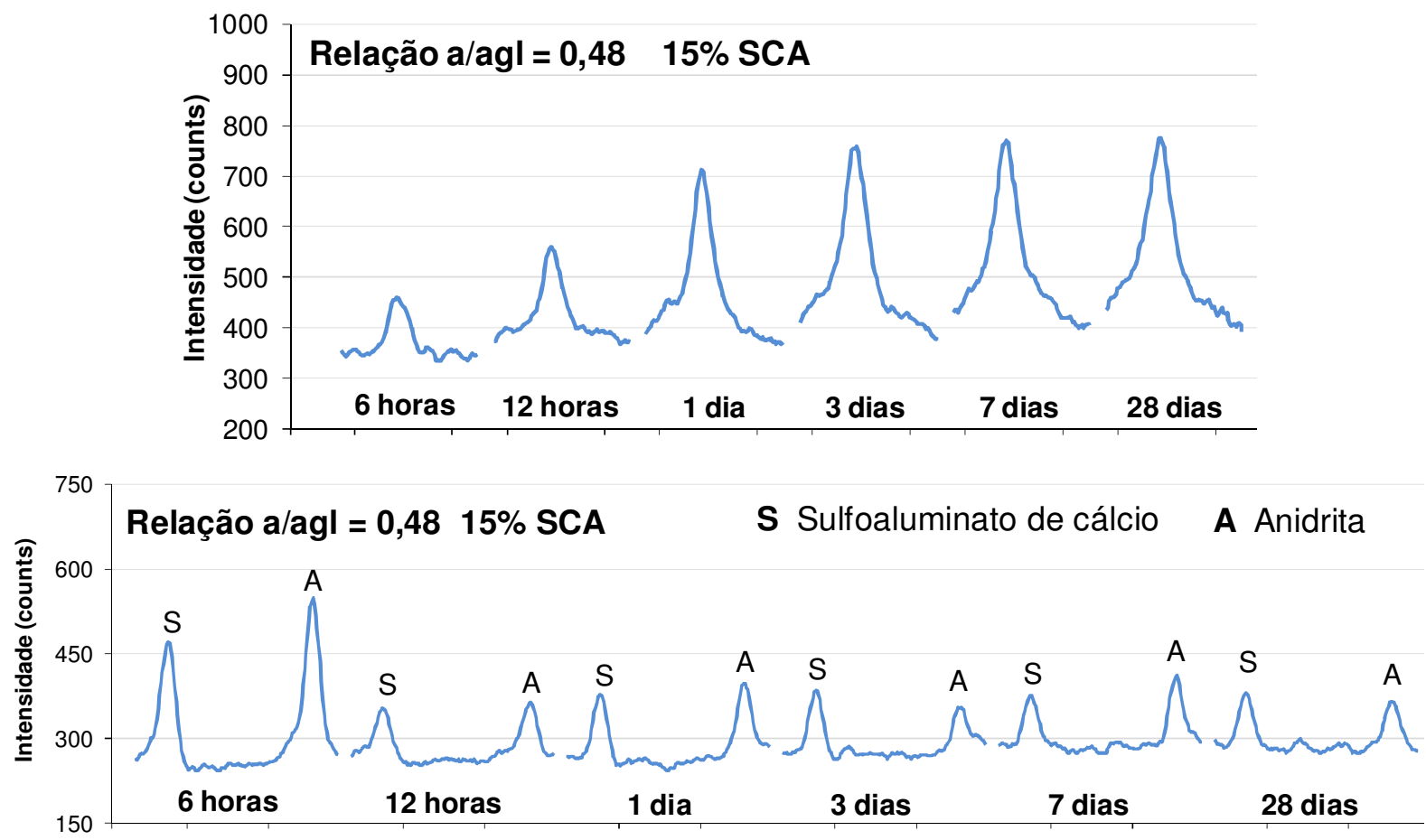

Figura 9.18 - Efeito do teor de aditivo compensador de retração (SCA) na evolução da intensidade do pico principal do C-S-H no ângulo ${ }^{\circ} 2 \Theta=29,36$ e nos picos principais do sulfoaluminato de cálcio no

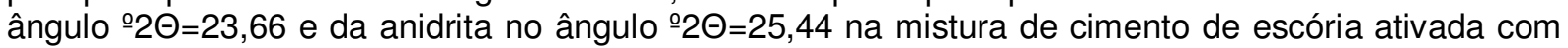
relação $\mathrm{a} / \mathrm{agl}=0,48$ (4NSB15). Teor de SCA $=15 \%$ 
O aumento da relação a/agl tornou evidente a redução da formação do C-S-H com a utilização do aditivo compensador de retração (SCA), decorrente do melhor desenvolvimento da reações de hidratação do aditivo SCA, em contraposição à queda na formação do C-S-H no cimento de escória ativada com silicato de sódio (Figura 9.19). Observa-se uma redução da intensidade do pico de C-S-H a partir dos 7 dias de idade, pois, como descrito anteriormente, a hidratação do aditivo SCA é mais intensa até os 7 dias de idade e seus produtos hidratados tem picos em faixas semelhantes à faixa de C-S-H. Portanto, explica-se a inexistência de diferença da intensidade do pico do C-S-H com a utilização do aditivo SCA até os 3 dias de idade, conforme detalhado na Figura 9.20.

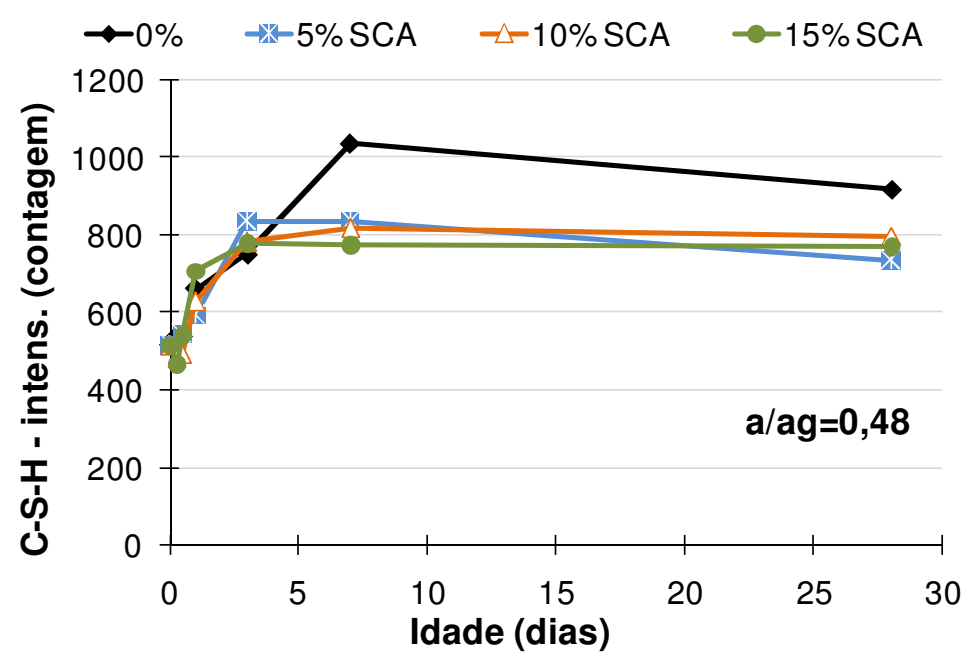

Figura 9.19 - Efeito do teor de aditivo compensador de retração (SCA) na intensidade do pico principal de C-S-H determinado no ensaio de difração de raios $X$ até os 28 dias de idade. $\mathrm{a} / \mathrm{agl}=0,48$

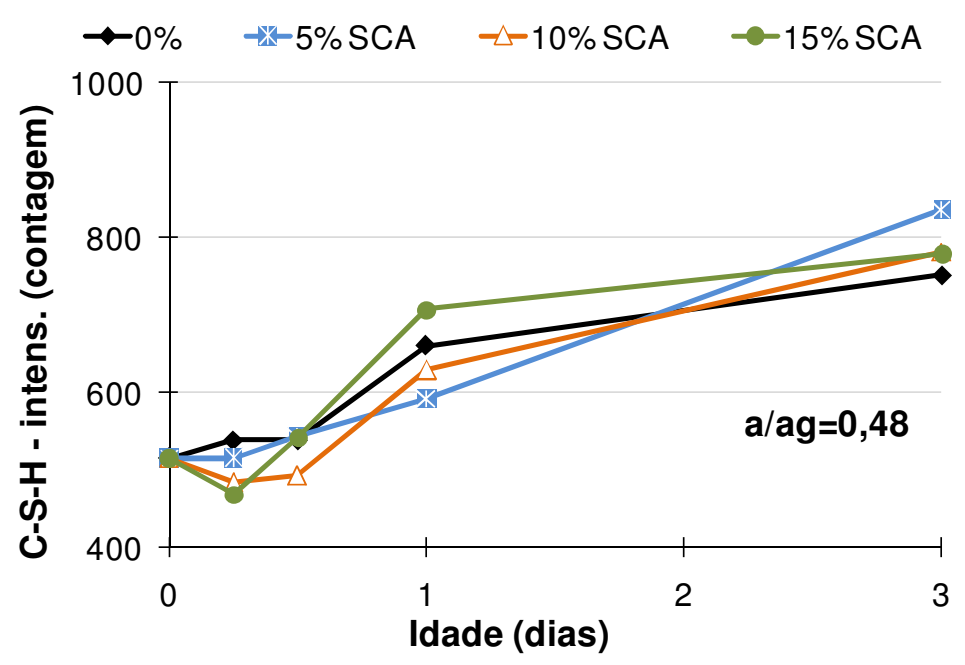

Figura 9.20 - Detalhamento do efeito do teor de aditivo compensador de retração (SCA) na intensidade do pico principal de $\mathrm{C}-\mathrm{S}-\mathrm{H}$ determinado no ensaio de difração de raios $\mathrm{X}$ nas primeiras idades. $\mathrm{a} / \mathrm{agl}=0,48$ 
Na mistura com relação a/agl igual a 0,56 (Figura 9.22 até Figura 9.24), ressalta-se o aumento significativo do pico principal do $\mathrm{C}-\mathrm{S}-\mathrm{H}$ aos 3 dias, fato este atribuído ao aumento da hidratação do aditivo SCA com a maior disponibilidade de água. Este comportamento é congruente com o aumento do consumo do sulfoaluminato de cálcio e da anidrita, caracterizado pela intensa redução da intensidade de seus respectivos picos. $O$ consumo destes compostos foi intenso nas primeiras idades $\mathrm{e}$ variou de acordo com a disponibilidade de aditivo SCA, porém sempre apresentou indícios de que a maior parte da sua hidratação ocorreu até os 7 dias idade.

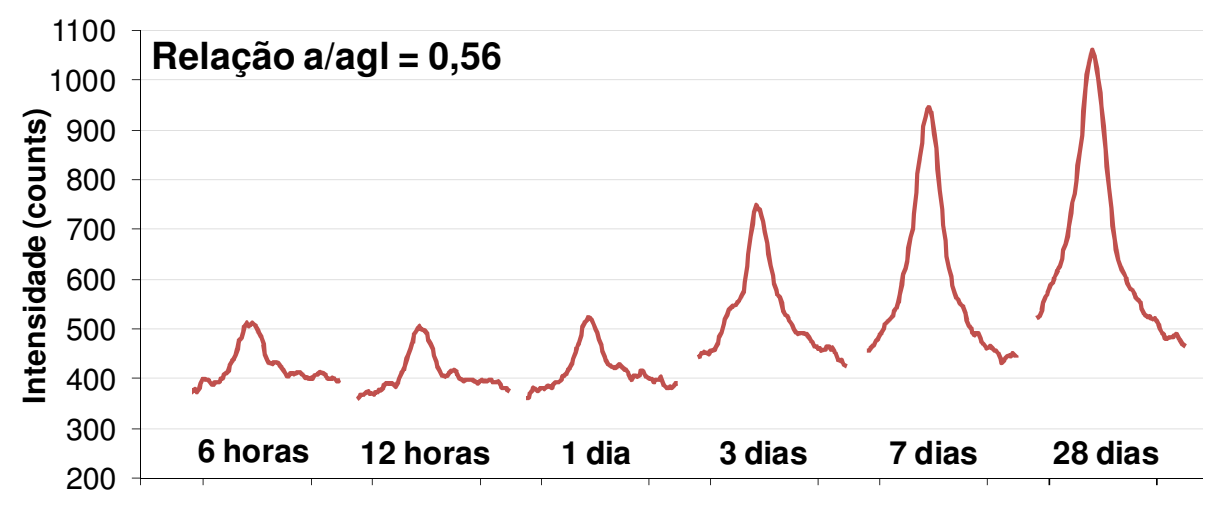

Figura 9.21 - Evolução da intensidade do pico principal do C-S-H no ângulo ${ }^{\circ} 2 \Theta=29,36(d(\AA)=3,040)$ na pasta de cimento de escória ativada com silicato de sódio com relação a/agl = 0,56 (4NSC0).
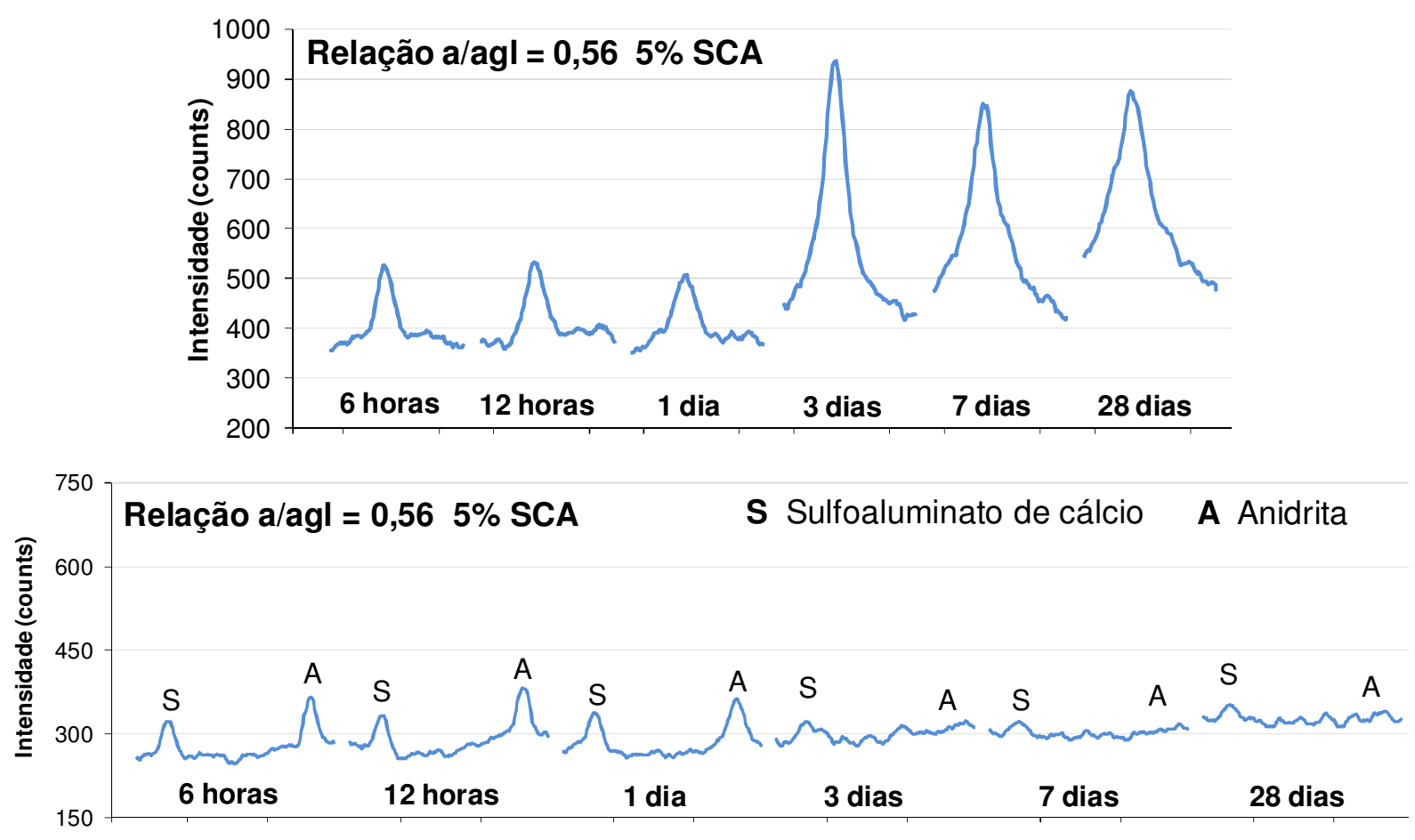

Figura 9.22 - Efeito do teor de aditivo compensador de retração (SCA) na evolução da intensidade do pico principal do C-S-H no ângulo ${ }^{\circ} 2 \Theta=29,36$ e nos picos principais do sulfoaluminato de cálcio no ângulo ${ }^{\circ} 2 \Theta=23,66$ e da anidrita no ângulo ${ }^{\circ} 2 \Theta=25,44$ na mistura de cimento de escória ativada com relação $\mathrm{a} / \mathrm{agl}=0,56$ (4NSC5). Teor de SCA $=5 \%$ 

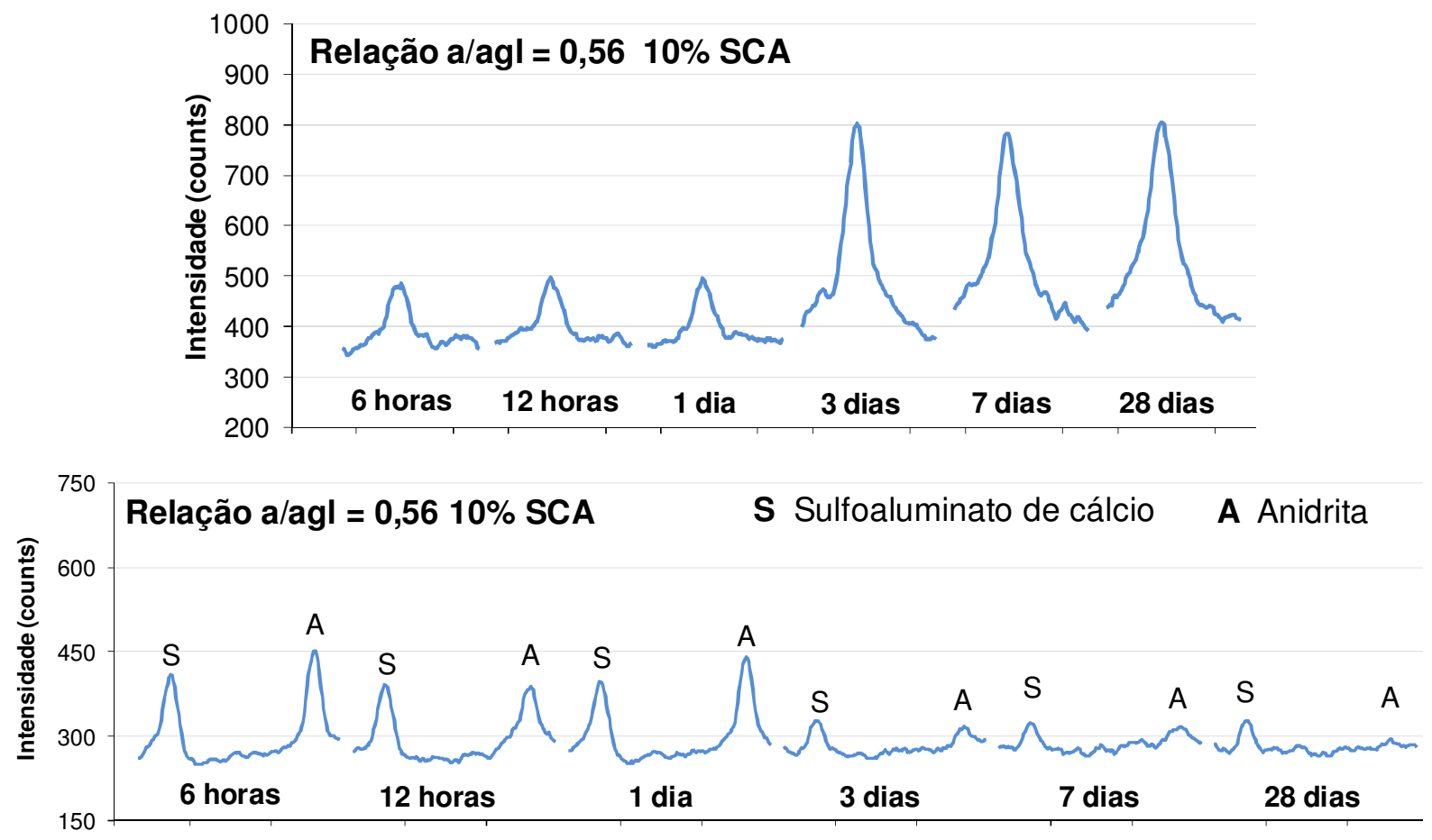

Figura 9.23 - Efeito do teor de aditivo compensador de retração (SCA) na evolução da intensidade do pico principal do C-S-H no ângulo ${ }^{\circ} 2 \Theta=29,36$ e nos picos principais do sulfoaluminato de cálcio no ângulo ${ }^{\circ} 2 \Theta=23,66$ e da anidrita no ângulo ${ }^{\circ} 2 \Theta=25,44$ na mistura de cimento de escória ativada com relação $\mathrm{a} / \mathrm{agl}=0,56$ (4NSC10). Teor de SCA $=10 \%$
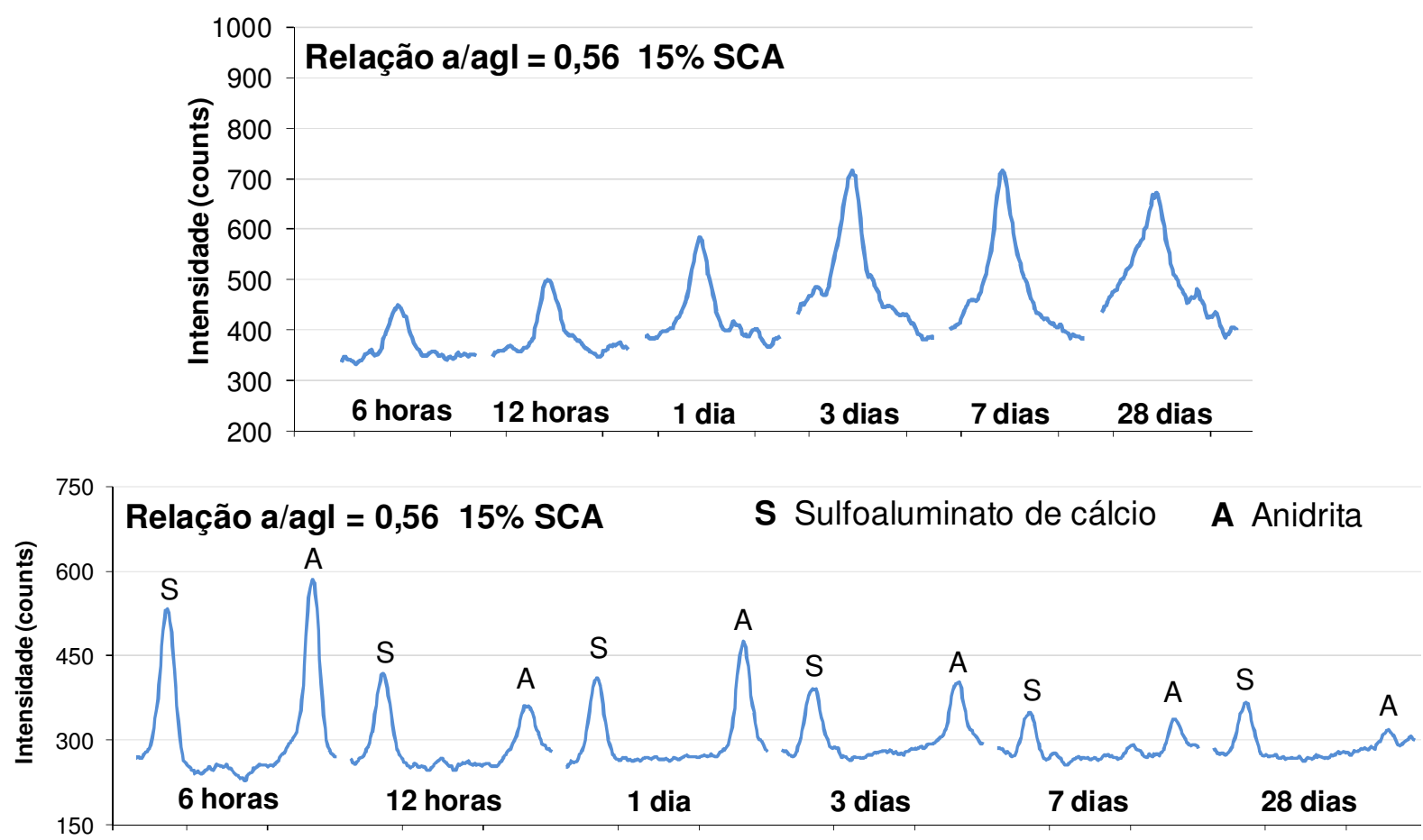

Figura 9.24 - Efeito do teor de aditivo compensador de retração (SCA) na evolução da intensidade do pico principal do C-S-H no ângulo ${ }^{\circ} 2 \Theta=29,36$ e nos picos principais do sulfoaluminato de cálcio no ângulo ${ }^{\circ} 2 \Theta=23,66$ e da anidrita no ângulo ${ }^{\circ} 2 \Theta=25,44$ na mistura de cimento de escória ativada com relação $\mathrm{a} / \mathrm{agl}=0,56(4 \mathrm{NSC} 15)$. Teor de SCA $=15 \%$ 
Na Figura 9.25 está apresentada a variação da intensidade do pico principal do C-S$\mathrm{H}$ do cimento de escória ativada com silicato de sódio para a relação a/agl igual a 0,56, com a utilização do aditivo compensador de retração (SCA) até os 28 dias. Observa-se que até os 3 dias de idade a intensidade do pico do C-S-H aumenta com a utilização do aditivo SCA, como descrito anteriormente, atribuído mais à formação de produtos hidratados oriundos do aditivo, do que à formação do C-S-H na hidratação do cimento de escória. Aos 28 dias já é evidente a redução da formação do C-S-H com a utilização deste tipo de aditivo.

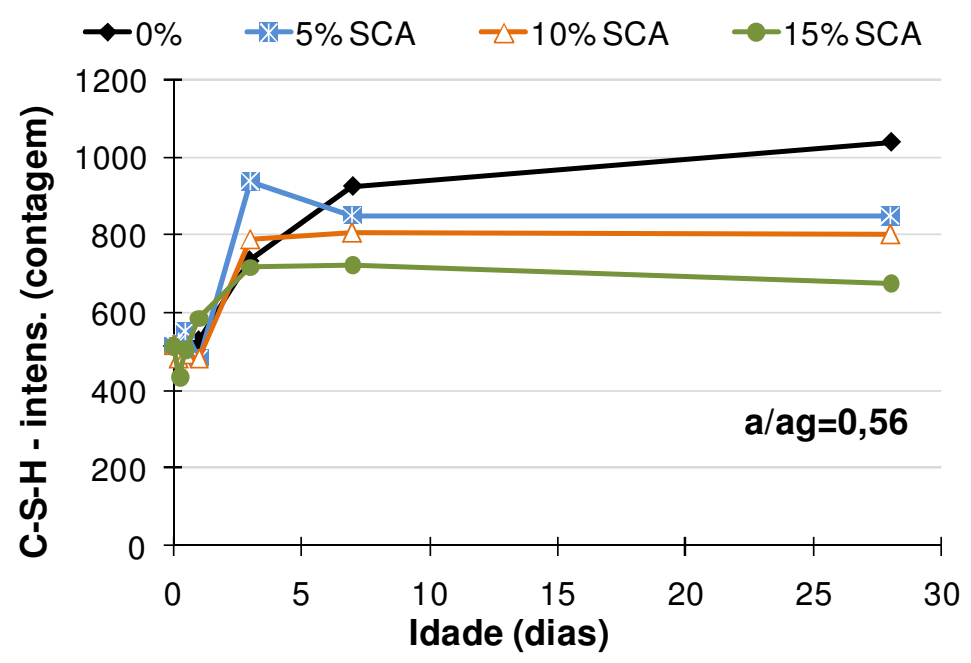

Figura 9.25 - Efeito do teor de aditivo compensador de retração (SCA) na intensidade do pico principal de C-S-H determinado no ensaio de difração de raios $X$ até os 28 dias de idade. $\mathrm{a} / \mathrm{agl}=0,56$

\subsection{Discussão e conclusões}

Em estudo exploratório, a hidratação das pastas confeccionadas apenas com 0 aditivo compensador de retração (SCA) foi constatada pelo consumo do sulfoaluminato de cálcio, do óxido de cálcio e da anidrita, caracterizada pela redução da intensidade dos picos principais destes compostos nos resultados de difração de raios $X$. Porém, não foi observada a formação de picos intensos da etringita, enquanto nos resultados de termogravimetria (Capítulo 10, pág.171), realizados nas mesmas amostras, identificaram-se picos nítidos de monossulfoaluminato de cálcio hidratado e de etringita. A pretensão inicial era de se utilizar a etringita como parâmetro para avaliar a hidratação do aditivo SCA no cimento de escória, mas, em razão deste comportamento, optou-se por avaliar a expansão gerada pelo aditivo de acordo com o consumo do sulfoaluminato de cálcio e anidrita. 
O aditivo interagiu quimicamente com o cimento de escória ativada com silicato de sódio, pois, além dos produtos hidratados observados na hidratação deste tipo de cimento, foi identificado o monocarboaluminato de cálcio hidratado. É possível que a formação deste composto ocorra em razão da reação entre o monossulfoaluminato de cálcio hidratado, resultante da hidratação do aditivo SCA, e o carbonato de cálcio, originário da escória anidra (BONAVETTI et al., 2001). A presença de fases hidratadas com carbonatos dificultou a análise da evolução da formação do C-S-H, pois os picos destas fases são muito próximos aos picos principais do $\mathrm{C}-\mathrm{S}-\mathrm{H}$, impedindo a identificação separada. Apesar deste fato, observou-se que a utilização do aditivo compensador de retração (SCA) causou a diminuição da formação do CS-H do cimento de escória ativada com silicato de sódio. De acordo com o princípio de hidratação do aditivo SCA, baseado na formação da etringita, é provável que na competição pela água para o desenvolvimento das reações de hidratação, o aditivo SCA tenha vantagem e acaba por prejudicar a hidratação do cimento de escória ativada com silicato de sódio. 


\section{Capítulo 10 \\ Termogravimetria}

\subsection{Introdução}

A metodologia empregada para a análise dos resultados de termogravimetria está descrita no Capítulo 5 (pág.74). De acordo com a caracterização do aditivo compensador de retração (SCA), os dados obtidos no levantamento bibliográfico (Capítulo 2, item 2.4.1, pág.30) e os resultados dos ensaios de difração de raios X, sabe-se que os principais compostos anidros deste tipo de aditivo são 0 sulfoaluminato de cálcio, anidrita e o óxido de cálcio, e os compostos hidratados são a portlandita, a etringita e o monossulfoaluminato de cálcio hidratado. Estas fases hidratadas foram o foco na análise do efeito do aditivo SCA nos resultados de termogravimetria do cimento de escória ativada com silicato de sódio, além, é claro, da quantificação do C-S-H.

\subsubsection{Hidratação do aditivo compensador de retração (SCA)}

Nesta análise foram analisadas as mesmas pastas preparadas para a difração de raios X. De acordo com o Taylor (1997), a termogravimetria da etringita (AFt) tem perfil caracterizado por apenas um pico máximo em torno de $100^{\circ} \mathrm{C}$ na curva da derivada da perda de massa. O monossulfoaluminato de cálcio hidratado (AFm) tem dois picos principais que caracterizam o perfil de sua termogravimetria, um pico em torno de $100^{\circ} \mathrm{C}$ e outro de maior intensidade em torno de $200^{\circ} \mathrm{C}$.

A Figura 10.1 exemplifica um resultado típico da perda de massa por termogravimetria da pasta preparada com apenas com o aditivo compensador de retração (SCA). O primeiro fato que chama a atenção é a identificação nítida da etringita (pico entre $100^{\circ} \mathrm{C}$ e $125^{\circ} \mathrm{C}$ ) e do monossulfoaluminato de cálcio hidratado (pico entre $200^{\circ} \mathrm{C}$ e $300^{\circ} \mathrm{C}$ ), pois o ensaio de difração de raios $\mathrm{X}$ não havia proporcionado informações suficientes para essa identificação de forma tão nítida. 



Figura 10.1 - Perda de massa (TG/\%) e derivada da curva de perda de massa (DTG) da pasta utilizando apenas o aditivo compensador de retração (SCAC) a 6 e 12 horas, 1,3,7 e 28 dias de idade. $\mathrm{a} / \mathrm{agl}=0,56$. Teor de SCA $=100 \%$.

$\mathrm{Na}$ análise da evolução da hidratação do aditivo SCA constata-se que a quantidade de portlandita, praticamente, se mantém constante; o pico em torno de $100^{\circ} \mathrm{C}$ referente à decomposição da etringita e de parte do monossulfoaluminato de cálcio hidratado alcança um máximo aos 3 dias de idade e depois diminui; e o pico em torno de $250^{\circ} \mathrm{C}$, referente à decomposição do restante do monossulfoaluminato de cálcio hidratado, alcança um máximo após 3 dias de idade. Este comportamento é coerente ao descrito na teoria de hidratação de fases aluminato em presença de sulfatos, onde, inicialmente ocorre a formação da etringita que, após um ápice, se converte em monossulfoaluminato de cálcio hidratado. A análise da hidratação do aditivo SCA deixa clara a conversão da etringita em monossulfoaluminato de cálcio hidratado entre 3 e 7 dias de idade. As pastas produzidas com as demais relações água/aditivo foram analisadas de modo idêntico e os resultados completos constam no Apêndice A.

Com base no perfil da curva de termogravimetria do aditivo SCA puro e hidratado, foram adotadas as seguintes faixas para a quantificação de perda de massa por termogravimetria: de $30^{\circ} \mathrm{C}$ até $195^{\circ} \mathrm{C}$ para as fases $\mathrm{AFt}$ e $\mathrm{AFm}$, de $195^{\circ} \mathrm{C}$ até $360^{\circ} \mathrm{C}$ para a fase $\mathrm{AFm}$ e de $360^{\circ} \mathrm{C}$ até $500^{\circ} \mathrm{C}$ para a quantificação da portlandita. $\mathrm{Na}$ Figura 10.2(a) consta a evolução da perda de massa entre $30^{\circ}$ e $195^{\circ} \mathrm{C}$, associada às fases AFt e AFm, observando-se que, para todas as relações a/agl estudadas, o máximo da formação da etringita ocorre aos três dias de idade. Também fica evidente que o aumento da relação a/agl proporciona a maior hidratação do aditivo 
SCA, confirmando os dados do levantamento bibliográfico. No detalhe das primeiras idades (Figura 10.2(b)), observa-se que o aumento da relação a/agl incorre no retardo da hidratação do aditivo.
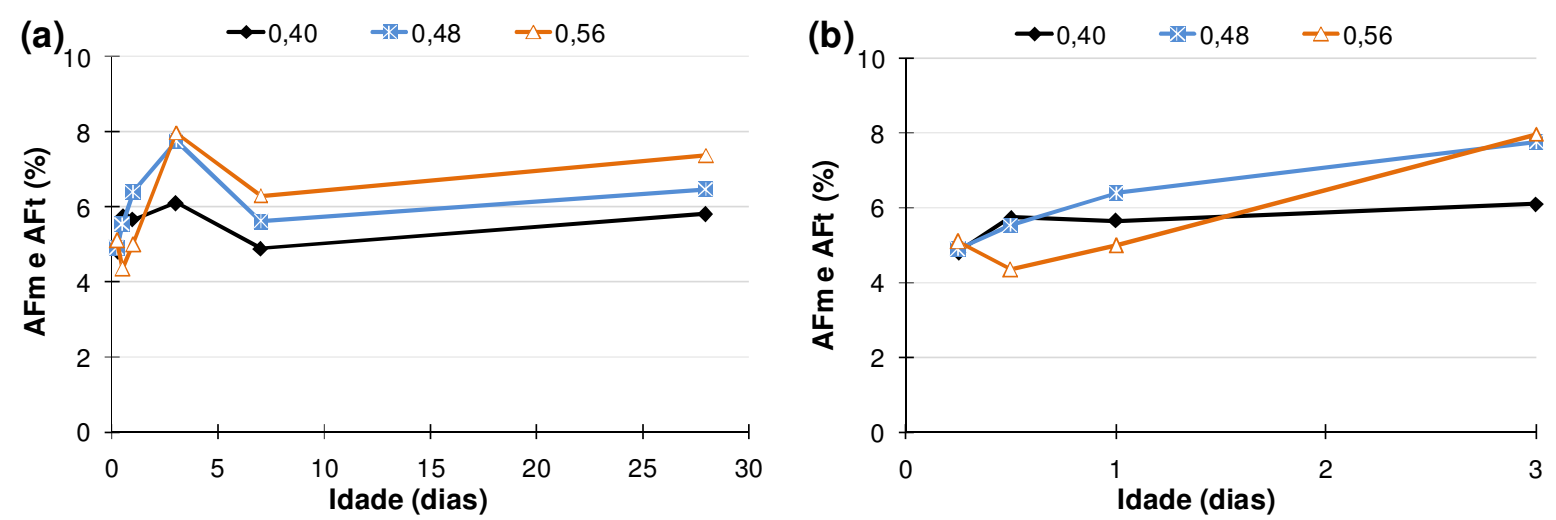

Figura 10.2 - Efeito da relação a/agl na quantidade de etringita (AFt) e monossulfoaluminato (AFm) entre $30^{\circ}$ e $195^{\circ} \mathrm{C}$ determinadas no ensaio de termogravimetria até os 28 dias de idade (a) e detalhada até os 3 dias de idade (b).

Na Figura 10.3(a) consta a evolução da quantidade de monossulfoaluminato de cálcio hidratado até 28 dias, detalhado na Figura 10.3(b) até os 3 dias de idade. Observa-se que o perfil da curva foi igual paras as três relações a/agl estudadas, ocorrendo um retardo da hidratação e 0 aumento da quantidade de monossulfoaluminato com o aumento da relação a/agl. A idade em que ocorre a conversão da etringita em monossulfoaluminato não é alterado com o aumento da relação a/agl, mantendo-se no período de 3 até 7 dias.
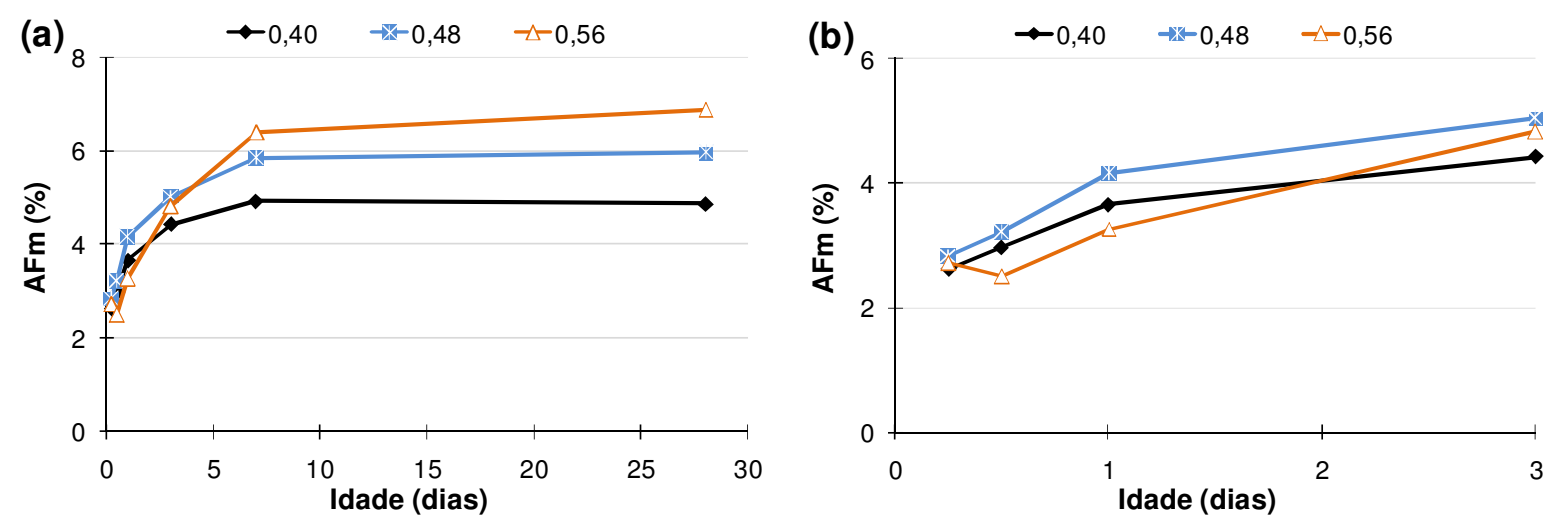

Figura 10.3 - Efeito da relação a/agl na quantidade de monossulfoaluminato (AFm) entre 195ㄷ e $360^{\circ} \mathrm{C}$ determinada no ensaio de termogravimetria até os 28 dias de idade (a) e detalhada até os 3 dias de idade (b). 


\subsection{Efeito do aditivo compensador de retração (SCA)}

A utilização do aditivo compensador de retração (SCA) resultou em alteração dos compostos hidratados, porém, manteve o C-S-H como principal produto hidratado. Na Figura 10.4 está exemplificado o perfil típico dos resultados de termogravimetria do cimento de escória ativada com silicato de sódio utilizando o aditivo SCA, constando os resultados completos no Apêndice A. Observa-se, em torno de $100^{\circ} \mathrm{C}$, a presença do pico referente ao C-S-H, o qual se sobrepõe ao pico da etringita; um evento térmico em torno de $350^{\circ} \mathrm{C}$ associado à hidrotalcita; a presença da portlandita entre $400^{\circ} \mathrm{C}$ e $500^{\circ} \mathrm{C}$; e a presença de um pico em torno de $640^{\circ} \mathrm{C}$ atribuído à perda de $\mathrm{CO}_{2}$ de alguma fase carbonato, em função da sua elevada temperatura de decomposição.

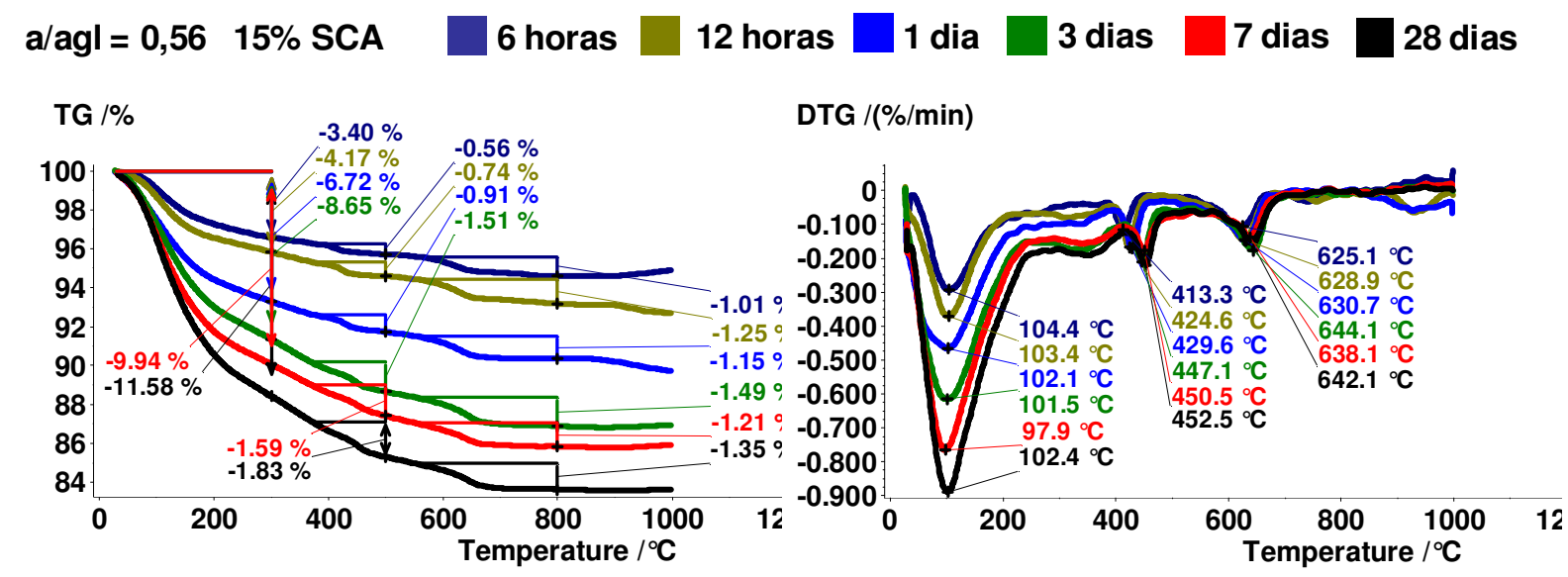

Figura 10.4 - Perda de massa (TG/\%) e derivada da curva de perda de massa (DTG) da pasta de cimento de escória ativada com silicato de sódio (4NSC15) a 6 e 12 horas, 1,3,7 e 28 dias de idade. $\mathrm{a} / \mathrm{agl}=0,56$. Teor de SCA $=15 \%$.

Inicialmente, a presença do pico de carbonato poderia ser atribuída à carbonatação em alguma etapa de preparo da amostra, ou ao carbonato originário da escória anidra. No entanto, a ausência deste pico nos resultados do cimento de escória ativada hidratado sem a utilização de aditivo e nos resultados da hidratação do aditivo SCA puro, indica que a origem deste pico seja outra. De acordo com os resultados de difração de raios $X$, observou-se a formação de monocarboaluminato apenas nas misturas de cimento de escória quando da utilização do aditivo SCA. A presença do monocarboaluminato é atribuída à reação entre o monossulfoaluminato de cálcio, oriundo da hidratação do aditivo SCA, e as fases carbonáticas, presentes 
na escória anidra. A temperatura de decomposição do pico de carbonato é mais um indicativo da sua origem, pois ocorre em uma faixa abaixo da decomposição de um carbonato de cálcio bem cristalizado, entre $700^{\circ} \mathrm{C}$ e $900^{\circ} \mathrm{C}$, o que caracteriza a decomposição de uma fase carbonática mal cristalizada.

O efeito do teor de aditivo SCA na evolução da quantidade de C-S-H do cimento de escória ativada com silicato de sódio, nas três relações a/agl ensaiadas, consta da Figura 10.5 até a Figura 10.7. Em qualquer das relações a/agl estudadas, observase a redução da quantidade de C-S-H formado no cimento de escória ativada com silicato de sódio causada pela utilização do aditivo SCA. Ressalta-se que a redução da quantidade de C-S-H ocorreu de fato, mesmo sabendo que parte dessa perda de massa calculada na faixa adotada também é decorrente da decomposição de produtos hidratados oriundos da hidratação do aditivo SCA, como a etringita e o monossulfoaluminato de cálcio, e da reação entre o aditivo e o cimento de escória, como o monocarboaluminato. A redução percentual do C-S-H calculada corrobora para esta afirmação, pois os percentuais de redução foram superiores aos percentuais de aditivo utilizados.

O aumento da relação a/agl proporciona o melhor desenvolvimento da hidratação do aditivo SCA, ressaltado pelo aumento da perda de massa aos 3 dias na mistura com relação a/agl igual a 0,56 (Figura 10.7), atribuído à formação de etringita e de monossulfoaluminato de cálcio hidratado. Neste estudo, os resultados indicam que a formação da etringita interfere na hidratação do cimento de escória ativada com silicato de sódio, diminuindo proporcionalmente a quantidade de C-S-H com aumento do teor de aditivo SCA em qualquer das relações a/agl estudadas, conforme apresentado na Figura 10.8. Conforme discutido na análise dos resultados de difração de raios $\mathrm{X}$, provavelmente a redução da formação do C-S-H do cimento de escória ativada com silicato de sódio com a utilização do aditivo compensador de retração (SCA) seja decorrente da competição ou interação entre a hidratação deste tipo de aditivo e a hidratação da escória ativada. Em relação ao sistema sem aditivo, a sua inclusão resulta no decréscimo da quantidade de água disponível para a hidratação do cimento de escória ativada, conseqüentemente, prejudicando a formação do C-S-H. 

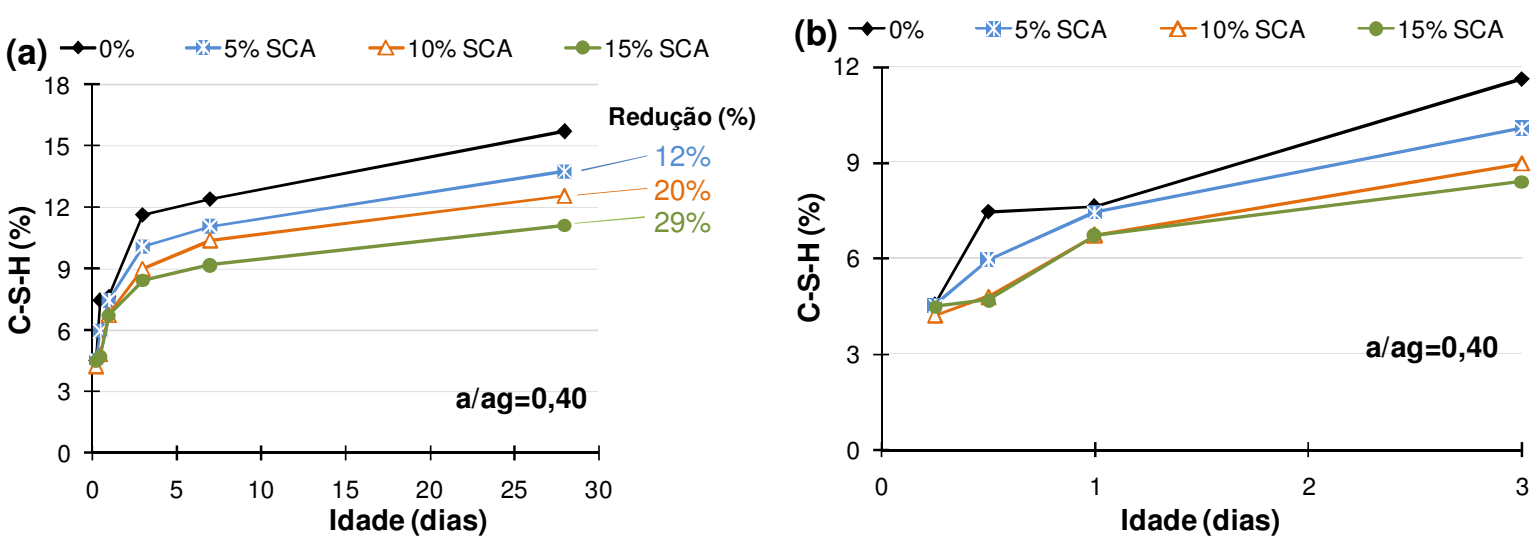

Figura 10.5 - Efeito do teor de aditivo compensador de retração (SCA) na quantidade de C-S-H determinado no ensaio de termogravimetria até os 28 dias (a) com a respectiva redução percentual, detalhado até os 3 dias de idade (b). a/agl = 0,40.
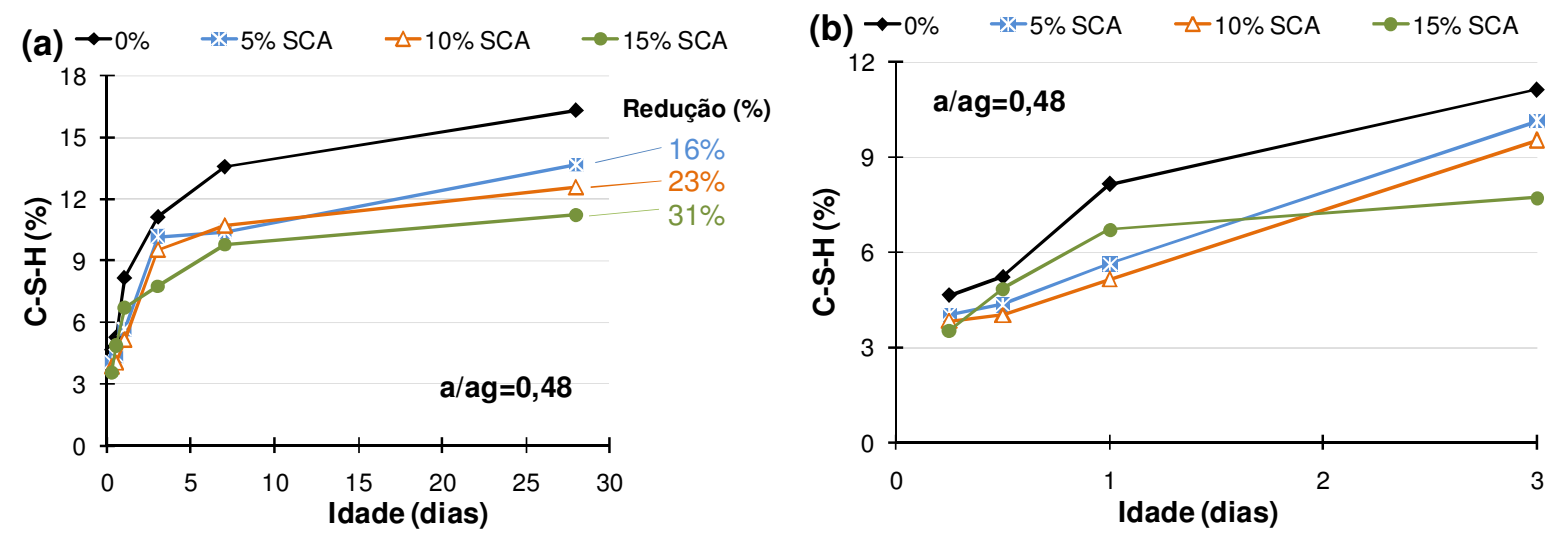

Figura 10.6 - Efeito do teor de aditivo compensador de retração (SCA) na quantidade de C-S-H determinado no ensaio de termogravimetria até os 28 dias (a) com a respectiva redução percentual, detalhado até os 3 dias de idade (b). a/agl = 0,48.
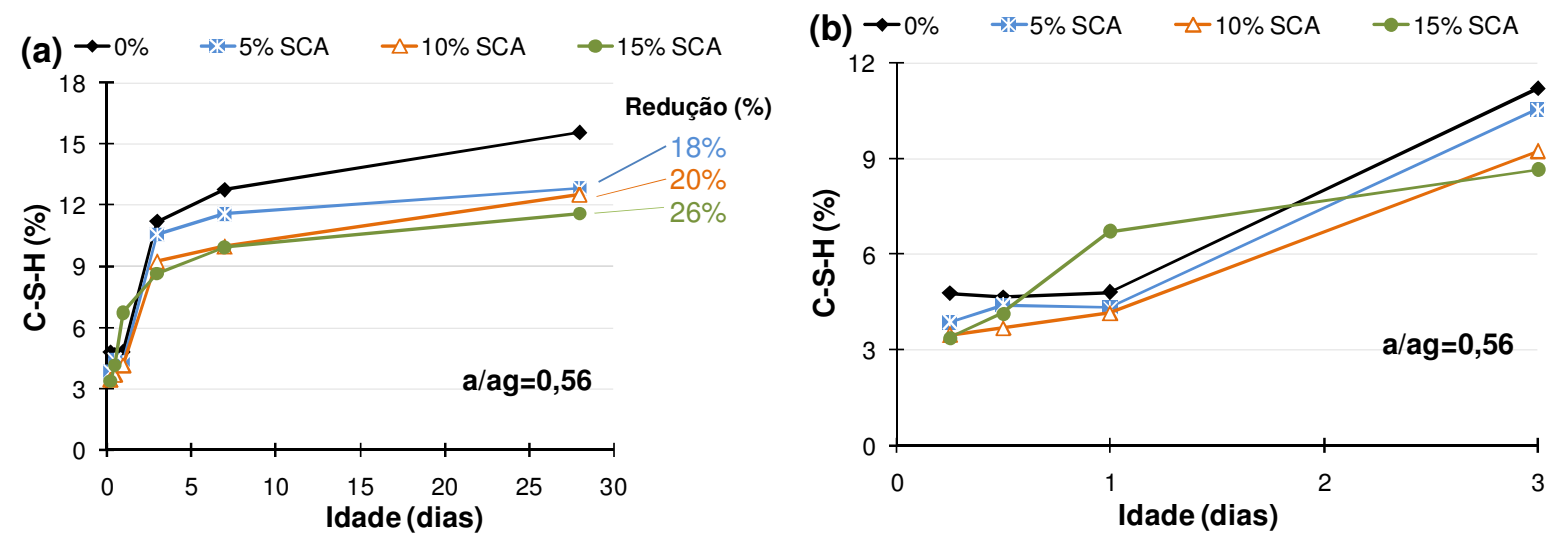

Figura 10.7 - Efeito do teor de aditivo compensador de retração (SCA) na quantidade de C-S-H determinado no ensaio de termogravimetria até os 28 dias (a) com a respectiva redução percentual, detalhado até os 3 dias de idade (b). a/agl = 0,56. 


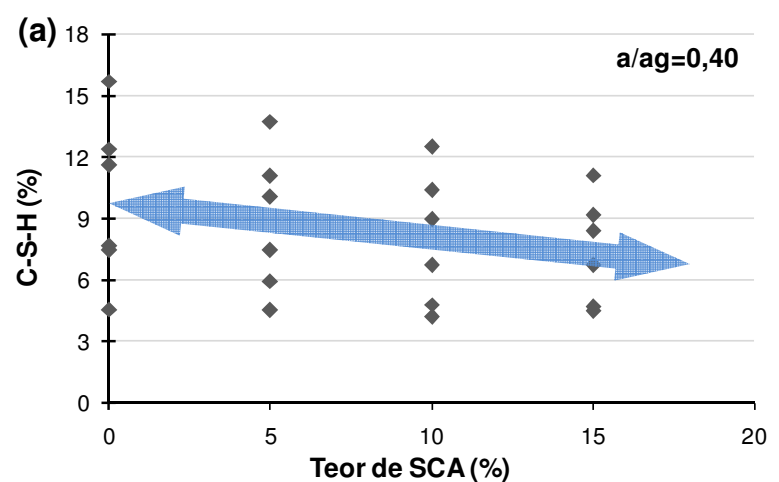

(c)

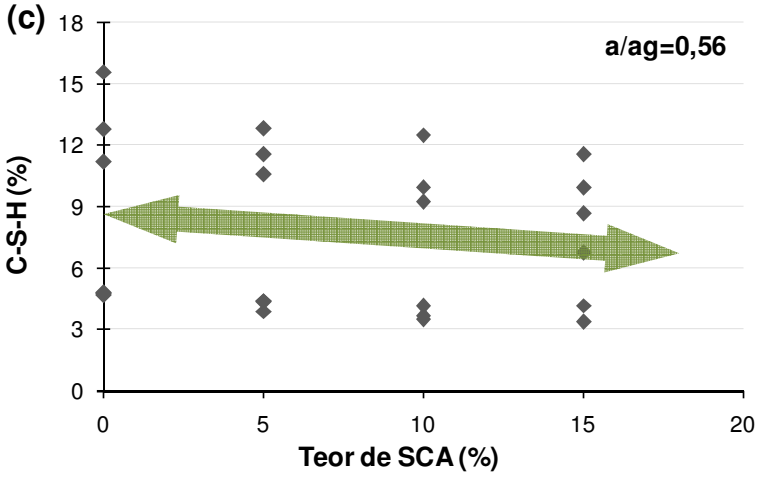

Figura 10.8 - Correlação entre o teor de aditivo compensador de retração (SCA) e quantidade de CS-H (\%) nas misturas com relação a/agl igual a 0,40 (a), 0,48 (b) e 0,56 (c). Gráfico construído com todos os pontos obtidos.

\subsection{Discussão e conclusões}

Em estudo exploratório, os resultados de termogravimetria das pastas confeccionadas apenas com o aditivo compensador de retração (SCA) demonstram a presença da etringita, do monossulfoaluminato de cálcio hidratado e da portlandita como principais fases hidratadas deste tipo de aditivo, permitindo a análise quantitativa.

Confirmando os resultados de difração de raios $\mathrm{X}$, o aditivo compensador de retração (SCA) interagiu quimicamente com o cimento de escória ativada com silicato de sódio, mas o C-S-H continuou como principal produto hidratado. Além do pico do C-S-H em torno de $100^{\circ} \mathrm{C}$, foi constatada a formação de um pico entre $400^{\circ} \mathrm{C}$ e $500^{\circ}$ referente à portlandita e um pico entre $600^{\circ} \mathrm{C}$ e $700^{\circ} \mathrm{C}$ referente à decomposição de fase carbonática mal cristalizada. Como não há indícios de carbonatação das amostras, pois não aparece nenhum pico nesta faixa nos resultados do cimento de escória sem aditivo SCA e nem nos resultados do aditivo 
SCA puro, é provável que esta fase carbonática seja resultante da reação das fases aluminatos hidratadas, oriundas da hidratação do aditivo SCA, e o carbonato de cálcio presente na escória anidra, resultando em monocarboaluminato de cálcio hidratado (BONAVETTI et al., 2001). Contribui para esta afirmação, a identificação deste composto na análise dos resultados de difração de raios $\mathrm{X}$ e o fato deste pico aparecer apenas quando se utiliza o aditivo SCA no cimento de escória ativada com silicato de sódio.

O principal efeito do aditivo compensador de retração (SCA) foi a diminuição da quantidade de C-S-H do cimento de escória ativada com silicato de sódio. Apesar da hidratação do aditivo SCA resultar em produtos hidratados com decomposição na mesma faixa do C-S-H, observou-se que a redução percentual da quantidade de C-S-H foi superior ao teor de aditivo empregado. É provável que ocorra uma competição pela água disponível para 0 desenvolvimento das reações de hidratação, na qual o aditivo SCA parece ter maior vantagem em função da elevada reatividade de seus compostos anidros. Este fato faz com que a hidratação do cimento de escória ativada com silicato de sódio seja prejudicada e, conseqüentemente, ocorra a diminuição da quantidade de C-S-H formado. O efeito do aditivo na redução da quantidade de C-S-H é mais nítido nas idades finais, pois nas primeiras idades ocorre a maior parte da hidratação do aditivo SCA, resultando em uma aparente maior quantidade de C-S-H por superposição dos picos. 


\section{Capítulo 11 Porosimetria}

\subsection{Efeito do aditivo compensador de retração (SCA)}

A metodologia empregada para a análise dos resultados de porosimetria está descrita no Capítulo 6 (pág.82). O efeito do teor de aditivo compensador de retração (SCA) está apresentado da Figura 11.1 até a Figura 11.4. Observa-se que a utilização do aditivo SCA incorre no aumento da porosidade total em todas as idades ensaiadas e na alteração da distribuição de poros. Com 1 dia de idade, o aditivo SCA provocou o aumento da porosidade total de $33 \%$ para $51 \%$, além de alterar significativamente a distribuição de poros, passando de uma proporção de mesoporos de 17\% para em torno de $9 \%$. Aos 3 dias de idade, observa-se a redução da porosidade total nas misturas com e sem aditivo SCA e o início do refinamento da porosidade das misturas com aditivo. Aos 7 e 28 dias, o perfil dos resultados é nítido, constatando-se o aumento da porosidade total e do volume de macroporos proporcionais ao aumento do teor de aditivo SCA.

Aos 28 dias, a proporção do volume de macroporos na porosidade total passa de $6 \%$ sem aditivo para em torno de $24 \%$ com a utilização de $15 \%$ de aditivo SCA. Portanto, além da expansão provocada pela formação da etringita, nas condições específicas aplicadas neste trabalho, o aditivo SCA também contribui para uma diminuição das tensões capilares decorrente da alteração da distribuição de poros, contribuindo para amenizar a retração do cimento de escória ativada com silicato de sódio. 

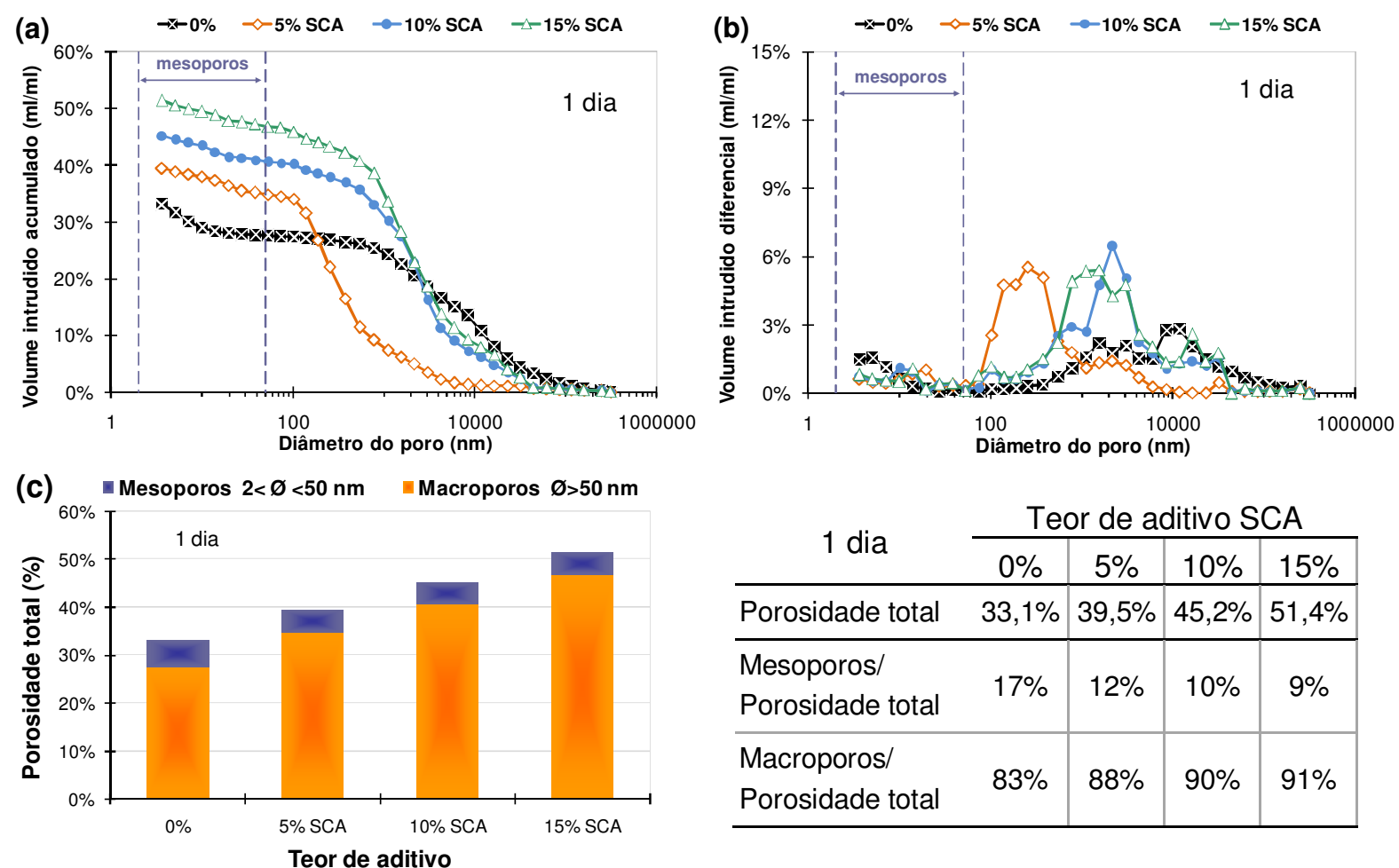

\begin{tabular}{lc|c|c|c|}
\multirow{2}{*}{1 dia } & \multicolumn{4}{c}{ Teor de aditivo SCA } \\
\cline { 2 - 5 } & $0 \%$ & $5 \%$ & $10 \%$ & $15 \%$ \\
\hline Porosidade total & $33,1 \%$ & $39,5 \%$ & $45,2 \%$ & $51,4 \%$ \\
\hline $\begin{array}{l}\text { Mesoporos/ } \\
\text { Porosidade total }\end{array}$ & $17 \%$ & $12 \%$ & $10 \%$ & $9 \%$ \\
\hline $\begin{array}{l}\text { Macroporos/ } \\
\text { Porosidade total }\end{array}$ & $83 \%$ & $88 \%$ & $90 \%$ & $91 \%$ \\
\hline
\end{tabular}

Figura 11.1 - Efeito do teor de aditivo compensador de retração (SCA) $(0 \%, 0,5 \%, 1,0 \%, 1,5 \%$ e $2,0 \%$ ) na porosidade acumulada (a), na porosidade diferencial (b) e na distribuição de poros (c) da pasta de escória ativada com silicato de sódio (4NS) com 1 dia de idade. a/agl=0,48(B).
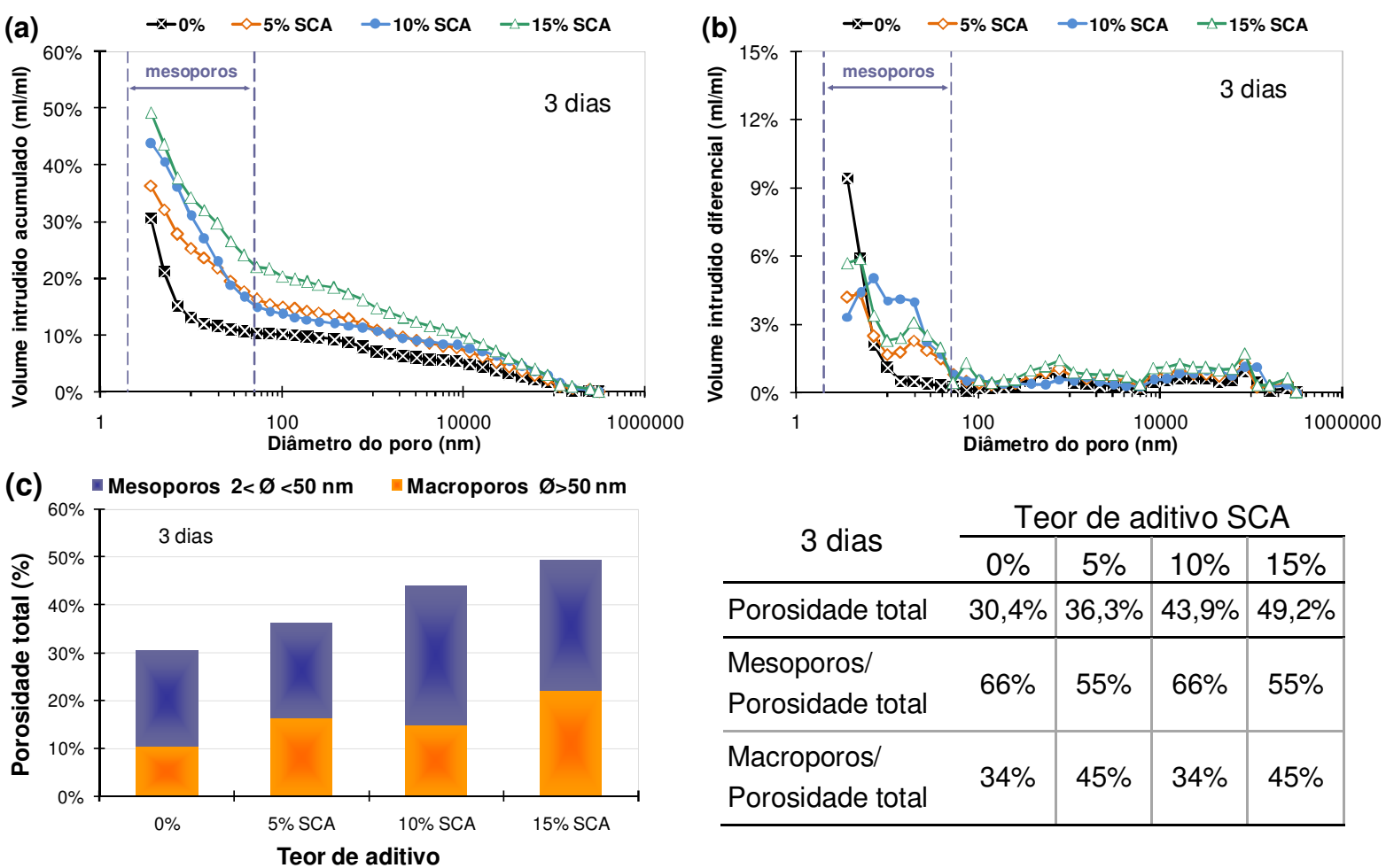

\begin{tabular}{|c|c|c|c|c|}
\hline \multirow{2}{*}{3 dias } & \multicolumn{4}{|c|}{ Teor de aditivo SCA } \\
\hline & $0 \%$ & $5 \%$ & $10 \%$ & $15 \%$ \\
\hline Porosidade total & $30,4 \%$ & $36,3 \%$ & $43,9 \%$ & $49,2 \%$ \\
\hline $\begin{array}{l}\text { Mesoporos/ } \\
\text { Porosidade total }\end{array}$ & $66 \%$ & $55 \%$ & $66 \%$ & $55 \%$ \\
\hline $\begin{array}{l}\text { Macroporos/ } \\
\text { Porosidade total }\end{array}$ & $34 \%$ & $45 \%$ & $34 \%$ & $45 \%$ \\
\hline
\end{tabular}

Figura 11.2 - Efeito do teor de aditivo compensador de retração (SCA) $(0 \%, 0,5 \%, 1,0 \%, 1,5 \%$ e $2,0 \%$ ) na porosidade acumulada (a), na porosidade diferencial (b) e na distribuição de poros (c) da pasta de escória ativada com silicato de sódio (4NS) com 3 dias de idade. a/agl=0,48(B). 

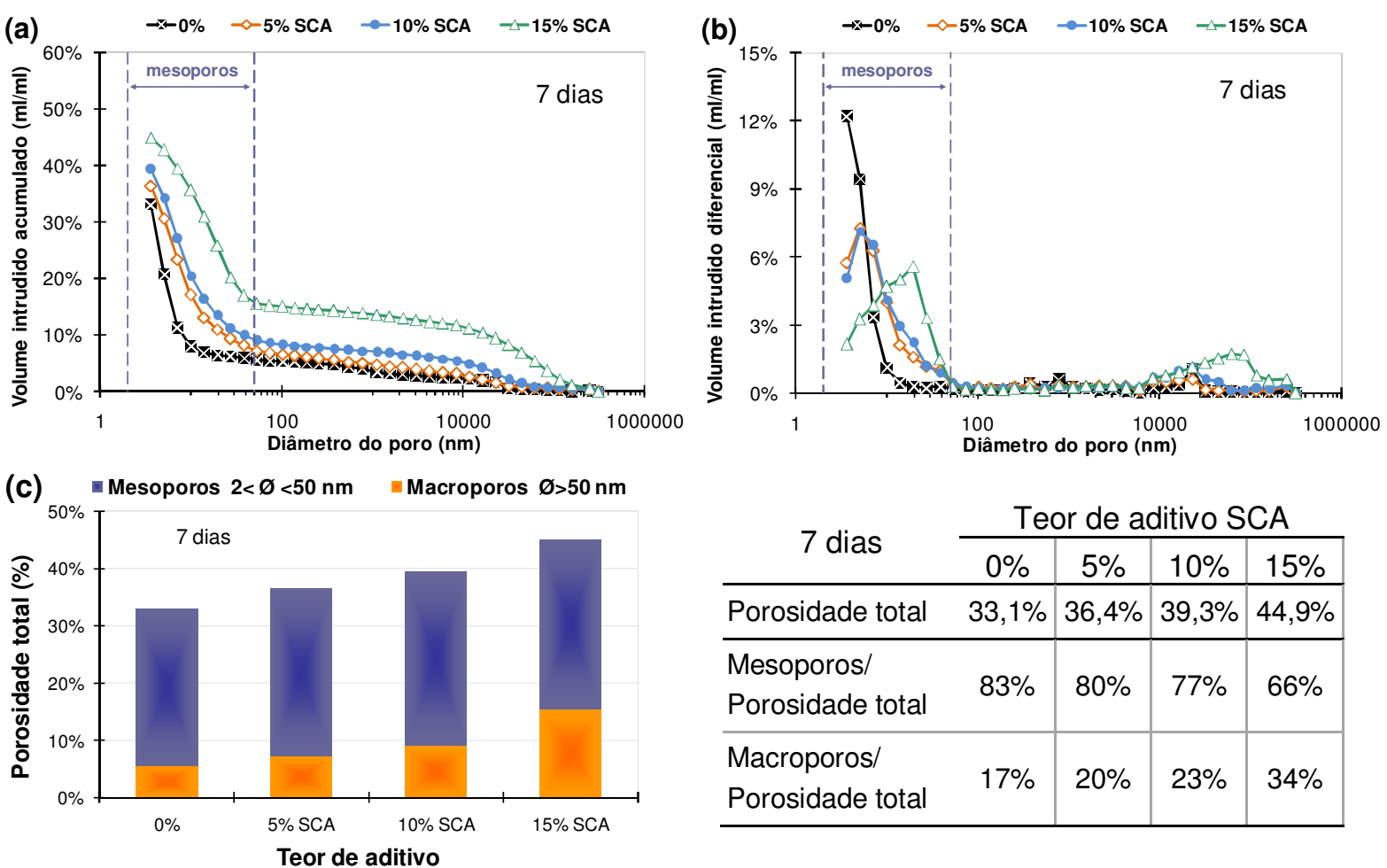

\begin{tabular}{lc|c|c|c|}
\multirow{2}{*}{7 dias } & \multicolumn{4}{c}{ Teor de aditivo SCA } \\
\cline { 2 - 5 } & $0 \%$ & $5 \%$ & $10 \%$ & $15 \%$ \\
\hline Porosidade total & $33,1 \%$ & $36,4 \%$ & $39,3 \%$ & $44,9 \%$ \\
\hline $\begin{array}{l}\text { Mesoporos/ } \\
\text { Porosidade total }\end{array}$ & $83 \%$ & $80 \%$ & $77 \%$ & $66 \%$ \\
\hline $\begin{array}{l}\text { Macroporos/ } \\
\text { Porosidade total }\end{array}$ & $17 \%$ & $20 \%$ & $23 \%$ & $34 \%$ \\
\hline
\end{tabular}

Figura 11.3 - Efeito do teor de aditivo compensador de retração (SCA) $(0 \%, 0,5 \%, 1,0 \%, 1,5 \%$ e $2,0 \%$ ) na porosidade acumulada (a), na porosidade diferencial (b) e na distribuição de poros (c) da pasta de escória ativada com silicato de sódio (4NS) com 7 dias de idade. a/agl=0,48(B).
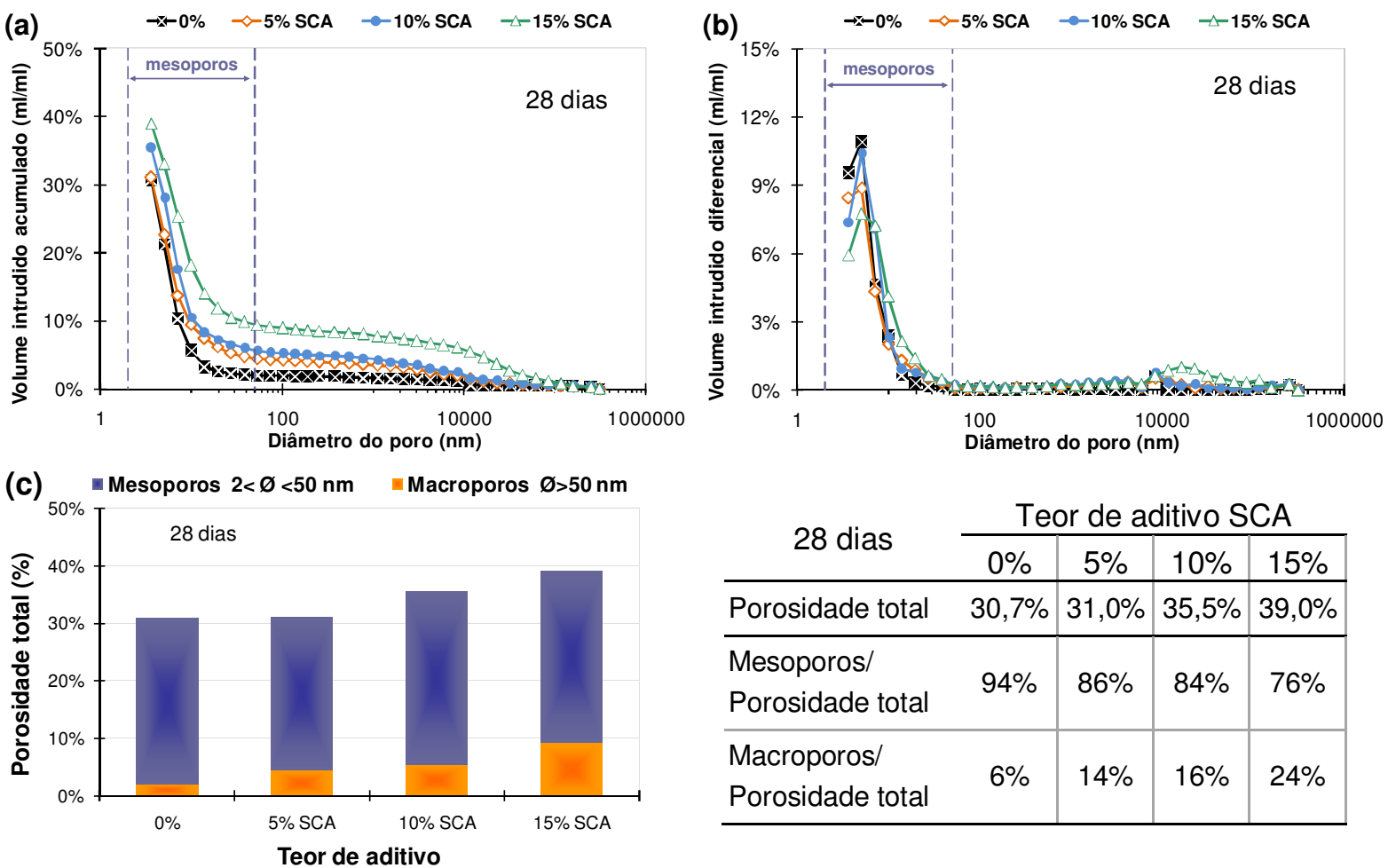

\begin{tabular}{lc|c|c|c|}
\multirow{2}{*}{28 dias } & \multicolumn{4}{c}{ Teor de aditivo SCA } \\
\cline { 2 - 5 } & $0 \%$ & $5 \%$ & $10 \%$ & $15 \%$ \\
\hline Porosidade total & $30,7 \%$ & $31,0 \%$ & $35,5 \%$ & $39,0 \%$ \\
\hline $\begin{array}{l}\text { Mesoporos/ } \\
\text { Porosidade total }\end{array}$ & $94 \%$ & $86 \%$ & $84 \%$ & $76 \%$ \\
\hline $\begin{array}{l}\text { Macroporos/ } \\
\text { Porosidade total }\end{array}$ & $6 \%$ & $14 \%$ & $16 \%$ & $24 \%$ \\
\hline
\end{tabular}

Figura 11.4 - Efeito do teor de aditivo compensador de retração (SCA) $(0 \%, 0,5 \%, 1,0 \%, 1,5 \%$ e $2,0 \%$ ) na porosidade acumulada (a), na porosidade diferencial (b) e na distribuição de poros (c) da pasta de escória ativada com silicato de sódio (4NS) com 28 dias de idade. a/agl = 0,48(B). 
Na Figura 11.5(a) consta o efeito do teor de aditivo compensador de retração (SCA) na evolução da porosidade total da mistura com relação a/agl igual a 0,48. Observase que o aumento do teor de aditivo SCA incorre no aumento da porosidade total, com efeito mais intenso nas primeiras idades. Apenas aos 28 dias, a mistura com $5 \%$ de aditivo SCA apresenta uma porosidade similar à mistura sem aditivo. No entanto, em qualquer idade e teores de aditivo SCA estudados (Figura 11.5(b)), ocorreu a alteração da distribuição de poros de uma matriz porosa mais fechada para uma mais aberta, caracterizada pela diminuição da proporção de mesoporos e o aumento da proporção de macroporos.

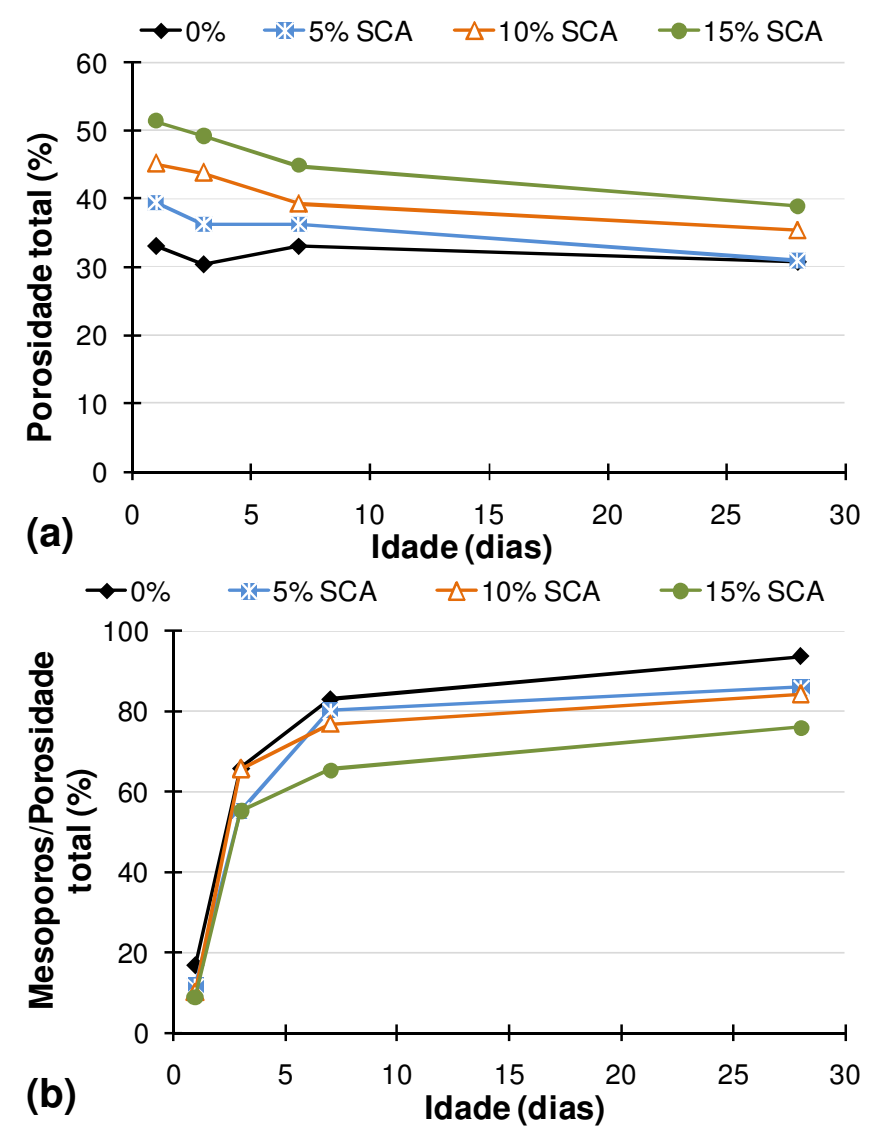

Figura 11.5 - Efeito do teor de aditivo compensador de retração (SCA) na evolução da porosidade total (a) e na proporção do volume de mesoporos em relação à porosidade total (b) da mistura com relação a/agl igual a 0,48 até os 28 dias.

Os gráficos da Figura 11.6 confirmam este comportamento e apresentam um panorama geral da correlação entre porosidade e o teor de aditivo compensador de retração (SCA). Observa-se que o aumento do teor de aditivo SCA incorre no aumento proporcional da porosidade total em qualquer idade ensaiada, assim como o aumento do volume de macroporos e diminuição do volume de mesoporos. 0 aumento do volume de macroporos do cimento de escória ativada com silicato de 
sódio com a utilização do aditivo compensador de retração (SCA) é explicado pela introdução de novos compostos hidratados oriundos do aditivo SCA, pois o cimento de escória ativada com silicato de sódio é caracterizado pela baixa porosidade e pela elevada proporção de volume de mesoporos.

Com a introdução de compostos hidratados, como a etringita, o monossulfoaluminato de cálcio hidratado e a portlandita, é natural que ocorra um aumento da porosidade total e da proporção de volume de macroporos decorrente da estrutura mais "aberta" destes compostos. A interação química e a interferência do aditivo SCA na hidratação do cimento de escória ativada com silicato de sódio, conforme descrito na análise dos resultados de difração de raios $X$ termogravimetria, também contribuem para a alteração da porosidade do cimento de escória ativada com silicato de sódio, pois diminuem a formação de C-S-H. E é consensual que o C-S-H contribui de forma intensa no refinamento da porosidade, pois apresenta diâmetros de poros situados, quase que em sua totalidade, na faixa de mesoporos.
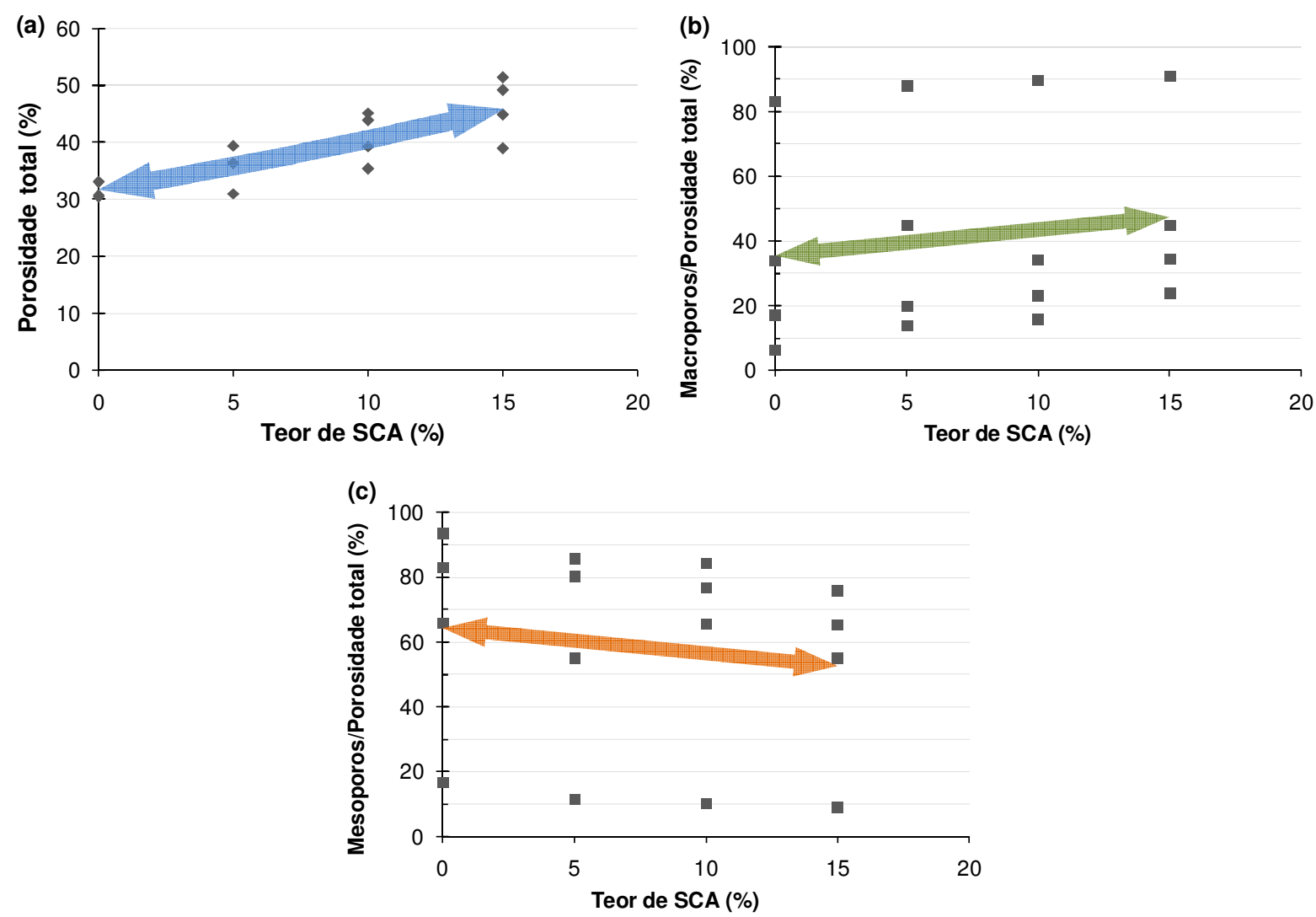

Figura 11.6 - Correlação entre o teor de aditivo compensador de retração (SCA) e a porosidade total (a), a proporção de macroporos (b) e de mesoporos (c) da mistura com relação a/agl igual a 0,48. Gráficos construídos com todos os pontos obtidos. 


\subsection{Discussão e conclusões}

A matriz porosa do cimento de escória ativada com silicato de sódio é caracterizada pelo elevado refinamento da sua distribuição de poros, apresentando em torno de 95\% de seus poros na faixa de diâmetro classificada como mesoporos. O aditivo compensador de retração (SCA) claramente altera a estrutura da matriz porosa, provocando um aumento da porosidade total e da proporção de macroporos. Por exemplo, com $15 \%$ de aditivo SCA ocorre a alteração da distribuição de poros de $95 \%$ de mesoporos para em torno de $76 \%$ aos 28 dias.

Conforme descrito na análise dos resultados de difração de raios $X$ e de termogravimetria, o aditivo compensador de retração (SCA) causa a diminuição da quantidade de $\mathrm{C}-\mathrm{S}-\mathrm{H}$ formado e introduz novos compostos hidratados, como a etringita, o monossulfoaluminato de cálcio hidratado e a portlandita. A diminuição da quantidade de C-S-H está diretamente relacionada ao aumento da porosidade total e à proporção de macroporos, pois, é consensual, em materiais cimentícios, que no CS-H se localiza a maior parte dos poros de menor diâmetro. Os novos compostos hidratados oriundos da hidratação do aditivo SCA têm estrutura mais aberta, ou porosa, portanto, é coerente que promovam uma alteração na distribuição de poros do cimento de escória ativada. Portanto, o aumento da porosidade e a alteração da distribuição de poros deste tipo de cimento é resultado do efeito conjunto da diminuição da quantidade de C-S-H e da introdução de novos compostos hidratados de estrutura mais porosa. 


\section{Capítulo 12 Propriedades mecânicas}

\subsection{Efeito do aditivo compensador de retração (SCA)}

\subsubsection{Resistência à compressão}

A influência do aditivo SCA na resistência à compressão do cimento de escória ativada com silicato de sódio nas três relações a/agl ensaiadas estão apresentadas nas Figura 12.1, Figura 12.2 e Figura 12.3. Observa-se que o aditivo compensador de retração (SCA) reduz a resistência à compressão do cimento de escória ativada com silicato de sódio. Basicamente, este comportamento é explicado pelo aumento da porosidade e diminuição do grau de hidratação com a utilização deste tipo de aditivo, conforme descrito na análise da microestrutura (Capítulo 9, Capítulo 10 e Capítulo 11). O aumento da relação a/agl, assim como nas misturas sem aditivo, causou a diminuição da resistência à compressão independentemente dos teores de aditivo SCA utilizados.

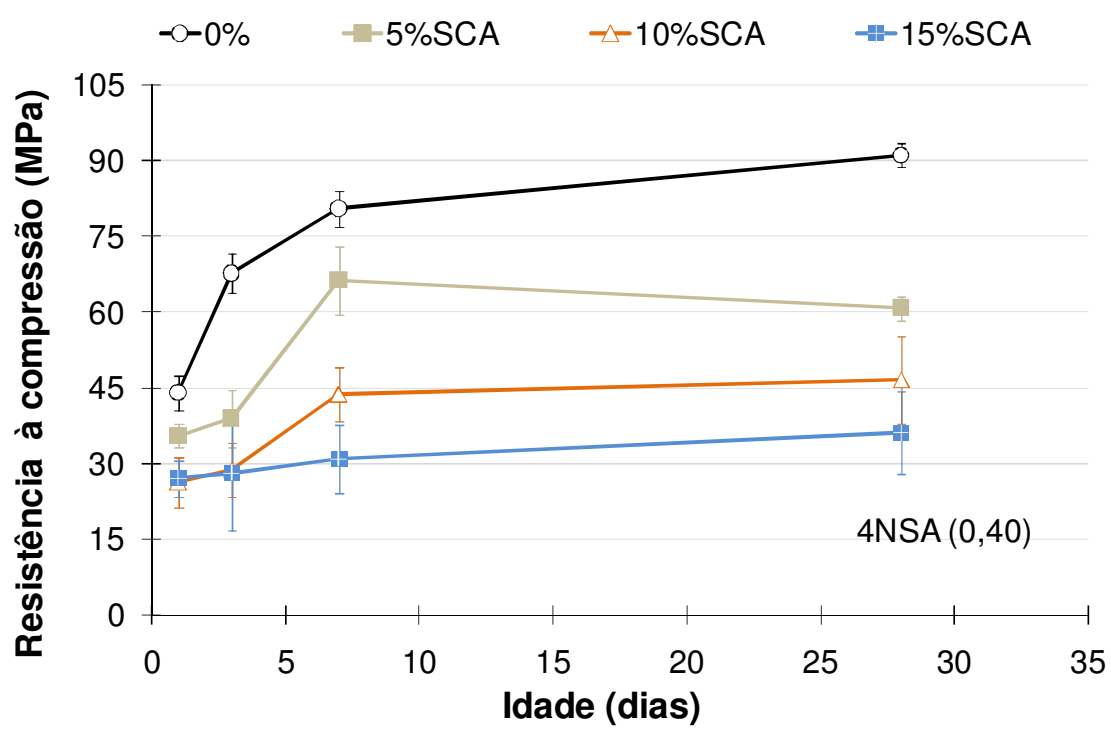

Figura 12.1 - Efeito do teor de aditivo SCA na resistência à compressão da argamassa de cimento de escória com relação a/agl igual a 0,40. 


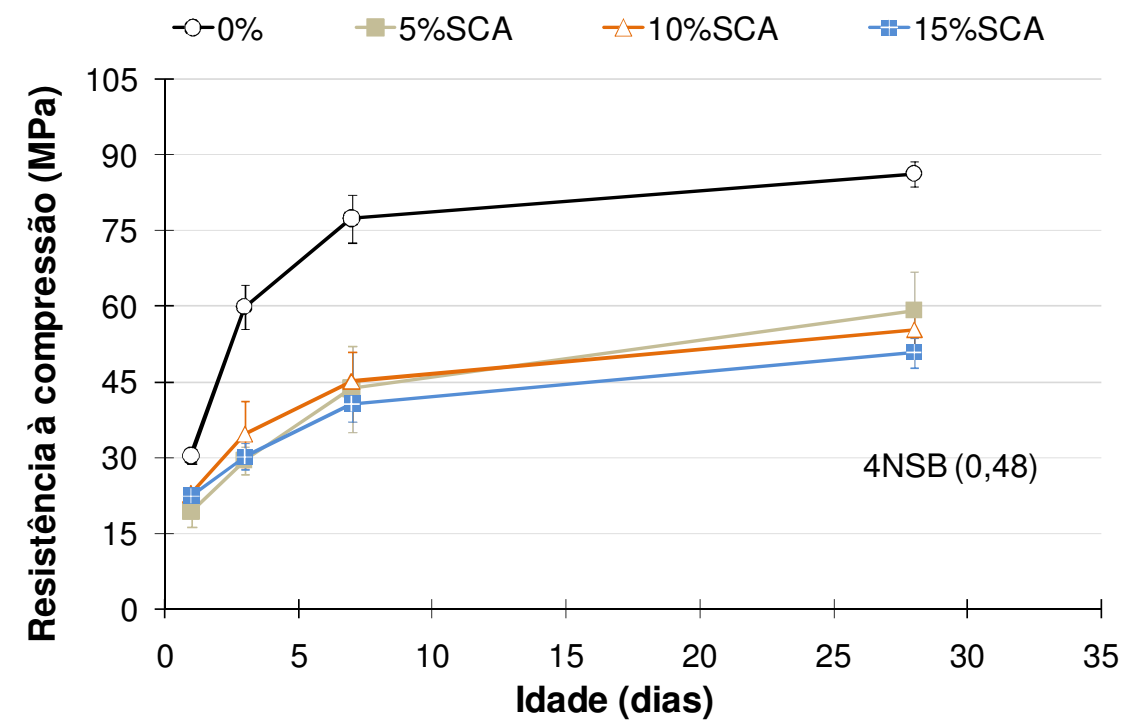

Figura 12.2 - Efeito do teor de aditivo SCA na resistência à compressão da argamassa de cimento de escória com relação a/agl igual a 0,48.

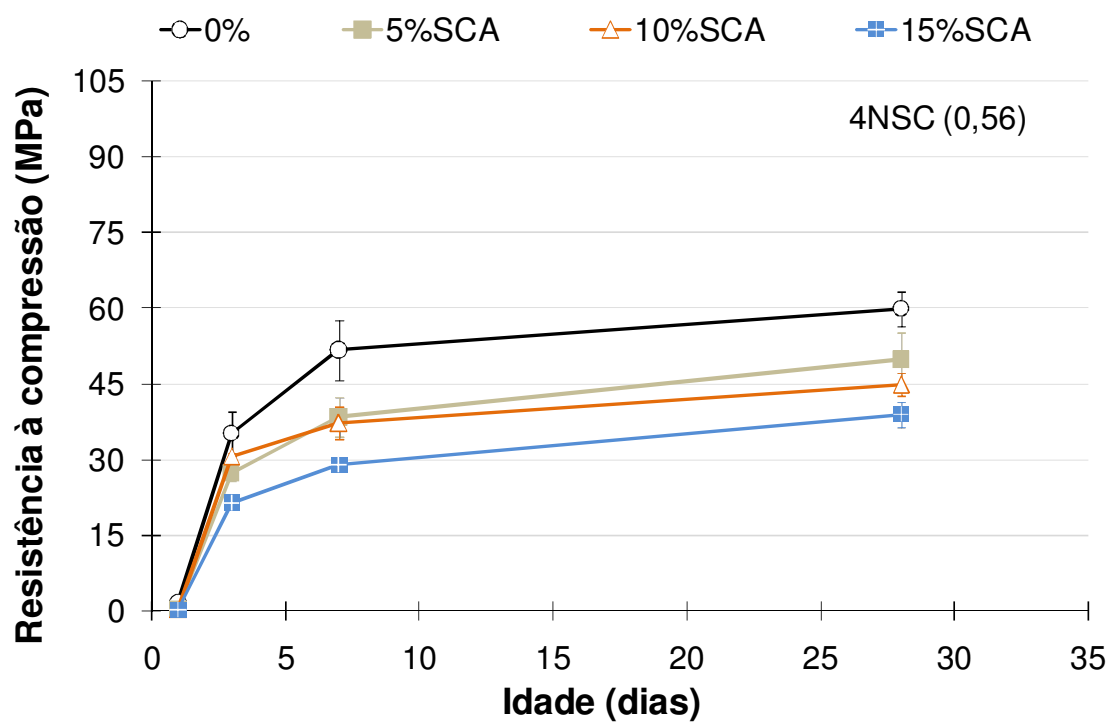

Figura 12.3 - Efeito do teor de aditivo SCA na resistência à compressão da argamassa de cimento de escória com relação a/agl igual a 0,56.

Diferentemente do efeito do aditivo redutor de retração (SRA), a interação entre o efeito do aumento do teor de aditivo SCA e o aumento da relação a/agl não causou a maximização da redução da resistência à compressão a ponto de anular a resistência mecânica nas primeiras idades. Nas misturas com relação a/agl igual a 0,48 e 0,56, o aditivo SCA causou a redução da resistência à compressão, porém não houve proporcionalidade com o aumento do teor de aditivo, constatando-se resultados similares para os três teores de aditivo estudados. Este comportamento pode estar relacionado pela maior eficiência da hidratação deste tipo de aditivo com maior disponibilidade de água, pois na mistura com relação a/agl igual a 0,40 foi 
observada uma correlação entre a diminuição da resistência à compressão e o aumento do teor de aditivo SCA.

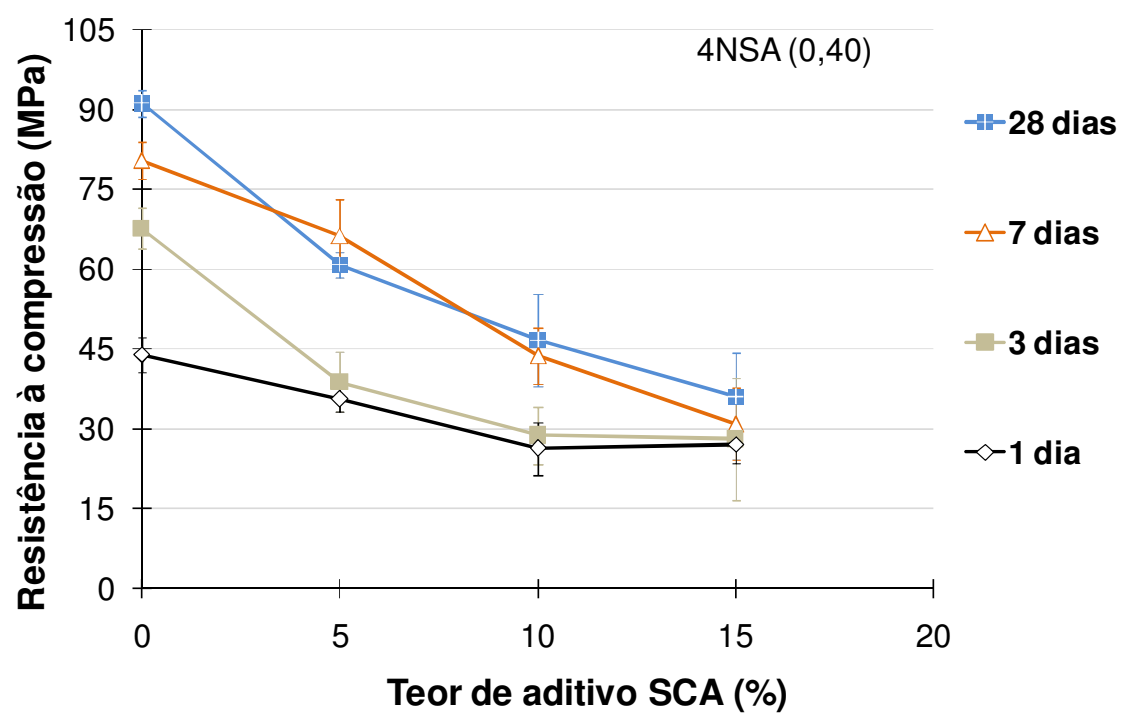

Figura 12.4 - Variação da resistência à compressão em função do teor de aditivo SCA na argamassa de cimento de escória com relação a/agl igual a 0,40.

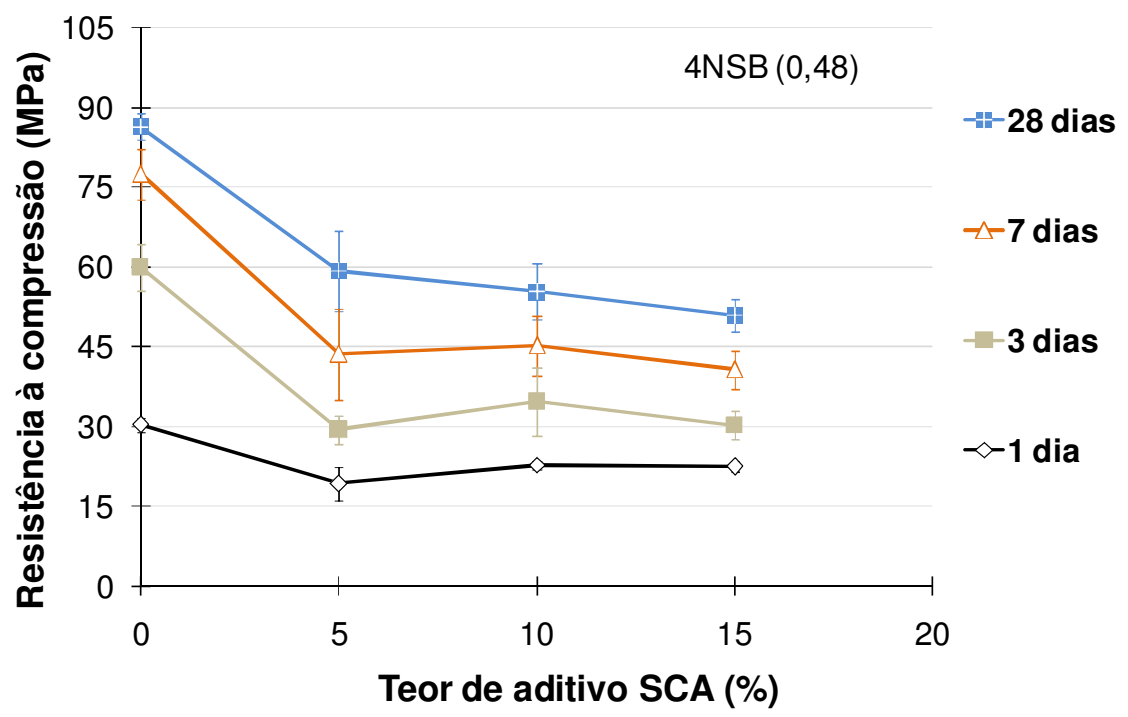

Figura 12.5 - Variação da resistência à compressão em função do teor de aditivo SCA na argamassa de cimento de escória com relação a/agl igual a 0,48.

Os resultados da resistência à compressão em função do teor de aditivo compensador de retração (SCA) obtidos nas três relações a/agl estudadas constam da Figura 12.4, Figura 12.5 e Figura 12.6. Confirma-se que a proporcionalidade entre a diminuição da resistência à compressão e o aumento do teor de aditivo SCA ocorre apenas na mistura com relação a/agl igual a 0,40 (Figura 12.4). Na mistura com relação a/agl igual a 0,48 (Figura 12.5), os resultados indicam que a redução da 
resistência à compressão ocorre sem uma proporcionalidade com o aumento do teor de aditivo SCA em qualquer idade estudada, ou seja, a redução foi praticamente a mesma para os três teores utilizados. Na mistura com relação a/agl igual a 0,56 (Figura 12.6), não houve proporcionalidade entre os resultados das misturas com teores iguais a $5 \%$ e $10 \%$ de aditivo SCA nas idades de 3 e 7 dias.

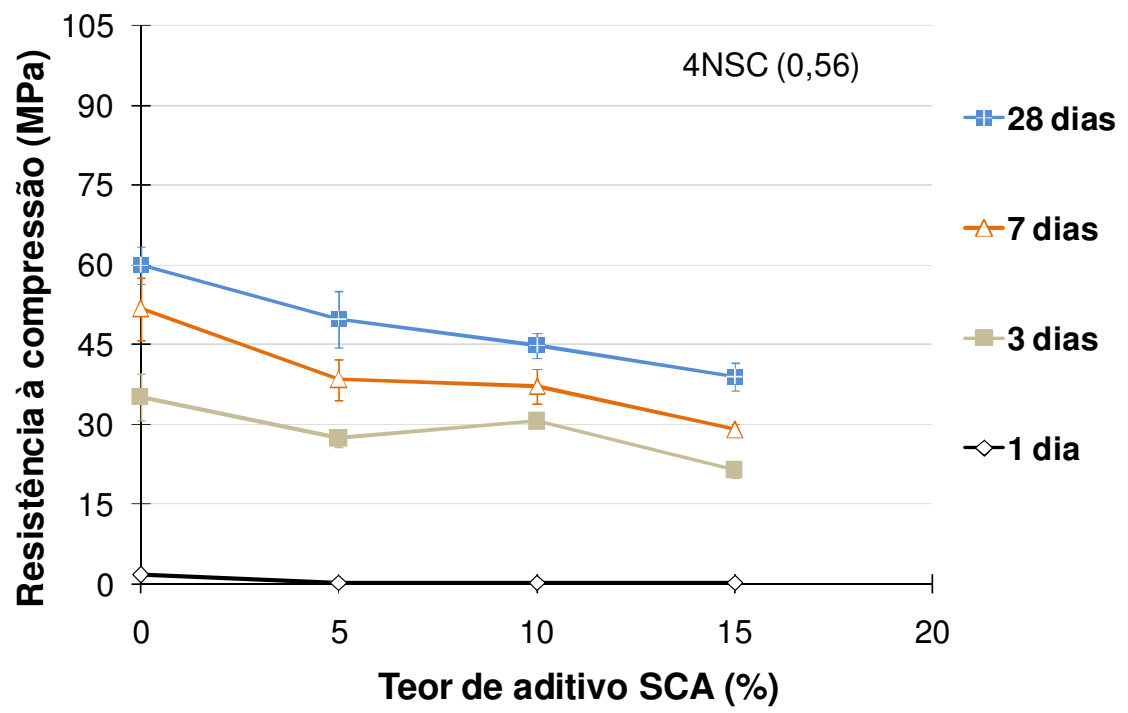

Figura 12.6 - Variação da resistência à compressão em função do teor de aditivo SCA na argamassa de cimento de escória com relação a/agl igual a 0,56.

Utilizando como referência as misturas sem utilização do aditivo SCA foi possível quantificar o efeito do aditivo na resistência à compressão, apresentado na Tabela 12.1, Tabela 12.2 e Tabela 12.3. Constata-se que a utilização do aditivo SCA provocou maior redução da resistência à compressão na mistura com relação a/agl de 0,40 , em torno de $60 \%$ aos 28 dias, do que a observada nas misturas com relação a/agl de 0,48 e 0,56, em torno de 40\% em ambas. Este comportamento associado à análise dos resultados de microestrutura permite afirmar que o aditivo compensador de retração (SCA) afeta mais a resistência à compressão do cimento de escória em misturas com pouca disponibilidade de água, porém, é consenso que as relações com menores relações a/agl apresentam maiores resistências mecânicas.

Este fato é atribuído aos prejuízos causados na hidratação do cimento de escória decorrente da pouca disponibilidade de água, a qual ainda tem que ser disputada com as reações de hidratação do aditivo SCA. Com o aumento da relação a/agl, 
este efeito é menor em virtude da maior disponibilidade de água para o desenvolvimento das reações de hidratação do aditivo SCA e do cimento de escória. Esta também é a provável explicação para a ausência de proporcionalidade entre a redução da resistência à compressão e o aumento do teor de aditivo SCA em algumas idades e teores estudados.

Tabela 12.1 - Médias aritméticas da resistência à compressão e o efeito do teor de aditivo compensador de retração (SCA) no cimento de escória ativada com relação a/agl igual a $\mathbf{0 , 4 0}$. CV = coeficiente de variação em \%.

\begin{tabular}{|c|c|c|c|c|c|c|c|c|c|}
\hline \multicolumn{2}{|c|}{ Relação a/agl = 0,40 } & \multicolumn{8}{|c|}{ Teor de aditivo compensador de retração (SCA) } \\
\hline & \multirow[b]{2}{*}{ Idade } & \multicolumn{2}{|c|}{$0 \%$} & \multicolumn{2}{|c|}{$5 \%$} & \multicolumn{2}{|c|}{$10 \%$} & \multicolumn{2}{|c|}{$15 \%$} \\
\hline & & Rc & $\overline{\mathrm{CV}}$ & Rc & $\mathrm{CV}$ & Rc & $\mathrm{CV}$ & Rc & $\mathrm{CV}$ \\
\hline \multirow{4}{*}{$\begin{array}{l}\text { Resistência à } \\
\text { compressão (MPa) }\end{array}$} & 1 dia & 44,0 & $3,9 \%$ & 35,5 & $3,4 \%$ & 26,3 & $9,5 \%$ & 27,1 & $6,8 \%$ \\
\hline & 3 dias & 67,7 & $2,9 \%$ & 38,9 & $7,4 \%$ & 28,8 & $9,4 \%$ & 28,1 & $20,8 \%$ \\
\hline & 7 dias & 80,5 & $2,2 \%$ & 66,3 & $5,2 \%$ & 43,8 & $6,1 \%$ & 30,9 & $11,2 \%$ \\
\hline & 28 dias & 91,1 & $1,4 \%$ & 60,8 & $2,0 \%$ & 46,6 & $9,5 \%$ & 36,1 & $11,7 \%$ \\
\hline \multirow{4}{*}{$\begin{array}{l}\text { Variação da } \\
\text { resistência à } \\
\text { compressão (\%) }\end{array}$} & 1 dia & \multicolumn{2}{|c|}{0,0} & \multicolumn{2}{|c|}{$-19,2$} & \multicolumn{2}{|c|}{$-40,1$} & \multicolumn{2}{|c|}{$-38,4$} \\
\hline & 3 dias & \multicolumn{2}{|c|}{0,0} & \multicolumn{2}{|c|}{$-42,6$} & \multicolumn{2}{|c|}{$-57,5$} & \multicolumn{2}{|c|}{$-58,5$} \\
\hline & 7 dias & \multirow{2}{*}{\multicolumn{2}{|c|}{$\begin{array}{l}0,0 \\
0,0\end{array}$}} & \multirow{2}{*}{\multicolumn{2}{|c|}{$\begin{array}{l}-17,6 \\
-33,3\end{array}$}} & \multicolumn{2}{|c|}{$-45,6$} & \multicolumn{2}{|c|}{$-61,6$} \\
\hline & 28 dias & & & & & \multicolumn{2}{|c|}{$-48,9$} & \multicolumn{2}{|c|}{$-60,4$} \\
\hline
\end{tabular}

Tabela 12.2 - Médias aritméticas da resistência à compressão e o efeito do teor de aditivo compensador de retração (SCA) no cimento de escória ativada com relação a/agl igual a $\mathbf{0 , 4 8}$. CV = coeficiente de variação em \%.

\begin{tabular}{|c|c|c|c|c|c|c|c|c|c|}
\hline \multicolumn{2}{|c|}{ Relação a/agl = 0,48 } & \multicolumn{8}{|c|}{ Teor de aditivo compensador de retração (SCA) } \\
\hline & \multirow[b]{2}{*}{ Idade } & \multicolumn{2}{|c|}{$0 \%$} & \multicolumn{2}{|c|}{$5 \%$} & \multicolumn{2}{|c|}{$10 \%$} & \multicolumn{2}{|c|}{$15 \%$} \\
\hline & & Rc & $\mathrm{CV}$ & Rc & $\mathrm{CV}$ & Rc & $\mathrm{CV}$ & Rc & $\mathrm{CV}$ \\
\hline \multirow{4}{*}{$\begin{array}{l}\text { Resistência à } \\
\text { compressão (MPa) }\end{array}$} & 1 dia & 30,3 & $2,4 \%$ & $\overline{19,3}$ & $8,3 \%$ & 22,8 & $1,9 \%$ & 22,5 & $2,3 \%$ \\
\hline & 3 dias & 60,0 & $3,7 \%$ & 29,5 & $4,7 \%$ & 34,7 & $9,5 \%$ & 30,2 & $4,5 \%$ \\
\hline & 7 dias & 77,4 & $3,1 \%$ & 43,7 & $10,0 \%$ & 45,2 & $6,4 \%$ & 40,7 & $4,5 \%$ \\
\hline & 28 dias & 86,4 & $1,5 \%$ & 59,3 & $6,5 \%$ & 55,3 & $4,9 \%$ & 50,8 & $3,0 \%$ \\
\hline \multirow{4}{*}{$\begin{array}{l}\text { Redução da } \\
\text { resistência à } \\
\text { compressão (\%) }\end{array}$} & $1 \mathrm{dia}$ & \multicolumn{2}{|c|}{0,0} & \multicolumn{2}{|c|}{$-36,3$} & \multicolumn{2}{|c|}{$-25,0$} & \multicolumn{2}{|c|}{$-26,0$} \\
\hline & 3 dias & \multicolumn{2}{|c|}{0,0} & \multicolumn{2}{|c|}{$-50,9$} & \multicolumn{2}{|c|}{$-42,2$} & \multicolumn{2}{|c|}{$-49,6$} \\
\hline & 7 dias & \multicolumn{2}{|c|}{0,0} & \multicolumn{2}{|c|}{$-43,6$} & \multicolumn{2}{|c|}{$-41,6$} & \multicolumn{2}{|c|}{$-47,4$} \\
\hline & 28 dias & \multicolumn{2}{|c|}{0,0} & \multicolumn{2}{|c|}{$-31,4$} & \multicolumn{2}{|c|}{$-35,9$} & \multicolumn{2}{|c|}{$-41,2$} \\
\hline
\end{tabular}

Tabela 12.3 - Médias aritméticas da resistência à compressão e o efeito do teor de aditivo compensador de retração (SCA) no cimento de escória ativada com relação a/agl igual a 0,56. CV = coeficiente de variação em \%.

\begin{tabular}{|c|c|c|c|c|c|c|c|c|c|}
\hline \multicolumn{2}{|c|}{ Relação a/agl = 0,56 } & \multicolumn{8}{|c|}{ Teor de aditivo compensador de retração (SCA) } \\
\hline & \multirow[b]{2}{*}{ Idade } & \multicolumn{2}{|c|}{$0 \%$} & \multicolumn{2}{|c|}{$5 \%$} & \multicolumn{2}{|c|}{$10 \%$} & \multicolumn{2}{|c|}{$15 \%$} \\
\hline & & Rc & $\overline{C V}$ & Rc & $\mathrm{CV}$ & Rc & $\mathrm{CV}$ & Rc & $\mathrm{CV}$ \\
\hline \multirow{4}{*}{$\begin{array}{l}\text { Resistência à } \\
\text { compressão (MPa) }\end{array}$} & 1 dia & 1,7 & $9,1 \%$ & 0,3 & $0,0 \%$ & 0,3 & $0,0 \%$ & 0,3 & $0,0 \%$ \\
\hline & 3 dias & 35,2 & $6,3 \%$ & 27,4 & $2,9 \%$ & 30,6 & $1,0 \%$ & 21,5 & $3,5 \%$ \\
\hline & 7 dias & 51,7 & $5,8 \%$ & 38,5 & $5,2 \%$ & 37,2 & $4,4 \%$ & 29,0 & $2,0 \%$ \\
\hline & 28 dias & 59,9 & $2,9 \%$ & 49,8 & $5,4 \%$ & 44,8 & $2,6 \%$ & 39,0 & $3,4 \%$ \\
\hline \multirow{4}{*}{$\begin{array}{l}\text { Variação da } \\
\text { resistência à } \\
\text { compressão (\%) }\end{array}$} & 1 dia & \multicolumn{2}{|c|}{0,0} & \multicolumn{2}{|c|}{$-85,3$} & \multicolumn{2}{|c|}{$-85,3$} & \multicolumn{2}{|c|}{$-85,3$} \\
\hline & 3 dias & \multicolumn{2}{|c|}{0,0} & \multicolumn{2}{|c|}{$-22,2$} & \multicolumn{2}{|c|}{$-13,1$} & \multicolumn{2}{|c|}{$-38,9$} \\
\hline & 7 dias & \multirow{2}{*}{\multicolumn{2}{|c|}{0,0}} & \multirow{2}{*}{\multicolumn{2}{|c|}{$-25,6$}} & \multicolumn{2}{|c|}{$-28,0$} & \multicolumn{2}{|c|}{$-43,9$} \\
\hline & 28 dias & & & & & \multicolumn{2}{|c|}{$-25,2$} & \multicolumn{2}{|c|}{$-34,9$} \\
\hline
\end{tabular}


Nos gráficos da Figura 12.7 está apresentado o efeito da interação entre o teor de aditivo compensador de retração $(S C A)$ e a relação a/agl na resistência à compressão no cimento de escória ativada com silicato de sódio. Conforme citado anteriormente, o aumento da relação a/agl no cimento de escória ativada com silicato de sódio causa a redução significativa da resistência à compressão nas primeiras idades. Confirma-se que o aditivo SCA tem maior impacto na redução da resistência à compressão da mistura com relação a/agl igual a 0,40 e nas idades finais, resultando em valores similares de resistência aos 7 e 28 dias para todas as relações a/agl estudadas com o aumento do teor de aditivo SCA.
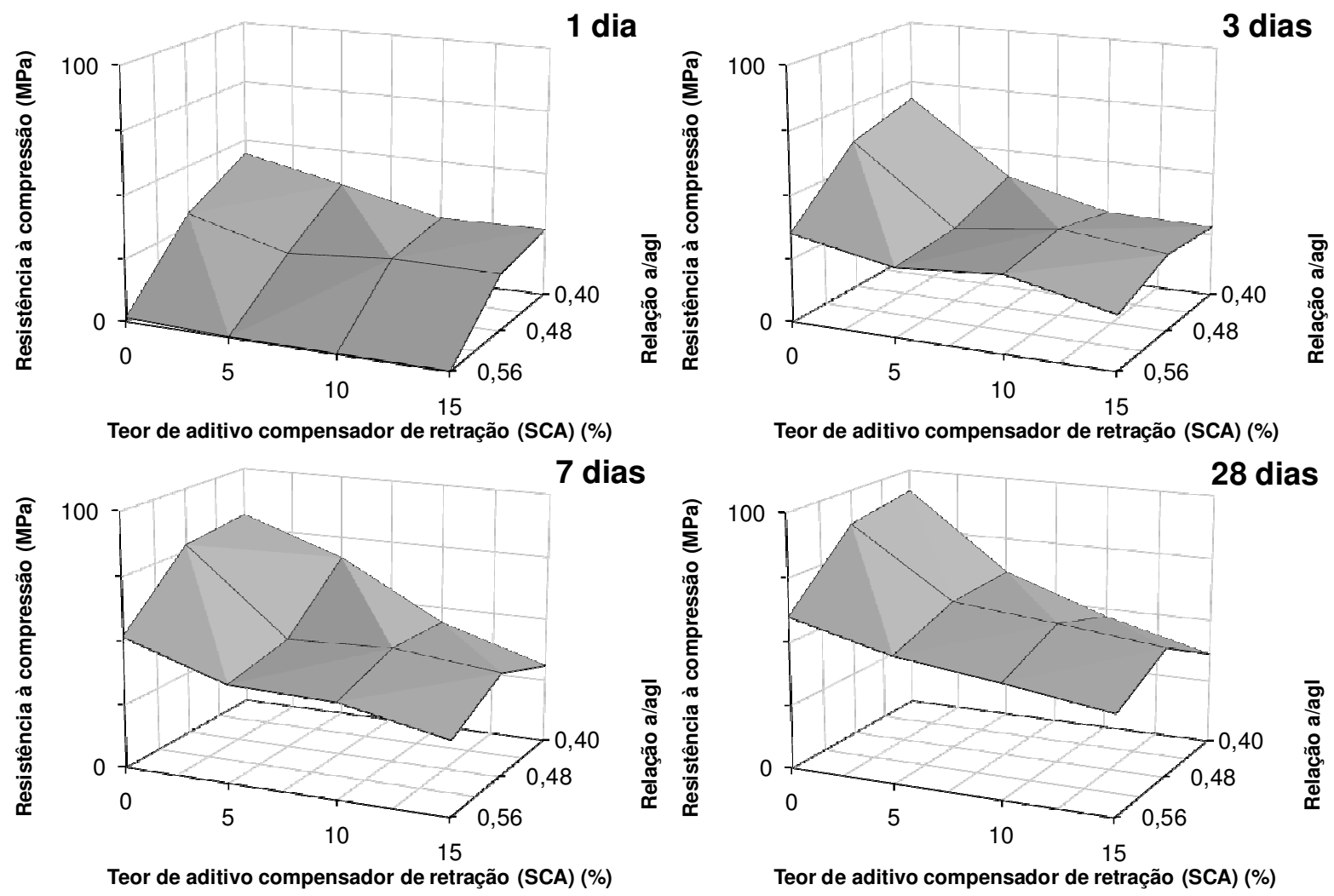

Figura 12.7 - Efeito do teor de aditivo SCA e da relação água/aglomerante na resistência à compressão.

Conclui-se que o aditivo compensador de retração (SCA) apresenta efeito intenso à longo prazo nas misturas de cimento de escória ativada com silicato de sódio com baixa relação a/agl, pois inibe a evolução da hidratação do cimento de escória. Com o aumento da relação a/agl, o efeito do aditivo SCA é menor, e a redução da resistência à compressão, apesar de significativa, ocorre em uma magnitude menor do que na mistura com relação a/agl igual a 0,40 . Com base nos resultados obtidos, 
conclui-se que a utilização do aditivo compensador de retração (SCA) pode inviabilizar a utilização do cimento de escória ativada com silicato de sódio com baixas relações a/agl em aplicações que necessitem resistências com ápice aos 28 dias. Por outro lado, com o aumento da relação a/agl ocorre a diminuição do efeito do aditivo SCA, embora o efeito da relação a/agl seja predominante na redução da resistência à compressão. Diferentemente do aditivo redutor de retração (SRA), o aditivo SCA não apresenta efeito intenso nas primeiras idades, o que torna possível sua aplicação em situações que exigem elevada resistência inicial. Portanto, na especificação do uso deste tipo de aditivo no cimento de escória deve ser realizado um balanço das características de maior impacto nas necessidades de aplicação e uso.

\subsubsection{Resistência à tração}

O efeito do aditivo compensador de retração (SCA) na resistência à tração na flexão foi similar ao observado na resistência à compressão (item 12.1.1). Assim como descrito na análise do efeito da relação água/aglomerante na resistência à tração na flexão sem a utilização de aditivos (Capítulo 7, pág.97), observa-se a elevada variabilidade deste ensaio (Tabela 12.4). Apesar deste fato, pode-se afirmar que 0 aditivo SCA reduz a resistência à tração, com mais intensidade na mistura com relação a/agl igual a 0,40 (Figura 12.8), e ocorre uma proporcionalidade entre o aumento do teor de aditivo SCA e a redução da resistência à tração (Figura 12.9).

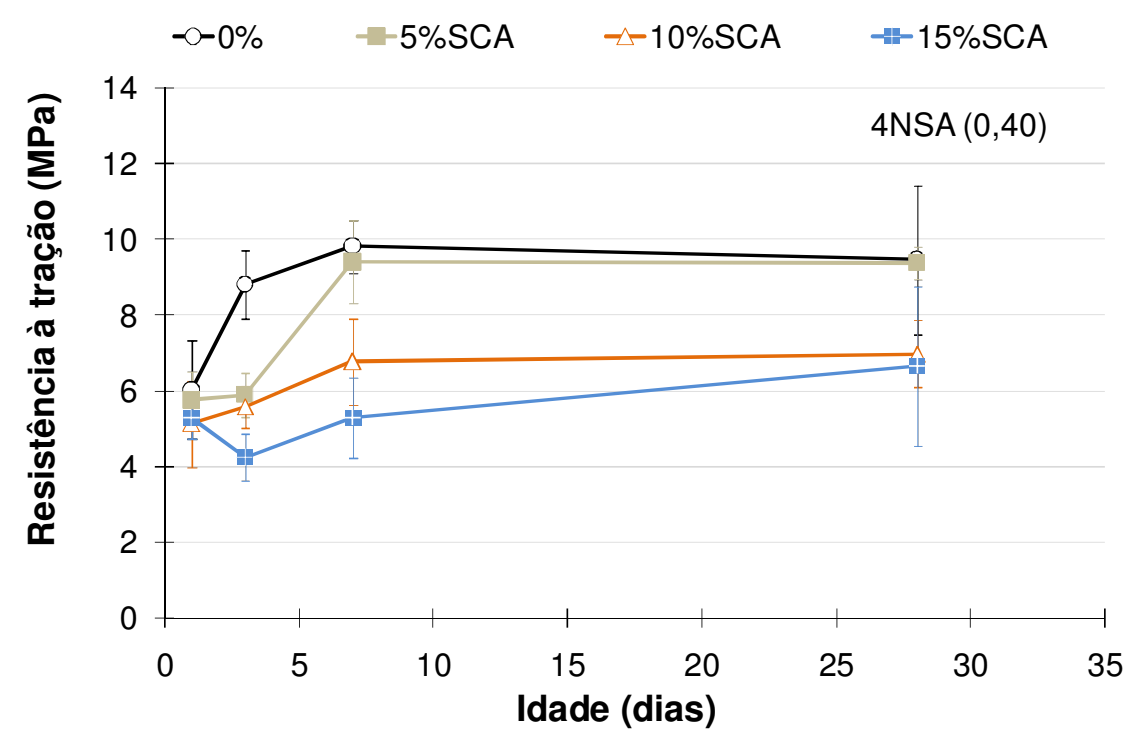

Figura 12.8 - Efeito do teor de aditivo SCA na resistência à tração da argamassa de cimento de escória com relação água/aglomerante igual a 0,40. 


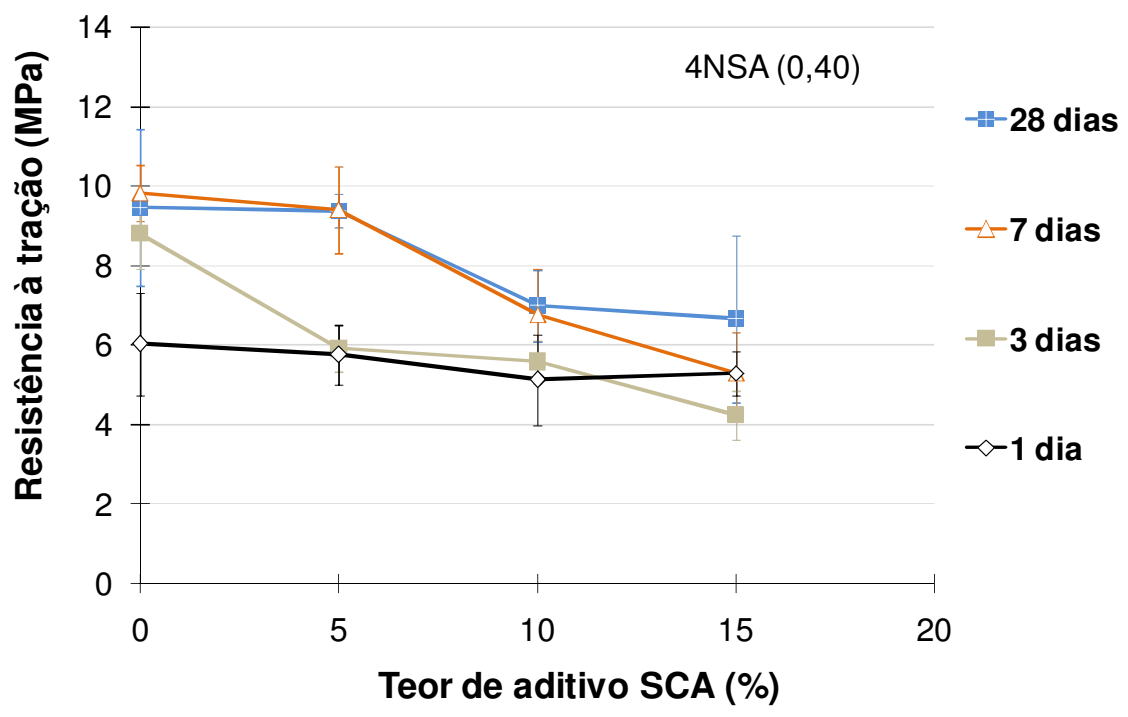

Figura 12.9 - Variação da resistência à tração em função do teor de aditivo SCA na argamassa de cimento de escória com relação água/aglomerante igual a 0,40.

Tabela 12.4 - Médias aritméticas da resistência à tração na flexão e o efeito do teor de aditivo compensador de retração (SCA) no cimento de escória ativada com relação a/agl igual a $\mathbf{0 , 4 0}$. CV = coeficiente de variação em \%.

\begin{tabular}{|c|c|c|c|c|c|c|c|c|c|}
\hline \multirow{2}{*}{\multicolumn{2}{|c|}{ Relação a/agl = 0,40 }} & \multicolumn{8}{|c|}{ Teor de aditivo compensador de retração (SCA) } \\
\hline & & \multicolumn{2}{|c|}{$0 \%$} & \multicolumn{2}{|c|}{$5 \%$} & \multicolumn{2}{|c|}{$10 \%$} & \multicolumn{2}{|c|}{$15 \%$} \\
\hline & Idade & $\mathbf{R t}$ & $\mathrm{CV}$ & $\mathbf{R t}$ & $\mathrm{CV}$ & $\mathbf{R t}$ & $\mathrm{CV}$ & $\mathbf{R t}$ & $\mathrm{CV}$ \\
\hline \multirow{4}{*}{$\begin{array}{l}\text { Resistência à tração } \\
\text { na flexão (MPa) }\end{array}$} & $1 \mathrm{dia}$ & 6,0 & $11,0 \%$ & 5,8 & $6,6 \%$ & 5,1 & $11,4 \%$ & 5,3 & $5,3 \%$ \\
\hline & 3 dias & 8,8 & $5,2 \%$ & 5,9 & $5,1 \%$ & 5,6 & $5,0 \%$ & 4,2 & $7,4 \%$ \\
\hline & 7 dias & 9,8 & $3,6 \%$ & 9,4 & $5,9 \%$ & 6,8 & $8,6 \%$ & 5,3 & $10,1 \%$ \\
\hline & 28 dias & 9,5 & $10,6 \%$ & 9,4 & $2,3 \%$ & 7,0 & $6,6 \%$ & 6,7 & $16,1 \%$ \\
\hline \multirow{4}{*}{$\begin{array}{l}\text { Variação da } \\
\text { resistência à tração } \\
\text { na flexão (\%) }\end{array}$} & $1 \mathrm{dia}$ & \multicolumn{2}{|c|}{0,0} & \multicolumn{2}{|c|}{$-4,5$} & \multicolumn{2}{|c|}{$-14,9$} & \multicolumn{2}{|c|}{$-12,4$} \\
\hline & 3 dias & \multicolumn{2}{|c|}{0,0} & \multicolumn{2}{|c|}{$-32,9$} & \multicolumn{2}{|c|}{$-36,7$} & \multicolumn{2}{|c|}{$-51,8$} \\
\hline & 7 dias & \multicolumn{2}{|c|}{0,0} & \multicolumn{2}{|c|}{$-4,2$} & \multicolumn{2}{|c|}{$-31,1$} & \multicolumn{2}{|c|}{$-46,1$} \\
\hline & 28 dias & \multicolumn{2}{|c|}{0,0} & \multicolumn{2}{|c|}{$-0,9$} & \multicolumn{2}{|c|}{$-26,2$} & \multicolumn{2}{|c|}{$-29,6$} \\
\hline
\end{tabular}

A Figura 12.10 apresenta o efeito do teor de aditivo compensador de retração (SCA) na evolução da resistência à tração até os 28 dias da mistura de escória ativada com silicato de sódio e relação a/agl igual a 0,48. Nota-se que a análise do efeito do aditivo foi prejudicada pela elevada variabilidade do ensaio, mas que é possível observar que ocorre a redução da resistência à tração com o aumento do teor de aditivo SCA a partir dos 3 dias de idade (Figura 12.11). Assim como na análise da resistência à compressão, observa-se que o aditivo não reduz a resistência nas primeiras idades de forma tão intensa quanto o observado na análise do aditivo redutor de retração (SRA), ocorrendo até mesmo valores superiores aos observados na mistura sem aditivo (Tabela 12.5). É provável que este fato resulte da maior disponibilidade de água nas primeiras idades, o que resulta na amenização do efeito nas primeiras idades. 


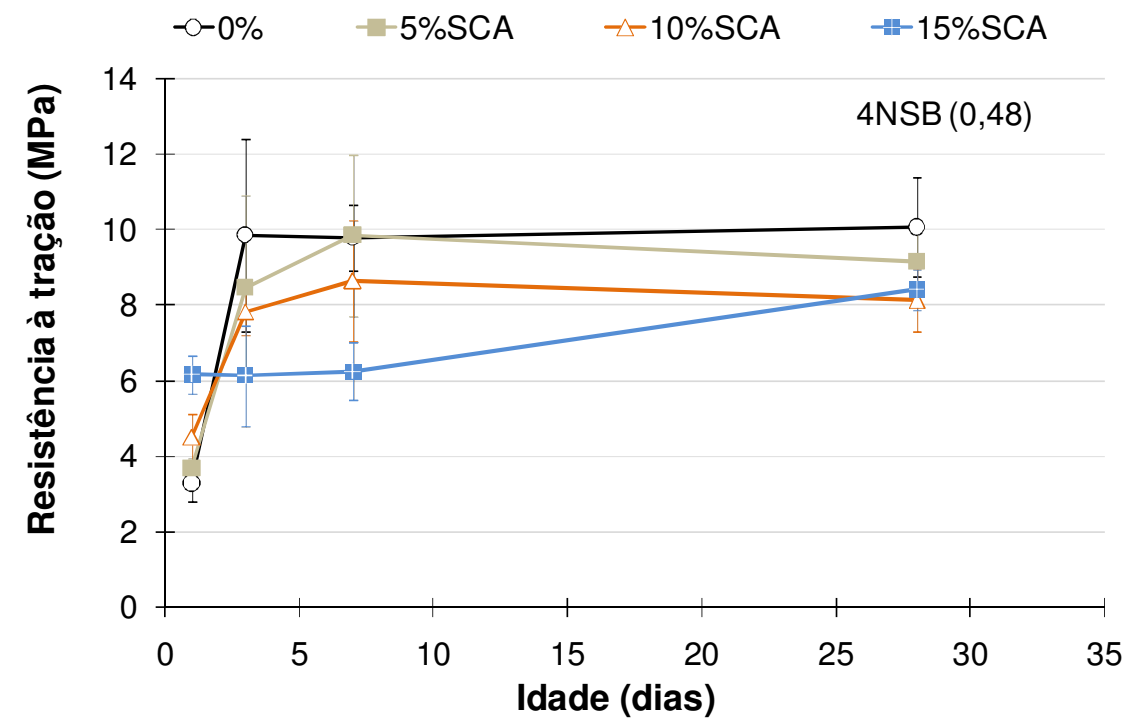

Figura 12.10 - Efeito do teor de aditivo SCA na resistência à tração da argamassa de cimento de escória com relação água/aglomerante igual a 0,48.

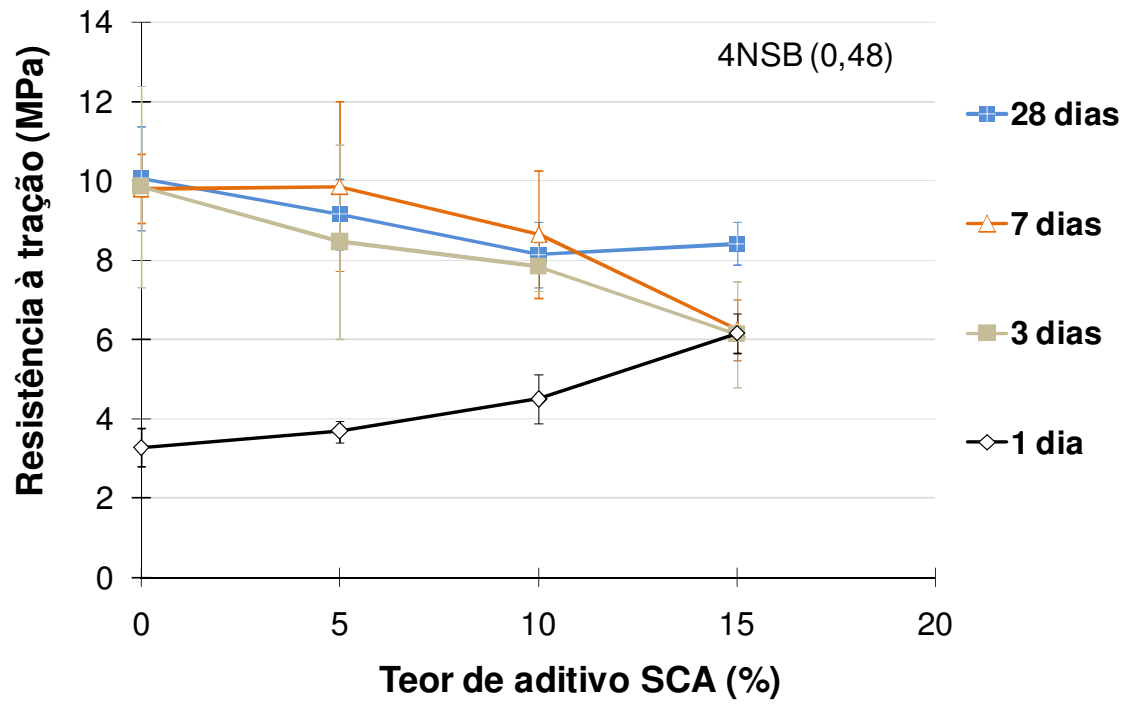

Figura 12.11 - Variação da resistência à tração em função do teor de aditivo SCA na argamassa de cimento de escória com relação água/aglomerante igual a 0,48

Tabela 12.5 - Médias aritméticas da resistência à tração na flexão e o efeito do teor de aditivo compensador de retração (SCA) no cimento de escória ativada com relação a/agl igual a $\mathbf{0 , 4 8}$. CV = coeficiente de variação em \%.

\begin{tabular}{|c|c|c|c|c|c|c|c|c|c|}
\hline \multicolumn{2}{|c|}{ Relação a/agl = 0,48 } & \multicolumn{8}{|c|}{ Teor de aditivo compensador de retração (SCA) } \\
\hline & \multirow[b]{2}{*}{ Idade } & \multicolumn{2}{|c|}{$0 \%$} & \multicolumn{2}{|c|}{$5 \%$} & \multicolumn{2}{|c|}{$10 \%$} & \multicolumn{2}{|c|}{$15 \%$} \\
\hline & & Rt & $\mathrm{CV}$ & $\mathbf{R t}$ & $\mathrm{CV}$ & $\mathbf{R t}$ & $\mathrm{CV}$ & $\mathbf{R t}$ & $\mathrm{cV}$ \\
\hline \multirow{4}{*}{$\begin{array}{l}\text { Resistência à tração } \\
\text { na flexão (MPa) }\end{array}$} & 1 dia & 3,3 & $7,4 \%$ & 3,7 & $3,8 \%$ & 4,5 & $7,0 \%$ & 6,2 & $4,1 \%$ \\
\hline & 3 dias & 9,9 & $13,2 \%$ & 8,5 & $14,7 \%$ & 7,8 & $4,0 \%$ & 6,1 & $11,1 \%$ \\
\hline & 7 dias & 9,8 & $4,5 \%$ & 9,9 & $11,0 \%$ & 8,7 & $9,5 \%$ & 6,3 & $6,2 \%$ \\
\hline & 28 dias & 10,1 & $6,6 \%$ & 9,2 & $4,9 \%$ & 8,1 & $5,2 \%$ & 8,4 & $3,3 \%$ \\
\hline \multirow{4}{*}{$\begin{array}{l}\text { Variação da } \\
\text { resistência à tração } \\
\text { na flexão (\%) }\end{array}$} & $1 \mathrm{dia}$ & \multicolumn{2}{|c|}{0,0} & \multicolumn{2}{|c|}{$+12,2$} & \multicolumn{2}{|c|}{$+36,8$} & \multicolumn{2}{|c|}{$+87,7$} \\
\hline & 3 dias & \multicolumn{2}{|c|}{0,0} & \multicolumn{2}{|c|}{$-14,2$} & \multicolumn{2}{|c|}{$-20,5$} & \multicolumn{2}{|c|}{$-37,7$} \\
\hline & 7 dias & \multirow{2}{*}{\multicolumn{2}{|c|}{0,0}} & \multicolumn{2}{|c|}{$+0,6$} & \multicolumn{2}{|c|}{$-11,8$} & \multicolumn{2}{|c|}{$-36,2$} \\
\hline & 28 dias & & 0,0 & \multicolumn{2}{|c|}{$-9,1$} & \multicolumn{2}{|c|}{$-19,2$} & \multicolumn{2}{|c|}{$-16,4$} \\
\hline
\end{tabular}


Com o aumento da relação a/agl para 0,56 , observa-se a redução da resistência à tração sem e com a utilização do aditivo SCA a valores nulos com 1 dia de idade (Figura 12.12), porém a utilização do aditivo SCA causou a diminuição significativa da resistência final (Figura 12.13 e Tabela 12.6). Mais uma vez o efeito do aditivo compensador de retração (SCA) foi menor nas primeiras idades na resistência à tração do cimento de escória ativada com silicato de sódio. Na Figura 12.14 consta o efeito da interação entre teor de aditivo SCA e relação a/agl na resistência à tração na flexão do cimento de escória ativada com silicato de sódio. Em todas as idades estudadas, o perfil da superfície de resposta é similar ao obtido nos resultados de resistência à compressão, indicando que o aumento do teor de aditivo SCA tem efeito de maior intensidade na mistura com menor relação a/agl.

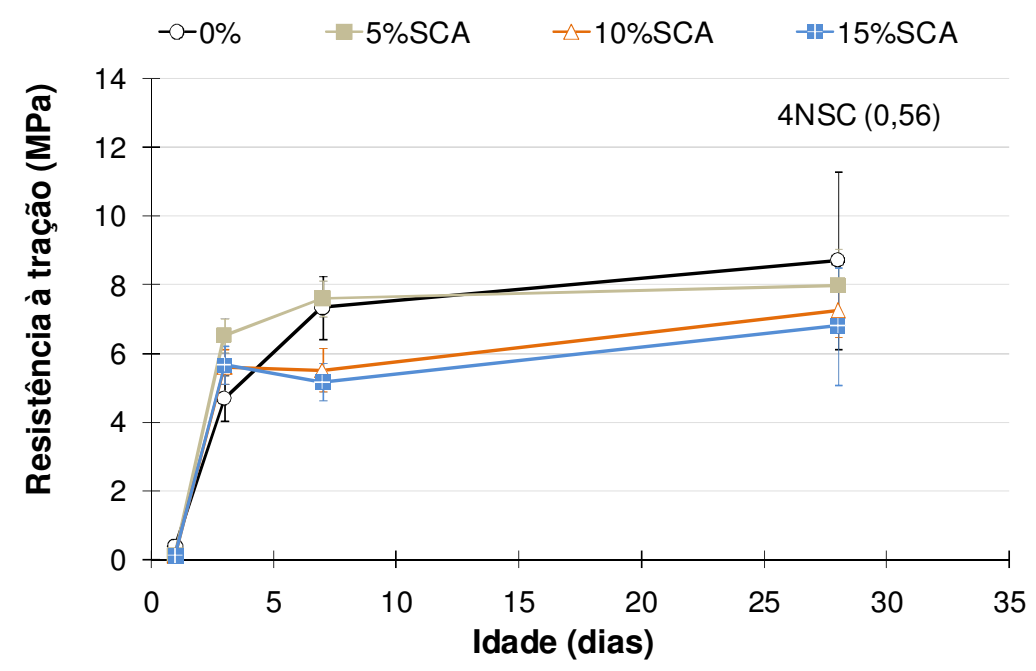

Figura 12.12 - Efeito do teor de aditivo SCA na resistência à tração da argamassa de cimento de escória com relação água/aglomerante igual a 0,56.

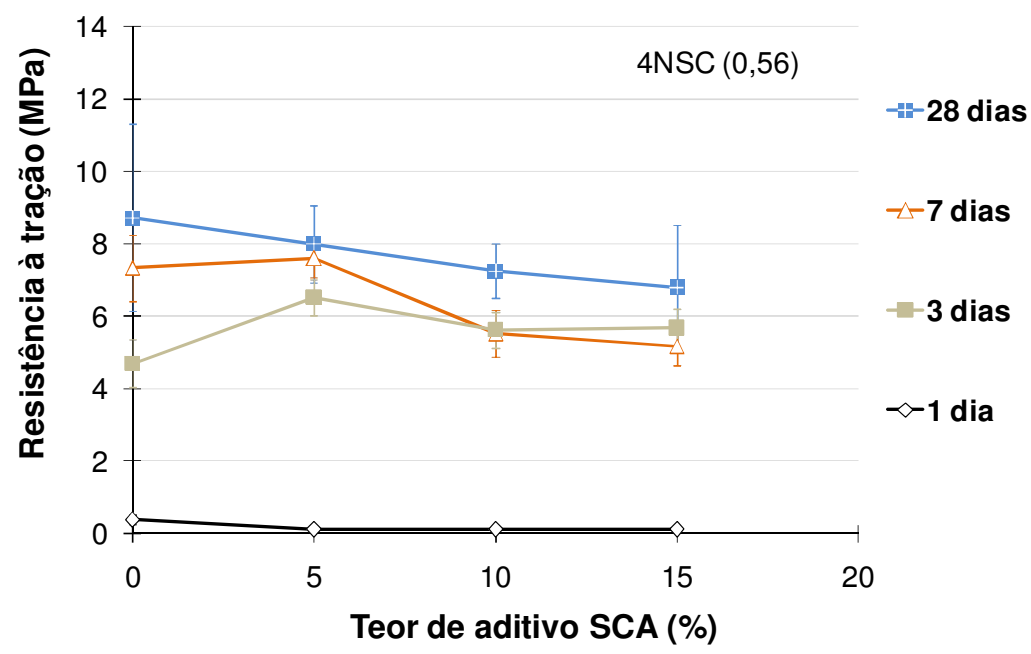

Figura 12.13 - Variação da resistência à tração em função do teor de aditivo SCA na argamassa de cimento de escória com relação água/aglomerante igual a 0,56 
Tabela 12.6 - Médias aritméticas da resistência à tração na flexão e o efeito do teor de aditivo compensador de retração (SCA) no cimento de escória ativada com relação a/agl igual a 0,56. CV = coeficiente de variação em \%.

\begin{tabular}{|c|c|c|c|c|c|c|c|c|c|}
\hline \multicolumn{2}{|c|}{ Relação a/agl = 0,56 } & \multicolumn{8}{|c|}{ Teor de aditivo compensador de retração (SCA) } \\
\hline & \multirow[b]{2}{*}{ Idade } & \multicolumn{2}{|c|}{$0 \%$} & \multicolumn{2}{|c|}{$5 \%$} & \multicolumn{2}{|c|}{$10 \%$} & \multicolumn{2}{|c|}{$15 \%$} \\
\hline & & $\mathbf{R t}$ & $\mathrm{CV}$ & $\mathbf{R t}$ & $\mathrm{CV}$ & $\mathbf{R t}$ & $\mathrm{CV}$ & $\mathbf{R t}$ & $\mathrm{CV}$ \\
\hline \multirow{4}{*}{$\begin{array}{l}\text { Resistência à tração } \\
\text { na flexão (MPa) }\end{array}$} & 1 dia & 0,4 & $17,9 \%$ & 0,1 & $7,4 \%$ & 0,1 & $7,4 \%$ & 0,1 & $7,4 \%$ \\
\hline & 3 dias & 4,7 & $7,2 \%$ & 6,5 & $3,9 \%$ & 5,6 & $4,6 \%$ & 5,7 & $4,9 \%$ \\
\hline & 7 dias & 7,3 & $6,3 \%$ & 7,6 & $3,5 \%$ & 5,5 & $5,9 \%$ & 5,2 & $5,4 \%$ \\
\hline & 28 dias & 8,7 & $15,1 \%$ & 8,0 & $6,8 \%$ & 7,2 & $5,3 \%$ & 6,8 & $12,9 \%$ \\
\hline \multirow{4}{*}{$\begin{array}{l}\text { Variação da } \\
\text { resistência à tração } \\
\text { na flexão (\%) }\end{array}$} & 1 dia & \multicolumn{2}{|c|}{0,0} & \multicolumn{2}{|c|}{$-69,7$} & \multicolumn{2}{|c|}{$-69,7$} & \multicolumn{2}{|c|}{$-69,7$} \\
\hline & 3 dias & \multicolumn{2}{|c|}{0,0} & \multicolumn{2}{|c|}{$+38,9$} & \multicolumn{2}{|c|}{$+19,7$} & \multicolumn{2}{|c|}{$+20,7$} \\
\hline & 7 dias & \multicolumn{2}{|c|}{0,0} & \multicolumn{2}{|c|}{$+3,5$} & \multicolumn{2}{|c|}{$-24,7$} & \multicolumn{2}{|c|}{$-29,4$} \\
\hline & 28 dias & \multicolumn{2}{|c|}{0,0} & \multicolumn{2}{|c|}{$-8,3$} & \multicolumn{2}{|c|}{$-16,9$} & \multicolumn{2}{|c|}{$-22,0$} \\
\hline
\end{tabular}
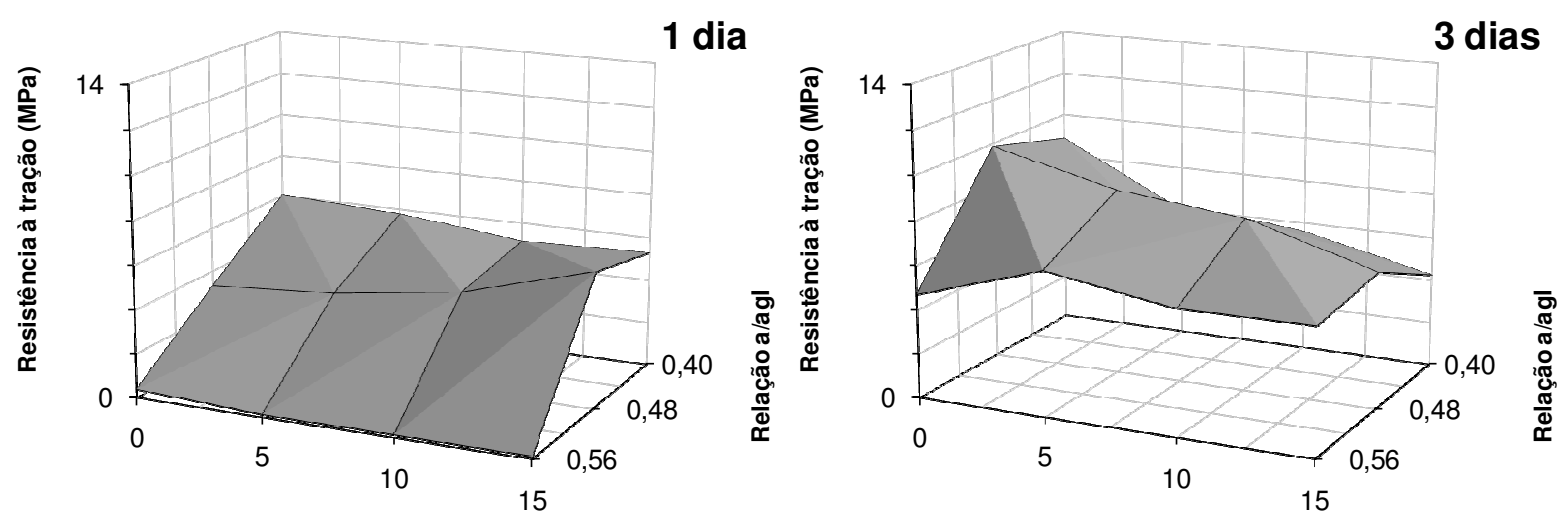

Teor de aditivo compensador de retração (SCA) (\%)

Teor de aditivo compensador de retração (SCA) (\%)

7 dias
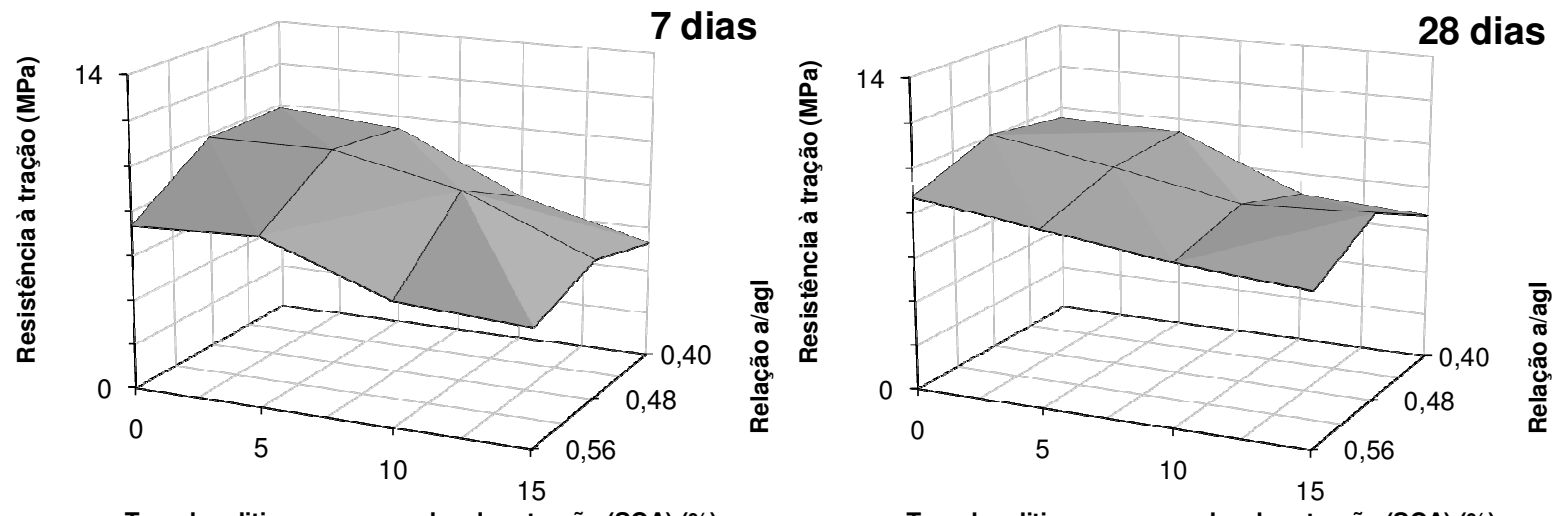

Teor de aditivo compensador de retração (SCA) (\%)

Teor de aditivo compensador de retração (SCA) (\%)

Figura 12.14 - Efeito do teor de aditivo SCA e da relação água/aglomerante na resistência à tração. 


\subsubsection{Módulo de elasticidade}

De acordo com os resultados obtidos, o módulo de elasticidade do cimento de escória ativada com silicato de sódio utilizando o aditivo compensador de retração (SCA) apresentou comportamento similar ao observado nos resultados de resistência à compressão. Apenas na mistura com relação a/agl igual a 0,40, 0 aditivo SCA causou uma diminuição do módulo de elasticidade em qualquer teor utilizado e idade ensaiada neste estudo (Figura 12.15). Mesmo em uma análise um pouco prejudicada pela elevada variabilidade dos resultados (Tabela 12.7), é possível observar uma tendência à proporcionalidade entre o aumento do teor de aditivo SCA e a diminuição do módulo de elasticidade (Figura 12.17).

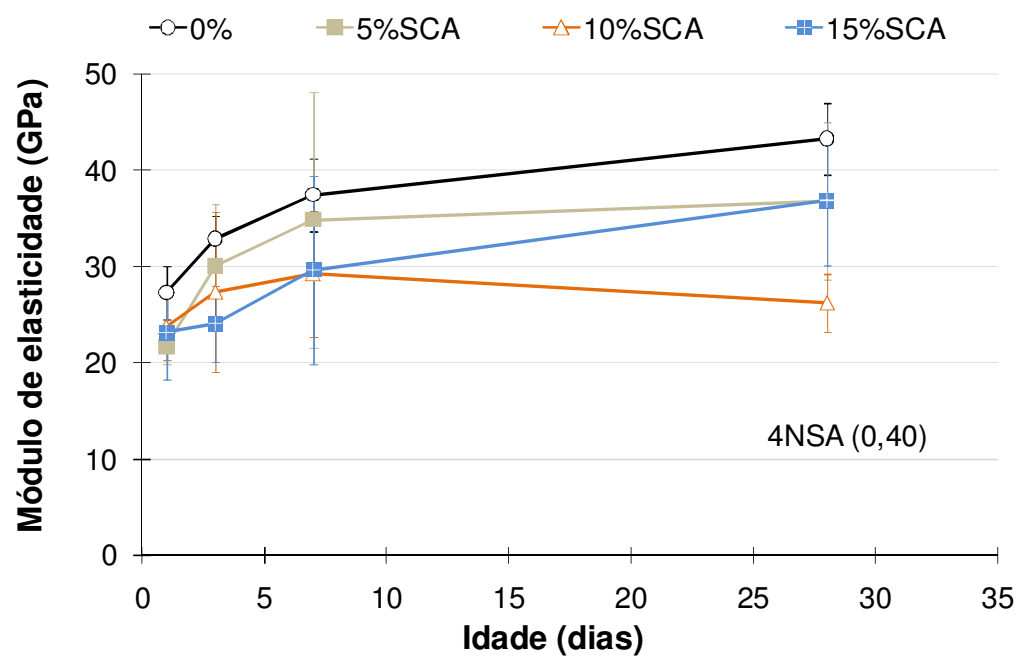

Figura 12.15 - Efeito do teor de aditivo SCA no módulo de elasticidade da argamassa de cimento de escória com relação água/aglomerante igual a 0,40.

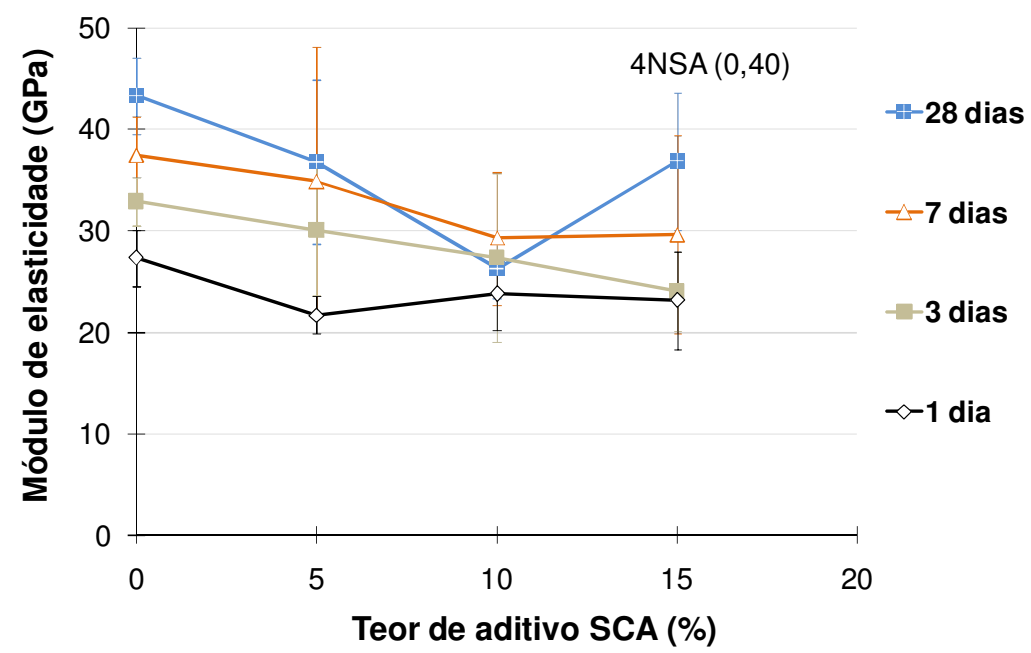

Figura 12.16 - Variação do módulo de elasticidade em função do teor de aditivo SCA na argamassa de cimento de escória com relação água/aglomerante igual a 0,40. 
Tabela 12.7 - Médias aritméticas do módulo de elasticidade e o efeito do teor de aditivo compensador de retração (SCA) no cimento de escória ativada com relação a/agl igual a $\mathbf{0 , 4 0}$. CV = coeficiente de variação em \%.

\begin{tabular}{|c|c|c|c|c|c|c|c|c|c|}
\hline \multicolumn{2}{|c|}{ Relação a/agl = 0,40 } & \multicolumn{8}{|c|}{ Teor de aditivo compensador de retração (SCA) } \\
\hline & \multirow[b]{2}{*}{ Idade } & \multicolumn{2}{|c|}{$0 \%$} & \multicolumn{2}{|c|}{$5 \%$} & \multicolumn{2}{|c|}{$10 \%$} & \multicolumn{2}{|c|}{$15 \%$} \\
\hline & & Md & $\mathrm{CV}$ & Md & $\mathrm{CV}$ & Md & $\mathrm{CV}$ & Md & $\mathrm{CV}$ \\
\hline \multirow{4}{*}{$\begin{array}{l}\text { Módulo de } \\
\text { elasticidade (GPa) }\end{array}$} & 1 dia & 27,3 & $5,2 \%$ & 21,7 & $4,3 \%$ & 23,8 & $7,5 \%$ & 23,1 & $10,6 \%$ \\
\hline & 3 dias & 32,9 & $3,7 \%$ & 30,1 & $10,9 \%$ & 27,4 & $15,5 \%$ & 24,1 & $8,4 \%$ \\
\hline & 7 dias & 37,4 & $5,2 \%$ & 34,9 & $19,4 \%$ & 29,3 & $11,4 \%$ & 29,6 & $16,8 \%$ \\
\hline & 28 dias & 43,3 & $4,4 \%$ & 36,8 & $11,3 \%$ & 26,3 & $5,8 \%$ & 36,9 & $9,3 \%$ \\
\hline \multirow{4}{*}{$\begin{array}{l}\text { Variação do módulo } \\
\text { de elasticidade (\%) }\end{array}$} & 1 dia & \multicolumn{2}{|c|}{0,0} & \multicolumn{2}{|c|}{$-20,5$} & \multicolumn{2}{|c|}{$-13,0$} & \multicolumn{2}{|c|}{$-15,2$} \\
\hline & 3 dias & \multicolumn{2}{|c|}{0,0} & \multicolumn{2}{|c|}{$-8,6$} & \multicolumn{2}{|c|}{$-16,7$} & \multicolumn{2}{|c|}{$-26,9$} \\
\hline & 7 dias & \multicolumn{2}{|c|}{0,0} & \multicolumn{2}{|c|}{$-6,9$} & \multicolumn{2}{|c|}{$-21,8$} & \multicolumn{2}{|c|}{$-20,8$} \\
\hline & 28 dias & \multicolumn{2}{|c|}{0,0} & \multicolumn{2}{|c|}{$-15,0$} & \multicolumn{2}{|c|}{$-39,3$} & \multicolumn{2}{|c|}{$-14,9$} \\
\hline
\end{tabular}

$\mathrm{Na}$ Figura 12.17 consta o efeito do aditivo compensador de retração (SCA) na evolução do módulo de elasticidade da argamassa com relação a/agl igual a 0,48. Nota-se que o aditivo SCA causou a redução do módulo de elasticidade apenas nos teores de $10 \%$ e $15 \%$, sendo os resultados com $5 \%$ de aditivo SCA similares aos observados na mistura sem aditivo (Figura 12.18 e Tabela 12.8).

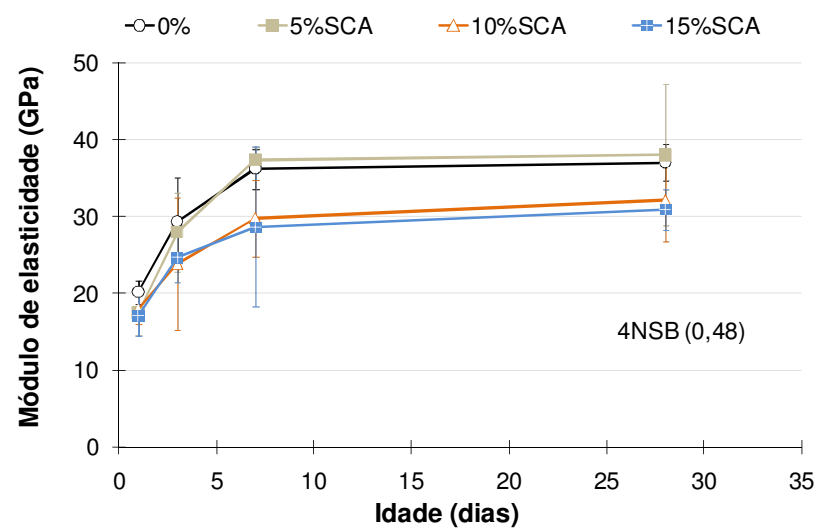

Figura 12.17 - Efeito do teor de aditivo SCA no módulo de elasticidade da argamassa de cimento de escória com relação água/aglomerante igual a 0,48.

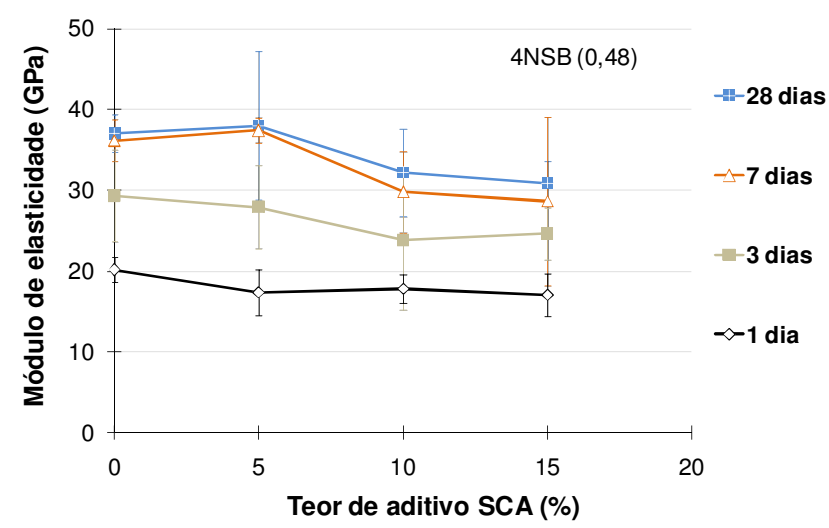

Figura 12.18 - Variação do módulo de elasticidade em função do teor de aditivo SCA na argamassa de cimento de escória com relação água/aglomerante igual a 0,48. 
Tabela 12.8 - Médias aritméticas do módulo de elasticidade e o efeito do teor de aditivo compensador de retração (SCA) no cimento de escória ativada com relação a/agl igual a $\mathbf{0 , 4 8}$. CV = coeficiente de variação em \%.

\begin{tabular}{|c|c|c|c|c|c|c|c|c|c|}
\hline \multicolumn{2}{|c|}{ Relação a/agl = 0,48 } & \multicolumn{8}{|c|}{ Teor de aditivo compensador de retração (SCA) } \\
\hline & \multirow[b]{2}{*}{ Idade } & \multicolumn{2}{|c|}{$0 \%$} & \multicolumn{2}{|c|}{$5 \%$} & \multicolumn{2}{|c|}{$10 \%$} & \multicolumn{2}{|c|}{$15 \%$} \\
\hline & & Md & $\mathrm{CV}$ & Md & $\mathrm{CV}$ & Md & $\mathrm{CV}$ & Md & $\mathrm{CV}$ \\
\hline \multirow{4}{*}{$\begin{array}{l}\text { Módulo de } \\
\text { elasticidade (GPa) }\end{array}$} & 1 dia & 20,1 & $4,0 \%$ & 17,4 & $8,4 \%$ & 17,8 & $5,1 \%$ & 17,1 & $7,8 \%$ \\
\hline & 3 dias & 29,3 & $9,9 \%$ & 27,9 & $9,4 \%$ & 23,8 & $18,5 \%$ & 24,6 & $6,7 \%$ \\
\hline & 7 dias & 36,2 & $3,7 \%$ & 37,4 & $2,1 \%$ & 29,8 & $8,6 \%$ & 28,7 & $18,6 \%$ \\
\hline & 28 dias & 37,0 & $3,2 \%$ & 38,0 & $12,4 \%$ & 32,2 & $8,6 \%$ & 30,9 & $4,4 \%$ \\
\hline \multirow{4}{*}{$\begin{array}{l}\text { Variação do módulo } \\
\text { de elasticidade (\%) }\end{array}$} & 1 dia & \multicolumn{2}{|c|}{0,0} & \multicolumn{2}{|c|}{$-13,8$} & \multicolumn{2}{|c|}{$-11,5$} & \multicolumn{2}{|c|}{$-15,3$} \\
\hline & 3 dias & \multicolumn{2}{|c|}{0,0} & \multicolumn{2}{|c|}{$-4,7$} & \multicolumn{2}{|c|}{$-18,7$} & \multicolumn{2}{|c|}{$-16,0$} \\
\hline & 7 dias & \multicolumn{2}{|c|}{0,0} & \multicolumn{2}{|c|}{$+3,3$} & \multicolumn{2}{|c|}{$-17,7$} & \multicolumn{2}{|c|}{$-20,8$} \\
\hline & 28 dias & \multicolumn{2}{|c|}{0,0} & \multicolumn{2}{|c|}{$+2,5$} & \multicolumn{2}{|c|}{$-13,1$} & \multicolumn{2}{|c|}{$-16,5$} \\
\hline
\end{tabular}

Com o aumento da relação a/agl para 0,56, observa-se na Figura 12.19 que a utilização do aditivo compensador de retração (SCA) reduz os valores de módulo de elasticidade com todos os teores estudados a partir de 3 dias de idade. Até 3 dias de idade, pode-se afirmar que o aditivo SCA não afeta o módulo de elasticidade do cimento de escória ativada com silicato de sódio na mistura com relação a/agl igual a 0,56 (Figura 12.20 e Tabela 12.9).

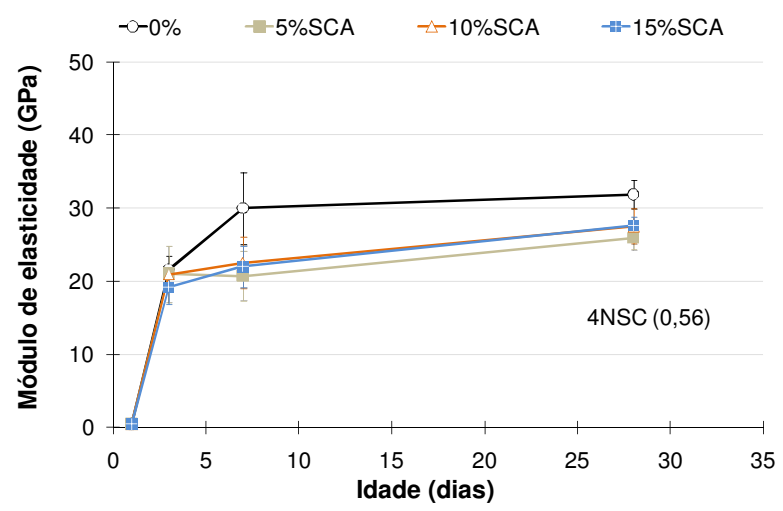

Figura 12.19 - Efeito do teor de aditivo SCA no módulo de elasticidade da argamassa de cimento de escória com relação água/aglomerante igual a 0,56.

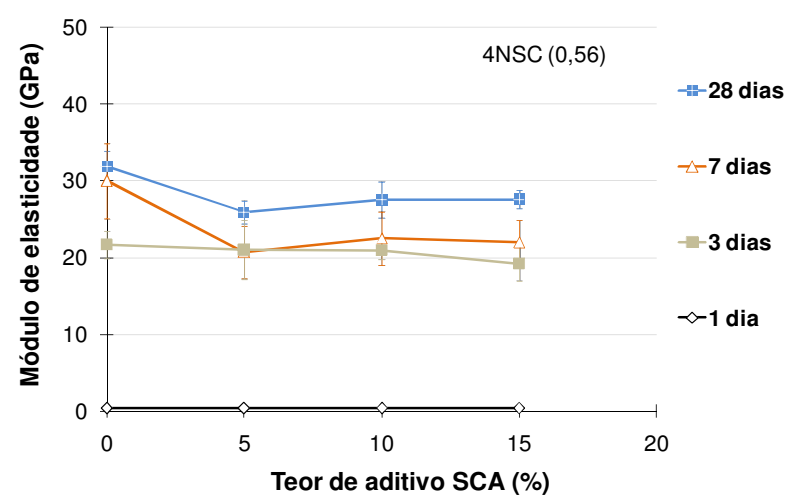

Figura 12.20 - Variação do módulo de elasticidade em função do teor de aditivo SCA na argamassa de cimento de escória com relação água/aglomerante igual a 0,56. 
Tabela 12.9 - Médias aritméticas do módulo de elasticidade e o efeito do teor de aditivo compensador de retração (SCA) no cimento de escória ativada com relação a/agl igual a 0,56. CV = coeficiente de variação em \%.

\begin{tabular}{|c|c|c|c|c|c|c|c|c|c|}
\hline \multicolumn{2}{|c|}{ Relação a/agl = 0,56 } & \multicolumn{8}{|c|}{ Teor de aditivo compensador de retração (SCA) } \\
\hline & \multirow[b]{2}{*}{ Idade } & \multicolumn{2}{|c|}{$0 \%$} & \multicolumn{2}{|c|}{$5 \%$} & \multicolumn{2}{|c|}{$10 \%$} & \multicolumn{2}{|c|}{$15 \%$} \\
\hline & & Md & $\mathrm{CV}$ & Md & $\mathrm{CV}$ & Md & $\mathrm{CV}$ & Md & $\mathrm{CV}$ \\
\hline \multirow{4}{*}{$\begin{array}{l}\text { Módulo de } \\
\text { elasticidade (GPa) }\end{array}$} & 1 dia & 0,4 & $20,4 \%$ & 0,4 & $20,4 \%$ & $\overline{0,4}$ & $20,4 \%$ & 0,4 & $20,4 \%$ \\
\hline & 3 dias & 21,7 & $4,3 \%$ & 21,0 & $9,2 \%$ & 21,0 & $2,9 \%$ & 19,2 & $6,0 \%$ \\
\hline & 7 dias & 30,0 & $8,4 \%$ & 20,7 & $8,3 \%$ & 22,6 & $7,9 \%$ & 22,0 & $6,5 \%$ \\
\hline & 28 dias & 31,9 & $3,2 \%$ & 25,9 & $2,9 \%$ & 27,5 & $4,4 \%$ & 27,6 & $2,1 \%$ \\
\hline \multirow{4}{*}{$\begin{array}{l}\text { Variação do módulo } \\
\text { de elasticidade (\%) }\end{array}$} & 1 dia & \multicolumn{2}{|c|}{0,0} & \multicolumn{2}{|c|}{$+0,0$} & \multicolumn{2}{|c|}{$+0,0$} & \multicolumn{2}{|c|}{$+0,0$} \\
\hline & 3 dias & \multicolumn{2}{|c|}{0,0} & \multicolumn{2}{|c|}{$-3,0$} & \multicolumn{2}{|c|}{$-3,2$} & \multicolumn{2}{|c|}{$-11,2$} \\
\hline & 7 dias & \multicolumn{2}{|c|}{0,0} & \multicolumn{2}{|c|}{$-30,9$} & \multicolumn{2}{|c|}{$-24,8$} & \multicolumn{2}{|c|}{$-26,6$} \\
\hline & 28 dias & \multicolumn{2}{|c|}{0,0} & \multicolumn{2}{|c|}{$-18,7$} & \multicolumn{2}{|c|}{$-13,7$} & \multicolumn{2}{|c|}{$-13,4$} \\
\hline
\end{tabular}

Na Figura 12.21 constam os gráficos do efeito da interação do teor de aditivo SCA e a relação a/agl no módulo de elasticidade do cimento de escória ativada com silicato de sódio. Observa-se que com 1 dia de idade, o aumento da relação a/agl causou maior efeito do que o aumento do teor de aditivo SCA, a partir desta idade a diminuição do módulo de elasticidade sempre ocorre com a utilização dos teores de $10 \%$ e $15 \%$ de aditivo SCA.

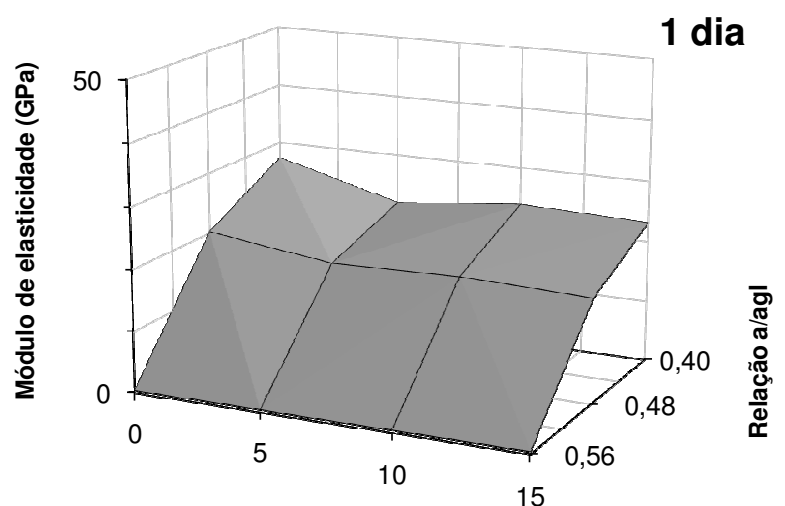

Teor de aditivo compensador de retração (SCA) (\%)

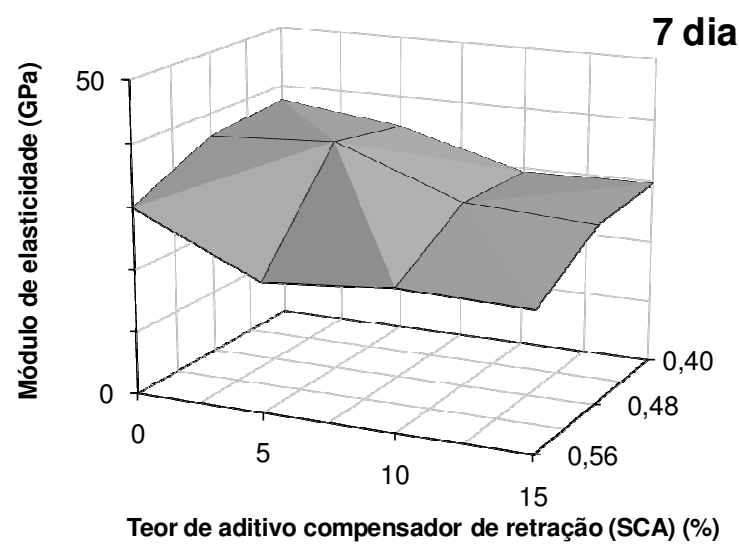

3 dias

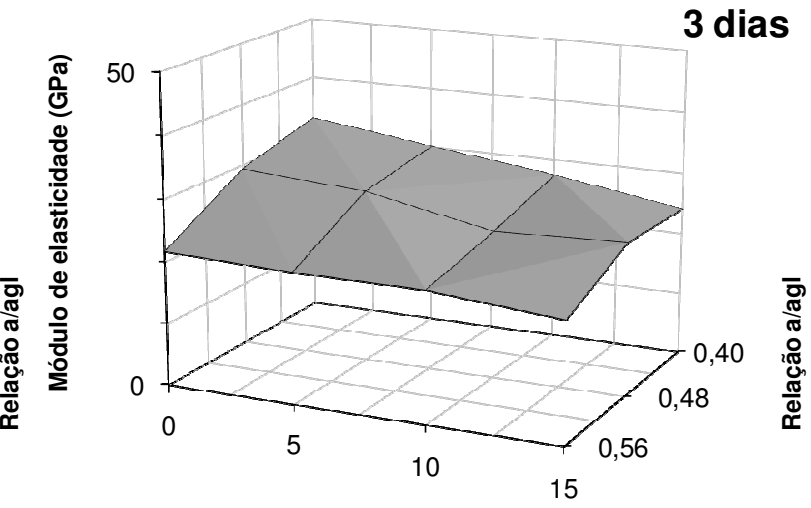

Teor de aditivo compensador de retração (SCA) (\%)

28 dias

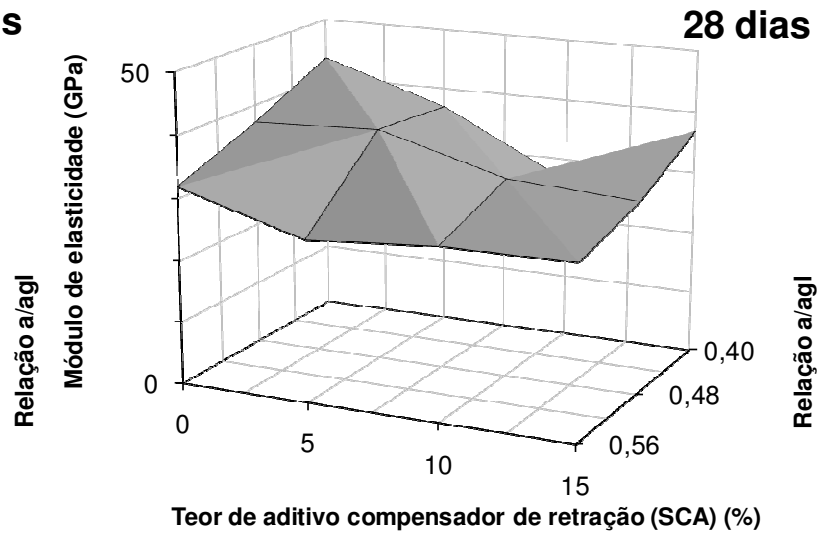

Figura 12.21 - Efeito da interação entre o teor de aditivo SCA e a relação água/aglomerante no módulo de elasticidade. 


\subsection{Discussão e conclusões}

O aditivo compensador de retração (SCA) foi responsável pela diminuição da resistência mecânica do cimento de escória ativada com silicato de sódio, porém, isto já era esperado pelo simples fato da utilização deste tipo de aditivo incorrer em uma "substituição" do cimento de escória, pois são utilizados teores elevados. Como o teor máximo utilizado neste trabalho foi de $15 \%$ da massa de aglomerantes, é de se supor que os resultados das propriedades mecânicas apresentem um decréscimo máximo em torno deste valor, visto que os produtos hidratados oriundos do aditivo SCA não são caracterizados como colaboradores para a resistência.

No entanto, os resultados indicam reduções das propriedades mecânicas acima dos teores de aditivo SCA utilizados, alcançando em torno de $60 \%$ de redução na mistura com relação a/agl igual a 0,40 e $15 \%$ de aditivo SCA. Este fato pode ser explicado pelos resultados de caracterização da microestrutura, onde é possível afirmar que o aditivo SCA incorre no aumento da porosidade total e da proporção de macroporos, assim como interfere na hidratação do cimento de escória, diminuindo a quantidade de $\mathrm{C}-\mathrm{S}-\mathrm{H}$ formado.

Quando se compara com o efeito do aditivo redutor de retração (SRA), está claro que 0 aditivo compensador de retração (SCA) afeta menos as propriedades mecânicas do cimento de escória nas primeiras idades, porém aos 28 dias são observadas reduções maiores do que as observadas com a utilização do aditivo SRA. Na interação da relação a/agl com o teor de aditivo SCA foi constatada a redução mais intensa das propriedades mecânicas na mistura com menor relação a/agl quando comparado com as demais relações estudadas. Com a diminuição da relação a/agl é possível que ocorra a falta de disponibilidade de água para o avanço das reações de hidratação do aditivo e do cimento de escória a contento.

Portanto, conclui-se que a utilização do aditivo SCA reduz a resistência mecânica do cimento de escória ativada com silicato de sódio, porém, não de modo que inviabilize seu uso em aplicação que necessitem de resistência nas primeiras idades. Deve-se atentar para a interação da relação a/agl com o aditivo SCA, pois, com relações muito baixas, a utilização do aditivo SCA e o aumento do seu teor 
afeta com maior intensidade as propriedades mecânicas deste tipo de cimento. Conforme descrito na análise do efeito da relação a/agl na retração por secagem e autógena do cimento de escória ativada com silicato de sódio (Capítulo 8, pág.123), a diminuição da relação a/agl é eficiente na redução da retração por secagem e autógena deste tipo de cimento, portanto, é salutar que todos os parâmetros que possivelmente interfiram no uso sejam analisados de forma abrangente. Deste modo é possível combinar relações a/agl com diferentes teores de SCA para usos específicos. 


\section{Capítulo 13 Retração por secagem e autógena}

\subsection{Retração por secagem}

O efeito do teor de aditivo compensador de retração (SCA) na retração por secagem do cimento de escória nas três relações a/agl estudadas está apresentado na Figura 13.1. Independentemente da relação a/agl, observa-se que o aditivo SCA foi eficiente na redução da retração por secagem, sendo a redução proporcional ao aumento do teor de aditivo SCA. Quanto à evolução da retração por secagem, observa-se que o aumento do teor do aditivo SCA causou, além da redução, a desaceleração da retração por secagem. Na mistura com relação a/agl igual a 0,56 a desaceleração foi mais intensa, de modo que o perfil da curva de retração foi alterado com o aumento do teor de aditivo para uma evolução gradual da retração, ao invés da evolução abrupta e posterior evolução gradual que caracteriza as misturas sem o uso do aditivo. Em nenhuma das relações a/agl e teores de aditivo SCA estudados foi constatada a expansão de modo a compensar a retração por secagem, sendo provável que a expansão ocorrida tenha sido capaz apenas de amenizar a retração por secagem.

A análise do efeito da interação entre a relação a/agl e o teor de aditivo SCA na retração por secagem consta da Figura 13.2. Observa-se que o comportamento foi similar em todas as idades, ocorrendo o melhor desempenho do aditivo SCA nos extremos da relação a/agl estudadas, 0,40 e 0,56, e no maior de teor de aditivo empregado, 15\%. Este comportamento pode indicar que o aditivo SCA se comporta de modo distinto no cimento de escória com a utilização de uma relação a/agl baixa ou alta. Conforme descrito na análise da variação de massa por evaporação com a utilização do aditivo SCA, com pouca disponibilidade de água, o aditivo SCA diminui a retração por secagem mais em função do seu efeito no desenvolvimento da microestrutura do que propriamente pela expansão gerada. 
(a) $-0 \%$ SCA $\quad-5 \%$ SCA $-\square-10 \%$ SCA $\rightarrow-15 \%$ SCA
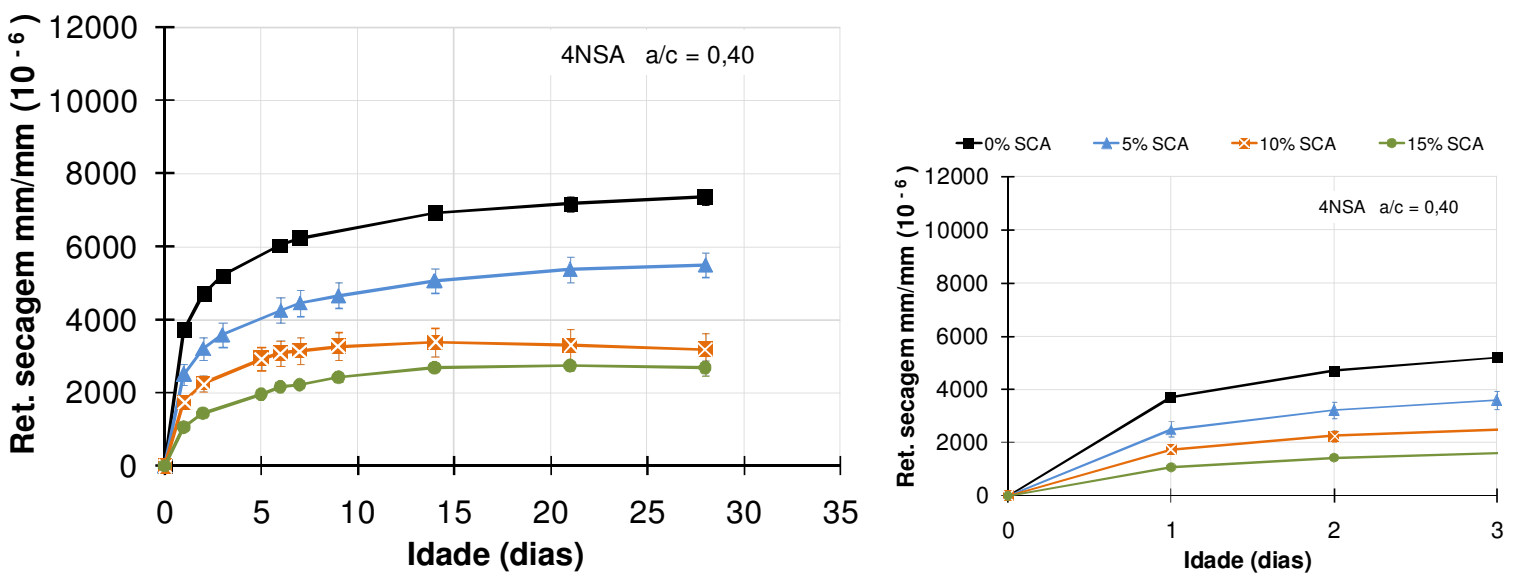

(b)
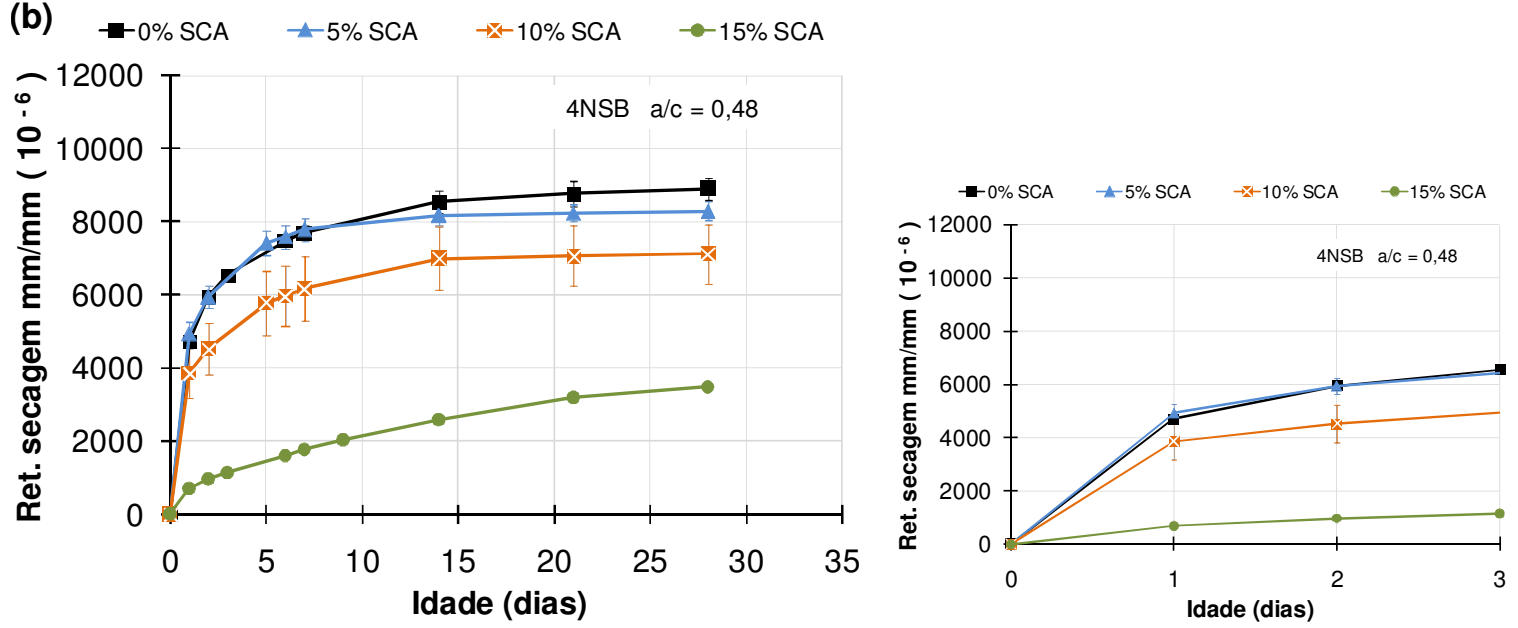

(c) $\rightarrow-0 \% \mathrm{SCA} \quad \pm-5 \% \mathrm{SCA} \quad \rightarrow-10 \% \mathrm{SCA} \quad \rightarrow-15 \% \mathrm{SCA}$
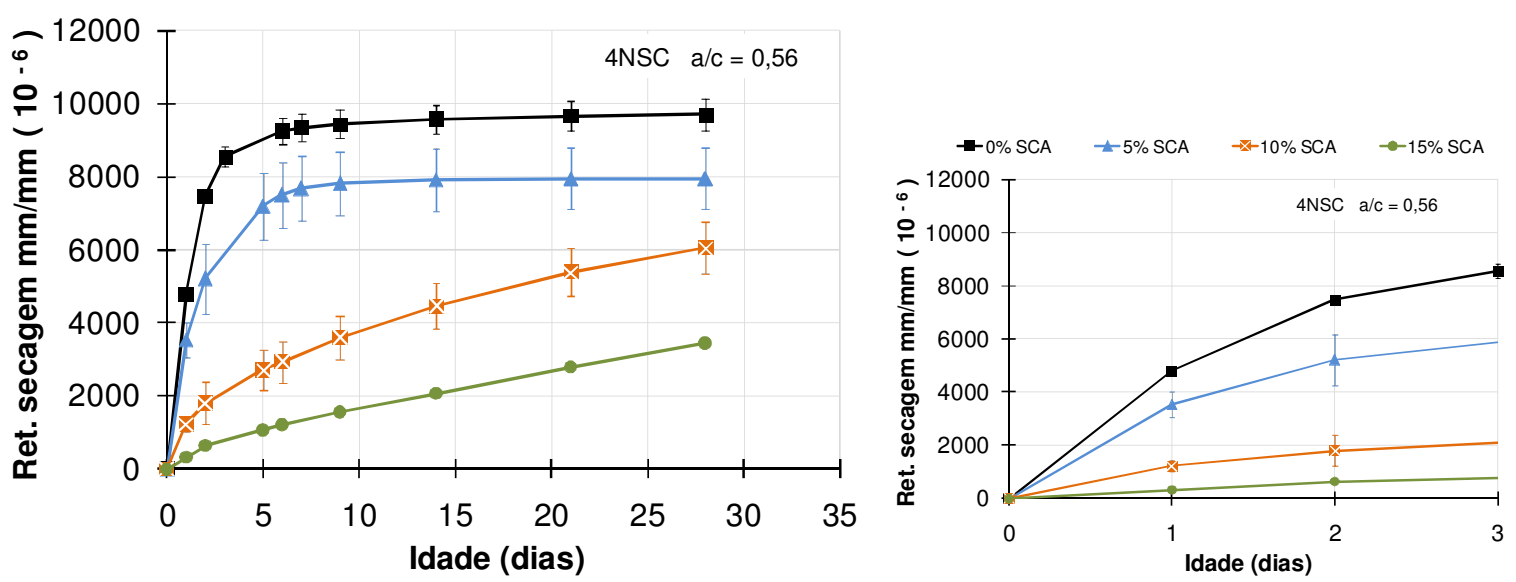

Figura 13.1 - Efeito do teor de aditivo compensador de retração (SCA) na retração por secagem das argamassas de cimento de escória ativada com relação a/agl igual 0,40 (a), 0,48 (b) e 0,56 (c). 
Na mistura com relação a/agl igual a 0,48, o acréscimo de água resulta na facilitação da hidratação do aditivo SCA, e também favorece a hidratação do cimento de escória, reduzindo a competição pela água entre o aditivo e o cimento de escória ativada com silicato de sódio. No balanço entre o melhor rendimento da expansão e o desenvolvimento da retração por secagem, fica claro que a maior disponibilidade de água provoca a redução da retração por secagem, porém sem atingir valores próximos aos obtidos com as misturas com relação a/agl igual a 0,40 e 0,56. Com o aumento da relação a/agl para 0,56, o balanço tende para o lado da expansão gerada pelo aditivo SCA e, conseqüentemente, na maior redução da retração por secagem relativa à mistura sem aditivo SCA.

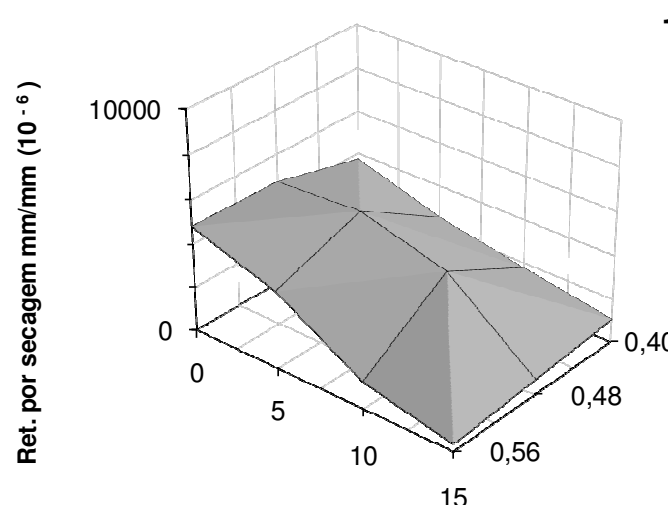

1 dia

3 dias

Teor de aditivo compensador de retração (SCA) (\%)

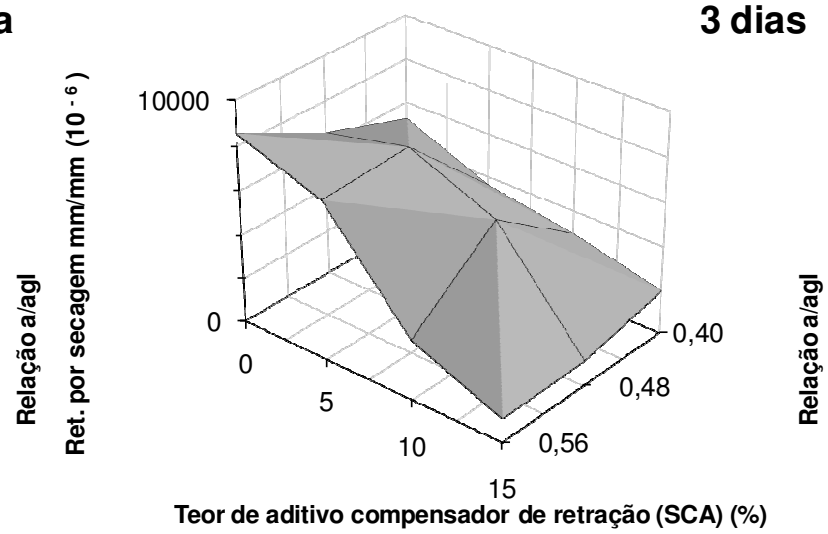

7 dias
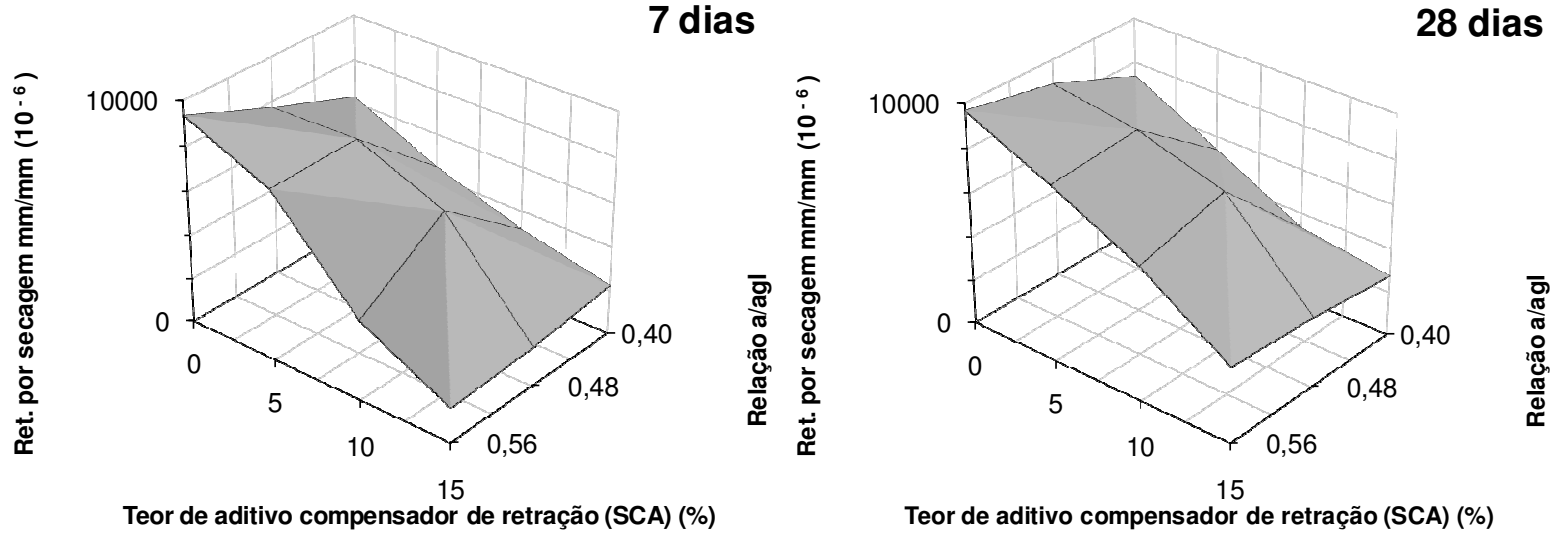

Figura 13.2 - Efeito da interação entre o teor de aditivo SCA e a relação água/aglomerante na retração por secagem.

Na Figura 13.3 consta a correlação entre a retração por secagem e o teor de aditivo compensador de retração (SCA) para as três relações a/agl estudadas. Observa-se a correlação entre a diminuição da retração por secagem e o aumento do teor de aditivo SCA em todas as relações a/agl. Confirma-se que o aumento da relação 
a/agl proporciona o melhor desempenho do aditivo SCA na geração da expansão, pois o coeficiente angular da reta de ajuste aumenta com o aumento da relação a/agl, indicando que ocorreu maior taxa de redução da retração por secagem. No entanto, é importante ressaltar que o efeito da relação a/agl foi preponderante na magnitude da retração por secagem, pois, independentemente do aditivo empregado, a diminuição da relação a/agl resulta na diminuição da retração por secagem.

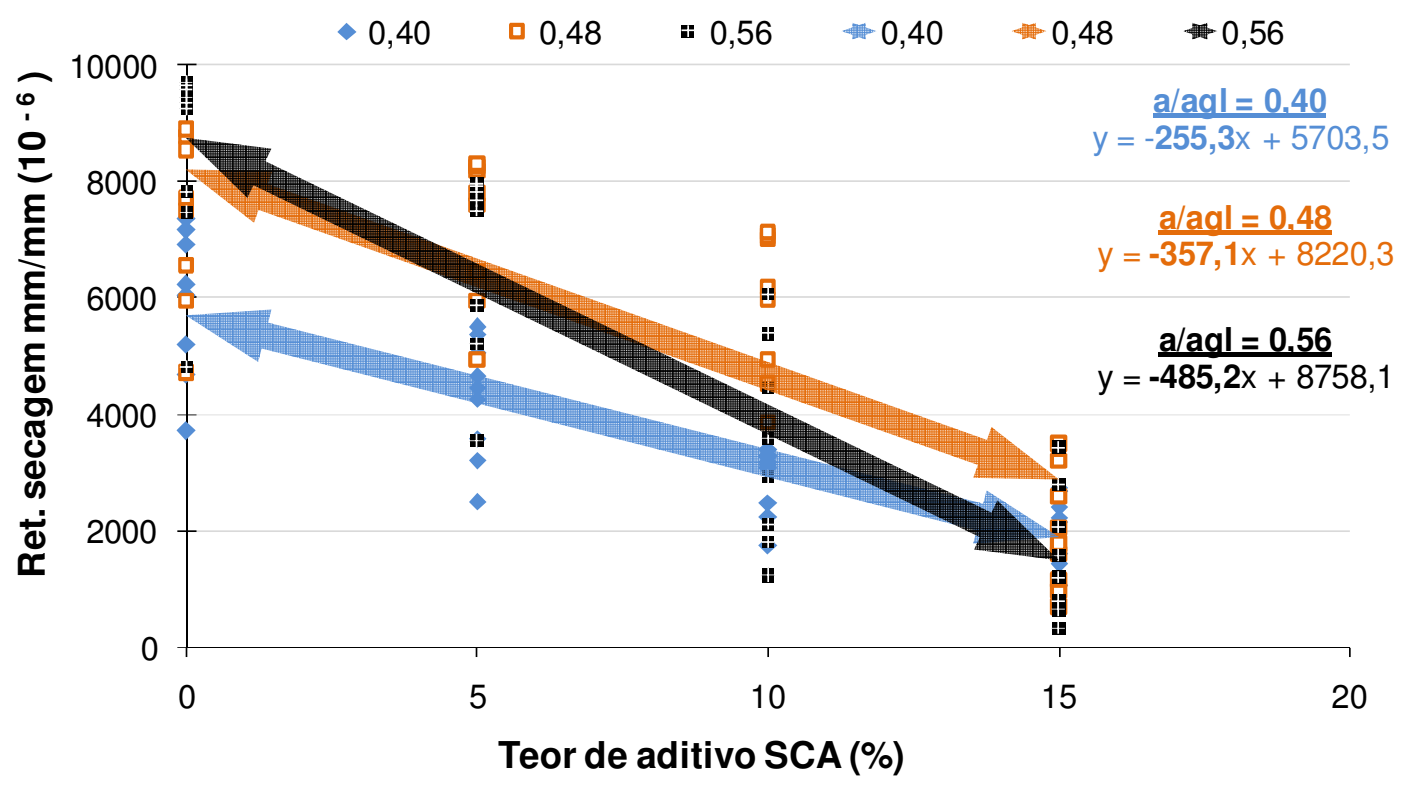

Figura 13.3 - Efeito do teor de aditivo compensador de retração (SCA) na retração por secagem das argamassas de cimento de escória ativada com relação a/agl igual 0,40, 0,48 e 0,56. Gráficos construídos com todos os pontos obtidos.

Tomando-se a mistura sem aditivo como referência, o cálculo indica que a utilização do aditivo SCA proporcionou a redução da retração por secagem em todas as idades e em todos os teores empregados nas três relações a/agl estudadas (Tabela 13.1, Tabela 13.2 e Tabela 13.3). Aos 28 dias, a redução na retração por secagem foi da ordem de $65 \%$ com a utilização de teor igual a $15 \%$, independentemente da relação a/agl, o que permite concluir que o aumento da relação a/agl tem um efeito bastante significativo na taxa de redução da retração por secagem, mas que a redução final, em termos percentuais, é similar para as três relações a/agl estudadas. 
Tabela 13.1 - Médias aritméticas da retração por secagem e o efeito do teor de aditivo compensador de retração (SCA) no cimento de escória ativada com relação a/agl igual a $\mathbf{0 , 4 0}$. CV = coeficiente de variação em \%.

\begin{tabular}{|c|c|c|c|c|c|c|c|c|c|}
\hline \multicolumn{2}{|c|}{ Relação a/agl = 0,40 } & \multicolumn{8}{|c|}{ Teor de aditivo compensador de retração (SCA) } \\
\hline & & \multicolumn{2}{|c|}{$0 \%$} & \multicolumn{2}{|c|}{$5 \%$} & \multicolumn{2}{|c|}{$10 \%$} & \multicolumn{2}{|c|}{$15 \%$} \\
\hline & Idade & Rsec & $\overline{c V}$ & Rsec & $\mathrm{CV}$ & Rsec & $\mathrm{CV}$ & Rsec & $\mathrm{CV}$ \\
\hline \multirow{4}{*}{$\begin{array}{l}\text { Retração por } \\
\text { secagem } \\
\mathrm{mm} / \mathrm{mm}\left(10^{-6}\right)\end{array}$} & $1 \mathrm{dia}$ & 3708,3 & $0,8 \%$ & 2496,9 & $5,9 \%$ & 1741,5 & $5,1 \%$ & 1060,8 & $1,5 \%$ \\
\hline & 3 dias & 5200,2 & $1,1 \%$ & 3584,8 & $4,7 \%$ & 2473,1 & $5,0 \%$ & 1606,4 & $0,4 \%$ \\
\hline & 7 dias & 6226,5 & $1,2 \%$ & 4452,5 & $4,1 \%$ & 3140,0 & $5,8 \%$ & 2223,0 & $0,8 \%$ \\
\hline & 28 dias & 7356,5 & $1,5 \%$ & 5497,9 & $3,1 \%$ & 3188,2 & $7,2 \%$ & 2674,2 & $3,7 \%$ \\
\hline \multirow{4}{*}{$\begin{array}{l}\text { Variação da } \\
\text { retração por } \\
\text { secagem (\%) }\end{array}$} & 1 dia & \multicolumn{2}{|c|}{0,0} & \multicolumn{2}{|c|}{$-32,7$} & \multicolumn{2}{|c|}{$-53,0$} & \multicolumn{2}{|c|}{$-71,4$} \\
\hline & $3 d$ & \multicolumn{2}{|c|}{0,0} & \multicolumn{2}{|c|}{$-31,1$} & \multicolumn{2}{|c|}{$-52,4$} & \multicolumn{2}{|c|}{$-69,1$} \\
\hline & 7 dias & \multirow{2}{*}{\multicolumn{2}{|c|}{0,0}} & \multicolumn{2}{|c|}{$-28,5$} & \multicolumn{2}{|c|}{$-49,6$} & \multicolumn{2}{|c|}{$-64,3$} \\
\hline & 28 dias & & & \multicolumn{2}{|c|}{$-25,3$} & \multicolumn{2}{|c|}{$-56,7$} & \multicolumn{2}{|c|}{$-63,6$} \\
\hline
\end{tabular}

Tabela 13.2 - Médias aritméticas da retração por secagem e o efeito do teor de aditivo compensador de retração (SCA) no cimento de escória ativada com relação a/agl igual a $\mathbf{0 , 4 8}$. CV = coeficiente de variação em \%.

\begin{tabular}{|c|c|c|c|c|c|c|c|c|c|}
\hline \multicolumn{2}{|c|}{ Relação a/agl = 0,48 } & \multicolumn{8}{|c|}{ Teor de aditivo compensador de retração (SCA) } \\
\hline & \multirow[b]{2}{*}{ Idade } & \multicolumn{2}{|c|}{$0 \%$} & \multicolumn{2}{|c|}{$5 \%$} & \multicolumn{2}{|c|}{$10 \%$} & \multicolumn{2}{|c|}{$15 \%$} \\
\hline & & Rsec & $\mathrm{CV}$ & Rsec & $\mathrm{CV}$ & Rsec & $\mathrm{CV}$ & Rsec & $\mathrm{CV}$ \\
\hline \multirow{4}{*}{$\begin{array}{l}\text { Retração por } \\
\text { secagem } \\
\mathrm{mm} / \mathrm{mm}\left(10^{-6}\right)\end{array}$} & $1 \mathrm{dia}$ & 4714,1 & $0,3 \%$ & 4940,5 & $3,3 \%$ & 3860,4 & $9,2 \%$ & 693,7 & $3,8 \%$ \\
\hline & 3 dias & 6554,1 & $1,2 \%$ & 6437,4 & $2,5 \%$ & 4940,1 & $8,0 \%$ & 1142,9 & $2,7 \%$ \\
\hline & 7 dias & 7712,3 & $1,2 \%$ & 7791,2 & $2,1 \%$ & 6174,0 & $7,2 \%$ & 1773,5 & $2,4 \%$ \\
\hline & 28 dias & 8899,8 & $1,8 \%$ & 8300,2 & $1,5 \%$ & 7125,1 & $5,8 \%$ & 3190,4 & $1,2 \%$ \\
\hline \multirow{4}{*}{$\begin{array}{l}\text { Variação da } \\
\text { retração por } \\
\text { secagem (\%) }\end{array}$} & $1 \mathrm{dia}$ & \multicolumn{2}{|c|}{0,0} & \multicolumn{2}{|c|}{4,8} & \multicolumn{2}{|c|}{$-18,1$} & \multicolumn{2}{|c|}{$-85,3$} \\
\hline & 3 dias & \multirow{2}{*}{\multicolumn{2}{|c|}{0,0}} & \multicolumn{2}{|c|}{$-1,8$} & \multicolumn{2}{|c|}{$-24,6$} & \multicolumn{2}{|c|}{$-82,6$} \\
\hline & 7 dias & & & \multicolumn{2}{|c|}{1,0} & \multicolumn{2}{|c|}{$-19,9$} & \multicolumn{2}{|c|}{$-77,0$} \\
\hline & 28 dias & \multicolumn{2}{|c|}{$\begin{array}{l}0,0 \\
0,0\end{array}$} & \multicolumn{2}{|c|}{$-6,7$} & \multicolumn{2}{|c|}{$-19,9$} & \multicolumn{2}{|c|}{$-64,2$} \\
\hline
\end{tabular}

Tabela 13.3 - Médias aritméticas da retração por secagem e o efeito do teor de aditivo compensador de retração $(\mathbf{S C A})$ no cimento de escória ativada com relação a/agl igual a $\mathbf{0 , 5 6}$. $\mathrm{CV}=$ coeficiente de variação em \%.

\begin{tabular}{|c|c|c|c|c|c|c|c|c|c|}
\hline \multicolumn{2}{|c|}{ Relação a/agl = 0,56 } & \multicolumn{8}{|c|}{ Teor de aditivo compensador de retração (SCA) } \\
\hline & \multirow[b]{2}{*}{ Idade } & \multicolumn{2}{|c|}{$0 \%$} & \multicolumn{2}{|c|}{$5 \%$} & \multicolumn{2}{|c|}{$10 \%$} & \multicolumn{2}{|c|}{$15 \%$} \\
\hline & & Rsec & $\mathrm{CV}$ & Rsec & $\mathrm{CV}$ & Rsec & $\mathrm{CV}$ & Rsec & $\mathrm{CV}$ \\
\hline \multirow{4}{*}{$\begin{array}{l}\text { Retração por } \\
\text { secagem } \\
\mathrm{mm} / \mathrm{mm}\left(10^{-6}\right)\end{array}$} & $1 \mathrm{dia}$ & 4805,8 & $0,9 \%$ & 3539,1 & $10,9 \%$ & 1230,9 & $8,9 \%$ & 328,3 & $5,2 \%$ \\
\hline & 3 dias & 8547,6 & $1,6 \%$ & 5866,2 & $12,8 \%$ & 2106,0 & $13,8 \%$ & 784,7 & $1,1 \%$ \\
\hline & 7 dias & 9349,2 & $2,0 \%$ & 7675,7 & $9,2 \%$ & 3592,8 & $8,6 \%$ & 1564,8 & $0,6 \%$ \\
\hline & 28 dias & 9666,1 & $2,2 \%$ & 7956,8 & $8,5 \%$ & 6056,0 & $5,9 \%$ & 3434,3 & $1,0 \%$ \\
\hline \multirow{4}{*}{$\begin{array}{l}\text { Variação da } \\
\text { retração por } \\
\text { secagem (\%) }\end{array}$} & 1 dia & \multicolumn{2}{|l|}{0,0} & \multicolumn{2}{|c|}{$-26,4$} & \multicolumn{2}{|c|}{$-74,4$} & \multicolumn{2}{|c|}{$-93,2$} \\
\hline & 3 dias & \multicolumn{2}{|c|}{0,0} & \multicolumn{2}{|c|}{$-31,4$} & \multicolumn{2}{|c|}{$-75,4$} & \multicolumn{2}{|c|}{$-90,8$} \\
\hline & 7 dias & \multicolumn{2}{|c|}{0,0} & \multicolumn{2}{|c|}{$-17,9$} & \multicolumn{2}{|c|}{$-61,6$} & \multicolumn{2}{|c|}{$-83,3$} \\
\hline & 28 dias & \multicolumn{2}{|l|}{0,0} & \multicolumn{2}{|c|}{$-17,7$} & \multicolumn{2}{|c|}{-37.3} & \multicolumn{2}{|c|}{$-64,5$} \\
\hline
\end{tabular}


Na Figura 13.4 consta o efeito do teor de aditivo compensador de retração (SCA) na variação de massa por evaporação das argamassas de cimento de escória ativada nas três relações a/agl estudadas. Esta análise evidenciou o papel da relação a/agl na utilização do aditivo SCA neste tipo de cimento, pois, com baixa relação a/agl (Figura 13.4(a)) tem-se maior quantidade de água perdida para o ambiente com a utilização do aditivo SCA, indicando que a pouca disponibilidade de água afeta tanto a hidratação do aditivo quanto a do cimento de escória. Com o aumento da relação a/agl para 0,48 (Figura 13.4(b)), observa-se ainda uma elevada evaporação de água com a utilização do aditivo SCA, porém, já é possível observar que o teor de $15 \%$ de aditivo apresenta menor quantidade de água liberada do que nos demais teores, indicando melhores condições de hidratação do aditivo. Com o aumento da relação a/agl para 0,56 (Figura 13.4(c)), o perfil dos resultados altera-se completamente, pois, a utilização do aditivo SCA incorre em uma redução da variação de massa por evaporação, decorrente da menor disponibilidade de água livre para evaporação em função da maior hidratação do aditivo SCA.

Com a análise da correlação entre a variação de massa por evaporação e o teor de aditivo (Figura 13.5), confirma-se que a utilização do aditivo SCA, assim como o aumento do teor de aditivo, incorre na maior quantidade de água perdida por evaporação nas misturas com relação a/agl igual a 0,40 e 0,48 (Figura 13.5(a)(b)). Na mistura com relação a/agl igual a 0,56 (Figura 13.5(c)), observa-se que, de modo geral, ocorre a redução da evaporação de água, sendo esta redução mais intensa até 7 dias de idade, o que se assemelha ao período de maior velocidade de hidratação do aditivo compensador de retração (SCA).

Portanto, de acordo com os resultados obtidos, é possível dividir o comportamento do aditivo SCA no cimento de escória em dois perfis baseados na disponibilidade de água: (a) com pouca disponibilidade ocorre maior interferência do aditivo SCA na hidratação do cimento escória, resultando em uma redução da retração por secagem, sendo esta mais em função de alterações no desenvolvimento da microestrutura, do que pela expansão gerada pelo aditivo; e, (b) com grande disponibilidade de água ocorre o melhor rendimento da hidratação do aditivo SCA, resultando na redução da retração por secagem com maior intensidade em função da expansão gerada pelo aditivo. 

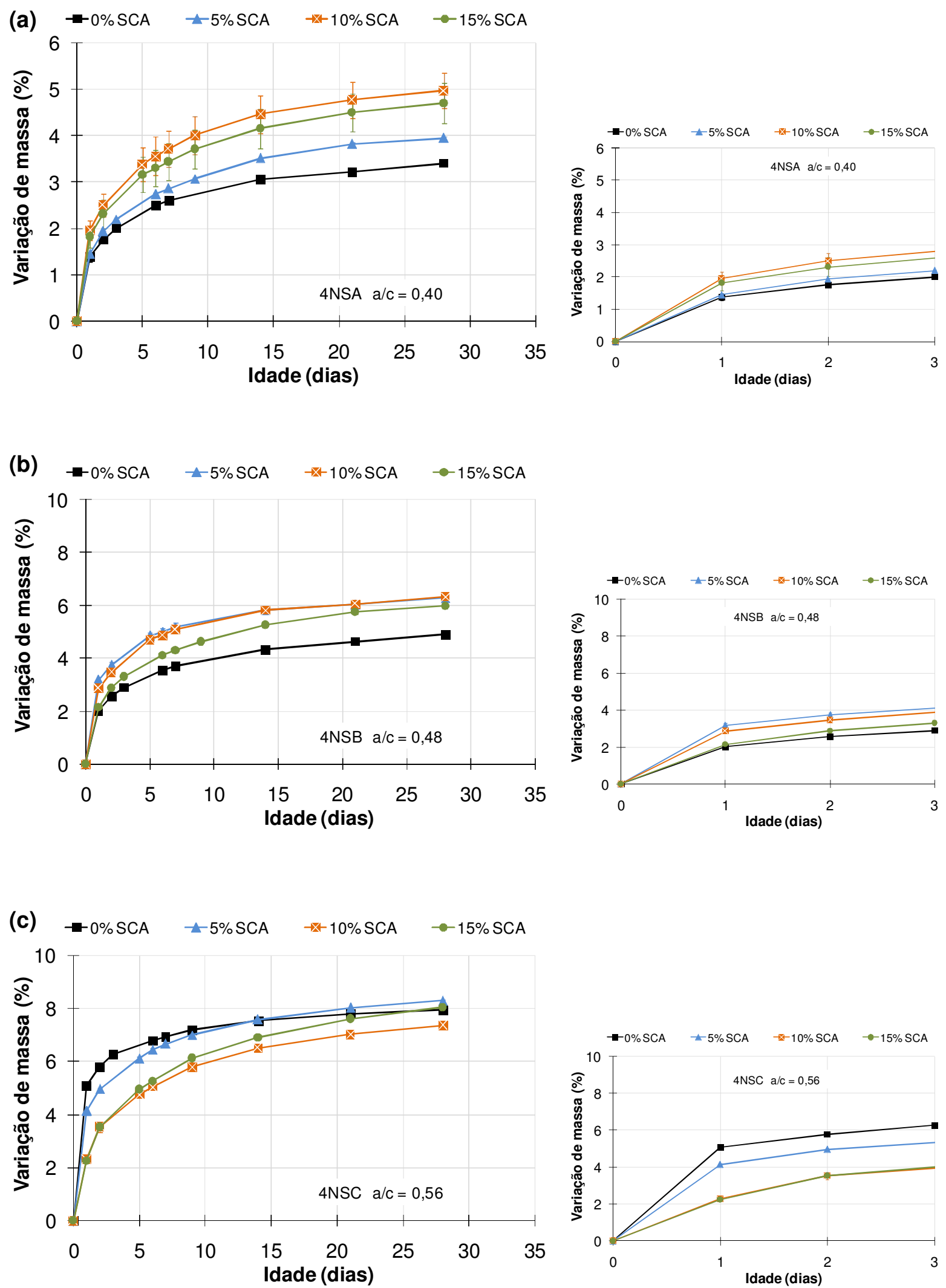

Figura 13.4 - Efeito do teor de aditivo compensador de retração (SCA) na variação de massa por evaporação das argamassas de cimento de escória ativada com relação a/agl igual 0,40 (a), 0,48 (b) e 0,56 (c). 

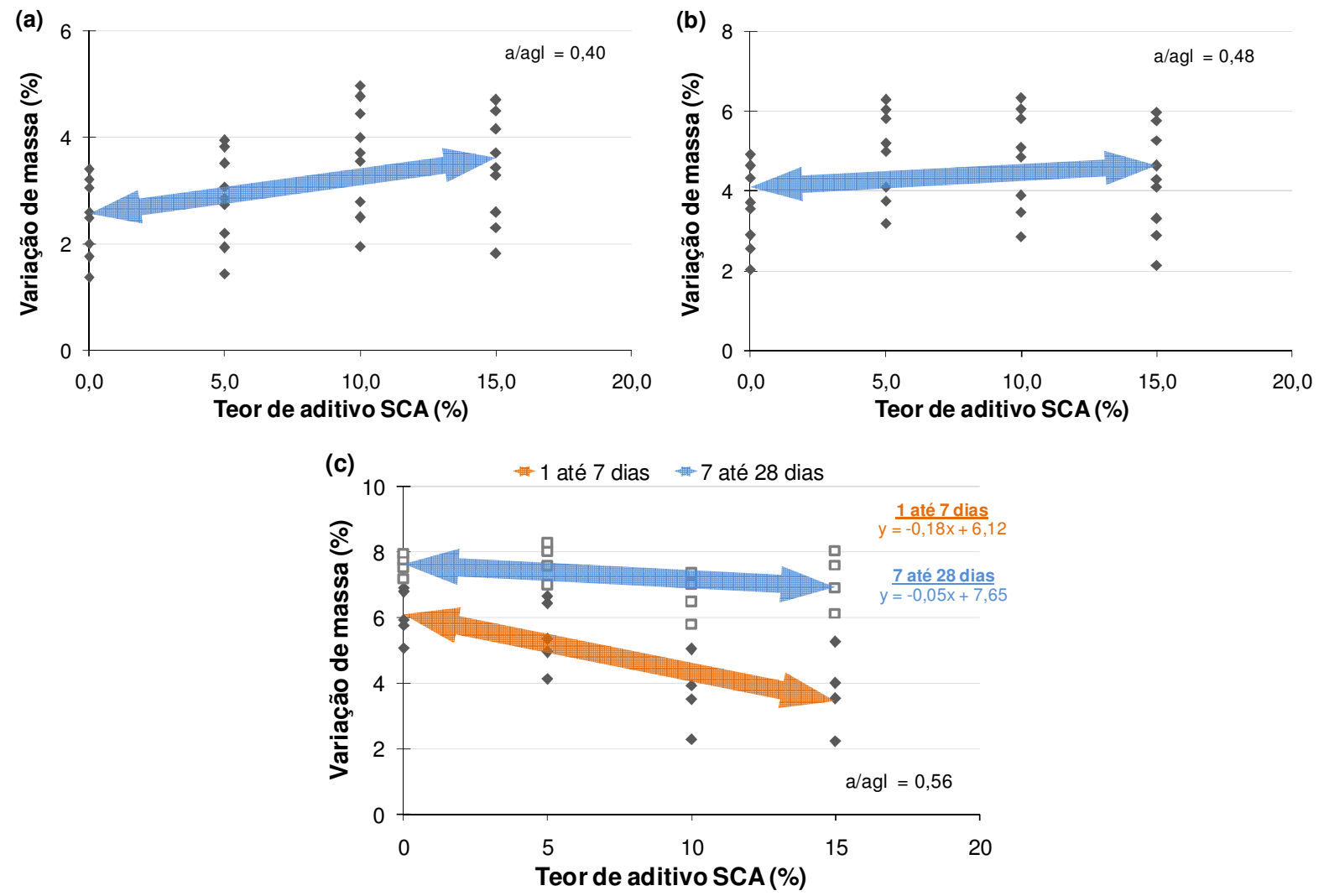

Figura 13.5 - Efeito do teor de aditivo compensador de retração (SCA) na variação de massa por evaporação das argamassas de cimento de escória ativada com relação a/agl igual 0,40 (a), 0,48 (b) e 0,56 (c). Gráficos construídos com todos os pontos obtidos.

\subsubsection{Retração por secagem versus perda de massa por evaporação}

Para analisar o efeito do aditivo compensador de retração (SCA) foi empregada a mesma análise utilizada para correlacionar a retração por secagem e a perda de massa por evaporação descrita no item 8.1.1.1 (pág.128). Na Figura 13.6 está o perfil da curva de correlação para a mistura com relação a/agl igual a 0,40 e sem a utilização do aditivo SCA, na qual se observa a existência de dois trechos caracterizados por diferentes taxas de retração. Com a utilização de $5 \%$ de aditivo SCA (Figura 13.7), observa-se que o perfil da curva continua apresentando dois trechos, porém, ocorrem mudanças significativas na dinâmica de secagem os quais são refletidos nas taxas de retração. A utilização do aditivo SCA no cimento de escória causou a alteração da distribuição de poros, resultando em maior porosidade total e no aumento da proporção de macroporos que, associado à expansão causada pela formação de etringita, reduz a taxa de retração no trecho $A B$ de $2675 \mu \mathrm{m} / \%$ na mistura de referência para $1674 \mu \mathrm{m} / \%$. No segundo trecho $B C$, a redução da taxa de retração foi menos intensa do que no primeiro trecho. 
Com o aumento do teor de aditivo para $10 \%$ e 15\%, o comportamento foi similar (Figura 13.8 e Figura 13.9), ocorrendo a maximização da redução da retração por secagem do primeiro trecho $(A B)$ e segundo trecho $(B C)$ de forma proporcional ao teor de aditivo empregado. Em relação à mistura de referência e à mistura com 5\% de aditivo SCA, o aumento do teor de aditivo também causou o aumento significativo do período de duração dos dois trechos observados, passando a duração do primeiro trecho de aproximadamente 3 dias para em torno de 14 dias com $10 \%$ e $15 \%$ de aditivo SCA.

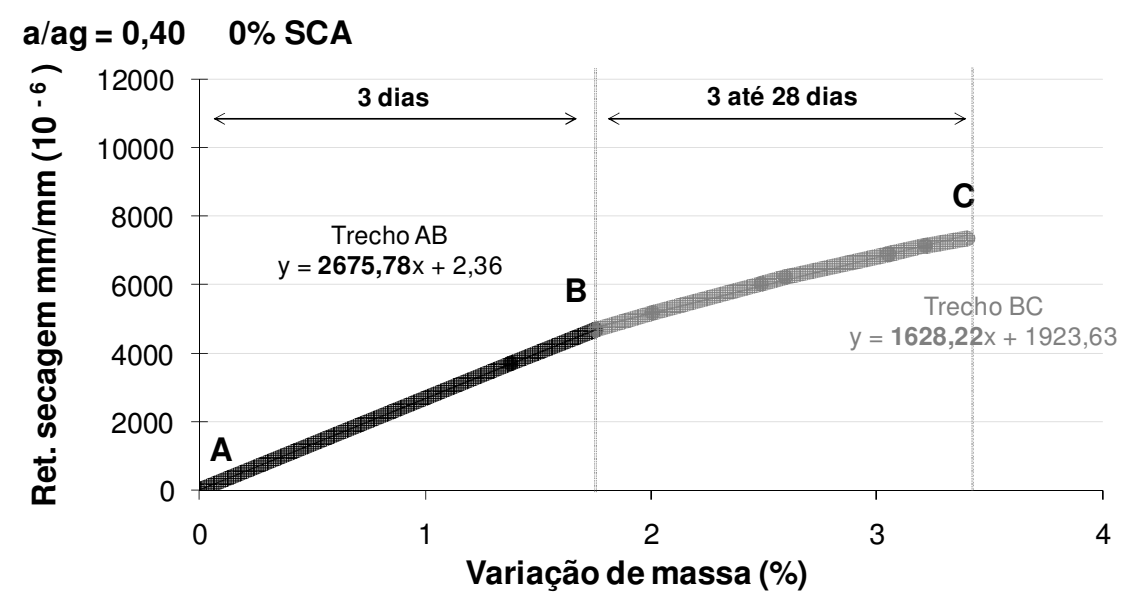

Figura 13.6 - Correlação entre a retração por secagem e a perda de massa por evaporação da argamassa de cimento de escória ativada com silicato de sódio com relação a/agl igual a 0,40.

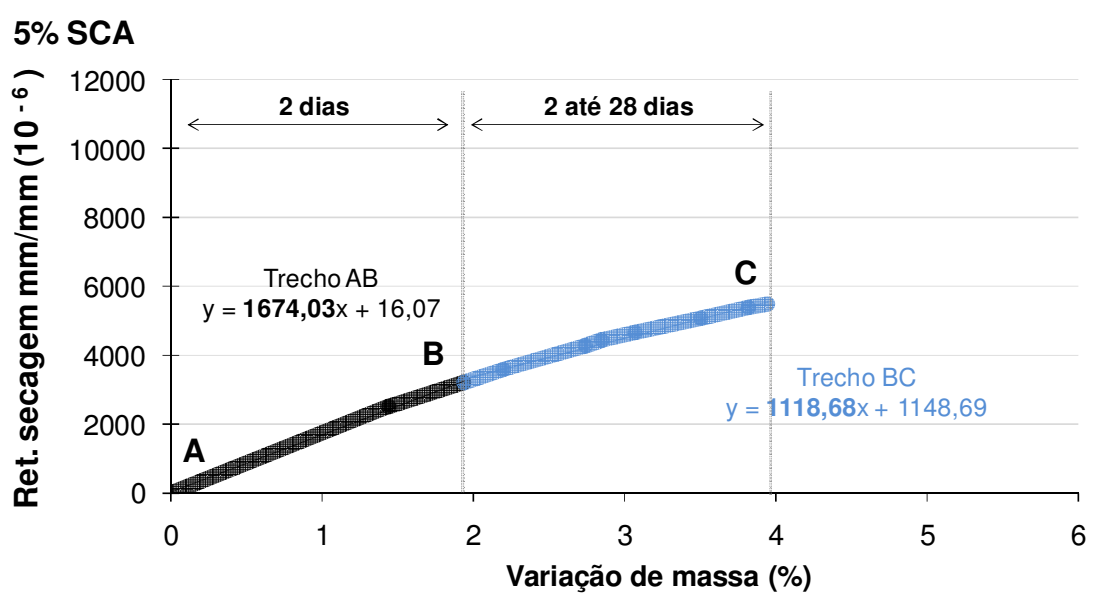

Figura 13.7 - Correlação entre a retração por secagem e a perda de massa por evaporação da argamassa de cimento de escória ativada com silicato de sódio com relação a/agl igual a 0,40 e utilizando $5 \%$ de aditivo compensador de retração (SCA). 


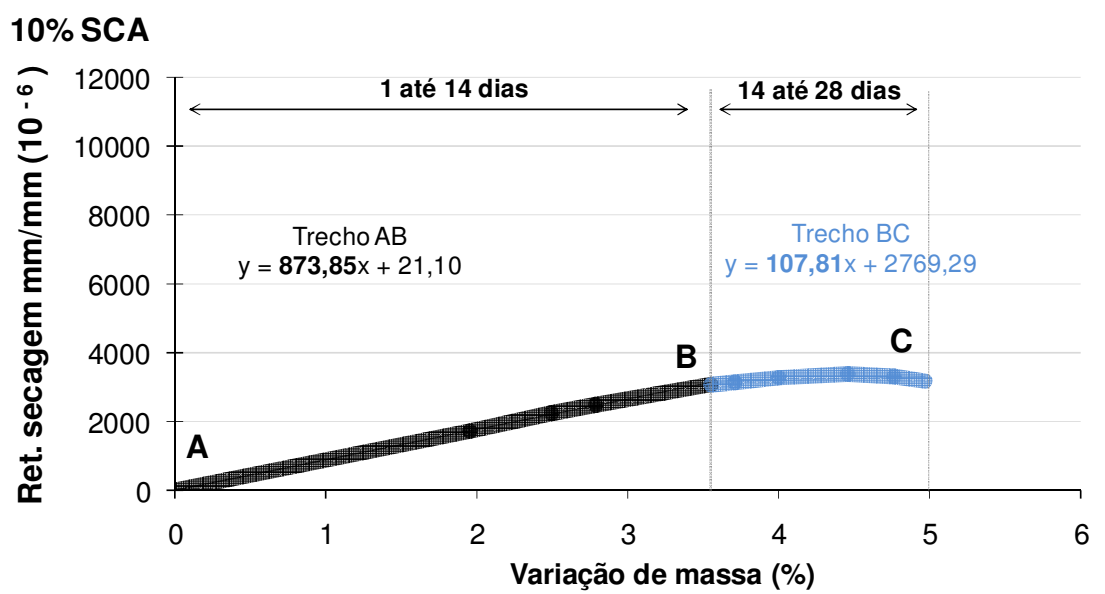

Figura 13.8 - Correlação entre a retração por secagem e a perda de massa por evaporação da argamassa de cimento de escória ativada com silicato de sódio com relação a/agl igual a 0,40 e utilizando $10 \%$ de aditivo compensador de retração (SCA).

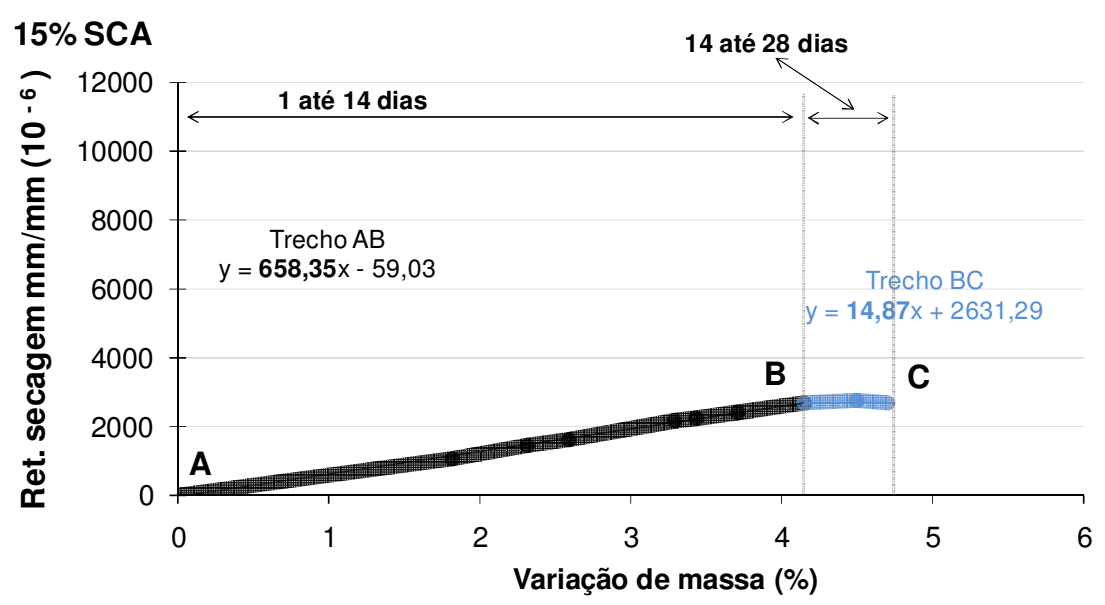

Figura 13.9 - Correlação entre a retração por secagem e a perda de massa por evaporação da argamassa de cimento de escória ativada com silicato de sódio com relação a/agl igual a 0,40 e utilizando $15 \%$ de aditivo compensador de retração (SCA).

Com o aumento da relação a/agl para 0,48 , observa-se, em todos os teores empregados, a alteração do perfil da curva de correlação da retração por secagem e a variação de massa, de três trechos (Figura 13.10) para dois trechos, com a utilização do aditivo SCA (Figura 13.11, Figura 13.12 e Figura 13.13). Além da redução da taxa de retração de forma proporcional ao aumento do teor de aditivo SCA, constata-se, de modo geral, que o aumento do teor de aditivo SCA incorre no aumento da duração do primeiro trecho da curva. Este comportamento é atribuído ao período de hidratação do aditivo SCA, o qual é mais intenso até os 7 dias de idade, conforme os resultados de caracterização do desenvolvimento da microestrutura. 


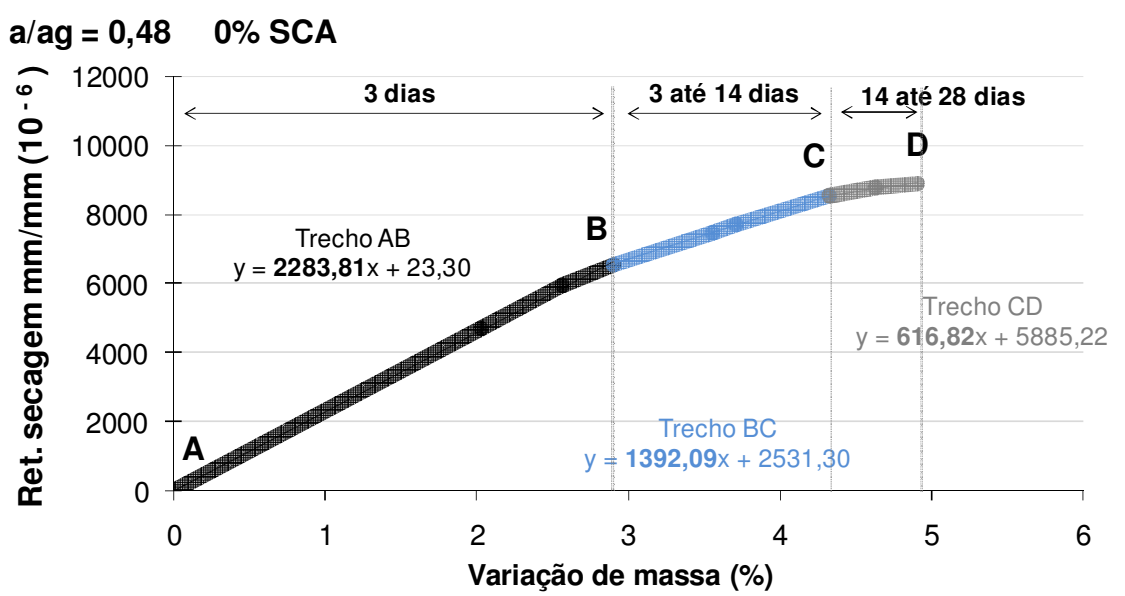

Figura 13.10 - Correlação entre a retração por secagem e a perda de massa por evaporação da argamassa de cimento de escória ativada com silicato de sódio com relação a/agl igual a 0,48.

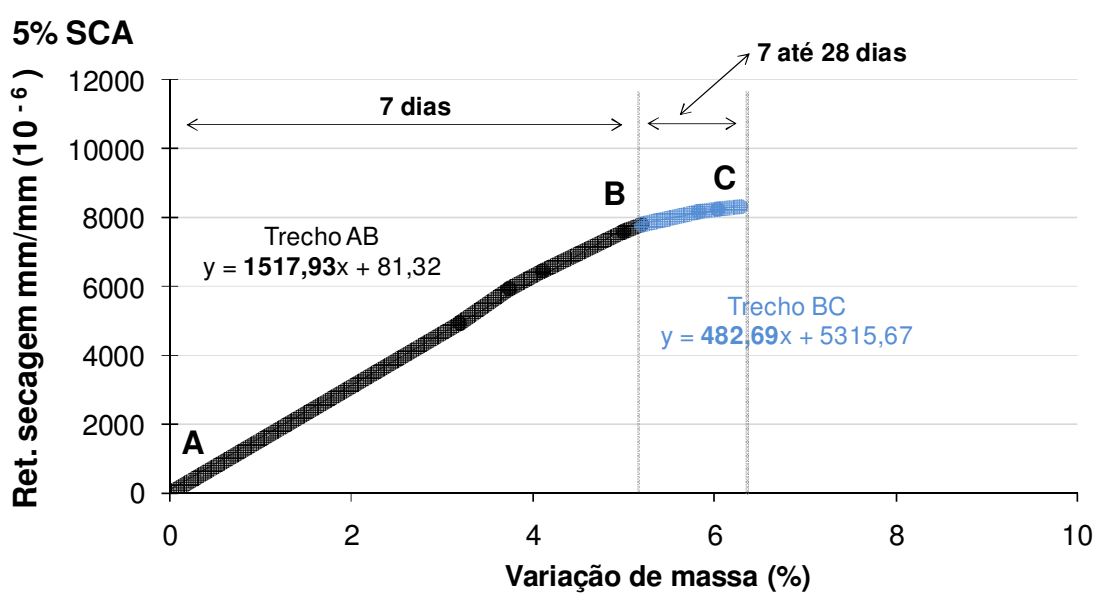

Figura 13.11 - Correlação entre a retração por secagem e a perda de massa por evaporação da argamassa de cimento de escória ativada com silicato de sódio com relação a/agl igual a 0,48 e utilizando $5 \%$ de aditivo compensador de retração (SCA).

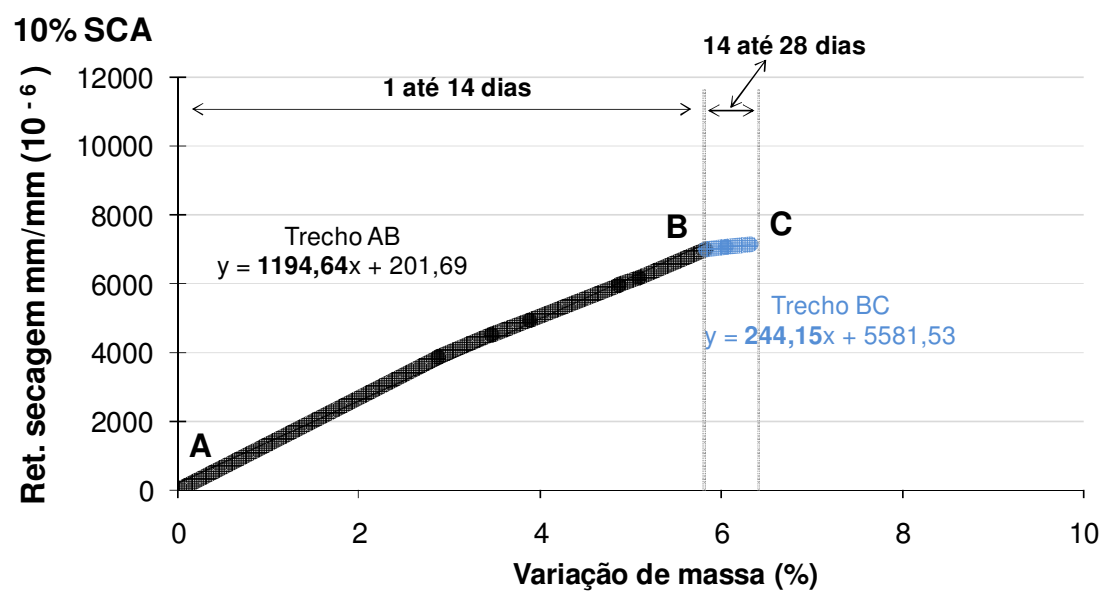

Figura 13.12 - Correlação entre a retração por secagem e a perda de massa por evaporação da argamassa de cimento de escória ativada com silicato de sódio com relação a/agl igual a 0,48 e utilizando $10 \%$ de aditivo compensador de retração (SCA). 


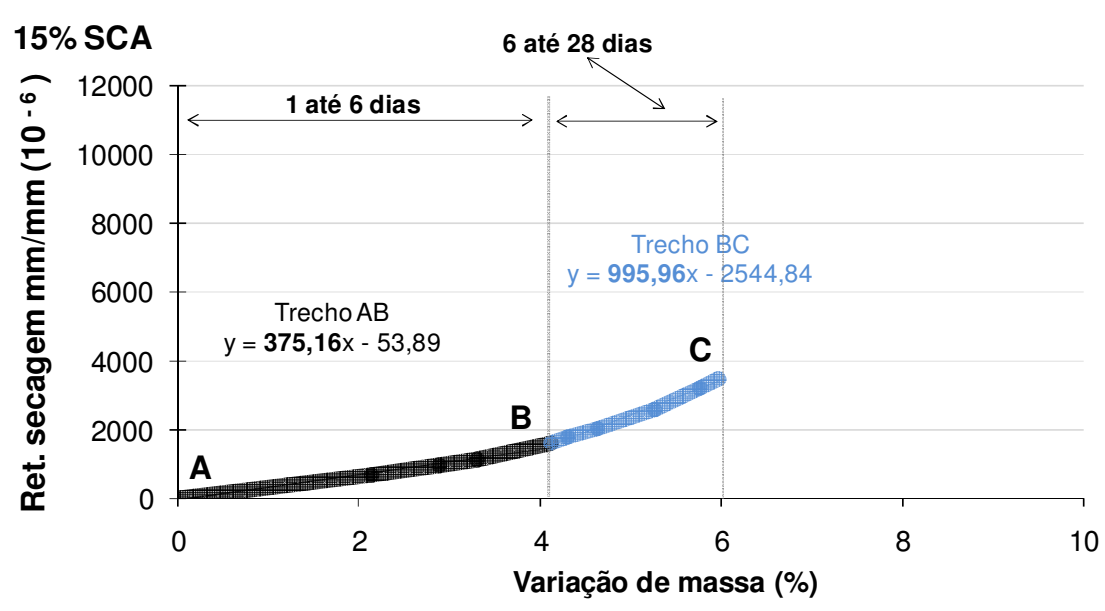

Figura 13.13 - Correlação entre a retração por secagem e a perda de massa por evaporação da argamassa de cimento de escória ativada com silicato de sódio com relação a/agl igual a 0,48 e utilizando $15 \%$ de aditivo compensador de retração (SCA).

$\mathrm{Na}$ mistura com relação a/agl igual a 0,56 e sem aditivo foram identificados três trechos (Figura 13.14), conforme descrito na análise do efeito da relação a/agl (item 8.3.1.1, pág.148). Com o aumento da disponibilidade de água, o aditivo SCA altera significativamente a dinâmica de retração por secagem nas primeiras idades, período referente ao primeiro e segundo trechos. No primeiro trecho $(A B)$ ocorre a redução da taxa de forma proporcional ao teor de aditivo SCA, sendo a taxa reduzida de $947 \mu \mathrm{m} / \%$ na mistura sem aditivo para em torno de $146 \mu \mathrm{m} / \%$ com a utilização de 15\% de aditivo SCA (Figura 13.17). Este comportamento é atribuído às alterações do desenvolvimento da microestrutura nas primeiras idades, pois nesta idade não há indícios da geração de uma expansão significativa pela hidratação do aditivo.

Como o ápice da expansão do aditivo compensador de retração (SCA) ocorre até os 7 dias de idade, torna-se evidente a intensa redução da taxa de retração do trecho BC. Neste segundo trecho, a taxa de retração passa de, em torno de $2545 \mu \mathrm{m} / \%$ na mistura de referência, para em torno de $319 \mu \mathrm{m} / \%$ na mistura com a utilização de $15 \%$ de aditivo SCA. Portanto, apesar de não ser possível constatar a compensação da retração por secagem com a utilização do aditivo SCA, é possível observar que a ocorrência da expansão se reflete na amenização da retração por secagem. 


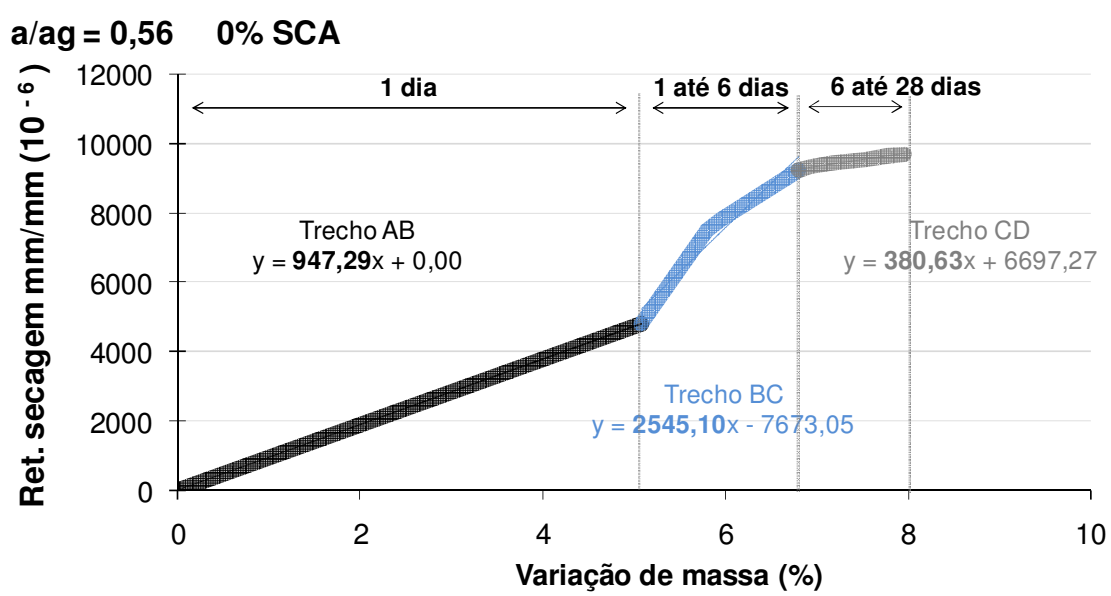

Figura 13.14 - Correlação entre a retração por secagem e a perda de massa por evaporação da argamassa de cimento de escória ativada com silicato de sódio com relação a/agl igual a 0,56.

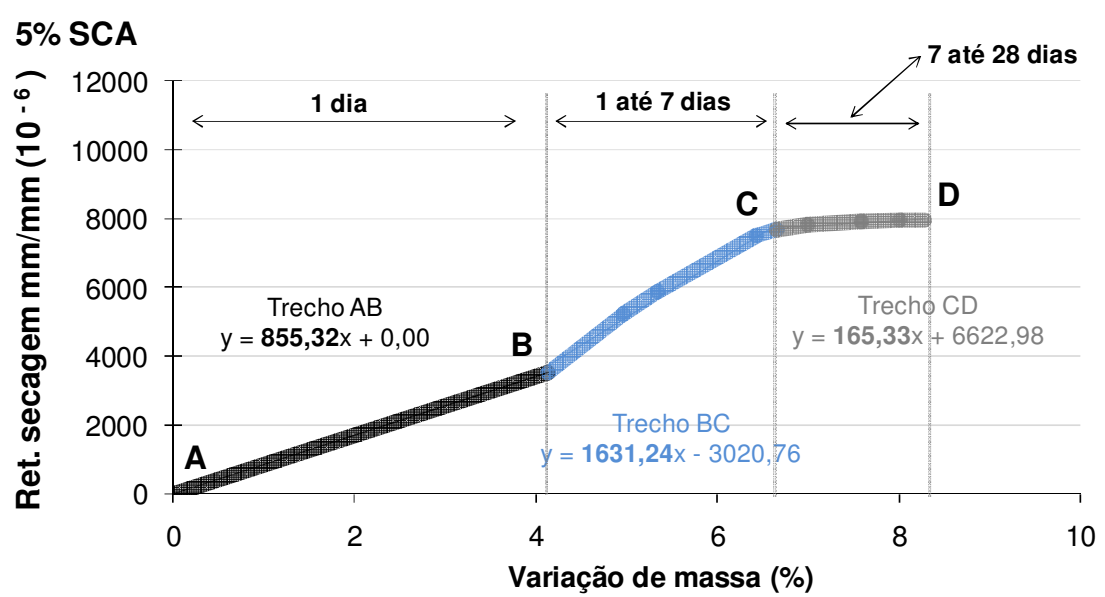

Figura 13.15 - Correlação entre a retração por secagem e a perda de massa por evaporação da argamassa de cimento de escória ativada com silicato de sódio com relação a/agl igual a 0,56 e utilizando $5 \%$ de aditivo compensador de retração (SCA).

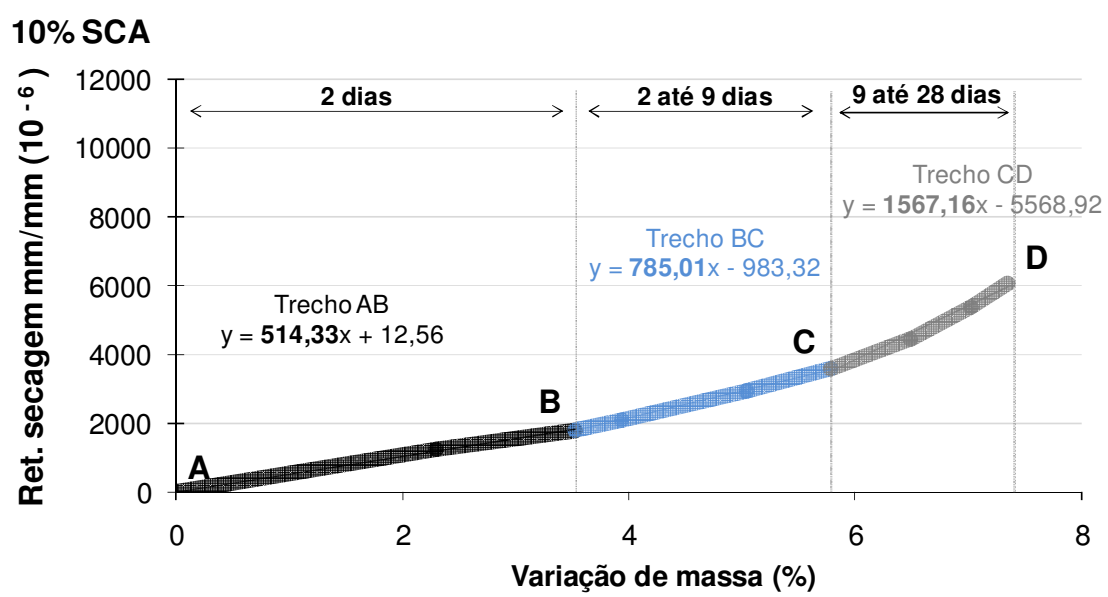

Figura 13.16 - Correlação entre a retração por secagem e a perda de massa por evaporação da argamassa de cimento de escória ativada com silicato de sódio com relação a/agl igual a 0,56 e utilizando $10 \%$ de aditivo compensador de retração (SCA). 


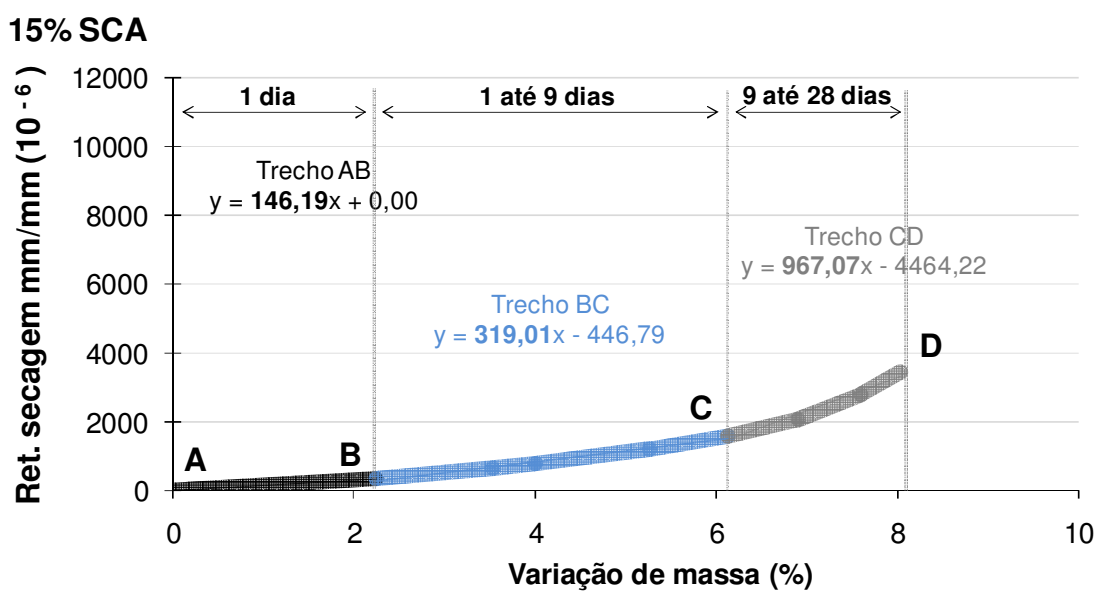

Figura 13.17 - Correlação entre a retração por secagem e a perda de massa por evaporação da argamassa de cimento de escória ativada com silicato de sódio com relação a/agl igual a 0,56 e utilizando $15 \%$ de aditivo compensador de retração (SCA).

\subsection{Retração autógena}

O efeito do teor de aditivo compensador de retração (SCA) na retração autógena do cimento de escória está apresentado na Figura 13.18. Observa-se que o aditivo SCA obteve êxito na redução da retração autógena, ao contrário do aditivo redutor de retração (SRA). Conforme descrito na análise da influência da relação a/agl (item 8.1.2, pág.133), a retração autógena está relacionada à distribuição de poros e ao volume de poros. Portanto, com base na análise dos resultados de porosidade, conclui-se que o aditivo SCA reduz a retração autógena do cimento de escória em razão da alteração da distribuição de poros do cimento de escória, resultando na diminuição das tensões capilares decorrente do aumento da proporção de macroporos, e da expansão gerada pela hidratação do aditivo.

Na Figura 13.19 consta a correlação entre a retração autógena e o teor de aditivo compensador de retração (SCA) para as três relações a/agl estudadas. Observa-se a correlação entre a diminuição da retração autógena e o aumento do teor de aditivo SCA em todas as relações a/agl. Em condição saturada, as misturas com relação a/agl iguais a 0,40 e 0,48 apresentam velocidades praticamente idênticas na redução da retração autógena, confirmado pelos valores similares obtidos no coeficiente angular da reta linear de ajuste. Com o aumento da relação a/agl para 0,56, o melhor desempenho da expansão gerada pelo aditivo SCA é nítido, 
confirmado pelo aumento significativo da velocidade de redução da retração autógena.
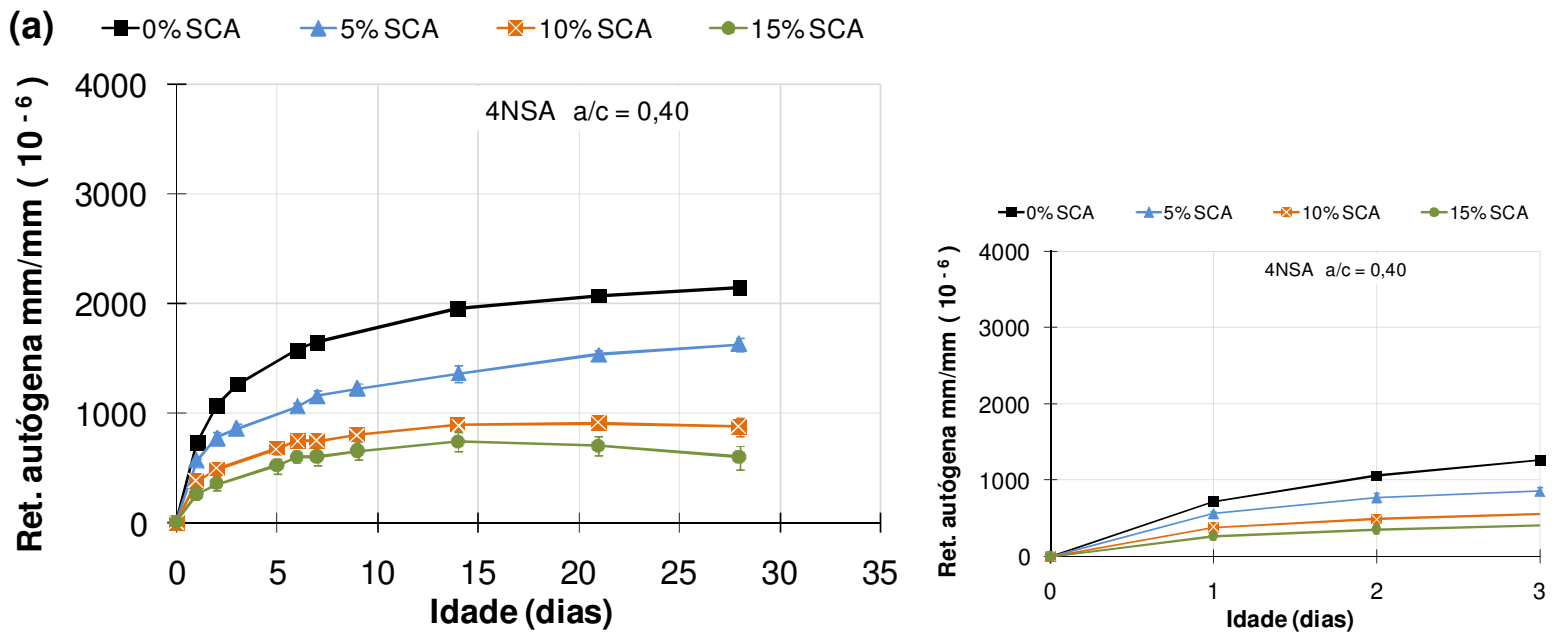

(b) $\rightarrow-0 \% \mathrm{SCA} \quad-5 \% \mathrm{SCA} \quad-\varangle-10 \% \mathrm{SCA} \quad-15 \% \mathrm{SCA}$
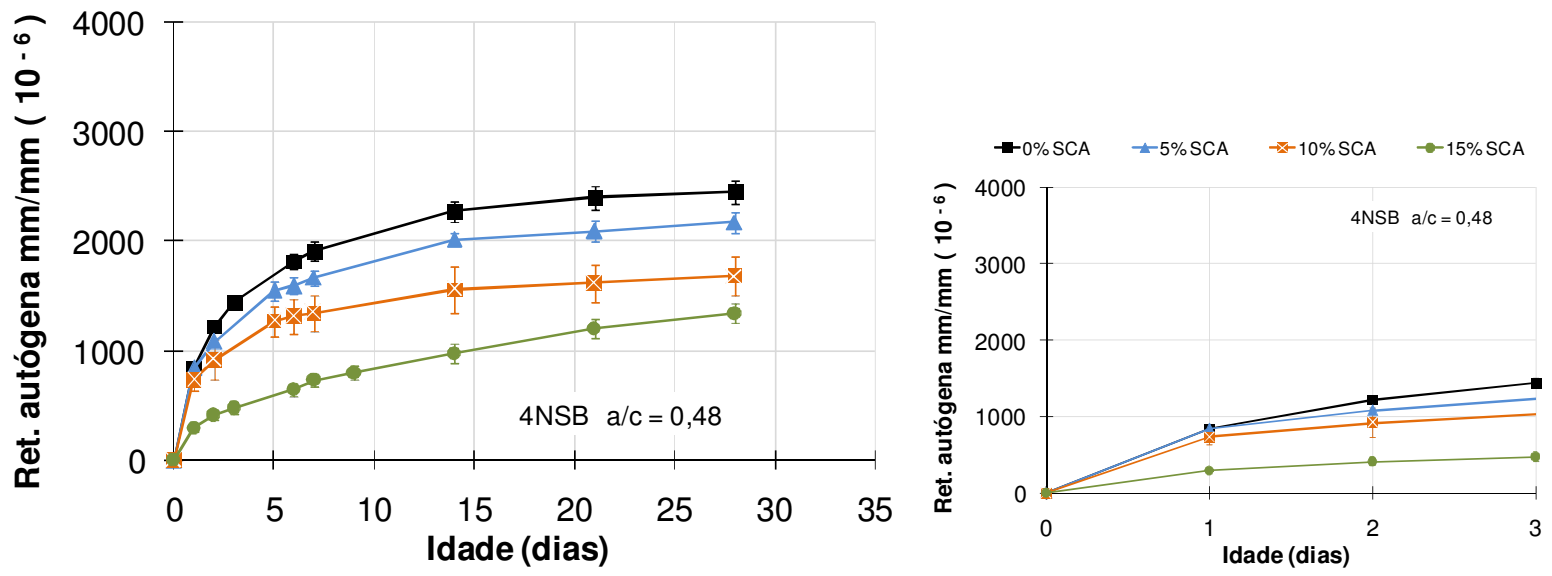

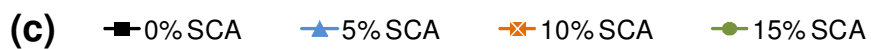
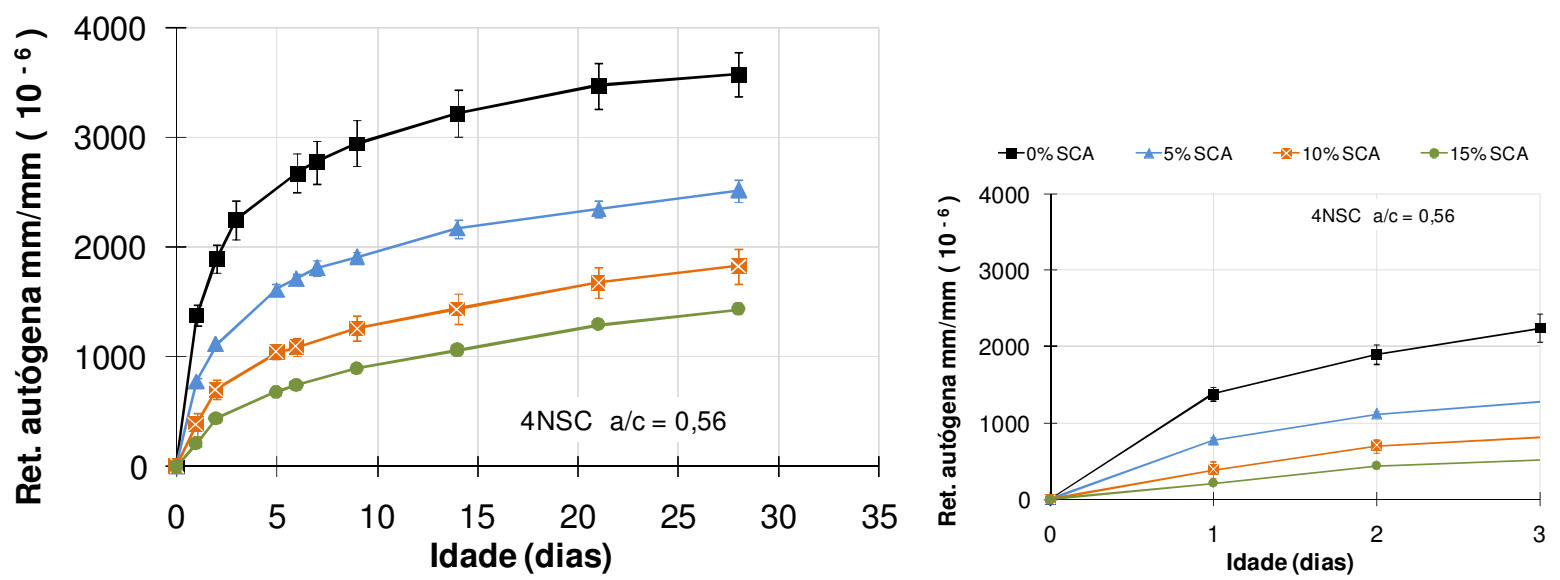

Figura 13.18 - Efeito do teor de aditivo compensador de retração (SCA) na retração autógena das argamassas de cimento de escória ativada com relação a/agl igual 0,40 (a), 0,48 (b) e 0,56 (c). 


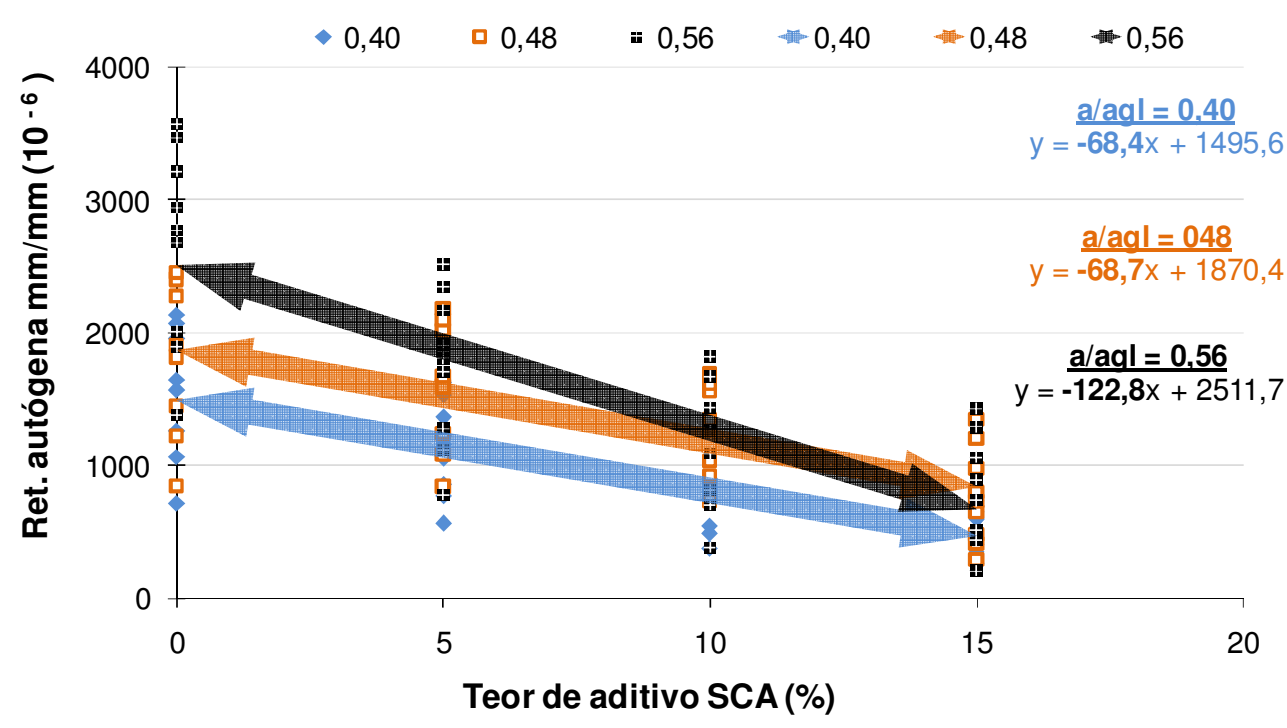

Figura 13.19 - Efeito do teor de aditivo compensador de retração (SCA) na retração autógena das argamassas de cimento de escória ativada com relação a/agl igual 0,40, 0,48 e 0,56. Gráficos construídos com todos os pontos obtidos.

Utilizando como referência a mistura sem aditivo nas três relações a/agl estudadas, calculou-se, em termos percentuais, o efeito da utilização do aditivo SCA durante os 28 dias de hidratação (Tabela 13.4, Tabela 13.5 e Tabela 13.6). Em todas as idades a redução da retração autógena foi proporcional ao aumento do teor de aditivo SCA, e apresentou maior intensidade nas primeiras idades, o que é coerente, visto que a hidratação deste tipo de aditivo ocorre em sua maior parte até 7 dias de idade. A redução aos 28 dias da retração por secagem foi em torno de $60 \%$ para a mistura com relação a/agl igual a 0,56 e $15 \%$ de aditivo SCA.

Tabela 13.4 - Médias aritméticas da retração autógena e o efeito do teor de aditivo compensador de retração (SCA) no cimento de escória ativada com relação a/agl igual a $\mathbf{0 , 4 0}$. CV = coeficiente de variação em \%.

\begin{tabular}{|c|c|c|c|c|c|c|c|c|c|}
\hline \multicolumn{2}{|c|}{ Relação a/agl = 0,40 } & \multicolumn{8}{|c|}{ Teor de aditivo compensador de retração (SCA) } \\
\hline & \multirow[b]{2}{*}{ Idade } & \multicolumn{2}{|c|}{$0 \%$} & \multicolumn{2}{|c|}{$5 \%$} & \multicolumn{2}{|c|}{$10 \%$} & \multicolumn{2}{|c|}{$15 \%$} \\
\hline & & Raut & $\mathrm{CV}$ & Raut & $\mathrm{CV}$ & Raut & $\mathrm{cV}$ & Raut & $\mathrm{CV}$ \\
\hline \multirow{4}{*}{$\begin{array}{l}\text { Retração autógena } \\
\mathrm{mm} / \mathrm{mm}\left(10^{-6}\right)\end{array}$} & 1 dia & 721,0 & $1,7 \%$ & $\overline{563,9}$ & $2,4 \%$ & $\overline{378,4}$ & $4,8 \%$ & 263,2 & $6,3 \%$ \\
\hline & 3 dias & 1261,1 & $1,6 \%$ & 854,7 & $3,1 \%$ & 549,9 & $5,1 \%$ & 408,7 & $7,5 \%$ \\
\hline & 7 dias & 1646,7 & $0,8 \%$ & 1155,4 & $2,3 \%$ & 742,1 & $3,0 \%$ & 604,2 & $7,0 \%$ \\
\hline & 28 dias & 2139,5 & $0,9 \%$ & 1627,6 & $2,0 \%$ & 872,2 & $4,5 \%$ & 598,3 & $9,3 \%$ \\
\hline \multirow{4}{*}{$\begin{array}{c}\text { Variação da } \\
\text { retração autógena } \\
\text { (\%) }\end{array}$} & 1 dia & \multicolumn{2}{|c|}{0,0} & \multicolumn{2}{|c|}{$-21,8$} & \multicolumn{2}{|c|}{$-47,5$} & \multicolumn{2}{|c|}{$-63,5$} \\
\hline & 3 dias & \multirow{2}{*}{\multicolumn{2}{|c|}{$\begin{array}{l}0,0 \\
0,0\end{array}$}} & \multicolumn{2}{|c|}{$-32,2$} & \multicolumn{2}{|c|}{$-56,4$} & \multicolumn{2}{|c|}{$-67,6$} \\
\hline & 7 dias & & & \multirow{2}{*}{\multicolumn{2}{|c|}{$\begin{array}{l}-29,8 \\
-23,9\end{array}$}} & \multirow{2}{*}{\multicolumn{2}{|c|}{$\begin{array}{l}-54,9 \\
-59,2\end{array}$}} & \multirow{2}{*}{\multicolumn{2}{|c|}{$\begin{array}{l}-63,3 \\
-72,0\end{array}$}} \\
\hline & 28 dias & \multicolumn{2}{|c|}{0,0} & & & & & & \\
\hline
\end{tabular}


Tabela 13.5 - Médias aritméticas da retração autógena e o efeito do teor de aditivo compensador de retração (SCA) no cimento de escória ativada com relação a/agl igual a $\mathbf{0 , 4 8}$. $\mathrm{CV}=$ coeficiente de variação em \%.

\begin{tabular}{|c|c|c|c|c|c|c|c|c|c|}
\hline \multicolumn{2}{|c|}{ Relação a/agl = 0,48 } & \multicolumn{8}{|c|}{ Teor de aditivo compensador de retração (SCA) } \\
\hline & \multirow[b]{2}{*}{ Idade } & \multicolumn{2}{|c|}{$0 \%$} & \multicolumn{2}{|c|}{$5 \%$} & \multicolumn{2}{|c|}{$10 \%$} & \multicolumn{2}{|c|}{$15 \%$} \\
\hline & & Raut & $\mathrm{CV}$ & Raut & $\mathrm{CV}$ & Raut & $\mathrm{CV}$ & Raut & $\overline{C V}$ \\
\hline \multirow{4}{*}{$\begin{array}{l}\text { Retração autógena } \\
\mathrm{mm} / \mathrm{mm}\left(10^{-6}\right)\end{array}$} & $1 \mathrm{dia}$ & 842,8 & $2,9 \%$ & 841,8 & $3,8 \%$ & 732,4 & $7,0 \%$ & 290,3 & $6,2 \%$ \\
\hline & 3 dias & 1446,6 & $2,1 \%$ & 1240,0 & $2,0 \%$ & 1035,7 & $8,4 \%$ & 476,0 & $5,1 \%$ \\
\hline & 7 dias & 1910,8 & $2,3 \%$ & 1670,8 & $2,2 \%$ & 1346,6 & $6,2 \%$ & 730,7 & $4,1 \%$ \\
\hline & 28 dias & 2453,6 & $2,3 \%$ & 2177,8 & $2,2 \%$ & 1685,4 & $5,4 \%$ & 1344,0 & $3,4 \%$ \\
\hline \multirow{4}{*}{$\begin{array}{c}\text { Variação da } \\
\text { retração autógena } \\
(\%)\end{array}$} & $1 \mathrm{dia}$ & \multicolumn{2}{|c|}{0,0} & \multicolumn{2}{|c|}{$-0,1$} & \multicolumn{2}{|c|}{$-13,1$} & \multicolumn{2}{|c|}{$-65,6$} \\
\hline & 3 dias & \multicolumn{2}{|c|}{0,0} & \multicolumn{2}{|c|}{$-14,3$} & \multicolumn{2}{|c|}{$-28,4$} & \multicolumn{2}{|c|}{$-67,1$} \\
\hline & 7 dias & \multirow{2}{*}{\multicolumn{2}{|c|}{$\begin{array}{l}0,0 \\
0,0\end{array}$}} & \multicolumn{2}{|c|}{$-12,6$} & \multicolumn{2}{|c|}{$-29,5$} & \multicolumn{2}{|c|}{$-61,8$} \\
\hline & 28 dias & & & \multicolumn{2}{|c|}{$-11,2$} & \multicolumn{2}{|c|}{$-31,3$} & \multicolumn{2}{|c|}{$-45,2$} \\
\hline
\end{tabular}

Tabela 13.6 - Médias aritméticas da retração autógena e o efeito do teor de aditivo compensador de retração (SCA) no cimento de escória ativada com relação a/agl igual a 0,56. $\mathrm{CV}=$ coeficiente de variação em \%.

\begin{tabular}{|c|c|c|c|c|c|c|c|c|c|}
\hline \multicolumn{2}{|c|}{ Relação a/agl = 0,56 } & \multicolumn{8}{|c|}{ Teor de aditivo compensador de retração (SCA) } \\
\hline & \multirow[b]{2}{*}{ Idade } & \multicolumn{2}{|c|}{$0 \%$} & \multicolumn{2}{|c|}{$5 \%$} & \multicolumn{2}{|c|}{$10 \%$} & \multicolumn{2}{|c|}{$15 \%$} \\
\hline & & Raut & $\mathrm{CV}$ & Raut & $\mathrm{CV}$ & Raut & $\mathrm{CV}$ & Raut & $\mathrm{CV}$ \\
\hline \multirow{4}{*}{$\begin{array}{l}\text { Retração autógena } \\
\mathrm{mm} / \mathrm{mm}\left(10^{-6}\right)\end{array}$} & $1 \mathrm{dia}$ & 1379,5 & $3,4 \%$ & 776,5 & $2,2 \%$ & 384,8 & $13,9 \%$ & 208,1 & $3,8 \%$ \\
\hline & 3 dias & 2244,4 & $4,1 \%$ & 1280,4 & $1,6 \%$ & 813,2 & $5,0 \%$ & 515,6 & $2,5 \%$ \\
\hline & 7 dias & 771,8 & $3,7 \%$ & 1808,5 & $1,9 \%$ & 1260,8 & $4,6 \%$ & 894,1 & $0,9 \%$ \\
\hline & 28 dias & 3572,7 & $2,8 \%$ & 2514,2 & $2,1 \%$ & 1826,3 & $4,4 \%$ & 1430,0 & $1,0 \%$ \\
\hline \multirow{4}{*}{$\begin{array}{c}\text { Variação da } \\
\text { retração autógena } \\
(\%)\end{array}$} & $1 \mathrm{dia}$ & \multicolumn{2}{|c|}{0,0} & \multicolumn{2}{|c|}{$-43,7$} & \multicolumn{2}{|c|}{$-72,1$} & \multicolumn{2}{|c|}{$-84,9$} \\
\hline & 3 dia & \multirow{2}{*}{\multicolumn{2}{|c|}{0}} & \multicolumn{2}{|c|}{$-43,0$} & \multicolumn{2}{|c|}{$-63,8$} & \multicolumn{2}{|c|}{$-77,0$} \\
\hline & 7 dias & & & \multicolumn{2}{|l|}{-34} & \multicolumn{2}{|c|}{$-54,5$} & \multicolumn{2}{|c|}{$-67,7$} \\
\hline & 28 dias & \multicolumn{2}{|c|}{$\begin{array}{l}0,0 \\
0,0\end{array}$} & \multicolumn{2}{|c|}{$-29,6$} & \multicolumn{2}{|c|}{$-48,9$} & \multicolumn{2}{|c|}{$-60,0$} \\
\hline
\end{tabular}

As condições de ensaio da retração autógena favorecem a hidratação do aditivo compensador de retração (SCA), pois a competição pela água disponível ocorre apenas com a hidratação do cimento de escória, sem perdas por evaporação. No entanto, assim como observado na análise da retração por secagem, não ocorre a compensação da retração autógena com a expansão gerada pelo aditivo SCA, apenas a redução da mesma. Para se obter mais detalhes é possível calcular a taxa de retração autógena com base na curva acumulada de retração autógena; com isto são observadas reduções na taxa que indicam a expansão. Nas três relações a/agl estudadas, pode-se constatar uma inflexão da curva de evolução da taxa de retração autógena sempre entre 5 e 9 dias de idade, atribuída à expansão resultante da hidratação do aditivo SCA. 

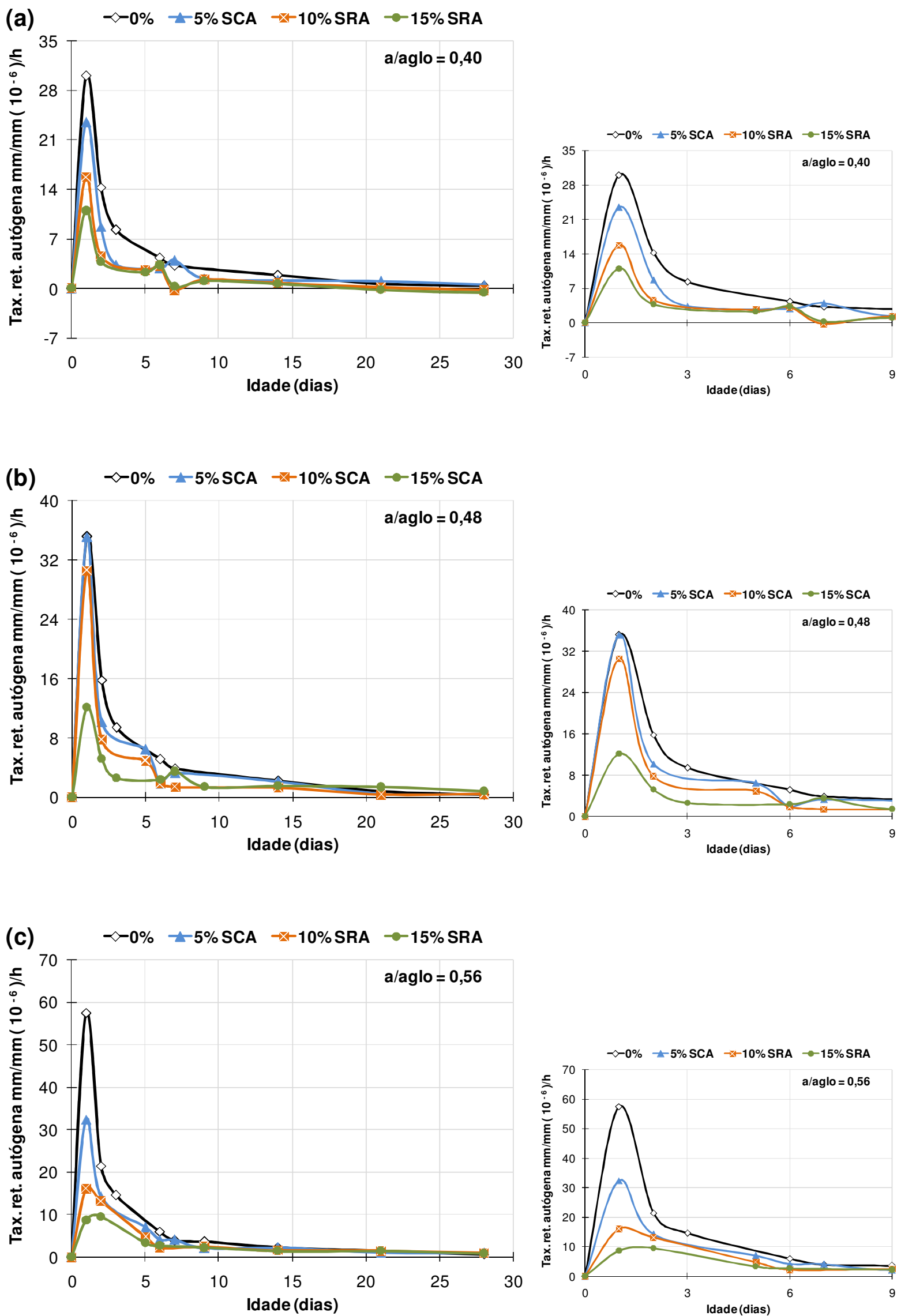

Figura 13.20 - Efeito do teor de aditivo compensador de retração (SCA) na taxa de retração autógena das argamassas de cimento de escória ativada com relação a/agl igual 0,40 (a), 0,48 (b) e 0,56 (c). 


\subsection{Discussão e conclusões}

\subsubsection{Retração por secagem}

De acordo com os resultados obtidos, o aditivo compensador de retração (SCA) foi capaz de diminuir a retração por secagem do cimento de escória ativada com silicato de sódio. A redução da retração por secagem atinge $65 \%$ com a utilização de $15 \%$ do aditivo e desacelerou o desenvolvimento da retração, pois, o perfil da curva de retração por secagem da mistura de referência, caracterizado por uma evolução abrupta e posterior evolução gradual, foi alterado para uma evolução gradual. Não foi observada a expansão em magnitude suficiente para compensar a retração por secagem em nenhuma das situações estudadas, sendo provável que a expansão apenas tenha tido a capacidade de amenizar a retração por secagem.

O efeito da relação a/agl na utilização do aditivo SCA foi o esperado, ou seja, quanto maior a disponibilidade de água, maior a expansão gerada pela hidratação do aditivo. Este fato foi confirmado pela análise da variação de massa por evaporação, na qual foi possível verificar a maior perda de água para o ambiente para as relações a/agl iguais a 0,40 e 0,48. Este comportamento provoca prejuízos tanto à hidratação do aditivo quanto à do cimento de escória em razão da pouca disponibilidade de água. Com o aumento da relação a/agl para 0,56, observa-se a redução da variação de massa por evaporação quando comparada à mistura de referência, atribuída à menor disponibilidade de água livre para evaporação em função da maior hidratação do aditivo SCA. Na menor relação a/agl $(0,40)$, a pouca disponibilidade de água resulta na maior interferência da hidratação do aditivo SCA no desenvolvimento da microestrutura do cimento de escória, fato este que, associado à expansão gerada pelo aditivo, contribui para a diminuição da retração por secagem.

Além da expansão, o aditivo compensador de retração (SCA) altera a distribuição de poros do cimento de escória, aumentando a proporção do volume de macroporos. Este fato contribui para a redução da retração por secagem e, com maior intensidade, na redução também da retração autógena do cimento de escória. No entanto, a alteração da estrutura da matriz porosa também afeta as propriedades 
mecânicas, diminuindo-as, o que precisa sempre ser levado em consideração antes de iniciar o emprego deste tipo de aditivo em aplicações práticas.

\subsubsection{Retração autógena}

A utilização do aditivo compensador de retração (SCA) resultou na diminuição da retração autógena do cimento de escória. Além da expansão, esta diminuição também é atribuída à alteração da distribuição de poros, com o aumento da proporção do volume de macroporos, resultando na redução das tensões capilares. Apesar do ensaio de retração autógena favorecer o resultado do aditivo SCA; pois impede a evaporação da água, disponibilizando maior quantidade para hidratação; assim como na retração por secagem, não foi constatada a expansão a ponto de compensar a retração autógena do cimento de escória. A expansão foi constatada apenas a partir da construção da curva de evolução da taxa de retração autógena, onde foi possível identificar a ocorrência de uma inflexão entre 5 e 9 dias em todas as misturas estudadas. Este comportamento é coerente com as características de desenvolvimento da hidratação do aditivo SCA, cujo ápice da expansão ocorre até os 7 dias de idade.

A utilização do aditivo compensador de retração (SCA) no cimento de escória ativada apresentou comportamentos distintos quando alterada a disponibilidade de água, pois, apesar de reduzir a retração autógena, apresentou as maiores reduções nos extremos estudados, 0,40 e 0,56. O aditivo SCA também diminuiu a retração autógena da mistura com relação a/agl igual a 0,48 , porém a redução máxima alcançada foi em torno de $45 \%$ com $15 \%$ de aditivo SCA, enquanto nas misturas com relação a/agl 0,40 e 0,56 foram alcançadas reduções em torno de $72 \%$ e $60 \%$, respectivamente, com o mesmo teor de aditivo SCA. Este comportamento, assim como os resultados de caracterização da microestrutura, indica que a utilização do aditivo SCA em um compósito de cimento de escória com baixa relação a/agl proporcionará a redução da retração, em virtude da expansão gerada pela hidratação do aditivo e pelas alterações da microestrutura causadas pelo aditivo SCA. 
Parte 4

Conclusões 


\section{Capítulo 14 Conclusões e considerações finais}

\subsection{Influência da relação água/aglomerante}

O conhecimento desenvolvido em trabalhos anteriores teve como objetivo principal o estudo de diferentes tipos e teores de espécies químicas para o preenchimento do papel de ativadores para a escória de alto forno, como o silicato de sódio, hidróxido de sódio, hidróxido de cálcio, carbonato de sódio, entre outros. Com a definição do silicato de sódio como o ativador que melhor atende às condições de uso objetivadas para o cimento de escória ativada, como a sua utilização em prémoldados, pisos industriais e reparo rápido de estruturas, foi possível verificar o efeito de diferentes relações a/agl neste tipo de cimento. Assim, neste trabalho foram estudadas três relações a/agl: 0,40, 0,48 e 0,56.

\subsubsection{Microestrutura}

Os compostos formados na hidratação do cimento de escória ativada com silicato de sódio, independentemente da maior ou menor disponibilidade de água, caracterizam-se pela presença nítida de picos associados ao C-S-H do tipo I e à hidrotalcita no resultados de difração de raios $X$. Também foram identificados picos referentes ao C-S-H do tipo II, porém, de modo aleatório, sem seguir nenhum padrão que caracterize uma situação específica.

O principal efeito da relação a/agl no desenvolvimento da hidratação do cimento de escória ativada foi o retardo do início da hidratação, proporcional ao aumento da relação a/agl. Porém, com o avanço da idade, as reações de hidratação se desenvolvem e não há, nas misturas estudadas, diferenças significativas entre as intensidades do pico principal do C-S-H determinado pela difração de raios $\mathrm{X}$ aos 28 dias. Todo o comportamento observado na análise de difração de raios $X$ foi confirmado nos resultados de termogravimetria, nos quais a quantificação do C-S-H apresentou o mesmo perfil identificado nos resultados de difração de raios $X$. A 
semelhança entre os resultados das duas técnicas empregadas é atribuída ao preparo homogêneo das amostras para a caracterização da microestrutura, proporcionando maior confiabilidade nos resultados obtidos.

Se no aspecto químico da hidratação do cimento de escória ativada com silicato de sódio a relação a/agl não apresentou efeito significativo, sua influência no desenvolvimento físico da matriz porosa foi determinante no entendimento do comportamento da microestrutura deste tipo de cimento. Conclui-se que o aumento da relação a/agl incorre no aumento proporcional da porosidade total aos 28 dias: $22 \%, 30 \%$ e $37 \%$ nas misturas com relação a/agl iguais a 0,40, 0,48 e 0,56, respectivamente.

O aumento da porosidade com o aumento da relação a/agl é um comportamento clássico, explicado pelo efeito físico do maior número de vazios na compacidade da matriz porosa causado pela maior quantidade de água. A principal diferença da porosidade do cimento de escória ativada com silicato de sódio para aglomerantes tradicionais é a distribuição de poros singular, caracterizada pela predominância de poros com diâmetros localizados na faixa de mesoporos $(2<\varnothing<50 \mathrm{~nm})$.

De acordo com os resultados obtidos, pode-se afirmar que o aumento da relação a/agl no cimento de escória ativada com silicato de sódio tem efeito totalmente distinto do observado no cimento Portland (Cincotto et al., 2003; Melo Neto et al., 2007; MELO NETO, 2002). Enquanto no cimento Portland, o aumento da relação a/agl causa o aumento da porosidade total e o menor refinamento da porosidade, no cimento de escória ativada com silicato de sódio também ocorre o aumento da porosidade total, porém, sem alteração do perfil da distribuição de poros com o avanço da idade. O detalhamento desta característica é fundamental no entendimento do comportamento das propriedades mecânicas e da retração, pois estas, apesar de estarem relacionadas com a porosidade total, também estão relacionadas com o perfil da distribuição de poros.

O aumento da relação a/agl no cimento de escória retarda o início do refinamento da porosidade nas primeiras idades, decorrente do retardo do desenvolvimento da hidratação, constatado na análise do resultados de difração de raios $X$ e 
termogravimetria. Com o avanço da idade, ocorre a aceleração da hidratação e o conseqüente refinamento da porosidade, o qual inicia-se às 12 horas na mistura com relação a/agl igual a 0,40, com 1 dia na mistura com relação 0,48 e 3 dias na mistura com relação 0,56. O refinamento da porosidade do cimento de escória resulta em matrizes porosas com elevadas proporções de mesoporos, em torno de $94 \%$ do volume total de poros, independentemente da relação a/agl empregada.

\subsubsection{Propriedades mecânicas}

De forma similar ao cimento Portland, o cimento de escória ativada com silicato de sódio é bastante influenciado pela relação água/aglomerante. No entanto, nas condições específicas aplicadas neste trabalho, conclui-se que a relação a/agl não influencia de modo significativo quando comparadas as misturas com relação a/agl iguais a 0,40 e 0,48 , sendo obtidas resistências similares. Porém, com o aumento da relação a/agl para 0,56 , já ocorre uma redução intensa da resistência mecânica deste tipo de cimento.

De acordo com os resultados da caracterização da microestrutura, está evidente que a redução da resistência mecânica está associada ao aumento da porosidade em razão do aumento da relação a/agl. Constatou-se também que o efeito mais intenso do aumento da relação a/agl nas primeiras idades, é explicado pela redução do grau de hidratação e retardo do refinamento da porosidade no mesmo período. A título de comparação com aglomerantes tradicionais, é importante ressaltar a elevada magnitude da resistência mecânica inicial e final do cimento de escória ativada, alcançando resistência à compressão em torno de $92 \mathrm{MPa}$ aos 28 dias com relação 0,40, $86 \mathrm{MPa}$ com relação 0,48 e $60 \mathrm{MPa}$ com relação 0,56 .

\subsubsection{Retração por secagem}

O aumento da relação a/agl causa o aumento significativo da retração por secagem do cimento de escória ativada com silicato de sódio, cerca de 30\% maior na mistura com relação 0,56 do que na mistura com relação 0,40. O desenvolvimento da microestrutura é coerente na explicação deste comportamento, pois é possível determinar a quantidade de água disponível para evaporação e o perfil da matriz 
porosa da qual a água livre é perdida. O grau de hidratação aos 28 dias foi igual para todas as relações a/agl estudadas, portanto, o aumento da relação a/agl possibilita a maior disponibilidade de água livre. Associada à porosidade singular deste cimento, caracterizada pela proporção majoritária de poros na faixa de mesoporos, conclui-se que a maior quantidade de água livre é responsável pelo aumento das tensões capilares com 0 aumento da relação a/agl e, conseqüentemente, pelo aumento da retração por secagem.

Analisando juntamente ao efeito da relação a/agl na resistência mecânica, conclui-se que a retração por secagem do cimento de escória está diretamente relacionada com a estrutura da matriz porosa, com a quantidade de água disponível para ser perdida para o ambiente e com a diminuição da resistência mecânica com o aumento da relação a/agl. Portanto, do ponto de vista prático, para amenizar a retração por secagem do cimento de escória ativada com silicato de sódio é recomendada a utilização de menores relações a/agl. Porém, ressalta-se que, mesmo diminuindo a relação a/agl, a retração observada neste tipo de cimento é em torno de 8 vezes maior do que a observada no cimento Portland de alta resistência inicial (MELO NETO, 2002), o que continua a limitar o uso do cimento de escória ativada.

\subsubsection{Retração autógena}

O efeito da relação a/agl na retração autógena do cimento de escória ativada com silicato de sódio foi inesperado, pois é consensual que a diminuição da relação incorre no aumento da retração autógena, pelo menos para o cimento Portland (JENSEN; HANSEN, 2001; TAZAWA et al., 1995). A retração autógena do cimento de escória continuou a apresentar valores de maior magnitude do que o observado no cimento portland (MELO NETO, 2002), mas a influência da relação a/agl foi oposta ao observado pelo cimento portland. De acordo com os resultados obtidos, o aumento da relação água/aglomerante incorre no aumento significativo da retração autógena do cimento de escória ativada com silicato de sódio. Este comportamento é contrário ao observado no cimento Portland, no qual o aumento da relação a/agl causa a diminuição da retração autógena. 
Além da diminuição da resistência mecânica em função do aumento da relação a/agl, o que favorece a susceptibilidade do matriz porosa frente às deformações resultantes das tensões capilares, atribui-se o aumento da retração autógena com o aumento da relação a/agl à porosidade singular do cimento de escória, caracterizada pela elevada proporção e volume de mesoporos. Constatou-se a correlação entre a retração autógena e o volume de mesoporos, na qual o aumento do volume de mesoporos na condição saturada incorre no aumento da retração autógena do cimento de escória ativada com silicato de sódio. O somatório das tensões capilares resultantes do consumo da água destes meniscos tende a ser maior quanto maior for o volume de mesoporos. Portanto, conclui-se que o aumento da retração autógena com o aumento da relação a/agl no cimento de escória ocorra em razão do aumento do efeito físico da auto-secagem decorrente da maior quantidade de meniscos formados em poros com diâmetros localizados na faixa de mesoporos.

É possível extrapolar a análise e explicar o motivo do aumento retração autógena com a diminuição da relação a/agl no cimento Portland, pois, como visto nos resultados de cimento de escória, a retração autógena está relacionada ao volume de mesoporos. Portanto, como no cimento portland a diminuição da relação a/agl incorre na diminuição da porosidade de total e no maior grau de refinamento da porosidade, estes fatos resultam no aumento do volume de mesoporos e, conseqüentemente, da retração autógena.

Portanto, do ponto de vista prático, para amenizar a retração autógena do cimento de escória ativada com silicato de sódio é recomendada a utilização de menores relações a/agl. Mais uma vez ressalta-se que a redução da a/agl por si só não é suficiente para amenizar a retração autógena do cimento de escória para patamares próximos aos observados no cimento Portland, visto que a retração autógena do cimento de escória é em torno de 4 vezes maior do que no cimento Portland (MELO NETO, 2002).

A relação água/aglomerante é de fundamental importância para a utilização do cimento de escória ativada com silicato de sódio, sendo inclusive um fator importante para a redução da elevada retração que caracteriza este tipo de cimento. A Tabela 14.1 apresenta o quadro resumo da influência da relação a/agl no cimento 
de escória nas condições específicas aplicadas neste trabalho. Com base neste quadro, é evidente o melhor desempenho na maioria das suas características com a diminuição da relação a/agl, até mesmo a retração autógena é amenizada com a redução da relação a/agl. Porém, é necessário atentar que apenas a redução da a/agl pode não ser suficiente para evitar a fissuração, pois a retração do cimento de escória ativada com silicato de sódio é bem maior do que no cimento Portland (Melo Neto, 2002), sendo importante utilizar métodos alternativos, como o emprego de aditivo compensadores e redutores de retração, indicados na tentativa de amenizar ainda mais a retração deste tipo de cimento.

Tabela 14.1 - Quadro resumo da influência da relação água/aglomerante no cimento de escória.

\begin{tabular}{ll} 
& \multicolumn{1}{c}{ Influência da relação água/aglomerante } \\
\hline Microestrutura & - Retardo da hidratação nas primeiras idades \\
& - Grau de hidratação similar aos 28 dias \\
& - Aumento da porosidade total \\
& - Retardo do início refinamento da porosidade \\
& - Não altera a distribuição de poros aos 28 dias \\
\hline Propriedades mecânicas & - Redução da resistência mecânica \\
& - Menor influência entre as relações a/agl 0,40 e 0,48 \\
& - Redução correlacionada ao aumento da porosidade \\
\hline Retração por secagem & - Aumento da retração por secagem \\
& - Aumento correlacionado com a porosidade, a quantidade de água \\
& livre para evaporação e a diminuição da resistência mecânica \\
\hline Retração autógena & - Aumento da retração autógena \\
& - Aumento correlacionado à distribuição de poros, especificamente, ao \\
& volume de mesoporos e à diminuição da resistência mecânica \\
\hline
\end{tabular}

\subsection{Influência do aditivo redutor de retração (SRA)}

O aditivo redutor de retração (SRA) tem como princípio de ação a diminuição da tensão superficial da água do poro, com isto, reduz a tensão capilar e, conseqüentemente, a retração. Este tipo de aditivo é a mais recente tentativa de amenizar a retração de compósitos de cimento Portland, existindo poucos relatos do seu uso no cimento de escória ativada. Neste trabalho foram empregados os seguintes teores de aditivo SRA: $0,5 \%, 1 \%, 1,5 \%$ e $2 \%$ em relação à massa de aglomerante. 


\subsubsection{Microestrutura}

Não foi constatada a interação química entre o aditivo SRA e o cimento de escória ativada com silicato de sódio, continuando o C-S-H e a hidrotalcita como os principais compostos hidratados deste tipo de cimento. De acordo com os resultados de difração de raios $X$ e de termogravimetria, o efeito mais intenso do aditivo redutor de retração (SRA) no cimento de escória ativada com silicato de sódio foram o retardo significativo do desenvolvimento do C-S-H e a diminuição da quantidade final do mesmo. A utilização do aditivo SRA provocou o retardo de até 3 dias no avanço das reações de hidratação, constatado pela redução da intensidade do pico principal do C-S-H. O teor de $0,5 \%$ de SRA apresentou um retardo de 1 dia no desenvolvimento da hidratação, mas logo em seguida apresentou um comportamento bastante semelhante ao observado no cimento de escória sem a utilização do aditivo.

Nas primeiras idades, observou-se a proporcionalidade entre a diminuição do C-S-H quantificado pela termogravimetria e o aumento do teor de aditivo SRA. Porém, aos 7 e 28 dias esta proporcionalidade já não ocorre mais e uma redução em torno de $20 \%$ da quantidade de C-S-H é constatada para qualquer teor de aditivo SRA utilizado. De acordo com os resultados obtidos e com o princípio de ação do aditivo SRA, é possível que a utilização deste tipo de aditivo afete a dissolução e a aglomeração nas primeiras idades, refletindo nas condições de desenvolvimento das reações químicas de hidratação. Resumindo, apesar ter seu mecanismo baseado na alteração de um aspecto físico, na utilização do aditivo SRA não é possível desprezar o seu efeito na cinética de hidratação do cimento de escória ativada com silicato de sódio.

A porosidade do cimento de escória é alterada com a utilização do aditivo SRA, apresentando o aumento da porosidade total e o retardo do início do refinamento da mesma. O aumento da porosidade total é mais intenso nas primeiras idades, onde com 1 dia de idade a porosidade total passa de em torno de 30\% na mistura sem aditivo para em torno de 50\% com qualquer teor de aditivo SRA utilizado. A distribuição de poros também é fortemente afetada nas primeiras idades, onde, com 
1 dia de idade, a proporção de mesoporos passa de em torno de $17 \%$ sem a utilização de aditivo para em torno de 5\% com a utilização do aditivo SRA.

Com o avanço da idade, a porosidade total continua maior do que na mistura sem aditivo, porém com um valor bem próximo, e ocorre o refinamento da distribuição de poros. Aos 28 dias, o perfil da distribuição de poros das misturas com aditivo SRA torna-se similar ao observado sem a utilização do aditivo, ou seja, com uma proporção de mesoporos em torno de 94\%. Como comentado anteriormente, o volume de mesoporos está relacionado à retração autógena do cimento de escória. Portanto, como o aditivo SRA não altera de forma significativa o volume de mesoporos e na condição autógena não há perda de água para o ambiente, é de se esperar que este tipo de aditivo não seja eficiente na redução da retração autógena do cimento de escória. Esta análise reversa é confirmada nos resultados de retração autógena.

\subsubsection{Propriedades mecânicas}

A utilização do aditivo redutor de retração (SRA) no cimento de escória ativada incorreu na redução significativa da resistência mecânica, de forma mais acentuada nas primeiras idades. Com base nos resultados de caracterização da microestrutura, sabe-se que o aditivo SRA retardou a hidratação, diminuiu a quantidade de C-S-H e aumentou a porosidade, fatores que causaram a diminuição da resistência mecânica deste tipo de cimento.

A diminuição da resistência mecânica foi diretamente proporcional ao aumento do teor de aditivo SRA e da relação a/agl, portanto, a utilização de teores de SRA superiores a $1 \%$, juntamente com relações água/aglomerante superiores a 0,48 , poderá inviabilizar a utilização do cimento de escória ativada com silicato de sódio nas primeiras idades, em razão das baixas resistências mecânicas apresentadas. Com base nos resultados obtidos, o teor de 0,5\% é mais adequado para situações onde se deseja utilizar o aditivo SRA sem que ocorra grande retardo da hidratação nas primeiras idades. Caso seja necessário utilizar teores maiores de aditivo SRA para o combate a retração, a redução da relação a/agl é benéfica, uma vez que propicia a aceleração do desenvolvimento das reações de hidratação e ainda reduz 
a retração por secagem e autógena do cimento de escória, conforme descrito anteriormente.

\subsubsection{Retração por secagem}

O aditivo redutor de retração (SRA) obteve êxito na diminuição da retração por secagem do cimento de escória ativada com silicato de sódio, reduzindo em até $74 \%$ com a utilização de $2 \%$ de aditivo SRA. Observou-se também que a redução da retração por secagem foi proporcional ao aumento do teor de aditivo SRA e que a utilização do aditivo retardou de forma significativa o início da retração. O efeito da redução da tensão superficial é ressaltado nos resultados da variação de massa por evaporação, constatando-se que a utilização deste tipo de aditivo permite a maior evaporação da água livre. Este efeito é atribuído ao enfraquecimento da ligação da água do poro com as partículas hidratadas, sendo este provocado pela redução da tensão superficial com a utilização do aditivo SRA.

Com base nos resultados de microestrutura, conclui-se que o aditivo SRA, além de minimizar as deformações oriundas das tensões capilares, retarda 0 desenvolvimento da hidratação. Este efeito na cinética de hidratação acaba por também contribuir para a redução da retração por secagem, pois, comprovou-se que este retardo proporciona uma quantidade maior de água livre, a qual é facilmente perdida para o ambiente sem que ocorra retração significativa. Este comportamento foi comprovado com a análise da correlação entre a retração por secagem e a variação de massa por evaporação, onde o aditivo SRA incorreu no aumento significativo da perda de água sem que ocorresse uma retração por secagem significativa.

\subsubsection{Retração autógena}

A utilização do aditivo redutor de retração (SRA) não foi capaz de reduzir a retração autógena do cimento de escória ativada com silicato de sódio, sendo observada apenas uma redução na intensidade da retração autógena nas primeiras idades. Porém aos 28 dias, os resultados da retração autógena da mistura com e sem aditivo SRA são praticamente idênticos, independentemente do teor estudado. 
Conforme constatado na análise do efeito do aditivo SRA na retração por secagem, a diminuição da tensão superficial é fundamental para a diminuição das tensões capilares resultantes da secagem. $\mathrm{Na}$ condição de cura autógena, este efeito não apresenta efeito algum na magnitude total da retração autógena do cimento de escória ativada com silicato de sódio, ocorrendo apenas uma redução da magnitude nas primeiras idades, atribuída ao retardo do desenvolvimento da microestrutura causado pelo aditivo.

Conforme descrito nas conclusões da influência da relação a/agl na retração autógena do cimento de escória ativada, a magnitude da retração autógena deste tipo de cimento é relacionada à distribuição de poros, especificamente pelo volume de mesoporos. Como o aditivo SRA não altera o perfil final da distribuição de poros, é coerente que para uma mesma relação a/agl tenhamos valores similares para o volume final de mesoporos independentemente do teor de aditivo SRA utilizado. Conseqüentemente, a retração autógena resultante da formação da matriz porosa vai ser a mesma com a utilização do aditivo redutor de retração (SRA), ocorrendo apenas um retardo inicial do seu crescimento. Portanto, conclui-se que o aditivo redutor de retração (SRA) não diminui a retração autógena do cimento de escória ativada com silicato de sódio, apenas causa um retardo na sua evolução inicial.

\subsubsection{Discussão e conclusões}

De acordo com os resultados obtidos, do ponto de vista de emprego do aditivo redutor de retração (SRA) no caso específico do cimento de escória ativada com silicato de sódio, está evidente que a sua utilização é eficiente apenas para amenizar a retração por secagem deste tipo de cimento. O aditivo SRA não é indicado para aplicações em que a retração autógena venha a ser um critério de uso.

Também é necessário o conhecimento das condições de aplicação necessárias e a análise do efeito do aditivo na retração e nas propriedades mecânicas. Pois, dependendo do uso, não tem sentido prático amenizar a retração do material, ao custo de prejudicar significativamente a sua resistência mecânica. Como exemplo de um critério de seleção do aditivo SRA, é o emprego do cimento de escória ativada 
com silicato de sódio em aplicações que necessitem de elevada resistência inicial e da minimização da retração. Neste caso é aconselhável a utilização de teores menores que $1 \%$ de SRA e relações a/agl menores que 0,48. Com isto possibilita a diminuição da retração por secagem em função do efeito conjunto da diminuição da relação a/agl e a utilização do aditivo SRA; e a diminuição da retração autógena em função do efeito da diminuição da relação a/agl. Aplicações que necessitem apenas de resistência à longo prazo podem fazer uso de teores maiores de aditivo SRA e maiores relações a/agl, pois são alcançados valores significativos aos 28 dias. A Tabela 14.2 apresenta o quadro resumo da influência do teor de aditivo redutor de retração (SRA) no cimento de escória nas condições específicas aplicadas neste trabalho.

Tabela 14.2 - Quadro resumo da influência do teor de aditivo SRA no cimento de escória.

Influência do teor de aditivo SRA

\begin{tabular}{ll}
\hline Microestrutura & - Retardo intenso da hidratação nas primeiras idades \\
& - Diminuição do grau de hidratação aos 28 dias \\
& - Retardo do início refinamento da porosidade \\
& - Aumento discreto da porosidade total \\
& - Não altera a distribuição de poros aos 28 dias, caracterizada pela \\
& elevada proporção do volume de mesoporos \\
\hline Propriedades mecânicas & - Diminuição significativa da resistência mecânica \\
& - Efeito mais intenso nas primeiras idades \\
& - Redução relacionada à diminuição do grau de hidratação \\
& - Redução da resistência mecânica proporcional ao teor de aditivo \\
& empregado \\
\hline Retração por secagem & - Redução significativa da retração por secagem \\
& - Redução relacionada à diminuição da tensão capilar \\
& - Redução com maior intensidade nas primeiras idades \\
& - Aumento da quantidade de água evaporada \\
& - Proporcionalidade entre a redução da retração e o aumento do teor \\
& de aditivo utilizado \\
\hline Retração autógena & - Não reduziu a retração autógena \\
& - Retardo discreto do início da retração autógena \\
\hline
\end{tabular}

\subsection{Influência do aditivo compensador de retração (SCA)}

O aditivo compensador de retração (SCA) tem funcionamento com base na expansão gerada pela formação da etringita com a hidratação do aditivo, de modo a compensar a retração. Este tipo de aditivo é mais antigo do que o aditivo redutor de retração, porém não há relatos da sua utilização no cimento de escória ativada com 
silicato de sódio. Neste trabalho foram empregados os seguintes teores de aditivo SCA: 5\%, 10\% e 15\% em relação à massa de aglomerante.

\subsubsection{Microestrutura}

Inicialmente, ressalta-se que os percentuais de aditivos empregados são significativos, portanto, nada mais normal do que o aparecimento de picos referentes a compostos anidros e hidratados oriundos do aditivo SCA nos resultados de difração de raios $X$ e termogravimetria. Nos resultados de difração de raios $X$ foram identificados picos associados ao sulfoaluminato de cálcio anidro, à anidrita e ao óxido de cálcio, além dos picos já conhecidos de C-S-H e hidrotalcita resultantes da hidratação do cimento de escória. O intuito inicial era utilizar a etringita como parâmetro para avaliar a hidratação do aditivo SCA no cimento de escória, porém sua identificação não foi possível no ensaio de difração de raios $\mathrm{X}$.

$\mathrm{Na}$ análise da termogravimetria foram identificados, além do pico do C-S-H em torno de $100^{\circ} \mathrm{C}$, um pico entre $400^{\circ} \mathrm{C}$ e $500^{\circ} \mathrm{C}$ referente à portlandita e um pico entre $600^{\circ} \mathrm{C}$ e $700^{\circ} \mathrm{C}$ referente à decomposição de fase carbonática mal cristalizada. Como não há indício de carbonatação das amostras é provável que esta fase carbonática seja resultante da reação das fases aluminatos hidratadas, oriundas da hidratação do aditivo SCA, e o carbonato de cálcio presente na escória anidra, resultando em monocarboaluminato de cálcio hidratado (BONAVETTI et al., 2001). A presença deste composto é confirmada na análise dos resultados de difração de raios $X$.

Em razão da localização do seu pico principal, em torno de $100^{\circ} \mathrm{C}$, sobreposto ao pico do C-S-H, não é possível identificar a etringita nos ensaios de termogravimetria. Apesar deste fato, conclui-se que o principal efeito do aditivo compensador de retração (SCA) foi a diminuição da quantidade de C-S-H do cimento de escória ativada com silicato de sódio. Este efeito pode ser atribuído a alterações na cinética de hidratação do cimento de escória com a interferência da hidratação do aditivo SCA, principalmente em razão do elevado consumo de água por parte do aditivo. A hidratação do aditivo é confirmada pelo consumo do sulfoaluminato de cálcio e da 
anidrita pelas reações de hidratação, observado com a redução da intensidade dos picos na análise de difração de raios $X$.

O aditivo compensador de retração (SCA) causou a alteração da estrutura da matriz porosa do cimento de escória ativada com silicato de sódio, provocando um aumento da porosidade total e da proporção de macroporos. Aos 28 dias, a utilização do aditivo SCA alterou a proporção do volume de mesoporos de $95 \%$ sem aditivo, para em torno de $76 \%$ com $15 \%$ de aditivo SCA. Esta alteração da porosidade é atribuída à introdução de compostos hidratados com estrutura mais porosa; como a portlandita, a etringita e o monossulfoaluminato de cálcio hidratado; e à diminuição da quantidade de C-S-H, consensualmente um composto de porosidade mais refinada.

\subsubsection{Propriedades mecânicas}

A utilização do aditivo compensador de retração (SCA) causou a redução da resistência mecânica do cimento de escória ativada com silicato de sódio. Tendo ciência de que este tipo de aditivo é utilizado em teores significativos, a simples substituição do cimento de escória com o uso do aditivo SCA já é suficiente para prever uma redução da resistência mecânica. No entanto, a redução da resistência à compressão constatada foi bem maior do que os percentuais de aditivo empregados, alcançando em torno de $60 \%$ na mistura com relação a/agl igual a 0,40 e $15 \%$ de aditivo SCA.

Este comportamento é explicado pelas alterações causadas pela utilização do aditivo SCA no desenvolvimento da microestrutura, principalmente o aumento da porosidade e da proporção do volume de macroporos. Contribui ainda a diminuição da quantidade de C-S-H e a introdução de novos produtos hidratados oriundos do aditivo SCA, os quais não têm a propriedade de colaborar no ganho de resistência. Ressalta-se também que a interação entre a relação a/agl e o teor de aditivo SCA na resistência mecânica do cimento de escória foi significativa. Onde, o uso de aditivos SCA na mistura com menor relação a/agl provocou uma redução mais intensa

propriedades mecânicas quando comparado com as demais relações estudadas. É possível que em condições de pouca disponibilidade de água ocorram dificuldades 
para o avanço das reações de hidratação, tanto do aditivo SCA quanto do cimento de escória.

\subsubsection{Retração por secagem}

O aditivo compensador de retração (SCA) foi capaz de diminuir a retração por secagem do cimento de escória ativada com silicato de sódio, reduzindo em percentuais de até $65 \%$ aos 28 dias com a utilização de 15\% de aditivo SCA. A redução da retração por secagem foi proporcional ao aumento do teor de aditivo SCA utilizado. O aditivo SCA também desacelerou o desenvolvimento da retração, alterando a evolução abrupta e posterior evolução gradual da mistura sem aditivo para uma evolução gradual com o uso do aditivo. Apesar de ter como objetivo gerar uma expansão de forma a compensar a retração, não se observa nenhuma expansão em magnitude suficiente para compensar a retração por secagem nas condições estudadas, provavelmente, a expansão produzida tenha sido capaz apenas de amenizar a retração por secagem.

A expansão gerada pelo aditivo SCA foi maior com o aumento da disponibilidade de água, comprovado pela análise da variação de massa por evaporação. Constatou-se que o aumento da relação a/agl incorre na menor perda de água para o ambiente, decorrente da menor disponibilidade de água livre para evaporação em função do consumo pela hidratação do aditivo SCA. É obvio que a principal contribuição do aditivo SCA na redução da retração por secagem do cimento de escória seja a expansão produzida por ele, mas também contribui para isto o efeito deste tipo de aditivo na porosidade, aumentando a proporção do volume de macroporos. Este fato contribui para redução da retração por secagem e, com maior intensidade, da retração autógena do cimento de escória. No entanto, a alteração da estrutura da matriz porosa também afeta as propriedades mecânicas, diminuindo-as, o que precisar ser avaliado no emprego deste tipo de aditivo.

\subsubsection{Retração autógena}

A utilização do aditivo compensador de retração (SCA) possibilitou a diminuição da retração autógena do cimento de escória, alcançando reduções em termos 
percentuais de até $72 \%$ com a utilização de $15 \%$ de aditivo SCA e relação a/agl igual a 0,40. Conforme descrito anteriormente, a principal diferença entre o efeito do aditivo SCA e SRA na microestrutura do cimento de escória foi a alteração da porosidade, diminuindo a proporção de macroporos de $95 \%$ para $76 \%$. Este fato, conjuntamente com a expansão gerada pelo aditivo, contribui para a diminuição da retração autógena em razão da redução das tensões capilares com o aumento do diâmetro de uma fração significativa da porosidade. Ressalta-se que, mesmo favorecido pela condição autógena, não foi observada a compensação da retração autógena, apenas a identificação de inflexões na curva de evolução da taxa de retração autógena que indicam o instante de maior expansão.

O efeito da relação a/agl no desempenho do aditivo compensador de retração (SCA) não apresentou uma tendência com o aumento da relação, constatando-se as maiores reduções percentuais nas relações a/agl iguais a 0,40 e 0,56 do que na mistura com relação a/agl igual a 0,48 . Portanto, com base no fato do aumento da relação a/agl causar o aumento da retração por secagem e autógena, para a redução mais intensa da retração é indicado utilizar este aditivo com menores relações a/agl. Porém, ressalta-se que características da trabalhabilidade do cimento de escória com este tipo de aditivo ainda necessitam de estudos para determinar o seu comportamento.

A utilização do aditivo compensador de retração (SCA) no cimento de escória ativada apresentou comportamentos distintos quando alterada a disponibilidade de água, pois, apesar de reduzir a retração autógena, apresentou as maiores reduções nos extremos estudados, 0,40 e 0,56. O aditivo SCA também diminuiu a retração autógena da mistura com relação a/agl igual a 0,48 , porém a redução máxima alcançada foi em torno de $45 \%$ com $15 \%$ de aditivo SCA, enquanto na mistura com relação 0,40 e 0,56 foram alcançadas reduções em torno de $72 \%$ e $60 \%$, respectivamente, com o mesmo teor de aditivo SCA. Este comportamento, juntamente com os resultados de caracterização da microestrutura, indica que a utilização do aditivo SCA em um compósito de cimento de escória com baixa relação a/agl proporcionará a redução da retração autógena em função da expansão gerada pela hidratação do aditivo, com contribuições em razão das alterações da microestrutura causadas pelo aditivo SCA. 


\subsubsection{Discussão e conclusões}

De acordo com os resultados obtidos, o aditivo compensador de retração (SCA) obteve êxito em amenizar a elevada retração por secagem e autógena do cimento de escória ativada com silicato de sódio. O fato de reduzir a retração autógena pode ser uma vantagem na aplicação deste tipo de aditivo, pois o aditivo redutor de retração (SRA) não obteve êxito nesta questão. A redução da resistência mecânica com o uso do aditivo SCA necessita de atenção na sua utilização, pois, apesar de reduzir de modo menos intenso nas primeiras idades quando comparado ao aditivo redutor de retração (SRA), causa a redução significativa da resistência a partir dos 7 dias de idade. A Tabela 14.2 apresenta o quadro resumo da influência do teor de aditivo redutor de retração (SRA) no cimento de escória nas condições específicas aplicadas neste trabalho.

Tabela 14.3 - Quadro resumo da influência do teor de aditivo SCA no cimento de escória.

Influência do teor de aditivo SCA

\begin{tabular}{ll} 
& Influência do teor de aditivo SCA \\
\hline Microestrutura & - Interação química com os produtos hidratados do cimento de escória \\
& - Diminuição do grau de hidratação aos 28 dias \\
& - Aumento porosidade total \\
& - Alteração da distribuição de poros com o aumento da proporção do \\
& volume de macroporos \\
\hline Propriedades mecânicas & - Diminuição significativa da resistência mecânica \\
& - Efeito mais intenso a partir de 7 dias de idade \\
& - Redução relacionada ao aumento da porosidade \\
& - Quanto menor a relação a/agl, mais intenso o efeito do aditivo na \\
& redução da resistência mecânica \\
& - Redução da resistência mecânica proporcional ao teor de aditivo \\
& empregado \\
\hline Retração por secagem & Não ocorre a compensação da retração por secagem \\
- Redução significativa da retração por secagem \\
- Redução relacionada à expansão gerada pelo aditivo e à alteração \\
da porosidade e da sua distribuição de poros \\
- Desaceleração da evolução da retração por secagem \\
- Melhor desempenho com o aumento da relação a/agl \\
- Diminuição da quantidade de água evaporada com o aumento da \\
relação a/agl \\
- Proporcionalidade entre a redução da retração e o aumento do teor \\
de aditivo utilizado \\
\hline - Não ocorre a compensação da retração autógena \\
- Redução significativa da retração autógena \\
- Redução atribuída à expansão gerada e à diminuição da proporção \\
do volume de mesoporos \\
- A influência da relação a/agl não apresentou resultados que \\
permitam estabelecer uma tendência \\
\hline Retração autógena \\
\end{tabular}




\subsection{Aditivo redutor de retração versus aditivo compensador de retração (SCA)}

\subsubsection{Microestrutura}

A principal diferença entre os efeitos dos aditivos na microestrutura foi a alteração da distribuição de poros causada pelo aditivo compensador de retração (SCA), enquanto o aditivo redutor de retração (SRA) apenas retardou o início do refinamento da porosidade. Ao contrário do aditivo SRA, o aditivo SCA alterou o perfil dos resultados de caracterização da hidratação do cimento de escória, introduzindo novos compostos hidratados e anidros e formando novos compostos hidratados, como o monocarboaluminato de cálcio hidratado. Ambos os aditivos diminuíram a quantidade de C-S-H formado na hidratação do cimento de escória ativada com silicato de sódio: o aditivo SRA em razão da interferência na dissolução e aglomeração nas primeiras idades, e o aditivo SCA em razão da interferência da sua hidratação na disponibilidade de água e na cinética de hidratação.

\subsubsection{Propriedades mecânicas}

Quando se compara com o efeito do aditivo redutor de retração (SRA), está claro que 0 aditivo compensador de retração (SCA) afeta menos as propriedades mecânicas do cimento de escória nas primeiras idades, porém aos 28 dias são observadas reduções maiores do que as observadas com a utilização do aditivo SRA. Portanto, conclui-se que a utilização do aditivo SCA reduz a resistência mecânica do cimento de escória ativada com silicato de sódio, porém, não de modo que inviabilize seu uso em aplicação que necessite de resistência nas primeiras idades. O aditivo redutor de retração (SRA) pode ter seu efeito negativo na resistência mecânica inicial do cimento de escória atenuado com a utilização de menores relações a/agl, visto que esta mudança causa a aceleração do desenvolvimento da hidratação. 


\subsubsection{Retração por secagem}

Ambos os aditivos obtiveram êxito na redução da retração por secagem do cimento de escória ativada com silicato de sódio. Porém, o aditivo redutor de retração (SRA) se mostrou mais eficiente do que o aditivo compensador de retração (SCA), obtendo reduções percentuais de $40 \%$ até $74 \%$ na retração por secagem aos 28 dias, enquanto o aditivo SCA obteve reduções de $20 \%$ até $64 \%$. Quanto à redução da retração por secagem nas primeiras idades, o aditivo SRA apresentou desempenho bem melhor do que o aditivo SCA, praticamente reduzindo pela metade a retração por secagem até os 3 dias de idade. Apesar de afetar a hidratação do aditivo SCA, a diminuição da relação a/agl pode ser utilizada para, em conjunto com a utilização dos aditivos, a obtenção de valores menores para a retração por secagem.

\subsubsection{Retração autógena}

Apenas o aditivo compensador de retração (SCA) foi capaz de diminuir a retração autógena do cimento de escória ativada com silicato de sódio. O aditivo redutor de retração (SRA) apenas retardou o início da evolução da retração autógena, explicado pelo retardo provocado no desenvolvimento da microestrutura. A redução da retração autógena com o uso do aditivo SCA foi proporcional ao aumento do teor de aditivo utilizado, porém não houve tendência de melhor redução da retração autógena com o aumento da relação a/agl.

\subsection{Sugestões para pesquisas futuras}

Com a finalização desta etapa do estudo do cimento de escória ativada, algumas sugestões para a continuidade do desenvolvimento do tema podem ser dadas.

- Os resultados obtidos indicam que o aditivo redutor de retração (SRA) apresentou melhor desempenho na redução da retração por secagem, porém não obteve êxito quanto à retração autógena. Portanto, seria válido o desenvolvimento do estudo da aplicação conjunta do aditivo SRA com o aditivo compensador de retração (SCA), pois este último obteve êxito na redução da retração autógena. 
- Os resultados obtidos e as análises realizadas no desenvolvimento evidenciaram que ainda restam lacunas sobre o comportamento da aglomeração do cimento de escória ativada com silicato de sódio nas primeiras horas. Portanto, seria válido o desenvolvimento de estudos sobre o comportamento reológico deste tipo de cimento.

- O desenvolvimento de uma metodologia e de equipamentos para a realização de medida da retração restringida foi iniciado nesta tese, constando os detalhes no Apêndice D. Porém, fatores diversos impossibilitaram a finalização do equipamento no período do doutorado. Portanto, seria importante a continuação do desenvolvimento deste equipamento e a realização de estudos sobre a retração restringida, não só no cimento de escória ativada, mas também no cimento Portland, visto que estudos sobre a retração restringida são escassos no Brasil. 


\section{Referências bibliográficas}

\section{A}

$\mathrm{ACl}$ Committee 223. Expansive cement concretes - Present state of knowledge. American Concrete Institute Journal, v.67, n.8, p. 583-610, 1970.

ALTOUBAT, S.A. Early age stresses and creep-shrinkage interaction of restrained concrete. 2000. Tese (Doutorado) - University of Illinois at UrbanaChampaign, Estados Unidos da America.

AMERICAN SOCIETY FOR TESTING AND MATERIALS (ASTM). Standard Practice for Use of Apparatus for Determination of Length Change of Hardened Cement Paste, Mortar, and Concrete(C 490). Annual Book of ASTM Standards, Philadelphia, 1997.

AMERICAN SOCIETY FOR TESTING AND MATERIALS (ASTM). Standard Specification for Expansive Hydraulic Cement (C 845). Annual Book of ASTM Standards, Philadelphia, 1996.

ANDERSSON, R.; GRAM, H.E. Properties of alkali-activated slag. In: Alkali activated slag (part I). Stockholm: Swedish Cement and Concrete Research Institute, 1988. p.9-63. (CBI Research to 1-88).

ASSOCIAÇÃO BRASILEIRA DE NORMAS TÉCNICAS. - NBR 7217 (NBRNM 248/2003) - Agregados - determinação da composição granulométrica. Rio de Janeiro, 1987.

ASSOCIAÇÃO BRASILEIRA DE NORMAS TÉCNICAS. - NBR 7251 - Agregado em estado solto - determinação da massa unitária. Rio de Janeiro,1982.

ASSOCIAÇÃO BRASILEIRA DE NORMAS TÉCNICAS. - NBR 8490 - Argamassas endurecidas para alvenaria - Retração por secagem. Rio de Janeiro,1984.

ASSOCIAÇÃO BRASILEIRA DE NORMAS TÉCNICAS. - NBR 9776 (NBRNM 56/2003) - Agregados - determinação da massa específica de agregados miúdos por meio do frasco de Chapman. Rio de Janeiro, 1987.

ATRUSHI, D.S. Tensile and Compressive Creep of Early Age Concrete: Testing and Modelling. 2003. 333p. Tese (Doutorado) - Norwegian University of Science and Technology, Noruega.

B

BAKHAREV, T., SANJAYAN, J.G., CHENG, Y.B. Alkali activation of Australian slag cements. Cement and Concrete Research, v.29, n.1, p.113-120, 1999. 
BAKHAREV, T., SANJAYAN, J.G., CHENG, Y.B. Effect of admixtures on properties of alkali-activated slag concrete. Cement and Concrete Research, v.30, n.9, p.1367-1374, 2000.

BAKHAREV, T.; SANJAYAN, J.G.; CHENG, Y.B. Resistance of alkali-activated slag concrete to alkali-aggregate reaction. Cement and Concrete Research, v.31, n.2, p. 331-334, 2001.

BARCELO, L.; BOIVIN, S.; RIGAUD, S.; ACKER, P.; CLAVAUD, B.; BOULAY, C. 'Linear vs. volumetric autogenous measurement: Material behavior or experimental artefact?'. In: 2nd International Research Seminary on Self-desiccation and its importance in concrete technology. Proceedings. Lund, Suécia, 1999, p.109-125.

BASTOS, P.K.X. Retração e desenvolvimento de propriedades mecânicas de argamassas mistas de revestimento. 2001. 172p. Tese (Doutorado) - Escola Politécnica, Universidade de São Paulo. São Paulo.

BENBOUDJEMA, F. Modelisation des deformations differees du beton sous sollicitations biaxiales. application aux enceintes de confinement de batiments reacteurs des centrales nucleaires. 2002. 258p. Tese (Doutorado) - Université de Marne-la-Vallée, França.

BENTUR, A.; KOVLER, K. Evaluation of early age cracking characteristics in cementitious systems. Materials and Structures, v.36, n.3, p.183-190, 2003.

BENTZ, D.P. Curing with Shrinkage-Reducing Admixtures: Beyond Drying Shrinkage Reduction. Concrete International, v.27, n.10, p.55-60, 2005.

BENTZ, D.P. Influence of Shrinkage-Reducing Admixtures on Early-Age Properties of Cement Pastes. Journal of Advanced Concrete Technology, v.4, n.3, p.423429, 2006.

BENTZ, D.P.; GEIKER, M.R.; HANSEN, K.K. Shrinkage-reducing admixtures and early-age desiccation in cement pastes and mortars. Cement and Concrete Research, v.31, n.7, p.1075-1085, 2001.

BISSONNETTE, B.; PIGEON, M. Tensile creep at early ages of ordinary, silica fume and fiber reinforced concretes. Cement and Concrete Research, v.25, n.5, p.10751085, 1995.

BLOOM, R.; BENTUR, A. Free and restrained shrinkage of normal and high-strength concretes. ACI Materials Journal, v.92, n.2, p.211-217, 1995.

BONAVETTI, V.L.; RAHHAL, V.F.; IRASSAR, E.F. Studies on the carboaluminate formation in limestone filler-blended cements. Cement and Concrete Research, v.31, n.6, p.853-859, 2001.

BREUGEL, K.V. Numerical modelling of volume changes at early ages - Potential, pitfalls and challenges. Materials and Structure, v.34, n.5, p.293-301, 2001. 
BREUGEL, K.V.; DE VRIES, J. Mixture optimization of HPC in view of autogenous shrinkage. In: Fifth International Symposium on Utilization of High Strength/High Performance Concrete. Proceedings. Sandefjord, 1999, p.1017-1026.

British Standard - European Norms - BS EN 196. Methods of testing cement. Determination of strength. Part 1. 1995

BRITO, S. L. M.; GOUVEA, D.; GANZELLA, R. Estudo da adsorção de dispersante à base de poliacrilato em um sistema varistor comercial: caracterização físico-química. Cerâmica, vol.51, n.317, p.30-36, 2005.

BROOKS, J.J.; JIANG, X. The influence of chemical admixtures on restrained drying shrinkage of concrete. In: V.M. Malhotra (Ed.), Superplasticizers and Other Chemical Admixtures in Concrete, ACI, SP 173 (1997) p.249-265.

BROOKS, J.J.; MEGAT JOHARI, M.A.; MAZLOOM, M. Effect of admixtures on the setting times of high-strength concrete. Cement and Concrete Composites, v.22, n.4, p.293-301, 2000.

BROUGH, A.R.; ATKINSON, A. Sodium silicate-based, alkali-activated slag mortars: Part I - Strength, hydration and microstructure. Cement and Concrete Research, v.32, n.6, p.865-879, 2002.

BUIL, M.; OLLIVIER, J.-P. Conception des bétons: la structure poreuse. In: chapitre 3, In: J. BARON, J.-P. OLLIVIER (Eds.), La durabilité des bétons, Paris: Presses de l'École Nationale des Ponts et Chaussées, 1992, p. 7-106.

\section{C}

CARVALHO, J. Análise de ciclo de vida ambiental aplicada a construção civil Estudo de caso: comparação entre os cimentos Portland com adição de resíduos. São Paulo, 2002. 102p. Dissertação (Mestrado) - Escola Politécnica, Universidade de São Paulo.

CINCOTTO, M.A.; MELO, A.A.; REPETTE, W.L. Effect of Different Activators Type and Dosages and Relation with Autogenous Shrinkage of Activated Blast Furnace Slag Cement. 11을 International Congress on the Chemistry of Cement - ICCC, 2003, p.1878-1888, Durban, Africa do sul.

COLLEPARDI, M.; BORSOI, A.; COLLEPARDI, S.; OLAGOT, J.J.O.; TROLI, R. Effects of shrinkage reducing admixture in shrinkage compensating concrete under non-wet curing conditions. Cement and Concrete Composites, v.27, n.6, p.704708, 2005.

COLLINS, F.; SANJAYAN, J.G. Effects of ultra-fine materials on workability and strength of concrete containing alkali-activated slag as the binder. Cement and Concrete Research, v.29, n.3, p. 459-462, 1999a 
COLLINS, F.; SANJAYAN, J.G. Microcracking and strength development of alkali activated slag concrete. Cement and Concrete Composites, v.23, n.4-5, p. 345352, 2001.

COLLINS, F.G., SANJAYAN, J.G. Cracking tendency of alkali-activated slag concrete subjected to restrained shrinkage. Cement and Concrete Research, v.30, n.5, p.791-798, 2000a.

COLLINS, F.G., SANJAYAN, J.G. Strength and shrinkage properties of alkaliactivated slag concrete containing porous coarse aggregate. Cement and Concrete Research, v.29, n.4, p.607-610, 1999b.

COLLINS, F.G.; SANJAYAN, J.G. Effect of admixtures on properties of alkaliactivated slag concrete. Cement and Concrete Research, v.30, n.9, p.1367-1374, $2000 b$.

COLLINS, F.G.; SANJAYAN, J.G. Effect of pore size distribution on drying shrinkage of alkali-activated slag concrete. Cement and Concrete Research, v.30, n.9, p.1401-1406, 2000c.

CUSSON, D.; HOOGEVEEN, T. An experimental approach for the analysis of earlyage behavior of high-performance concrete structures under restrained shrinkage. Cement and Concrete Research, v.37, p.200-209, 2007.

CUSSON, D.; REPETTE, W.L. Early-Age Cracking in Reconstructed Concrete Bridge Barrier Walls. ACI Materials Journal, v.97, n.4, p.438-446, 2000.

D

DUBRAWSKI, J.V. Thermal characteristics of aged granulated blast furnace slags. Journal of Thermal Analysis and Calorimetry, v.48, n.1, p.63-72, 1997.

$\mathbf{F}$

FOLLIARD, K.J., BERKE, N.S. Properties of High-performance Concrete Containing Shrinkage-reducing Admixture. Cement and Concrete Research, v.27, n.9, p.13571364, 1997.

FOLLIARD, K; SMITH, C; SELLERS, G; BROWN, M; BREEN, J.E. Evaluation of alternative materials to control drying-shrinkage cracking in concrete bridge decks. 1998. 250p. Research Report: 0-4098-4, University of Texas, Texas Department of Transportation and Federal Highway Administration. 2003. 170p. Estados Unidos da America.

FREDERICCI, C.; ZANOTTO, E.D.; ZIEMATH, E.C. Crystallization mechanism and properties of a blast furnace slag glass. Journal of Non-Crystalline Solids, v.273, n.1-3, p.64-75, 2000. 
G

GLUKHOVSKY, V.D. Ancient, modern and future concretes. In: ALKALINE CEMENTS AND CONCRETES, First International Conference, v.1, Proceedings, Kiev, Russia, 1994, p.1-9.

GLUKHOVSKY, V.D.; ROSTOVSKAJA,G.S.; RUMYNA, G.V. High strength slagalkaline cements. In: INTERNATIONAL CONGRESS ON THE CHEMISTRY OF CEMENT, 7. Paris, 1980. Proceedings. Paris : Spetima, 1980. v.5, p.164-168.

H

HÄKKINEN, T. The microstructure of high strength blast furnace slag concrete. Nordic Concrete Research, n.11, p. 67-82, 1992.

HAMMER, T.A. 'Is there a relationship between pore water pressure and autogenous shrinkage before and during setting?'. In: 3rd International Research Seminary on Self-desiccation and its importance in concrete technology. Proceedings. Lund, Suécia, 2002, p. 27-38.

HE, Z.; LI, Z.J.; CHEN, M.Z.; LIANG, W.Q. Properties of shrinkage-reducing admixture-modified pastes. Materials and Structures, v.39, n.4, p. 445-453, 2006.

HOLT, E. 'Very early age autogenous shrinkage: governed by chemical shrinkage or self-desiccation ?'. In: 3rd International Research Seminary on Self-desiccation and its importance in concrete technology. Proceedings. Lund, Suécia, 2002, p. 27-38.

HOLT, E.E., LEIVO, M.T. Methods of reducing early shrinkage. In: International RILEM workshop on shrinkage of concrete "Shrinkage 2000", Edited by V. BaroghelBouny and P.-C. Aïtcin. Proceedings. Paris, 2000, p. 435-447.

HOSSAIN, A.B. Assessing residual stress development and stress relaxation in restrained concrete ring specimens. 2003. 120p. Tese (Doutorado) - Purdue University, Estados Unidos da America.

HUA, C.; ACKER, P.; ERLACHER, A. Analyses and models of the autogenous shrinkage of hardening cement paste, I. Modelling at the macroscopic scale. Cement and Concrete Research, v.25, n.7, p.1457-1468, 1995.

INTERNATIONAL UNION OF PURE AND APPLIED CHEMISTRY - (IUPAC). Compendium of chemical terminology - online version, corresponds to the second edition (1997), compiled by Alan D. McNaught and Andrew Wilkinson. Disponível na Internet www.iupac.org/publications/compendium/. 
$\mathbf{J}$

JAPAN CONCRETE INSTITUTE (JCl) - Technical Committee on Autogenous Shrinkage of concrete. Committee Report. In: Ei-ichi Tazawa (Ed.), Autogenous Shrinkage of concrete: Proceedings of the International Workshop, organized by $\mathrm{JCl}$ (Japan Concrete Institute), Hiroshima, 1998, p.1-63.

JENSEN, O.M; HANSEN, P.F. Autogenous deformation and RH-change in perspective. Cement and Concrete Research, v.31, n.12, p.1859-1865, 2001.

JIMÉNEZ, A.F.; PALOMO, J.G.; PUERTAS, F. Alkali-activated slag mortars: Mechanical strength behavior. Cement and Concrete Research, v.29, n.8, p. 13131321, 1999.

JIMÉNEZ, A.F.; PUERTAS, F. Alkali-activated slag cements: Kinetic studies. Cement and Concrete Research. v.27, n.3, p.359-368, 1997.

JOHN, V.M. Cimentos de escória ativada com silicatos de sódio. São Paulo, 1995. 189p. Tese(Doutorado) - Escola Politécnica, Universidade de São Paulo.

K

KANGVANPANICH, K. Early age creep of self-compacting concrete using low heat cement at different stress/strength ratios. 2002. 69p. Dissertação (Mestrado) - Kochi University of Technology, Japão.

KOENDERS, E.A.B; VAN BREUGEL, K. Numerical modelling of autogenous shrinkage of hardening cement paste. Cement and Concrete Research, v.27, n.10, 1997, p.1489-1499.

KONIK, Z.; MALOLEPSZY, J.; ROSZCZYNIALSKI, W.; STOK, A. Production of expansive additive to portland cement. Journal of the European Ceramic Society, v.27, n.2-3, p. 605-609, 2007.

KOVLER, K. A new look at the problem of drying creep of concrete under tension. Journal of materials in civil engineering, v.11, n.1, p.84-87, 1999.

KOVLER, K. Testing system for determining the mechanical behavior of early age concrete under restrained and free uniaxial shrinkage. Materials and Structures, v.27, n.6, p. 324-330, 1994.

KUPERMAN, S.C. Estudos para o desenvolvimento de um concreto expansivo. São Paulo, 1989. 246p. Tese(Doutorado) - Escola Politécnica, Universidade de São Paulo. 
$\mathbf{L}$

LEES, J.M.; JONES, B.G.; BURGOYNE C.J. Expansive Cement Couplers- A means of pre-tensioning fibre-reinforced plastic tendons. Construction and Building Materials, v.9, n.6, p.413-423, 1996.

LUCO, L.F., POMBO, R., TORRENT, R. Hormigon con Retraccion Compensada para un Gran Piso Industrial. Congreso Interamericano Del Concreto, Cidade do México, Set. 1999.

LURA, P. Autogenous deformation and internal curing of concrete. 2003. 180p. Tese (Doutorado) - Delft University Press, Holanda.

LURA, P.; PEASE, B.; MAZZOTTA, G.B.; RAJABIPOUR, F.; WEISS, J. Influence of Shrinkage-Reducing Admixtures on Development of Plastic Shrinkage Cracks. ACI Materials Journal, v.104, n.2, p.187-194, 2007.

M

MANICKUM, C.K.; VERBEEK, A.A. Determination of Aluminium, Barium, Magnesium and Manganese in Tea Leaf by Slurry Nebulization Inductively Coupled Plasma Atomic Emission Spectrometry. Journal of analytical atomic spectrometry, v.9, n.3, p.227-229, 1994.

MEHTA, K.; MONTEIRO, P. J. M. Concreto, Estrutura, Propriedades e Materiais. Pini. $1^{\text {a }}$ Edição, 1994, 616 páginas.

MELO NETO, A.A. Estudo da retração em argamassa com cimento de escória ativada. São Paulo, 2002. 161p. Dissertação (Mestrado) - Escola Politécnica, Universidade de São Paulo.

MELO NETO, A.A.; CiNCOTTO, M.A., REPETTE, W.L. Drying and autogenous shrinkage of pastes and mortars with activated slag cement. Cement and Concrete Research, 2007. No prelo.

MIHASHI, H.; LEITE, J.P.B. State-of-art report on control of cracking in early age concrete. Journal of advance concrete technology, v.2, n.2, p.141-154, 2004.

MINDESS, S.; YOUNG, J.F. Concrete. New Jersey, Prentice-Hall, Inc. 1981.

MIRANDA, L.F.R. Estudo de fatores que influem na fissuração de revestimentos de argamassa com entulho reciclado. São Paulo, 2000. 172p. Dissertação (Mestrado) - Escola Politécnica, Universidade de São Paulo.

MOKAREM, D.W. Development of concrete shrinkage performance specifications. 2002. 236p. Tese (Doutorado) - Virginia Polytechnic Institute and State University.

MONTGOMERY, D.C. Design and analysis of experiments. 4 nd, John Wiley, 1997. 
MORIOKA, M.; SAKAI, E.; DAIMON, M. Influence of Preparation Method on Performance of Expansive Additive Containing Free - lime, Hauyne and Anhydrite. Concrete Research and Technology, v.14, No.2, 2003a.

MORIOKA, M.; SAKAI, E.; DAIMON, M. Study on hydration mechanism and material design of expansive additive. International Congress on the Chemistry of Cement, 2003b, p.710-718.

\section{$\mathbf{N}$}

NAGATAKI, S., GOMI, H. Expansive Admixtures( mainly ettringite ). Cement and Concrete Composites, v.20, n.2-3, p.163-170, 1998.

NEVILLE, A.M. Properties of concrete. Pitman. $3^{\text {a }}$ Edição, 1981, 779 páginas.

NMAI, C.K.; TOMITA, R.; HONDO, F.; BUFFENBARGER, J. Shrinkage reducing admixture. Concrete International, v.20, n.4, p.31-37, 1998.

0

OLIVEIRA, C.T.A. Água do poro de pastas de cimentos de escória. São Paulo, 2000. 162p. Tese(Doutorado) - Escola Politécnica, Universidade de São Paulo.

ØSTERGAARD, L. Early-Age Fracture Mechanics and Cracking of Concrete: Experiments and Modelling. 2003. 299p. Tese (Doutorado) - Technical University of Denmark, Dinamarca.

$\mathbf{P}$

PAILLÈRE, A.M.; BUIL, M.; SERRANO, J.J. Effect of fiber addition on the autogenous shrinkage of silica fume concrete. ACI Materials Journal, v.86, No.2, p.139-144, 1989.

PALACIOS, M.; PUERTAS, F. Effect of superplasticizer and shrinkage-reducing admixtures on alkali-activated slag pastes and mortars. Cement and Concrete Research, v.35, n.7, p.1358-1367, 2005.

PERSSON, B. Quasi-instantaneous and Long-term Deformations of HighPerformance Concrete with Some Related Properties. 1998. 250p. Tese (Doutorado) - Lund University, Suécia.

PIGEON, M.; TOMA, G.; DELAGRAVE, A.; BISSONNETTE, B.; MARCHAND, J.; PRINCE, J.C. Equipment for the analysis of the behavior of concrete under restrained shrinkage at early ages. Magazine of Concrete Research, v.52, No.4, p.297-302, 2000. 
POWERS, T.C. The thermodynamics of volume change and creep. Matériaux et Constructions, v.1, n.6, p.487-507, 1968.

PURDON, A.O The action of alkalis on blast-furnace slag. Journal of the Society of Chemical Industry, vol. 59, sep. 1940. p.191-202.

Q

QUAGLIANO, J.V.; VALLARINO, L.M. Química, Ed. Guanabara Dois, Rio de Janeiro, 1985.

$\mathbf{R}$

REPETTE, W.L., MAILVAGANAM, N.P. Pre-hydrated High Alumina Cement Based Admixture for Compensating Autogenous Shrinkage in HPC. Proceedings of the International Conference on High-Performance and Quality of Concrete Structures; CANMET/ACI International Conference, 2, Gramado, Brasil 1999.

REPETTE, W.L.; MAILVAGANAM, N. Hydrated Calcium Aluminate Based Expansive Admixture. 2001. Patente no Exterior. n.97745-US. Depósito: 04 de fevereiro de 2000.

REPETTE, W.L.; MAILVAGANAM, N.; SHEIKH, S. Calcium Sulfoaluminate Based Expansion Producing Admixtures. In: Two-Day CANMET/ACI International Workshop on Supplementary Cementing Materials, Superplasticizers and Other Chemical Admixtures in Concrete, Toronto, 1998.

RICHARDSON, I.G.; CABRERA, J.G. The nature of C-S-H in model slag-cements. Cement and Concrete Composites, v.22, n.4, p.259-266, 2000.

RONGBING, B.; JIAN, S. Synthesis and evaluation of shrinkage-reducing admixture for cementitious materials. Cement and Concrete Research, v.35, n.3, p.445-448, 2005.

ROY, D.M. Alkali-activated cements: Opportunities and challenges. Cement and Concrete Research, v.29, n.2, p. 249-254, 1999.

ROY, D.M.; JIANG, W.; SILSBEE, M.R. Chloride diffusion in ordinary, blended, and alkali-activated cement pastes and its relation to other properties. Cement and Concrete Research, v.30, n.12, p. 1879-1884, 2000.

S

SETTER, N.; ROY, D.M. Mechanical features of chemical shrinkage of cement paste. Cement and Concrete Research, v.8, n.5, p.623-634, 1978. 
SHAH, S.P.; KARAGULER, M.E.; SARIGAPHUTI, M. Effects of shrinkage-reducing admixtures on restrained shrinkage cracking of concrete. ACI Materials Journal, v.89, n.3, p. 291-295, 1992.

SHAH, S.P.; KARAGULER, M.E.; SARIGAPHUTI, M. Effects of shrinkage-reducing admixtures on restrained shrinkage cracking of concrete. ACI Materials Journal, v.89, n.3, p. 291-295, 1992.

SHI, C. Strength, pore structure and permeability of alkali-activated slag mortars. Cement and Concrete Research, v.26, n.12, p.1789-1799, 1996.

SHI, C.; DAY, R.L. Some factors affecting early hydration of alkali-slag cements. Cement and Concrete Research, v.26, n.3, p.439-447, 1996.

SHI, C.; DAY, R.L.; WU, X.; TANG, M. Comparison of microstructure and performance of alkali-slag and portland cement pastes. In: INTERNATIONAL CONGRESS ON THE CHEMISTRY OF CEMENT, 9., Proceedings. New Delhi: 1992, p. 298-304.

SHI, C.; STEGEMANN, J.A. Acid corrosion resistance of different cementing materials. Cement and Concrete Research, v.30, n.5, p. 803-808, 2000.

SILVA, M.G. Influência da cura térmica em pastas e argamassas de cimentos de escória de alto-forno. São Paulo, 1998. 232p. Tese(Doutorado) - Escola Politécnica, Universidade de São Paulo.

SILVA, M.G., SILVA, V.G., JOHN, V.M., OLIVEIRA, C.T.A., AGOPYAN, V. Painéis de Cimentos de Escória Reforçados com Fibra de Vidro E (E-GRS). Workshop Reciclagem e Reutilização de Resíduos como Material de Construção Civil, São Paulo, 1996, p.93-98.

SILVA, P.F.A.; PITTA, A.C. A importância da retração hidráulica na durabilidade das estruturas de concreto. In: 42ํㅜ REUNIÃO DO IBRACON, Fortaleza, 2000, p. 179.

SPRINGENSCHMID, R.; BREITENBÜCHER, R.; MANGOLD, M. Development of thermal cracking frame and the temperature-stress testing machine. In: Thermal Cracking in Concrete at Early Ages, International RILEM, Edited by Springenschmid. Proceedings. Munich, 1995, p.137-144.

$\mathbf{T}$

TALLING, B.; BRANDSTETR, J. Present state and future of alkali-activated slag concretes. In: Fly Ash, Silica Fume, Slag, and Natural Pozzolons, In: Concrete, Volume 2, Proceedings of the Third International Conference, Trondheim, Norway, ACI SP114, 1989, p.1519-1545.

TAYLOR, H.F.W. Cement chemistry, London: Thomas Telford, 2ed, 1997, 459 p.

TAYLOR, H.F.W. Ettringite in Cement Paste and Concrete. Seminaire Rilem, Béton: du Matériau à la Structure. Les II - ET 12, Arles, France, 1996. 
TAZAWA, E.; MIYAZAWA, S; KASAI, T. Chemical shrinkage and autogenous shrinkage of hydrating cement paste. Cement and Concrete Research, v.25, n.2, p. 288-292, 1995.

TAZAWA, E.; SATO, R.; SAKAI, E.; MIYAZAWA, S. Work of JCl committee on autogenous shrinkage. In: International RILEM workshop on shrinkage of concrete "Shrinkage 2000", Edited by V. Baroghel-Bouny and P.-C. Aïtcin. Proceedings. Paris, 2000, p.21-40.

TAZAWA, E.; SATO, R.; SAKAI, E.; MIYAZAWA, S. Work of JCl committee on autogenous shrinkage. In: International RILEM workshop on shrinkage of concrete "Shrinkage 2000", Edited by V. Baroghel-Bouny and P.-C. Aïtcin. Proceedings. Paris, 2000, p.21-40.

TOMA, G.; PIGEON, M.; MARCHAND, J.; BISSONNETTE, B.; BARCELO, L. Early age autogenous restrained shrinkage: In: 2nd International Research Seminary on Self-desiccation and its importance in concrete technology. Proceedings. Lund, Sweden, 1999, p.61-72.

\section{V}

VOINOVITCH, I.; RAVERDY, M.; DRON, R. Slag cement without clinker. In: INTERNATIONAL CONGRESS ON THE CHEMISTRY OF CEMENT, 7th. Paris, 1980. Proceedings. Paris : Spetima, 1980. v.3, p.122-127.

\section{W}

WANG, S.D. and PU, X.C. and SCRIVENER, K.L. and PRATT, P.L. Alkali-activated slag cement and concrete: a review of properties and problems. Advances in cement research, vol.7, n.27, p. 93-102, 1995.

WANG, S.D.; SCRIVENER, K.L. hydration products of alkali activated slag cement. Cement and Concrete Research, v.25, n.3, p. 561-571, 1995.

WITTMANN, F.H. Creep and shrinkage mechanisms. In: Z.P. Bazant, F.H. Wittmann (Eds.), Creep and Shrinkage in Concrete Structures, Wiley, Chichester, p.129-161, 1982.

WŁODEK, T.; SOPICKA-LIZER, M.; GOCMEZB, H.; DURAN, C. Influence of the milling environment on the reaction progress in the $\mathrm{Si}-\mathrm{Al}_{2} \mathrm{O}_{3}$ system. Journal of the European Ceramic Society, v.27, n.2-3, p.739-742, 2007. 


\section{$\mathbf{X}$}

XI, Y., JENNINGS, H.M. Relationships between microstructure and creep and shrinkage of cement paste. Materials science of concrete III, Ed. Jan Skalny, p.3769, 1989.

Y

YAMAMOTO, K.; MORIOKA, M.; SAKAI, E.; DAIMON, M. Expansion Mechanism of Cement Added with Expansive Additive. Concrete Research and Technology, v.14, n.3, 2003.

YOUNG, J.F. Physical mechanisms and their mathematical descriptions. In: Z.P. Bazant (Ed.), Mathematical Modelling of Creep and Shrinkage of Concrete, Wiley, Chichester, 1988, p.63-98. 


\section{Apêndice A - Resultados da termogravimetria}

Neste apêndice constam os resultados do ensaio de termogravimetria. Os ensaios foram realizados em pastas (descrição do método no item 3.5.4) e nas variações determinadas no planejamento experimental (item 3.3.3.1).

\section{Termogravimetria}

Relação a/agl igual a 0,40 e utilização do aditivo compensador de retração (SCA).

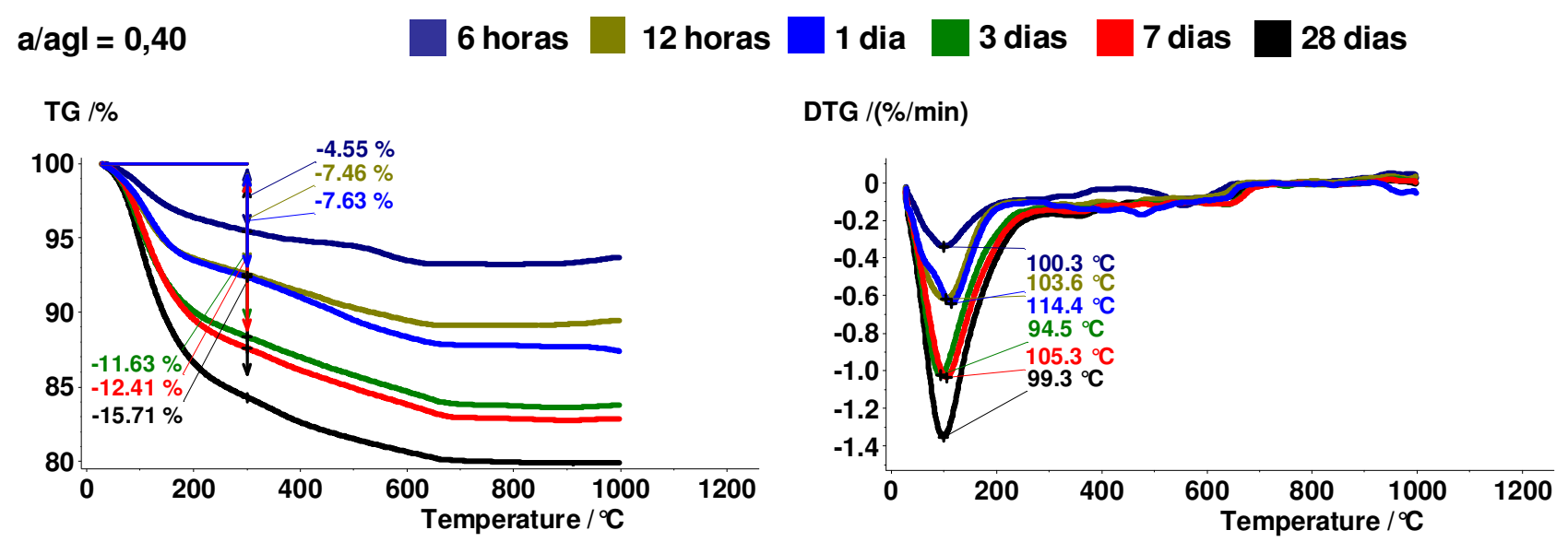

Figura A.1 - Perda de massa (TG/\%) e derivada da curva de perda de massa (DTG) da pasta de cimento de escória ativada com silicato de sódio (4NSA0) a 6 e 12 horas, 1,3,7 e 28 dias de idade. a/agl = 0,40.
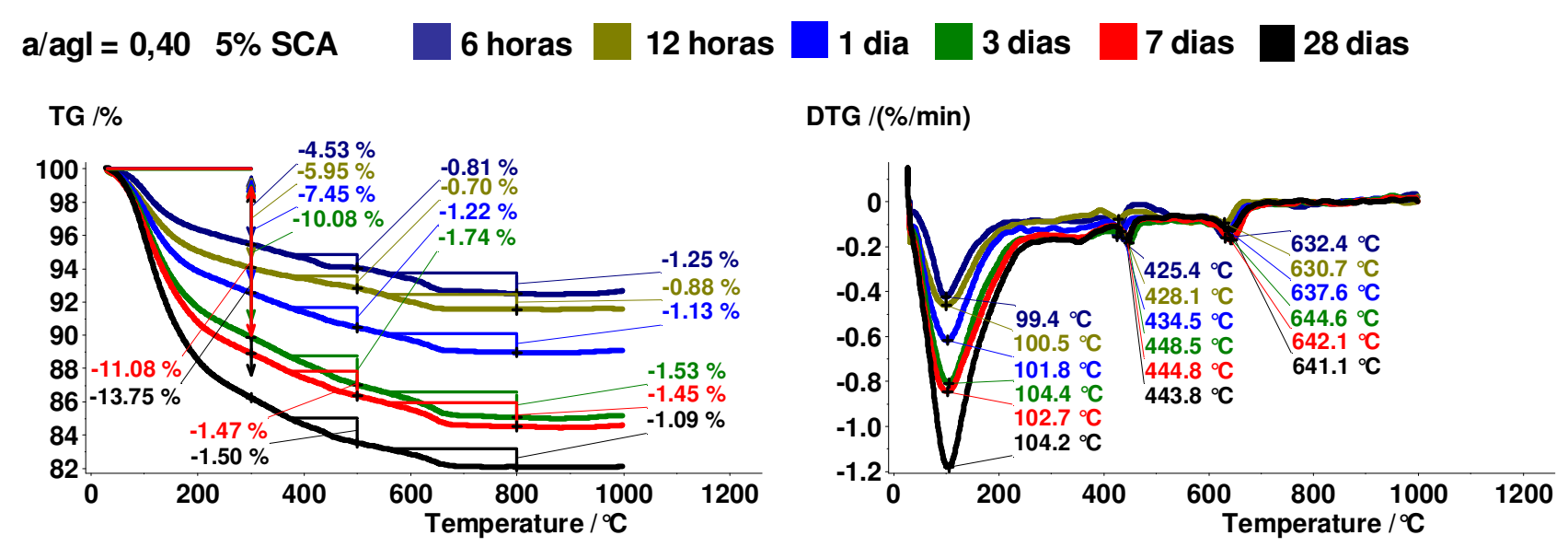

Figura A.2 - Perda de massa (TG/\%) e derivada da curva de perda de massa (DTG) da pasta de cimento de escória ativada com silicato de sódio (4NSA5) a 6 e 12 horas, 1,3,7 e 28 dias de idade. a/agl= 0,40. Teor de $\mathrm{SCA}=5 \%$. 

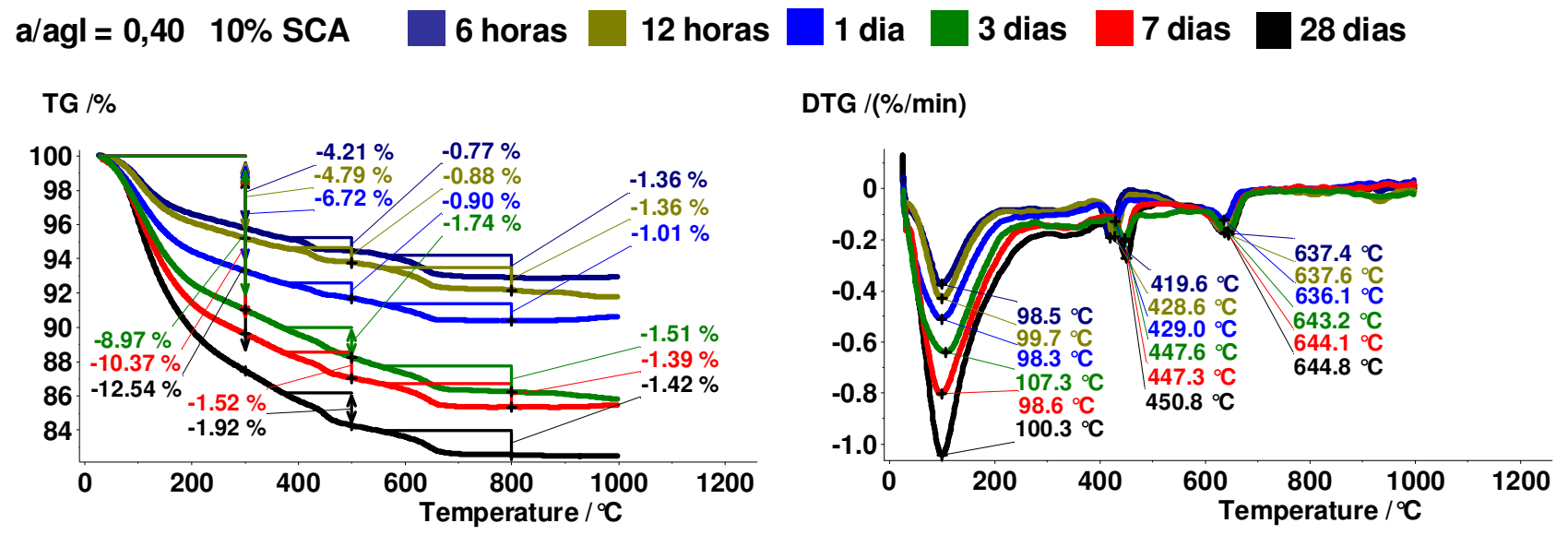

Figura A.3 - Perda de massa (TG/\%) e derivada da curva de perda de massa (DTG) da pasta de cimento de escória ativada com silicato de sódio (4NSA10) a 6 e 12 horas, 1,3,7 e 28 dias de idade. a/agl= 0,40. Teor de $\mathrm{SCA}=10 \%$.

\section{a/agl $=0,4015 \%$ SCA $\square$ horas 12 horas $\square 1$ dia $\square$ dias $\square$ dias $\square 28$ dias}
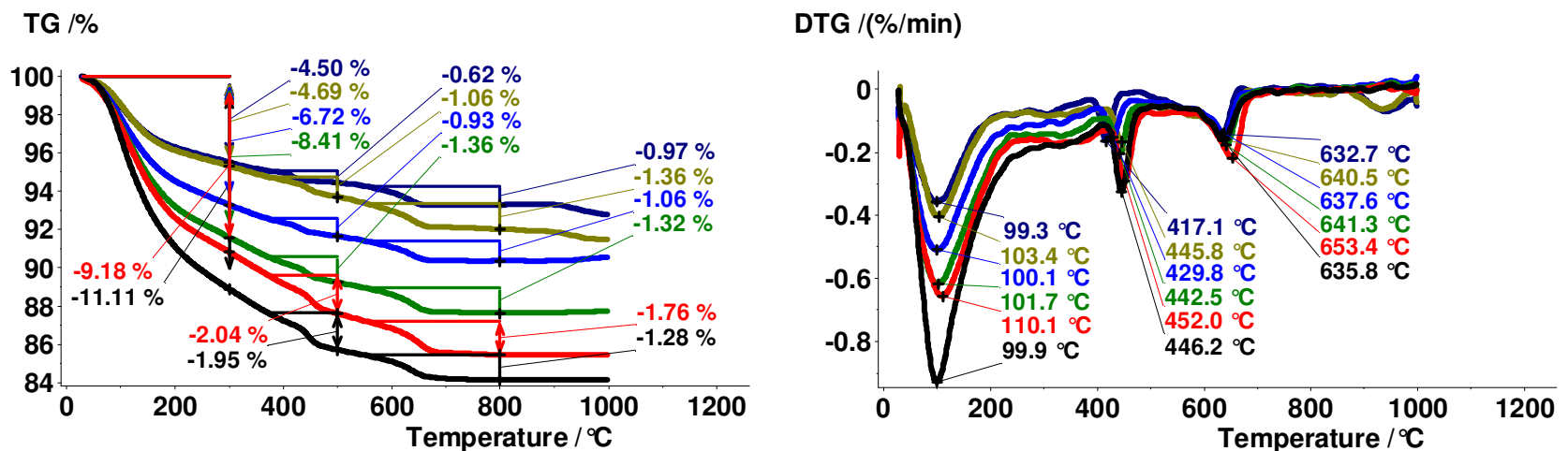

Figura A.4 - Perda de massa (TG/\%) e derivada da curva de perda de massa (DTG) da pasta de cimento de escória ativada com silicato de sódio (4NSA15) a 6 e 12 horas, 1,3,7 e 28 dias de idade. a/agl= 0,40. Teor de $\mathrm{SCA}=15 \%$.

\section{Relação a/agl igual a 0,48 e utilização do aditivo redutor de retração (SRA).}

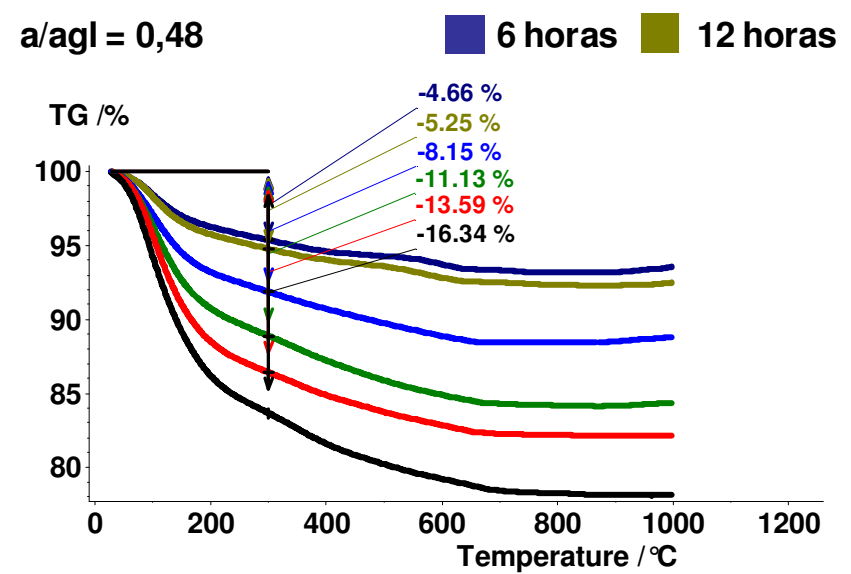
1 dia $\quad 3$ dias $\quad 7$ dias 28 dias DTG /(\%/min)

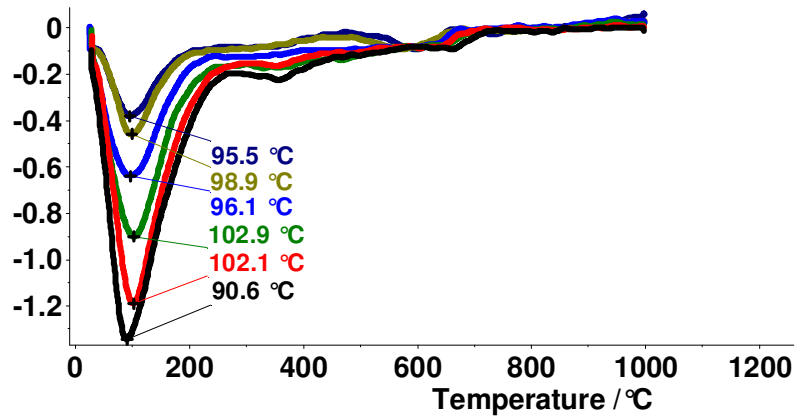

Figura A.5 - Perda de massa (TG/\%) e derivada da curva de perda de massa (DTG) da pasta de cimento de escória ativada com silicato de sódio (4NSB0) a 6 e 12 horas, 1,3,7 e 28 dias de idade. a/agl= 0,48. 

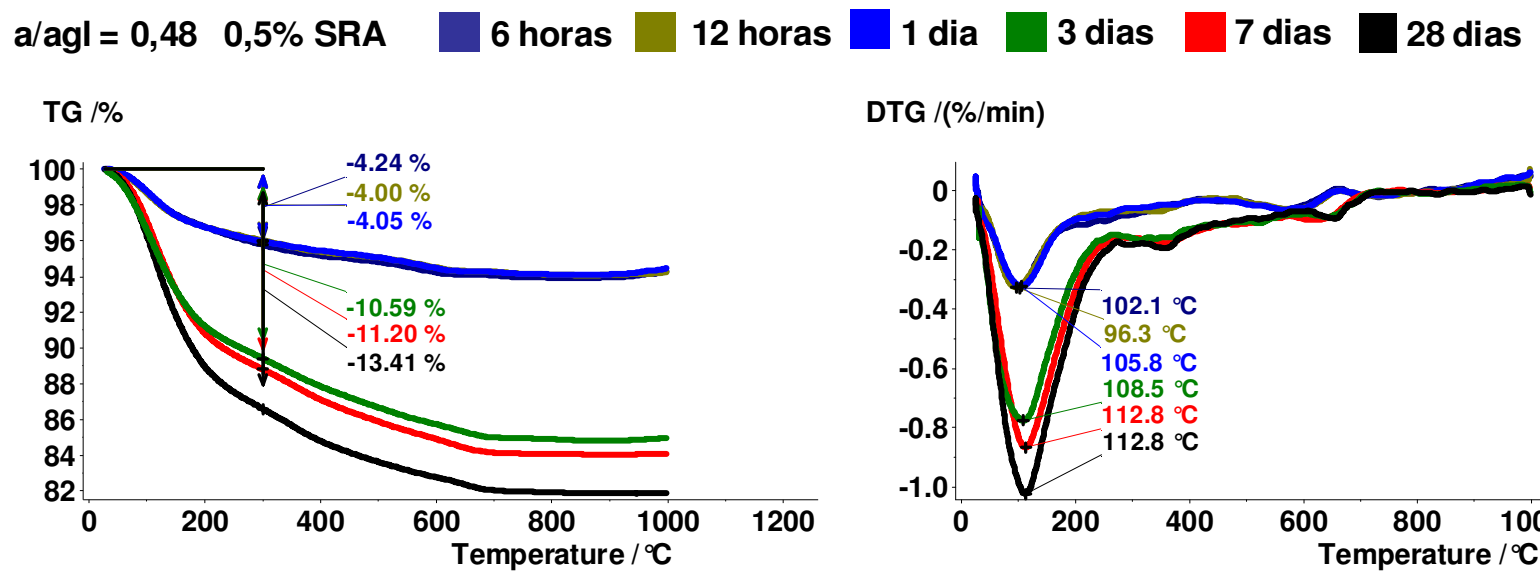

Figura A.6 - Perda de massa (TG/\%) e derivada da curva de perda de massa (DTG) da pasta de cimento de escória ativada com silicato de sódio (4NSB0,5) a 6 e 12 horas, 1,3,7 e 28 dias de idade. a/agl= 0,48. Teor de SRA $=0,5 \%$.
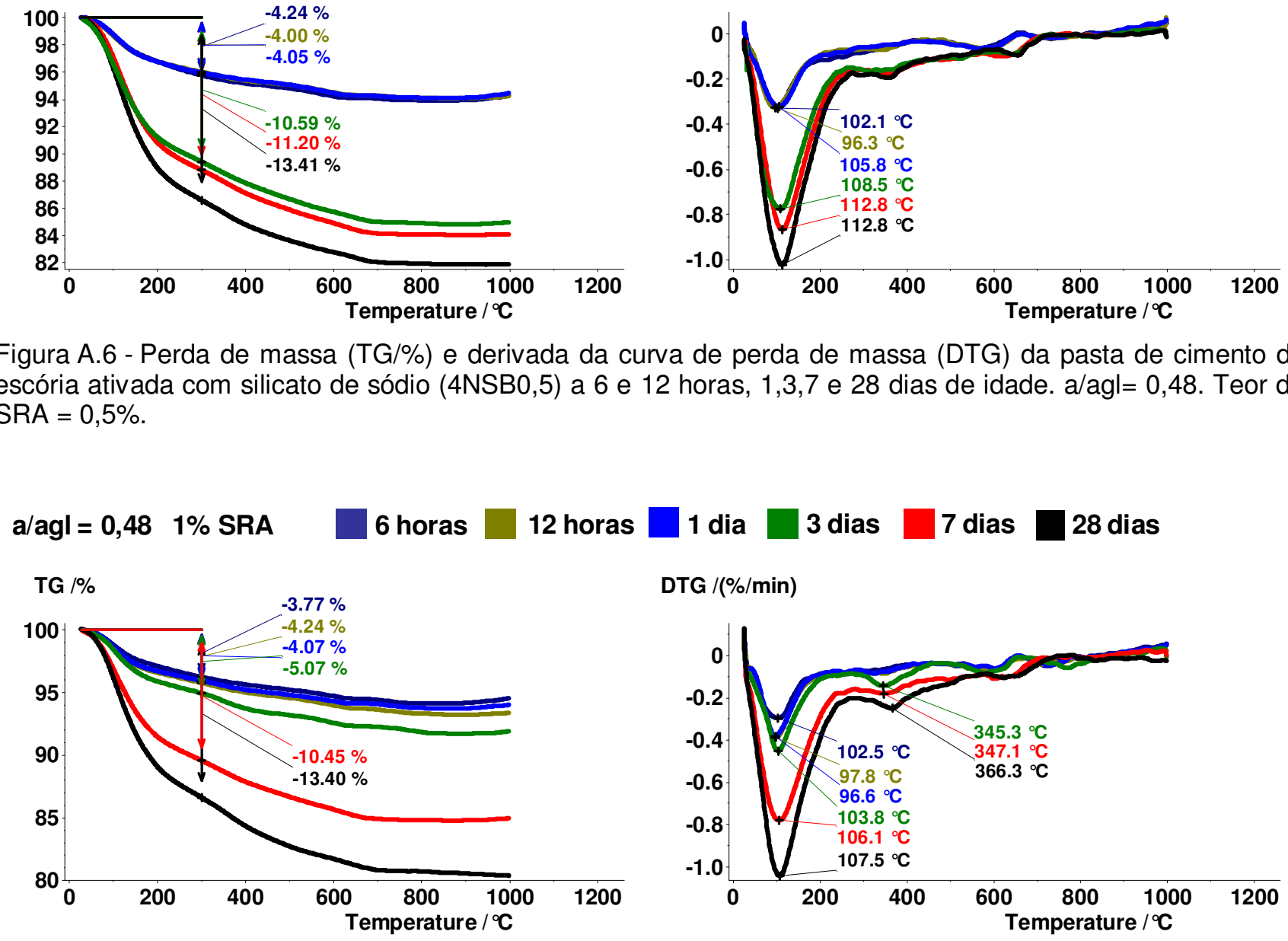

Figura A.7 - Perda de massa (TG/\%) e derivada da curva de perda de massa (DTG) da pasta de cimento de escória ativada com silicato de sódio (4NSB1) a 6 e 12 horas, 1,3,7 e 28 dias de idade. a/agl= 0,48. Teor de $\mathrm{SRA}=1 \%$.
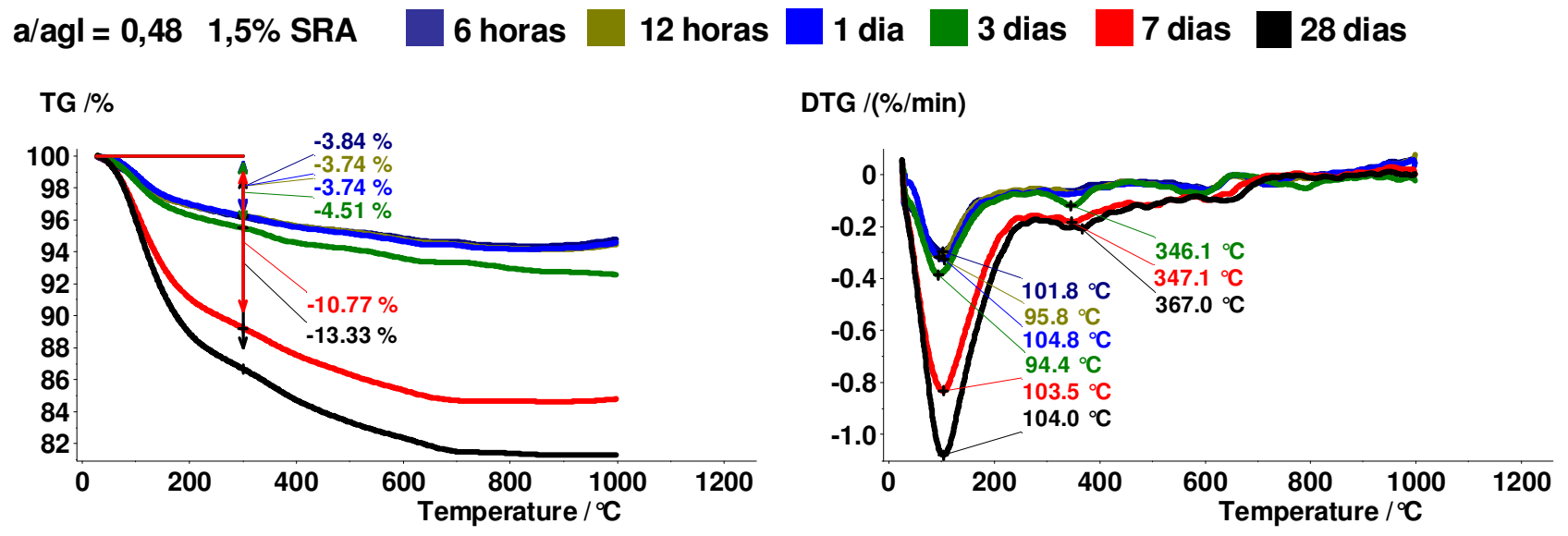

Figura A.8 - Perda de massa (TG/\%) e derivada da curva de perda de massa (DTG) da pasta de cimento de escória ativada com silicato de sódio (4NSB1,5) a 6 e 12 horas, 1,3,7 e 28 dias de idade. a/agl= 0,48. Teor de SRA $=1,5 \%$. 

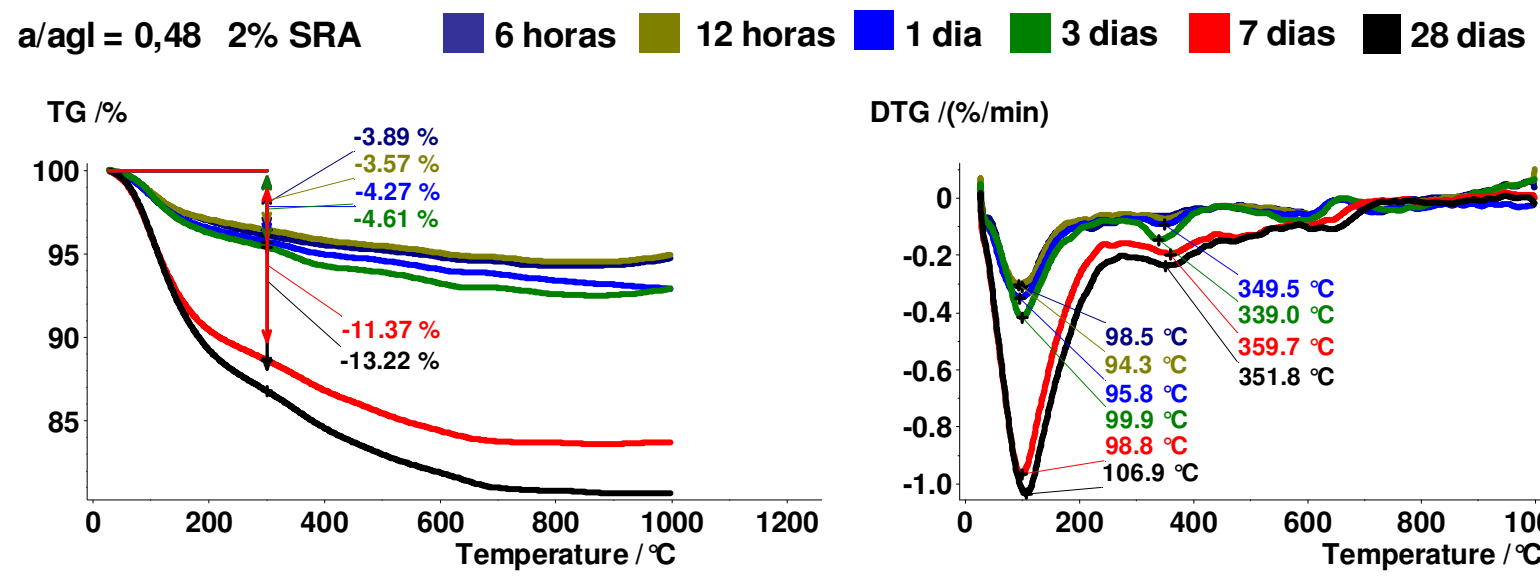

Figura A.9 - Perda de massa (TG/\%) e derivada da curva de perda de massa (DTG) da pasta de cimento de escória ativada com silicato de sódio (4NSB2) a 6 e 12 horas, 1,3,7 e 28 dias de idade. a/agl= 0,48. Teor de $\mathrm{SRA}=2 \%$.

\section{Relação a/agl igual a 0,48 e utilização do aditivo compensador (SCA).}
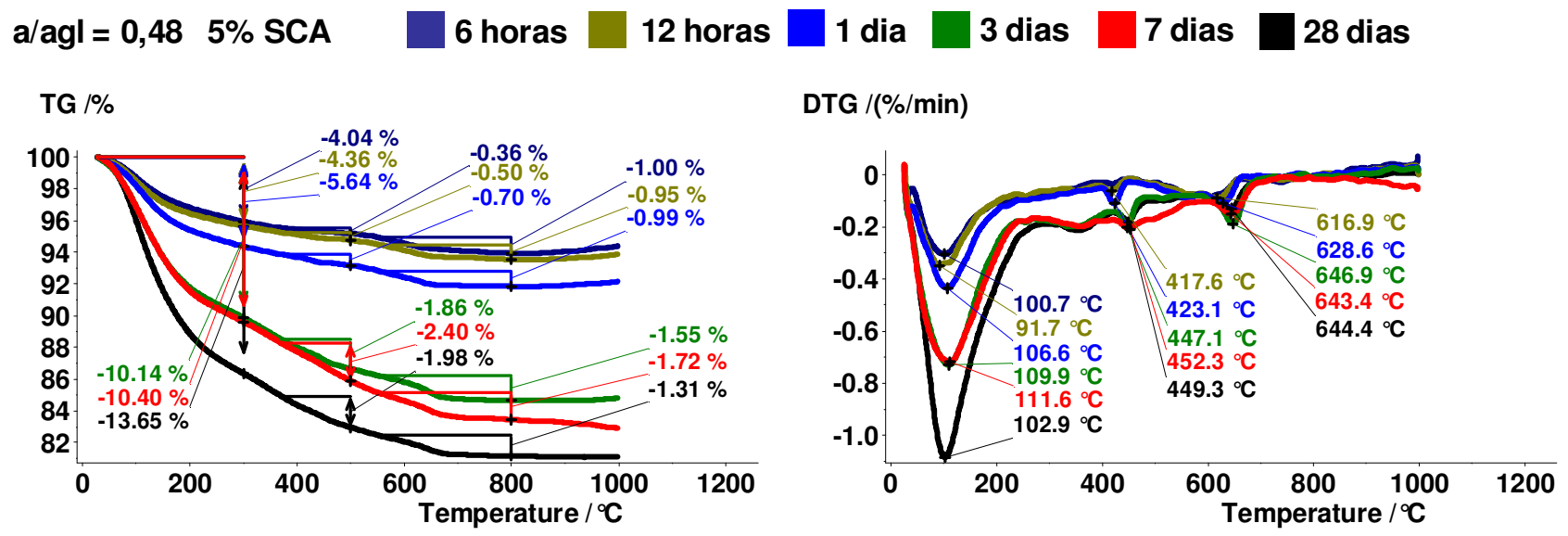

Figura A.10 - Perda de massa (TG/\%) e derivada da curva de perda de massa (DTG) da pasta de cimento de escória ativada com silicato de sódio (4NSB5) a 6 e 12 horas, 1,3,7 e 28 dias de idade. a/agl= 0,48. Teor de $\mathrm{SCA}=5 \%$.
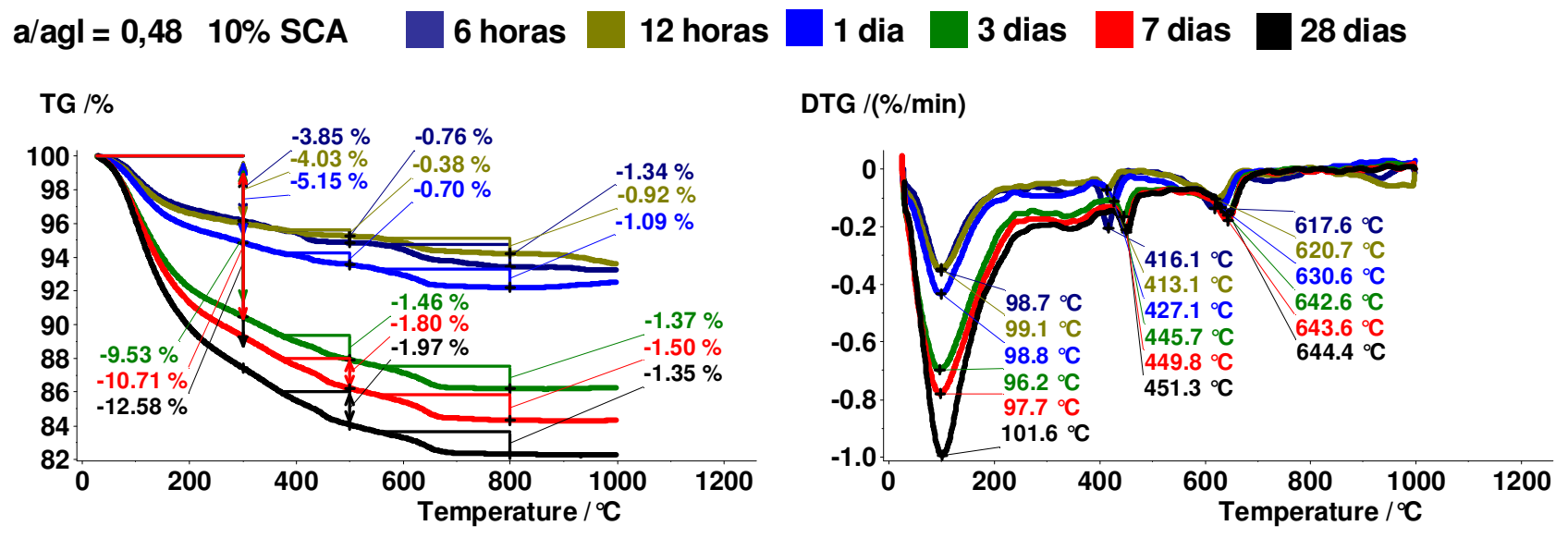

Figura A.11 - Perda de massa (TG/\%) e derivada da curva de perda de massa (DTG) da pasta de cimento de escória ativada com silicato de sódio (4NSB10) a 6 e 12 horas, 1,3,7 e 28 dias de idade. a/agl= 0,48. Teor de $\mathrm{SCA}=10 \%$. 

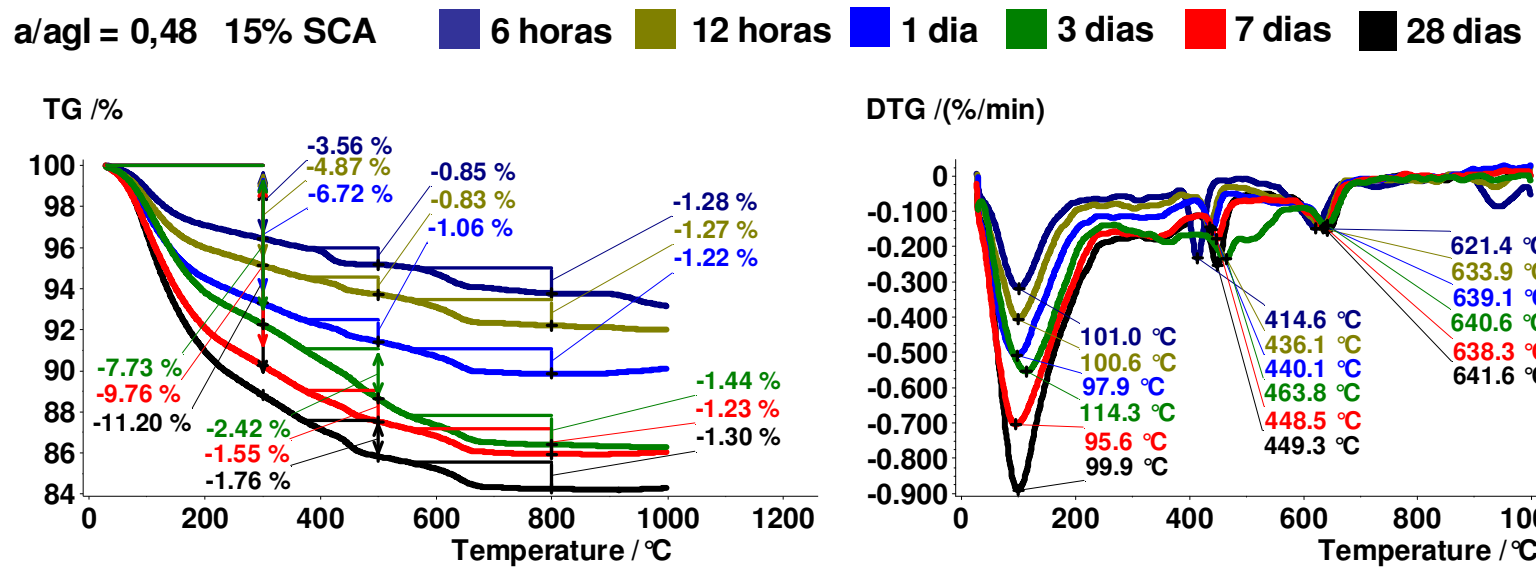

Figura A.12 - Perda de massa (TG/\%) e derivada da curva de perda de massa (DTG) da pasta de cimento de escória ativada com silicato de sódio (4NSB15) a 6 e 12 horas, 1,3,7 e 28 dias de idade. a/agl= 0,48. Teor de $\mathrm{SCA}=15 \%$.

\section{Relação a/agl igual a 0,56 e utilização do aditivo compensador de retração (SCA).}

a/agl $=0,56 \quad 6$ horas 12 horas 1 dia $\quad 3$ dias 7 dias $\square 28$ dias
TG $/ \%$
DTG $/(\% / \mathrm{min})$
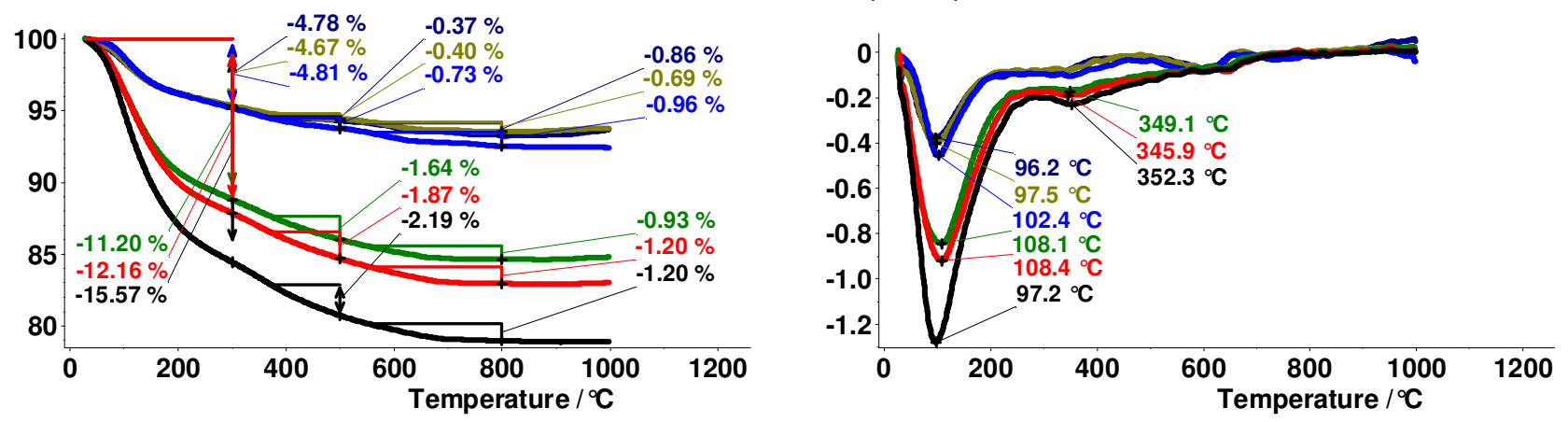

Figura A.13 - Perda de massa (TG/\%) e derivada da curva de perda de massa (DTG) da pasta de cimento de escória ativada com silicato de sódio (4NSC0) a 6 e 12 horas, 1,3,7 e 28 dias de idade. a/agl= 0,56.

\section{a/agl $=0,565 \%$ SCA $\quad 6$ horas 12 horas $\square 1$ dia $\square$ dias 7 dias $\square 28$ dias}
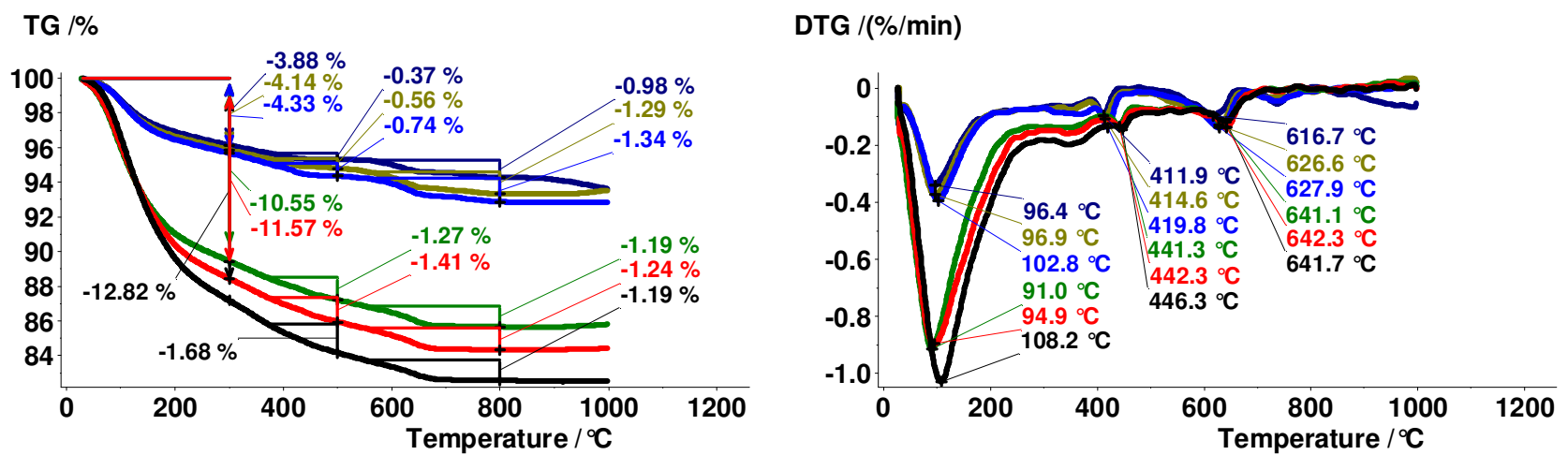

Figura A.14 - Perda de massa (TG/\%) e derivada da curva de perda de massa (DTG) da pasta de cimento de escória ativada com silicato de sódio (4NSC5) a 6 e 12 horas, 1,3,7 e 28 dias de idade. a/agl= 0,56. Teor de $\mathrm{SCA}=5 \%$. 

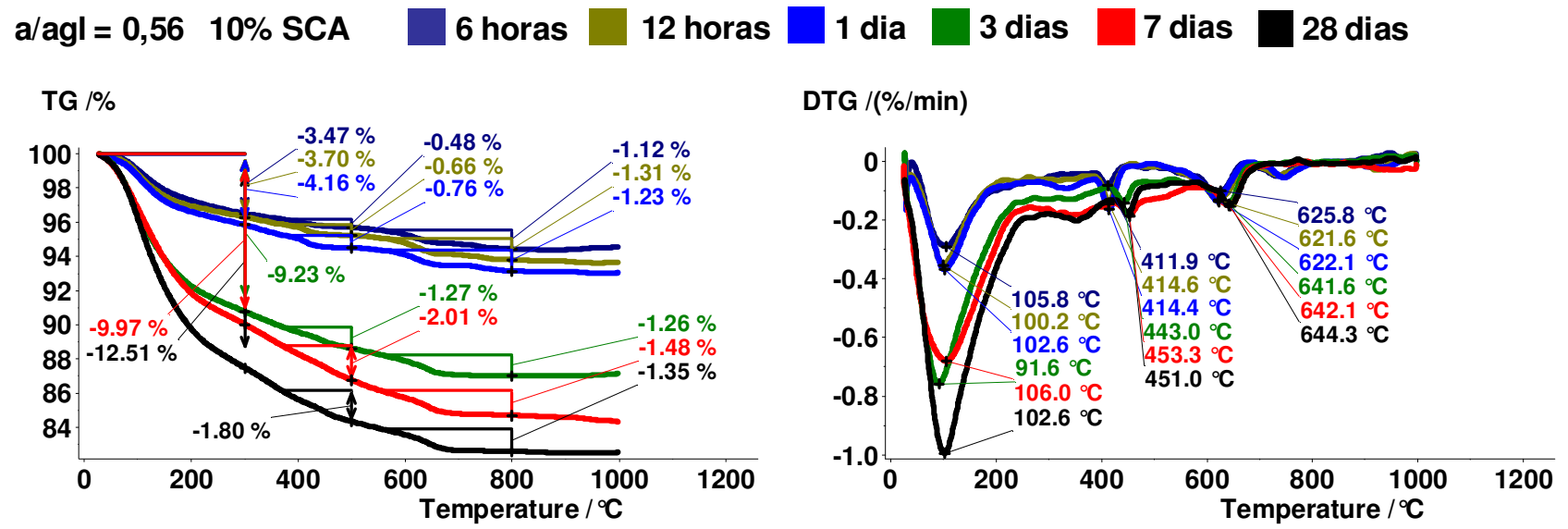

Figura A.15 - Perda de massa (TG/\%) e derivada da curva de perda de massa (DTG) da pasta de cimento de escória ativada com silicato de sódio (4NSC10) a 6 e 12 horas, 1,3,7 e 28 dias de idade. a/agl= 0,56. Teor de $\mathrm{SCA}=10 \%$.

\section{a/agl $=0,5615 \%$ SCA $\quad 6$ horas 12 horas $\square 1$ dia $\square$ dias $\square$ dias $\square 28$ dias}
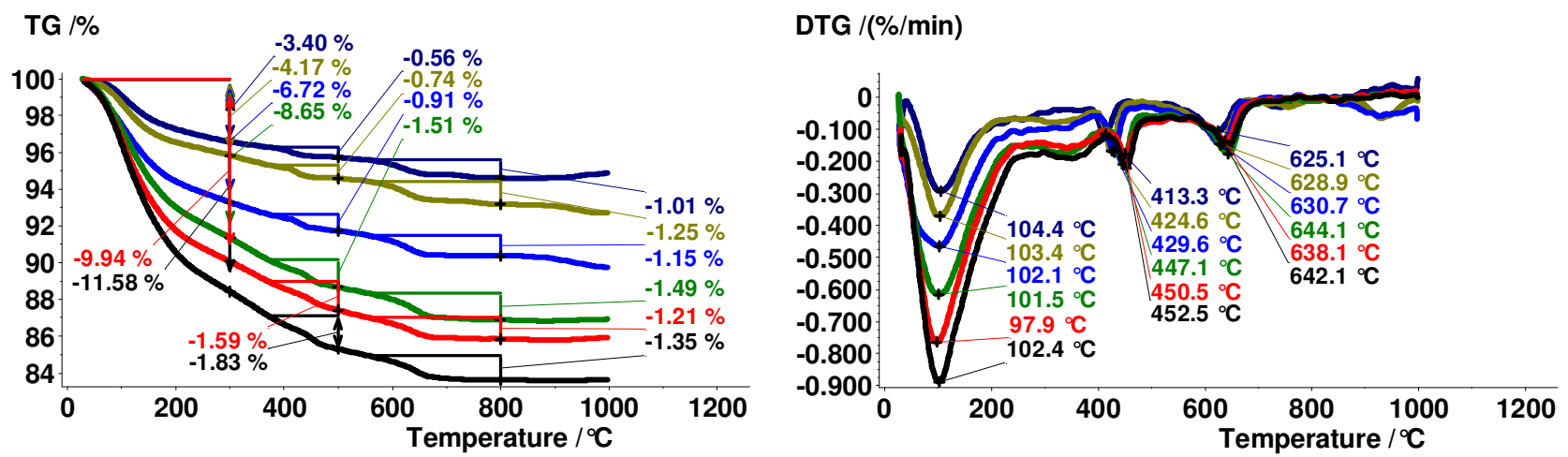

Figura A.16 - Perda de massa (TG/\%) e derivada da curva de perda de massa (DTG) da pasta de cimento de escória ativada com silicato de sódio (4NSC15) a 6 e 12 horas, 1,3,7 e 28 dias de idade. a/agl= 0,56. Teor de SCA $=15 \%$.

\section{Pasta utilizando apenas o aditivo compensador de retração (SCA) puro.}
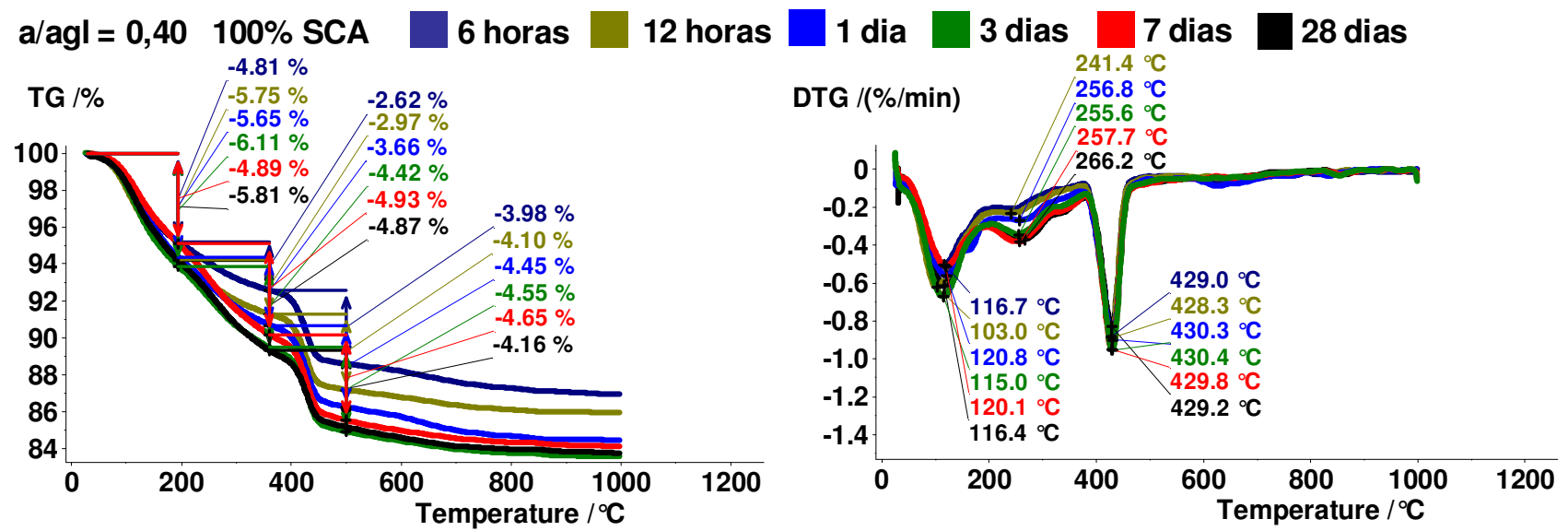

Figura A.17 - Perda de massa (TG/\%) e derivada da curva de perda de massa (DTG) da pasta utilizando apenas o aditivo compensador de retração (SCAA) a 6 e 12 horas, 1,3,7 e 28 dias de idade. a/agl= 0,40. Teor de SCA $=100 \%$. 

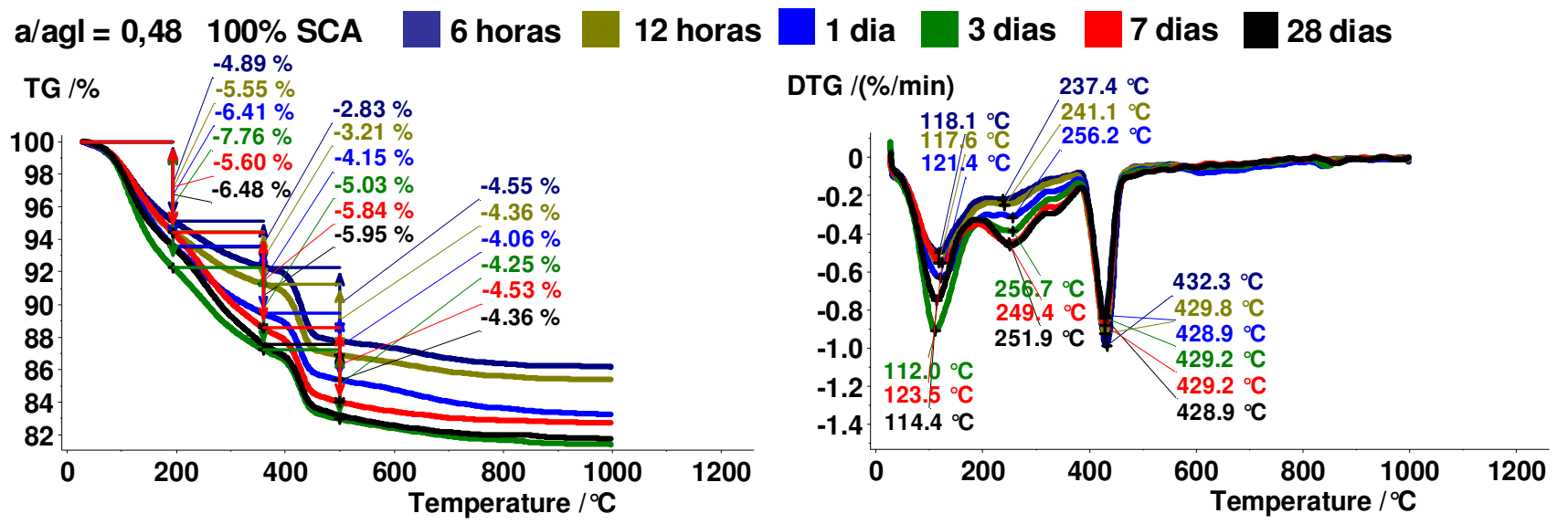

Figura A.18 - Perda de massa (TG/\%) e derivada da curva de perda de massa (DTG) da pasta utilizando apenas o aditivo compensador de retração (SCAB) a 6 e 12 horas, 1,3,7 e 28 dias de idade. a/agl=0,48. Teor de SCA $=100 \%$.
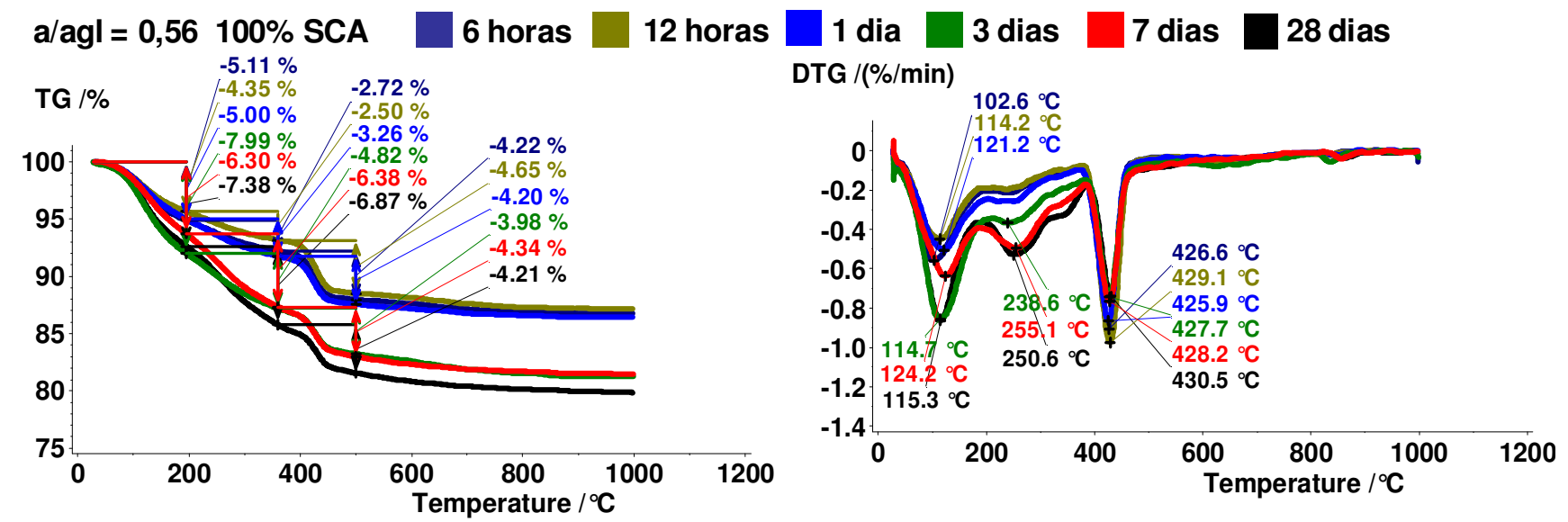

Figura A.19 - Perda de massa (TG/\%) e derivada da curva de perda de massa (DTG) da pasta utilizando apenas o aditivo compensador de retração (SCAC) a 6 e 12 horas, 1,3,7 e 28 dias de idade. a/agl= 0,56. Teor de SCA $=100 \%$. 


\section{Apêndice B - Resultados da porosimetria}

Neste apêndice constam os resultados do ensaio de porosimetria por intrusão de mercúrio. Os ensaios foram realizados em pastas (descrição do método no item 3.5.5) e nas variações determinadas no planejamento experimental (item 3.3.3.3).

\section{Porosimetria}

\section{Relação a/agl igual a 0,40}
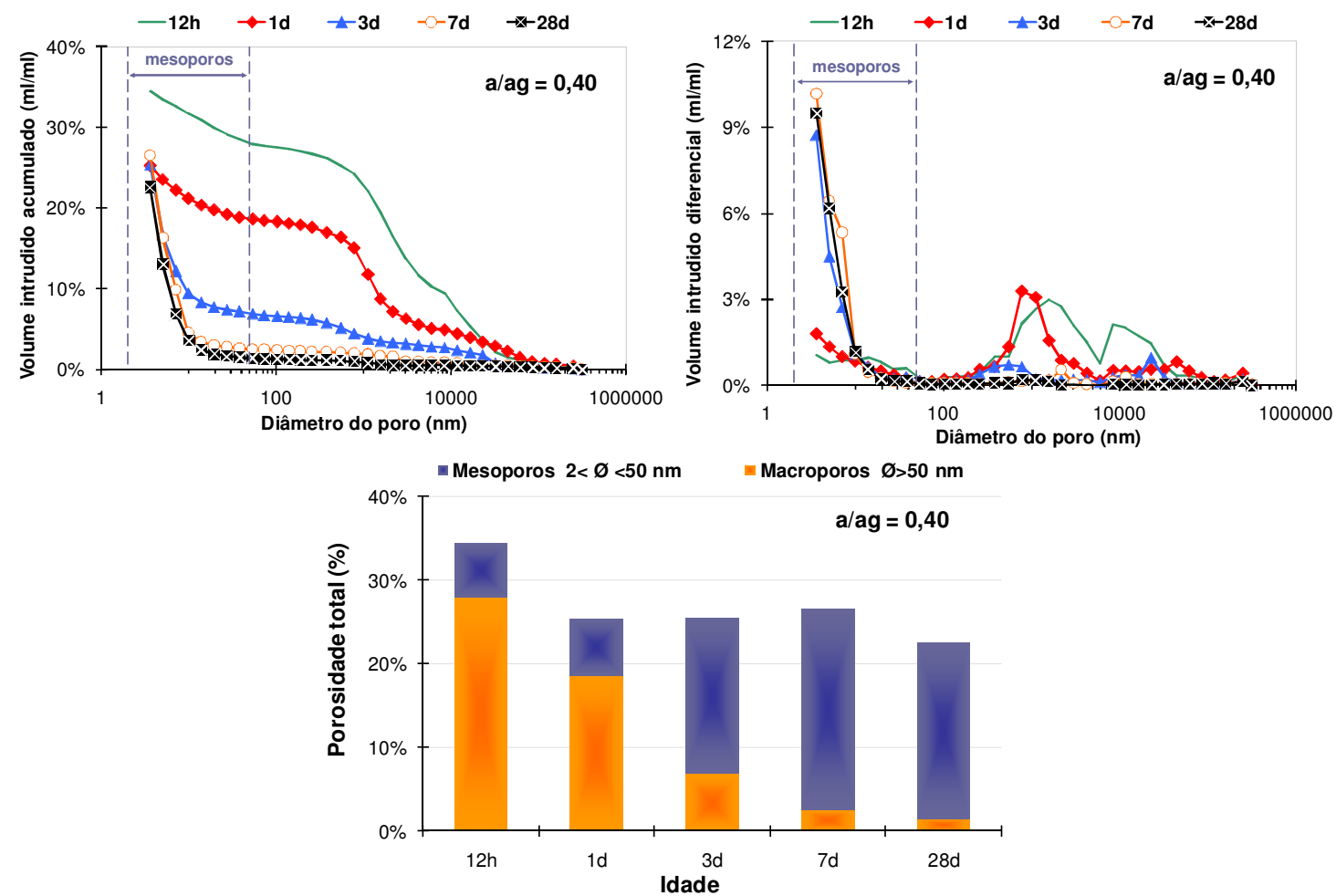

Figura B.1 - Evolução da porosidade acumulada, porosidade diferencial e a distribuição de poros da pasta de cimento de escória ativada com silicato de sódio (4NSA0). A/agl=0,40. 


\section{Relação a/agl igual a 0,48}
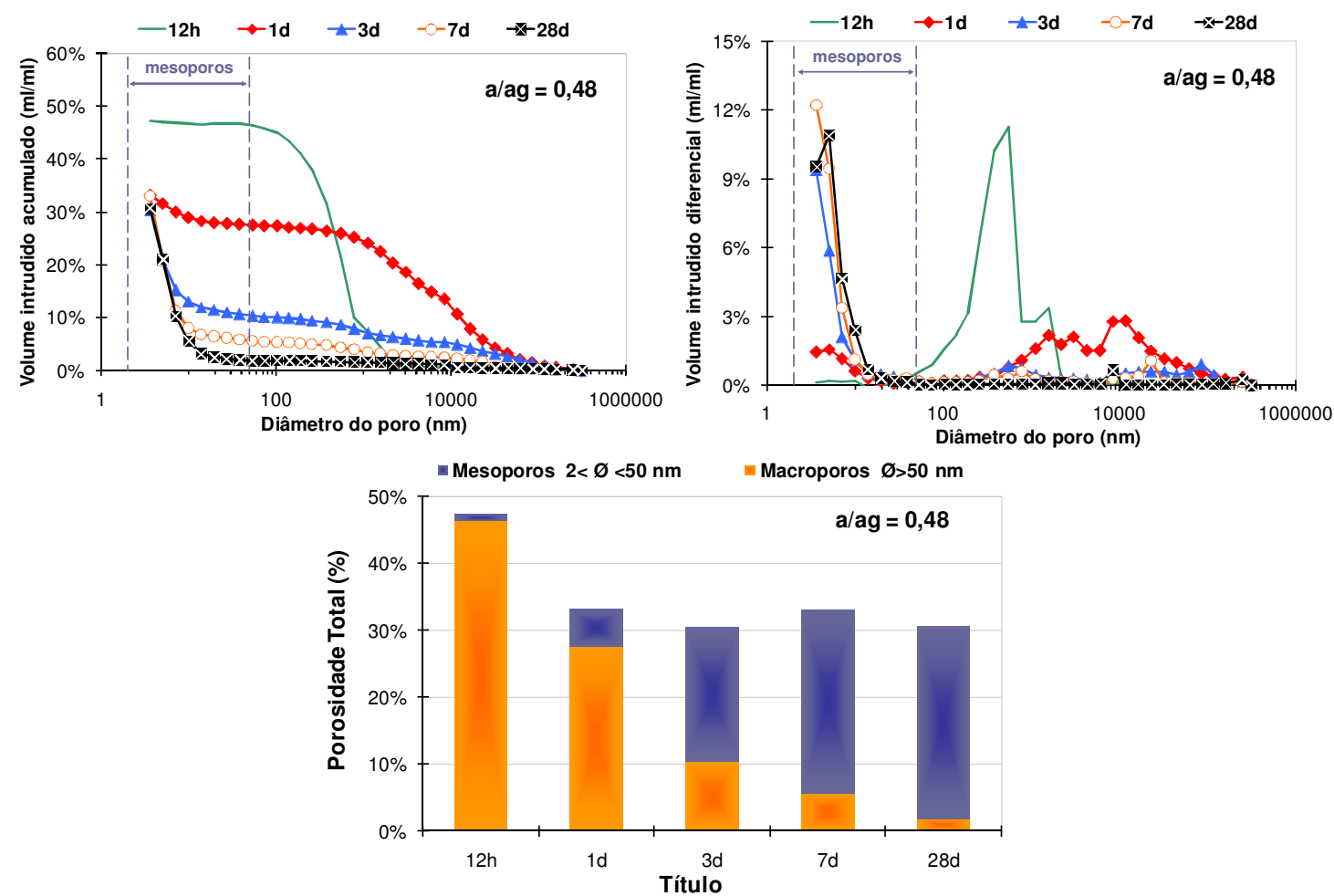

Figura B.2 - Evolução da porosidade acumulada, porosidade diferencial e a distribuição de poros da pasta de cimento de escória ativada com silicato de sódio (4NSB0). A/agl=0,48.

\section{Relação a/agl igual a 0,56}
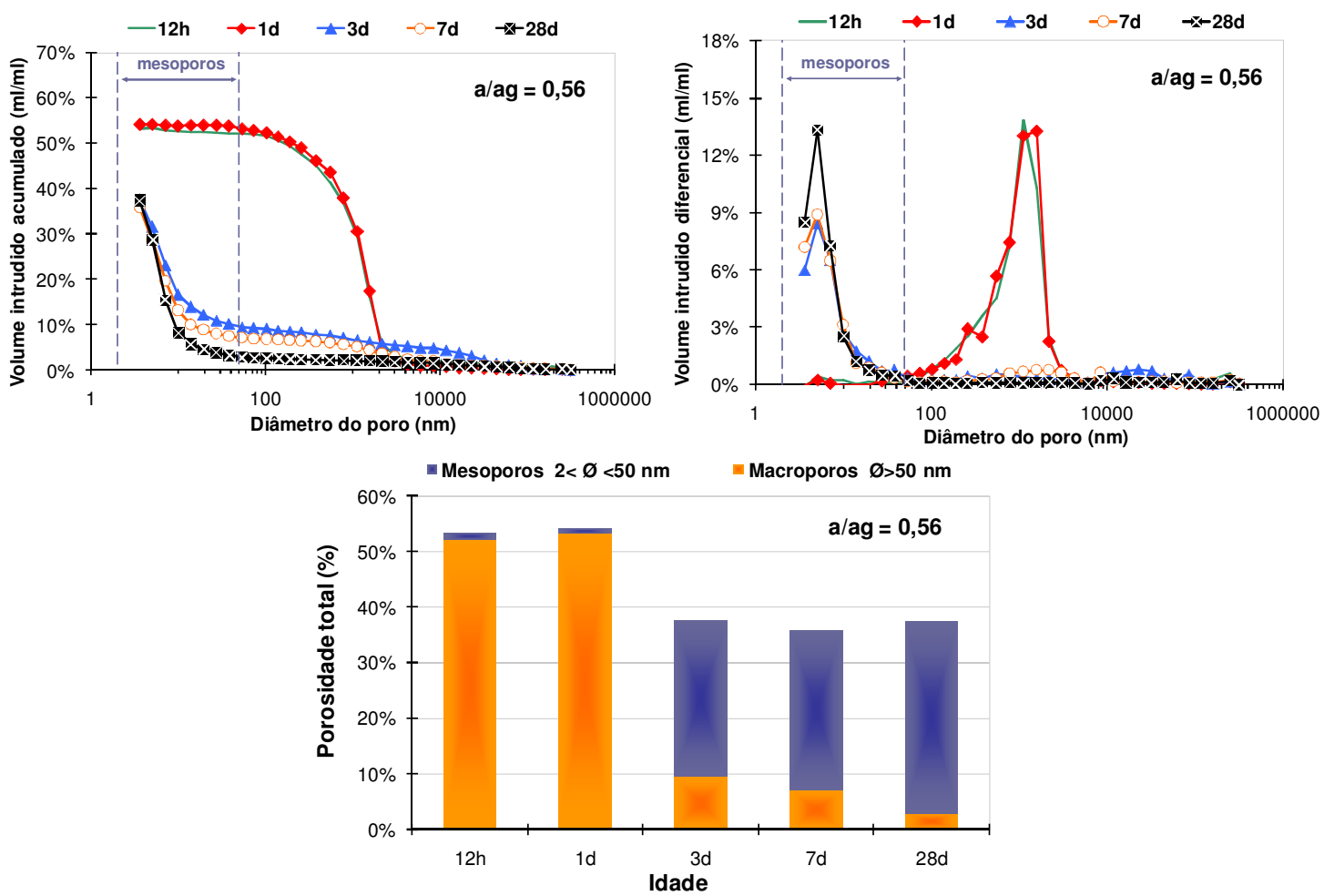

Figura B.1 - Evolução da porosidade acumulada, porosidade diferencial e a distribuição de poros da pasta de cimento de escória ativada com silicato de sódio (4NSC0). A/agl=0,56. 


\section{Relação a/agl igual a 0,48 e utilização do aditivo redutor de retração (SRA)}
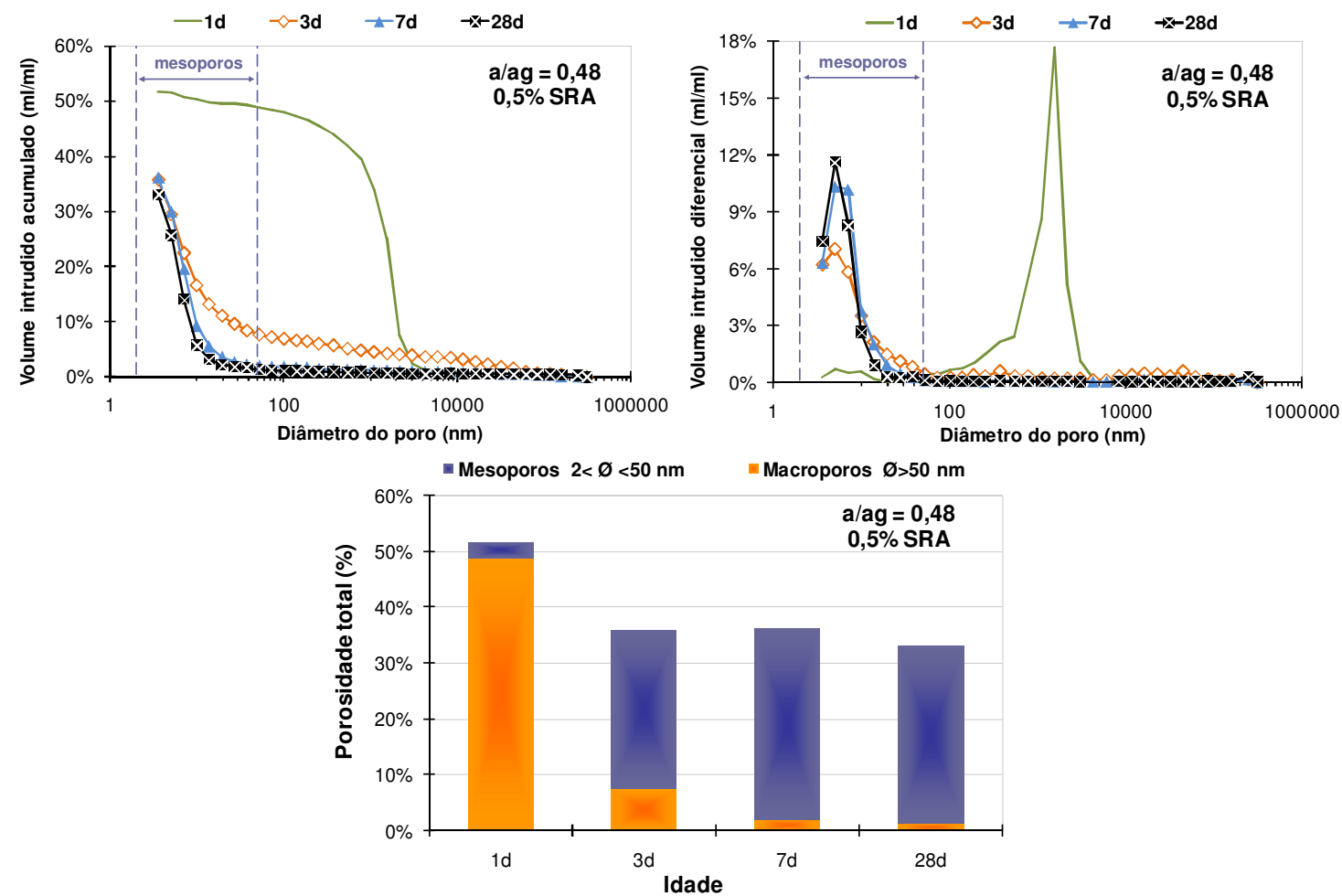

Figura B.2 - Evolução da porosidade acumulada, porosidade diferencial e a distribuição de poros da pasta de cimento de escória ativada com silicato de sódio $(\mathbf{4 N S B 0 , 5 )}$. A/agl=0,48. Teor de aditivo redutor de retração $($ SRA $)=0,5 \%$.
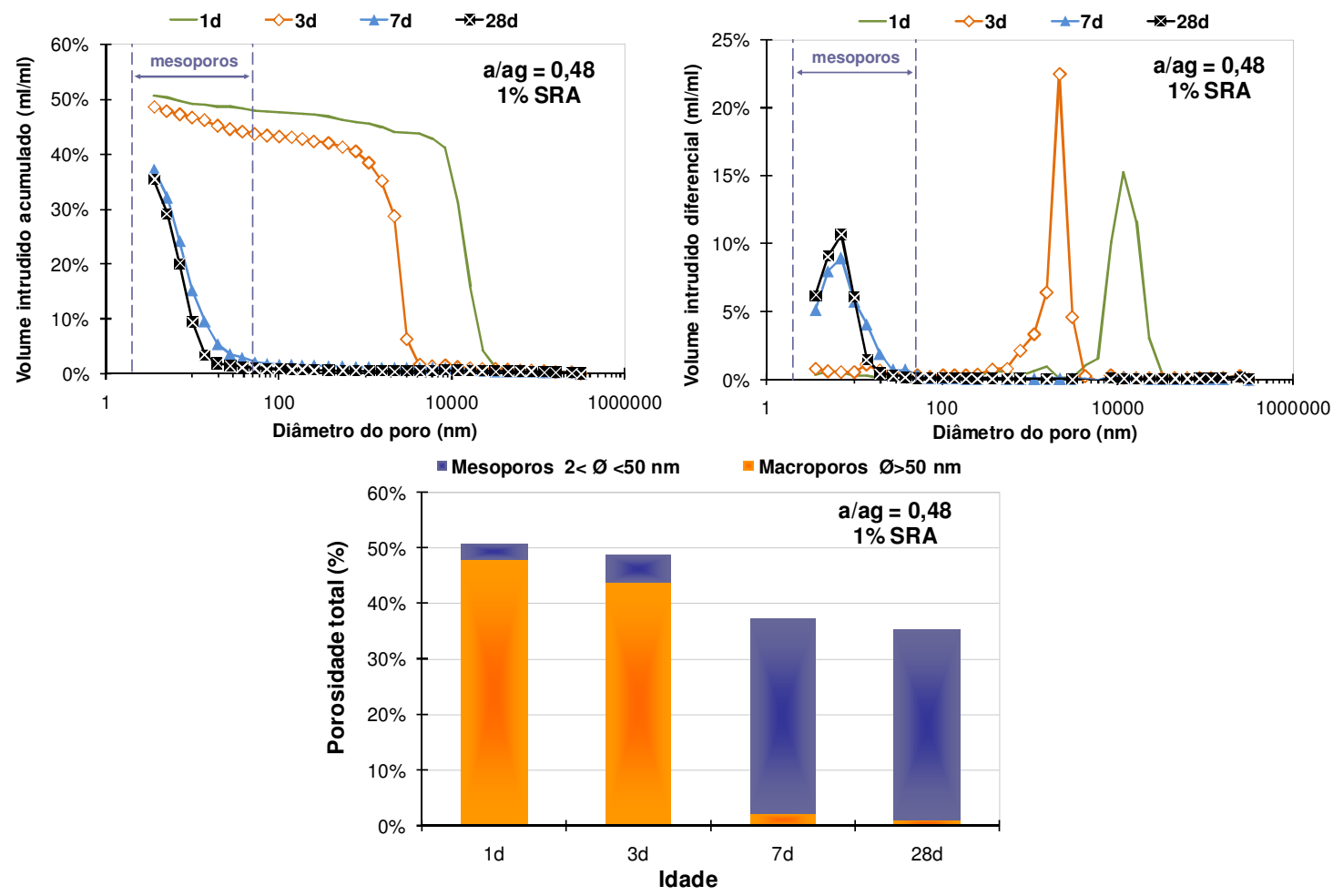

Figura B.3 - Evolução da porosidade acumulada, porosidade diferencial e a distribuição de poros da pasta de cimento de escória ativada com silicato de sódio (4NSB1). A/agl=0,48. Teor de aditivo redutor de retração $($ SRA $)=1 \%$. 

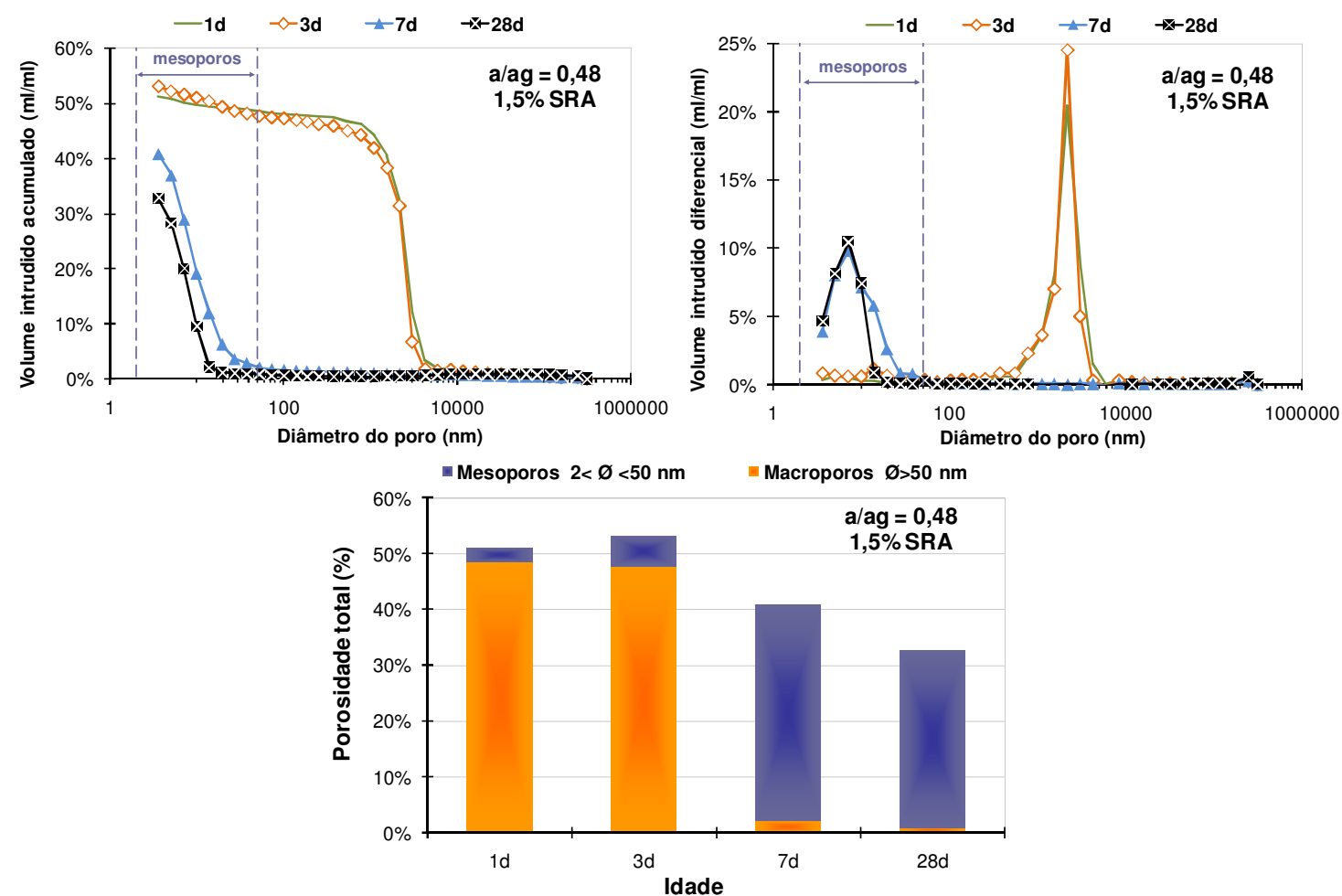

Figura B.4 - Evolução da porosidade acumulada, porosidade diferencial e a distribuição de poros da pasta de cimento de escória ativada com silicato de sódio $(\mathbf{4 N S B 1 , 5 ) . ~ A / a g l = 0 , 4 8 . ~ T e o r ~ d e ~ a d i t i v o ~ r e d u t o r ~ d e ~ r e t r a c ̧ a ̃ o ~}$ $($ SRA $)=1,5 \%$.
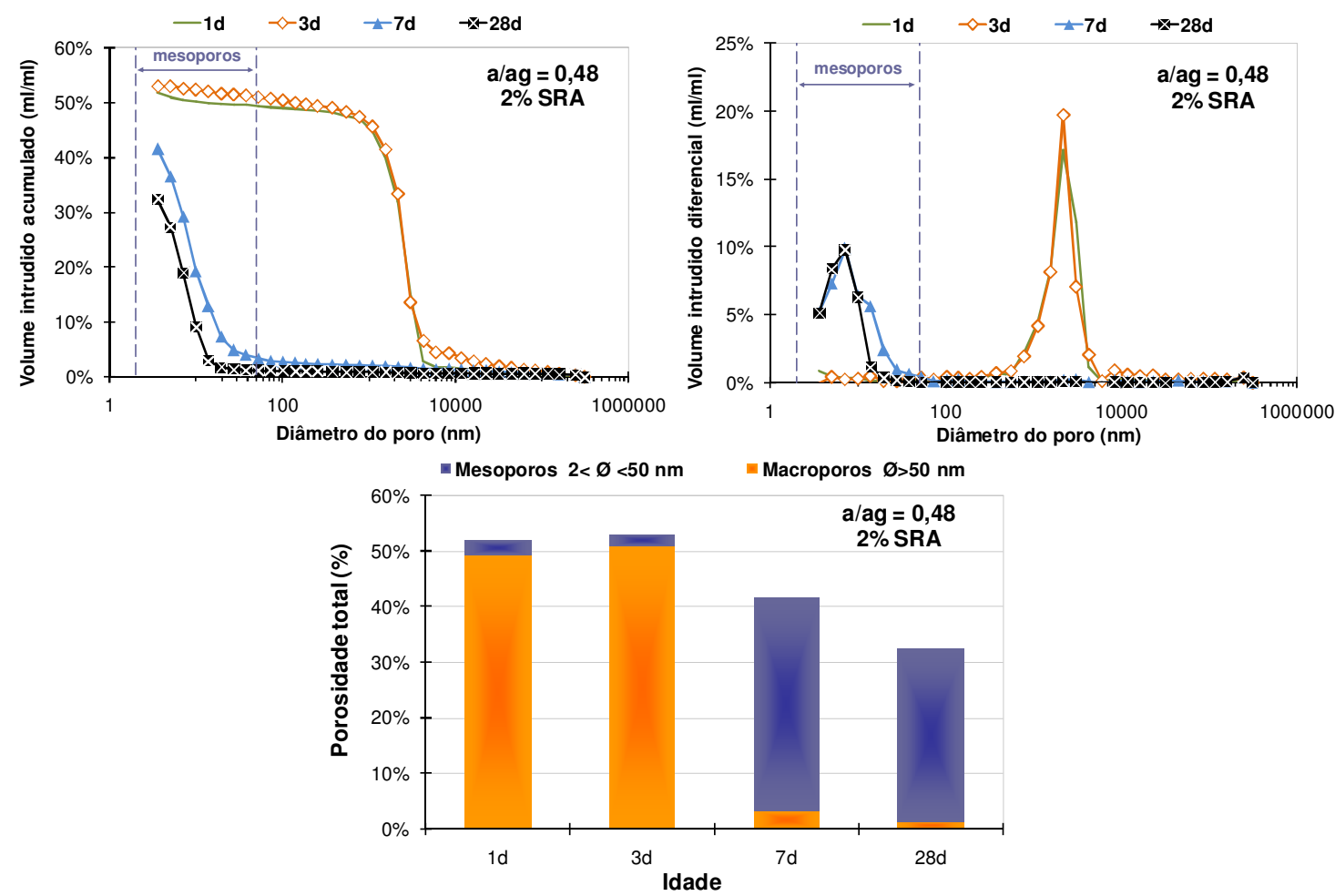

Figura B.5 - Evolução da porosidade acumulada, porosidade diferencial e a distribuição de poros da pasta de cimento de escória ativada com silicato de sódio (4NSB2). A/agl=0,48. Teor de aditivo redutor de retração $($ SRA $)=2 \%$. 


\section{Relação a/agl igual a 0,48 e utilização do aditivo compensador de retração (SCA)}
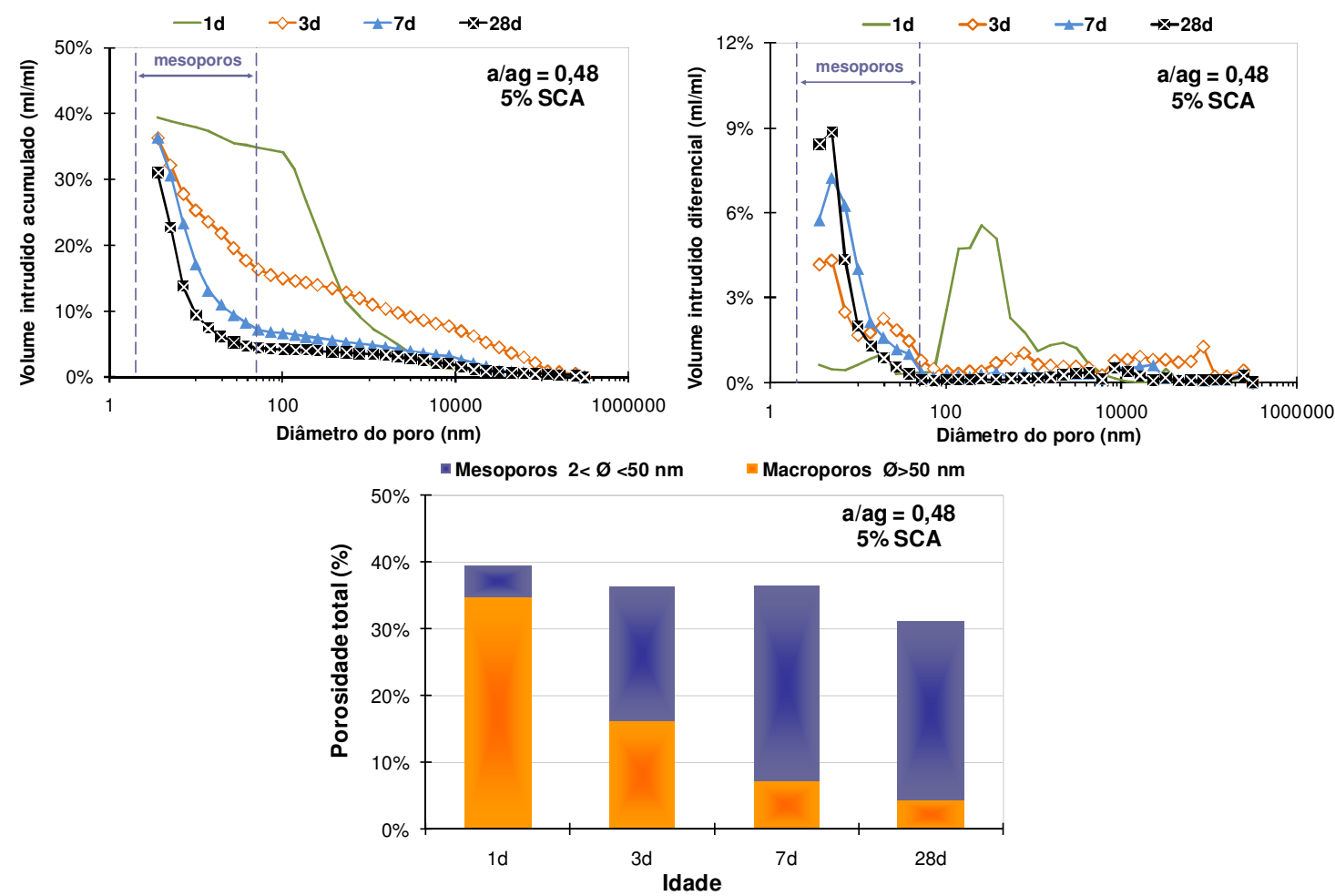

Figura B.6 - Evolução da porosidade acumulada, porosidade diferencial e a distribuição de poros da pasta de cimento de escória ativada com silicato de sódio (4NSB5). A/agl=0,48. Teor de aditivo compensador de retração $(\mathbf{S C A})=5 \%$.
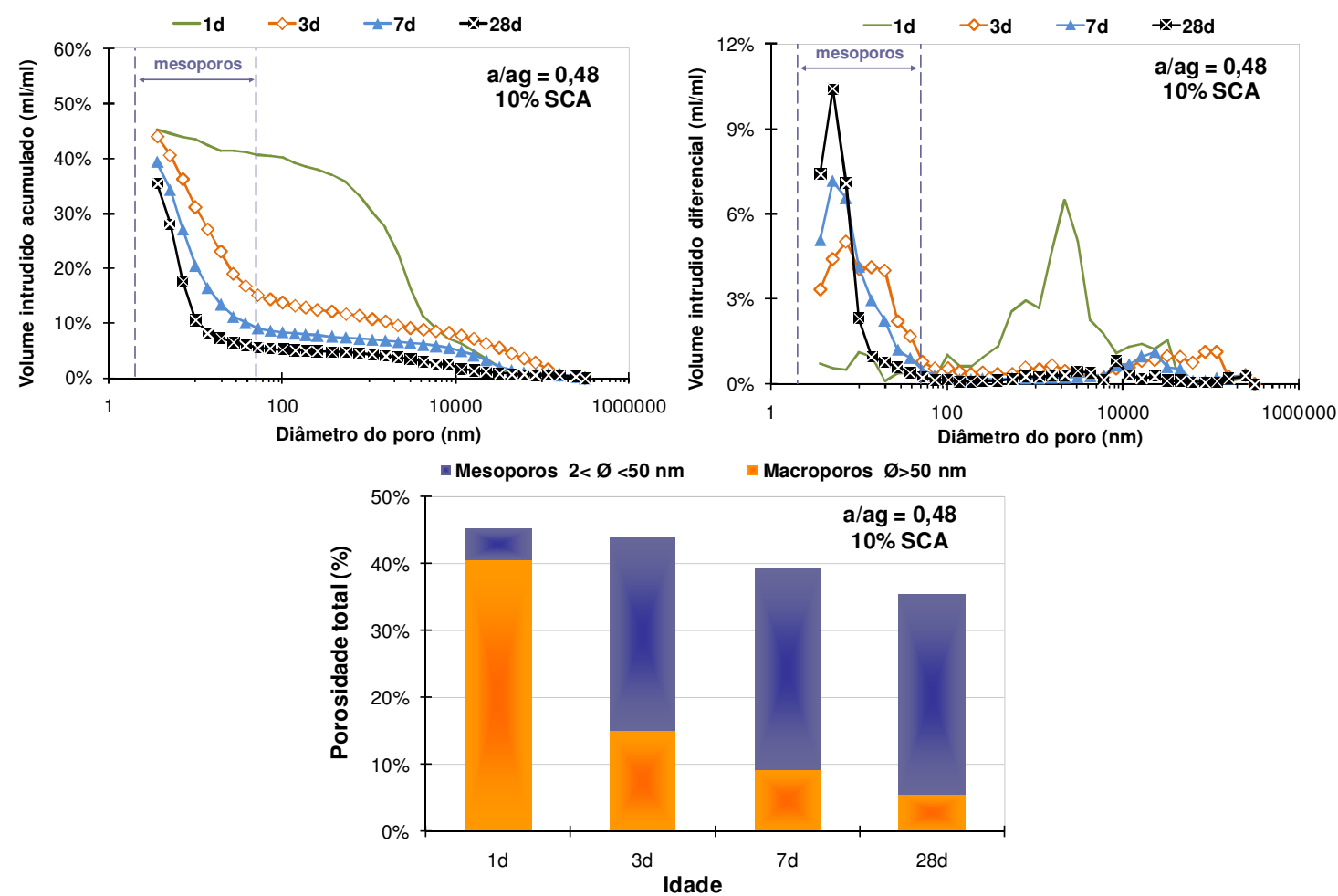

Figura B.7 - Evolução da porosidade acumulada, porosidade diferencial e a distribuição de poros da pasta de cimento de escória ativada com silicato de sódio (4NSB10). A/agl=0,48. Teor de aditivo compensador de retração $(\mathbf{S C A})=10 \%$. 

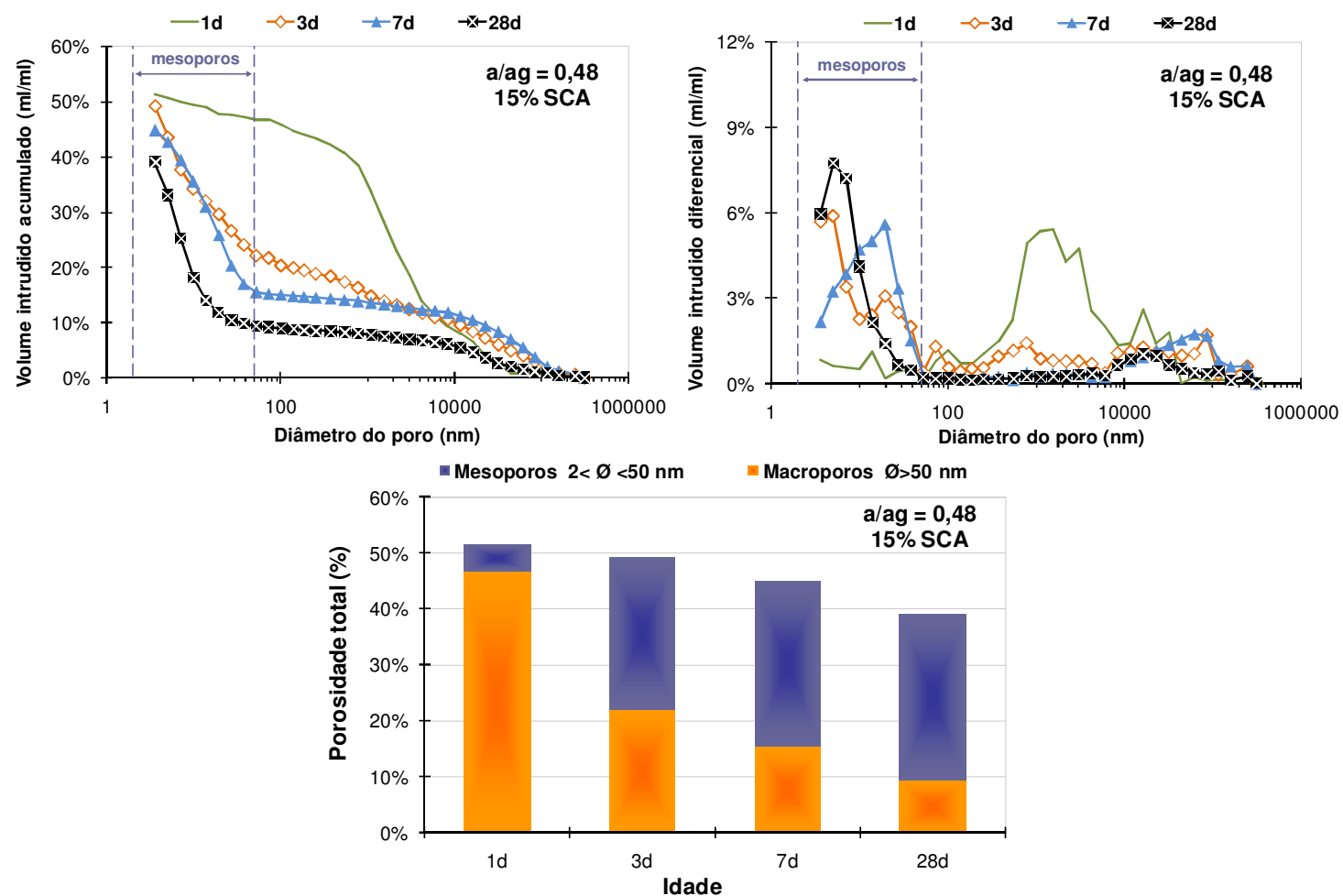

Figura B.8 - Evolução da porosidade acumulada, porosidade diferencial e a distribuição de poros da pasta de cimento de escória ativada com silicato de sódio (4NSB15). A/agl=0,48. Teor de aditivo compensador de retração $(\mathbf{S C A})=15 \%$. 


\section{Apêndice C - Resultados da difração de raios X}

Neste apêndice constam os resultados do ensaio de difração de raios X. Os ensaios foram realizados em pastas (descrição do método no item 3.5.6) e nas variações determinadas no planejamento experimental (item 3.3.3.2). Neste apêndice também estão apresentadas as fichas utilizadas na interpretação dos resultados, com os respectivos picos principais e distâncias interplanares. Em seguida, os compostos estão listados em ordem crescente na escala angular $2 \Theta$.

Tabela C.1 - Fichas utilizadas para a identificação dos compostos no ensaio de difração de raios X. Constam o código de referência ICDD e a posição dos picos de maior intensidade.

\begin{tabular}{|c|c|c|c|c|c|}
\hline \multirow{2}{*}{ Espécie química } & \multirow{2}{*}{ Formula química } & \multirow{2}{*}{$\begin{array}{l}\text { Código de referência } \\
\text { ICDD/ano }\end{array}$} & \multicolumn{3}{|c|}{ Posição dos picos mais intensos } \\
\hline & & & 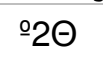 & $d(\AA)$ & Intensidade $\mathrm{I} / \mathrm{I}_{0}(\%)$ \\
\hline Aluminato de cálcio & $\mathrm{Ca}_{3} \mathrm{Al}_{2} \mathrm{O} 6$ & $32-0150(1979)$ & $\begin{array}{l}33,24 \\
32,98 \\
47,33 \\
59,03\end{array}$ & $\begin{array}{l}2,69 \\
2,71 \\
1,92 \\
1,56\end{array}$ & $\begin{array}{c}100 \\
65 \\
35 \\
35\end{array}$ \\
\hline \multirow{5}{*}{$\begin{array}{l}\text { Aluminato de cálcio } \\
\text { hidratado }\end{array}$} & \multirow{5}{*}{$4 \mathrm{CaO} \cdot \mathrm{Al}_{2} \mathrm{O}_{3} \cdot 13 \mathrm{H}_{2} \mathrm{O}$} & 33-0254 (1982) & $\begin{array}{l}24,70 \\
27,25 \\
31,88 \\
31,97\end{array}$ & $\begin{array}{l}3,60 \\
3,27 \\
2,81 \\
2,80\end{array}$ & $\begin{array}{c}100 \\
86 \\
83 \\
81\end{array}$ \\
\hline & & $24-0178(1970)$ & $\begin{array}{l}24,64 \\
31,85 \\
27,17 \\
31,61\end{array}$ & $\begin{array}{l}3,61 \\
2,81 \\
3,28 \\
2,83\end{array}$ & $\begin{array}{c}100 \\
70 \\
55 \\
50\end{array}$ \\
\hline & & $11-0203(1963)$ & $\begin{array}{l}10,98 \\
31,25 \\
55,30 \\
33,28\end{array}$ & $\begin{array}{l}8,05 \\
2,86 \\
1,66 \\
2,69\end{array}$ & $\begin{array}{c}100 \\
90 \\
80 \\
60\end{array}$ \\
\hline & & $16-0333(1959)$ & $\begin{array}{l}11,25 \\
22,61 \\
30,92 \\
36,81\end{array}$ & $\begin{array}{l}7,86 \\
3,93 \\
2,89 \\
2,44\end{array}$ & $\begin{array}{c}100 \\
60 \\
50 \\
40\end{array}$ \\
\hline & & $02-0083$ & $\begin{array}{l}11,56 \\
23,58 \\
31,25 \\
55,66\end{array}$ & $\begin{array}{l}7,65 \\
3,77 \\
2,86 \\
1,65 \\
\end{array}$ & $\begin{array}{c}100 \\
90 \\
70 \\
70 \\
\end{array}$ \\
\hline \multirow{3}{*}{ Aluminato tricálcico $-\mathrm{C}_{3} \mathrm{~A}$} & \multirow{3}{*}{$\mathrm{Ca}_{3} \mathrm{Al}_{2} \mathrm{O}_{6}$} & 06-0495 (1995) & $\begin{array}{l}33,15 \\
47,62 \\
21,77 \\
32,09\end{array}$ & $\begin{array}{l}2,70 \\
1,91 \\
4,08 \\
2,79\end{array}$ & $\begin{array}{c}100 \\
36 \\
16 \\
14\end{array}$ \\
\hline & & $38-1429$ (1987) & $\begin{array}{l}33,17 \\
47,63 \\
59,27 \\
21,76\end{array}$ & $\begin{array}{l}2,70 \\
1,91 \\
1,56 \\
4,08\end{array}$ & $\begin{array}{c}100 \\
30 \\
24 \\
12\end{array}$ \\
\hline & & $32-0148$ (1979) & $\begin{array}{l}33,18 \\
33,23 \\
32,95 \\
58,94\end{array}$ & $\begin{array}{l}2,70 \\
2,69 \\
2,72 \\
1,57\end{array}$ & $\begin{array}{c}100 \\
95 \\
75 \\
35\end{array}$ \\
\hline
\end{tabular}


Tabela C.2 - Fichas utilizadas para a identificação dos compostos no ensaio de difração de raios X. Constam o código de referência ICDD e a posição dos picos de maior intensidade.

\begin{tabular}{|c|c|c|c|c|c|}
\hline \multirow{2}{*}{ Espécie química } & \multirow{2}{*}{ Formula química } & \multirow{2}{*}{$\begin{array}{c}\text { Código de referência } \\
\text { ICDD/ano }\end{array}$} & \multicolumn{3}{|c|}{ Posição dos picos mais intensos } \\
\hline & & & $\stackrel{\circ}{2} \Theta$ & $d(\AA)$ & Intensidade $\mathrm{I} / \mathrm{I}_{0}(\%)$ \\
\hline \multirow{3}{*}{ Anidrita } & \multirow{3}{*}{$\mathrm{CaSO}_{4}$} & $37-0184(1983)$ & $\begin{array}{l}25,44 \\
31,32 \\
38,58 \\
40,78\end{array}$ & $\begin{array}{l}3,50 \\
2,85 \\
2,33 \\
2,21\end{array}$ & $\begin{array}{c}100 \\
80 \\
50 \\
50\end{array}$ \\
\hline & & 06-0226 (1955) & $\begin{array}{l}25,44 \\
31,37 \\
38,64 \\
40,84\end{array}$ & $\begin{array}{l}3,50 \\
2,85 \\
2,33 \\
2,21\end{array}$ & $\begin{array}{c}100 \\
35 \\
20 \\
20\end{array}$ \\
\hline & & $37-1496(1986)$ & $\begin{array}{l}25,44 \\
31,37 \\
38,64 \\
40,82\end{array}$ & $\begin{array}{l}3,50 \\
2,85 \\
2,33 \\
2,21\end{array}$ & $\begin{array}{c}100 \\
29 \\
20 \\
20\end{array}$ \\
\hline Akermanita & $2 \mathrm{CaO} \cdot \mathrm{MgO} \cdot 2 \mathrm{SiO}_{2}$ & $35-0592(1984)$ & $\begin{array}{l}31,12 \\
28,90 \\
51,88 \\
36,22\end{array}$ & $\begin{array}{l}2,87 \\
3,09 \\
1,76 \\
2,48\end{array}$ & $\begin{array}{c}100 \\
23 \\
20 \\
15\end{array}$ \\
\hline \multirow{4}{*}{ Carbonato de cálcio } & \multirow{4}{*}{$\mathrm{CaCO}_{3}$} & $47-1743(1994)$ & $\begin{array}{l}29,40 \\
48,50 \\
47,51 \\
39,41\end{array}$ & $\begin{array}{l}3,04 \\
1,88 \\
1,91 \\
2,28\end{array}$ & $\begin{array}{c}100 \\
23,2 \\
21,7 \\
20,2\end{array}$ \\
\hline & & 24-0027 (1973) & $\begin{array}{l}29,46 \\
48,58 \\
23,07 \\
43,17\end{array}$ & $\begin{array}{l}3,03 \\
1,87 \\
3,85 \\
2,09\end{array}$ & $\begin{array}{c}100 \\
34 \\
29 \\
27\end{array}$ \\
\hline & & 05-0586 (1953) & $\begin{array}{l}29,41 \\
39,40 \\
43,15 \\
47,49\end{array}$ & $\begin{array}{l}3,04 \\
2,29 \\
2,10 \\
1,91\end{array}$ & $\begin{array}{c}100 \\
18 \\
18 \\
17 \\
\end{array}$ \\
\hline & & $41-1475(1989)$ & $\begin{array}{l}26,21 \\
33,13 \\
45,85 \\
27,22 \\
\end{array}$ & $\begin{array}{l}3,40 \\
2,70 \\
1,98 \\
3,27 \\
\end{array}$ & $\begin{array}{c}100 \\
60 \\
55 \\
50 \\
\end{array}$ \\
\hline \multirow{3}{*}{$\begin{array}{l}\text { Etringita (sulfoaluminato de } \\
\text { cálcio hidratado) }\end{array}$} & \multirow{3}{*}{$\begin{array}{c}3 \mathrm{CaO} \cdot 3 \mathrm{CaSO}_{4} \cdot \\
\quad \mathrm{Al}_{2} \mathrm{O}_{3} \cdot 32 \mathrm{H}_{2} \mathrm{O}\end{array}$} & $41-1451(1970)$ & $\begin{array}{c}9,09 \\
15,78 \\
22,94 \\
35,02\end{array}$ & $\begin{array}{l}9,72 \\
5,61 \\
3,87 \\
2,56\end{array}$ & $\begin{array}{c}100 \\
76 \\
31 \\
29\end{array}$ \\
\hline & & 09-0414 (1960) & $\begin{array}{c}9,08 \\
15,78 \\
22,90 \\
34,97\end{array}$ & $\begin{array}{l}9,73 \\
5,61 \\
3,88 \\
2,56\end{array}$ & $\begin{array}{c}100 \\
80 \\
50 \\
45\end{array}$ \\
\hline & & $41-0217(1989)$ & $\begin{array}{c}9,22 \\
15,98 \\
18,04 \\
35,37\end{array}$ & $\begin{array}{l}9,58 \\
5,54 \\
4,91 \\
2,54\end{array}$ & $\begin{array}{c}100 \\
70 \\
65 \\
55\end{array}$ \\
\hline \multirow{3}{*}{$\begin{array}{l}\text { Ferroaluminato tetracálcico } \\
\qquad-\mathrm{C}_{4} \mathrm{AF}\end{array}$} & \multirow{3}{*}{$\mathrm{Ca}_{2}(\mathrm{Al}, \mathrm{Fe})_{2} \mathrm{O}_{5}$} & $30-0226(1964)$ & $\begin{array}{l}33,88 \\
12,20 \\
50,23 \\
33,50\end{array}$ & $\begin{array}{l}2,64 \\
7,25 \\
1,81 \\
2,67\end{array}$ & $\begin{array}{c}100 \\
45 \\
45 \\
35\end{array}$ \\
\hline & & $10-0032$ & $\begin{array}{l}33,97 \\
12,20 \\
32,17 \\
47,25\end{array}$ & $\begin{array}{l}2,64 \\
7,25 \\
2,78 \\
1,92\end{array}$ & $\begin{array}{c}100 \\
80 \\
80 \\
80\end{array}$ \\
\hline & & $42-1469(1991)$ & $\begin{array}{l}34,07 \\
33,75 \\
47,52 \\
32,45 \\
\end{array}$ & $\begin{array}{l}2,63 \\
2,65 \\
1,91 \\
2,76 \\
\end{array}$ & $\begin{array}{c}100 \\
50 \\
35 \\
30 \\
\end{array}$ \\
\hline Gelenita & $2 \mathrm{CaO} \cdot \mathrm{Al}_{2} \mathrm{O}_{3} \cdot \mathrm{SiO}_{2}$ & $35-0755(1968)$ & $\begin{array}{l}31,42 \\
52,10 \\
29,13 \\
36,95 \\
\end{array}$ & $\begin{array}{l}2,84 \\
1,75 \\
3,06 \\
2,43 \\
\end{array}$ & $\begin{array}{c}100 \\
25 \\
21 \\
17 \\
\end{array}$ \\
\hline
\end{tabular}


Tabela C.3 - Fichas utilizadas para a identificação dos compostos no ensaio de difração de raios X. Constam o código de referência ICDD e a posição dos picos de maior intensidade.

\begin{tabular}{|c|c|c|c|c|c|}
\hline \multirow[b]{2}{*}{ Espécie química } & \multirow{2}{*}{ Formula química } & \multirow{2}{*}{$\begin{array}{c}\text { Código de referência } \\
\text { ICDD/ano }\end{array}$} & \multicolumn{3}{|c|}{ Posição dos picos mais intensos } \\
\hline & & & 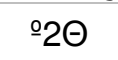 & $d(\AA)$ & Intensidade $\mathrm{I} / \mathrm{I}_{0}(\%)$ \\
\hline Gipsita & $\mathrm{CaSO}_{4} \cdot 2 \mathrm{H}_{2} \mathrm{O}$ & $\begin{array}{l}36-0432(1958) \\
33-0311(1980)\end{array}$ & $\begin{array}{l}20,74 \\
11,65 \\
29,15 \\
31,08 \\
11,59 \\
20,72 \\
29,11 \\
31,10\end{array}$ & $\begin{array}{l}4,28 \\
7,59 \\
3,06 \\
2,88 \\
7,63 \\
4,28 \\
3,07 \\
2,87\end{array}$ & $\begin{array}{c}100 \\
77 \\
55 \\
42 \\
100 \\
100 \\
75 \\
45\end{array}$ \\
\hline Hidrotalcita & $\begin{array}{l}\mathrm{Mg}_{6} \mathrm{Al}_{2} \cdot\left(\mathrm{CO}_{3}\right) \\
(\mathrm{OH})_{16} \cdot 4 \mathrm{H}_{2} \mathrm{O}\end{array}$ & $41-1428(1984)$ & $\begin{array}{c}11,27 \\
22,70 \\
5,48 \\
34,36\end{array}$ & $\begin{array}{c}7,84 \\
3,91 \\
16,12 \\
2,61\end{array}$ & $\begin{array}{c}100 \\
80 \\
55 \\
30\end{array}$ \\
\hline Mervinita & $\mathrm{Ca}_{3} \mathrm{Mg} \cdot\left(\mathrm{SiO}_{4}\right)_{2}$ & 35-0591 (1984) & $\begin{array}{l}33,32 \\
33,52 \\
33,76 \\
47,54\end{array}$ & $\begin{array}{l}2,69 \\
2,67 \\
2,65 \\
1,91\end{array}$ & $\begin{array}{c}100 \\
65 \\
47 \\
35\end{array}$ \\
\hline & & $50-1607$ (1997) & $\begin{array}{c}9,85 \\
19,82 \\
38,07 \\
41,19\end{array}$ & $\begin{array}{l}8,97 \\
4,48 \\
2,36 \\
2,19\end{array}$ & $\begin{array}{l}100 \\
70 \\
40 \\
40\end{array}$ \\
\hline Monossulfoaluminato de & $3 \mathrm{CaO} \cdot 3 \mathrm{CaSO}_{4}$ & $42-0065$ (1989) & $\begin{array}{l}10,10 \\
20,28 \\
31,05 \\
38,74\end{array}$ & $\begin{array}{l}8,75 \\
4,38 \\
2,88 \\
2,32\end{array}$ & $\begin{array}{l}100 \\
70 \\
45 \\
37\end{array}$ \\
\hline cálcio hidratado & - $\mathrm{Al}_{2} \mathrm{O}_{3} \cdot 12 \mathrm{H}_{2} \mathrm{O}$ & $42-0062(1984)$ & $\begin{array}{c}9,25 \\
18,55 \\
36,11 \\
32,50\end{array}$ & $\begin{array}{l}9,55 \\
4,78 \\
2,49 \\
2,75\end{array}$ & $\begin{array}{l}100 \\
65 \\
45 \\
30\end{array}$ \\
\hline & & $45-0158(1989)$ & $\begin{array}{c}9,93 \\
19,94 \\
38,10 \\
41,19\end{array}$ & $\begin{array}{l}8,90 \\
4,45 \\
2,36 \\
2,19\end{array}$ & $\begin{array}{l}100 \\
70 \\
40 \\
40\end{array}$ \\
\hline & & 48-1467 (1992) & $\begin{array}{c}37,36 \\
53,86 \\
32,20 \\
147,79 \\
\end{array}$ & $\begin{array}{l}2,41 \\
1,70 \\
2,78 \\
0,80\end{array}$ & $\begin{array}{c}100 \\
51 \\
40 \\
19\end{array}$ \\
\hline Oxıdo de calcıo & $\mathrm{CaO}$ & $37-1497$ (1986) & $\begin{array}{l}37,35 \\
53,86 \\
32,20 \\
64,15\end{array}$ & $\begin{array}{l}2,41 \\
1,70 \\
2,78 \\
1,45\end{array}$ & $\begin{array}{l}100 \\
54 \\
36 \\
16\end{array}$ \\
\hline Periclásio & $\mathrm{MgO}$ & $45-0946$ (1993) & $\begin{array}{c}42,92 \\
62,30 \\
109,76 \\
127,28 \\
\end{array}$ & $\begin{array}{l}2,11 \\
1,49 \\
0,94 \\
0,86 \\
\end{array}$ & $\begin{array}{c}100 \\
39 \\
19 \\
14 \\
\end{array}$ \\
\hline Portlandita & $\mathrm{Ca}(\mathrm{OH})_{2}$ & 04-0733 (1953) & $\begin{array}{l}34,09 \\
18,09 \\
47,12 \\
50,80 \\
34,10 \\
18,01 \\
50,81 \\
47,12\end{array}$ & $\begin{array}{l}2,63 \\
4,90 \\
1,93 \\
1,80 \\
2,63 \\
4,92 \\
1,80 \\
1,93\end{array}$ & $\begin{array}{c}100 \\
74 \\
42 \\
36 \\
100 \\
72 \\
31 \\
30 \\
\end{array}$ \\
\hline
\end{tabular}


Tabela C.4 - Fichas utilizadas para a identificação dos compostos no ensaio de difração de raios X. Constam o código de referência ICDD e a posição dos picos de maior intensidade.

\begin{tabular}{|c|c|c|c|c|c|}
\hline \multirow{2}{*}{ Espécie química } & \multirow{2}{*}{ Formula química } & \multirow{2}{*}{$\begin{array}{l}\text { Código de referência } \\
\text { ICDD/ano }\end{array}$} & \multicolumn{3}{|c|}{ Posição dos picos mais intensos } \\
\hline & & & $\stackrel{2}{2} \Theta$ & $d(\AA)$ & Intensidade $\mathrm{I} / \mathrm{I}_{0}(\%)$ \\
\hline \multirow{22}{*}{$\begin{array}{c}\text { Silicato de cálcio hidratado } \\
\text { C-S-H }\end{array}$} & \multirow{22}{*}{$\mathrm{Ca}_{3} \mathrm{H}_{2} \mathrm{SiO}_{5}$} & 33-0306 (1980) & $\begin{array}{l}29,36 \\
32,05 \\
50,08\end{array}$ & $\begin{array}{l}3,04 \\
2,79 \\
1,82\end{array}$ & $\begin{array}{c}100 \\
60 \\
60\end{array}$ \\
\hline & & & 29,36 & 3,04 & 100 \\
\hline & & $15-0641$ (1958) & 30,92 & 2,89 & 100 \\
\hline & & & $\begin{array}{l}4,, 73 \\
26,59\end{array}$ & $\begin{array}{l}1,90 \\
3,35\end{array}$ & $\begin{array}{l}100 \\
80\end{array}$ \\
\hline & & & 27,23 & 3,27 & 100 \\
\hline & & $29-0373(1952)$ & 37,15 & 2,42 & 60 \\
\hline & & $29-0010(1902)$ & 21,03 & 4,22 & 50 \\
\hline & & & 31,03 & 2,88 & 50 \\
\hline & & & 7,82 & 11,30 & 100 \\
\hline & & $45-1480(1989)$ & $\begin{array}{l}28,97 \\
30,04\end{array}$ & $\begin{array}{l}3,08 \\
2,97\end{array}$ & $\begin{array}{l}92 \\
70\end{array}$ \\
\hline & & & 31,87 & 2,81 & 68 \\
\hline & & & 28,59 & 3,12 & 100 \\
\hline & & $29-0374(1976)$ & 29,06 & 3,07 & 95 \\
\hline & & $60-0014(1010)$ & 31,59 & 2,83 & 95 \\
\hline & & & 30,38 & 2,94 & 90 \\
\hline & & & 28,68 & 3,11 & 100 \\
\hline & & $03-0548$ (1943) & 39,86 & 2,26 & 80 \\
\hline & & $20-8040(10+4)$ & $\begin{array}{l}43,69 \\
53,89\end{array}$ & $\begin{array}{l}2,07 \\
170\end{array}$ & $\begin{array}{l}80 \\
80\end{array}$ \\
\hline & & & 8,41 & 10,50 & 100 \\
\hline & & & 30,59 & 2,92 & 80 \\
\hline & & $18-1206(1966)$ & 29,36 & 3,04 & 60 \\
\hline & & & 31,59 & 2,83 & 60 \\
\hline \multirow{22}{*}{ Silicato dicálcico - $\mathrm{C}_{2} \mathrm{~S}$} & \multirow{22}{*}{$\mathrm{Ca}_{2} \mathrm{SiO}_{4}$} & & 32,01 & 2,79 & 100 \\
\hline & & $49-1673(1995)$ & 32,57 & 2,75 & 98 \\
\hline & & $49-10 / 3(1990)$ & 32,15 & $\begin{array}{l}2,78 \\
2 ? 0\end{array}$ & $\begin{array}{l}89 \\
64\end{array}$ \\
\hline & & & 32,14 & 2,78 & 100 \\
\hline & & & 32,05 & 2,79 & 97 \\
\hline & & 33-0302 (1982) & 32,59 & 2,75 & 83 \\
\hline & & & 41,21 & 2,19 & 51 \\
\hline & & & 32,08 & 2,79 & 100 \\
\hline & & $29-0369$ (1968) & 32,53 & 2,75 & 85 \\
\hline & & $29-0369(1968)$ & 31,97 & 2,80 & 70 \\
\hline & & & 30,61 & 2,92 & 25 \\
\hline & & & 32,89 & 2,72 & 100 \\
\hline & & $24-0234(1968)$ & 32,20 & 2,78 & 75 \\
\hline & & $24-0234$ (1968) & 32,07 & 2,79 & 65 \\
\hline & & & 30,60 & 2,92 & 12 \\
\hline & & & 32,79 & 2,73 & 100 \\
\hline & & $31-0297(1964)$ & 29,64 & 3,01 & 80 \\
\hline & & $31-0297(1964)$ & 32,53 & 2,75 & 70 \\
\hline & & & 47,61 & 1,91 & 60 \\
\hline & & & 33,42 & 2,68 & 100 \\
\hline & & 33-0303 (1970) & 32,55 & 2,75 & 85 \\
\hline & & & 32,64 & 2,74 & 80 \\
\hline & & & 32,36 & 2,76 & 40 \\
\hline
\end{tabular}


Tabela C.5 - Fichas utilizadas para a identificação dos compostos no ensaio de difração de raios X. Constam o código de referência ICDD e a posição dos picos de maior intensidade.

\begin{tabular}{|c|c|c|c|c|c|}
\hline \multirow{2}{*}{ Espécie química } & \multirow{2}{*}{ Formula química } & \multirow{2}{*}{$\begin{array}{l}\text { Código de referência } \\
\text { ICDD/ano }\end{array}$} & \multicolumn{3}{|c|}{ Posição dos picos mais intensos } \\
\hline & & & $\stackrel{0}{2} \Theta$ & $d(\AA)$ & Intensidade $\mathrm{I} / \mathrm{I}_{0}(\%)$ \\
\hline \multirow{3}{*}{ Silicato tricálcico $-\mathrm{C}_{3} \mathrm{~S}$} & \multirow{3}{*}{$\mathrm{Ca}_{3} \mathrm{SiO}_{5}$} & 49-0442 (1995) & $\begin{array}{l}32,13 \\
32,46 \\
51,75 \\
29,30\end{array}$ & $\begin{array}{l}2,78 \\
2,76 \\
1,77 \\
3,05\end{array}$ & $\begin{array}{c}100 \\
85 \\
77 \\
74\end{array}$ \\
\hline & & 31-0301 (1964) & $\begin{array}{l}32,07 \\
34,29 \\
41,15 \\
32,33\end{array}$ & $\begin{array}{l}2,79 \\
2,61 \\
2,19 \\
2,77\end{array}$ & $\begin{array}{c}100 \\
90 \\
75 \\
70\end{array}$ \\
\hline & & 42-0551 (1979) & $\begin{array}{l}34,41 \\
32,26 \\
29,51 \\
32,68\end{array}$ & $\begin{array}{l}2,60 \\
2,77 \\
3,03 \\
2,74\end{array}$ & $\begin{array}{c}100 \\
85 \\
75 \\
75\end{array}$ \\
\hline Sulfato de alumínio & $\mathrm{Al}_{2}\left(\mathrm{SO}_{4}\right)_{3}$ & $42-1410(1991)$ & $\begin{array}{l}25,43 \\
25,16 \\
15,20 \\
21,03\end{array}$ & $\begin{array}{l}3,50 \\
3,54 \\
5,82 \\
4,22\end{array}$ & $\begin{array}{c}100 \\
42 \\
35 \\
18\end{array}$ \\
\hline \multirow{2}{*}{$\begin{array}{l}\text { Sulfoaluminato de cálcio - } \\
\text { CSA }\end{array}$} & \multirow{2}{*}{$\begin{array}{l}3 \mathrm{CaO} \cdot 3 \mathrm{Al}_{2} \mathrm{O}_{3} \\
\cdot \mathrm{CaSO}_{4}\end{array}$} & 42-1478 (1992) & $\begin{array}{l}23,66 \\
23,73 \\
33,72 \\
27,42\end{array}$ & $\begin{array}{l}3,76 \\
3,75 \\
2,66 \\
3,25\end{array}$ & $\begin{array}{c}100 \\
100 \\
30 \\
8\end{array}$ \\
\hline & & 33-0256 (1962) & $\begin{array}{l}23,64 \\
33,80 \\
41,66 \\
27,42\end{array}$ & $\begin{array}{l}3,76 \\
2,65 \\
2,17 \\
3,25\end{array}$ & $\begin{array}{c}100 \\
25 \\
20 \\
8\end{array}$ \\
\hline Wollastonita & $\mathrm{CaSiO}_{3}$ & 29-0372 (1973) & $\begin{array}{l}1,+, 1< \\
30,00 \\
26,90 \\
25,35 \\
28,97\end{array}$ & $\begin{array}{l}, C, 98 \\
3,31 \\
3,51 \\
3,08\end{array}$ & $\begin{array}{c}100 \\
80 \\
70 \\
70\end{array}$ \\
\hline
\end{tabular}


Apêndice $C$ - Resultados da difração de raios $X$

Tabela C.6 - Picos principais compostos utilizados na análise dos resultados de difração de raios X. Os compostos estão ordenados em ordem crescente de acordo com posição angular ํㅡㄹ.

\begin{tabular}{|c|c|c|c|c|c|}
\hline 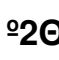 & Espécie química & Código ICDD & $\underline{-20}$ & $d(\AA ̊)$ & Intensidade $\mathrm{I} / \mathrm{I}_{0}(\%)$ \\
\hline & Hidrotalcita & $41-1428(1984)$ & 5,48 & 16,12 & 55 \\
\hline & Silicato de cálcio hidratado C-S-H & $45-1480(1989)$ & 7,82 & 11,30 & 100 \\
\hline & Silicato de cálcio hidratado C-S-H & $18-1206(1966)$ & 8,41 & 10,50 & 100 \\
\hline & Etringita (sulfoaluminato de cálcio hidratado) & $09-0414(1960)$ & 9,08 & 9,73 & 100 \\
\hline & Etringita (sulfoaluminato de cálcio hidratado) & $41-1451(1970)$ & 9,09 & 9,72 & 100 \\
\hline & Etringita (sulfoaluminato de cálcio hidratado) & $41-0217(1989)$ & 9,22 & 9,58 & 100 \\
\hline & Monossulfoaluminato de cálcio hidratado & $42-0062(1984)$ & 9,25 & 9,55 & 100 \\
\hline $10^{\circ}$ & Monossulfoaluminato de cálcio hidratado & 50-1607 (1997) & 9,85 & 8,97 & 100 \\
\hline & Monossulfoaluminato de cálcio hidratado & $45-0158(1989)$ & 9,93 & 8,90 & 100 \\
\hline & Monossulfoaluminato de cálcio hidratado & $42-0065(1989)$ & 10,10 & 8,75 & 100 \\
\hline $10^{\circ}$ & Aluminato de cálcio hidratado & $11-0203(1963)$ & 10,98 & 8,05 & 100 \\
\hline & Aluminato de cálcio hidratado & $16-0333(1959)$ & 11,25 & 7,86 & 100 \\
\hline & Hidrotalcita & $41-1428(1984)$ & 11,27 & 7,84 & 100 \\
\hline & Aluminato de cálcio hidratado & $02-0083$ & 11,56 & 7,65 & 100 \\
\hline & Gipsita & $33-0311(1980)$ & 11,59 & 7,63 & 100 \\
\hline & Gipsita & $36-0432(1958)$ & 11,65 & 7,59 & 77 \\
\hline & Ferroaluminato tetracálcico - C4AF & $30-0226(1964)$ & 12,20 & 7,25 & 45 \\
\hline & Ferroaluminato tetracálcico - C4AF & $10-0033$ & 12,20 & 7,25 & 80 \\
\hline & Sulfato de alumínio & $42-1410(1991)$ & 15,20 & 5,82 & 35 \\
\hline & Etringita (sulfoaluminato de cálcio hidratado) & $41-1451(1970)$ & 15,78 & 5,61 & 76 \\
\hline & Etringita (sulfoaluminato de cálcio hidratado) & $09-0414(1960)$ & 15,78 & 5,61 & 80 \\
\hline & Etringita (sulfoaluminato de cálcio hidratado) & $41-0217(1989)$ & 15,98 & 5,54 & 70 \\
\hline & Portlandita & 44-1481 (1992) & 18,01 & 4,92 & 72 \\
\hline & Etringita (sulfoaluminato de cálcio hidratado) & $41-0217(1989)$ & 18,04 & 4,91 & 65 \\
\hline & Portlandita & 04-0733 (1953) & 18,09 & 4,90 & 74 \\
\hline & Monossulfoaluminato de cálcio hidratado & $42-0062(1984)$ & 18,55 & 4,78 & 65 \\
\hline 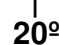 & Monossulfoaluminato de cálcio hidratado & $50-1607(1997)$ & 19,82 & 4,48 & 70 \\
\hline & Monossulfoaluminato de cálcio hidratado & $45-0158(1989)$ & 19,94 & 4,45 & 70 \\
\hline & Monossulfoaluminato de cálcio hidratado & $42-0065$ (1989) & 20,28 & 4,38 & 70 \\
\hline $20^{\circ}$ & Gipsita & $33-0311(1980)$ & 20,72 & 4,28 & 100 \\
\hline & Gipsita & $36-0432(1958)$ & 20,74 & 4,28 & 100 \\
\hline & Silicato de cálcio hidratado C-S-H & $29-0373(1952)$ & 21,03 & 4,22 & 50 \\
\hline & Sulfato de alumínio & $42-1410(1991)$ & 21,03 & 4,22 & 18 \\
\hline & Aluminato tricálcico - C3A & $38-1429(1987)$ & 21,76 & 4,08 & 12 \\
\hline & Aluminato tricálcico - C3A & $06-0495(1995)$ & 21,77 & 4,08 & 16 \\
\hline & Aluminato de cálcio hidratado & $16-0333(1959)$ & 22,61 & 3,93 & 60 \\
\hline & Hidrotalcita & $41-1428(1984)$ & 22,70 & 3,91 & 80 \\
\hline & Etringita (sulfoaluminato de cálcio hidratado) & $09-0414(1960)$ & 22,90 & 3,88 & 50 \\
\hline & Etringita (sulfoaluminato de cálcio hidratado) & $41-1451(1970)$ & 22,94 & 3,87 & 31 \\
\hline & Carbonato de cálcio & $24-0027$ (1973) & 23,07 & 3,85 & 29 \\
\hline & Aluminato de cálcio hidratado & $02-0084$ & 23,58 & 3,77 & 90 \\
\hline & Sulfoaluminato de cálcio - CSA & $33-0256(1962)$ & 23,64 & 3,76 & 100 \\
\hline & Sulfoaluminato de cálcio - CSA & $42-1478$ (1992) & 23,66 & 3,76 & 100 \\
\hline 250 & Sulfoaluminato de cálcio - CSA & $42-1478$ (1992) & 23,73 & 3,75 & 100 \\
\hline & Aluminato de cálcio hidratado & $24-0178(1970)$ & 24,64 & 3,61 & 100 \\
\hline & Aluminato de cálcio hidratado & $33-0254(1982)$ & 24,70 & 3,60 & 100 \\
\hline & Sulfato de alumínio & $42-1410(1991)$ & 25,16 & 3,54 & 42 \\
\hline $25^{\circ}$ & Wollastonita & 29-0372 (1973) & 25,35 & 3,51 & 70 \\
\hline & Sulfato de alumínio & $42-1410(1991)$ & 25,43 & 3,50 & 100 \\
\hline & Anidrita & $37-0184(1983)$ & 25,44 & 3,50 & 100 \\
\hline & Anidrita & $06-0226(1955)$ & 25,44 & 3,50 & 100 \\
\hline & Anidrita & $37-1496(1986)$ & 25,44 & 3,50 & 100 \\
\hline & Carbonato de cálcio & $41-1475(1989)$ & 26,21 & 3,40 & 100 \\
\hline & Silicato de cálcio hidratado C-S-H & $15-0641(1958)$ & 26,59 & 3,35 & 80 \\
\hline & Wollastonita & 29-0372 (1973) & 26,90 & 3,31 & 80 \\
\hline & Aluminato de cálcio hidratado & $24-0178(1970)$ & 27,17 & 3,28 & 55 \\
\hline & Carbonato de cálcio & $41-1475(1989)$ & 27,22 & 3,27 & 50 \\
\hline & Silicato de cálcio hidratado C-S-H & $29-0373(1952)$ & 27,23 & 3,27 & 100 \\
\hline & Aluminato de cálcio hidratado & $33-0254$ (1982) & 27,25 & 3,27 & 86 \\
\hline & Sulfoaluminato de cálcio - CSA & $42-1478(1992)$ & 27,42 & 3,25 & 8 \\
\hline
\end{tabular}


Apêndice $C$ - Resultados da difração de raios $X$

Tabela C.7 - Picos principais compostos utilizados na análise dos resultados de difração de raios X. Os compostos estão ordenados em ordem crescente de acordo com posição angular ํㅡㄹ.

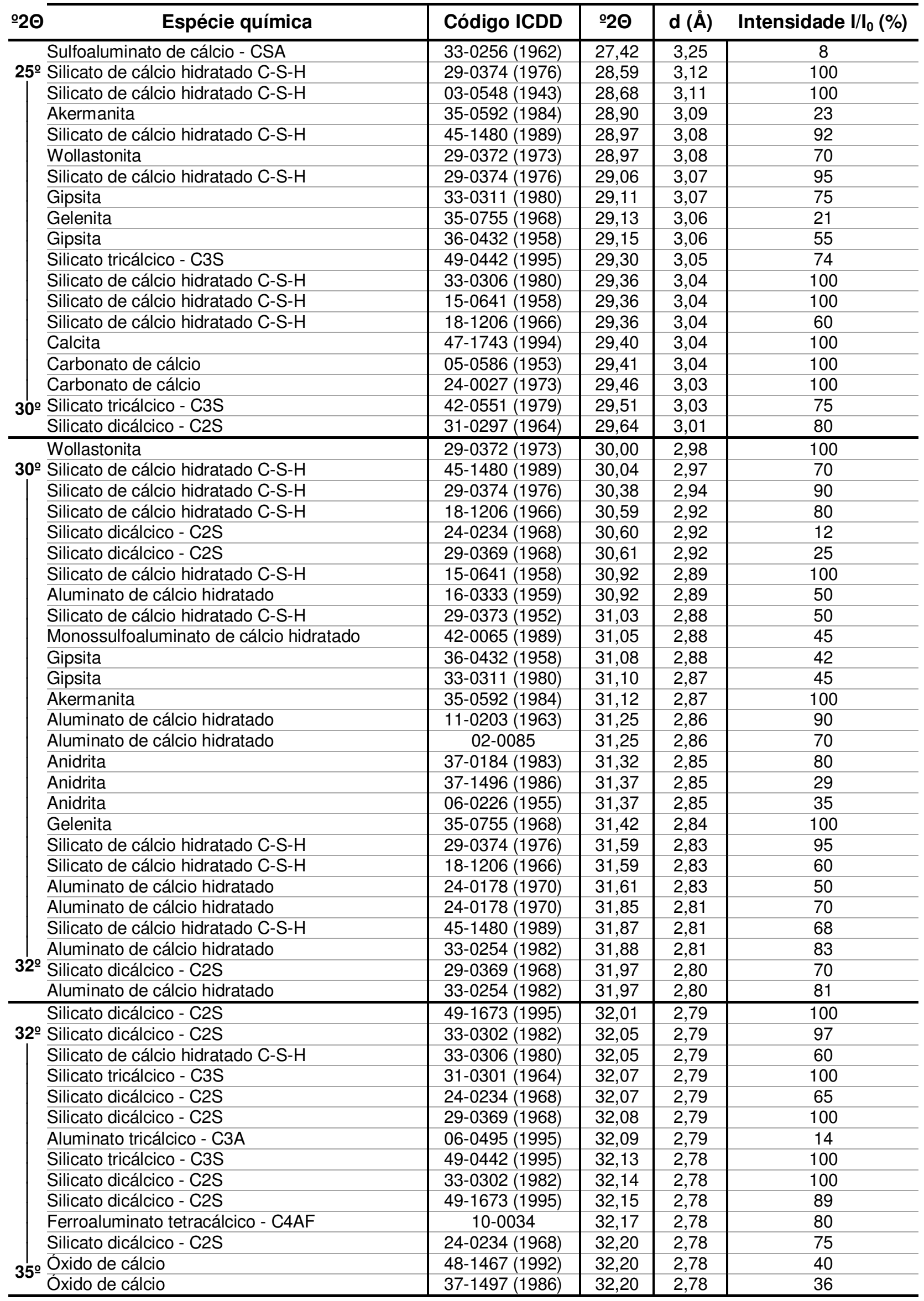


Apêndice $C$ - Resultados da difração de raios $X$

Tabela C.8 - Picos principais compostos utilizados na análise dos resultados de difração de raios X. Os compostos estão ordenados em ordem crescente de acordo com posição angular ํㅡㄹ.

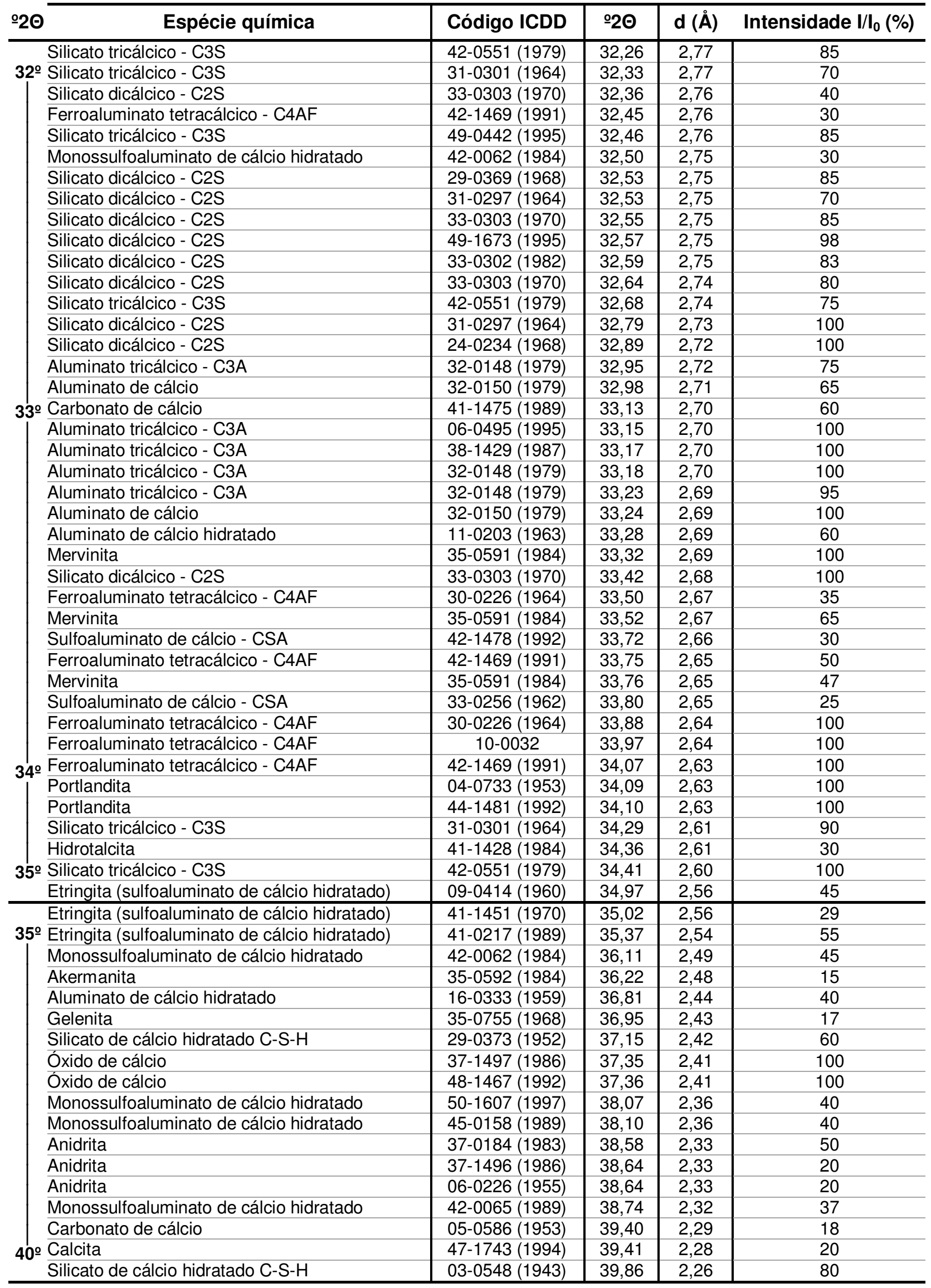


Tabela C.9 - Picos principais compostos utilizados na análise dos resultados de difração de raios X. Os compostos estão ordenados em ordem crescente de acordo com posição angular ํㅡㄹ.

\begin{tabular}{|c|c|c|c|c|c|}
\hline$\stackrel{20}{2}$ & Espécie química & Código ICDD & $\mathbf{2 0}$ & $d(\AA ̊)$ & Intensidade $\mathrm{I} / \mathrm{I}_{0}(\%)$ \\
\hline & Anidrita & $37-0184(1983)$ & 40,78 & 2,21 & 50 \\
\hline & Anidrita & $37-1496$ (1986) & 40,82 & 2,21 & 20 \\
\hline & Anidrita & 06-0226 (1955) & 40,84 & 2,21 & 20 \\
\hline & Silicato dicálcico - C2S & $49-1673$ (1995) & 41,03 & 2,20 & 64 \\
\hline & Silicato tricálcico - C3S & 31-0301 (1964) & 41,15 & 2,19 & 75 \\
\hline & Monossulfoaluminato de cálcio hidratado & $50-1607$ (1997) & 41,19 & 2,19 & 40 \\
\hline & Monossulfoaluminato de cálcio hidratado & $45-0158$ (1989) & 41,19 & 2,19 & 40 \\
\hline & Silicato dicálcico - C2S & $33-0302$ (1982) & 41,21 & 2,19 & 51 \\
\hline & Sulfoaluminato de cálcio - CSA & $33-0256$ (1962) & 41,66 & 2,17 & 20 \\
\hline & Periclásio & $45-0946$ (1993) & 42,92 & 2,11 & 100 \\
\hline & Carbonato de cálcio & 05-0586 (1953) & 43,15 & 2,10 & 18 \\
\hline & Carbonato de cálcio & 24-0027 (1973) & 43,17 & 2,09 & 27 \\
\hline & Silicato de cálcio hidratado C-S-H & 03-0548 (1943) & 43,69 & 2,07 & 80 \\
\hline & Carbonato de cálcio & $41-1475$ (1989) & 45,85 & 1,98 & 55 \\
\hline & Portlandita & $44-1481$ (1992) & 47,12 & 1,93 & 30 \\
\hline & Portlandita & 04-0733 (1953) & 47,12 & 1,93 & 42 \\
\hline & Ferroaluminato tetracálcico - C4AF & $10-0035$ & 47,25 & 1,92 & 80 \\
\hline & Aluminato de cálcio & $32-0150$ (1979) & 47,33 & 1,92 & 35 \\
\hline & Carbonato de cálcio & 05-0586 (1953) & 47,49 & 1,91 & 17 \\
\hline & Calcita & $47-1743$ (1994) & 47,51 & 1,91 & 21,7 \\
\hline & Ferroaluminato tetracálcico - C4AF & $42-1469$ (1991) & 47,52 & 1,91 & 35 \\
\hline & Mervinita & 35-0591 (1984) & 47,54 & 1,91 & 35 \\
\hline & Silicato dicálcico - C2S & 31-0297 (1964) & 47,61 & 1,91 & 60 \\
\hline & Aluminato tricálcico - C3A & 06-0495 (1995) & 47,62 & 1,91 & 36 \\
\hline & Aluminato tricálcico - C3A & $38-1429$ (1987) & 47,63 & 1,91 & 30 \\
\hline 50 - & Silicato de cálcio hidratado C-S-H & $15-0641$ (1958) & 47,73 & 1,90 & 100 \\
\hline & Calcita & $47-1743$ (1994) & 48,50 & 1,88 & 23,2 \\
\hline & Carbonato de cálcio & $24-0027$ (1973) & 48,58 & 1,87 & 34 \\
\hline 50 - & Silicato de cálcio hidratado C-S-H & $33-0306$ (1980) & 50,08 & 1,82 & 60 \\
\hline & Ferroaluminato tetracálcico - C4AF & $30-0226$ (1964) & 50,23 & 1,81 & 45 \\
\hline & Portlandita & p4-0733 (1953) & 50,80 & 1,80 & 36 \\
\hline & Portlandita & $44-1481$ (1992) & 50,81 & 1,80 & 31 \\
\hline & Silicato tricálcico - C3S & 49-0442 (1995) & 51,75 & 1,77 & 77 \\
\hline & Akermanita & 35-0592 (1984) & 51,88 & 1,76 & 20 \\
\hline & Gelenita & 35-0755 (1968) & 52,10 & 1,75 & 25 \\
\hline & Óxido de cálcio & $37-1497$ (1986) & 53,86 & 1,70 & 54 \\
\hline & Óxido de cálcio & 48-1467 (1992) & 53,86 & 1,70 & 51 \\
\hline & Silicato de cálcio hidratado C-S-H & 03-0548 (1943) & 53,89 & 1,70 & 80 \\
\hline & Aluminato de cálcio hidratado & $11-0203$ (1963) & 55,30 & 1,66 & 80 \\
\hline & Aluminato de cálcio hidratado & $02-0086$ & 55,66 & 1,65 & 70 \\
\hline & Aluminato tricálcico - C3A & $32-0148$ (1979) & 58,94 & 1,57 & 35 \\
\hline & Aluminato de cálcio & $32-0150$ (1979) & 59,03 & 1,56 & 35 \\
\hline & Aluminato tricálcico - C3A & $38-1429$ (1987) & 59,27 & 1,56 & 24 \\
\hline & Periclásio & $45-0946$ (1993) & 62,30 & 1,49 & 39 \\
\hline & Öxido de cálcio & $37-1497$ (1986) & 64,15 & 1,45 & 16 \\
\hline
\end{tabular}




\section{Relação a/agl igual a 0,40 e utilização do aditivo compensador de retração (SCA)}

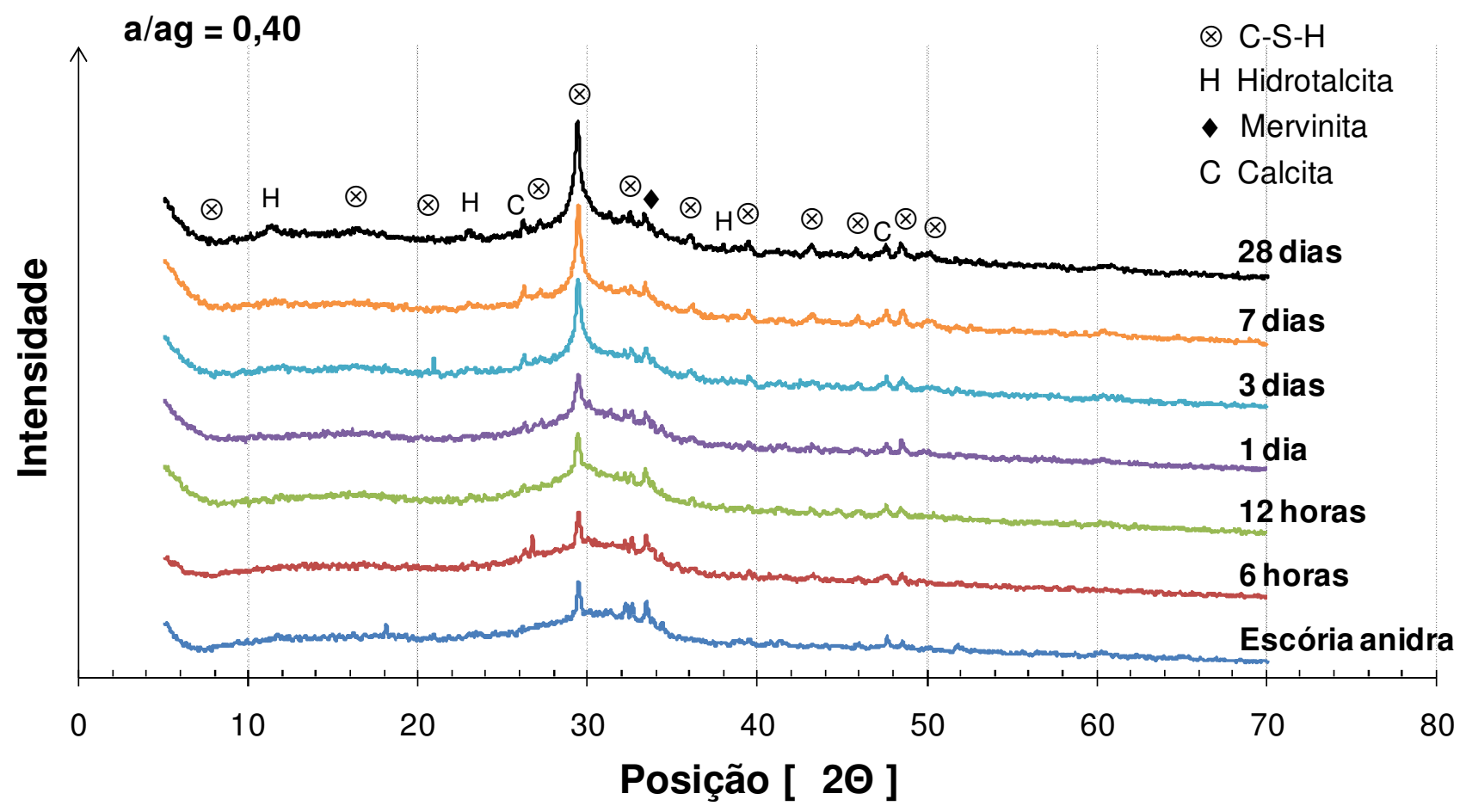

Figura C.1 - Difratogramas da pasta de cimento de escória ativada com silicato de sódio (4NSA0) a 6 e 12 horas, $1,3,7$ e 28 dias de idade. a/agl= 0,40.

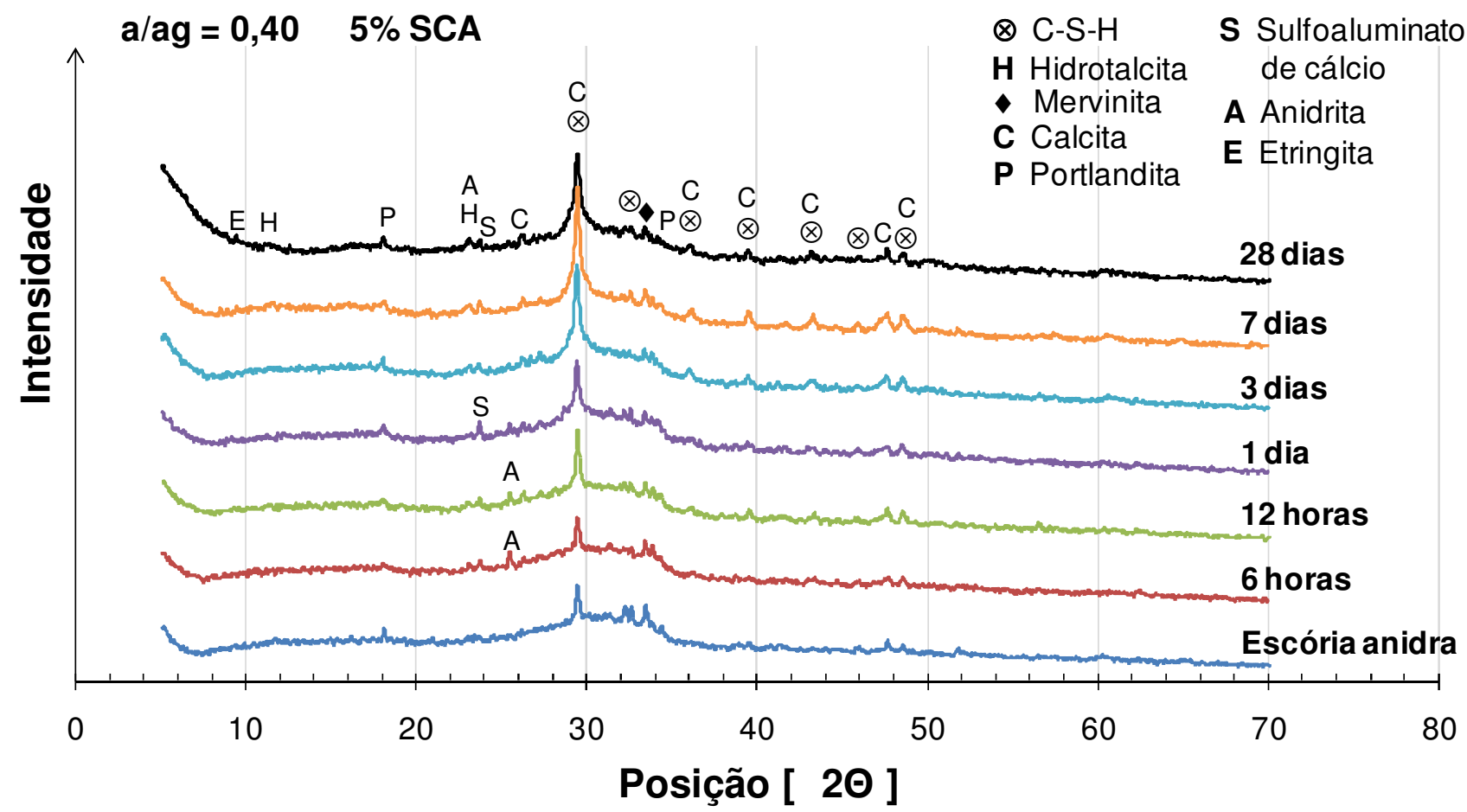

Figura C.2 - Difratogramas da pasta de cimento de escória ativada com silicato de sódio (4NSA5) a 6 e 12 horas, $1,3,7$ e 28 dias de idade. a/agl= 0,40. Teor de SCA $=5 \%$. 


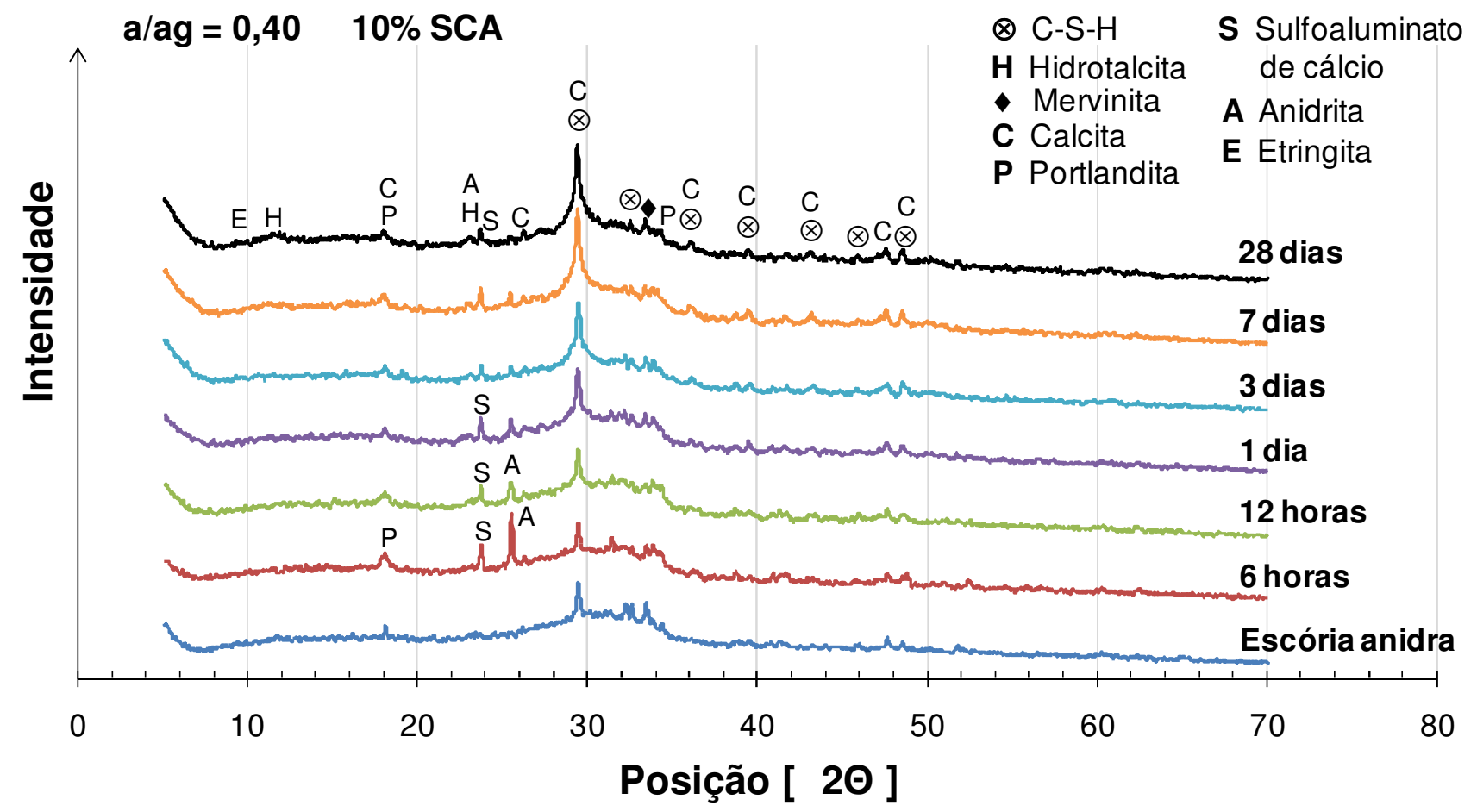

Figura C.3 - Difratogramas da pasta de cimento de escória ativada com silicato de sódio (4NSA10) a 6 e 12 horas, $1,3,7$ e 28 dias de idade. $\mathrm{a} / \mathrm{agl}=0,40$. Teor de SCA $=10 \%$.

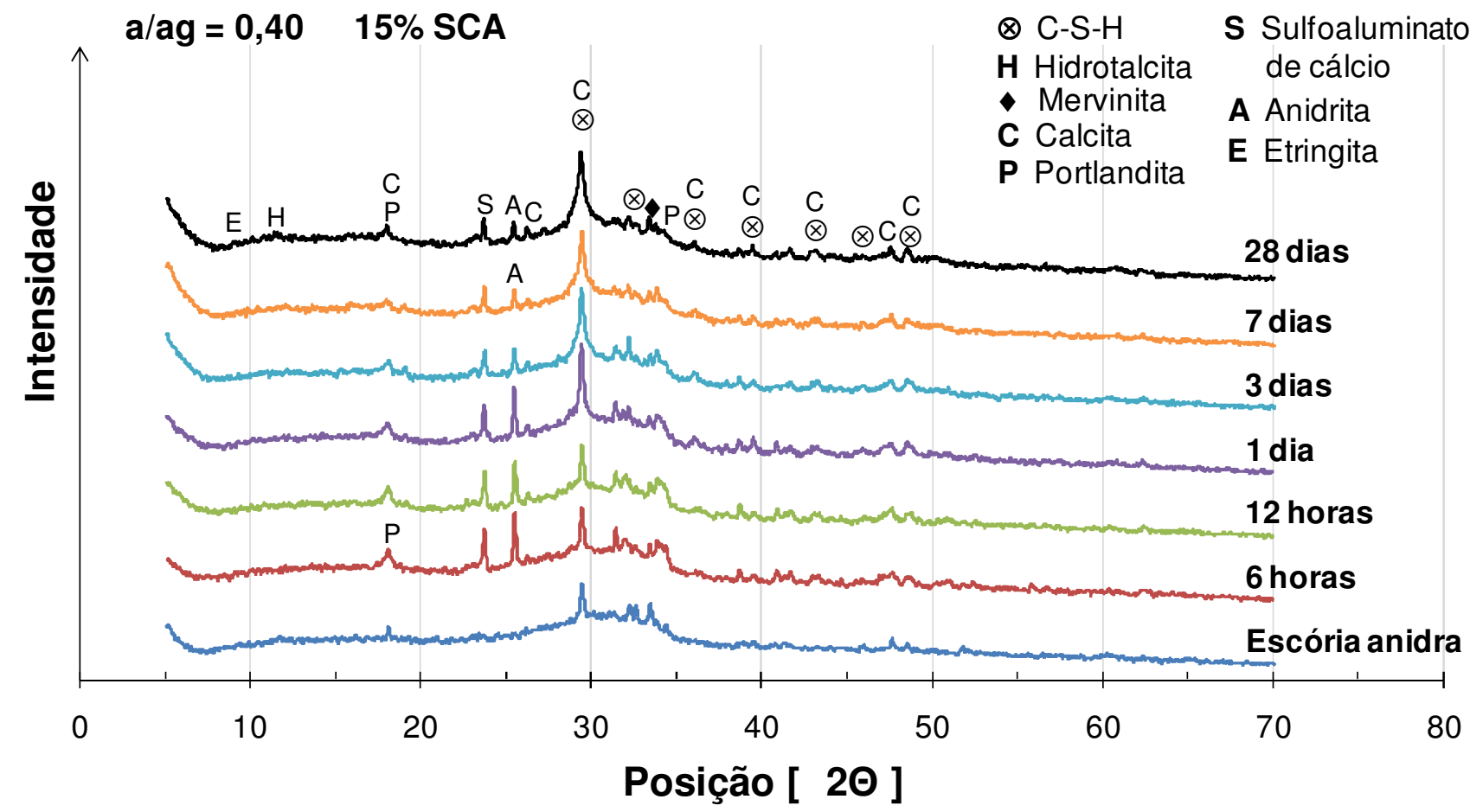

Figura C.4 - Difratogramas da pasta de cimento de escória ativada com silicato de sódio (4NSA10) a 6 e 12 horas, $1,3,7$ e 28 dias de idade. $\mathrm{a} / \mathrm{agl}=0,40$. Teor de SCA $=15 \%$. 
Relação a/agl igual a 0,48 e utilização do aditivo redutor de retração (SRA).

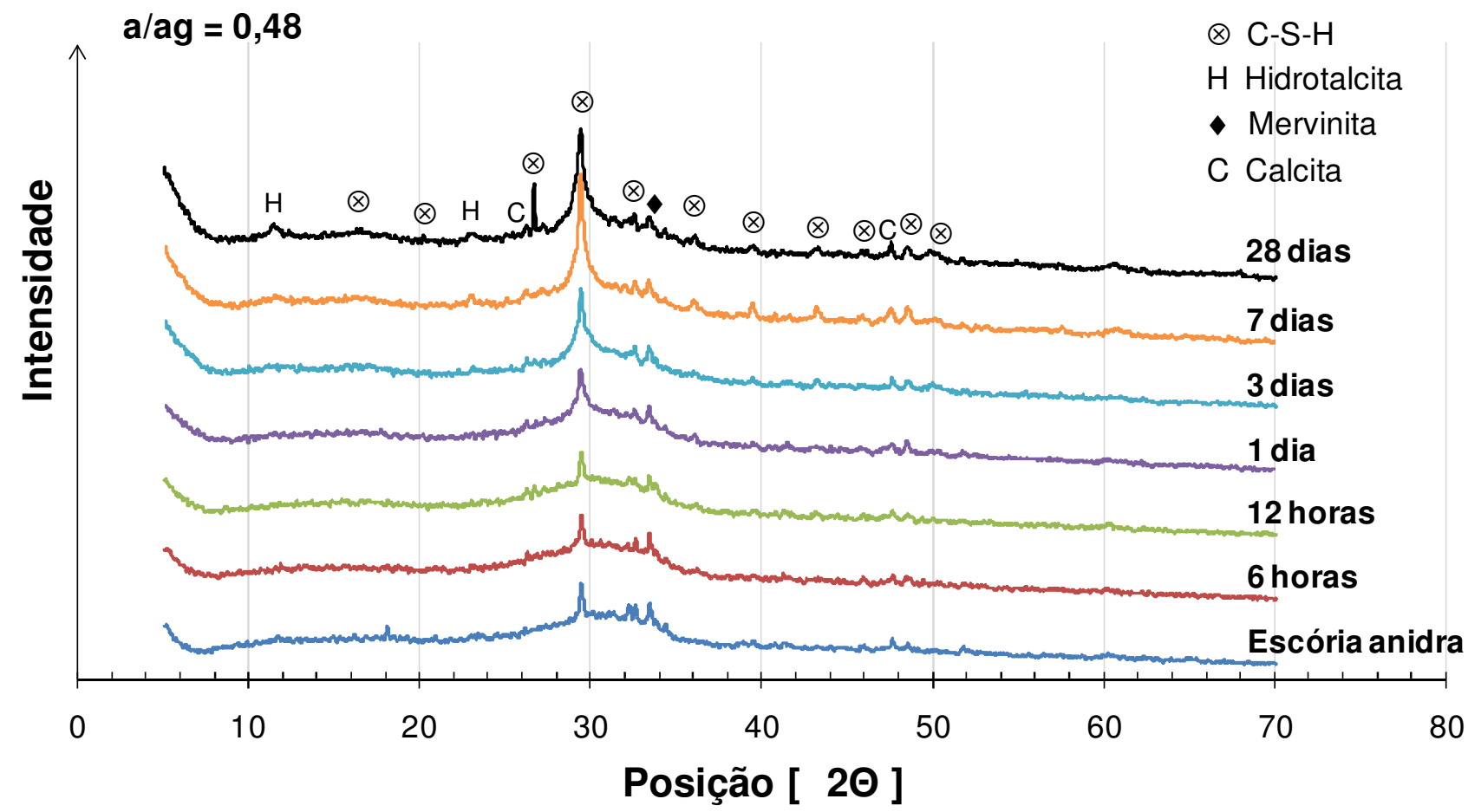

Figura C.5 - Difratogramas da pasta de cimento de escória ativada com silicato de sódio (4NSB0) a 6 e 12 horas, $1,3,7$ e 28 dias de idade. a/agl= 0,48.

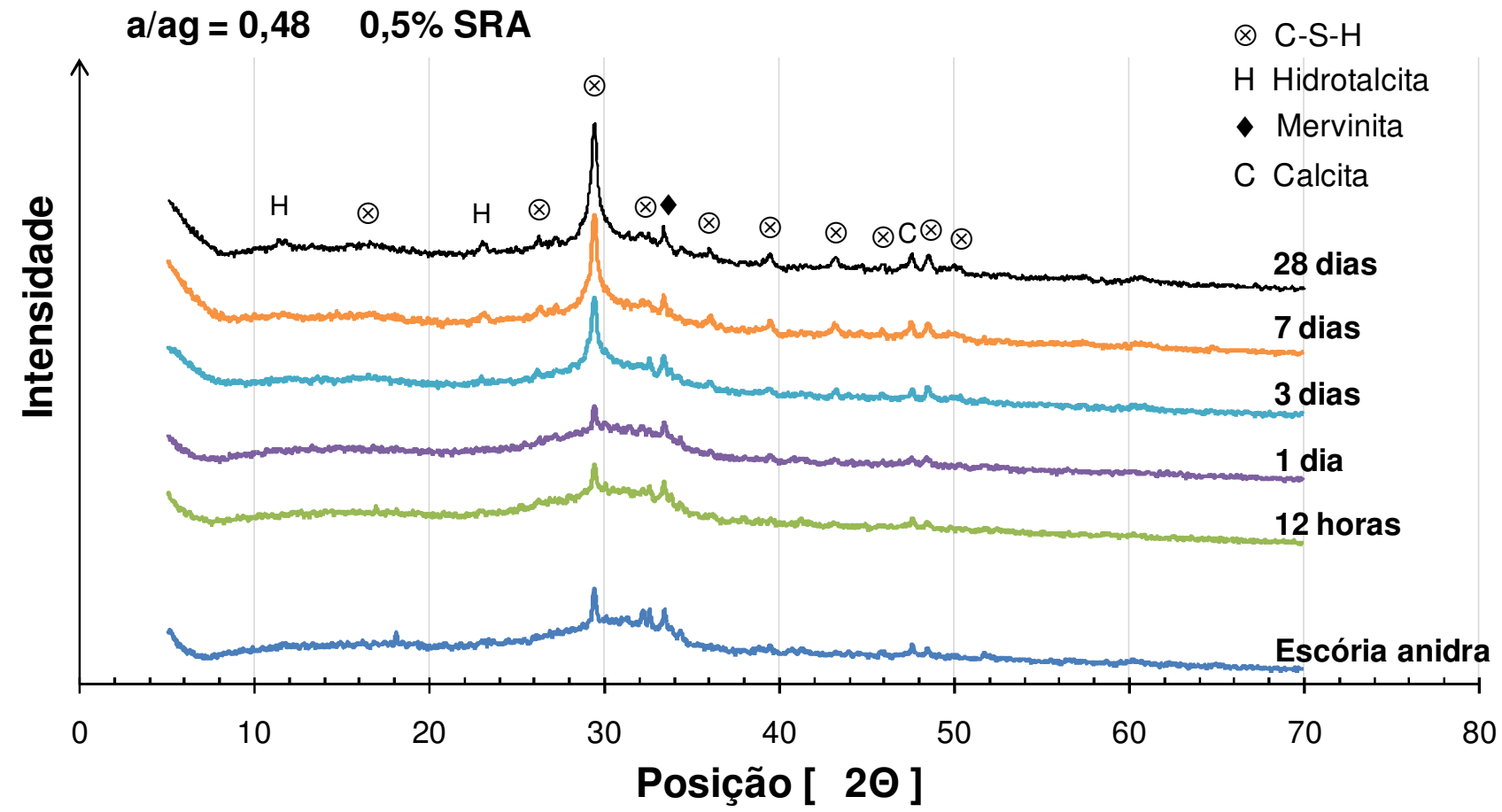

Figura C.6 - Difratogramas da pasta de cimento de escória ativada com silicato de sódio $(4 \mathrm{NSB} 0,5)$ a 12 horas, $1,3,7$ e 28 dias de idade. a/agl $=0,48$. Teor de $\mathrm{SRA}=0,5 \%$. 


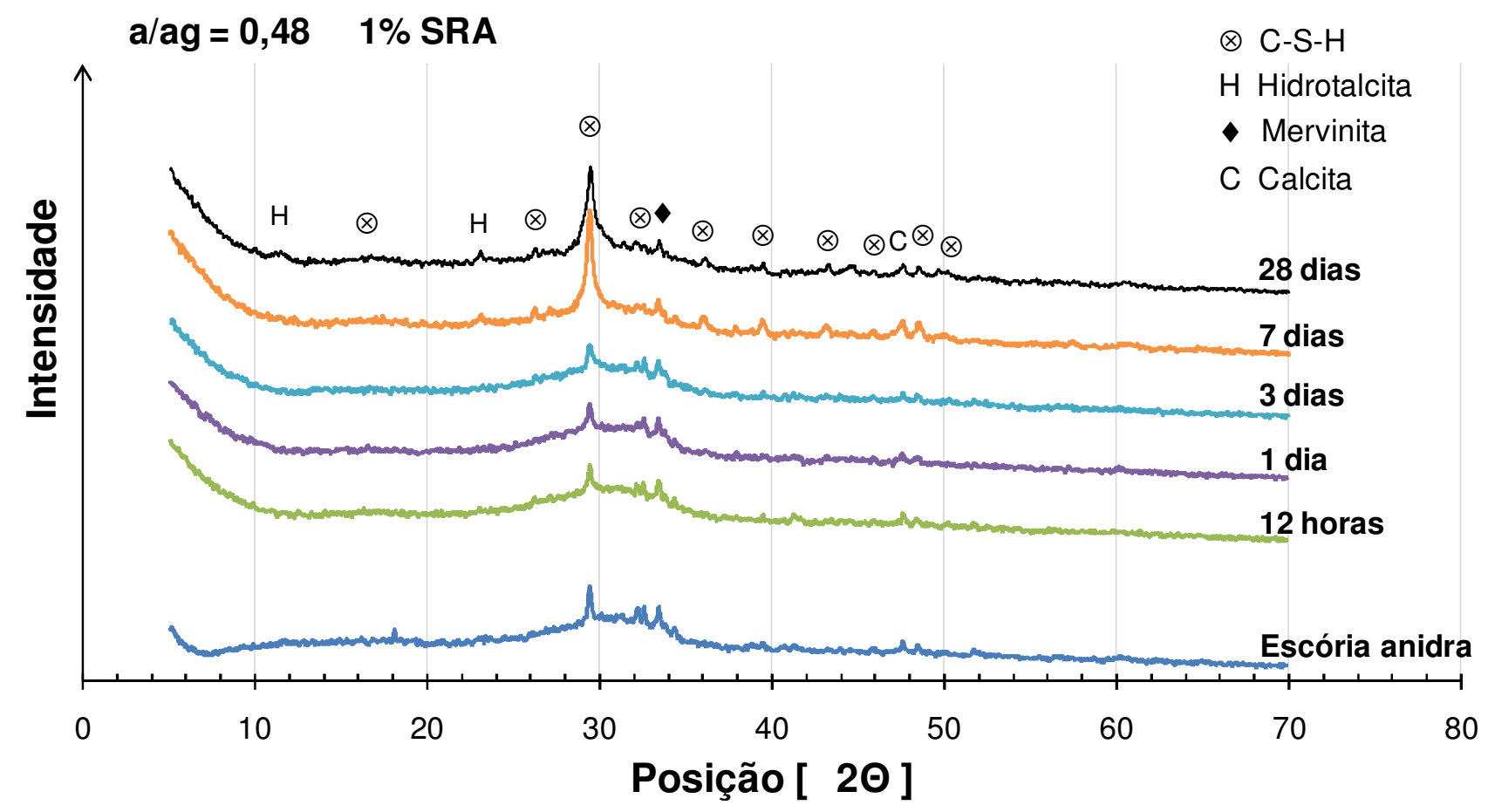

Figura C.7 - Difratogramas da pasta de cimento de escória ativada com silicato de sódio (4NSB1) a 12 horas, $1,3,7$ e 28 dias de idade. a/agl= 0,48 . Teor de $S R A=1 \%$.

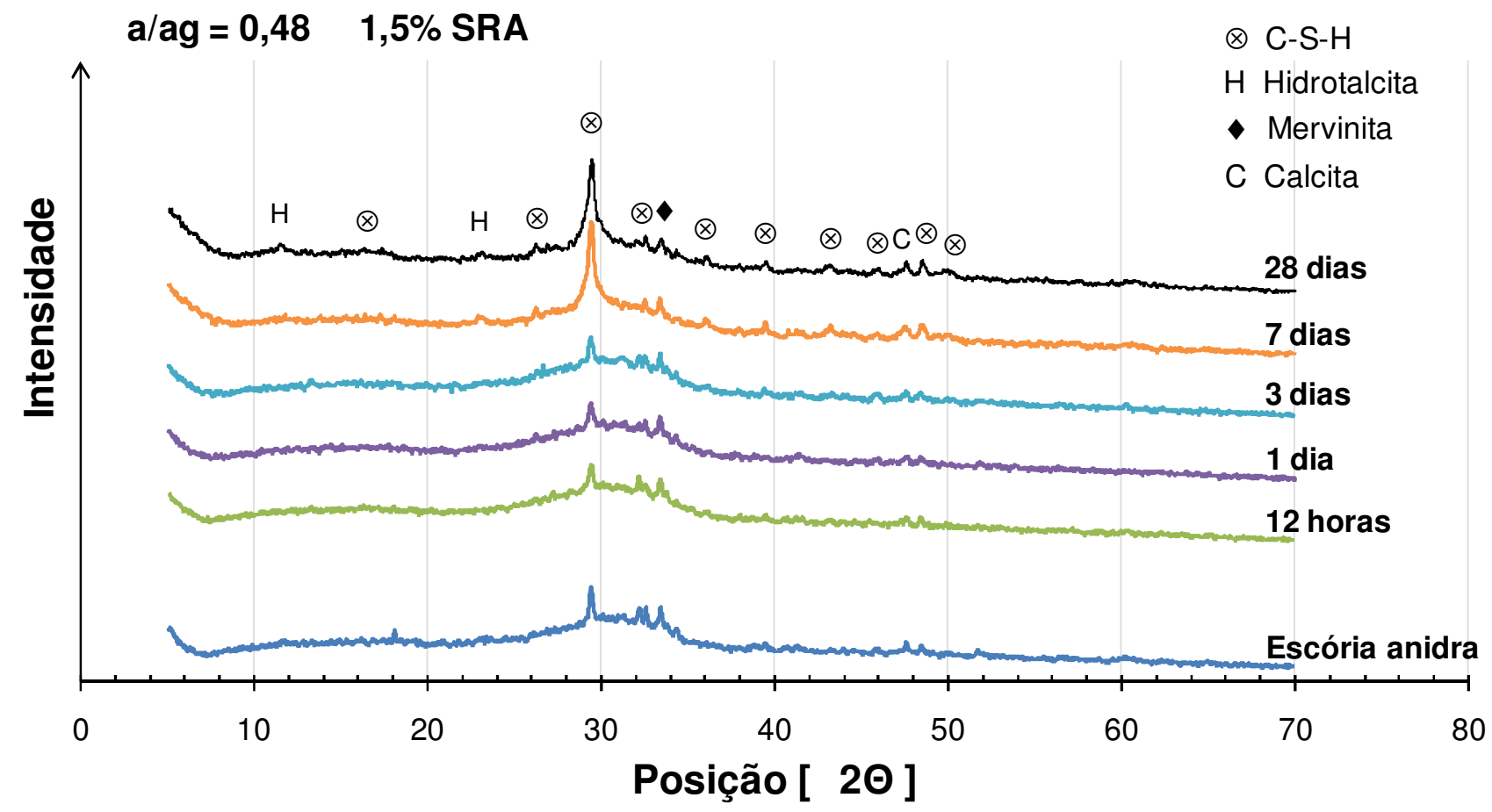

Figura C.8 - Difratogramas da pasta de cimento de escória ativada com silicato de sódio (4NSB1,5) a 6 e 12 horas, $1,3,7$ e 28 dias de idade. a/agl= 0,48. Teor de SRA $=1,5 \%$. 
Relação a/agl igual a 0,48 e utilização do aditivo compensador de retração (SCA).

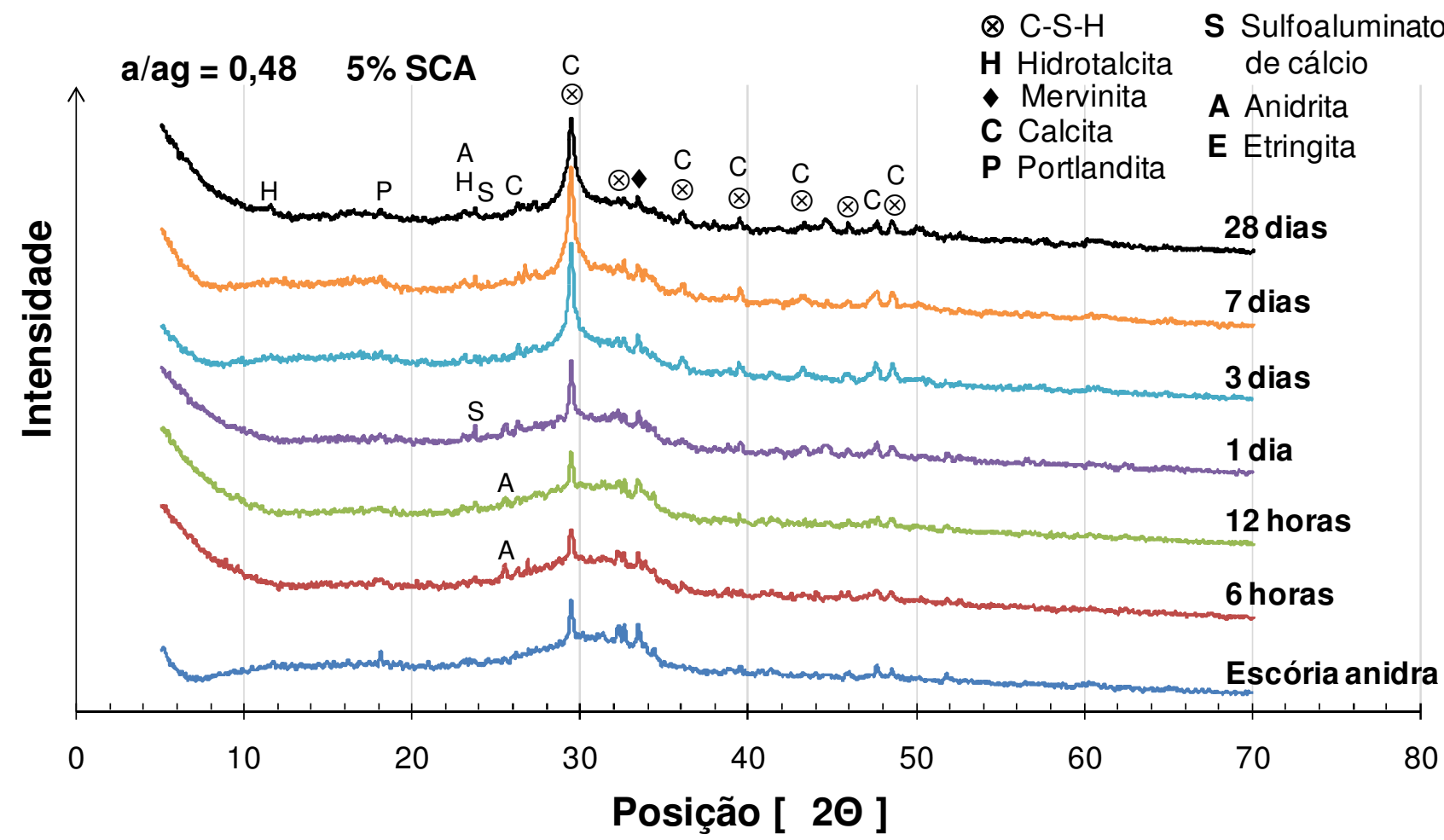

Figura C.9 - Difratogramas da pasta de cimento de escória ativada com silicato de sódio (4NSB5) a 6 e 12 horas, $1,3,7$ e 28 dias de idade. $a / a g l=0,48$. Teor de SCA $=5 \%$.

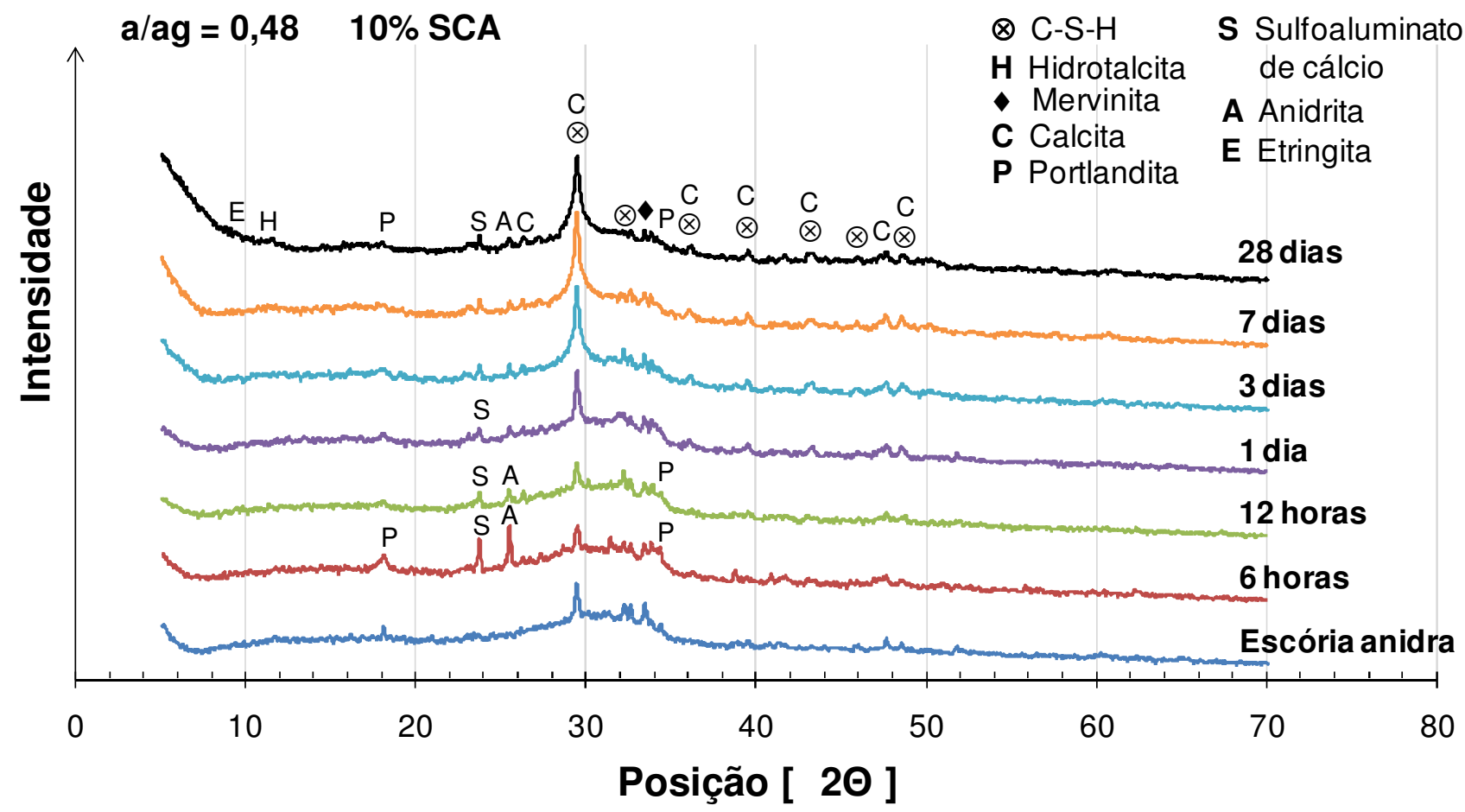

Figura C.10 - Difratogramas da pasta de cimento de escória ativada com silicato de sódio (4NSB10) a 6 e 12 horas, $1,3,7$ e 28 dias de idade. $\mathrm{a} / \mathrm{agl}=0,48$. Teor de SCA $=10 \%$. 


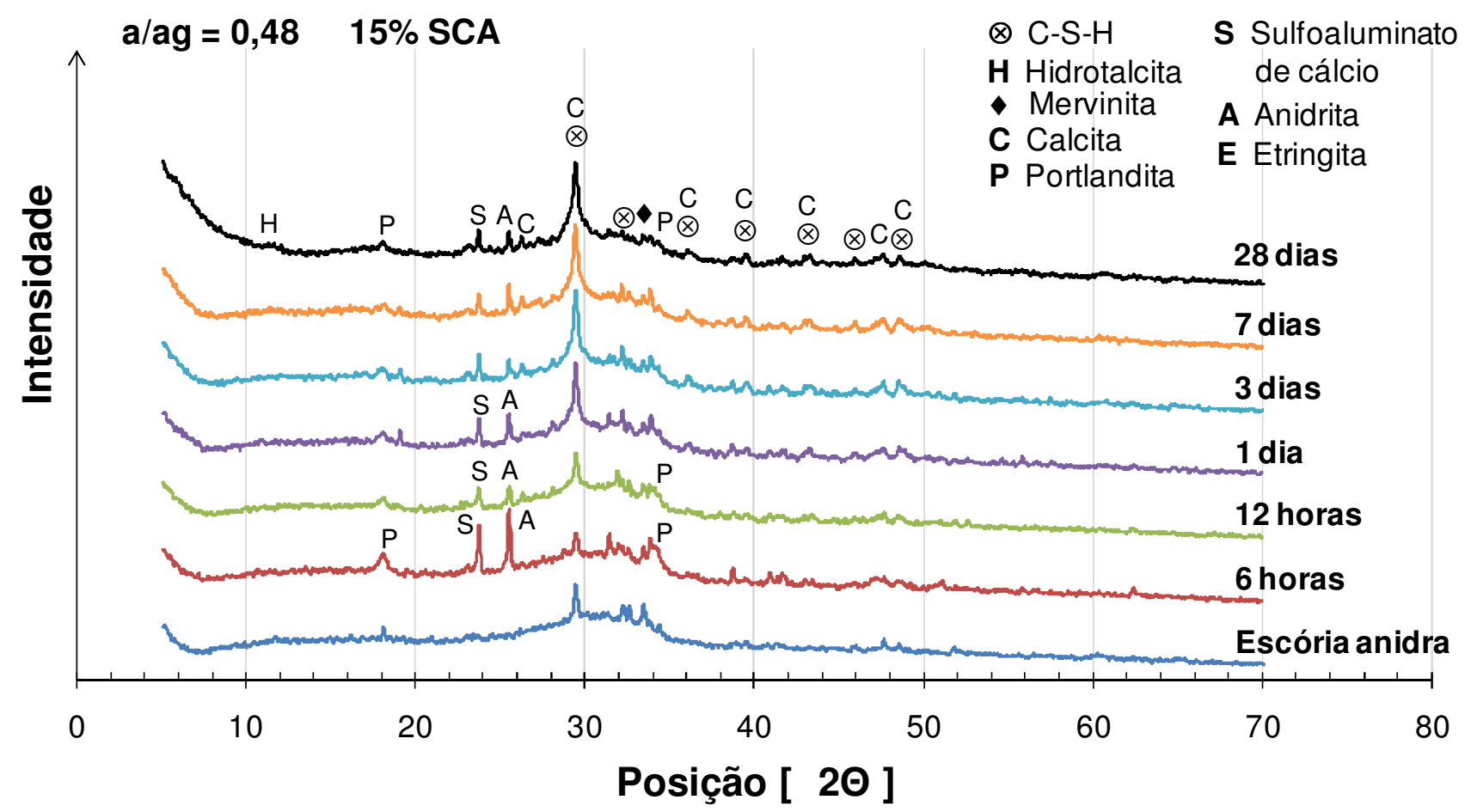

Figura C.11 - Difratogramas da pasta de cimento de escória ativada com silicato de sódio (4NSB15) a 6 e 12 horas, $1,3,7$ e 28 dias de idade. $\mathrm{a} / \mathrm{agl}=0,48$. Teor de SCA $=15 \%$.

\section{Relação a/agl igual a 0,56 e utilização do aditivo compensador de retração (SCA)}

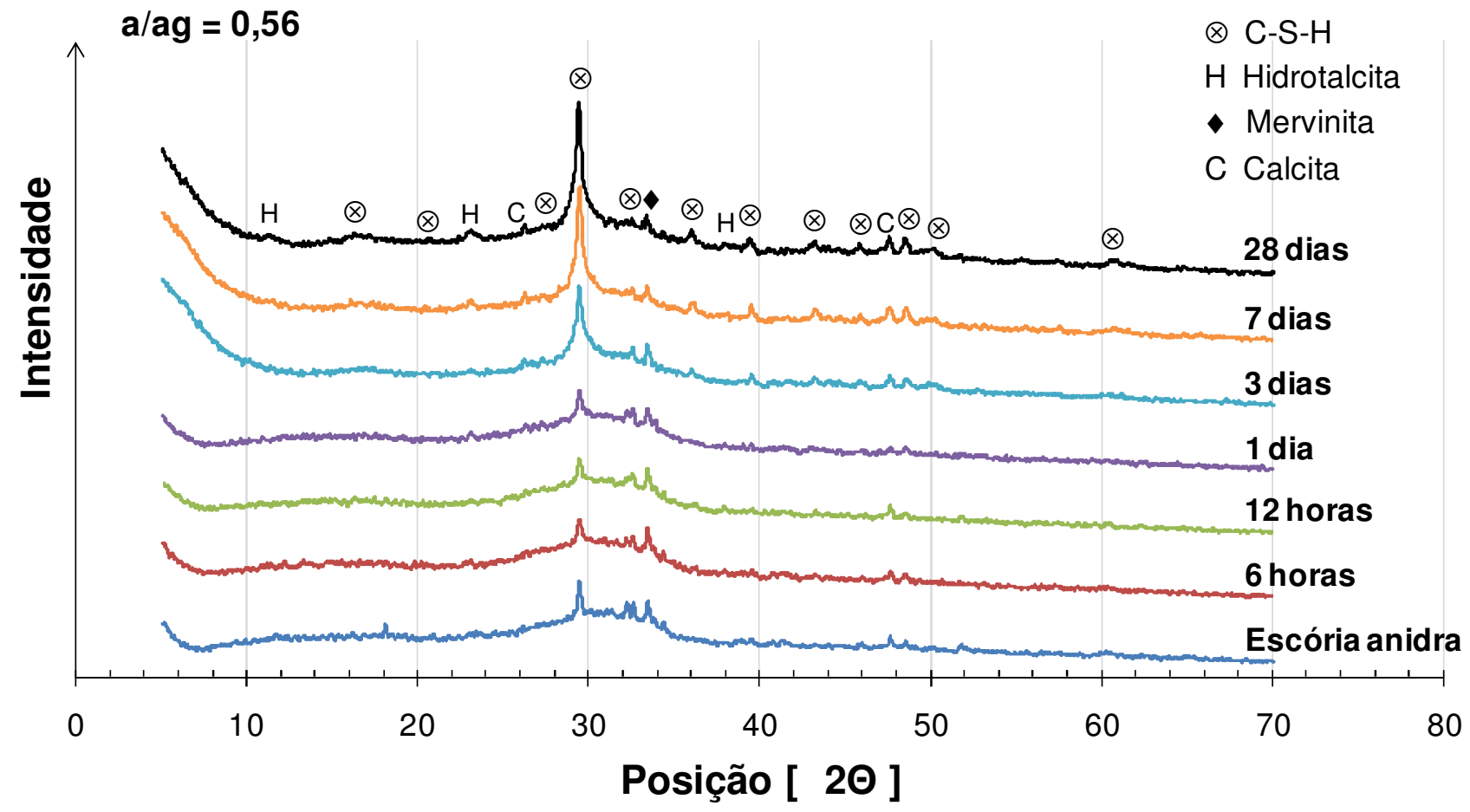

Figura C.12 - Difratogramas da pasta de cimento de escória ativada com silicato de sódio (4NSC0) a 6 e 12 horas, $1,3,7$ e 28 dias de idade. a/agl= 0,56. 


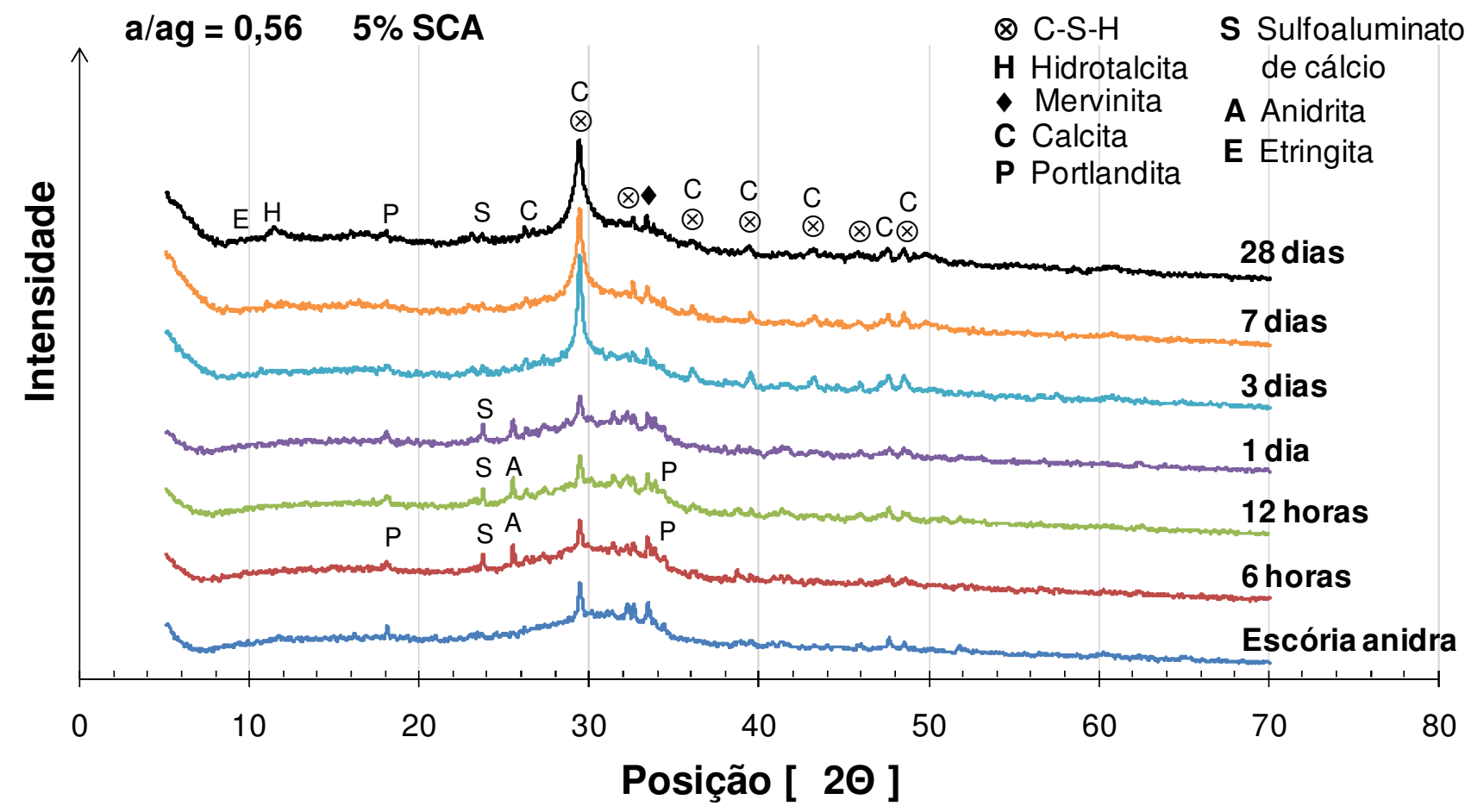

Figura C.13 - Difratogramas da pasta de cimento de escória ativada com silicato de sódio (4NSC5) a 6 e 12 horas, $1,3,7$ e 28 dias de idade. $a / a g l=0,56$. Teor de SCA $=5 \%$.

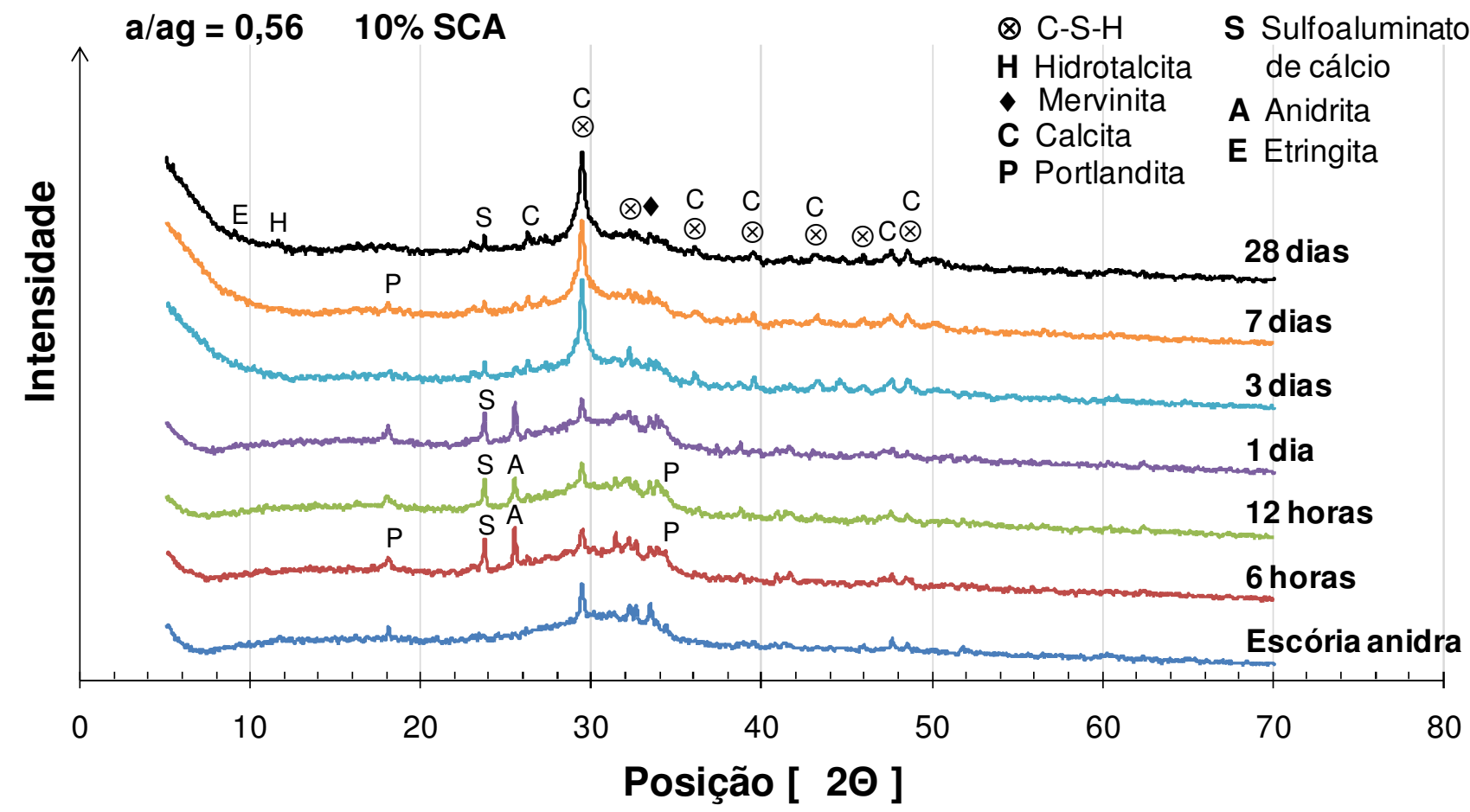

Figura C.14 - Difratogramas da pasta de cimento de escória ativada com silicato de sódio (4NSC10) a 6 e 12 horas, $1,3,7$ e 28 dias de idade. $\mathrm{a} / \mathrm{agl}=0,56$. Teor de SCA $=10 \%$. 


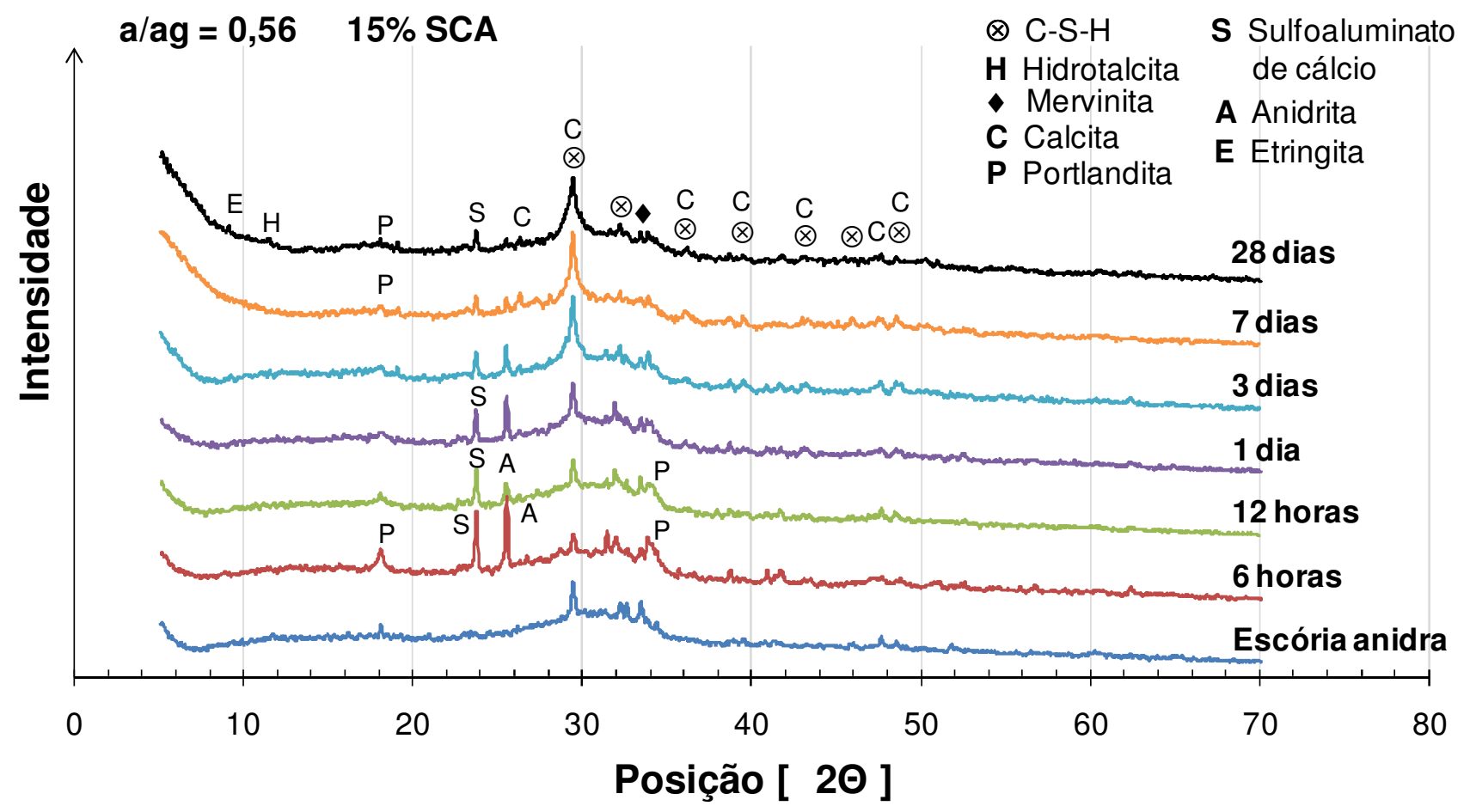

Figura C.15 - Difratogramas da pasta de cimento de escória ativada com silicato de sódio (4NSC15) a 6 e 12 horas, $1,3,7$ e 28 dias de idade. $\mathrm{a} / \mathrm{agl}=0,56$. Teor de SCA $=15 \%$.

Efeito do teor de aditivo compensador de retração (SCA) na mistura de cimento de escória com relação a/agl $=0,48$.

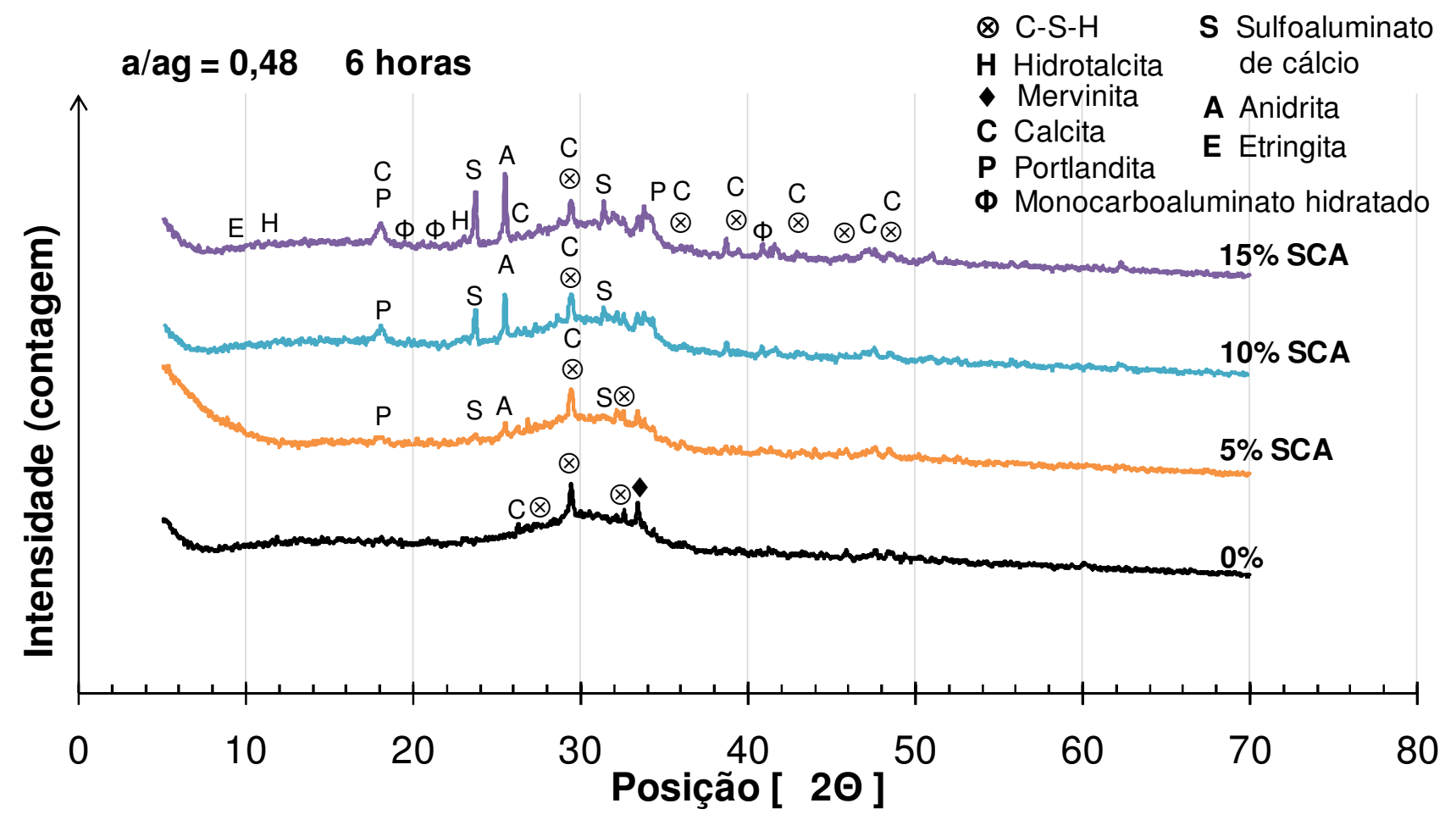

Figura C.16 - Efeito do teor de aditivo compensador de retração (SCA) na difração de raios $\mathrm{X}$ com 6 horas de idade. $\mathrm{a} / \mathrm{agl}=0,48$. 


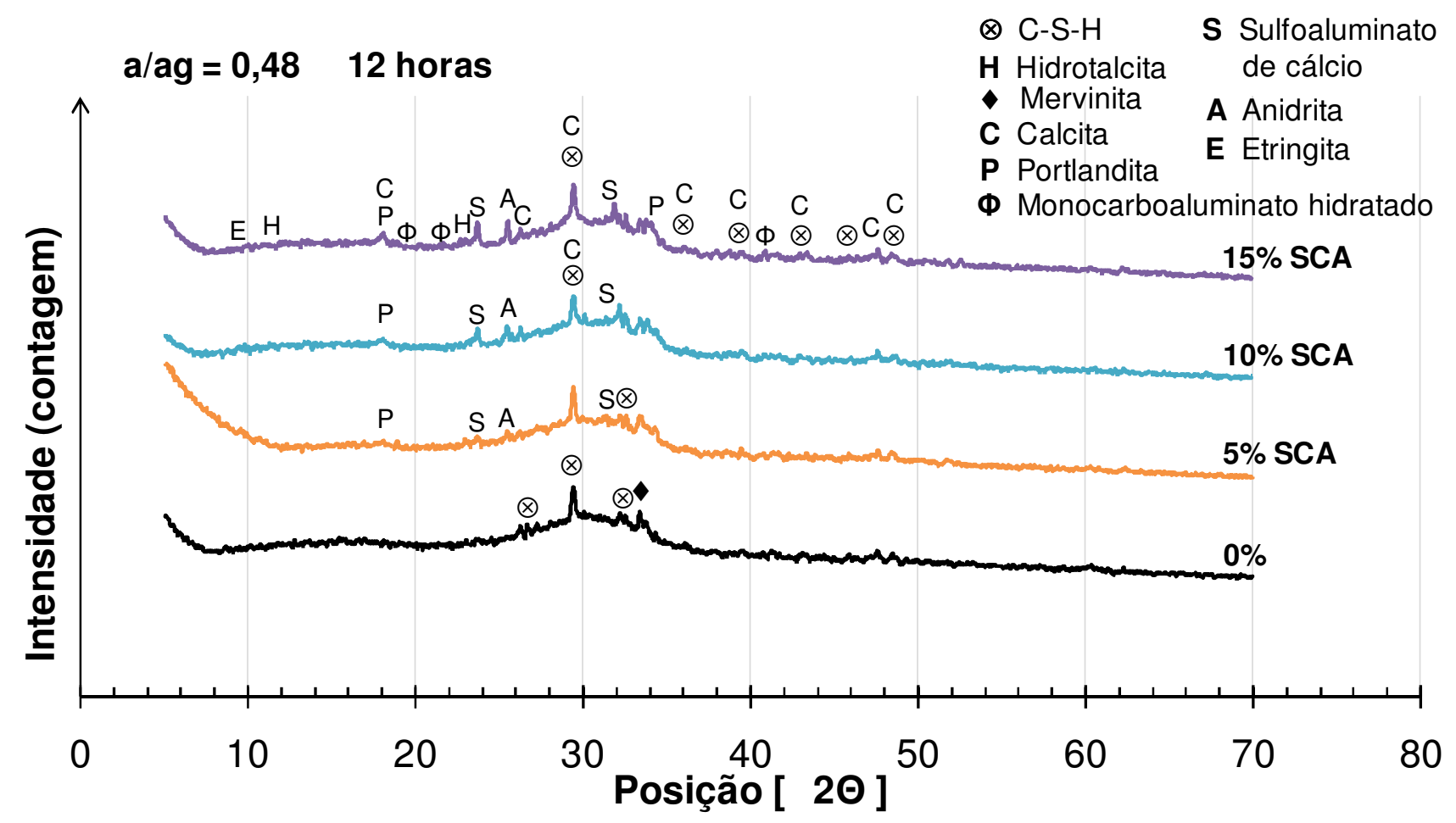

Figura C.17 - Efeito do teor de aditivo compensador de retração (SCA) na difração de raios $\mathrm{X}$ com 12 horas de idade. $\mathrm{a} / \mathrm{agl}=0,48$.

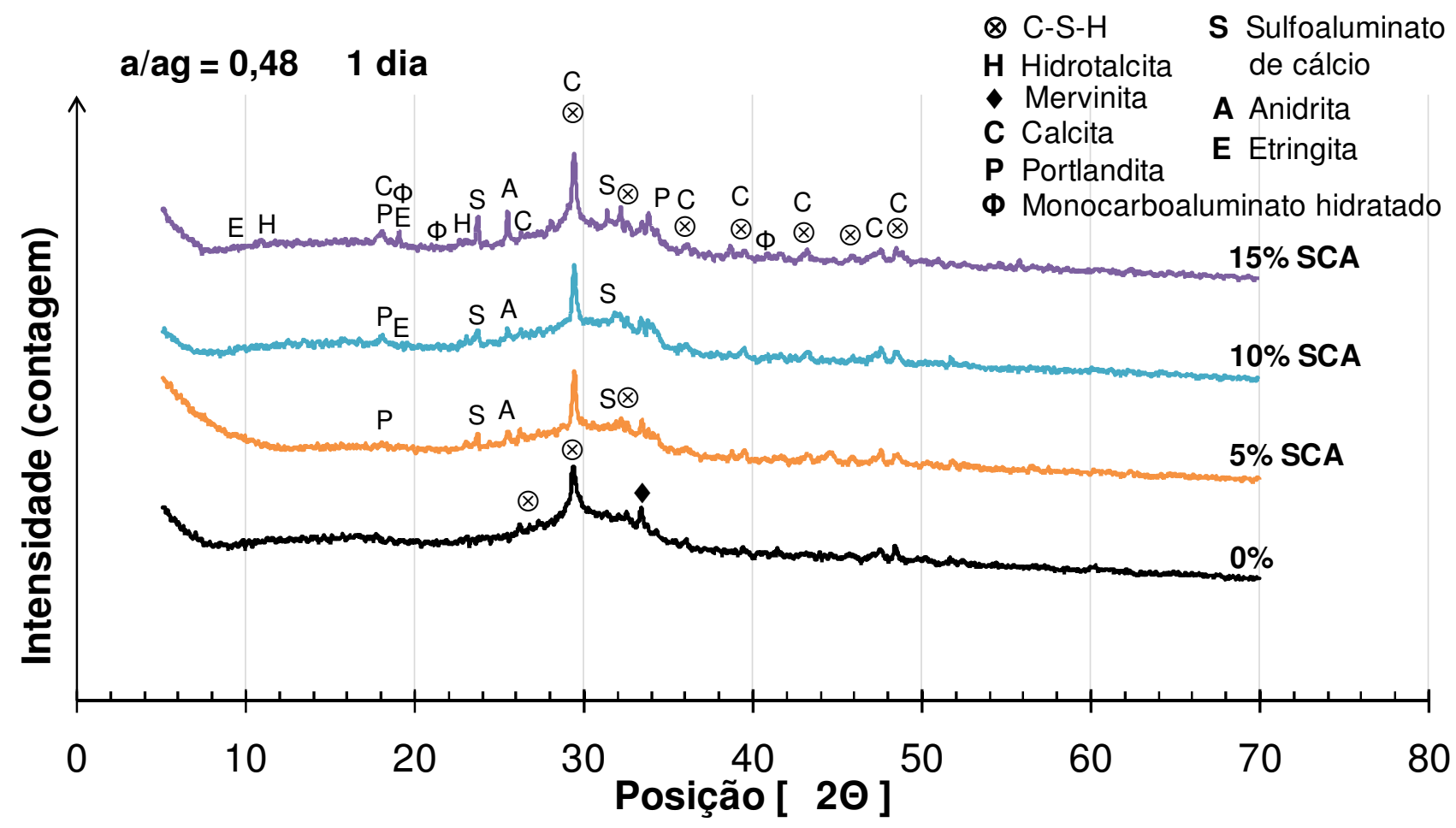

Figura C.18 - Efeito do teor de aditivo compensador de retração (SCA) na difração de raios X com 1 dia de idade. $\mathrm{a} / \mathrm{agl}=0,48$. 


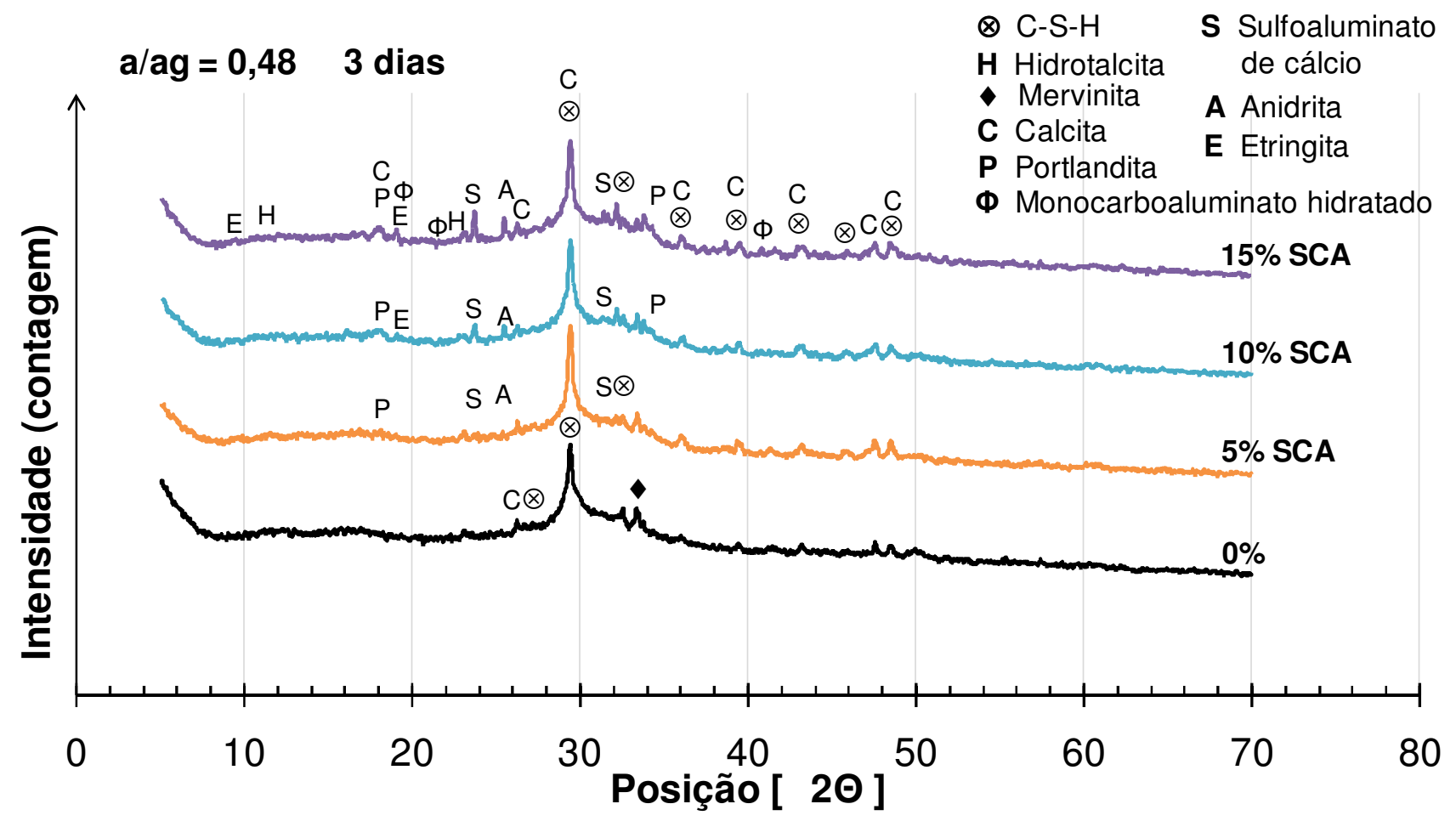

Figura C.19 - Efeito do teor de aditivo compensador de retração (SCA) na difração de raios X com 3 dias de idade. $\mathrm{a} / \mathrm{agl}=0,48$.

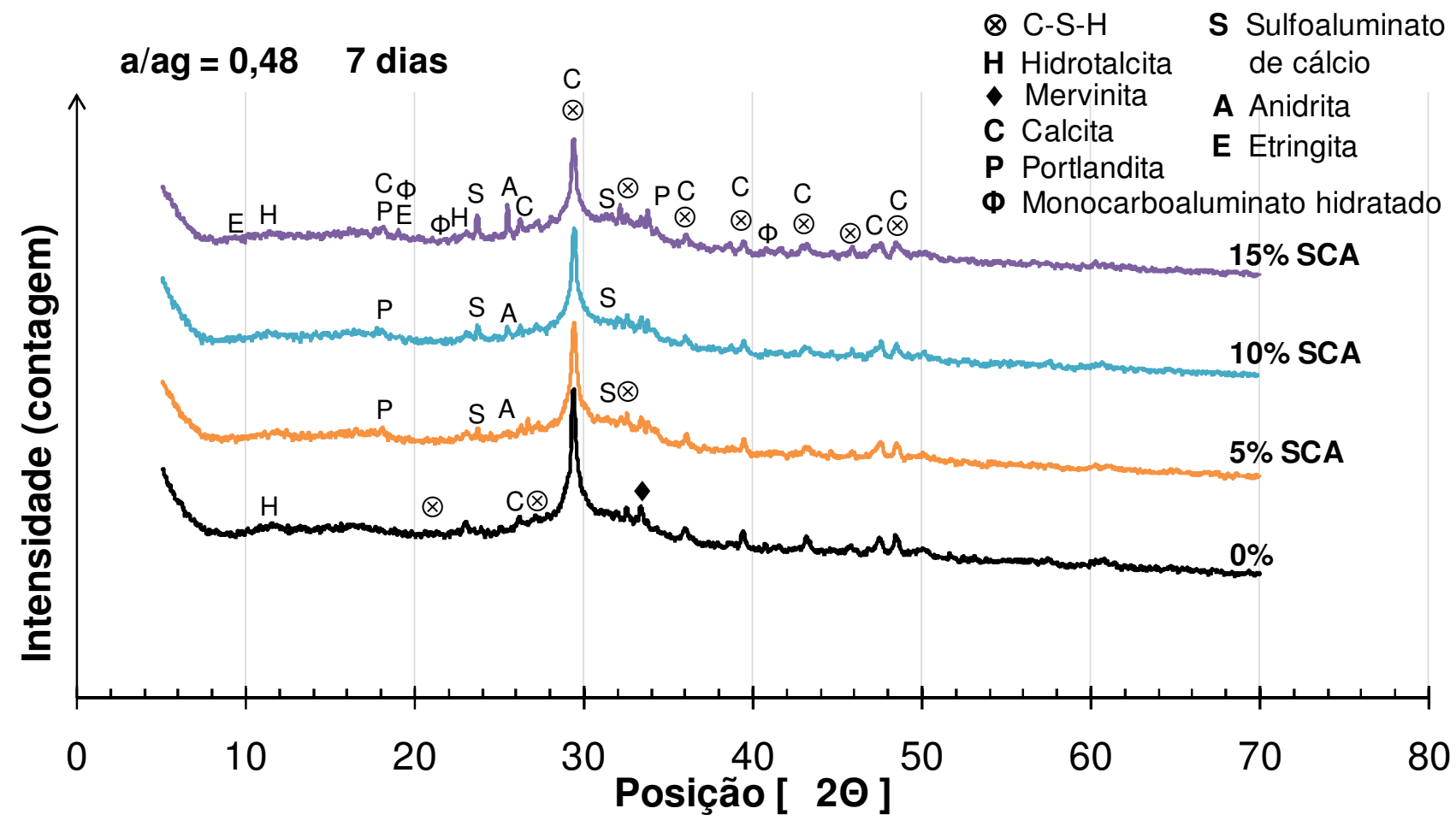

Figura C.20 - Efeito do teor de aditivo compensador de retração (SCA) na difração de raios X com 7 dias de idade. $\mathrm{a} / \mathrm{agl}=0,48$. 


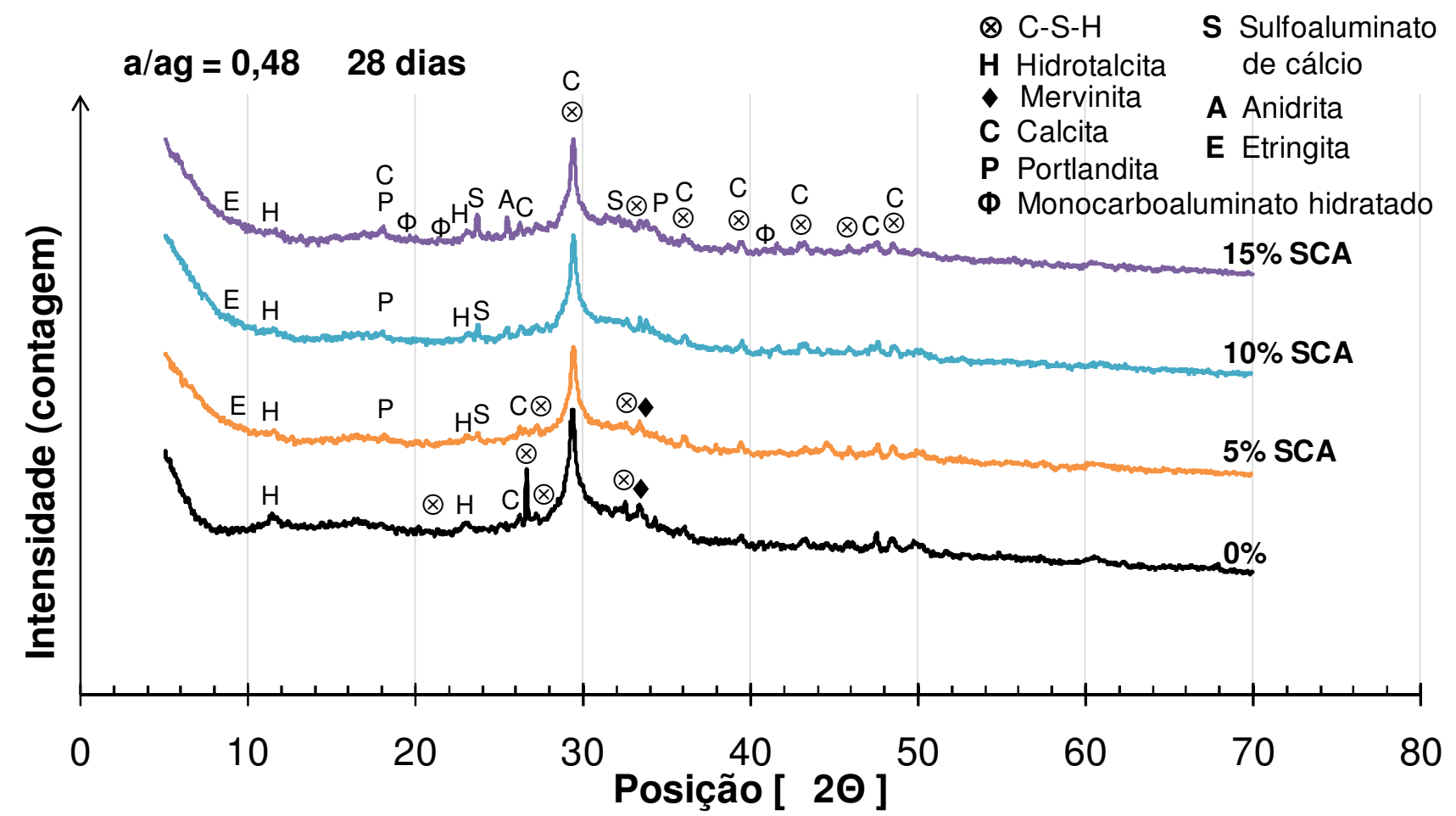

Figura C.21 - Efeito do teor de aditivo compensador de retração (SCA) na difração de raios $\mathrm{X}$ com 28 dias de idade. $\mathrm{a} / \mathrm{agl}=0,48$.

Efeito do teor de aditivo compensador de retração (SCA) na mistura de cimento de escória com relação a/agl $=0,56$.

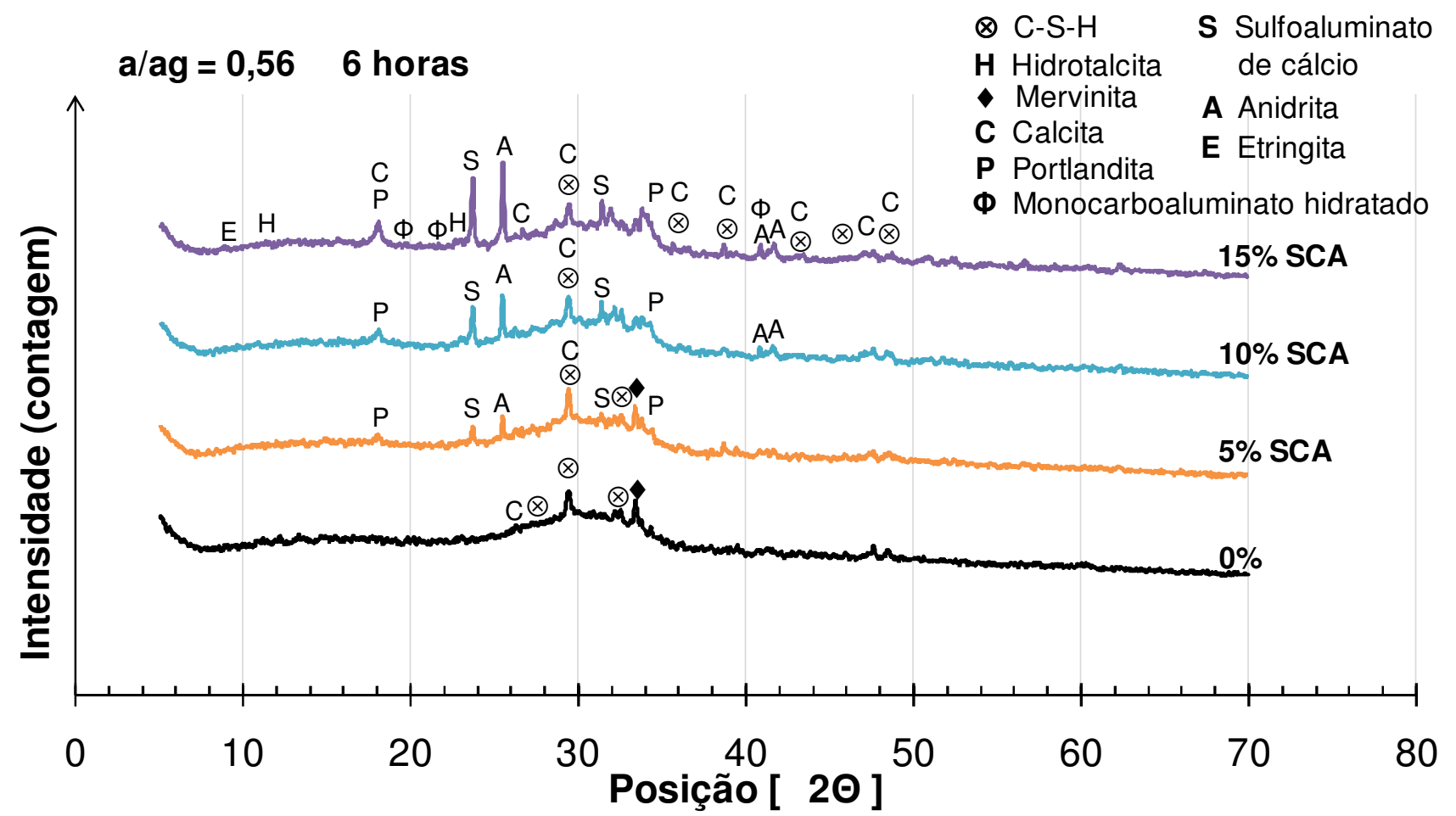

Figura C.22 - Efeito do teor de aditivo compensador de retração (SCA) na difração de raios X com 6 horas de idade. $\mathrm{a} / \mathrm{agl}=0,56$. 


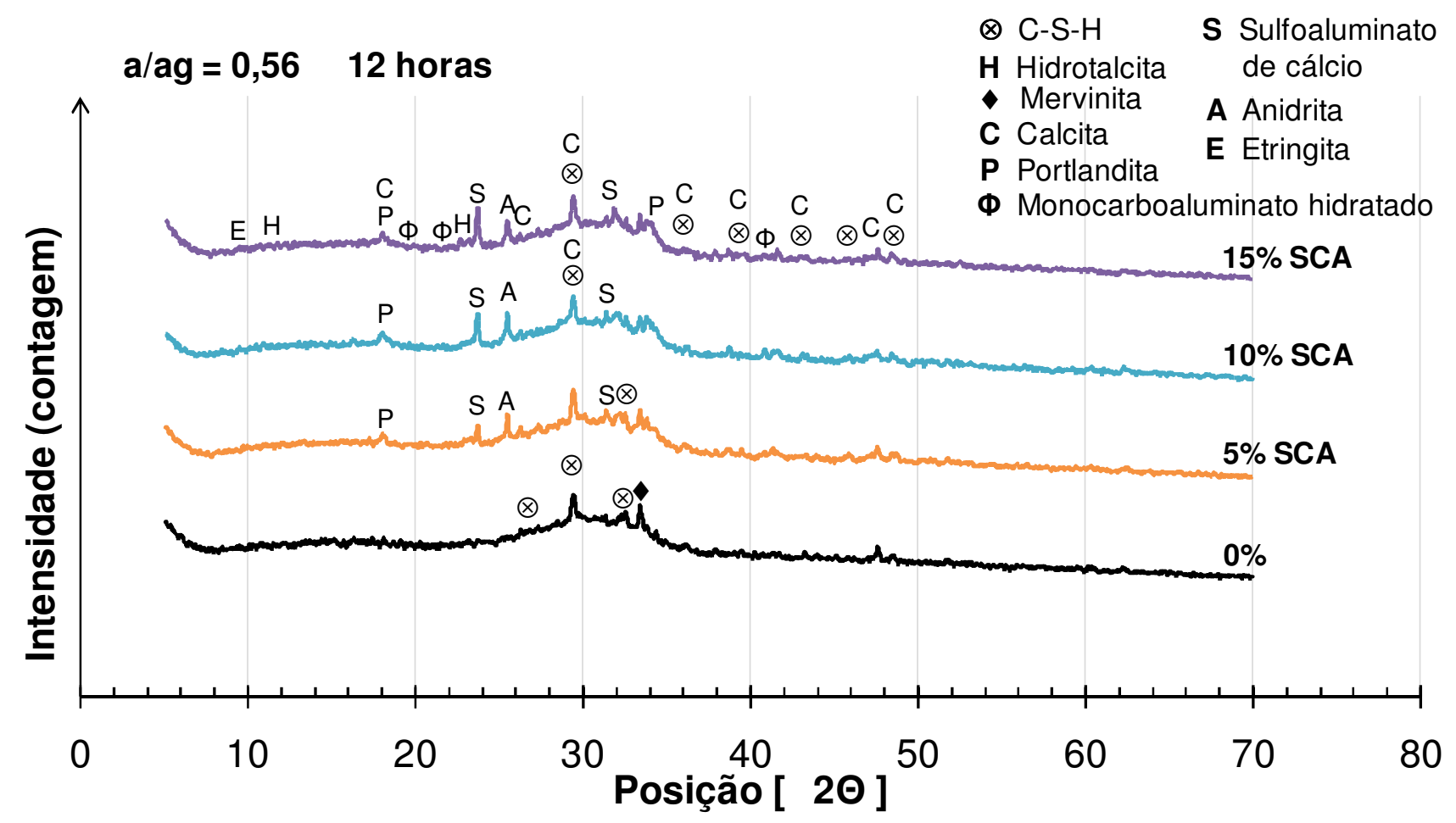

Figura C.23 - Efeito do teor de aditivo compensador de retração (SCA) na difração de raios $\mathrm{X}$ com 12 horas de idade. $\mathrm{a} / \mathrm{agl}=0,56$.

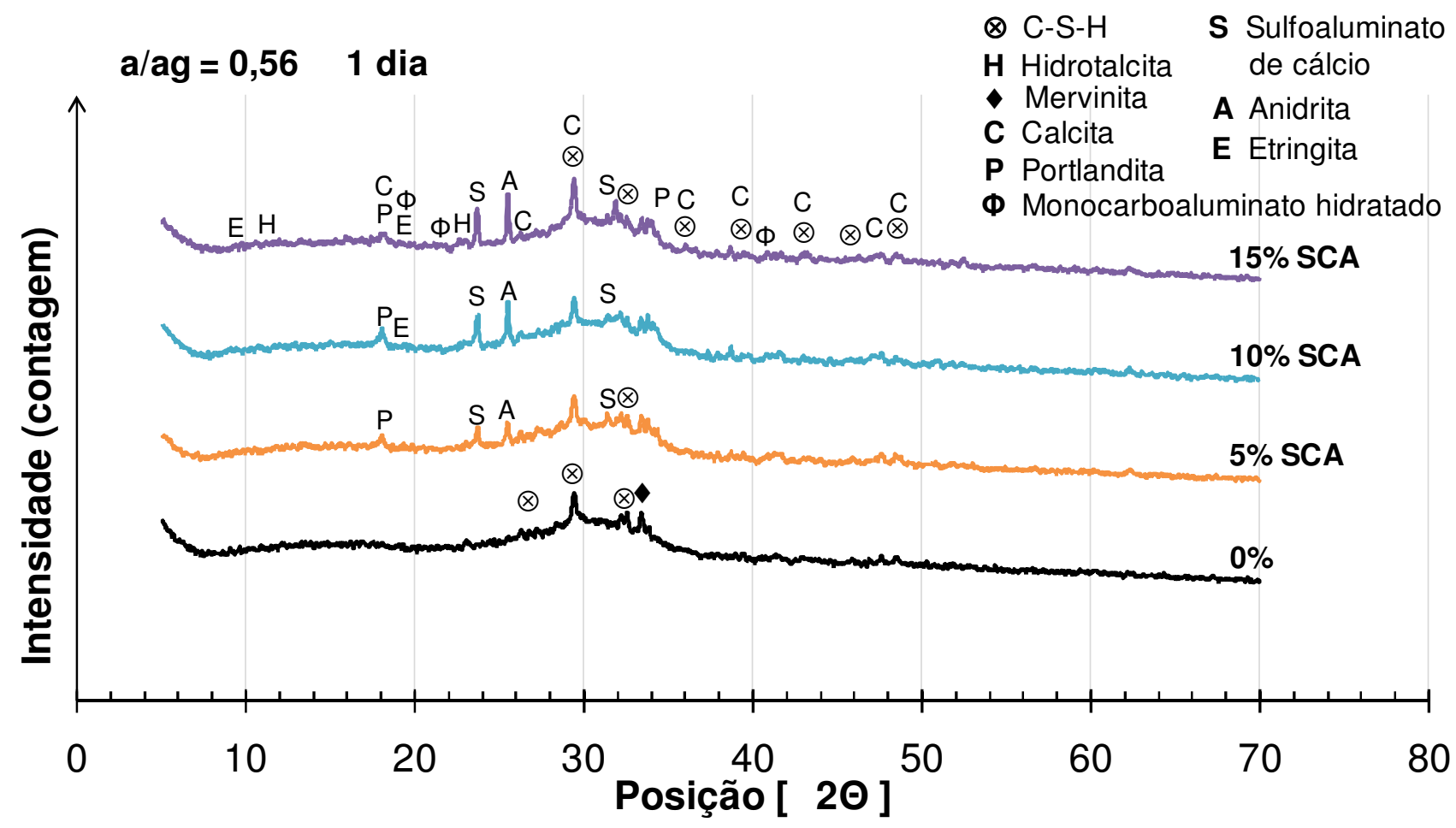

Figura C.24 - Efeito do teor de aditivo compensador de retração (SCA) na difração de raios X com 1 dia de idade. $\mathrm{a} / \mathrm{agl}=0,56$. 


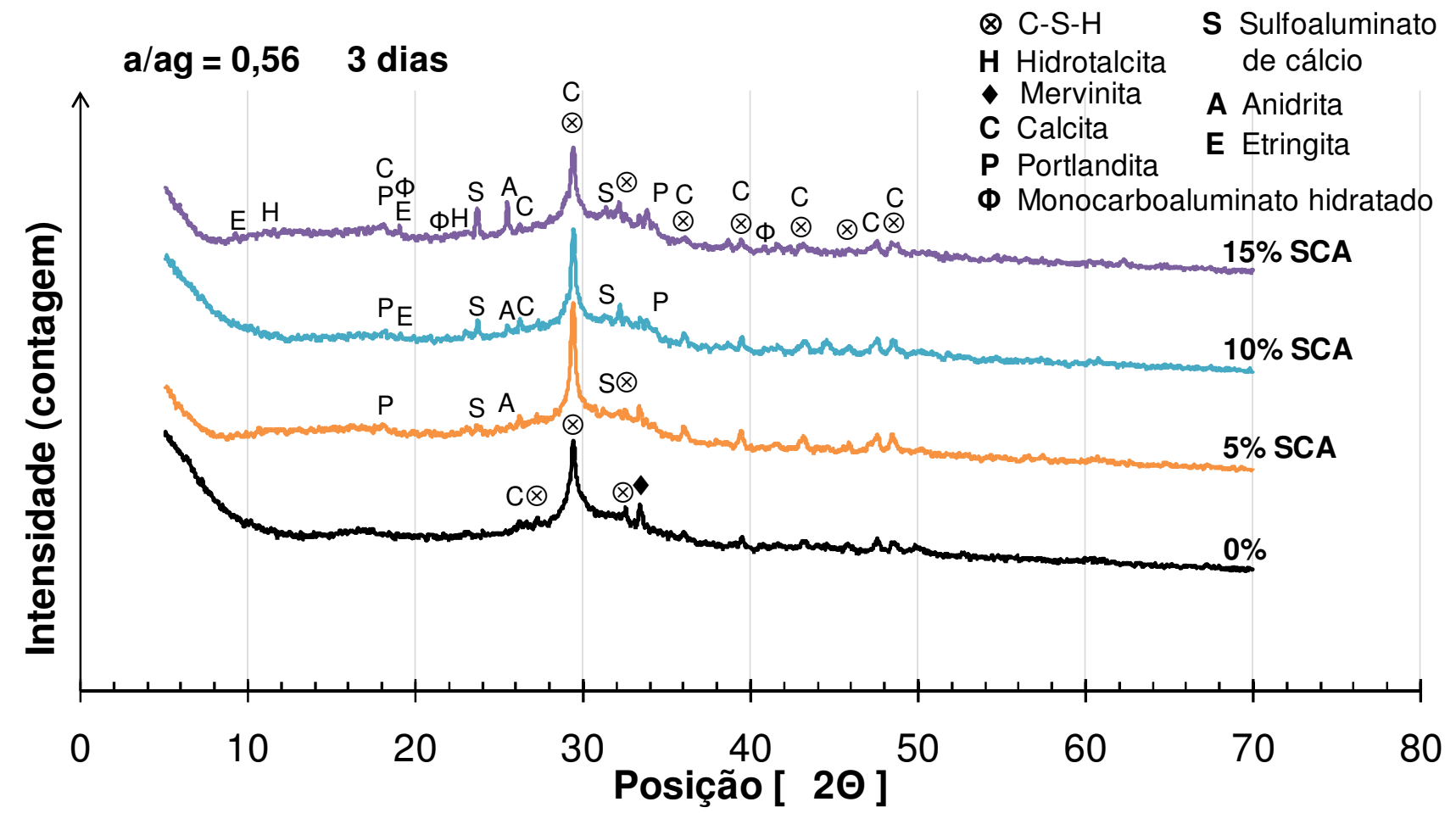

Figura C.25 - Efeito do teor de aditivo compensador de retração (SCA) na difração de raios X com 3 dias de idade. $\mathrm{a} / \mathrm{agl}=0,56$.

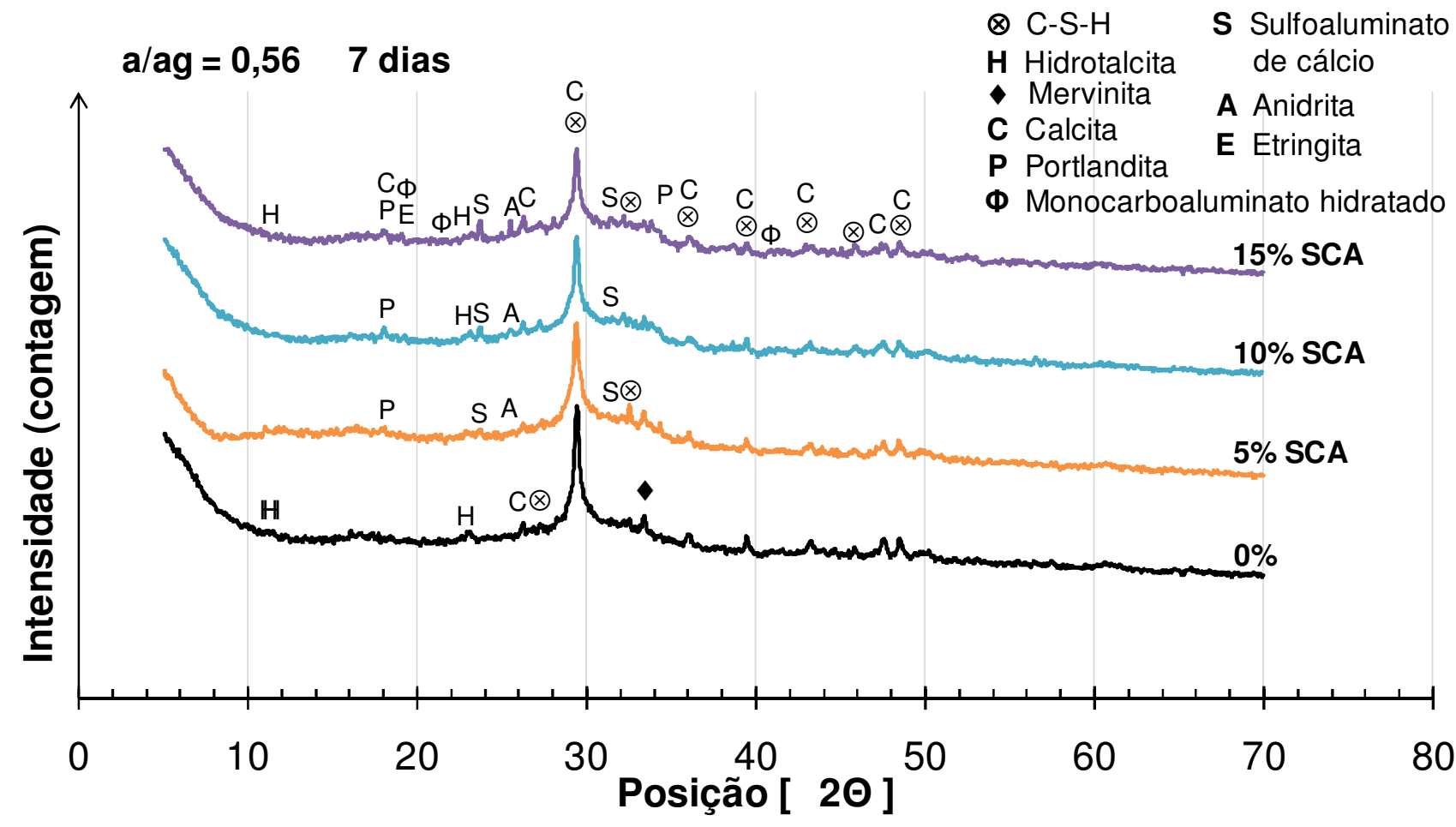

Figura C.26 - Efeito do teor de aditivo compensador de retração (SCA) na difração de raios X com 7 dias de idade. $\mathrm{a} / \mathrm{agl}=0,56$. 


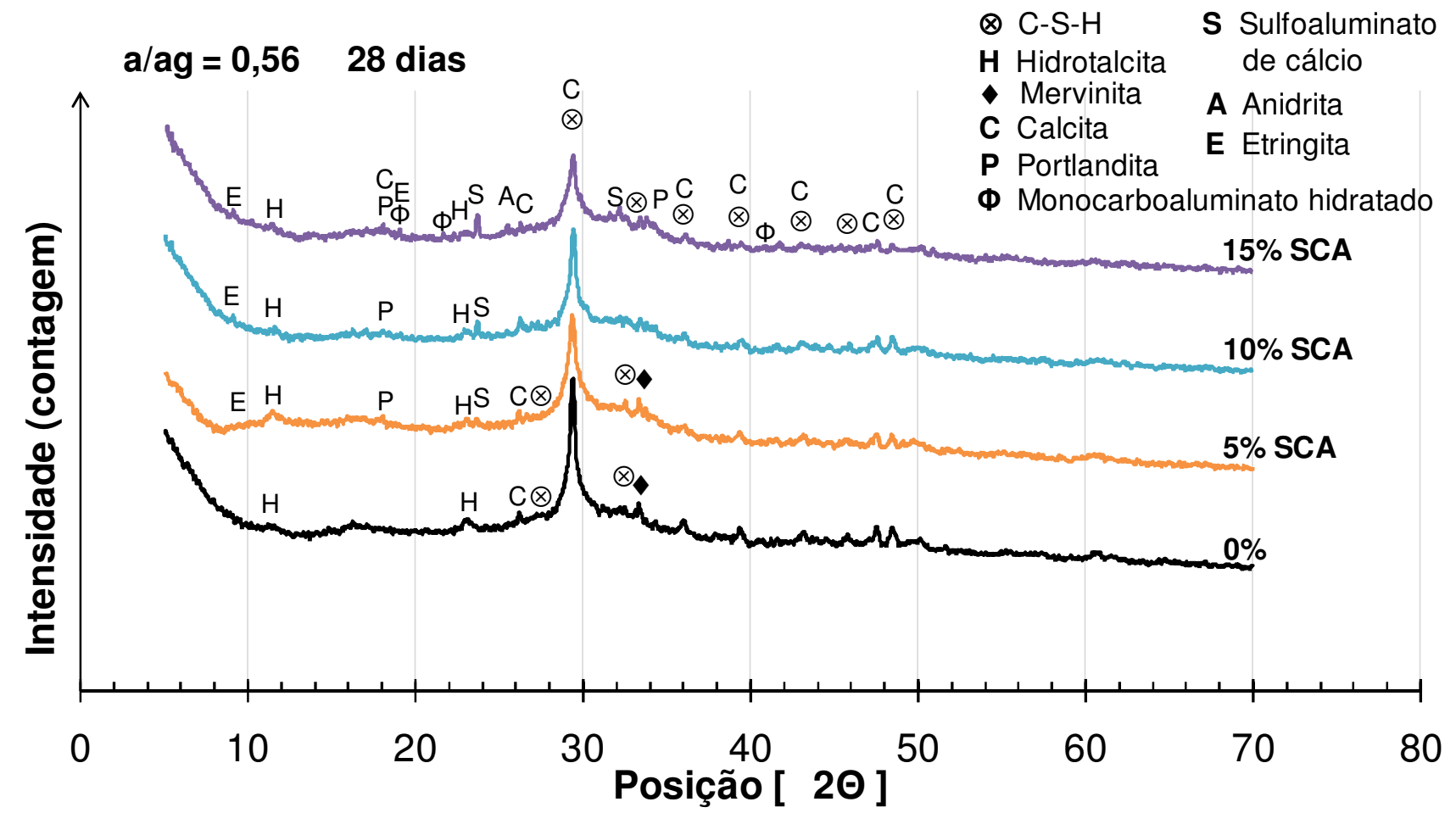

Figura C.27 - Efeito do teor de aditivo compensador de retração (SCA) na difração de raios $\mathrm{X}$ com 28 dias de idade. $\mathrm{a} / \mathrm{agl}=0,56$.

Pasta utilizando apenas o aditivo compensador de retração (SCA) puro.

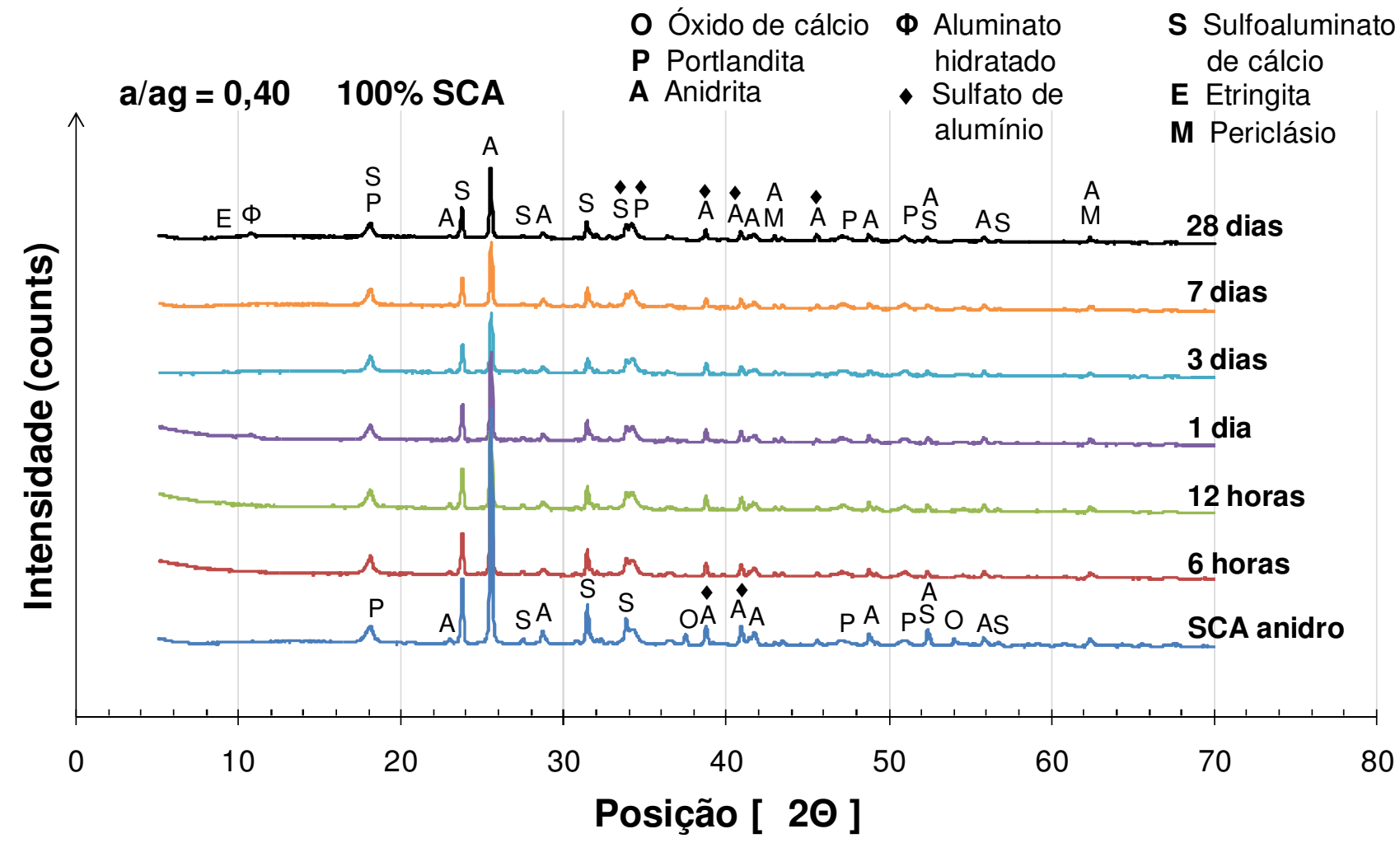

Figura C.28 - Difratogramas da pasta utilizando apenas o aditivo compensador de retração (SCAA) a 6 e 12 horas, $1,3,7$ e 28 dias de idade. a/agl= 0,40. Teor de SCA $=100 \%$. 


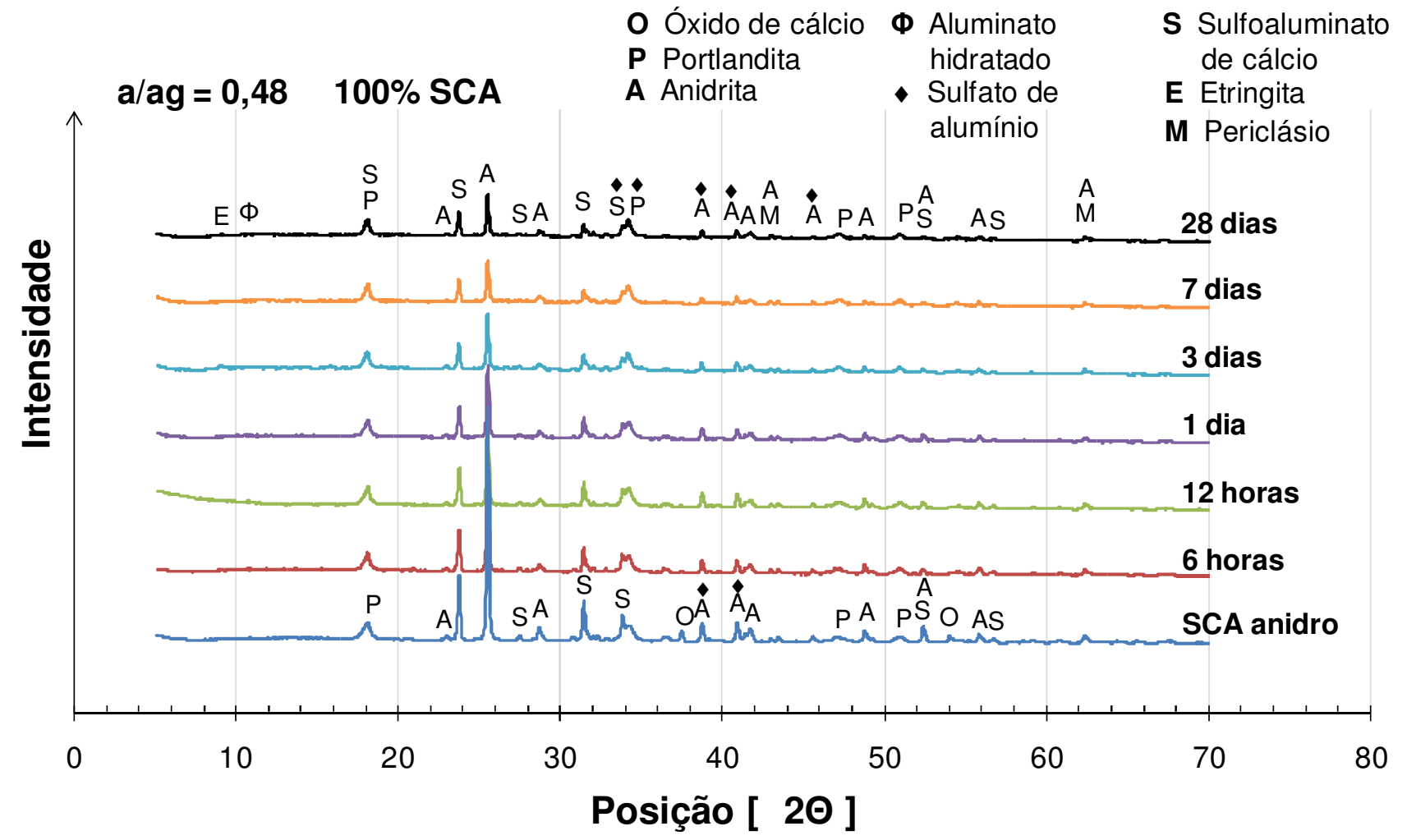

Figura C.29 - Difratogramas da pasta utilizando apenas o aditivo compensador de retração (SCAB) a 6 e 12 horas, $1,3,7$ e 28 dias de idade. a/agl=0,48. Teor de SCA $=100 \%$.

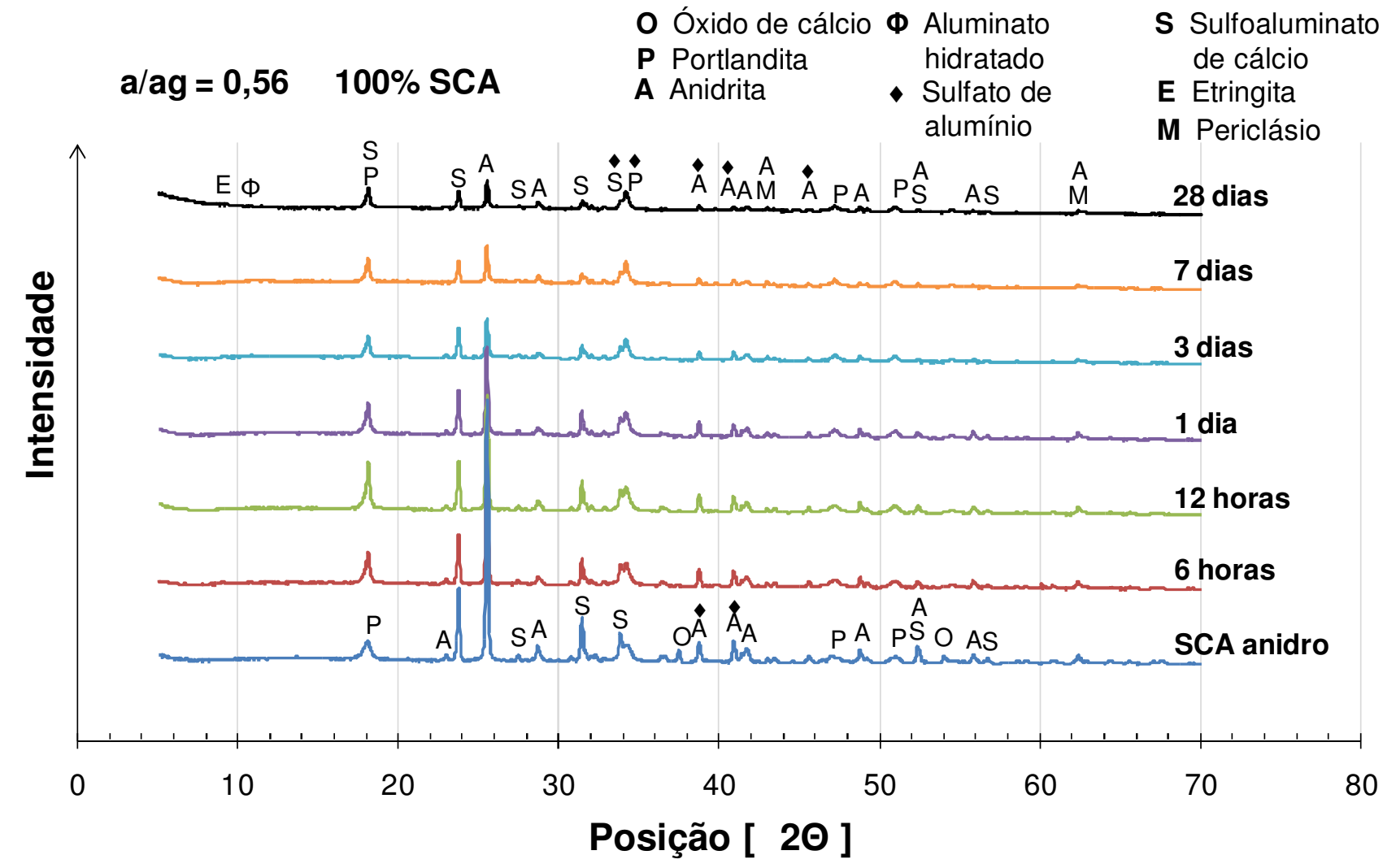

Figura C.30 - Difratogramas da pasta utilizando apenas o aditivo compensador de retração (SCAC) a 6 e 12 horas, $1,3,7$ e 28 dias de idade. a/agl=0,56. Teor de SCA $=100 \%$. 


\section{Apêndice D - Equipamento de retração restringida}

Neste apêndice constam o levantamento bibliográfico e todo processo de desenvolvimento de um equipamento para avaliar a retração restringida. Originalmente, este equipamento seria incluído na tese, porém fatores diversos não possibilitaram a concretização deste objetivo. A divulgação do método e do equipamento na tese, mesmo que em anexo, é considerada como importante por se tratar do primeiro equipamento do gênero em desenvolvimento na America Latina que se tem conhecimento.

\section{D.1 - Levantamento bibliográfico}

\section{D.1.1 - Métodos de determinação da retração restringida}

A mensuração das tensões devido à restrição da retração em concretos é critica na determinação da sua susceptibilidade à fissuração nas primeiras idades. Apresenta como dificuldade a manutenção e a garantia de uma restrição total. Atualmente, ainda são utilizados métodos ditos "passivos" para o estudo da tendência, como o anel de restrição (conhecido também como anel de Coutinho) e quadros passivos, exemplificados na Figura D.1 e na Figura D.2, respectivamente. Por isso mesmo, observa-se uma tendência para a quantificação das tensões associadas à restrição da retração com a utilização de quadros de ensaio uniaxial capazes de simular um estado de restrição total com métodos ditos "ativos". Estes sistemas permitem a determinação do acumulo de tensões e a relaxação por fluência em uma condição restringida.
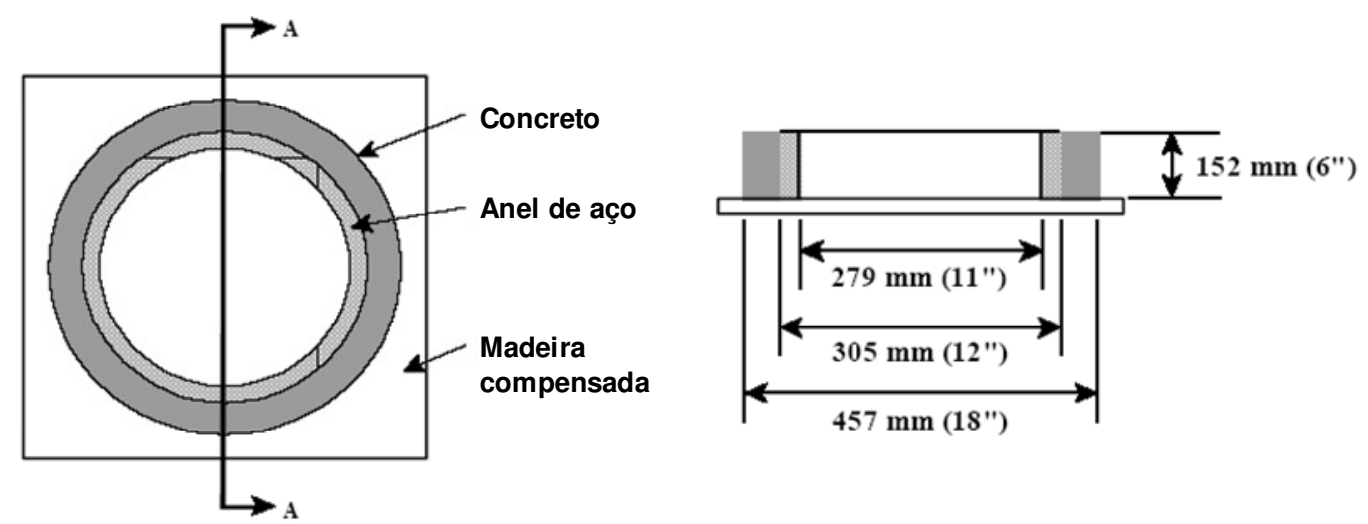

Figura D.1 - Exemplo de um sistema de medida passiva com anel de restrição das tensões oriundas da retração restringida (MOKAREM; 2002). 


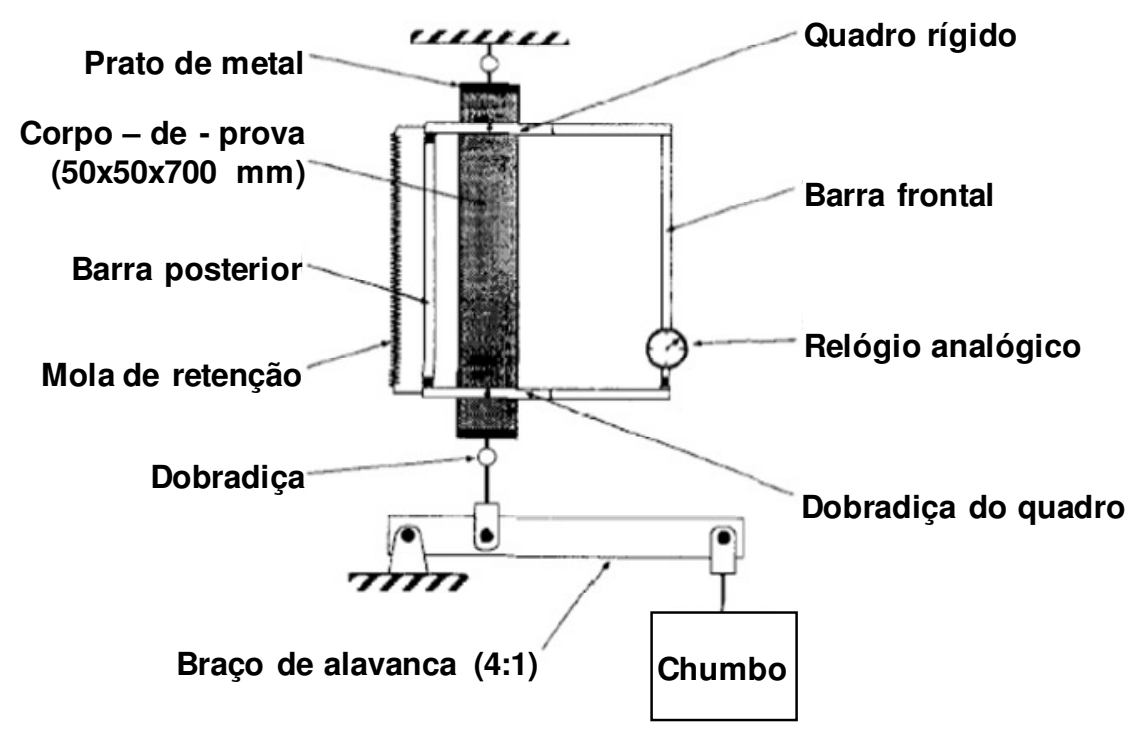

Figura D.2 - Figura D.2 - Exemplo de um sistema de medida passiva das tensões oriundas da retração restringida (BISSONNETTE, PIGEON; 1995).

\section{D.1.1.1 - Princípios do método}

Usualmente, pensa-se na fluência como a deformação lenta que ocorre em razão da aplicação de uma carga constante; porém a maioria das pesquisas realizadas sobre a fluência aborda apenas métodos de determinação para o estado de compressão. No caso da retração restringida, também ocorrerá a fluência, mas no estado de tração, sendo a tensão denominada de "fluência por tração" (tensile creep). Métodos convencionais foram utilizados para determinar a fluência por tração utilizando cargas constantes, como o desenvolvido por Bissonnette e Pigeon (1995) apresentado na Figura D.2, porém neste sistema não foi possível garantir a restrição total.

Segundo Bentur e Kovler (2003), o desenvolvimento de tensões em ensaios realizados em equipamentos passivos é função da relação entre a rigidez do concreto e do aparato de restrição. Este tipo de equipamento possibilita a obtenção de resultados importantes, porém, sabe-se que o concreto tem suas características físicas em constante mudança com o avanço da hidratação e que, sob restrição, a fluência e a relaxação do mesmo ocorrem simultaneamente. Este comportamento faz com que os resultados obtidos não expressem com exatidão suficiente o fenômeno (BENTUR; KOVLER, 2003), uma vez que o grau de restrição varia com o tempo, impossibilitando a mensuração acurada das tensões oriundas da retração restringida (MIHASHI; LEITE, 2004). 
Assim, com o intento de obter resultados consistentes foram desenvolvidos vários sistemas nos últimos 15 anos. De modo geral, estão baseados no desenvolvimento de sistemas longitudinais com funcionamento ativo na restrição das deformações (KOVLER, 1994; BENTUR; KOVLER, 2003). Como o princípio básico do sistema, qualquer deformação que ocorra no corpo-de-prova deve ser "zerada" (ou para um valor bem próximo) e, simultaneamente, mensurada a tensão gerada necessária para retornar o corpo-de-prova para a posição original (BENTUR; KOVLER, 2003). A principal vantagem deste tipo de equipamento é a garantia da restrição total sem depender da rigidez do equipamento para garantir a restrição (PIGEON et al., 2000; BENTUR; KOVLER, 2003).

A Figura D.3 apresenta a descrição esquemática do desenvolvimento das tensões e o controle das deformações em um equipamento com princípio ativo de restrição. Do instante 0 (Figura D.3a) para o instante 1 (Figura D.3b), tensões $\left(\delta \sigma_{1}\right)$ surgem como resultado da restrição das deformações por retração e fluência, e por relaxação Neste tipo de equipamento, estabelece-se que será permitido que o corpo-de-prova deforme até atingir um valor pré-definido $\left(\Delta \varepsilon_{1}\right)$ que, geralmente, é pré-definidos como valores o mais baixo possível de acordo com a precisão do equipamento para a mensuração da deformação. Por exemplo, Bloom e Bentur (1995) definem a deformação máxima do corpo-de-prova em $2 \mu \mathrm{m}$, já Kovler (1994) define em $5 \mu \mathrm{m}$.

Ao atingir a deformação limite $\left(\Delta \varepsilon_{1}\right)$, aplica-se uma força axial adicional $\left(\Delta \sigma_{1}\right)$ para retornar o corpo-de-prova à posição original, conforme apresentado na Figura D.3c. Isto faz com que ocorra a deformação elástica $\left(\Delta \varepsilon_{2}\right)$ e que a tensão total $\left(\sigma_{1}\right)$ seja igual ao acúmulo da tensão resultante da restrição das deformações $\left(\delta \sigma_{1}\right)$ mais a tensão adicional $\left(\Delta \sigma_{1}\right)$ para o retorno à posição original. Então, permite-se que o corpo-de-prova deforme novamente sob a tensão total acumulada $\left(\sigma_{1}\right)$ alcançada no instante anterior. Com isto, no instante 2, novas tensões $\left(\delta \sigma_{2}\right)$ surgem com a restrição das deformações por retração e fluência até o limite prédefinido $\left(\Delta \varepsilon_{1}\right)$ (Figura D.3d). Quando a deformação limite é novamente atingida, mais uma vez é aplicada uma força axial adicional $\left(\Delta \sigma_{2}\right)$ para retornar o corpo-de-prova à posição original, conforme apresentado na Figura D.3e. Este procedimento é realizado de modo contínuo e permite obtenção do histórico de tensões ao longo do tempo (Figura D.3h). 


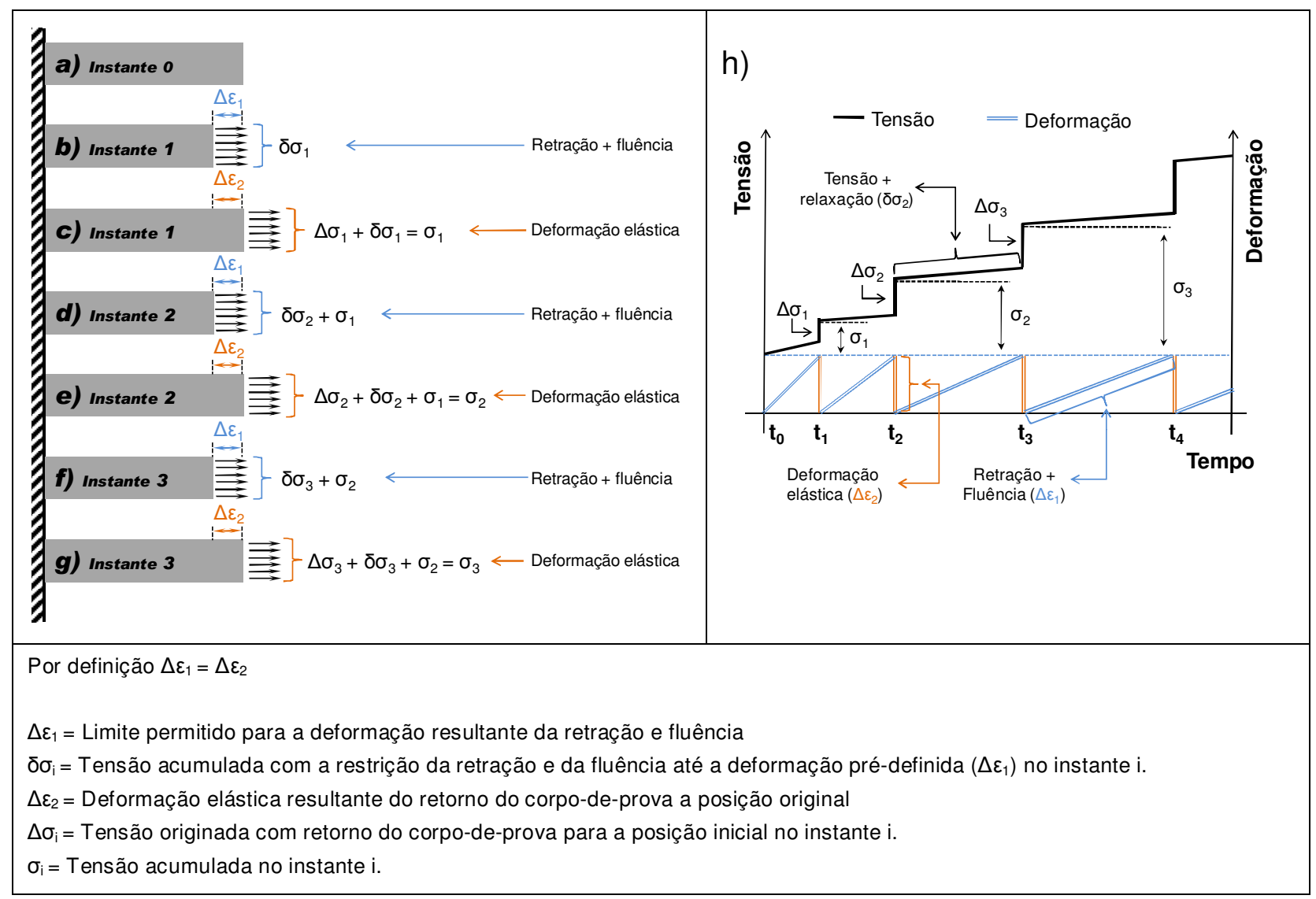

Figura D.3 - Descrição esquemática do desenvolvimento de tensões durante ensaio em equipamento com controle de deformação (ATRUSHI, 2003).

Assim como nos ensaios tradicionais de fluência à compressão, a utilização deste tipo de equipamento baseia se na mensuração simultânea da tensão induzida pela restrição das deformações e da deformação resultante da retração em um corpo-de-prova livre (Figura D.4) (MIHASHI; LEITE, 2004). Segundo Bentur e Kovler (2003), o "núcleo" deste tipo de equipamento de retração restringida é o sistema de compensação cíclica (Figura D.5). Cada ciclo corresponderá a uma deformação pré-definida $\left(\Delta \varepsilon_{2}\right)$, sendo esta definida como uma deformação elástica $\left(\varepsilon_{\mathrm{EL}}\right)$ resultante da aplicação de carga necessária para retornar o corpode-prova à posição original. A deformação que ocorre entre duas aplicações de carga, ou seja, entre dois ciclos de compensação, também é limitada a uma deformação pré-definida $\left(\Delta \varepsilon_{1}\right)$, sendo esta composta por duas parcelas: a primeira é resultante da retração livre $\left(\varepsilon_{\mathrm{RT}}\right)$ que ocorre durante cada ciclo (mensurada no corpo-de-prova em paralelo); e, a segunda, é conseqüência da fluência $\left(\varepsilon_{\mathrm{FT}}\right)$ que ocorre sob a carga aplicada durante cada ciclo no tempo $t$. 


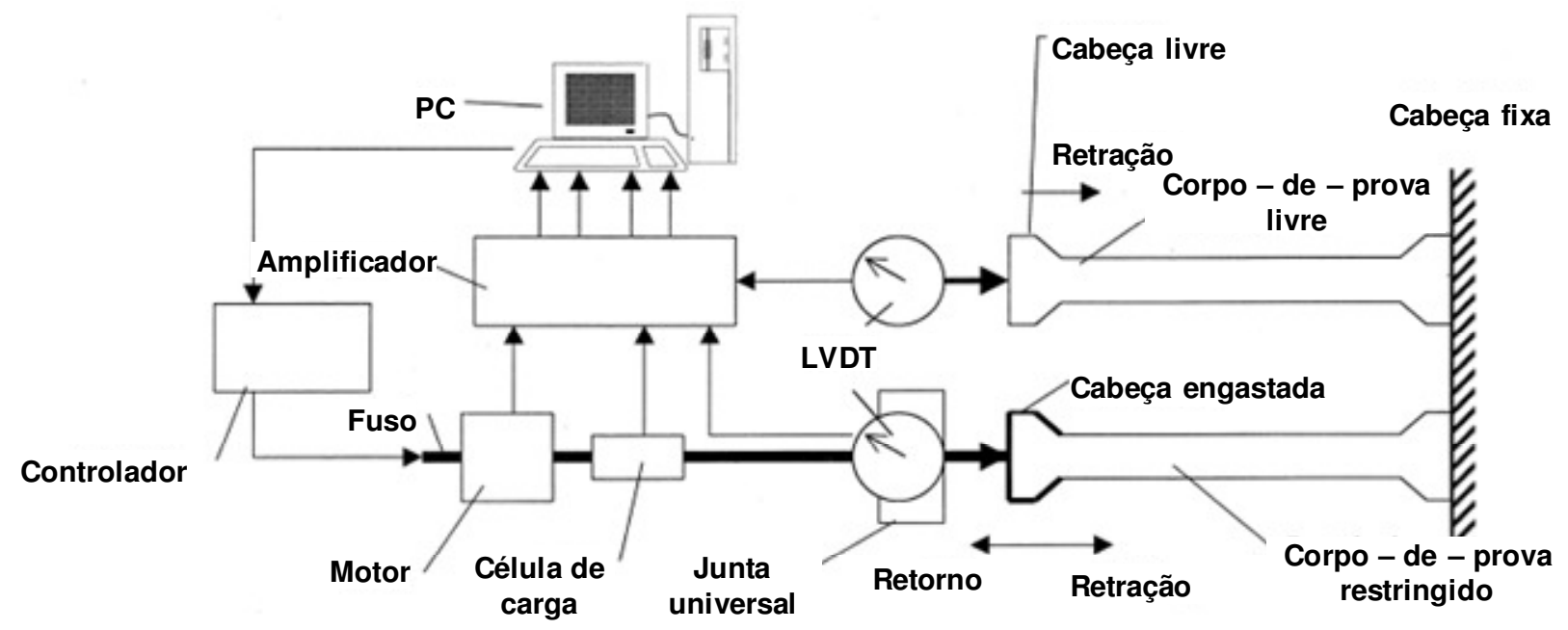

Figura D.4 - Desenho esquemático do aparato para o ensaio de retração restringida (Kovler, 1994).

Com isto, são aplicados cálculos matemáticos para a determinação da fluência, do módulo de elasticidade à tração e da relaxação. De acordo com os conceitos descritos no item 2.2.2 (pág.13), em cada ciclo a deformação total ( $\varepsilon$ ) é a soma das deformações elásticas $\left(\varepsilon_{\mathrm{EL}}\right)$, das deformações resultantes da retração $\left(\varepsilon_{\mathrm{RT}}\right)$ e resultantes da fluência $\left(\varepsilon_{\mathrm{FT}}\right)$ (Equação D.1). No caso do ensaio de retração restringida, a deformação total deverá ser igual a zero, portanto, pode-se afirmar que a soma das deformações elásticas $\left(\varepsilon_{\mathrm{EL}}\right)$ no tempo $(t)$ será igual à soma da deformação resultante da retração e fluência $\left(\varepsilon_{\mathrm{RT}}+\varepsilon_{\mathrm{FT}}\right)$.

Segundo Kovler (1994), a soma da retração e da fluência até um determinado tempo $\left(t_{k}\right)$ pode ser calculada como sendo igual à metade da soma dos valores absolutos de todos os incrementos de deformação precedentes (entre os tempos $t_{i-1}$ e $t_{i}$ ). Assim, a curva acumulada da retração mais a fluência pode ser calculada pela Equação D.2, estando representada na Figura D.5. Com a obtenção dos valores da retração mais a fluência, pode-se calcular a deformação resultante da fluência, que será a diferença entre a curva de retração livre e a curva acumulada da retração mais a fluência (Figura D.5).

$\varepsilon(t)=\varepsilon_{\mathrm{EL}}(t)+\varepsilon_{\mathrm{RT}}(t)+\varepsilon_{\mathrm{FT}}(t)=0$

Equação D.1

$\varepsilon_{\mathrm{RT}}\left(t_{k}\right)+\varepsilon_{\mathrm{FT}}\left(t_{k}\right)=1 / 2 \sum\left|\varepsilon\left(t_{i}\right)-\varepsilon\left(t_{i-1}\right)\right|$

Equação D.2 


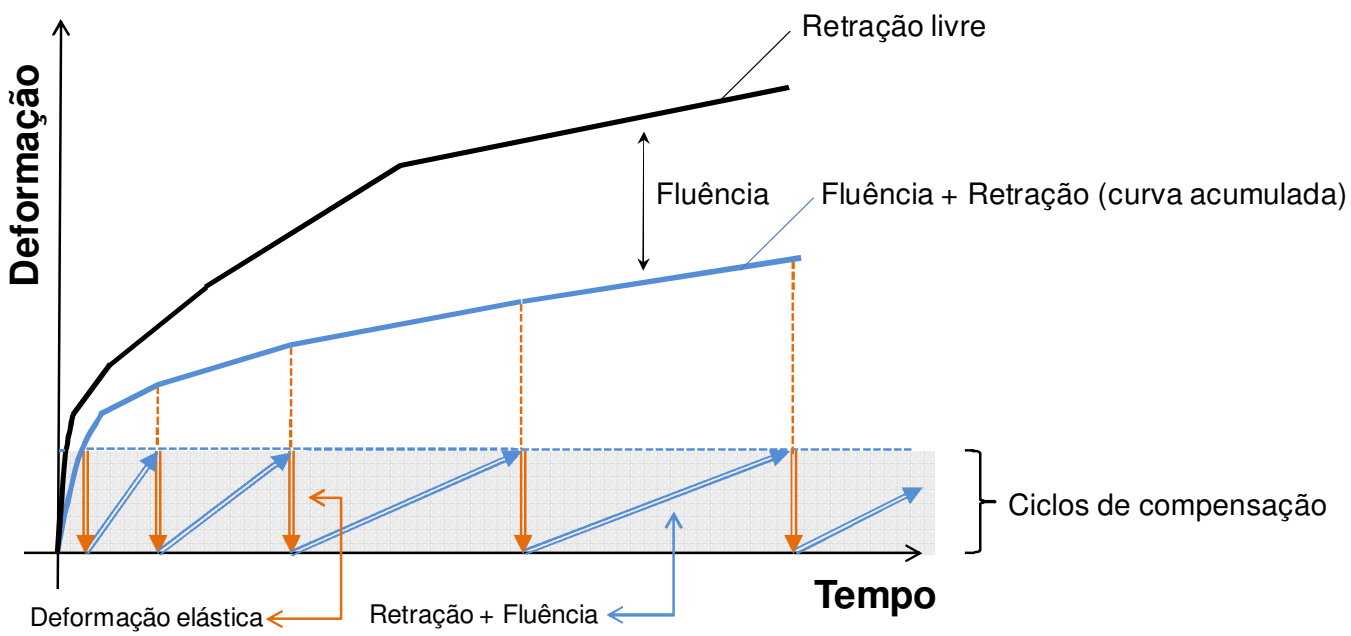

Figura D.5 - Resultado típico obtido com o ensaio de retração restringida (Kovler, 1994).

Toma et al. conseguem explicar de forma simples a análise matemática do princípio deste tipo de equipamento. Considerando inicialmente que o material seja puramente elástico (ou seja, sem fluência e relaxação), as tensões que surgem no corpo-de-prova restringido são basicamente elásticas e a soma das deformações deve ser igual à deformação resultante da retração livre. No caso do concreto, a soma das deformações no corpo-de-prova restringido não é igual à deformação verificada no ensaio de retração livre. A explicação desta diferença é que, com a retração, o corpo-de-prova apresenta deformações resultantes da fluência restringida sob a carga aplicada para restringir o corpo-de-prova. Portanto, a deformação resultante da fluência é igual à diferença entre a soma das deformações mensuradas no ensaio de retração restringida e a retração livre obtida em corpo-de-prova idêntico ensaiado simultaneamente.

\section{D.1.1.2 - Sistemas longitudinais de determinação da retração restringida}

Paillière et al. (1989) desenvolveu no Laboratoire Central des Ponts et Chaussées (LCPC) um sistema uniaxial que utilizava um corpo-de-prova com extremidades mais largas, conforme a Figura D.6. O sistema inovou com aplicação da restrição total por meio do controle da deformação. O corpo-de-prova é moldado diretamente no quadro do equipamento seguido da aplicação da restrição por meio de uma bomba de ar, sendo a tensão de tração mensurada com uma célula de carga. A deformação é monitorada para que qualquer deslocamento seja restringido (retornando o corpo-de-prova para a posição "zero") com a aplicação de carregamento por acionamento manual da bomba de ar. $\mathrm{O}$ equipamento permite a determinação desde as primeiras idades, com o corpo-de-prova posicionado na horizontal; em seguida, dependendo da idade, o aparato é girado em torno de um eixo para a posição vertical. A utilização deste equipamento nesta posição trouxe conhecimentos 
importantes para a evolução dos métodos, pois foi observado que o sistema de aplicação de carga para a restrição total associado à fragilidade do corpo-de-prova resulta na sua ruptura prematura na posição vertical. Atualmente, é consensual a utilização deste tipo de sistema apenas na posição horizontal, pois ameniza o risco de ruptura prematura do corpo-de-prova, e permite também o estudo no concreto ainda no estado fresco.

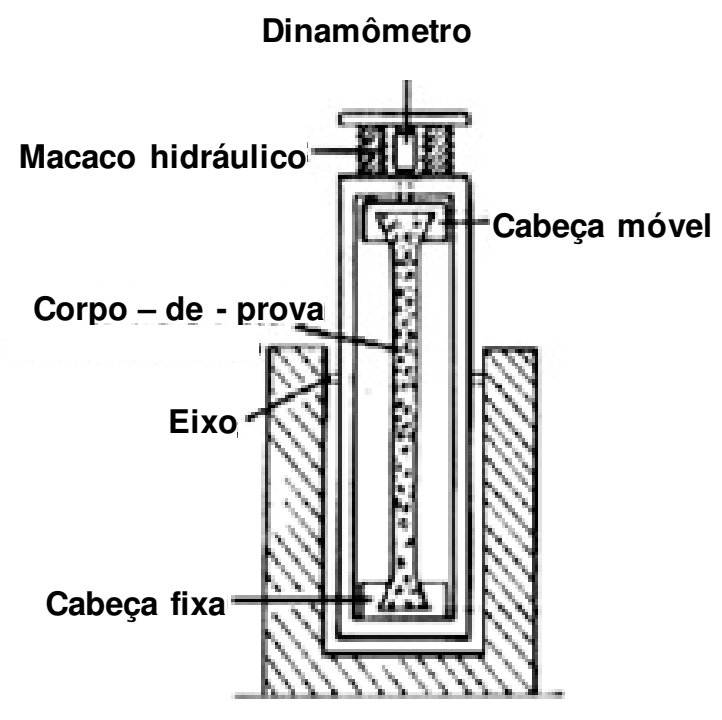

Figura D.6 - Sistema uniaxial para mensuração das tensões oriundas da retração restringida (PALLIĖRE et al., 1989).

Com base neste sistema, desenvolvido por Pallière et al. (1989), o Instituto Tecnológico de Israel - Technion desenvolveu um sistema uniaxial horizontal para determinações com situação de restrição total (BLOOM; BENTUR, 1995). O sistema difere dos demais existentes pelo controle da deformação para a garantia da restrição total. Este sistema utiliza um parafuso para este fim (parte 7 da Figura D.7), ao invés de utilizar uma bomba de ar para o retorno da deformação. Resumidamente, o funcionamento do equipamento estava baseado na movimentação da extremidade móvel (parte 4 da Figura D.7); quando esta movimenta $2 \mu \mathrm{m}$, o parafuso é girado manualmente (parte 8 da Figura D.7) até que a leitura do sensor de deslocamento indique que a extremidade móvel retornou à posição original. Simultaneamente, o sistema mensura a carga necessária para este retorno à posição original. Paralelamente, um corpo-de-prova é ensaiado em outro sistema exatamente igual, mas que permite o deslocamento do corpo-de-prova, obtendo-se assim a retração livre. Com isto, pode-se calcular a fluência como sendo a diferença entre as deformações acumuladas dos dois corpos-de-prova (item D.1.1.1). 


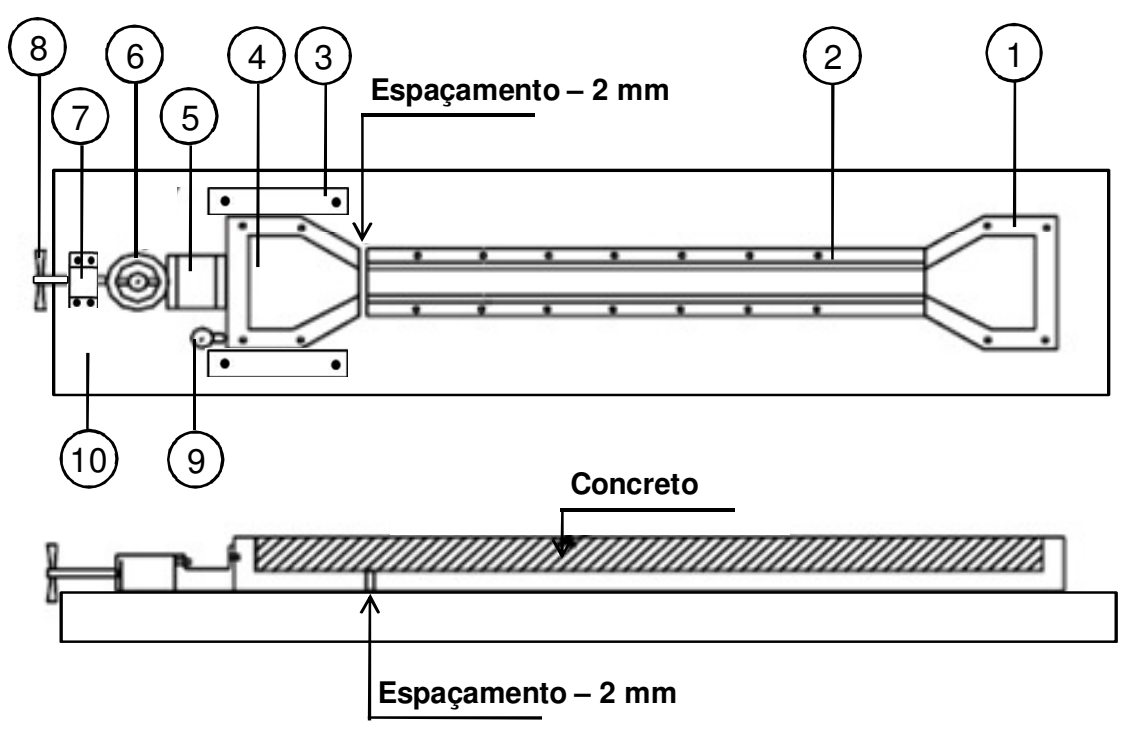

Figura D.7 - Equipamento de retração restringida (BLOOM; BENTUR, 1995).

Kovler (1994) modificou esse sistema incluindo um controle computadorizado (closed-loop) com sensores LVDTs ao invés de relógios comparadores analógicos. $\mathrm{O}$ desenho esquemático do sistema é apresentado na Figura D.4. Quando a deformação alcança um determinado limite, uma força de restrição é acionada automaticamente para restabelecer o comprimento original do corpo-de-prova. O gráfico que resume os objetivos deste ensaio está apresentado na Figura D.5. Pigeon et al. (2000), cujo trabalho anterior utilizou um sistema passivo (Figura D.2), basearam-se no aparato desenvolvido por Kovler (1994) e construíram um equipamento similar, utilizando um sistema computadorizado para controlar o sistema de aplicação de cargas (Figura D.8).

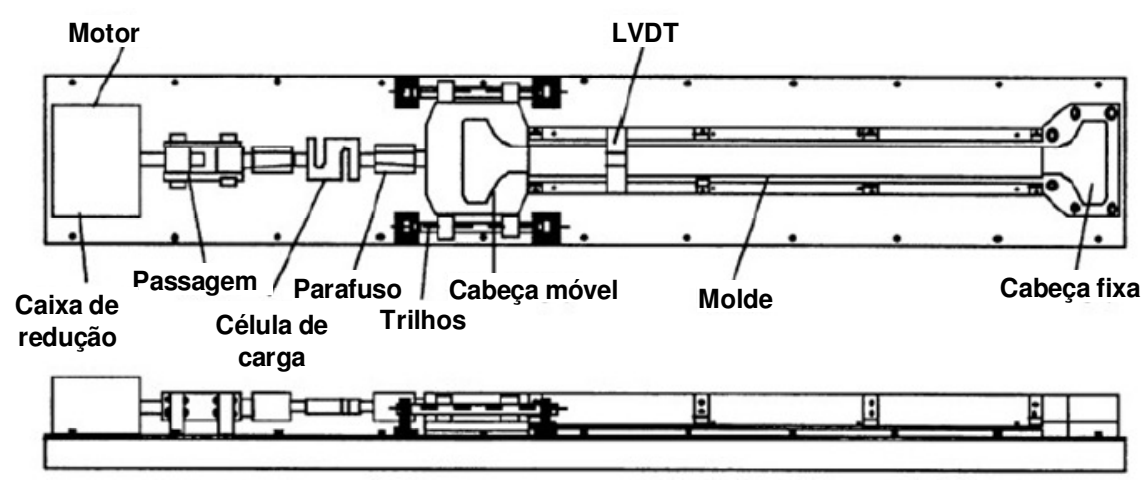

Figura D.8 - Equipamento de retração restringida (PIGEON et al., 2000).

Springenschmid et al. (1995) desenvolveram um aparato uniaxial denominado "Máquina para teste de tensões térmicas" (Temperature Stress Testing Machine - TSTM) apresentado na Figura D.9. Este equipamento foi desenvolvido especificamente para a determinação das tensões de origem térmica devido à hidratação do cimento e mudanças da temperatura externa. Com o aumento do interesse no estudo da retração restringida, este equipamento 
passou também a ser utilizado para este fim, trazendo a vantagem de permitir o controle e simulação de temperaturas. Baseado neste sistema, Van Breugel e Vreis (1999) também desenvolveram um equipamento TSTM utilizando um atuador hidráulico ao invés de um motor de passo para aplicar as cargas na condição de restrição total.

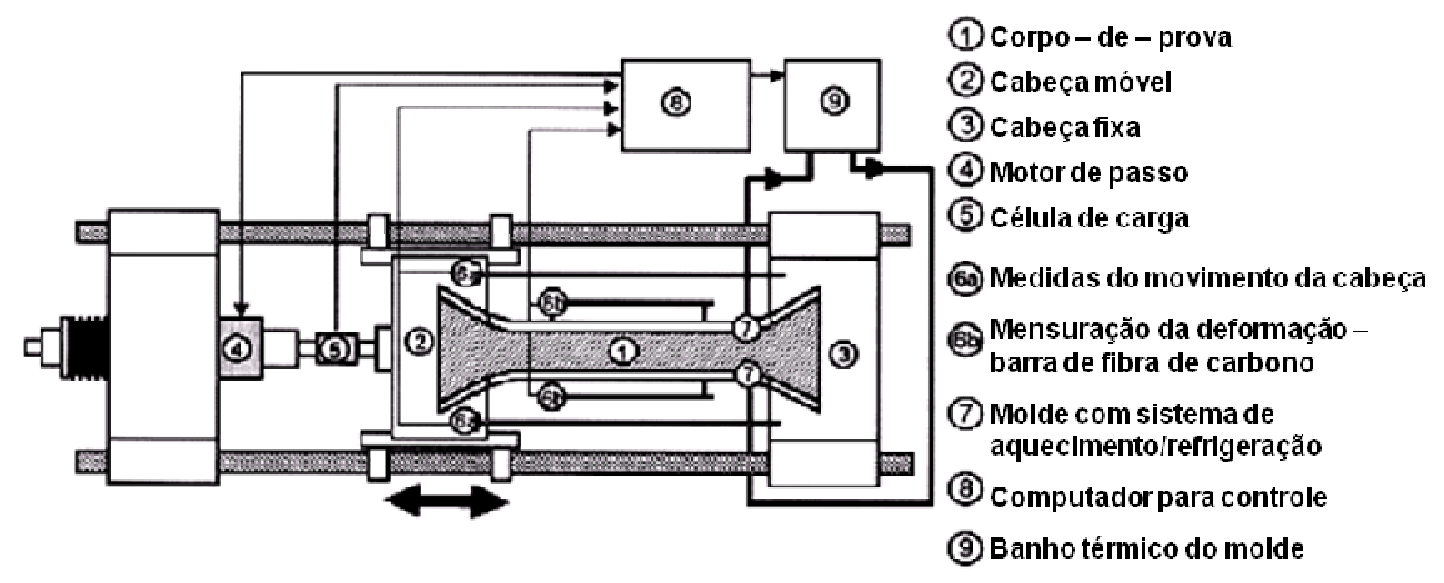

Figura D.9 - Aparato uniaxial para a determinação das tensões térmicas (SPRINGENSCHMID et al., 1995).

\section{D.1.2 - Métodos de determinação da retração livre}

Observa-se na literatura a grande variedade de métodos para a mensuração da retração livre. Na retração por secagem, esta variedade de métodos não aparenta refletir na coerência quando da comparação de resultados entre si. Já entre os métodos empregados na medida da retração autógena ainda existe uma grande variedade na magnitude da deformação de concretos e pastas de cimento (LURA, 2003). Jensen e Hansen (2001) também afirmam que os problemas nas técnicas de medida da retração autógena são o principal motivo para o desacordo existente nos resultados observados na literatura. Este fato interfere diretamente no objetivo de traçarem-se paralelos e análises entre os resultados reportados pela literatura, pois dependendo do método empregado os resultados podem diferir significativamente.

Um princípio básico que pode ser aplicado na mensuração de propriedades do concreto é realizar as medidas em pastas de cimento ou argamassas e possivelmente aplicá-las na estimativa dessa propriedade no concreto. É fato que a mensuração feita diretamente em corpos-de-prova de concreto traria resultados mais condizentes com a prática, mas em certas situações a viabilidade da mensuração em corpos-de-prova de concreto fica comprometida. 
A mensuração da retração autógena pode ser realizada, em geral, com determinação da deformação volumétrica ou da deformação linear. Em geral, a determinação volumétrica da deformação autógena é realizada com base no princípio de flutuação (buoyancy) de uma amostra imersa (Figura D.10a). A amostra no estado fresco é colocada em um balão de borracha bem apertado e, em seguida, vedado e imerso em água. A mudança de volume da amostra decorrente da retração autógena é determinada pela quantidade de água deslocada pela amostra imersa. Este método é basicamente aplicado em pastas de cimento.

A determinação linear da retração autógena é, geralmente, realizada em pastas de cimento colocadas em moldes rígidos com a interface pasta-molde possuindo baixo atrito, e mensurada a variação linear de comprimento do corpo-de-prova (Figura D.10b). Segundo Barcelo et al. (1999), a lógica seria que a deformação autógena mensurada pelo método volumétrico e pelo método linear fossem idênticas ou bastante similares, porém não é isto o que ocorre, pois, em geral, a retração autógena volumétrica quando transformada em retração autógena linear por meio de cálculos matemáticos é até 5 vezes maior do que a retração autógena linear determinada (BREUGUEL, 2001).

(a)

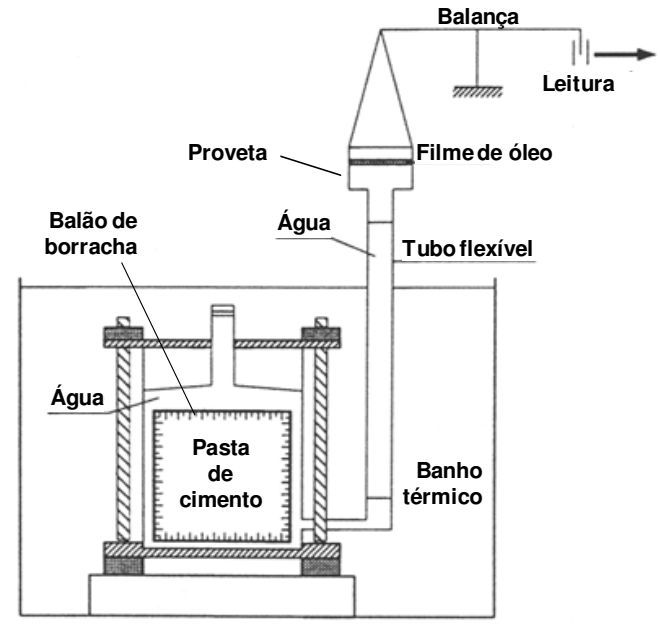

(b)

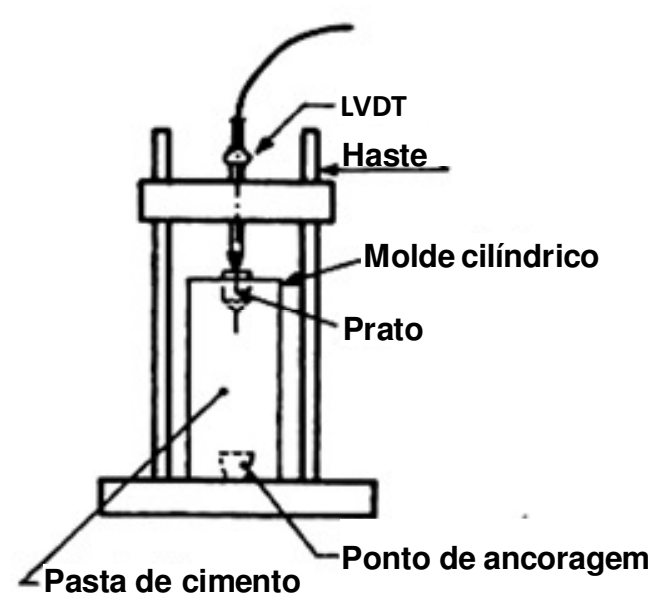

Figura D.10 - (a) Exemplo de medida volumétrica da deformação autógena (SETTER; ROY, 1978) e (b) de medida linear da deformação autógena (BUIL ${ }^{13}, 1979$ apud LURA, 2003).

Ambos os métodos apresentam vantagens e desvantagens. A medida volumétrica tem como principal vantagem a possibilidade de iniciar a mensuração imediatamente após a moldagem. Porém, segundo Lura (2003), apresenta como desvantagem a possibilidade de formar uma película de água (em razão da exsudação) entre o balão de borracha e a pasta de cimento. Isto pode prejudicar o ensaio, pois, com a retração química, a película poderá

\footnotetext{
${ }^{13}$ BUIL, M. Contribution à l'étude du retrait de la pâte de ciment durcissante. 1979. 72p. Tese (Doutorado) - Laboratoire Central des Ponts et Chaussées, Paris, França.
} 
ser absorvida pela pasta de cimento causando uma redução do volume interno e, conseqüentemente, um erro na determinação da retração autógena.

Na mensuração linear, a principal vantagem é a maior ancoragem do sistema de medida ao corpo-de-prova, o que evita alguns problemas descritos anteriormente, porém alguns autores consideram esta vantagem como principal desvantagem pelo fato da medição só poder ser realizada após o início da pega. A medida linear também apresenta problemas adicionais: a possibilidade de restrição da retração pelo atrito com o molde (BARCELO et al., 1999) e a possibilidade da água de exsudação ser reabsorvida e causar uma expansão ou reduzir a retração autógena (HAMMER, 2002).

Na mensuração da retração autógena em concreto é praticamente impossível a aplicação do método volumétrico, pois a presença de agregados acaba por danificar o balão de borracha. Diferentes métodos lineares têm sido empregados com este propósito, utilizando corpos-deprova cilíndricos, prismáticos ou em placas. Em concretos, os principais problemas apontados por Lura (2003) são: garantir a boa ancoragem entre o sistema de mensuração da deformação e o corpo-de-prova; minimizar a restrição e a perda de massa; e manter a temperatura constante. Cabe ressaltar que este último inconveniente pode ser tratado de duas formas: pode-se manter a temperatura (com auxílio de sistemas de refrigeração) ou pode-se acompanhar a evolução da temperatura (utilizando termopares) e descontar da deformação total a deformação em razão da variação de temperatura.

Os dois modos para contornar este problema têm vantagens e desvantagens. A principal vantagem da manutenção da temperatura constante é a garantia de que a deformação resultante será em razão apenas da retração autógena. Porém, a construção de sistemas para a manutenção da temperatura constante é, por vezes, de difícil elaboração e com possibilidade significativa de não garantir a constância da temperatura.

A forma mais difundida para analisar o efeito da variação da temperatura no ensaio de retração é a inserção de sensores de temperatura (ex: termopares). Com os resultados obtidos da variação de temperatura é calculada a deformação e descontada do resultado obtido no ensaio de retração. Este método tem como principal vantagem a simplicidade na elaboração do sistema de medição da variação de temperatura, em virtude da boa aplicabilidade e baixo custo dos sensores de temperatura. Porém, a principal desvantagem deste método é que o cálculo da deformação resultante da variação de temperatura é função 
do coeficiente de dilatação do corpo-de-prova. Este parâmetro é determinado em condições específicas (idade de ensaio, resistência, entre outras) e varia significativamente do estado fresco para o estado endurecido, variando ainda com a evolução da hidratação da amostra no estado endurecido.

\section{D.1.3 - Determinação da retração química}

A retração química ocorre em razão do volume absoluto dos produtos hidratados ser menor do que o volume total do cimento não hidratado mais a água, antes da hidratação (Figura D.11) (JAPAN CONCRETE INSTITUTE - JCI, 1998). A retração química pode ser expressa de acordo com a Equação D.3:

$R q(\%)=\frac{\left(V_{C}+V_{A}\right) V_{p h}}{V_{C i} V_{A i}} \times 100$

Equação D.3

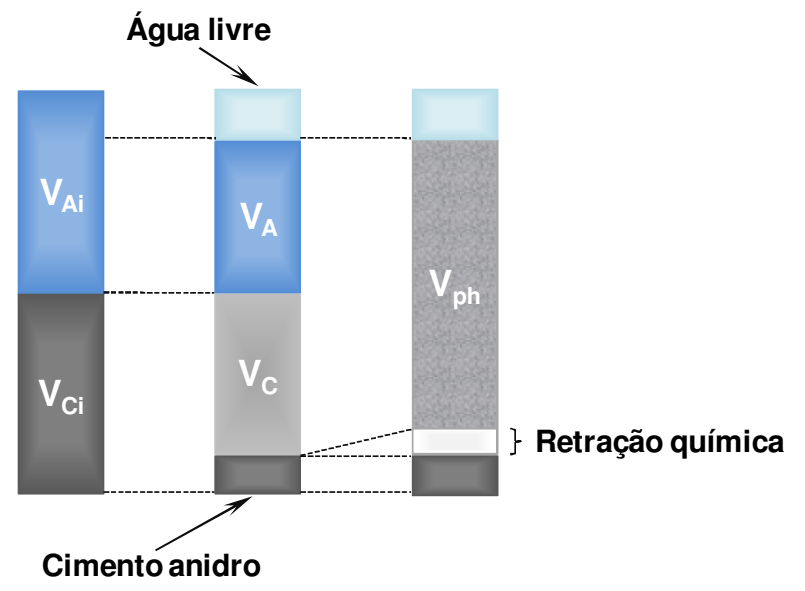

Onde:

$\mathrm{Rq}=$ Retração química (\%)

$\mathrm{V}_{\mathrm{Ci}}=$ Volume de cimento antes da mistura

$V_{C}=$ Volume de cimento hidratado

$\mathrm{V}_{\mathrm{Ai}}=$ Volume de água antes da mistura

$\mathrm{V}_{\mathrm{A}}=$ Volume de água quimicamente combinada

$\mathrm{V}_{\mathrm{ph}}=$ Volume de produtos hidratados

\section{Antes da mistura $\rightarrow$ Após a hidratação}

Figura D.11 - Desenho esquemático da variação volumétrica em razão da retração química (JCI, 1998).

A diferenciação e análise conjunta com a retração autógena volumétrica externa, cujo método de mensuração foi citado no item D.1.2, é comum na maioria das publicações sobre a retração química. Isto pode ser explicado pelo fato de ambos os ensaios serem baseados na variação volumétrica e pela semelhança entre a natureza dos dois fenômenos. A definição do Japan Concrete Institute - JCI (1998) é útil para a diferenciação entre a retração química e a retração autógena externa.

O JCI (1998) define a pasta de cimento endurecido como um compósito de fase sólida (produtos hidratados e cimento não hidratado), fase líquida (água não quimicamente combinada) e fase gasosa (vazios oriundos da hidratação e bolhas de ar existentes após a 
mistura). E que a retração química é a redução do volume absoluto dos reagentes, já a retração autógena volumétrica externa pode ser considerada a redução do volume externo em razão da formação do "esqueleto" sólido da matriz cimentícia (Figura D.12).

Com o ganho de resistência da matriz cimentícia, a formação dos produtos hidratados na ausência de uma fonte externa de água implica na formação de vazios no interior da estrutura da matriz cimentícia endurecida. Este comportamento é a base para explicar o fato da retração química continuar a evoluir em uma taxa e magnitude bem maior do que retração autógena volumétrica externa (HOLT, 2002). Pois, como descrito anteriormente, a retração autógena externa é causada pela redução do volume externo, a qual não apresentará uma taxa de evolução significativa com o avanço da hidratação, pois a redução do volume externo pouco mudará em razão da formação de vazios internos na estrutura da matriz cimentícia.

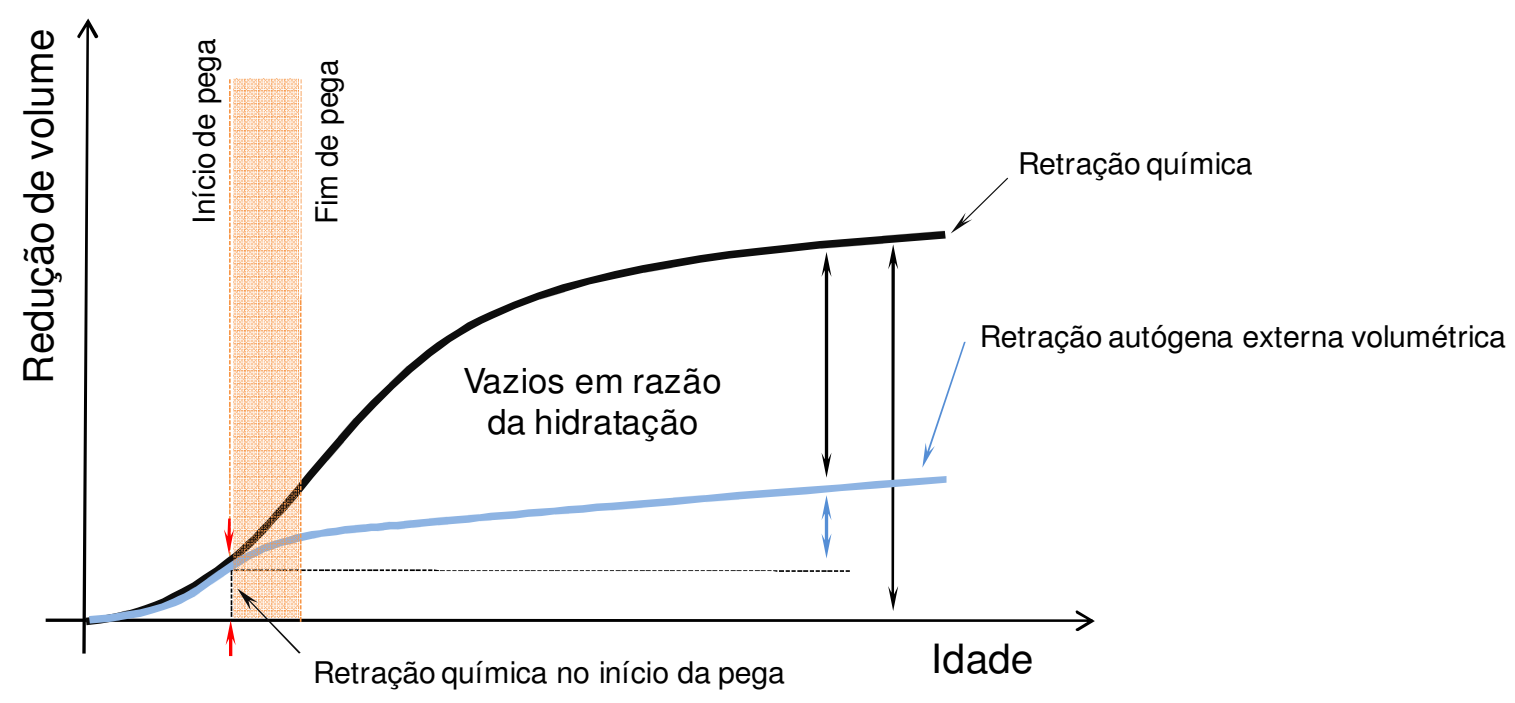

Figura D.12 - Gráfico comparativo da relação da retração química com a retração autógena externa volumétrica (JCl, 1998).

O JCl (1998) recomenda e estabelece procedimentos para a determinação da retração química, os quais estão baseados nos estudos realizados por Le Chatelier no início do século 20. O método consiste na mensuração do decréscimo do nível de uma coluna de água acima de uma pasta de cimento, cujo procedimento resumido pode ser ilustrado na Figura D.13. 


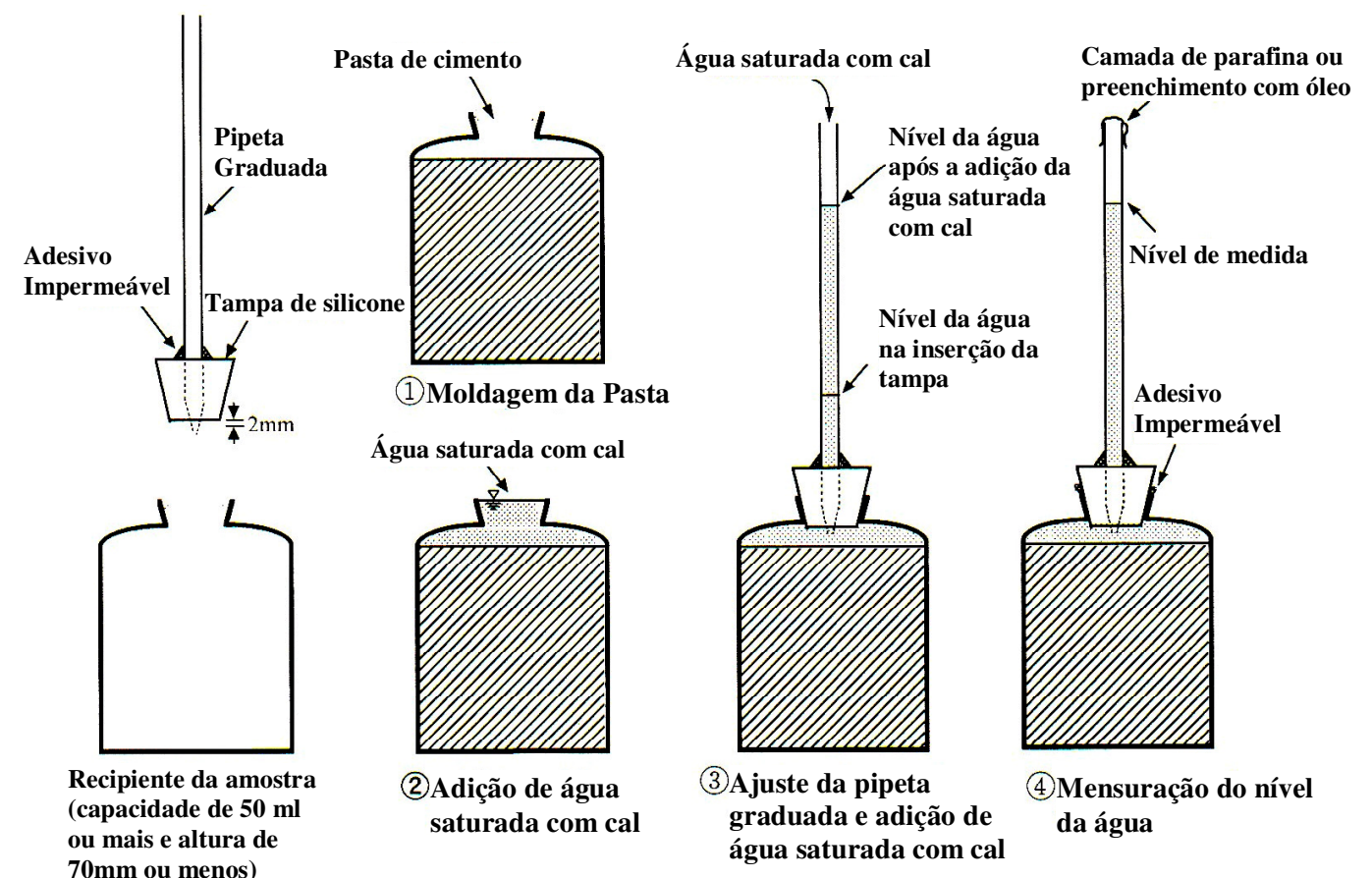

Figura D.13 - Método para a mensuração da retração química (JCl, 1998).

\section{D.2 - Desenvolvimento do equipamento}

A idéia de construção deste equipamento teve início quando parte dos dados obtidos na dissertação de mestrado de Melo Neto (2002) foram divulgados e apresentados no 11th International Congress on the Chemistry of Cements no mês de maio de 2003, quando foi possível coletar artigos, teses e idéias surgidas com a discussão com outros pesquisadores, principalmente com o Dr. Pietro Lura, na época pesquisador da Universidade de Delft da Holanda. Desse fato originou a idéia de implementar no Brasil o estudo da retração restringida, pois se trata de um tema importante e que representa uma recente tendência mundial para o desenvolvimento de ensaios de retração restringida objetivando a obtenção de resultados mais consistentes no estudo de materiais cimentícios e, principalmente, um detalhamento do comportamento da tendência à fissuração nas primeiras idades.

Para a concepção do equipamento de retração restringida, contou-se com o auxilio do Prof. Dr. Konstantin Kovler do Instituto Tecnológico de Israel - Technion que neste instituto desenvolveu um sistema uniaxial horizontal para determinações com situação de restrição total. Por meio de discussões via correio eletrônico, Prof. Kovler gentilmente se ofereceu para nos auxiliar e enviou vários desenhos esquemáticos com algumas especificações técnicas. Também houve a colaboração do Professor Dr. K.van Breugel, o qual recebeu o 
doutorando Antônio Acacio de Melo Neto na Universidade de Delft e se mostrou solícito para a discussão de métodos de mensuração da retração e ainda permitiu a visita ao laboratório para visualização (Figura D.14) do equipamento desenvolvido por eles para a mensuração da retração restringida (LURA, 2003).

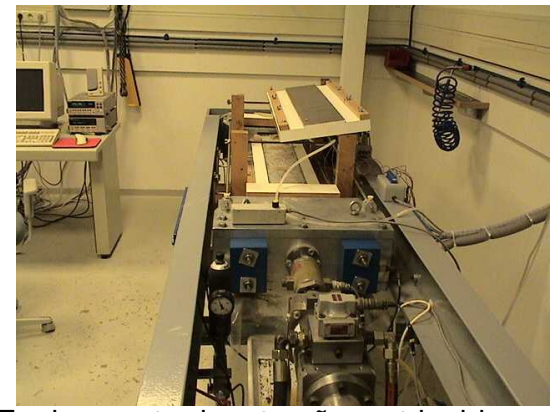

Equipamento de retração restringida

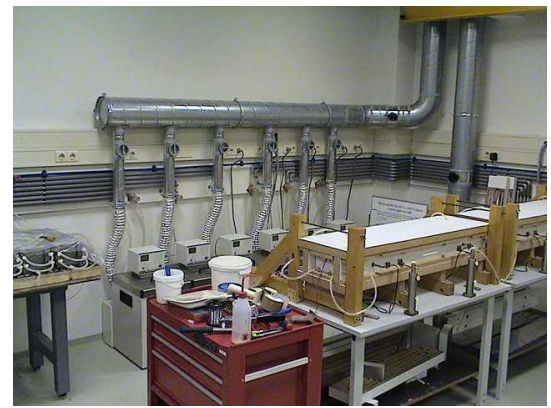

Banhos térmicos para controle da temperatura dos corpos-de-prova durante o ensaio

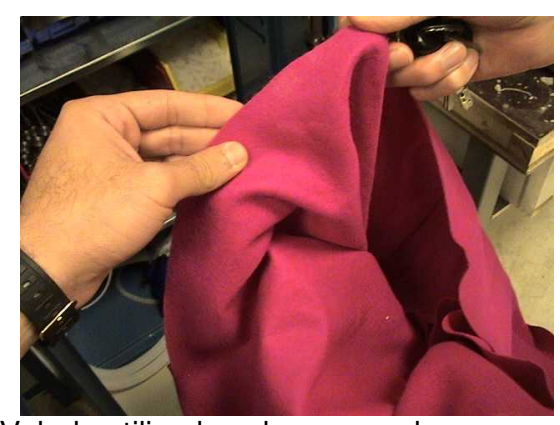

Veludo utilizado sob o corpo-de-prova vedado com plástico para redução do atrito

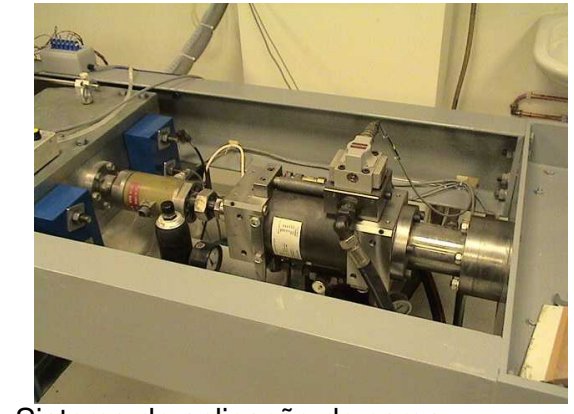

Sistema de aplicação de carga

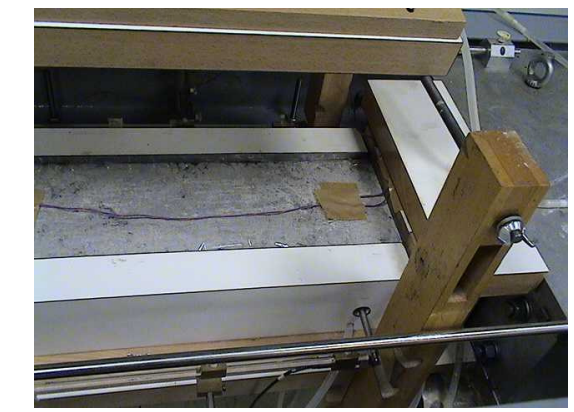

Detalhe do sistema de medição da deformação

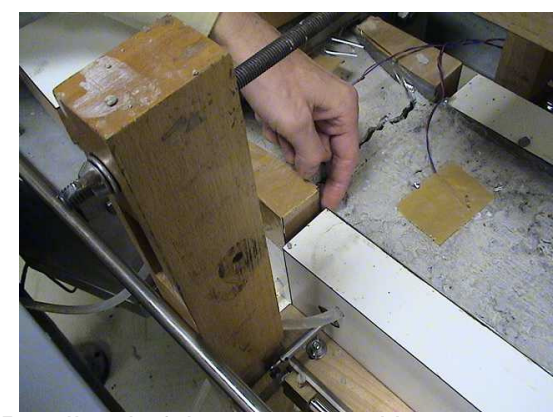

Detalhe da folga para permitir que o corpo-de-prova se desloque

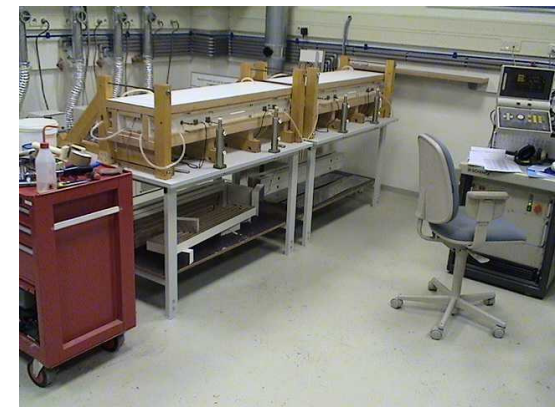

Equipamento de retração livre

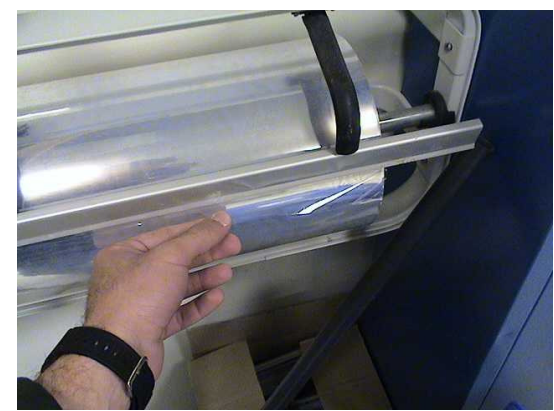

Plástico para vedação durante ensaio de retração autógena

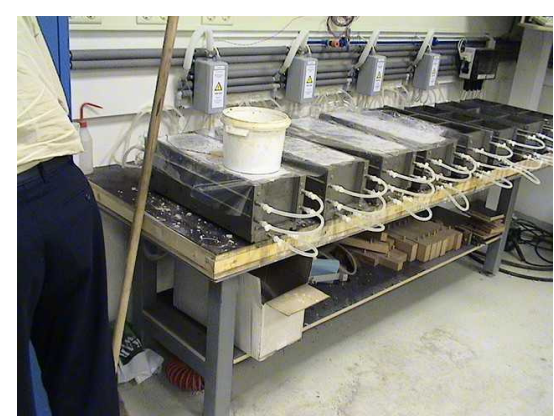

Os corpos-de-prova para ensaios mecânicos também tem sua temperatura controlada

Figura D.14 - Equipamento de retração restringida e retração livre da Universidade de Delft - Holanda.

Com base no sistema desenvolvido pelo Prof. Kovler e nos princípios de funcionamento do equipamento foi elaborado um projeto mecânico de um equipamento de retração restringida, composto basicamente por duas mesas de ensaios (Figura D.15(a)), uma para corpo-deprova restringido e outra para o corpo-de-prova livre. O sistema para o corpo-de-prova livre é constituído de um molde prismático com dimensões de $5 \mathrm{~cm}$ de largura, $5 \mathrm{~cm}$ de altura e 100 cm de comprimento (Figura D.15(b)). Estas dimensões foram projetadas com o principal intuito de possibilitar que as deformações resultantes da retração tenham valores com 
magnitudes mensuráveis, pois corpos-de-prova com pequenas dimensões exigem maiores precisões no sistema de mensuração das deformações. Os moldes foram revestidos com material antiaderente para minimizar possíveis restrições ao movimento do corpo-de-prova decorrente do atrito. No molde do corpo-de-prova para o ensaio restringindo é necessário garantir as condições de restrição do método, para isto as extremidades do molde, comumente chamada de "cabeça", foram projetadas de modo a garantir o engaste com corpo-de-prova de concreto sem o acumulo significativo de tensões (Figura D.15(e)). A cabeça do molde é um detalhe crítico do projeto, pois o seu formato dever proporcionar uma boa distribuição de tensões, caso contrário, pode ocorrer a perda do ensaio com a ruptura prematura do corpo-de-prova no engaste com o molde.

De acordo com os princípios do método, uma das cabeças do corpo-de-prova foi fixada à mesa de aço e outra cabeça foi engastada ao sistema cíclico de compensação automatizado (Figura D.15(c)). Este sistema é basicamente constituído de um motor de passo, caixa de redução e fuso de esferas (Figura D.15(f)(i)), com precisão e força suficientes para realizar deslocamento da cabeça móvel de acordo roteiro de ensaio desejado. Para a mensuração das deformações lineares do corpo-de-prova foram empregados LVDTs de alta precisão $(0,64 \mu \mathrm{m})$. No sistema de compensação cíclica também adicionada uma célula de carga para a medida da tensão acumulada para tracionar ou comprimir o corpo-de-prova (Figura D.15(d)(g)(h)).

Este equipamento foi projetado para possibilitar a configuração de parâmetros, como velocidade de carregamento, controle de deslocamento ou de carga, criando roteiros de ensaio específicos para cada situação desejada. Para a medida da retração restringida, o roteiro de ensaio é focado no controle de deformações do corpo-de-prova, no qual a deformação é mensurada por meio dos LVDTs e quando atinge o limite estabelecido na configuração do roteiro aciona o sistema de compensação para tracionar ou comprimir o corpo-de-prova de modo que a leitura do LVDT seja zero. Simultaneamente, as tensões acumulada pela movimentação do sistema de controle de deformação são registradas pela célula de carga. Outro roteiro de ensaio é o denominado de carga controlada, exatamente igual ao roteiro para a medida da retração restringida, só que o limite estabelecido na configuração é a leitura da célula de carga. Este tipo de roteiro é utilizado para a simulação de grau de restrição e para ensaios de fluência por compressão. O roteiro mais simples é de ruptura à tração direta do corpo-de-prova, no qual o corpo-de-prova é tracionado até atingir a 
ruptura, sendo mensurada a deformação e carga. Com este roteiro é possível obter o módulo de elasticidade à tração direta, pouco relatado para concretos e argamassas.

Ainda restam alguns detalhes de construção mecânica do equipamento, especificamente o aparato para a fixação do LVDT ao sistema que está em fase de desenvolvimento. Outro item do sistema que está em desenvolvimento é o software em linguagem Delphi. Será este software que proporcionará a integração entre os componentes eletromecânicos, o controle do ensaio e a aquisição de dados.

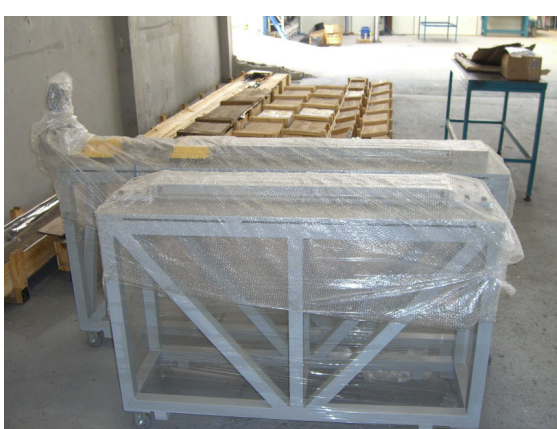

(a)

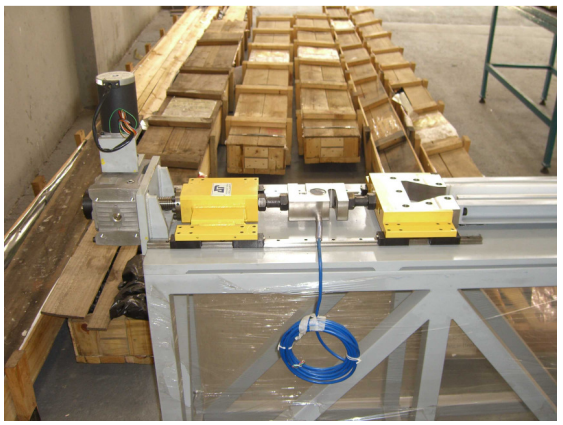

(d)

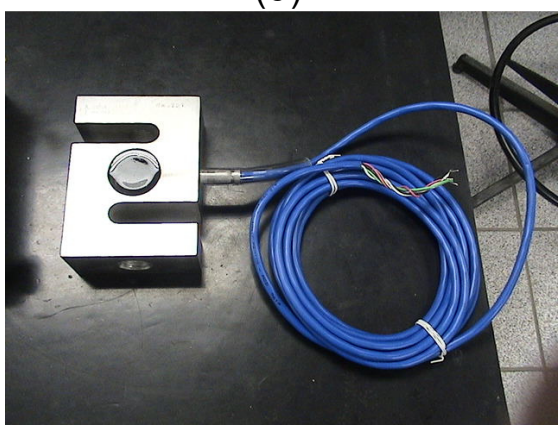

(g)

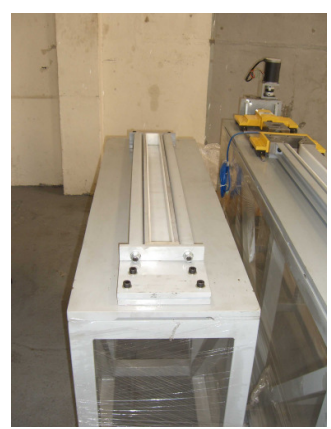

(b)

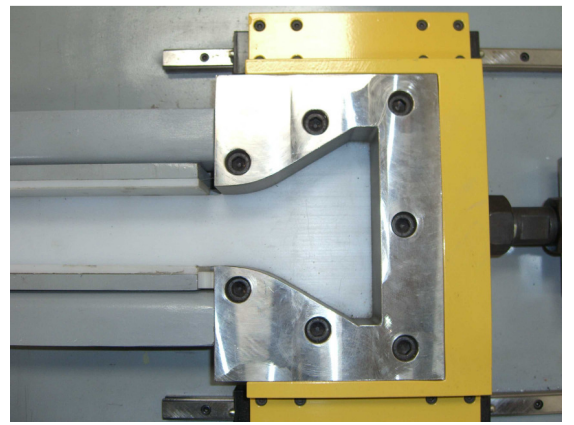

(e)

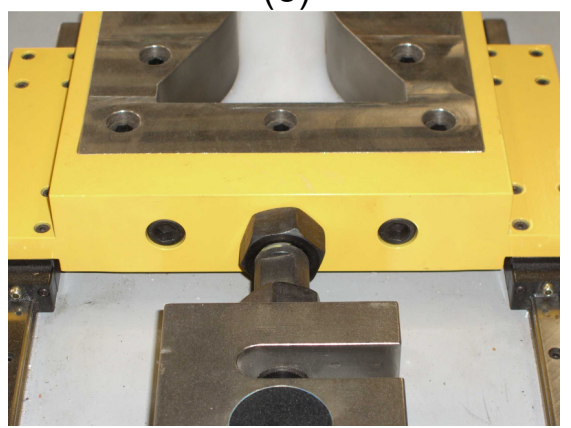

(h)

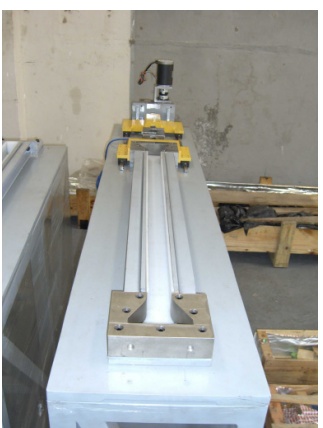

(c)

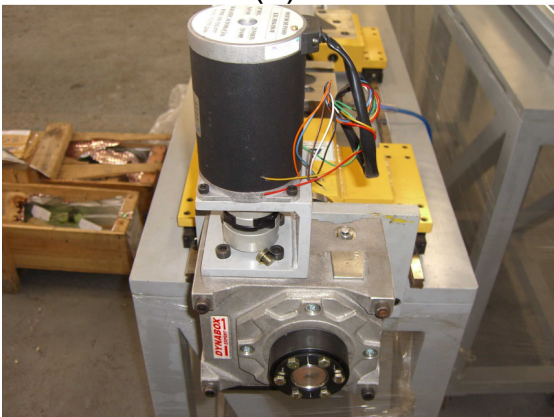

(f)

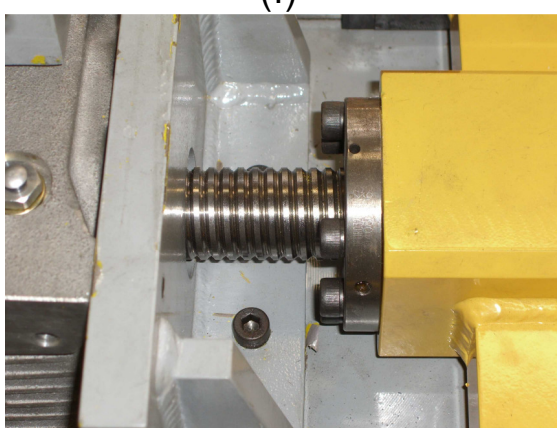

(i)

Figura D.15 - Equipamento de retração restringida. 